\title{
Realising the right to water and sanitation in Nigeria
}

\author{
Citation for published version (APA):
}

Balarabe, K. (2018). Realising the right to water and sanitation in Nigeria: a human rights-basedecosystem approach. [Doctoral Thesis, Maastricht University]. Maastricht University. https://doi.org/10.26481/dis.20180709kb

Document status and date:

Published: 01/01/2018

DOI:

10.26481/dis.20180709kb

Document Version:

Publisher's PDF, also known as Version of record

\section{Please check the document version of this publication:}

- A submitted manuscript is the version of the article upon submission and before peer-review. There can be important differences between the submitted version and the official published version of record.

People interested in the research are advised to contact the author for the final version of the publication, or visit the DOI to the publisher's website.

- The final author version and the galley proof are versions of the publication after peer review.

- The final published version features the final layout of the paper including the volume, issue and page numbers.

Link to publication

\footnotetext{
General rights rights.

- You may freely distribute the URL identifying the publication in the public portal. please follow below link for the End User Agreement:

www.umlib.nl/taverne-license

Take down policy

If you believe that this document breaches copyright please contact us at:

repository@maastrichtuniversity.nl

providing details and we will investigate your claim.
}

Copyright and moral rights for the publications made accessible in the public portal are retained by the authors and/or other copyright owners and it is a condition of accessing publications that users recognise and abide by the legal requirements associated with these

- Users may download and print one copy of any publication from the public portal for the purpose of private study or research.

- You may not further distribute the material or use it for any profit-making activity or commercial gain

If the publication is distributed under the terms of Article $25 \mathrm{fa}$ of the Dutch Copyright Act, indicated by the "Taverne" license above, 


\title{
Realising the $R_{\text {Ight to }} \mathbf{W}_{\text {ater and }}$ Sanitation in Nigeria:
}

A Human Rights-Based-Ecosystem Approach

\author{
DISSERTATION \\ to obtain the degree of Doctor at Maastricht University, \\ on the authority of the Rector Magnificus, Prof. Dr. Rianne M. Letschert \\ in accordance with the decision of the Board of Deans, \\ to be defended in public \\ on Monday 9 July 2018 at 16:00 hours
}

by

Kasim Balarabe 
SUPERVISOR: $\quad$ Prof. Dr. Fons Coomans

Co-SuPERvisor: Dr. Gustavo Arosemena

\section{Assessment Committee}

1. Prof. Dr. Jure Vidmar (Chairman)

2. Prof. Cees Flinterman

3. Prof. Koen de Feyter (University of Antwerp, Belgium)

4. Prof. Muhammed Tawfiq Ladan (Ahmadu Bello University, Zaria, Nigeria)

5. Dr. Jennifer Sellin 
CHAPTER ONE

1.1 Background to the Research Context 1

1.2 Country Background and Water and Sanitation Coverage 5

1.2.1 Political Context 8

1.2.2 Legal Context 9

1.2.3 Economic Context 14

1.2.4 Social Context 15

1.2.5 Cultural Context 16

1.2.6 Environmental Context 16

1.2.7 Nigeria's Water and Sanitation Coverage $\quad 17$

1.3 Geographical Scope of the Study 25

$\begin{array}{lll}1.4 & \text { Objectives of the Study } & 25\end{array}$

1.5 Research Questions 26

1.6 Methodology of the Research 26

1.7 Background to the Empirical Study and its Justification 27

1.8 Theoretical and Conceptual Framework 29

1.9 Proposed Approaches 31

1.9.1 Human Right-Based Approach 32

1.9.2 Justification for the Adoption of a Human Rights-Based Approach in Water and Sanitation Sector in Nigeria 35

1.9.3 The Ecosystems Approach $\quad 35$

1.9.4 Justification for the Adoption of an Ecosystems Approach in Water and $\begin{array}{ll}\text { Sanitation Sector in Nigeria } & 37\end{array}$

1.9.5 Compatibility of a Human Rights Based-Approach and an Ecosystem Approach 
Realising the Right to Water and Sanitation in Nigeria

1.10 Structure of the Research $\quad 40$

1.11 Limitation of the Study 40

$\begin{array}{ll}\text { CHAPTER TWO } & 43\end{array}$

ANALYSIS OF LEGAL OBLIGATIONS UNDER THE HUMAN RIGHT TO WATER AND SANITATION $\quad 43$

2.1 Introduction $\quad 43$

2.2 The Right to Water and Sanitation: United Nations Committee on ESCR, HRC and UNGA 43

2.3 General Obligations in Human Rights Law 49

2.4 Some Specific Obligations on the Right to Water and Sanitation 55

2.5 Contents and Scope of the Right to Water and Sanitation 61

$\begin{array}{lll}2.5 .1 & \text { Sufficiency (Availability) } & 62\end{array}$

$\begin{array}{lll}2.5 .2 & \text { Quality } & 65\end{array}$

$\begin{array}{lll}2.5 .3 & \text { Accessibility } & 68\end{array}$

$\begin{array}{lll}2.5 .4 & \text { Acceptability } & 76\end{array}$

2.6 Distinct Nature of Sanitation as Human Right and its Gender Dimension 76

2.7 Freedoms and Entitlements in the Right to Water 79

2.8 Obligations of Non-State Actors as Service Providers 79

$\begin{array}{llr}2.9 & \text { Conclusions } & 80\end{array}$

$\begin{array}{lr}\text { CHAPTER THREE } & 83\end{array}$

HUMAN RIGHTS PROTECTION IN NIGERIA AND THE RIGHT TO WATER AND SANITATION: PERSPECTIVES AND INSTITUTIONAL STRUCTURES $\quad 83$

$\begin{array}{llr}3.1 & \text { Introduction } & 83\end{array}$

3.2 Nigeria's Human Rights Environment: Power Politics and Judicial Struggles 84

3.3 Nigeria's Human Rights Environment in Relations to Economic, Social and Cultural $\begin{array}{ll}\text { Rights } & 91\end{array}$

3.4 Institutional Structures on Human Rights Protection in Nigeria 97

3.4.1 National Human Rights Commission 98 
3.4.2 Public Complaint Commission 99

3.4.3 The Legal Aid Council 100

3.4.4 Committees of the National Assembly 100

3.5 Administration and Management of Water and Sanitation: Institutional Structures in Nigeria

3.5.1 Institutions at the Federal Level 104

3.5.2 Institutions at the States and Local Governments Levels 108

3.6 Problems Associated with the Operation and Functioning of Institutional Structures on $\begin{array}{ll}\text { Water and Sanitation in Nigeria } & 109\end{array}$

$\begin{array}{lll}3.6 .1 & \text { Technical Capacity } & 110\end{array}$

3.6.2 Infrastructural Capacity and Operational Challenges 111

3.6.3 Weak Institutional Framework 11

3.6.4 Fragmented and Inadequate Data and Statistics $\quad 112$

3.6.5 Weak Synergy among Stakeholders 114

$\begin{array}{lll}3.6 .6 & \text { Bureaucracy } & 115\end{array}$

3.6.7 Lack of Cost-Recovery Mechanism 115

3.6.8 Lack of Motivation $\quad 115$

3.6.9 Lack of Consultation and Participation of Beneficiaries 116

3.6.10 Low Involvement of Private Corporate Actors 117

$\begin{array}{llr}3.7 & \text { Conclusions } & 119\end{array}$

CHAPTER FOUR

NIGERIA'S COMPLIANCE WITH THE LEGAL OBLIGATIONS UNDER THE HUMAN RIGHT TO WATER AND SANITATION: LEGAL, POLICY AND EMPIRICAL PERSPECTIVES $\quad 121$

$\begin{array}{llr}4.1 & \text { Introduction } & 121\end{array}$

4.2 Constitutional Regulation of Water Resources and the Right to Water and Sanitation

$\begin{array}{lll}4.3 & \text { Legislative Measures on Water } & 124\end{array}$

$\begin{array}{lll}\text { 4.3.1 Water Resources Act } & 125\end{array}$

4.3.2 River Basins Development Authorities $\quad 126$

4.3.3 National Agency for Food and Drug Administration and Control Act $\quad 127$

4.3.4 Drugs and Related Products (Registration, Etc.) Act (As Amended) 127

4.3.5 Criminal Code Act, Penal Code Act and Shariah Penal Code Law 128

4.3.6 Customary Law (Practices) on Water 128

4.3.7 National Environmental (Surface and Groundwater Quality Control) Regulations, S. I. No. 22 of $2011 \quad 130$

4.4 Legislative Measures on Sanitation and Environment $\quad 130$ 
Realising the Right to Water and Sanitation in Nigeria

4.4.1 National Environmental Standards and Regulations Enforcement Agency (Establishment) Act, $2007 \quad 131$

4.4.2 Harmful Waste (Special Criminal Provisions, etc.) Act 131

4.4.3 Nigerian Urban and Regional Planning Act 132

4.4.4 National Environmental (Sanitation and Wastes Control) Regulations, S. I. No. 28 of 2009

4.5 Policy Measures on Water and Sanitation 132

4.5.1 National Water Supply and Sanitation Policy, $2000 \quad 134$

4.5.2 National Water Policy, $2004 \quad 135$

4.5.3 National Water Resources Roadmap 2016-2030 135

4.5.3 National Water Sanitation Policy $2004 \quad 136$

4.5.4 National Environmental Sanitation Policy, $2005 \quad 138$

4.5.5 National Policy on the Environment, $2017 \quad 139$

4.5.6 Nigeria Standards for Drinking Water Quality $2007 \quad 141$

4.5.7 Other Policies 142

4.6 Compatibility of Legislative and Policy Measures with International Obligations 143

4.6.1 Water and Sanitation as Human Right in Nigeria 143

4.6.2 Compatibility of Legislative and Policy Instruments with Contents of the Right to Water 146

4.6.3 Nigeria and the Obligations to Respect, Protect and Fulfil the Right to Water and $\begin{array}{ll}\text { Sanitation } & 147\end{array}$

4.6.4 Observations and Comments on Nigeria's Legal and Policy Frameworks in Relations to Obligations on Water and Sanitation 153

4.7. Problems Associated with Legal and Policy Frameworks 154

4.7.1 Non-Justiciability of ESC Rights under the Constitution 155

4.7.2 Non-domestication of International Human Rights Instruments: 159

4.7.3 Non-Recognition of Water and Sanitation as Human Rights 160

4.7.4 Weak Implementation $\quad 160$

4.7.5 Inconsistencies and Policy Reversals 160

4.8 Empirical Perspective on the Contents of the Right to Water in Nigeria 161

$\begin{array}{lll}\text { 4.8.1 Availability (Sufficiency) } & 162\end{array}$

4.8.2 Water Quality: Respondents Perception on Water Quality 164

4.8.3 Accessibility 165

4.8.4 Non-Discrimination $\quad 169$

4.8.5 Compliance with Legal Obligations from an Empirical Perspective 174

$\begin{array}{lll}4.9 & \text { Conclusion } & 175\end{array}$

CHAPTER FIVE $\quad 179$

HUMAN RIGHTS AWARENESS AND THE RIGHT TO WATER AND SANITATION AMONG SELECTED NIGERIANS 179 
5.2 Composition of the Respondents: Duty-Bearers and Rights-Holders 179

5.2.1 Duty-Bearers

5.2.2 Rights-Holders

5.3. Assessment of Human Rights Awareness and the Existence of the Right to Water and Sanitation among Selected Duty-Bearers

5.4 Assessment of Human Rights Awareness and the Existence of the Right to Water and Sanitation among Selected Rights-Holders in Nigeria

5.5 The Human Right to Water and Sanitation in Relationship to Other Critical ESC Rights and Likelihood of Asserting Legal Claim

5.6 Human Rights Complaints and Claims 186

5.7 Influence of Some Formal and Informal Factors on Human Rights Claims $\quad 189$

$\begin{array}{lll}5.8 & \text { Conclusions } & 192\end{array}$

CHAPTER SIX

POLITICAL, ECONOMIC, SOCIAL, CULTURAL AND ENVIRONMENTAL FACTORS CONTRIBUTING TO POOR WATER AND SANITATION COVERAGE IN NIGERIA

6.1 Introduction

6.2 Political Factors

6.2.1 Prolonged Military System of Governance 194

6.2.2 Inept and Corrupt Leadership 194

6.2.3 Cost of Governance 194

6.2.4 Lack of Political Will 196

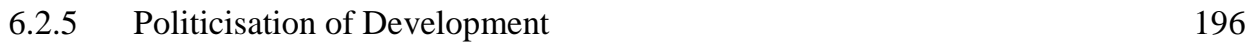

6.3 Economic Factors 196

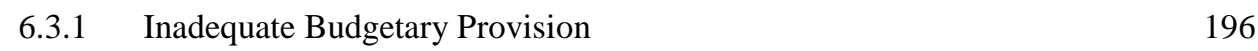

6.3.2 Untimely and Limited Appropriation Releases 199

6.3.3 Impact of Business Activities: Oil Extraction and Oil Companies 200

$\begin{array}{ll}\text { 6.3.4 Corruption and Corrupt Practices } & 201\end{array}$

6.3.5 Economic Activities 203

6.4 Social Factors $\quad 203$

6.4.1 Population Explosion 203

6.4.2 Rural-Urban Migratory Movement and Informal Settlements 204

$\begin{array}{ll}\text { 6.4.3 Discrimination and Marginalisation } & 205\end{array}$ 
Realising the Right to Water and Sanitation in Nigeria

6.4.4 Sanitation Practices and Lack of Awareness 206

6.4.5 Lack of Access to Information/Non-Utilisation of Available Sources 207

6.4.6 Poverty 208

6.4.7 Low-level Literacy and Lack of Awareness 210

6.4.8 Culture and Traditions, Religious Beliefs and Practices and Family Influence

6.4.9 Population Passivity

6.5 Natural and Environmental Factors 211

$\begin{array}{lll}\text { 6.5.1 Climate Change } & 213\end{array}$

6.5.2 Geographical Location: Inaccessibility and Distance 214

6.6 Assessment of Human Rights Obligations and Political, Economic, Social and Environmental Factors Contributing to Poor Water and Sanitation Coverage in Nigeria

$\begin{array}{lll}\text { 6.7. Conclusions } & 216\end{array}$

CHAPTER SEVEN

POTENTIALS OF LIBERAL (DYNAMIC, PROGRESSIVE) LEGAL INTERPRETATION APPROACHES IN THE PROMOTION OF NON-JUSTICIABLE $\begin{array}{ll}\text { RIGHTS } & 217\end{array}$

$\begin{array}{lll}7.1 & \text { Introduction } & 217\end{array}$

7.2 The Concept and Arguments on the Justiciability of ESC Rights 218

7.3 Justiciability of ESC Rights and its Relevance to Water and Sanitation in Nigeria 220

7.4 Enforcement of ESC Rights through the African Charter Act 222

7.5 Approaches to Legal Interpretation 224

7.5.1 Judicial Activism in Legal Interpretation 225

7.5.2 Purposive, Liberal and Integrated Interpretation Approaches 228

$\begin{array}{lll}\text { 7.5.3 Interpretation of Constitution } & 228\end{array}$

7.5.4 Purposive Interpretation Approach to Fundamental Objectives and Directive Principles of State Policy 230

7.5.6 Liberal and Integrated Interpretation Approach to ESC Rights through $\begin{array}{ll}\text { Fundamental (Justiciable) Rights } & 237\end{array}$

7.6 Accountability in the Case of Omission 242

7.7 Downside of Judicial Activism 245

7.8 Relevance of Interpretation Approaches to the Realisation of the Right to Water and Sanitation 
POTENTIALS OF A HUMAN RIGHTS-BASED APPROACH TO THE REALISATION OF THE RIGHT TO WATER AND SANITATION IN NIGERIA

8.1 Introduction

8.2 The Concept of a Human Rights-Based Approach

8.3 A Human Rights-Based Approach in Relations to other Approaches

8.4 Arguments against a Human Rights-Based Approach

8.5 Principles of a Human Rights-Based Approach

8.5.1 Principle of Equality and Non-Discrimination 256

$\begin{array}{ll}\text { 8.5.2 Principle of Empowerment } & 257\end{array}$

8.5.3 Principle of Participation 258

8.5.4 Principle of Responsibility and Accountability 259

8.6 Potentials of a Human Rights-Based Approach to Nigeria's Water and Sanitation $\begin{array}{ll}\text { Sector } & 260\end{array}$

8.6.1 Use of Language of 'Right' in the Nigerian Context 262

8.6.2 Relevance of Principles of Human Rights-Based Approach to Challenges in $\begin{array}{ll}\text { Water and Sanitation Sector } & 264\end{array}$

8.6.3 Empowerment of Duty-Bearers and Rights-Holders 268

8.7 Relevance of Local and National Conditions in the Application of a Human RightsBased Approach in Nigeria

8.8 Proposed Methodology for the Application of a Human Rights-Based Approach in Nigeria

8.9 Relevance of Civil Society and International Organisations in a Human Rights-Based Approach

8.10 Monitoring the Application of a Human Rights-Based Approach

$\begin{array}{lll}8.11 & \text { Contextual Challenges } & 280\end{array}$

$\begin{array}{lll}8.12 & \text { Conclusions } & 281\end{array}$ 
Realising the Right to Water and Sanitation in Nigeria

POTENTIALS OF AN ECOSYSTEMS APPROACH TO THE REALISATION OF THE RIGHT TO WATER AND SANITATION AND PROTECTION OF THE ENVIRONMENT

9.1 Introduction

9.2 The Right to a Healthy Environment and its Relationship with Ecosystem

9.3 Water Resources and Ecosystem

9.4 Imperative of Preserving Ecosystems Goods and Services

9.5 An Ecosystems Approach and Integrated Water Resources Management

9.6 Principles of an Ecosystems Approach

9.6.1 Principle One: The Objectives of Management of Land, Water and Living Resources are a Matter of Societal Choice

9.6.2 Principle Two: Management should be Decentralized to the Lowest Appropriate Level

9.6.3 Principle Three: Ecosystem Managers Consider the Effects (Actual or Potential) of their Activities on Adjacent and other Ecosystems

9.6.4 Principle Four: Need to Understand and Manage the Ecosystem in an Economic Context

9.6.5 Principle Five: Conservation of Ecosystem Structure and Functioning, for Maintenance of Ecosystem Services as a Priority Target 296

9.6.6 Principle Six: Ecosystems Must Be Managed Within the Limits of their Functioning

9.6.7 Principle Seven: The Ecosystem Approach Should Be Undertaken at the Appropriate Spatial and Temporal Scales

9.6.8 Principle Eight: Objectives for Ecosystem Management Should Be Set for the $\begin{array}{ll}\text { Long Term } & 297\end{array}$

9.6.9 Principle Nine: Management Must Recognize that Change is Inevitable 297

9.6.10 Principle 10: The Ecosystem Should Seek the Appropriate Balance Between, and Integration of, Conservation and Use of Biological Diversity 298

9.6.11 Principle 11: The Ecosystem Approach Should Consider all Forms of Relevant Information, Including Scientific and Indigenous and Local Knowledge, Innovations and Practices

9.6.12 Principle 12: The Ecosystem Approach Should Involve all Relevant Sectors of Society and Scientific Disciplines.

9.7 Legal and Institutional Bases for the Adoption of an Ecosystem Approach in Nigeria

9.8 Potentials of the Principles of an Ecosystems Approach in Water Resources Management in Nigeria

9.8.1 Development of Defined Management Objectives of Water 301

$\begin{array}{ll}\text { 9.8.2 Decentralisation of Management } & 302\end{array}$

$\begin{array}{lll}\text { 9.8.3 Consideration of other Ecosystems } & 303\end{array}$ 
9.8.4 Understanding and Managing Ecosystems in an Economic Way 304

9.8.5 Prioritising Conservation of Ecosystem Structure and Functioning 305

9.8.6 Managing Ecosystems Within the Limits of their Functioning 305

9.8.7 Undertaking Ecosystem Approach at the Appropriate Spatial and Temporal $\begin{array}{ll}\text { Scales } & 306\end{array}$

9.8.8 Setting of Long-Term Ecosystem Management 307

9.8.9 Recognising and Managing Change in the Ecosystem 307

9.8.10 Ensuring Appropriate Balance Between, and Integration of, Conservation and Use of Biological Diversity 308

9.8.11 Considering Relevant Information: Scientific, Indigenous, Local Knowledge, $\begin{array}{ll}\text { Innovations and Practices } & 308\end{array}$

9.8.12 Involvement and Participation of Relevant Sectors of the Society and Scientific Disciplines

9.9 Role of International Community and the Obligation to Seek for International Assistance and Cooperation

9.10 Ensuring and Monitoring of Minimum Environmental Flow

9.11 Relevant Stakeholders and Coordination of an Ecosystem Approach Application in Nigeria

9.12 Possible Challenges

9.13 Complementarity of a Human Rights-Based Approach and an Ecosystems Approach

9.14 Conclusions

CHAPTER TEN

10.1 Findings

10.2 Recommendations 336

$\begin{array}{lll}\text { 10.2.1 Government } & 337\end{array}$

10.2.2 Civil Society $\quad 342$

10.2.3 General Population 343

10.2.4 International and Donor Organisations $\quad 344$

TABLES AND FIGURES 
LIST OF TABLE AND FIGURES 


\section{List of Abbreviation}

$\begin{array}{ll}\text { ACHPR } & \text { African Charter on Human and Peoples Rights } \\ \text { BBM } & \text { Building Block Methodology } \\ \text { CBD } & \text { Convention on Biological Diversity } \\ \text { CEDAW } & \text { Convention on the Elimination of All Forms of Discrimination against } \\ & \text { Women } \\ \text { CP } & \text { Civil and Political } \\ \text { CRC } & \text { Convention on the Rights of the Child } \\ \text { CSOs } & \text { Civil Society Organisations } \\ \text { EFCC } & \text { Economic and Financial Crimes Commission } \\ \text { ESC } & \text { Economic, Social and Cultural } \\ \text { FEC } & \text { Federal Executive Council } \\ \text { FEPA } & \text { Federal Environmental Protection Agency } \\ \text { FME } & \text { Federal Ministry of Environment } \\ \text { FMWR } & \text { Federal Ministry of Water Resources } \\ \text { FOI } & \text { Freedom of Information Act } \\ \text { GDP } & \text { Gross Domestic Product } \\ \text { GNI } & \text { Gross National Income } \\ \text { HDI } & \text { Human Development Index } \\ \text { HRC } & \text { Human Rights Council } \\ \text { ICCPR } & \text { International Covenant on Civil and Political Rights } \\ \text { ICESCR } & \text { International Covenant on Economic, Social and Cultural Rights } \\ \text { ICJ } & \text { International Commission of Jurists } \\ \text { ICPC } & \text { Independent Corrupt Practices Commission } \\ \text { IPCC } & \text { Intergovernmental Panel on Climate Change } \\ \text { IUCN } & \text { International Union for the Conservation of Nature and Natural Resources } \\ \text { MDG } & \text { Millennium Development Goals } \\ \text { NBS } & \text { National Bureau of Statistics } \\ \text { NCE } & \text { National Council on Environment } \\ \text { NCWR } & \text { National Council on Water Resources } \\ \text { NESREA } & \text { National Environmental Standards and Regulations Enforcement Agency } \\ \text { NGO } & \text { Non-Governmental Organisation } \\ \text { NHRIs } & \text { National Human Rights Institutions } \\ \text { NWRI } & \text { National Water Resources Institute } \\ \text { PCC } & \text { Public Complaint Commission } \\ \text { RBDAs } & \text { River Basin Development Authorities } \\ \text { SDG } & \text { Sustainable Development Goals } \\ \text { UDHR } & \text { Universal Declaration of Human Rights } \\ \text { UN } & \text { United Nations } \\ & \end{array}$


Realising the Right to Water and Sanitation in Nigeria

UNEP United Nations Environmental Programme

WHO World Health Organisation 


\section{ACKNOWLEDGMenT}

When I finished my second LLM degree at the Vrije Universiteit Amsterdam, I was convinced that Netherlands is one of the best countries to further my studies and as such one of the happiest moments of my life was receiving acceptance from Prof. Fons Coomans of the Maastricht University to pursue a research and develop a thesis on one of the most important human rights issues currently receiving global attention. As such, my $\mathrm{PhD}$ trajectory will be incomplete without expressing my sincere appreciation to all those who have contributed to its success. I wish to express my special gratitude to Almighty Allah for enabling me to accomplish the task of writing this thesis and for giving me the opportunity to interact with the best brains in the field. I am deeply indebted to my respected supervisors, Prof. Fons Coomans and Dr. Gustavo Arosemena who have been extremely supportive in refining my ideas and shaping my focus to develop an acceptable $\mathrm{PhD}$ manuscript. I am deeply indebted to them for their invaluable support, patience and assistance. I wish to also express my sincere gratitude to Mrs. Licette Poll, Secretary to the Maastricht Graduate School of Law. Mrs. Licette has been extremely helpful at various times in my research with valuable information and support. I owe her an incalculable debt. I wish to also thank members of the Assessment Committee (Prof. Jure Vidmar, Prof. Cees Finterman, Prof. M.T Ladan, Prof. Koen De Feyter and Dr. Jennifer Sellin) for their useful comments toward finalising the contents of the manuscript and their availability for oral defence at short notice. A special appreciation to Biddle Law Library of the University of Pennsylvania, United States for granting me unrestricted access to the library and its resources in the course of writing this thesis.

My deepest appreciation goes to the members of my family for their prayers, support, patience and understanding over the years and particularly for the period of this research. My special gratitude goes to my brother, friend and colleague Dr. Tajudeen Sanni who was instrumental to my change of career from Government to academic environment for his support, advice and guidance. My special appreciation also goes to my head of department, my brother, friend and colleague Mr. Abdulkareem Azez for the invaluable support over the years and for being a trusted and reliable neighbour. I also wish to thank the Deans of Kampala International University and Islamic University in Uganda for the patience, support and understanding. To my trusted boss and mentor Hajiya Hadiza Sani Kangiwa a very big thank you and I pray there will be opportunity to continue to work with you. Your inspiration, support and understanding have been invaluable to me.

I wish to also thank my friends and brothers Mal. Isah Usman, Mustapha Shaba, Sada Danmusa, Abubakar Gajam, Nasiru Sadiq, Mahmud Ibrahim, Adamu Musa, Iliyasu Balarabe and Buhari Muhammad for their support and encouragement. Last but not the least, my special appreciation to my students at Kampala International University and Islamic University in Uganda for their support. 


\section{Chapter One}

\section{General Introduction ANd Research Context}

\subsection{Background to the Research Context}

Globally, about a billion people lack access to basic water supply and over two billion do Jot have access to adequate sanitation. ${ }^{1}$ The target of Sustainable Development (SDG) Goal 6 is to achieve universal and equitable access to water and sanitation for all by 2030 . Although the United Nations General Assembly (UNGA) in resolution 58/217 proclaimed the International Decade for Action, "Water for Life" 2005-2015, resolution 61/192 declared the International Year of Sanitation, 2008, as well as the follow-up resolution 65/153, which called upon all Member States to support the global effort to realise "Sustainable sanitation: the five-year-drive to 2015", not much progress has been recorded in several countries including Nigeria.

Water as a resource is a God-given gift to mankind, animals and environment. It "is an extraordinary resource with unique characteristics" ${ }^{2}$ and viewed from many contextual perspectives: it is a natural resource, economic resource, social resource, cultural resource, environmental resource, as well as public resource. Its availability, generation and prioritisation affect lives, socially, culturally and economically. The complex relationship between water and various aspects of life and environment makes its effective utilisation imperative. General Comment (GC) 15 viewed water as a limited natural resource and a public good. ${ }^{3}$

It will be a huge task to attempt to exhaust the importance of water or how water impact on lives and organisms. Importantly, it is essential in sustaining life: ${ }^{4}$ its availability or inability directly impacts on lives and environment; hence it is linked to right to life, health and adequate standard of living. These are core human rights essential for meaningful existence which international law guarantees, protects and promotes. It is from these rights that the right to water was derived or implied. Additionally, environment and surrounding ecosystems are directly or indirectly affected by availability or otherwise of water. Availability of water in the environment sustains the continued functioning of the ecosystem and its goods and services which are of fundamental importance to the survival of human beings.

Linking water with right to life, health, food, and adequate standard of living, GC 15 of the Committee on Economic, Social and Cultural Rights (Committee on ESR) stated that "an

\footnotetext{
${ }^{1}$ UNCESCR, General Comment No. 15: The Right to Water (Arts. 11 and 12 of the Covenant) (20 January, 2003) Para. 1

${ }^{2}$ Inga T. Winkler, The Human Right to Water: Significance, Legal Status and Implications for Water Allocation (Hart Pub. 2012) P. 2.

${ }^{3}$ UNCESCR, General Comment No. 15: The Right to Water (Arts. 11 and 12 of the Covenant) para. 1

4 UNHCHR, 'The Right to Water: Fact Sheet No. 35' (UNHCHR, August 2010) $<$ http://www.ohchr.org/Documents/Publications/FactSheet35en.pdf > accessed 8 January
} 
Realising the Right to Water and Sanitation in Nigeria

adequate amount of safe water is necessary to prevent death from dehydration, to reduce the risk of water-related disease and to provide for consumption, cooking, personal and domestic hygienic requirements. ${ }^{5}$ The Nigerian National Policy on Water Sanitation had already in 2004 noted that contaminated water is one of the sources of epidemic and responsible for many deaths in Nigeria. Ensuring right to life therefore requires the State to ensure adequate provision and access to the means of survival such as water. ${ }^{6}$ Article 1(2) of both International Covenant on Economic, Social and Cultural Rights (ICESCR) and International Covenant on Civil and Political Rights (ICCPR) provided that "in no case may a people be deprived of its own means of subsistence" ${ }^{7}$ which as a matter of necessity and for survival, include water. ${ }^{8}$ Water and sanitation are also linked to the right to dignity of human person recognised under civil and political rights (CP rights) treaty and many countries' constitution. Implicitly also, the right is linked to many Economic, Social and Cultural rights (ESC rights) such as the right to heath and the right to food.

Access to safe and clean water for personal and domestic purposes and good sanitation is a human right that is essential for the full enjoyment of life and all other human rights. The right has been recognised by the UNGA in resolution $64 / 292^{9}$ and several other international documents. ${ }^{10}$ It "entitles everyone, without discrimination, to water and sanitation that is sufficient, safe, acceptable, physically accessible and affordable for personal and domestic uses". 11

Recognition of an issue as a right in a legal document not only strengthens the power of the right-holder to lay a legal claim when and where it is compromised, but also imposes obligation on the duty-bearer to take steps to ensure the right is realised in a meaningful way. States and international organisations are required to provide financial resources, capacitybuilding and technology transfer to scale up efforts to the realisation of the right. Rationally, protecting the quality of drinking water supplies and resources requires ensuring access to adequate sanitation as a principal mechanism because lack of adequate sanitation is a primary cause of water contamination and diseases linked to water. ${ }^{12}$

The inextricable link between water and sanitation ensures that not only there are specific obligations in human rights law relating to access to basic sanitation but also that there are other obligations flowing from the recognition of ensuring quality water supply, because the protection of drinking water supplies largely depends on the quality of sanitation in a geographical area. In the guidelines for the realisation of the human right to water and sanitation, the Sub-Commission on the Promotion and Protection of Human Rights defined

\footnotetext{
${ }^{5}$ UNCESCR, General Comment No. 15: The Right to Water (Arts. 11 and 12 of the Covenant) para. 2.

${ }^{6}$ See UN Human Rights Committee, General Comment No. 6: Article 6 (Right to Life) (30 April, 1982) Para. 5

${ }^{7}$ See International Covenant on Economic, Social and Cultural Rights, Art. 1(2) and International Covenant on Civil and Political Rights, Art. 1(2)

${ }^{8}$ Amanda Cahill, 'The Human Right to Water - A Right of Unique Status': The Legal Status and Normative Content of the Right to Water' (2005) 9 The International Journal of Human Rights 389 P. 391.

${ }^{9}$ United Nations General Assembly Resolution (UNGA Res 64/292 (28 July 2010) UN Doc A/RES/64/292 on The Human Right to Water and Sanitation

${ }^{10}$ See for example International Covenant on Economic, Social and Cultural Rights, 1966, Convention on the Rights of the Child and Convention on the Elimination of all Forms of Discrimination Against Women,

${ }^{11}$ UNCESCR, General Comment No. 15: The Right to Water (Arts. 11 and 12 of the Covenant)

${ }^{12}$ Ibid. Para. 29.
} 


$$
\text { Chapter One }
$$

right to sanitation as "the right of everyone to have access to adequate and safe sanitation that is conducive to the protection of public health and the environment". ${ }^{13}$ Sanitation is linked to other recognised human rights including the right to health, protection of the environment and the right to adequate housing. Health and environment are undoubtedly connected, and the right to health cannot be fully realised in a constantly polluted environment.

An opportunity to address the effect of pollution on health arose in the African Commission on Human Rights case of The Social and Economic Rights Action Center and the Center for Economic and Social Rights v. Nigeria. ${ }^{14}$ The case involved a complaint against the Nigerian Military Government alleging that the operations of oil production in the Niger-Delta area by the Government and other stakeholders have caused environmental degradation and health problems to the Ogoni people due to the contamination of the environment and water sources. The contamination of water, air and soil has among others, caused serious short and long-term health impacts, including skin infections, gastrointestinal and respiratory ailments, and increased risk of cancers, and neurological and reproductive problems. ${ }^{15}$ The Commission finds no difficulty in declaring that there has been a violation of the right to health and healthy environment. This case demonstrated the interconnectivity of the right to health and the protection of the environment and by extension the inextricable link between water and sanitation.

Admittedly, the Bills of Right have not explicitly recognised or listed water and sanitation as 'self-standing human right' but there exist obligations under human rights law to ensure access to safe drinking water. ${ }^{16}$ It is therefore possible that, at the time of the drafting of the Bills of Rights, the availability of water was taken for granted ${ }^{17}$ and the need to incorporate it into the corpus of rights was thus overlooked. ${ }^{18}$

While the existence of the human right to water and sanitation is not strongly disputed, a very vital area connected to the realisation of the right deserves a very critical consideration: the relationship between the realisation of the right to water, the protection of the environment and preservation of biodiversity and ecosystems goods and services. Water is an environmental resource as much as it is a social and public resource. Hence, abstraction or depletion of water to discharge obligations under the right to water has impacts on the environment and surrounding ecosystem especially in context where the process is not sustainable. Hence, there exists a strong link and sometimes, tension between the realisation of human rights to water for personal and domestic uses and the protection of the environment

\footnotetext{
${ }^{13}$ See ECOSOC, Realization of the Right to Drinking Water and Sanitation: Report of the Special Rapporteur, El Hadji Guissé (11 July, 2005 )

${ }^{14}$ African Commission on Human and Peoples' Rights Comm. No. 155/96 (2001).

${ }^{15}$ African Commission on Human and Peoples' Rights Comm. No. 155/96 (2001)

${ }^{16}$ UNHCHR, 'The Right to Water: Fact Sheet No. 35'some of these obligations for example include Convention on the Elimination of All Forms of Discrimination against Women (CEDAW) Art. 14(2); International Labour Organization (ILO) Convention No. 161 concerning Occupational Health Services, Art. 5); Convention on the Rights of the Child (CRC), Arts. 24 and 27(3) and Convention on the Rights of Persons with Disabilities, Art. 28.

${ }^{17}$ Eibe Riedel, 'The Human Right to Water' in Klaus Dicke (ed), Weltinnenrecht: Liber Amicorum Jost Delbrück (Weltinnenrecht: Liber Amicorum Jost Delbrück, Duncker \& Humblot 2005) P. 589.

${ }^{18}$ Amanda Cahill, 'The Human Right to Water - A Right of Unique Status': The Legal Status and Normative Content of the Right to Water' P. 390.
} 
Realising the Right to Water and Sanitation in Nigeria

including water management, ${ }^{19}$ the preservation of natural resources and biodiversity. These issues are receiving increasing attention worldwide. ${ }^{20}$ In realising the right to water therefore attention must also be on the environment such that water abstraction for personal and domestic uses does not lead to depletion or extinction of ecosystems goods and services. Sound environmental management practices and standards are necessary and should control water generation and supply.

The connection between water and environment imposes an obligation on States to among others, assess the impacts of their actions in relation to water generation as may impinge upon water availability and natural-ecosystems watersheds, such as climate changes, desertification and increased soil salinity, deforestation and loss of biodiversity. ${ }^{21}$

The increase in demand of water for various uses, in some cases in a non-sustainable manner has been shown to negatively impact on surface water and aquifers, examples being Lake Chad, the Aral Sea, Colorado River and the Jordan River. ${ }^{22}$ In the above examples, the rivers presently "cover only a fraction of their original area or carry very little water in their downstream part." 23 This not only poses danger to the surrounding environment but also deprived the population the consequential benefits of their goods and services. Environmental needs and concerns are to be factored in projects aiming at meeting the requirements of the right to water. These environmental needs relate to river basin, lakes, aquifers, oceans and ecosystems surrounding watercourses. ${ }^{24}$ To this extent, mechanisms to ensure minimum environmental flow requirements of rivers, protection of national reserves and protected areas for environmental purposes, water trading and environment, water trusts and implementation of environmental impact assessment among others are necessary and are to be mainstreamed into relevant water legislations.

The necessity for environmental protection has been embodied in several international instruments and documents, ${ }^{25}$ States' constitution ${ }^{26}$ and legislations while domestic courts have actively been involved in the interpretation of certain human rights as they relate to environmental protection. ${ }^{27}$ Preservation of ecosystem goods and services is imperative for

\footnotetext{
${ }^{19}$ See Jonathan Verschuuren, 'The Right to Water as a Human Right or a Bird's Right: Does Cooperative Governance offer a Way Out of a Conflict of Interest and Legal Complexity?' in Philippe Cullet and others (eds), Water Governance in Motion: Towards Socially and Environmentally Sustainable Water Laws (Water Governance in Motion: Towards Socially and Environmentally Sustainable Water Laws, Cambridge University Press India Pvt. Ltd. 2010) Pp. 359-387.

${ }^{20}$ See Stefano Sensi, 'Human Rights and the Environment: A Practical Guide for Environmental Activists' (July, 2007) Policy Matters

${ }^{21}$ See the Convention on Biological Diversity, the Convention to Combat Desertification, the United Nations Framework Convention on Climate Change, and subsequent protocols

${ }^{22}$ Inga T. Winkler, The Human Right to Water: Significance, Legal Status and Implications for Water Allocation P. 23.

${ }^{23}$ Ibid.

${ }^{24}$ See John Scanlon, Angela Cassar and Noemi Nemes, Water as a Human Right? (IUCN Publications 2004) P. 27

${ }^{25}$ See World Health Organisation, Right to Water (World Health Organisation 2003) (see Jonathan Verschuuren, 'The Right to Water as a Human Right or a Bird's Right: Does Cooperative Governance offer a Way Out of a Conflict of Interest and Legal Complexity?'

${ }^{26}$ See for example Constitution of the Federal Republic of Nigeria S. 20.

${ }^{27}$ See Alan E. Boyle and Micheal R. Anderson, Human Rights Approaches to Environmental Protection (Oxford University Press 1996)
} 


\section{Chapter One}

safeguarding ESC rights such as the rights to health, and adequate standard of living, and by extension, access to quality water and basic sanitation. ${ }^{28}$

Globally, renewable resources including water are facing threat by several factors most notably population growth. Adequate management of water is therefore imperative to ensure optimal use for the present and future generations. There exist a profound connection between the ecosystem and the realisation of the human rights to water and sanitation as they both are fundamental ethical values and accordingly "( $\mathrm{t}$ )heir mutual and integrated pursuit embodies the highest aspirations for a healthy planet and sustainable, fulfilling and dignified human livelihoods." ${ }^{29}$ At the same time, there appears to be a significant tension and the need to balance human and ecosystems competing interests with respect to water. ${ }^{30}$ In the light of this, it is opined that any approach in the realisation of the human right to water and sanitation which excluded consideration of ecosystems can impact negatively, and undermine the realisation of the right. ${ }^{31}$

In the light of growing literature on poor water and sanitation coverage in Nigeria this research is aimed at evaluating the right to water and sanitation in the Nigerian context and how it can be realised through the adoption of alternative approaches which have the potentials of increasing access to the population, ensures sustainability and environmental protection. The research is conducted through the focal lenses of human rights-based and ecosystems approaches.

\subsection{Country Background and Water and Sanitation Coverage}

Nigeria derived its name from River Niger, one of the greatest rivers in Africa. ${ }^{32}$ The country is located in the Western part of Africa and shares borders with Niger Republic to the north, Chad and Cameroon to the east, Benin Republic to the west and Atlantic Ocean to the south. The present geographical structure of Nigeria came into being in 1914 when the northern and southern protectorates were amalgamated and colonised by the United Kingdom until $1^{\text {st }}$ October 1960 when it was granted independence. Nigeria has a total land area of 923, 768 square kilometres. It is the most populous African State. As at 2013 the population was estimated at $174,507,539,{ }^{33}$ growing at the rate of $2.54 \% .{ }^{34}$ Out of this figure, $49.6 \%$ of the population is estimated to be living in the urban areas and $50.4 \%$ in the rural areas. ${ }^{35}$ The National Population Commission of Nigeria estimated the figure as at 2016 to be 177, 071, 800 consisting of $89,510,808$ males and $87,560,992$ females. $^{36}$

\footnotetext{
28 See UN Water, UN DESA and UNICEF, The Post 2015 Water Thematic Consultation, 2013)

29 Jessica Campese and others (eds), Rights-Based Approaches: Exploring Issues and Opportunities for Conservation (Center for International Forestry Research 2009) P. xvii

${ }^{30}$ See Jonathan Verschuuren, 'The Right to Water as a Human Right or a Bird's Right: Does Cooperative Governance offer a Way Out of a Conflict of Interest and Legal Complexity?'

${ }^{31}$ John Scanlon, Angela Cassar and Noemi Nemes, Water as a Human Right? P. 27.

${ }^{32}$ I. Gabriel and B. Angwe, 'Legal and Institutional Framework for the Preservation and Protection of Water Resources in Nigeria' (1997) 3 Current Jos Law Journal P. 31.

33 Central Intelligence Agency, 'Nigeria' July, 2013) <https://www.cia.gov/library/publications/the-worldfactbook/geos/ni.html> accessed 25 August, 2013

34 Ibid. Officially however, the figure was put at 3.16 see Federal Republic of Nigeria, 'Nigeria' 2014) <www.nigeria.gov.ng > accessed 24 June, 2014

${ }^{35}$ Central Intelligence Agency, 'Nigeria'.

${ }^{36}$ These figures were received through email correspondence with the Commission on $5^{\text {th }}$ May 2016.
} 
Realising the Right to Water and Sanitation in Nigeria

Nigeria is a secular State $^{37}$ with population consisting of about $50 \%$ Muslims, $40 \%$ Christians and the rest either practice traditional religion or no religion at all. The State has over 300 ethnic groups and about 400 languages which make it one of the most culturally rich States in Africa. The three major ethnic groups which accounted for about $70 \%$ of the population are the Hausa-Fulani mainly in the North, The Yoruba in the West and the Igbo in the East. ${ }^{38}$

Nigeria is a Federal Republic comprising of 36 States, the Federal Capital Territory and a total of 774 local governments. In order to address socio-economic and political imbalances, Nigeria is further divided into six geopolitical zones. Currently, Nigeria operates a democratic system of Government after a period of long military administration. Its economy is said to be one of the fastest growing economies in the world and was recently acclaimed the first in the African continent. Despite these however, about half of the population lives below poverty line.

In many places around the world including Nigeria, realisation of the right to water and sanitation for everyone is a huge task. Although globally noticeable progress is being made, the Nigerian situation is worrisome and calls for concerted efforts. The figures showing water and sanitation coverage in Nigeria have not been consistent but have clearly demonstrate the slow or lack of progress in the realisation of the right. Admittedly, countries and regions are unique in their circumstances and different factors account for lack of/or slow progress in the realisation of adequate water and sanitation. Factors contributing to the problem in Nigeria can be traced to legal and policy, political, economic, social, geographical, natural/environmental, institutional and societal/individual factors. It has been acknowledged that "human rights are more than a collection of formal norms; they are dynamic political, social, economic, juridical, as well as moral, cultural and philosophical conditions which define the intrinsic value of man and his inherent dignity." ${ }^{39}$ It is equally under these circumstances that human rights deprivations occur.

Admittedly, promotion and protection of human rights cannot be done in isolation of country's economic, social, political and possibly geographical conditions. It is through understanding these conditions that human rights progress or lack of it can be plausibly explained, notwithstanding that human rights are universal and indivisible. States are unique in their individual circumstances and realisation of human rights to a large extent is circumscribed by these conditions which serve as key considerations in the measurement of human rights progress, and in any attempt at deconstructing the prevailing factors for lack of progress. It is through these conditions, struggles for human rights are fought. ${ }^{40}$

Realisation of ESC rights largely depends upon the political will and commitment of governments at various levels. This is usually demonstrated by governments' political and socio-economic policies, projects and programmes and whether or not these have been sanctioned by appropriate legal or policy frameworks. The functioning and success of

\footnotetext{
${ }^{37}$ S. 10 of the Constitution states "The Government of the Federation or of a State shall not adopt any religion as State Religion"

${ }^{38}$ For more about Nigeria see the official Country webpage www.nigeria.gov.ng

${ }^{39}$ Moses Moskowitz, International Concern with Human Rights (Oceana Publications Inc. 1974) P. 3.

${ }^{40}$ Todd Landman, Studying Human Rights (Routledge 2006) P. 1.
} 
agencies and institutions saddled with responsibility of promoting the progressive realisation of ESC rights are to be measured in the light of government's political will and commitments and in the enabling environment under which established institutions are to operate. The success of institutions largely is circumscribed by the resources at their disposal with which their capacity can be improved periodically and their projects can be implemented. Similarly, promotion and protection of human rights take place in complex social settings where multiple factors, organisations and institutions interact. A logical analysis of these interactions cannot be ignored as this holds the key to understanding how these have influence human rights progress in Nigerian contextual settings.

Nigeria is a party to several international instruments relevant to water and sanitation. In pursuance to these and specifically General Comment 15, Nigeria has adopted national policies on water and sanitation targeted at addressing its perennial water and sanitation problems. Over the years Nigeria has pursued several programmes, either independently or in partnership with international organisations, aimed at increasing access to water and basic sanitation to communities but not much progress has been recorded. It is against the above background that this chapter takes a contextual analysis of the political, economic, social, and environmental conditions of Nigeria. A review of these issues demonstrated that a myriad of problems is associated with lack of progress in human rights protection and promotion in general and water and sanitation in particular.

From the legal and policy frameworks perspective, the issues include lack of adequate legal framework at the domestic level which imposes obligations to work towards the realisation of the right to water and sanitation. There is problem relating to incoherent and sometimes inconsistent government policies. From the political perspective, issues can be traced to instability, lack of political commitment by government at various levels, cost of governance and politicisation of development. From the economic perspective, issues include inadequate budgetary provisions over the years, significant disparity of revenue among the States, corruption, untimely and limited release of funds to agencies and lack of transparency and accountability. These perpetuates culture of projects abandonment and impacts on the capacity of the administrative agencies to discharge their duties. Social issues include uncontrolled population growth, rural-urban migration, poverty, widening gap of social classes, social isolation, exclusion and marginalisation, insecurity, illiteracy and attitudinal issues associated with the population.

Other factors hampering progress in water and sanitation are geographical such as poor road network and inaccessibility of certain locations which contribute to isolation, marginalisation and exclusion of service delivery. Natural and environmental factors include climate change, and depletion of water resources and ecosystems. Institutional issues range from weak institutional structures, lack of capacity, maladministration, lack of coordination mechanism between relevant stakeholders, lack of adequate data for planning, and infrastructural decay. These issues would be explored in detail. 
Realising the Right to Water and Sanitation in Nigeria

\subsubsection{Political Context}

When Nigeria became an independent State in 1960, it operated parliamentary system of government. The first Republic was poised to pursue prosperous socio-economic policies, projects and programmes designed to transform Nigeria into a giant country within the African continent. This aspiration was however, curtailed by the first extra-constitutional change of government in 1966.

The bloody military intervention resulted to a change of government and the death of many prominent figures in Northern and Western parts including the Prime Minister and the Premiers of the North and Western regions. This marked a turning point in Nigeria's history. The continued stay/series of military interventions in the following decades controlled the policies and directions of the country, its relationship with citizens in the context of human rights and socio-economic developments and its relations with international community. The combined effects of these culminated to the present economic and social conditions characterised by poverty, backwardness, deprivations, isolation, human insecurity and political instability although limited growth and development have been noted in certain areas.

Following the first coup d'état, Nigeria was plunged into more than two years' civil war from 1967 - 1970 with unimaginable consequences. From 1966 until 1979, Nigeria was ruled by the Military with coup d'états in between. In 1979 Nigeria returned to democratic governance for four years. The country was ruled by the military until 1999 with brief civilian interim government between 26 August to 17 November $1993 .{ }^{41}$ For nearly 30 years, Nigeria was ruled by the Military. From 1960 to 2017, Nigeria has had six elected head of States, one appointed, one military successor and 6 coups d'état.

Currently, Nigeria is operating presidential system of democratic governance and a semiFederal system. In order to address socio-political and economic imbalances due to the unique nature of the Country, six geopolitical zones have been recognised as a matter of practice. ${ }^{42}$ The common understanding is that power is to be divided and rotate between the geopolitical zones.

The intermittent military administrations and their attendant consequences have had tremendous impact on Nigeria's political, economic and social environments and contributed to the present human rights situation in the country which by extension includes the slow

\footnotetext{
${ }^{41}$ From 1960 to date Nigeria had been ruled by the following systems of government: From 1960-1966 civilian parliamentary system of government led by the Prime Minister Tafawa Balewa; Jan-July 1966 military regime led by Aguiyi Ironsi; 1966-1975 military regime led by Yakubu Gowon; 1975-1976 military regime led by Murtala Muhammed; 1976-1978 military regime led by Olusegun Obasanjo; 1979-1983 presidential system led by Shehu Shagari; 1984-1985 military regime led by Muhammadu Buhari; 1985-1993 military regime led by Ibrahim B. Babangida; Aug-Nov interim regime led by Ernest Shonekan; 1993-1998 military regime led by Sani Abacha; 1998-1999 military regime led by Abdussalam Abubakar; 1999-2007; 2007-2010 presidential system led by Ummaru Musa Yar'adua; from 2010-2015 presidential system led by Goodluck Jonathan and from 2015 to date President Muhammadu Buhari. See BBC News, 'Nigeria Profile - Timeline' (BBC, 13 July 2017) <http://www.bbc.com/news/world-africa-13951696> accessed 16 August 2017

${ }^{42}$ These zones are North-West: Jigawa, Kaduna, Kano, Katsina, Kebbi, Sokoto and Zamfara States; North-Central: Benue, Kogi, Kwara, Nasarawa, and Plateau States; North-East: Adamawa, Bauchi, Borno, Gombe, Taraba and Yobe States, South-West: Ekiti, Lagos, Ogun, Ondo, Osun and Oyo States; South-East: Abia, Anmbra, Ebonyi, Enugu and Imo States; South-South: Akwa Ibom, Bayelsa, Cross River, Delta, Edo and Rivers States.
} 


\section{Chapter One}

progress in the realisation of access to safe and adequate water for personal and domestic uses and basic sanitation.

The military lack of democratic structures and institutions, limited consultation and almost lack of citizen's participations on legal and policy issues, intolerance to constructive criticisms and in some cases, insensitivity have and continued to affect many aspects of life of Nigerians. A bulk of the Nigerian laws including those relating to water resources and environment was either adopted during the colonial era or military administration in the form of decrees and edicts. In many instances these laws are inadequate, inconsistent and fall short of international standards and best practices.

Currently, Nigeria is operating a new constitution adopted in 1999 which largely followed the 1979 Constitution with Presidential System of Government as the underlying basis. The System recognised a multi-party system and maximum of two-tenures of four years each for the President and the State Governors. There is however, no limit for the legislatures at the Federal and State levels. Similarly, the Constitution recognises three levels of governments: Federal, State and Local Governments. This arrangement makes multiple sources of law applicable throughout the Federation. ${ }^{43}$

\subsubsection{Legal Context}

Before colonisation, distinct and separate legal systems applied in the various regions of the present-day Nigeria. Pre-colonial 'Nigeria' consisted of caliphates, kingdoms, chiefdoms, empires, city-states and village republics. ${ }^{44}$ In the North, for example, which is predominantly Muslim, Islamic Legal System regulates civil and criminal cases whereas different sets of customary law were applied in the South. British Colonial Administration annexed Lagos in 1861 and formal administration began in 1863. In 1914 the northern and southern protectorates were amalgamated. Colonial administration ended with attainment of independence on the $1^{\text {st }}$ day of October 1960.

Like many legal systems and civilisations around the world, colonisation impacted on the Nigerian Legal System. Typical of colonisation's nature of the $19^{\text {th }}$ century Europe, combined with the glaring and complex multi-ethnic, multi-linguistic, multi-religious and multi-cultural compositions, Nigeria was forced to receive Common Law as a unifying legal system on major issues of concern to the colonial administrators. However, the adoption of this system did not; even during colonisation period precluded the continuous applicability of other systems albeit in limited scope. The Charter of the Royal Niger Company (a company which played significant role during colonisation and enabled British to establish control in Nigeria against other competitors notably Germany) recognised that laws and customs of the people where it operates must be respected and upheld in the administration of justice. ${ }^{45}$ To

\footnotetext{
${ }^{43}$ For the history of Nigeria see the following: Toyin Falola and Matthew M. Heaton, A History of Nigeria (Cambridge University Press 2008); Toyin Falola (ed), Nigerian History, Politics and Affairs: The Collected Essays of Adiele Afigbo (Africa World Press, Inc. 2005)

${ }^{44}$ Bethel Chuks Uweru, 'Repugnancy Doctrine and Customary Law in Nigeria: A Positive Aspect of British Colonialism' (2008) 2 African Research Review P. 291

${ }^{45}$ C. W. Newbury, British Policy Towards West Africa: Selected Documents (1875 - 1914) (Hutchinson \& Co. Ltd 1960) P. 254.
} 
Realising the Right to Water and Sanitation in Nigeria

limit the scope of courts' observance and applicability of other legal systems particularly customary law (which was defined to include Islamic Law) ${ }^{46}$ however, the British introduced the so-called repugnancy test. ${ }^{47}$

Repugnancy test requires all customary laws to conform to natural justice, equity and good conscience and the existing written laws in the Country before such customs can be applied. ${ }^{48}$ The test was first observed in Eshugbayi Eleko v. Government of Nigeria ${ }^{49}$ wherein Lord Atkin observed that " $[\mathrm{t}]$ he court cannot itself transform a barbarous custom into a milder one. If it stands in its barbarous character it must be rejected as repugnant to natural justice, equity and good conscience. ${ }^{50}$ It is worth noting that a number of Nigerian and by extension African customs were declared repugnant. In Nigeria, an interesting example can be seen from the cases of Mariama v. Sadiku Ejo ${ }^{51}$ and Okonkwo v. Okagbue \& 2 Ors. ${ }^{52}$ In Mariama's case a custom which holds that a child born within 10 months after divorce belonged to the divorced husband was held to be repugnant to natural justice, equity and good conscience. In Okonkwo's, the issue centred on whether the defendants (sisters of the plaintiff's late father) could, after the father's death; marry a wife for the plaintiff's late father. The defendants asserted their right to do so under their custom and the Supreme Court declares the custom repugnant. There was no reported case on customs declared inconsistent with written law. ${ }^{53}$ Today all the 36 States including the Federal Capital Territory have equivalent provision on repugnancy test. ${ }^{54}$

Regarding the sources of Nigeria's Legal System, as a former British colony, Common Law was administered conjunctively with local legislations, Islamic law and over 300 customary laws. This made the legal system pluralistic. However, it is worth noting that repugnancy test eliminated several local customs. ${ }^{55}$ This system continues after independence. Interestingly, despite the applicability of Islamic Law and Customary Law in some part of the Country, Nigeria is regarded as a secular State. ${ }^{56}$ Notwithstanding this claim,

\footnotetext{
${ }^{46}$ The term Customary Law was used to connote a blanket description covering many different systems (S.H. Makeri, 'Jurisdictional Issues in the Application of Customary Law in Nigeria' (All Nigerian Judges Conference: The Judiciary and the Challenges of Nation Building) P. 6

${ }^{47}$ Proclamation No. 6 of 1900 . This doctrine was said to have originated in the Medieval period and linked to the evolution of English Equity and introduced in Nigeria towards the end of the $19^{\text {th }}$ Century (Bethel Chuks Uweru, 'Repugnancy Doctrine and Customary Law in Nigeria: A Positive Aspect of British Colonialism' P.286.

${ }^{48}$ This is now encapsulated in the proviso to section 14 of the Evidence Act, Cap. 112 Laws of the Federation of Nigeria 1990 and reflected in various State's Customary Courts Law

49 (1931) A.C 622

${ }^{50}$ Ibid.

51 (1961) NRNLR 81

52 (1994) 12 SCNJ 89

${ }^{53}$ Bethel Chuks Uweru, 'Repugnancy Doctrine and Customary Law in Nigeria: A Positive Aspect of British Colonialism'p.294)

${ }^{54}$ For example, Section 15 (1) (a) of the Anambra State Customary Courts Law, 1984; section 24(a) of Kaduna State Customary Courts Law, No. 9 of 2001

${ }^{55}$ Some have argued that because a large number of these customs were particularly harsh and further complicated by superstitions which rendered their proof and judicial notice difficult, the repugnancy serves to eliminate the harshness and superstitions by bringing them to "universal standards of morality". According to these authors therefore the repugnancy test serves a positive test for the development of customary law (Bethel Chuks Uweru, 'Repugnancy Doctrine and Customary Law in Nigeria: A Positive Aspect of British Colonialism'p. 293); T. O. Elias, The Nature of African Customary Law (Manchester University Press 1956)

${ }^{56}$ The Constitution of the Federal Republic of Nigeria, 1999 prohibited the adoption of any religion as a State religion under section 10 .
} 


\section{Chapter One}

however, religion and to some extent culture, continues to play significant if not dominant role in political and socio-economic lives of ordinary Nigerians and have tremendous impact on Nigerians' willingness to assert human rights claims.

Currently, the following are the sources of Nigerian Legal System: The Constitution, Legislations, Received English Law, Customary Law, Islamic Law, and Judicial Precedents, ${ }^{57}$ and treaties.

\section{Constitution}

From 1914 to date, Nigeria has had nine constitutions. ${ }^{58}$ The current constitution comes into effect on the $29^{\text {th }}$ of May 1999. It is the supreme law of the land and regulates the functioning of organs and the tiers of government such that no State within the Federal structure has the power to enact or adopt its separate constitution. It is binding on all authorities and persons ${ }^{59}$ and from which all laws must derive their validity. If any law is inconsistent with the Constitution, it is to the extent of its inconsistency null and void. ${ }^{60}$ There are currently, 36 States under the Constitution and the Constitution provided for the three tiers of Government: The Federal Government (headed by the President), State Government (headed by the State Governor) and Local Government councils, consisting of 774 local governments (each headed by a Chairman).

\section{Legislations}

The 1999 Constitution had distributed the legislative power among the Federal and States Houses of Assembly. The power to legislate for the Federal Government is vested in the National Assembly which consists of the Senate and House of Representatives ${ }^{61}$ while the power to legislate for a State is vested in that State House of Assembly. ${ }^{62}$ Similarly, the Constitution had listed matters which the Federal Government can legislate upon (Exclusive Legislative List), ${ }^{63}$ matters which a State can legislate upon (matters not included in Exclusive Legislative List i.e. Residual List) ${ }^{64}$ and other matters which the Federal and States have concurrent legislative powers (Concurrent Legislative List). ${ }^{65}$ Currently, the laws passed by the National Assembly including their subsidiary legislations in force as at $31^{\text {st }}$ December, 2002 are contained in the 16 volumes of the Laws of Federation of Nigeria 2004 while subsequent legislations from January 2003 are contained in the Annual Volumes of the Laws of the Federal Republic of Nigeria. Previous decrees passed by military administrations were converted as Acts of the National Assembly.

\footnotetext{
${ }^{57}$ A.O. Obilade, Nigerian Legal System (Sweet \& Maxwell 1979)

58 These constitutions are: The Nigerian Constitution 1914, The Nigerian Constitution 1922, The Nigerian (Richard's) Constitution of 1946, The Nigerian (Macpherson) Constitution of 1951, The Nigerian (Lyttelton) Constitution of 1954, Independence Constitution 1960, The Nigerian Constitution 1963, The Constitution of Nigeria 1979 and The Constitution of Nigeria 1999.

${ }^{59}$ Constitution of the Federal Republic of Nigeria S. 1(1)

${ }^{60}$ Ibid. S. 1(3)

${ }^{61}$ Ibid. S. 4(1)

${ }^{62}$ Ibid. S. 4(6)

${ }^{63}$ Ibid. S. 4(2) and Part 1, Second Schedule

${ }^{64}$ Ibid. S. 4(7)

${ }^{65}$ Ibid. Part II of the Second Schedule
} 
Realising the Right to Water and Sanitation in Nigeria

On matters within the residual list, each State and the Federal Capital Territory has their own laws. Military edicts were similarly converted as Laws of the States House of Assembly. Local Governments councils operate within the framework of States legislative power which provides for the establishment, structure, composition, finance, and function of the local governments. This current structure which subordinated the local governments has been opined to pose a challenging feature of the federal structure. ${ }^{66}$ Legislations are regarded as the most important sources of law after the Constitution.

\section{Received English Law}

This consists of Common Law of England, doctrines of Equity, Statutes of General Application in force in England on the $1^{\text {st }}$ day of January 1900, statutes and subsidiary legislations on specified matters including the yet to be repealed Statutes made under English law before $1^{\text {st }}$ day of October 1960 and extending to Nigeria. Many of these laws continue to apply in Nigeria.

\section{Islamic Law}

Majority of people in Northern Nigeria are Muslims and Islamic Law provisions (civil and criminal matters) were applicable during the pre-colonial period. As a system of law, the sources of Islamic Law are written and derived from the Qur'an, the authentic traditions of the Prophet and the consensus (ijma) of the jurists (ulama). After the conquest of the North by the British, application of Islamic Law was restricted to matters of personal status only (marriage, divorce, inheritance etc.) This position continued even after independence until the year 2000 when several Northern States restored the application of Islamic (Sharia) Criminal Justice System. With the adoption of Sharia Penal Code in many Northern States, Sharia courts were established. Islamic Law has tremendous influence on the lives of its adherents. In many areas in the North, Islamic Law supplanted the pre-existing customary laws which hitherto were operating.

\section{Customary Law}

Judicially, customary law has been held to reflect the practices accepted as binding or obligatory on the community it regulates. ${ }^{67}$ According to Obaseki, JSC (as he then was) in the case of Oyewumi v. Ogunsesan ${ }^{68}$ customary law was defined as:

The organic or living law of the indigenous people of Nigeria regulating their lives and transactions. It is organic in that it is not static. It is regulatory in that it controls the lives and transactions of the community subject to it. It is said that custom is a mirror of the culture of the people. I would say that the customary law goes further and imports justice to the lives of all those subject to it.

As a mirror of accepted usages, customary law is unwritten and its "main sources are the memory of elders and leaders of the community" who "usually have special knowledge of the customary laws and the traditions in their communities" which are "transmitted from

\footnotetext{
66 Enyinna Nwauche, 'Nigeria: Introductory Notes' (University of Pretoria, <https://web.up.ac.za/sitefiles/file/47/15338/Nigeria.pdf> accessed 13 May, 2014

${ }^{67}$ Eshugbayi Eleko v. Government of Nigeria (1931) A.C. 622 at 673

${ }^{68}$ (1990) NWLR 182
} 


\section{Chapter One}

generation to generation" ${ }^{99}$ and changes from one community to another such that even in one community a myriad of customs could exist. ${ }^{70}$ Some differences in customs could be traced to history, language, proximity, economy or social structure. ${ }^{71}$ The range of diversity among numerous customs has been a "major obstacle to uniformity of customary law systems in Nigeria". ${ }^{72}$ Persons who are presumed to have knowledge of customary laws are appointed as judges of customary courts. They have been empowered to settle disputes using their personal knowledge of the customs without prejudice to the party claiming the existence or otherwise of a custom to prove it. ${ }^{73}$ Well established customs may also be judicially noticed. ${ }^{74}$

\section{Judicial Precedent}

As a legacy of colonial administration and Common Law System, judicial precedent is also a source of Nigerian law. The Nigerian Supreme Court is the apex court. Its decisions bind all other courts while the Court is not bound by its decision. Below Supreme Court is the Court of Appeal. Decisions of the Courts bind all other courts below. Below the Court of Appeal is the High Court (consisting of the Federal High Court, High Court of the Federal Capital Territory and High Courts of States); National Industrial Court, Sharia Court of Appeal, (Federal Capital Territory and State); Customary Court of Appeal (Federal Capital Territory and State). The next in the hierarchy are the Magistrate Courts/District Courts then followed by Customary Courts/Area Courts/Sharia Courts.

\section{Treaties}

The stark distinction between the theory of monism and dualism and their relationship with domestic human rights are of fundamental importance in the implementation and enforcement of treaties. In this context, monist States suffer little bureaucratic procedures concerning accepted international legal norms or obligations embodied in a treaty signed or ratified by such States. By contrast, in dualist States like Nigeria, a treaty though signed and ratified will fail to have the force of law within the domestic or municipal court until domesticated as national legislation. ${ }^{75}$ In the light of this, the driving force and enforcement of the rights contained in treaties therefore largely depends on the level of their recognition within the legislative documents of a dualist State.

\footnotetext{
${ }^{69}$ Muhammed Tawfiq Ladan, 'Review of the Regulatory and Policy Frameworks of the Nigerian Water Sector and International Legal Response for Sustainable Management and Protection of Water Resources' 7 January, 2013) <https://ssrn.com/abstract=2358884> accessed 26 April, 2014 P. 12

${ }^{70}$ Relevant texts on this issue are A.O. Obilade, Nigerian Legal System p.83; M. A. Ajomo and O. Adewale (eds), Environmental Law and Sustainable Development in Nigeria (Nigerian Institute of Advanced Legal Studies 1994) P. 157.

${ }^{71}$ Paul Kuruk, 'Customary Water Laws and Practices: Nigeria' (Food and Agriculture Organization, 2004) <http://www.fao.org/legal/advserv/FAOIUCNcs/Nigeria.pdf> accessed 27 January, 2017 P. 2

${ }^{72}$ Bethel Chuks Uweru, 'Repugnancy Doctrine and Customary Law in Nigeria: A Positive Aspect of British Colonialism' P. 293.

${ }^{73}$ Paul Kuruk, 'Customary Water Laws and Practices: Nigeria' P. 7.

${ }^{74}$ Ibid.

${ }^{75}$ S. 12(1) of the Constitution provides "No treaty between the Federation and any other country shall have the force of law except to the extent to which any such treaty has been enacted into law by the National Assembly."
} 
Realising the Right to Water and Sanitation in Nigeria

In Nigeria, the National Assembly has the exclusive power to legislate on matters concerning treaties signed by Nigeria. ${ }^{76}$ Where such treaties have been domesticated, the power to enforce them is vested in the Executive. In pursuance to this, the Executive sometimes adopt policy measures on the programmes and projects it intends to pursue towards the actualisation or realisation of the objectives of the legislation. In some cases, where domestication was not pursued or where the procedure is complicated or lengthy, some States including Nigeria adopt policies on the measures they will pursue to enable them to meet their national and international obligations. Treaties are a source of law in Nigeria only to the extent of their domestication as national legislation.

\subsubsection{Economic Context}

Nigeria is a middle income, emerging market and operating a mixed economy. There is no doubt that the Nigerian economy is one of the fastest growing on the African continent. Before April 2014 Nigeria was known to have the second largest economy in Africa after South Africa. However, in April 2014, Nigeria 'rebases' it GDP by including other areas of the economy which were not previously included and became first on the Continent. In 2018 the Nigeria's Gross Domestic Product (GDP) ${ }^{77}$ was estimated at $\$ 443.932$ billion with GDP per capita at $\$ 2,289.788^{78}$ At the end of first quarter of 2018, Nigeria's National Bureau of Statistics stated that the Nominal GDP and Real GDP stood at N28.464 trillion and N16.106 trillion respectively. ${ }^{79}$ The Nigeria's economy is projected to be growing at $2.1 \%$ in $2018 .{ }^{80}$

In addition to the huge oil and gas reserves, Nigeria is endowed with coal, tin, limestone, gold, columbite, iron ore and quartz sand. Additionally, the country has a fertile agricultural land with agriculture accounting for $43.71 \%$ of the GDP by the end of fourth quarter of $2017 .{ }^{81}$ With its abundant natural resources, and huge oil revenue which accounts for about $95 \%$ of export revenues and $70 \%$ of revenue to the government, ${ }^{82}$ it was estimated that $62.8 \%$ of the population lives below poverty line. ${ }^{83}$ The rising GDP clearly does not necessarily mean economic development although it is an important contributing factor. ${ }^{84}$ It is also true that that the growth in GDP does not always reduce poverty and unemployment but a booming economy is expected to provide jobs and reduce societal poverty and inequality.

\footnotetext{
${ }^{76}$ Ibid.

${ }^{77}$ GDP is the market value of all officially recognized final goods and services produced within a country in a given period. See Yemi Kale, 'Measuring Better: Rebasing/Re-benchmarking of Nigeria's Gross Domestic Product ' (Presentation of the Results of Nigeria's GDP Rebasing/Re-benchmarking Exercise ) Slide 15.

78 International Monetary Fund, 'World Economic Outlook Database' October 2016) $<$ https://www.imf.org/external/pubs/ft/weo/2016/02/weodata/weorept.aspx?pr.x=68\&pr.y=9\&sy=2016\&ey=2021 $\&$ scsm $=1 \&$ ssd=1\&sort=country \&ds=.\&br=1\&c=694\&s=NGDP_R\%2CNGDP_RPCH\%2CNGDPD $\% 2 C N G D P P$ C\%2CNGDPDPC\&grp=0\&a=> accessed 22 May 2018

${ }^{79}$ National Bureau of Statistics, Nigerian Gross Domestic Product Report Q1 2018, May, 2018) P. 6

${ }^{80}$ International Monetary Fund, World Economic Outlook Update, January 2018: Brighter Prospects, Optimistic Markets, Challenges Ahead, 22 January 2018)

${ }^{81}$ National Bureau of Statistics, 'Key Statistics' 2018) <http://www.nigerianstat.gov.ng/> accessed 22 May 2018

${ }^{82}$ Ministry of Budget and National Planning, 'Nigeria's Oil Sector Contribution to GDP Lowest in OPEC - Blueprint' 2017) <http://www.nationalplanning.gov.ng/index.php/news-media/news/news-summary/333-nigeria-s-oil-sectorcontribution-to-gdp-lowest-in-opec-blueprint> accessed 19 August 2017

${ }^{83}$ UNDP, 'About Nigeria' 2017) <http://www.ng.undp.org/content/nigeria/en/home/countryinfo/> accessed 19 August 2017

${ }^{84}$ Yemi Kale, 'Measuring Better: Rebasing/Re-benchmarking of Nigeria's Gross Domestic Product ' Slide 22.
} 


\section{Chapter One}

While figures on GDP have increased the economic situation has not significantly helped the water and sanitation sector. Several economic factors have over the years accounted for the poor situation. Economically associated factors impacting on poverty, unemployment, inequality and social isolation among the citizenry include corruption, inadequate budgetary provisions, and untimely and limited release of appropriations. These factors contribute to the present water and sanitation coverage.

\subsubsection{Social Context}

In 2016, Nigeria's Human Development Index (HDI) ${ }^{85}$ is 0.527 , lying in the low human development category and ranked $152^{\text {nd }}$ out of 188 countries and territories on UNDP Human Development Index with average life expectancy of 53.1 years. ${ }^{86}$ With sub-Saharan Africa (as a region) HDI index standing at 0.523 (regional average) and 0.497 average for countries in the low human development group respectively, Nigeria is above these averages. ${ }^{87}$ The Human Development Report indicated that "[b]etween 1990 and 2015, Nigeria's life expectancy at birth increased by 7.0 years, mean years of schooling increased by 0.8 years and expected years of schooling increased by 3.3 years.

Between 1990 and 2015, Nigeria's Gross National Income (GNI) per capita increased by about $98.4 \%{ }^{88}$ On the basis of the 2013 data collected according to the Report, $50.9 \%$ of Nigeria's population lived in multidimensional poverty with additional $18.4 \%$ near multidimensional poverty. ${ }^{89}$ It further stresses that the "breadth of deprivation (intensity) in Nigeria, which is the average deprivation score experienced by people in multidimensional poverty, is 54.8 percent." 90 The official figures put the country's birth rate at 43.26 per 1000 people, death rate at 12.01 per 1000 people while life expectancy was put at 55.98 years. ${ }^{91}$ Diarrhoea resulting from poor sanitary and hygiene habits as well as the consumption of water of poor quality ranked second main cause of infant mortality after malaria. ${ }^{92}$ As at 2004 , it was estimated that 150,000 to 200,000 diarrhoea-related deaths occur annually among children below the age of five years. ${ }^{93}$ Diarrhoea's prevalence is higher in the rural compared to urban areas and lower in the North compared to the South. ${ }^{94}$

\footnotetext{
85 "The HDI is a summary measure for assessing long-term progress in three basic dimensions of human development: a long and healthy life, access to knowledge and a decent standard of living." See UNDP, 'The Rise of the South: Human Progress in a Diverse World' 2013) <http://hdr.undp.org/en/2013-report> accessed 19 October, 2013

86 UNDP, 'Human Development Report 2016: Nigeria' 2016)

<http://hdr.undp.org/sites/all/themes/hdr_theme/country-notes/NGA.pdf> accessed 22 May 2018

${ }^{87}$ Ibid.

${ }^{88}$ Ibid.

${ }^{89}$ Ibid.

${ }^{90}$ Ibid.

${ }^{91}$ Federal Republic of Nigeria www.nigeria.gov.ng accessed 24 June 2014.

${ }^{92}$ Department of Water Supply and Quality Control, National Rural Water Supply and Sanitation Programme: A Strategic Framework (Federal Ministry of Water Resources 2004) P. 5; See also Federal Republic of Nigeria, National Environmental Sanitation Policy (2005) para.1.1.3

${ }^{93}$ Department of Water Supply and Quality Control, National Rural Water Supply and Sanitation Programme: A Strategic Framework P. 5

${ }^{94}$ Ibid. P. 5
} 
Realising the Right to Water and Sanitation in Nigeria

Nigeria's unemployment and crime rates, incidences of sectarian violence around the country, communicable diseases including HIV-AIDS, cholera, environmental and water diseases are on the increase. A large number of the population mostly in rural areas cannot read and write. There is no social security system for the population in place although several programmes have been pursued in the past designed to improve the social and economic condition of the people with limited success. Clearly, achieving human emancipation, economic and social security under this atmosphere would be challenging.

Nigeria may be regarded as one of the most religious States in the world. According to Gallup Worldview Poll, 96\% of Nigerians have considered religion as important in their daily lives. ${ }^{95}$ During elections, political leaders often appeal to religious leaders for support and religious leaders command significant respect among followership. The teachings of religions impact significantly on the attitudes of most Nigerians towards governance issues. Religions preach peace, patience, perseverance and respect to leaders. Religion provides succour, peace and tranquillity to mind and many Nigerians find peace in religion especially during periods of difficulties. Some of the current social issues impacting on development are population explosion, rural-urban migration, sanitation awareness and practices, discrimination, marginalisation, isolation, poverty, and low-level literacy. These issues are impediments to the realisation of the right to water and sanitation.

\subsubsection{Cultural Context}

Nigeria is home to many and diverse cultural groups. With over 250 ethnic groups and 400 languages and dialects, ${ }^{96}$ Nigeria is one of the most diverse States in the world. Generally, there are two major religions: Islam and Christianity with small number of people following traditional African Religion. In the context of water and sanitation certain cultural and religious beliefs exist which to an extent impact on the realisation of safe water for personal and domestic purposes. Example include drinking water used to wash dead bodies which is believed to prevent pregnancy ${ }^{97}$ and defecating in the open mostly in farms as a source of manure for the crops. These cultural practices impact on water quality and basic sanitation.

\subsubsection{Environmental Context}

There are agencies saddled with the responsibility of environmental protection in Nigeria, but this was a recent development. During the colonial administration, environmental protection was not given priority and the focus was the economic interests of the colonial administration. Environmental laws were therefore couched with laxity and were poorly enforced. This culture continues to the present day notwithstanding several legal and policy instruments designed to address environmental degradation, abate environmental pollution and promote environmental sanitation. The National Policy on the Environment 2017 noted

\footnotetext{
95 Steve Crabtree, 'Religiosity Highest in World's Poorest Nations' (Gallup, 2010) <http://www.gallup.com/poll/142727/religiosity-highest-world-poorest-nations.aspx> accessed 31 July, 2016

${ }^{96}$ APRM, APRM Country Review Report No. 8: Federal Republic of Nigeria 2009)

${ }^{97}$ S. Keller, 'Traditional Beliefs Part of People's Lives' (1996) 17 Netw Res Triangle Park N C
} 


\section{Chapter One}

that in 2016 Nigeria's Environmental Performance Index (EPI) ${ }^{98} 58.27$ and ranked 133 out of 190 countries which were surveyed which is below many countries in Africa and indicating much is required to be done to achieve the relevant goal of SDG. ${ }^{99}$

In the Niger-Delta area, the activities of oil companies have been widely known to have caused series of environmental degradation, polluted water, air and sources and means of livelihood of the people. ${ }^{100}$ Although the Niger-Delta Commission has been established to address these environmental programmes, not much success has been recorded. The National Policy on the Environment 2017 in order to address emerging environmental issues and concerns. ${ }^{101}$ The revision of the Policy was a response to the constitutional requirement ${ }^{102}$ and international legal obligations of Nigeria arising from treaties relating to environmental protection. ${ }^{103}$ The Policy "prescribes sectoral and cross-sectoral strategic policy statements and actions for the management of the country's environment for sustainable development."104

The dwindling rates of rainfall, irrigation schemes, desertification, unregulated grazing and migration of people and animals have been putting significant pressure on the environment. Inaccessible geographical locations and poor infrastructural development throughout the country in addition to human and industrial activities including poor sanitation culture of the people are impacting on water and the environment.

The conclusion to be drawn from political, economic, social and environmental factors combined with relative underdevelopment is that these, without a doubt have impacted on the promotion and protection of human rights in general and profoundly contributed to the current state of water and sanitation poverty in Nigeria. These have been responsible for the high level of illiteracy, poverty, collapse of social and institutional infrastructures, unemployment, incessant military interventions and political instability. ${ }^{105}$

\subsubsection{Nigeria's Water and Sanitation Coverage}

Water potentials in Nigeria is not in doubt yet availability for personal and domestic uses is a challenge. As a matter of semantics, the term "availability" is not clear or has not been

\footnotetext{
${ }^{98}$ The Environmental Performance Index (EPI) ranks countries' performance on high-priority environmental issues in two areas: protection of human health and protection of ecosystems.

${ }^{99}$ Federal Republic of Nigeria, National Policy on the Environment (2017) P. 8

${ }^{100}$ The yearly report of Amnesty International since 2008 has consistently documented the impact of oil exploration and extraction on the environment and the host communities. Similarly, the 2011 study of United Nations Environment Programme has revealed the impact of these activities not only on surface water but also on groundwater. See UNEP, Environmental Assessment of Ogoniland (UNEP 2011)

${ }^{101}$ The Policy addresses issues concerning Sustainable management of natural resources; Environmentally sound technology; Climate change and disaster management; Land degradation and desertification; Waste management; Pollution; Environmental hazards and disasters; Urban decay; Weak environmental governance; Inadequate environmental education and awareness; Limited private sector participation in environmental management among others. A review of the Policy will be undertaken in Chapter Four.

${ }^{102}$ Constitution of the Federal Republic of Nigeria Section 20.

${ }^{103}$ Federal Republic of Nigeria, National Policy on the Environment P. 6.

${ }^{104}$ Ibid.

105 See Jacob Abiodun Dada, 'Impediments to Human Rights Protection in Nigeria ' (2012) 18 Annual Survey of International \& Comparative Law 67 P. 84
} 
Realising the Right to Water and Sanitation in Nigeria

adequately addressed from the available literature. ${ }^{106}$ The scope and indicators are essential to enable objective assessment of State's compliance with its obligation of ensuring water availability in sufficient quantity for personal and domestic uses. What would amount to sufficient quantity per individual is however a question of fact depending on context, social group, climate, culture, health status and such other related factors. However, according to the World Health Organisation an individual would require between 50 and 100 litres per day to meet basic needs. ${ }^{107}$

Water is not evenly distributed. According to Feitelson and Chenoweth "[a]vailability problems are an outcome of the spatial variability and temporal fluctuations in fresh water supply and demand, as fresh water is not uniformly distributed in time and space and does not conform to the patterns of human demand." 108

In assessing water scarcity, the most widely used indicator is that which was based on renewable water resources per capita advanced by Falkenmark. ${ }^{109}$ It is possible by the use of this indicator to ascertain whether or not a country is suffering from water scarcity. The index threshold revolves around $1,700 \mathrm{~m} 3$ and $1000 \mathrm{~m} 3$ per capita per year which are used as indicators between water stressed and scarce areas, respectively. ${ }^{110}$ Greater than $1,700 \mathrm{~m} 3$ signifies no water stress, between $1,000 \mathrm{~m} 3$ to $1,700 \mathrm{~m} 3$ signifies stress, $500 \mathrm{~m} 3$ to $1000 \mathrm{~m} 3$ shows scarcity and less than $500 \mathrm{~m} 3$ per capita shows absolute scarcity. ${ }^{111}$

The data on the annual rainfall pattern around the regions puts the northern part of Nigeria at a significant disadvantage and the current utilisation of ground and surface water demonstrated a level of inequality in terms of access and availability. This confirms Feitelson's and Chenoweth's position that:

In some areas and time periods there is excess water, relative to demand, while in other time periods (dry seasons or drought years) and in other areas a shortage may appear. Thus, although water may be abundant globally, water scarcity may be a problem regionally or locally, especially if quality and sustainability considerations are included in the assessment of the resources. ${ }^{112}$

Nigeria's water coverage is one of the lowest in the context of achieving Goal 7 of the Millennium Development Goals and Goal 6 of the Sustainable Development Goals. Relying on the Falkenmark's index, it had been projected that by 2025 Nigeria would be among the

\footnotetext{
${ }^{106}$ Eran Feitelson and Jonathan Chenoweth, 'Water Poverty: Towards a Meaningful Indicator' (2002) 4 Water Policy 263 P. 264

${ }^{107}$ Guy Howard and Jamie Bartram, Domestic Water Quantity, Service Level and Health (World Health Organisation 2003) P. 22.

${ }^{108}$ Eran Feitelson and Jonathan Chenoweth, 'Water Poverty: Towards a Meaningful Indicator' P. 264.

${ }^{109}$ Malin Falkenmark, 'The Massive Water Scarcity Threatening Africa - Why isn't it Being Addressed' (1989) 18 Ambio 112

${ }^{110}$ Amber Brown and Marty D. Matlock, A Review of Water Scarcity Indices and Methodologies (The Sustainability Consortium April, 2011)

${ }^{111}$ Malin Falkenmark, 'The Massive Water Scarcity Threatening Africa - Why isn't it Being Addressed'p. 115)

${ }^{112}$ Eran Feitelson and Jonathan Chenoweth, 'Water Poverty: Towards a Meaningful Indicator' P. 264
} 


\section{Chapter One |}

25 countries in Africa that will be subject to water scarcity or stress. ${ }^{113}$ Specifically, Nigeria is expected to witness water stress with about $1,000-1,700 \mathrm{~m} 3$ per person per year. ${ }^{114}$

The differences in hydrological cycle, increasing population and long-term neglect by State's institutions put certain areas at significant disadvantage. "In the rural areas of Nigeria, water is still the most sought-after commodity and it ranks very highly on the people's scale of developmental preferences." "115 An empirical study reveals that among the major problems identified by rural households in Nigeria, water ranked first over electricity, poverty, healthcare, roads, fertilizer, education and latrines in the priority ranking. ${ }^{116}$

There are disparities in the figures generated by the government and other independent organisations or researchers. Even among the government figures, it is possible to point differences between the agencies generating the data. Recently, the National Water Resources Roadmap ${ }^{117}$ indicated that as at 2015 , the National access to basic ${ }^{118}$ water supply is $69 \%$ while that of sanitation is $29 \% .{ }^{119}$ While that of water was somewhat near sufficient to achieve the MDGs target, it is below the SDGs. ${ }^{120}$ Of significant concern as noted by the document is the decline in sanitation coverage and increase in open defecation. ${ }^{121}$ If this trend continues, access to water will increase but access to sanitation will continue to decrease. ${ }^{122}$ Indicating that a shift in the way sanitation is managed is required. The National Roadmap on Making Nigeria defecation free noted that as at 2015, 46 million Nigerians defecate in the open and that in order to achieve an open defecation fee Nigeria, there is the need to construct "nearly 20 million household toilets and 43,000 toilets in schools, health centres and public places requiring an average annual investment of about NGN 100 billion". ${ }^{123}$

\footnotetext{
${ }^{113}$ UNEP, Global Environmental Outlook, 2000 (UNEP 1999), cited in WaterAid Nigeria, 'Water and Sanitation in Nigeria: $\quad$ Briefing on National Policy' <http://www.wsscc.org/sites/default/files/publications/wateraid_water_and_sanitation_in_nigeria_briefing_on_nat ional_policy_2008.pdf> accessed 6 July, 2014

${ }^{114}$ UNEP, Global Environmental Outlook, 2000, cited in WaterAid Nigeria, 'Water and Sanitation in Nigeria: Briefing on National Policy'

${ }^{115}$ J. O. Ayoade, 'Water Resources and their Development in Nigeria' (1975) XX, 4 Hydrological Sciences - Bulletin - des Sciences Hydrologiques P. 589)

${ }^{116}$ See UNICEF, Knowledge, Attitude and Practice Studies, 1999), cited in Department of Water Supply and Quality Control, National Rural Water Supply and Sanitation Programme: A Strategic Framework

${ }^{117}$ Federal Ministry of Water Resources, Immediate and Longterm Strategies for the Water Sector 2016-2030 (August 2016)

${ }^{118}$ Basic was defined as "safe water within 30 minutes round-trip including queuing time" see Federal Ministry of Water Resources, Partnership for Expanded Water Supply, Sanitation and Hygiene (PEWASH): Programme Strategy 2016-2030 (2016) P. 15.

${ }^{119}$ Federal Ministry of Water Resources, Immediate and Longterm Strategies for the Water Sector 2016-2030 Pp. 9-10.

${ }^{120}$ Federal Ministry of Water Resources, Nigeria Overview: Water, Sanitation and Hygiene (Achieving the SDGs Targets for Water, Sanitation and Hygiene, 2017) P. 1

${ }^{121}$ Federal Ministry of Water Resources, Immediate and Longterm Strategies for the Water Sector 2016-2030 See also Federal Ministry of Water Resources, Partnership for Expanded Water Supply, Sanitation and Hygiene (PEWASH): Programme Strategy 2016-2030 P. 6 (This document noted that over the years there has been a decrease in access to sanitation and an increase in open defecation and Nigeria.)

${ }^{122}$ Federal Ministry of Water Resources, Immediate and Longterm Strategies for the Water Sector 2016-2030 P. 10.

${ }^{123}$ Federal Ministry of Water Resources, Making Nigeria Open-Defecation-Free by 2025: A National Road Map (Federal Ministry of Water Resources 2016) Pp. vi-vii.
} 
Realising the Right to Water and Sanitation in Nigeria

The statistic released by the Federal Ministry of Water Resources indicated that $69 \%$ of the population has access to improved ${ }^{124}$ water supply, $49 \%$ of the population has access to tubewell/boreholes, $36 \%$ has access to protected dug well, $7 \%$ has access to public tabs/stand pipes and $3 \%$ has access to improved water piped into premises. ${ }^{125}$ This coverage did not however take into consideration some of the contents of the right to water such as affordability, quality and quantity. In areas where water is supplied through pipe bone, availability and quantity depend on electricity supply which in most cases, is erratic. Similarly, in areas with boreholes there are issues with water quality. It had been pointed out that groundwater can be contaminated by several factors including oil extraction and industrial activities. ${ }^{126}$ In certain areas, several communities are using single water source like borehole or centrally situated water tap. This impacts on availability and accessibility. Under this situation, vulnerable groups are forced to resort to private service providers which in turn creates questions of affordability.

In the context of sanitation, the report indicated that while $29 \%$ of the population has access to basic sanitation, ${ }^{127} 53 \%$ has access to improved sanitation ${ }^{128}$ including shared facilities, $35 \%$ has access to improved sanitation, dry latrines, $13 \%$ has access to improved private sanitation, and 5\% are using improved toilets with sewer connection. ${ }^{129}$

The Nigerian Policy on water and sanitation imposes a duty on the Federal Government ("FG") to generate data for policy formulations and implementation. However due to several factors including lack of capacity and political considerations, disparities and discrepancies in the data generated by government, international organisations and the non-governmental organisations are noticeable. The most recent figures released by the National Population Commission in the 2013 Nigeria Demographic and Health Survey (NDHS), 76\% of urban and semi-urban population and $49 \%$ living in the rural communities have access to improved water supplies. ${ }^{130}$ This is an improvement from the 2008 NDHS where the figures were $56 \%$ and $29 \%$ respectively. ${ }^{131}$ The Survey showed that the "most common source of improved drinking water in Nigeria is tube well or borehole water, used by 44 percent of urban and 32 percent of rural households. Thirteen percent of urban households and 10 percent of rural households have access to drinking water from a protected well." ${ }^{132}$ On sanitation, the Survey showed that only $37 \%$ of households in urban areas and $25 \%$ in rural areas are using improved toilet facilities which are not shared. ${ }^{133}$ The Survey further found that:

\footnotetext{
${ }^{124}$ Improved access within the government strategy document are dug wells, unprotected springs with more than 30 minutes collection time. See Federal Ministry of Water Resources, Partnership for Expanded Water Supply, Sanitation and Hygiene (PEWASH): Programme Strategy 2016-2030 P. 15.

${ }^{125}$ Federal Ministry of Water Resources, Nigeria Overview: Water, Sanitation and Hygiene P. 2

${ }^{126}$ See for example UNEP, Environmental Assessment of Ogoniland

${ }^{127}$ Basic within the government strategy document are pour flush to sewer, septic tank or pit latrine, composting toilet or pit latrine with slab, not shared. See Federal Ministry of Water Resources, Partnership for Expanded Water Supply, Sanitation and Hygiene (PEWASH): Programme Strategy 2016-2030 P. 19.

${ }^{128}$ These are pit latrine without slab or platform, hanging latrines, bucket latrines. See ibid.

${ }^{129}$ Federal Ministry of Water Resources, Nigeria Overview: Water, Sanitation and Hygiene

${ }^{130}$ National Population Commission, Nigeria Demographic and Health Survey 2013, June 2014) P. 12.

${ }_{131}$ National Population Commission, 'Nigeria Demographic and Health Survey (NDHS) Fact Sheet: North West Zone' 2008) <http://www.measuredhs.com/pubs/pdf/OF12/OF12.NW.4.english.pdf> accessed 22 July, 2013

${ }^{132}$ National Population Commission, Nigeria Demographic and Health Survey 2013 P. 12.

${ }^{133}$ Ibid. P. 13.
} 


\section{Chapter One}

Twenty-five percent of households (40 percent in urban areas and 13 percent in rural areas) use shared toilet facilities, while 45 percent use non-improved facilities (62 percent in rural areas and 23 percent in urban areas). The most common type of non-improved toilet facility is an open pit latrine or pit latrine without slabs, used by 20 percent of households in rural areas and 6 percent of households in urban areas. Overall, 29 percent of households have no toilet facility (16 percent in urban areas and 40 percent in rural areas). ${ }^{134}$

Several case studies have equally reported a relatively very low average access for both urban and rural water and sanitation services. ${ }^{135}$ The more recent Multiple Indicator Cluster Survey report ${ }^{136}$ showed that $64.1 \%$ of household members in Nigeria are using are using improved sources of drinking water in line with SDG Goal 6.1 .1 and only $2.3 \%$ of household members who are using unimproved drinking water are using appropriate treatment method. The report further showed that in the context of Goal 7.9 of the MDGs and Goal 1.4.1 of the SDGs, only $35.9 \%$ of household members are using improved sanitation facilities which are not shared, only $58.1 \%$ of children age $0-2$ years last stools were disposed safely in the context of SDG 6.2.1, only $12.4 \%$ have specific place for hand washing with water and soap or other cleansing agents in accordance with SDG Goal 6.1.2 and 42\% have soap or other cleansing agent and shockingly, $90.8 \%$ of household members are drinking water contaminated by E. coli.

As at 2010 as revealed by a joint report of UNICEF and World Health Organisation only $31 \%$ of the population had accessed to improved sanitation, ${ }^{137} 109$ million people $(68.8 \%$ of the population) are without access to sanitation and standing as No. 4 after India, China and Indonesia of the top 10 countries without access to improved sanitation. ${ }^{138}$ The UNICEF/World Health Organisation data also shows that 66 million people (41.7.2\% of the population) are without access to safe drinking water thereby becoming No. 3 after China and India of the top 10 countries without access to an improved drinking water source. ${ }^{139}$

In another recent study, ${ }^{140}$ it had been estimated that $72 \%$ of urban dwellers and $47 \%$ of the rural population have access to improved water sources. The percentage of those having access to sanitation is however only 26\%. The United States Central Intelligence Agency (CIA) estimated that $74 \%$ of urban population and $43 \%$ of rural population have access to improved drinking water source while only $35 \%$ of urban population and $27 \%$ of rural population have accessed to improved sanitation. ${ }^{141}$ By the CIA figures, over 73 million

\footnotetext{
${ }^{134}$ Ibid.

${ }^{135}$ See A. O. Nyong and P. S. Kanaroglou, 'Domestic Water Use in Rural Semi-Arid Africa: A Case Study of Katarko Village in Northeastern Nigeria' (2007) 27 Human Ecology 537; S. Stoveland and B. U. Bassey, 'Status of Water Supply and Sanitation in 37 Small Towns in Nigeria' (Donor Conference); Y. A. Sanusi, 'Water, Sanitation and Human Development in Urban Fringe Settlements in Nigeria' (2010) 8 Theoretical and Empirical Researches in Urban Management 14

${ }^{136}$ National Bureau of Statistics and others, Multiple Indicator Cluster Survey 2016-17, February 2018) P. vi

137 UNICEF and WHO, 'Progress on Drinking Water and Sanitation: 2012 Update' 2012) <http://www.wssinfo.org/fileadmin/user_upload/resources/JMP-report-2012-en.pdf> accessed 12 February, 2014, P. 19

${ }^{138}$ Ibid.

${ }^{139}$ Ibid.

${ }^{140}$ WHO and UNICEF, Joint Monitoring Programme for Water Supply and Sanitation: Meeting the MDG Drinking Water and Sanitation Target: Mid-term Assessment of Progress, 2010); National Bureau of Statistics, Multiple Indicator Cluster Survey 2007, 2007)

${ }^{141}$ Central Intelligence Agency, 'Nigeria'
} 
Realising the Right to Water and Sanitation in Nigeria

Nigerians have no access to improved drinking water sources and over 120 million Nigerians have no accessed to improved sanitation facility. From these figures, it is evident that Nigeria had failed to utilise the enormous amount of money accrued from oil to the discharge of its obligations on ESC rights including on water and sanitation.

Nigeria is divided into six geopolitical zones and statistics showed that access to improved $^{142}$ drinking water in the North-Central is $52.2 \%$, North-East $27.3 \%$, North-West $42.5 \%$, South-West $72.7 \%$, and South-East $54.1 \%$ respectively. On improved sanitation, ${ }^{143}$ statistics showed that North-Central has 29\%, North-East has 34.4\%, North-West has $34.1 \%$, South-East has $55.5 \%$ and South-West has $55.0 \%$ respectively. ${ }^{144}$

The 2013 Nigeria Demographic Health Survey (NDHS) ${ }^{145}$ shows that in the North-West, where the empirical study of the research focussed, the percentage of population who are having improved drinking water source stands at 57.2\% with Jigawa State having $74.4 \%$, Kaduna State 64.2\%, Kano State 70.7\%, Katsina State 49.3\%, Kebbi State 21\%, Sokoto State $64.4 \%$ and Zamfara State $35.6 \% .^{146}$ The percentage of population using non-improved sources in the region is $42.6 \%$ with Jigawa State having $25.2 \%$, Kaduna State $35.6 \%$, Kano State $28.9 \%$, Katsina State 50.6\%, Kebbi State 79\%, Sokoto State 35.4\% and Zamfara $64.3 \%$ respectively. ${ }^{147}$ Out of these, only $2 \%$ of the population are using appropriate treatment method $^{148}$ in the region, $1.7 \%$ in Jigawa State, 5.2\% in Kaduna State, 1.4\% in Kano State, $0.5 \%$ in Katsina and Kebbi States, $0.7 \%$ and $3.4 \%$ in Sokoto and Zamfara States respectively. ${ }^{149}$

On sanitation, the average percentage in the North-West of population with improved toilet/latrine facilities which is not shared is $45.7 \%$ with Jigawa State having 51\%, Kaduna State $26.6 \%$, Kano State 66.1\%, Katsina State 45.8\%, Kebbi State 55\%, Sokoto State 46.5\% and Zamfara State $7.5 \%$ respectively. ${ }^{150}$ Similarly, the percentage of the population using non-improved facility ${ }^{151}$ in the region is $54.3 \%$ with Jigawa State having $49 \%$, Kaduna State 73.4\%, Kano State 33.9\%, Katsina State 54.2\%, Kebbi State 45\%, Sokoto State $53.5 \%$ and Zamfara State $95.5 \%{ }^{152}$

\footnotetext{
${ }^{142}$ According to WHO improved drinking water sources are Household connection, Public standpipe, Borehole Protected dug well, Protected spring, and Rainwater collection. See WHO, 'Definitions of Indicators ' <http://www.who.int/water_sanitation_health/monitoring/jmp04_2.pdf > accessed 19 August 2017

${ }^{143}$ Improved sanitation facilities are those more likely to ensure privacy and hygienic use. These are Connection to a public sewer, Connection to a septic system, Pour-flush latrine, Simple pit latrine, Ventilated improved pit latrine. See ibid.

${ }^{144}$ National Bureau of Statistics, Multiple Indicator Cluster Survey 2007

145 The 2008 NDHS was implemented by the National Population Commission of Nigeria. ICF Macro, an ICF International Company, provided technical assistance in the design, implementation and analysis of the survey through the USAID-funded MEASURE DHS programme.

${ }^{146}$ National Population Commission, Nigeria Demographic and Health Survey 2013 P. 369.

${ }^{147}$ Ibid.

${ }^{148}$ Appropriate water treatment methods according to the Survey include boiling, bleaching, filtering, and solar disinfecting.

${ }^{149}$ National Population Commission, Nigeria Demographic and Health Survey 2013 P. 369

${ }^{150}$ Ibid. P. 370.

${ }^{151}$ According to the Survey, non-improved facility includes shared facilities that would be considered improved if they were not shared by two or more households.

152 National Population Commission, Nigeria Demographic and Health Survey 2013 P. 370
} 


\section{Chapter One}

The National Water Sanitation Policy 2004 noted that $15 \%$ of households in Nigeria ${ }^{153}$ have access to flush toilet, $57 \%$ use traditional pit latrine (most of which were unsafe) while $28 \%$ have no facility at all. These figures demonstrated that while the Country's international obligations in terms of water and sanitation increased; it has not been followed by a corresponding increase in the provision/facilitation of access to quality water and basic sanitation. Similarly, the gap between those areas that have reasonably safe access to water supply and sanitation and those without is growing wider. ${ }^{154}$ This lack of improvement made it difficult for Nigeria to meet its MDG target, and the United Kingdom's Department of Foreign and International Development (DFID) classified Nigeria as "one of the four most off-track MDG countries in Africa." 155 In 2010 the UN MDG indicator shows that 49\% access to improved water and $69 \%$ access to improved sanitation is needed in Nigeria to meet Goal 7 of the MDG target. ${ }^{156}$ Currently, if no adequate measures are taken, for example if the current water resources and sanitation strategies are not vigorously implemented, the SDG targets will equally be missed. ${ }^{157}$

The impacts of water and sanitation crisis on Nigeria is alarming: for example, it had been estimated that about 8.5 million children of which majority are females are currently out of school for reason connected to lack of separate basic sanitation facilities. ${ }^{158}$ Yearly, about 130,000 children of under the age of five years die from preventable water borne disease. ${ }^{159}$ As at 2012, 34 million people of Nigeria (46 million according to the Nigeria's Road Map on Making Nigeria Defecation Free) defecate in the open making the country to stand as No.5 after India, Indonesia, Pakistan and Ethiopia among the top 10 countries with this practice. ${ }^{160}$ While this is shocking, seven in 10 women have no access to safe toilet, 54 million Nigerian women and girls lacked safe and adequate sanitation and 17 million of them have no toilet at all making them spend 3.1 billion hours each year finding an open space to defecate. ${ }^{161}$ Additionally, 194, 000 children under the age of five die of diarrhoea every year while 240,000 die of respiratory infections due poor sanitary conditions. ${ }^{162}$ Nigeria accounted for $7.3 \%$ of the countries accounting for $90 \%$ of people in the developing world without access to water facilities, $4 \%$ of the countries accounting for $90 \%$ of people in the developing world without access to sanitation facilities. ${ }^{163}$ The poor sanitation condition is costing Nigeria

\footnotetext{
${ }^{153}$ According to the Policy Household is averaged 5 persons.

${ }^{154}$ USAID, 'Nigeria Water and Sanitation Profile' <www.usaid.gov> accessed 15 October, 2013

${ }^{155}$ Ibid., P. 1

${ }^{156}$ Ibid., Pp. 2-3

${ }^{157}$ Federal Ministry of Water Resources, Nigeria Overview: Water, Sanitation and Hygiene P. 2.

158 Society for Water and Sanitation, 'Newsletter' January-March, 2013) <http://www.wiser.org/uploads/file_partitioned/6/3/0/e/630e78dea4499330d261048bcc398a72/newsan\%20newsle tter\%20pdf[1].pdf> accessed 18 February, 2014.P. 2

159 Assembly Online, 'Nigeria: WASH Media Network Calls on FG to Fulfil WASH Commitments' <http://assemblyonline.info/?p=16520> accessed 18 February, 2014

${ }^{160}$ UNICEF and WHO, 'Progress on Drinking Water and Sanitation: 2012 Update' P. 20

${ }^{161}$ Abbas Jimoh, 'Nigeria: 17 Million Women Have No Toilet - Wateraid' Daily Trust (Abuja 20 November)

162 Ibrahim Musa Giginyu, 'Nigeria: 194,000 Children Die of Diarrhoea Every Year' Daily Trust (Abuja 21 November)

${ }^{163}$ WaterAid, Off Track, off Target: Why Investment in Water, Sanitation and Hygiene is not Reaching Those Who Need it Most, 2011)
} 
Realising the Right to Water and Sanitation in Nigeria

US $\$ 3$ billion annually, representing US\$20 per person per year or $1.3 \%$ of the national GDP. ${ }^{164}$

In attempting to address the perennial problem, Nigeria had enacted laws and adopted policies on water and sanitation. For example, in 2000, a National Water Supply and Sanitation Policy which along with many other initiatives, encourages private-sector participation and the expansion and improvement of rural water-supply systems. In the case of urban water sector, the policy focussed on improving the performance of service providers through institutional and policy reforms at the State level. The "Presidential Water Initiative (PWI): Water for People, Water for Life was launched in 2003 aimed at increasing access to water supply and sanitation services to $100 \%$ in State capitals, $75 \%$ access in other urban and peri-urban areas, and 66\% access in rural areas. The objective of the National Water Sanitation Policy 2004 is for all Nigerians to have access to adequate, affordable and sustainable sanitation. Unfortunately, these and many other initiatives did not yield the desired result. It seemed Nigeria has merely been pursuing the shadow, attacking the symptoms and allowing the causes to flourish. It needs to be noted that under the current dispensation, Nigeria has adopted a roadmap in both water and sanitation sectors which are designed to address the problems bedevilling the sectors. These documents will be analysed later.

While adopting legal and policy documents is important, to achieve a meaningful result, an integrated approach and sets of specific actions are necessary to harmonise and properly direct the legal instruments and policies. Many factors are responsible for the poor handling of access to quality water and basic sanitation in Nigeria. Some of these are: lack of technical capacity at the appropriate level to address water and sanitation problems which is associated with the way in which responsibility was apportioned among the three tiers of Government: The Federal Government is responsible for policy formation, data collection, monitoring and coordinating water supply development, and funding research and development, the States are responsible for sanitation and for the establishment, operation, quality control, and maintenance of urban and semi-urban water supply while Local Government Authorities are responsible for the establishment, operation, and maintenance of rural water supply schemes and sanitation facilities in their areas. Unfortunately, however, at the Federal level, there is often no reliable data with which to plan, the States do not have the capacity and skills and very few local governments have rural water supply divisions able to construct small water systems such as open wells and small impoundments of surface water. ${ }^{165}$

Other factors militating against the expansion of access to sanitation are associated with uncoordinated policies, lack of awareness, poor planning, poor funding, and poor implementation of hygiene programs by different agencies. ${ }^{166}$ There is the problem of weak and inefficient institutions, unsustainable public-sector spending, and persistent

\footnotetext{
164 World Bank, 'Nigeria Loses NGN455 Billion Annually Due to Poor Sanitation' March, 2012) <https://www.wsp.org/sites/wsp.org/files/publications/WSP-ESI-Nigeria-brochure.pdf> accessed 12 February, 2014 P. 1

${ }^{165}$ USAID, 'Nigeria Water and Sanitation Profile' P. 2

${ }^{166}$ Ibid., P. 3
} 


\section{Chapter One}

implementation failures. At the rural level, most rights-holders are either unaware of their rights or have no knowledge of how to assert a claim.

The poor water infrastructure and the very low access to an improved sanitation no doubt are serious public health issues. The combined effects of these problems are numerous: preventable diseases continue to be on the rise due to contaminated water and insanitary conditions. This negatively impacts on the enjoyment of highest attainable standard of health prescribed in the ICESCR. For example, half of Nigerian population has experience at least one episode of malaria annually. ${ }^{167}$ Lack of sustainable access to water supply and basic sanitation also lead to environmental mismanagement and pollution with their attendant impacts on the environment. The situation calls for the recognition of the right to water and sanitation in a legally binding document and adoption of an approach that build the needed technical capacity of duty-bearers and empowers rights-holders as important stakeholders in the realisation of the right to water and sanitation.

\subsection{Geographical Scope of the Study}

This study is limited to the Federal Republic of Nigeria ("Nigeria") and takes into consideration country's specific situations and circumstances. As a Federal Republic, existing legal and policy frameworks apportioned responsibility of providing access to quality water and basic sanitation to the three tiers of Government: Federal, States and the Local Governments. Nigeria consist of 36 States and the Federal Capital Abuja. The theoretical aspects of the study cover Nigeria in general while the empirical aspects cover some selected areas defined in section 1.7 below.

\subsection{Objectives of the Study}

This study is interdisciplinary and utilised a human right-based, and ecosystem approaches in investigating access to water and sanitation in Nigeria. It is interdisciplinary in the sense of combining normative and social science approaches and insights in assessing issues relating to water and sanitation in this research. A Human rights-based approach is not technically a legal concept, the concept is used by both legal and social science scholars to advocate for the realisation of human rights. The insights from social science perspective is therefore important to be assessed and utilised. Additionally, ecosystem approach is not also a legal concept as shall be demonstrated. However, in the way it is utilised in scientific writings and research, it can be used in promoting human rights and environmental protection. Through the utilisation of these approaches and insights, the research identifies factors impacting on the realisation of the right to water and sanitation and suggested how the right can be realised through a paradigm shift and focus on the local and national perspectives. ${ }^{168}$ Generally, the research is centred on three major objectives:

1. analysing existing legal and policy frameworks on water and sanitation and environmental protection in Nigeria: their quality, adequacy, standards,

\footnotetext{
${ }^{167}$ Federal Republic of Nigeria, National Water Sanitation Policy (Federal Government Printing Press 2004)

168 The Human Rights Council resolution 18/1 affirmed the need to focus on local and national perspectives in considering the human right to safe drinking water and sanitation, see UN Human Rights Council, The Human Right to Safe Drinking Water and Sanitation (A/HRC/18/L1, 23 September 2011) Preamble 10
} 
Realising the Right to Water and Sanitation in Nigeria

discrepancies, and compatibility with relevant and binding international legal instruments as well as investigating the operation of institutional frameworks responsible for the provision of water and sanitation and protection of the Nigerian environment;

2. examining the legal and non-legal impediments and challenges to the progressive realisation of the human right to water and sanitation in Nigeria; and

3. exploring mechanisms and processes on how rights-holders can be empowered to claim their rights and duty-bearers' capacity can be improved to discharge their obligations through the prisms of a human rights-based and ecosystems approaches.

\subsection{Research Questions}

From the three objectives, four research questions will be investigated in this study:

1. To what extent are Nigeria's laws, policies and practices in conformity with its obligations under the right to water and sanitation?

2. To what extent are Nigerians aware of the existence of human rights to water and sanitation?

3. What are the factors contributing to or sustaining poor water and sanitation coverage in Nigeria?

4. What do principles of judicial interpretation, a human rights-based and an ecosystems approaches entail and how can these be utilised in the realisation of the right to water and sanitation in Nigeria?

\subsection{Methodology of the Research}

In addressing the research questions, analysis in this study combined two sets of methodologies: normative legal research (doctrinal legal research) and social science research methods. An approach combining an epistemological discourse analysis, quantitative, qualitative analysis and empirical study have helped in addressing major issues in furtherance to the research objectives. The methodological approach was considered a suitable response to the interdisciplinary nature of the research inquiry ${ }^{169}$ and provided insights into the understanding and dimensions of the problems under investigation. It had been suggested that "understanding the social world is a necessary precursor to improving it." ${ }^{170}$ The databases of Waterlex ${ }^{171}$ and ESCR-Net ${ }^{172}$ which translated relevant foreign cases were utilised in analysing some of the concepts used in this research.

The first research question was addressed through the utilisation of normative legal research approach (desk-based) through which relevant Nigeria's legislations and policies were analysed. This method was considered more suitable in analysing national legal and

\footnotetext{
${ }^{169}$ For a consideration on the need to be methodologically explicit see Dvora Yanow and Peregrine Schwartz-Shea (eds), Interpretation and Method: Empirical Research Methods and the Interpretive Turn (M.E. Sharpe 2006) P. xiii

${ }^{170}$ Patrick White, Developing Research Questions: A Guide for Social Scientists (Palgrave Macmillan 2009) P. 51

${ }^{171}$ Waterlex, 'The Human Rights to Water and Sanitation in Courts Worldwide: A Selection of National, Regional and International Case Law' <https://www.waterlex.org/publications/the-human-rights-to-water-and-sanitation-incourts-worldwide/> accessed 17 November 2017

${ }^{172}$ ESCR-Net, 'Caselaw Database' <https://www.escr-net.org/caselaw> accessed 17 November 2017
} 


\section{Chapter One}

policy instruments and their compatibility with international legal materials relating to the right to water and sanitation.

The second and third research questions were addressed using a combination of qualitative and quantitative approaches. Qualitative provided the insights required to understand the various dimensions of the problems impacting on the realisation of the right to water and sanitation and quantitative provided the empirical evidence of the extent and magnitude of the issues and challenges. This is considered more appropriate as it will provide a sound basis through which contextualised and evidenced-based suggestions could be made to address the issues and challenges.

Empirical research has been considered the first step to helping a disadvantaged group "through the provision of accurate information about the nature and extent of their disadvantage, and the context in which it arises and is sustained." 173

The fourth research question was answered using a theoretical exploration approach that documents analyses of the concepts of human rights-based, ecosystems, and interpretation approaches.

\subsection{Background to the Empirical Study and its Justification}

In responding to the research questions, empirical study was conducted in the seven North-western States of Nigeria as a case study: These States consisted of Jigawa, Kaduna, Kano, Katsina, Kebbi, Sokoto and Zamfara States. These States are indicated in Figure 1.1. State capitals were automatically included to represent urban centres and a local government was randomly selected in each State using Excel Software for the administration of Type A Questionnaire. The names and locations of the areas are indicated in Table 1.1 (Page 42).

Selection of North-West Nigeria was occasioned by technical, personal and operational considerations. By technical consideration, the region has the largest number of population among the six geo-political zones with a combined population according to the 2006 national census, of about 35.5 million. North-West is among the less economically and socially developed regions with significant poor water and sanitation coverage and has the lowest reported human rights litigations or claims. Personal consideration includes familiarity of the terrain, access to relevant stakeholders, and local language competence. Operational consideration includes limited time and resources. North-West's population is predominantly Muslims ${ }^{174}$ with Hausa as a dominant language. ${ }^{175}$ The population share similar culture and numerous inter-marital relationships exist which are linked to religion, language and culture. The empirical study was conducted in the State capitals and some randomly selected local governments. ${ }^{176}$ It investigated the correlation between economic, social, cultural, religious and political factors and the state of human rights with specific reference to the right to water and sanitation. Although the findings in this study are limited to Nigeria, some may be

\footnotetext{
${ }^{173}$ Patrick White, Developing Research Questions: A Guide for Social Scientists

${ }^{174}$ A relatively large population living in the southern part of Kaduna State is Christian.

175 There are however dialectical differences across the region.

${ }^{176}$ The selection was done randomly using Excel Software where all the local governments in a State were included and the software randomly selected one of the local governments. The procedure adopted can be found at https://www.extendoffice.com/documents/excel/2768-excel-select-random-names.html.
} 
Realising the Right to Water and Sanitation in Nigeria

relevant in deconstructing how developing countries, especially those with multicultural, social and economic challenges are struggling to realise human rights.

The empirical study was funded by the Maastricht University. It was carried out from $15^{\text {th }}$ July to $5^{\text {th }}$ August 2015. Three sets of questionnaires were used: Type A for the General Population; Type B for the Ministries, Departments and Agencies of Government; and Type $\mathrm{C}$ for the Civil Society organisations. Development of the questionnaires was guided by consideration of the two approaches being applied in this study: human rights-based and ecosystems approaches. Type A was designed to among others, generate information from the population about awareness of human rights, awareness of how to claim human rights, sources of water, practical reflection of contents of the right to water, and awareness of marginalisation and existence of marginalised groups. Responses provided insights into the existing position on these issues and the level of intervention needed in empowering the population to claim their right to water and sanitation. Type B was designed to generate information relating to the capacity of duty-bearers, their human rights awareness, awareness of the obligations under the right to water and sanitation, and their operational challenges. These provided insights into the existing capacity of duty-bearers and factors militating against the realisation of the right to water and sanitation. Type $\mathrm{C}$ was designed to generate information on the awareness of civil society organisations ${ }^{177}$ relating to the existence of marginalised groups on water and sanitation and possible reasons for such marginalisation.

Two graduate assistants (male and female) were used in administering and collating Type A (General Populations) questionnaire. The assistants were recommended and selected based on their educational level, ability to interact with the population and their previous experience in questionnaire administration. Training on the contents of the questionnaire such as on the meaning of human rights, discrimination, marginalisation and how to explain to those who could not read/write and how to seek for clarification where necessary was provided to the assistants.

In both capitals and local governments, a stratified random sampling was used to divide locations into groups and a systematic random sampling was used to select the households where the questionnaires will be administered. Type A questionnaire was administered in two languages: English and Hausa. ${ }^{178}$ A total of 800 questionnaires were distributed while 777 were retrieved, representing $97.125 \%$ of the total questionnaires distributed. ${ }^{179}$ Where necessary a follow-up interview was conducted for clarifications in relations to open-ended questions. Type B (Ministries, Department and Agencies) Questionnaire was administered at the offices of the ministries, departments and agencies. These are the Ministry of Water Resources and Water Board in each State. ${ }^{180}$ Civil society organisations working in the sector were identified through a research and questionnaires administered through

\footnotetext{
177 The Civil Society Organisations contacted are The Environmental Rights Action; The Procurement Observation and Advocacy Initiative; The National Coalition on Gas Flaring and Oil Spill in the Niger Delta (NACGOND); Transition Monitoring Group Nigeria; and The Institute of Human Right and Humanitarian Law.

${ }^{178}$ Sample of the questionnaire is attached as Appendix A

${ }^{179}$ Explanation for the high rate is that questionnaires were mostly distributed hand to hand and were filled in the presence of the distributor and subsequently received. A limited number was left with the respondents for later collection some of which could not be retrieved.

${ }^{180}$ Sample of the questionnaire is attached as Appendix B
} 
correspondence. ${ }^{181}$ All the data in the three sets of questionnaires can be accessed via http://www.kasimb.com/425257197.

The questionnaires contained an informed consent clause which each respondent read and signed before filling the questionnaires. Except in very few questions, the questionnaires were in closed-questions format. In this format, a combination of leading questions, importance questions, Likert questions, dichotomous questions, bipolar questions, and rating scale questions were used. This provided the opportunity for a standardised way of measuring responses. In cases where the opinion of the relevant stakeholder is considered relevant, open-ended questions were used. All the responses (Data) generated through the empirical study were entered in Qualtrics software and analysed using a combination of statistical and graphical representations in order to provide insights into water and sanitation associated problems, their causes and perceptions of the respondents on these issues. Conclusions were drawn from the data and trends indicated which made the research qualitative in nature. The demographics of the respondents and analysis of responses are provided in the appropriate chapters. Findings in this empirical research were used in chapters four, five, and six of this thesis. It must be stated that the findings in the empirical study relate only to the areas where the empirical study was conducted and not necessarily the entire country. Nonetheless, they may be suggestive of trends we may find in other parts of Nigeria.

\subsection{Theoretical and Conceptual Framework}

The study applied two approaches as its underpinning theories: a human rights-based approach and an ecosystems approach. A human rights-based approach provided the theoretical and conceptual framework for the realisation of human rights and how to assess, understand and appreciate how individuals and marginalised peoples and groups can be empowered to claim their human rights and how duty-bearers' capacity can be improved to discharge their obligations in concrete human rights terms. Access to safe water and basic sanitation is a legal entitlement and right-based approach is understood as a conceptual framework normatively based on international human rights standards and operationally directed towards promoting and protecting human rights. The approach integrates norms, standards and principles of international human rights system into the plans, policies and processes of development. ${ }^{182}$ These principles are equality, equity, accountability, empowerment and participation. A Human rights-based approach provides principles for addressing water and sanitation crisis.

Although the right to water applies strictly to personal and domestic uses, a right-based approach is suitable when considering larger issues, such as water resource management. This approach particularly promotes equality and non-discrimination by requiring that no group should be excluded. Similarly, priority in allocating limited public resources should be given to those who do not have access or who face discrimination in accessing safe drinking water. A human rights-based approach informs water management by clearly prioritising, in

\footnotetext{
${ }^{181}$ Sample of the questionnaire is attached as Appendix C

182 See International Human Rights Network, 'Our Rights, Our future Human Rights based Approaches in Ireland: Principles, Policies and Practice' 2005) <http://www.ihrnetwork.org/files/IHRNAI\%20HRBA\%20Ireland\%20Sept05\%20FINAL.pdf> accessed 11 May, 2013
} 
Realising the Right to Water and Sanitation in Nigeria

the allocation of water among competing uses and users. Another central feature of a human rights-based approach is its focus on accountability, which underlines the obligations of the duty-bearer, to ensure access to safe drinking water and sanitation to rights-holders. In practice, accountability requires the development of laws, policies, institutions, administrative procedures and mechanisms of redress to promote and protect access to safe drinking water and sanitation.

An ecosystems approach is a strategy providing a workable framework for the integrated management of land, water and living resources in an equitable way that promotes conservation and sustainability. ${ }^{183}$ The term ecosystem is used in ecology to essentially connotes studying a system as a whole, at first, before considering specific components of that system. ${ }^{184}$ Through this way, a sound management approach to the components of the system would be realised. There are several components of ecosystem. These include land, water, living and non-living organisms, aquifers etc. Water is generally considered a scarce resource and an essential and integral component of the ecosystem. ${ }^{185}$ The needs and calls for ecosystem management was occasioned by deepening biodiversity crisis in today's world. ${ }^{186}$ It is a necessary holistic management for sustaining resources in complex ecological or political situations, ${ }^{187}$ and serves as a policy framework in sustainable management. The approach "integrates scientific knowledge of ecological relationships within a complex socio-political and values framework toward the general goal of protecting native ecosystem integrity over the long term." 188

The two approaches were combined necessarily to respond to human and environmental concerns creating crisis, poverty, hunger and drought among others. While a human rightsbased approach focussed on realisation of human rights, its sole application on a resource subject to several competitions could lead to further crisis which equally impacts on the realisation of other human rights. For example, applying a human rights-based approach to the realisation of the human right to water and sanitation alone without concern for the health of the environment where human beings live could potentially lead to other crisis where if water is denied to other important living or non-living organisms, food, health, and living condition of the people could be drastically affected. In other words, concentrating only on human right-based approach in realising the right to water by making it available to human beings in sufficient quantity and quality would affect the remaining or rest of the organisms (which directly or indirectly interact with human beings and for which in some cases, the human beings depend upon) living in the ecosystem. It is generally recognised that human beings cannot be separated from nature. Human beings have fundamental influences on

\footnotetext{
${ }^{183}$ Secretariat of the Convention on Biological Diversity, Ecosystem Approach (CBD Guidelines) (Secretariat of the Convention on Biological Diversity 2004) P. 6

${ }^{184}$ See Eugene P. Odum, 'The Ecosystem Approach in the Teaching of Ecology Illustrated with Sample Class Data' (1957) 38 Ecology 531

${ }^{185}$ See United Nations, 'Agenda 21' (United Nations Conference on Environment \& Development, Rio de Janerio, Brazil, 3-14 June 1992) Chapter 18, para. 18.1

${ }^{186}$ R. Edward Grumbine, 'What Is Ecosystem Management?' (March, 1994) 8 Conservation Biology 27 P. 31

${ }^{187}$ Tim W. Clark and Steven C. Minta, Greater Yellowstone's Future: Prospects for Ecosytem Science, Management, and Policy (Homestead Pub. 1994)

${ }^{188}$ R. Edward Grumbine, 'What Is Ecosystem Management?' P. 31.
} 


\section{Chapter One}

ecological patterns and processes and they are, at the same time affected by them. ${ }^{189}$ To realise the right to water in a sustainable manner, therefore, the entire ecosystem must be considered, and a human rights-based approach should be supplemented by an ecosystems approach for the health and continued survival of our planet. ${ }^{190}$ This position has been advocated by the MDGs, ${ }^{191}$ The SDGs, ${ }^{192}$ and the UN Committee on ESC rights in its General Comment 15 on the right to water in order to ensure sufficient and safe water for both the present and future generation as well as ensuring sustainable extraction of water, assessing the impacts of actions on water availability and natural-ecosystems watersheds. ${ }^{193}$ Sustainability is an important concept in both development and human rights realisation and enjoyment. It has been referred to in the Millennium Development Goals and recently in the Sustainable Development Goals. ${ }^{194}$ Attention has also been paid to Integrated Water Resources Management with UN calling on States to develop and implement this strategy to ensure among others sustainability of water extraction and protection of the ecosystems. ${ }^{195}$ These theoretical and conceptual frameworks underpinned and controlled the focus of this research.

\subsection{Proposed Approaches}

Multiple factors identified below undermined several programmes adopted in the realisation of access to water and sanitation in Nigeria. Failure of existing approaches clearly demonstrated that addressing the problems requires the adoption of a holistic approach which holds at the centre, the overarching interest of protecting human lives, promoting social and economic development in a manner which promotes transparency and accountability in the management of governmental projects. Similarly, existing approaches paid little attention to beneficiaries' participation in the success of projects and programmes. The adoption of a human right-based approach would provide mechanisms through which the identified impediments could be addressed. The Ecosystems approach recognises the cross-cutting nature of water, its scarcity and the intense competitions which it is subjected to. The recognition of the fundamental importance of ecosystems goods and services on human lives, security and development and the role of water in sustaining the ecosystems suggested, in the context of water scarcity, the need to adopt an integrated approach in the management and allocation of water. The subsections below, further highlight the approaches while detailed discussion follows in chapters seven and eight respectively.

\footnotetext{
${ }^{189}$ Ibid. P. 31

${ }^{190}$ See John Scanlon, Angela Cassar and Noemi Nemes, Water as a Human Right? P. 27. See also United Nations General Assembly, Report of the Special Rapporteur on the Issue of Human Rights Obligations Relating to the Enjoyment of a Safe, Clean, Healthy and Sustainable Environment (UN Doc A/HRC/34/49

19 January 2017)

${ }^{191}$ See Goal 7, Millennium Development Goals.

192 See Goal 6, Sustainable Development Goals.

${ }^{193}$ UNCESCR, General Comment No. 15: The Right to Water (Arts. 11 and 12 of the Covenant) Para. 28.

${ }^{194}$ See Goal 6, Sustainable Development Goals.

${ }^{195}$ See Goals 7 of Millennium Development Goals; Goal 6 of Sustainable Development Goals.
} 
Realising the Right to Water and Sanitation in Nigeria

\subsubsection{Human Right-Based Approach}

General Comment 15 of the UN Committee on ESC rights stressed the obligation of adopting a strategy or plan of action based on human rights law and principles in realising the right to water and sanitation. ${ }^{196}$ The strategy or plan of action must necessarily respect the principle of non-discrimination, ensures right-holders participation and access to information concerning water, water services and the environment ${ }^{197}$ and establish accountability mechanisms on the part of duty-bearers. ${ }^{198}$ Failure to observe these would be considered a violation ${ }^{199}$ which entails provision of adequate mechanisms for redress. ${ }^{200}$

The most basic definition of a human right-based approach is that it "is a framework that integrates the norms, principles, standards and goals of the international human rights system into the plans and processes of development. It is characterised by methods and activities that link the human rights system and its inherent notion of power and struggle with development." 201 The human rights principles which the approach entails are encapsulated by the acronym 'PANEL' (Participation, Accountability, Non-discrimination, Empowerment and Linkage to human rights norms). ${ }^{202}$ The Principles and Guidelines for a Human Rights Approach to Poverty Reduction Strategies developed by the office of the United Nations High Commissioner for Human Rights did not define the approach. However, the guidelines and principles clearly pointed out what the approach focuses on, and how it can be applied in the context of poverty reduction. These guidelines include identification of the poor; utilisation of national and international human rights instruments; equality and nondiscrimination; setting of targets, benchmarks and priorities; participation, monitoring and accountability; and international assistance and cooperation. ${ }^{203}$ Essentially, it involves the application of human rights norms in addressing economic and social imbalances.

Within development discourse, human right-based approaches to addressing economic, social, and cultural imbalances are gaining prominence in the $21^{\text {st }}$ century. ${ }^{204}$ This development draws our attention to the values and opportunities guaranteed by the approach and the promises it contains which are unavailable in other approaches. It is in this context that the advantages embedded in the approach can be identified and justification for its adoption can be found. The concept of 'rights' has values and opportunities. Different from preference, rights concern entitlements which can legally be claimed. ${ }^{205}$ Recognising certain

\footnotetext{
${ }^{196}$ UNCESCR, General Comment No. 15: The Right to Water (Arts. 11 and 12 of the Covenant) para. 47.

${ }^{197}$ Ibid. para. 48

${ }^{198}$ Ibid. para. 47.

${ }^{199}$ Ibid. paras. $39-44$.

200 ibid. para. 55.

${ }^{201}$ Jakob Kirkemann Boesen and others, Applying a Rights-based Approach: An Inspirational Guide for Civil Society (Danish Institute for Human Rights 2007) P. 9

202 Wouter Vandenhole and Paul Gready, 'Failures and Successes of Human Rights-Based Approaches to Development: Towards a Change Perspective' (2014) 32 Nordic Journal of Human Rights

${ }^{203}$ UNHCHR, Principles and Guidelines for a Human Rights Approach to Poverty Reduction Strategies (UNHCHR)

204 The Human Rights Council in Resolution 24/L.31 urged "development partners to adopt a human rights-based approach when designing and implementing development programmes in support of national initiatives and plans of action related to the right to safe drinking water and sanitation”, see UN Human Rights Council, The Human Right to Safe Drinking Water and Sanitationpara. 14

${ }^{205}$ John G. Merrils, 'Environmental Rights' in Daniel Bodansky, Jutta Brunnée and Ellen Hey (eds), The Oxford Handbook of International Environmental Law (The Oxford Handbook of International Environmental Law, Oxford University Press 2008) P. 665
} 


\section{Chapter One}

economic, social, or cultural issues for example as rights, invariably imposes an obligation not to deny or temper with them except in accordance with a prescribed procedure. In other words, the significance of those issues is recognised within the legal and administrative settings and good reasons must be provided for their denial. ${ }^{206}$

Human rights are tools for the protection of human dignity. ${ }^{207}$ Rights correlate with duties and human rights impose obligations on duty-bearers to take appropriate steps through which right-holders can meaningfully enjoy the rights. Importantly as put by Ellen Dorsey, human right-based approach mirrors " "the tenor of the discourse from charity to entitlement" and elevates development goals to "recognised standards and principles" with enhanced international legitimacy. ${ }^{208}$ It has been submitted that "a persuasive rationale for human rights is that they enable us to address the realisation of individual and group autonomy, which would be difficult, if not impossible, to achieve in other ways, thereby giving them a special place in legal and moral argument."209

Another value of a human rights-based approach as argued by some is in the context of its potentials for sustainability. ${ }^{210}$ That the approach reduces government and population dependency on external aid. This is achieved when right-holders (individuals and communities) having been empowered, independently can obligate duty-bearers (government and its agencies) to fulfil their obligations in the delivery of services and in the rights-holders' capacity to monitor the quality of services provided. ${ }^{211}$ In this way, rightsholders can be able to challenge governmental actions which negatively impact on the realisation of the right. The universality of human rights makes human right-based approach more suitable to development issues although understanding local context is a pre-requisite to human right-based approach's successful implementation. Several researches on the effectiveness of this approach have documented how its utilisation affected the effectiveness of development interventions in many countries. ${ }^{212}$

The way in which a human rights-based approach is applied defines the relationship between State and relevant actors applying it (development or human rights actors) which may be cooperative or confrontational. ${ }^{213}$ Human right-based approaches are usually applied in two contextual situations depending on whether the government is unable or unwilling to fulfil its obligations. If the government's failure to fulfil its obligation is on account of its inability, the approach is usually cooperative wherein financial and technical assistance are provided to the respective government in order to among others, develop its capacity, enhance its accountability and transparency measures, and incorporate participatory approach in the development and execution of its policies and programmes for the benefits

\footnotetext{
206 Ibid.

${ }^{207}$ Ibid.

${ }^{208}$ Quoted in Uwe Gneiting and others, 'Setting Higher Goals: Rights and Development' (December, 2009) Monday Developments (P. 19)

${ }^{209}$ John G. Merrils, 'Environmental Rights' P. 665

${ }^{210}$ Uwe Gneiting and others, 'Setting Higher Goals: Rights and Development' Pp. 19-20.

211 Ibid.

${ }^{212}$ See for example ibid. P. 19

213 Wouter Vandenhole and Paul Gready, 'Failures and Successes of Human Rights-Based Approaches to Development: Towards a Change Perspective' P. 295.
} 
Realising the Right to Water and Sanitation in Nigeria

of the rights-holders. Similarly, right-holders are enabled through empowerment to demand accountability from duty-bearers. ${ }^{214}$ This approach is done usually by development actors and the type of relationship is cooperative in nature. ${ }^{215}$ However, where the failure is on account of government' unwillingness, attention is on strengthening the capacity of local civil society organisations to put pressure on the relevant governmental authorities to fulfil their obligations. ${ }^{216}$ Human rights actors are involved in this approach which essentially is confrontational in nature. ${ }^{217}$ The major difference in the two approaches is therefore their 'legitimising anchors'. ${ }^{218}$ Each context has its advantages and disadvantages.

The advantage of cooperating with government is that it reduces reliance on aid by nongovernmental organisations through ensuring performance and delivery by the appropriate duty-bearer. ${ }^{219}$ The disadvantage however is that "it does not necessarily address underlying power inequalities and structural barriers that often inhibit rights claims of marginalized populations." 220 The advantage of NGOs adopting right-based is to develop appropriate strategies aimed at decreasing government reliance on external aid by translating "an analysis of why those services were not provided in the first place" which "entails looking beyond technical support and adopting advocacy efforts designed to challenge political and social factors affecting the accountability of the public authorities to local communities." ${ }^{221}$ It also has the advantage of identifying the marginalised and vulnerable groups. However, NGOs or their partners may experience difficulties in overcoming "deeply rooted patterns of social and economic inequality." 222

Human rights-based approach identifies, in the context of a particular right, duty-bearers and rights-holders and addresses issues interfering with human rights realisation. Water as public utility has multiple stakeholders. Generally, identifying the stakeholders requires reviewing the institutions empowered or vested with responsibility by the relevant legal and policy instruments. Identifying duty-bearers is a major step to improving capacity and ensuring accountability. However, accountability is not limited or restricted to duty-bearers. In certain circumstances, even the right-holders can be held accountable especially in the wake of several abandoned projects. Human right-based approach holds the promise of addressing these situations.

\footnotetext{
${ }^{214}$ Uwe Gneiting and others, 'Setting Higher Goals: Rights and Development' P. 19.

215 Wouter Vandenhole and Paul Gready, 'Failures and Successes of Human Rights-Based Approaches to Development: Towards a Change Perspective'P. 295).

${ }^{216}$ Uwe Gneiting and others, 'Setting Higher Goals: Rights and Development' P. 19.

217 Wouter Vandenhole and Paul Gready, 'Failures and Successes of Human Rights-Based Approaches to Development: Towards a Change Perspective' (P. 295)

${ }^{218}$ Human rights actors' approach is norm-based while development actors' approach is evidenced-based. See ibid. (p. 297)

${ }^{219}$ Uwe Gneiting and others, 'Setting Higher Goals: Rights and Development' P. 19.

${ }^{220}$ Ibid.

${ }^{221}$ Ibid.

${ }^{222}$ Ibid.
} 


\section{Chapter One \\ 1.9.2 Justification for the Adoption of a Human Rights-Based Approach in Water and Sanitation Sector in Nigeria}

The choice of a human rights-based approach in the realisation of access to water and sanitation in Nigeria is informed by the normative, pragmatic and ethical consideration discourse surrounding the approach and its focus which distinguishes it from other approaches such as need-based and utilitarian-driven approaches. ${ }^{223}$ Human right-based approach holds the promise of addressing social and economic imbalances. Its principles of equality, equity, accountability, empowerment and participation when juxtaposed with the political, economic, social, cultural and institutional factors inhibiting the realisation of access to water and sanitation in Nigeria, its adoption paints a promising future not only in the realisation of the right to water and sanitation but also the broader ESC rights in Nigeria. If utilised, the approach ensures that water and sanitation not only will be recognised as human rights, but also will shape focus on how projects and programmes are executed. Human rights-based principles will reshape how duty-bearers perceive their work and discharge their obligations; rights-holders understand their rights and demand their protection, promotion and fulfilment; the State discharges its international legal obligations; and efficiency and effectiveness are introduced into governance.

\subsubsection{The Ecosystems Approach}

The term "ecosystem" is an ecological term first coined by Arthur Roy Clapham ${ }^{224}$ upon a request by A.G Tansley and appeared in print in $1935 .{ }^{225}$ The term was then used to denote "the physical and biological components of an environment considered in relation to each other as a unit". ${ }^{226}$ It is a sort of a top-down approach to management in conservation. Ever since its coinage, it entered the common parlance and loosely used as a general framework especially in scientific literature. ${ }^{227}$ The term has been used in variety of ways ${ }^{228}$ more prominently in the context of conservation. Ecosystem is therefore not a legal term or a concept with protection or connoting certain obligations under the law. The term is used loosely in relations to techniques which States may adopt in sustainable development. Because of its loose nature especially in law, review of literature suggested that it has no strict definition under international law. Rather it's being used in broad manner and its definitions under international law remain to this day, inconsistent. ${ }^{229}$ At the most, it is an approach by which States' and human activities are 'restraint' on the basis of their detrimental effects to objects of significant importance.

\footnotetext{
${ }^{223}$ These issues have been discussed in chapter seven.

${ }^{224}$ A. J. Willis, 'Arthur Roy Clapham. 24 May 1904-18 December 1990' (1994) 39 Biographical Memoirs of Fellows of the Royal Society 73 P. 81.

${ }^{225}$ In Arthur G. Tansley, 'The Use and Abuse of Vegetational Concepts and Terms' (1935) 16 Ecology 284 (see A. J. Willis, 'The Ecosystem: An Evolving Concept Viewed Historically' (1997) 11 Functional Ecology 268 at P. 268. ${ }^{226}$ A. J. Willis, 'The Ecosystem: An Evolving Concept Viewed Historically' P. 268.

227 Timothy P. Moulton, 'Ecosystem Theory and Conservation' (2012) 22 Aquatic Conservation: Marine and Freshwater Ecosystems 423 P. 423.

${ }^{228}$ A. J. Willis, 'The Ecosystem: An Evolving Concept Viewed Historically' (at p. 268); see also Raymond Laurel Lindeman, 'The Trophic-Dynamic Aspect of Ecology' (1942) 23 Ecology 399

${ }^{229}$ Dan Tarlock, 'Ecosystems' in Daniel Bodansky, Jutta Brunnée and Ellen Hey (eds), The Oxford Handbook of International Environmental Law (The Oxford Handbook of International Environmental Law, Oxford University Press 2008) P. 576
} 
Realising the Right to Water and Sanitation in Nigeria

The underlying idea behind it in law seems to "refer to a process of decision as well as to a substantive obligation to protect a defined resource or geographical area." ${ }^{230}$ Clearly, in legal instruments, ecosystem as a term is also used very loosely "and interchangeably with other similar terms such as environment, nature, balance of nature, ecological balance, or ecological stability."231

In science, the term ecosystem was defined in descriptive term which does not provide much guidance to a legal or policy maker relating to the designing of protection levels and processes. ${ }^{232}$ For example, it was used to refer to "a biological community of interdependent plants, animals, and microorganisms that occurs in a specific place associated with particular soils, temperatures, and disturbance patterns and the physical and chemical factors that make up that community's abiotic, non-living environment."233 The Convention on Biological Diversity defines it as "a dynamic complex of plant, animal and micro-organism communities and their non-living environment interacting as a functional unit." ${ }^{234}$ It is used "as a general framework" in situations where there is interaction of multiple factors, ${ }^{235}$ and where there is intense competition in the use and management of a single resource. The concept appeared to be a powerful organising principle of public policy, which, as an approach puts restraints on individuals, States and organisations in their modification or activities, scientific or otherwise to have concern for the organisms which are part of the man's environment and for which directly or indirectly are beneficial to human beings. In other words, to have respect for the environment for which human beings depend on and in which they derive their means of livelihood.

Although, legally and environmentally, the term ecosystem does not connote obligation, it must however be noted that in many States, legislations have imposed obligation of environmental impact assessment/analysis on any programme or project with potential impact on the environment. It is in the context of protecting these objects and organisms of fundamental importance to the well-being of human beings that the term is used as a powerful public policy approach and a framework which mainstreams environmental considerations in policies, projects and programmes in development issues.

In keeping with the tradition on the use of the term, this research is utilising it in relation to concern for 'environmental health' ${ }^{236}$ within the context of sustainable development and preservation of the functions of natural environment. The concept of sustainable development had "highlighted the need for an integrative science to safeguard ecosystems at risk."237 Sustainable development may be regarded as one if not the best approach for maintaining a healthy planet. Sustainable development was defined as 'the integration of conservation and

\footnotetext{
${ }^{230}$ John G. Merrils, 'Environmental Rights'

${ }^{231}$ Such as the way the term was used in the 1988 Convention on the Regulation of Antarctic Mineral Resources Activities defines as harm as 'any harm on the living and non-living components of that environment or those ecosystems.' See generally Dan Tarlock, 'Ecosystems' in John G. Merrils, 'Environmental Rights' P. 576.

${ }^{232}$ John G. Merrils, 'Environmental Rights' P. 576.

233 Ibid.

${ }^{234}$ Convention on Biological Diversity, 1992, S. 2

235 Timothy P. Moulton, 'Ecosystem Theory and Conservation' P. 423.

${ }^{236}$ David J. Rapport, Connie L. Gaudet and Peter Calow (eds), Evaluating and Monitoring the Health of Large-Scale Ecosystems (Springer Berlin Heidelberg 2013)

${ }^{237}$ A. J. Willis, 'The Ecosystem: An Evolving Concept Viewed Historically' P. 270.
} 


\section{Chapter One}

development to ensure that modifications to the planet do indeed secure the survival and wellbeing of all people." 238

Ecosystem is an "overarching paradigm for both development and environmental protection" 239 and in the sense that it serves as catalyst to both development and environmental protection it may not be an abstract concept. It was developed and used with the best of intentions and which at the heart of it, lies the concern for human development. Principle 1 of Rio Declaration on Environment and Development correctly posited that "[h]uman beings are at the centre of concerns for sustainable development" because as humans "[t]hey are entitled to a healthy and productive life in harmony with nature." ${ }^{240}$ Goal 7 of MDGs and goal 6 of Sustainable Development Goals (SDGs) have reiterated the sustainability of environment by utilising appropriate methodologies/approaches in the management of environment. Human beings cannot be separated from nature and in this regard, the concept of sustainable development has featured in many international legal instruments. ${ }^{241}$

The Ecosystems Approach is therefore a strategy that is aimed at ensuring the sustainable and peaceful coexistence of the various organisms, living and non-living things and the conservation of resources in which the organisms depend on for the common and mutual benefits of all. The approach is necessary because of the ways the components of ecosystem interact, influence and impact on each other. Hence, water and environment are to be managed in a mutually reinforcing manner. Additionally, since human beings heavily rely on these two for their survival, it presupposes that they and their means of livelihood are to be considered alongside conservation measures. ${ }^{242}$ An ecosystems approach is flexible, and its application is required to be adapting due to dynamic nature in time and space of ecosystems and uncertainties surrounding their potential futures. ${ }^{243}$

\subsubsection{Justification for the Adoption of an Ecosystems Approach in Water and Sanitation Sector in Nigeria}

Water is a cross-cutting resource and a necessary ingredient in human and environmental protection. It is integral in economic, social and cultural developments and in some cases, a political resource capable of creating tension among competing users, States or communities. Undoubtedly, water is needed for human consumption, it is necessary for rivers and lakes to

\footnotetext{
${ }^{238}$ IUCN, World Conservation Strategy: Living Resource Conservation for Sustainable Development (IUCN 1980)

${ }^{239}$ Daniel Barstow Magraw and Lisa D. Hawke, 'Sustainable Development' in Daniel Bodansky, Jutta Brunnée and Ellen Hey (eds), The Oxford Handbook of International Environmental Law (The Oxford Handbook of International Environmental Law, Oxford University Press 2008) P. 613.

240 United Nations, 'Rio Declaration on Environment and Development' (UNEP, 1992) <http://www.unep.org/documents.multilingual/default.asp?documentid=78\&articleid=1163> accessed 11 February, 2014 Principle 1.

${ }^{241}$ See for example The United Nations Framework Convention on Climate Change which provides, in Article 3, on principles that ' $[\mathrm{t}]$ he Parties have a right to, and should, promote sustainable development.' The Convention on Biological Diversity, which strives to conserve the world's genetic, species, and ecosystem diversity emphasizes 'sustainable use' and the Statement of Principles on Forests which expressed the global consensus on the management, conservation, and 'sustainable development' of the world's forests.

${ }^{242}$ Gill Shepherd (ed), Ecosystem Approach: Learning from Experience (IUCN 2008)

${ }^{243}$ Ibid. P. 4
} 
Realising the Right to Water and Sanitation in Nigeria

flow; it is required for agriculture, irrigation, industrialisation and indeed for a healthy maintenance of environment among others.

Internationally, water has been recognised as a basic human need. A human rights-based approach transforms this water need to water right ${ }^{244}$ with attendant obligations to fulfil. Provision of clean and quality water for personal and domestic uses obliges States to generate and refine water in sufficient quantity to satisfy people's demand. The use of technology in this context in some ways interferes with the natural environment which if no adequate measures are taken could put the environment at risk and render it unsustainable. Water is either generated from the underground sources or the surface. The methods of generating it could in ways significantly, impact on the availability of water in sufficient quantity to sustain other living and non-living things such as the lakes and aquifers and the surrounding ecosystems for which the health of the environment and human beings depend on. The importance of putting the health of the ecosystems and their carrying capacity at the centre hence, cannot be overemphasised. Unrestricted generation of water from underground sources through boreholes constructions and other mechanical means, for example, has been a subject of complaint by the Lagos State Government to the National Council of Water due to its consequential effects.

Lagos State Government alarmingly noted the unsustainable rate at which abstraction of underground water is posing "a serious risk of irreversible deterioration on an increasingly widespread basis in the aquifers." 245 This underscores a point that technology and social organisation are affecting the natural environment. ${ }^{246}$ According to the State Government "Groundwater over-exploitation can lead to imbalance in the hydrological cycle and consequent effects such as aquifer depletion/degradation, saline intrusion risk in coastal city centres and subsidence in susceptible environment." 247 The danger posed by over abstraction forces the State Government to adopt a legislation ${ }^{248}$ to regulate, control and monitor the rates of abstraction for sustainable groundwater supplies in the State and in order to protect vulnerable aquifers.

It was rightly pointed out that "[w]hen speaking of the 70-20-10 per cent division of water use between the agricultural, industrial and household sectors, water for ecosystems is not considered at all. Yet the preservation of rivers, lakes and wetlands evidently relies on sufficient water resources." ${ }^{249}$ Modern States, in their attempt to contain the situation are mainstreaming environmental considerations in the reforms or review of their water legislations. ${ }^{250}$ The competing and competitive needs of water in the light of the concept of

\footnotetext{
${ }^{244}$ Amanda Cahill, 'The Human Right to Water - A Right of Unique Status': The Legal Status and Normative Content of the Right to Water' P. 390.

${ }^{245}$ Lagos State Government, Action Memorandum on Groundwater Regulation in Lagos State (Federal Ministry of Water Resources 2008)

${ }^{246}$ World Commission on Environment and Development, Our Common Future (Oxford University Press 1987)

${ }^{247}$ Lagos State Government, Action Memorandum on Groundwater Regulation in Lagos State NCWR/08/19/AM4, submitted to the National Council on Water.

${ }^{248}$ Known as Lagos State Water Sector Law, No. 14 of 2004

${ }^{249}$ Inga T. Winkler, The Human Right to Water: Significance, Legal Status and Implications for Water Allocation p. 30

${ }^{250}$ See Stefano Burchi, Balancing Development and Environmental Conservation and Protection of the Water Resource Base: The 'Greening' of Water Laws (Foundation Books 2010)
} 


\section{Chapter One |}

"sustainability" makes it necessary that an integrative or a combination of approaches be adopted which ensures that in providing water for personal and domestic uses, the interest of future generation is not put at risk and the manner in which water is generated and managed is environment friendly. Water generation, distribution and management is consistent with an ecosystems approach. Human, institutional and environmental demands of water necessitate the adoption of holistic approach to how these can be balanced in an equitable manner. $^{251}$

A human right-based approach is a recognised concept in development centred on respect for human rights while the ecosystems approach is a technique aimed at ensuring the protection of the environment, the surrounding ecosystems goods and services and preservation of biodiversity. Although concerns may be raised when these approaches are combined, ${ }^{252}$ but with strategic management, they provide a holistic approach to the realisation of ESC rights in general and access to water and sanitation in particular.

\subsubsection{Compatibility of a Human Rights Based-Approach and an Ecosystem Approach}

There is a tendency to argue in favour of a human rights-based approach against an ecosystems approach because of its emphasis on the need to concentrate on the marginalised. However, there is no significant tension when the two approaches are combined, and their promotion are pursued concurrently. Human rights are interdependent and interrelated. Their enjoyment is impacted by multiple factors and processes including availability and sound management of resources, environmental conditions and other externalities. Relevance of ecosystems approach is better appreciated when conditions contributing to the enjoyment of rights are factored into consideration. It is not sufficient to argue that authorities must make available food for their population. The quantity and quality of the food are to a large extent determined by other processes. It is a matter of logical understanding to appreciate that ecosystem controls the extent to which authorities would be able to discharge their human rights obligations. A classic example could be seen from Ruhl and Salzman illustration:

When we bite into a juicy apple and pause to think about where it came from, once we look beyond the store where it was purchased and the orchard where it was grown, we may think of soil and water, but it is unlikely we also consider the natural pollinators that fertilized the apple blossom so the fruit can set. When we drink a cool glass of water from the tap we may think of the local reservoir, but the real source of the water quality lies many miles upstream in the wooded watershed that filters and cleans the water as it flows downhill. When we enjoy a fun holiday at the beach we may think of the warm sun, but not of the carbon sequestration by plants that contributes to climate stability. ${ }^{253}$

The idea here is that natural goods and services are controlled by components of ecosystems. When the two approaches are compared, similarities are identifiable. Chapters seven and eight address the principles of human rights-based and ecosystems approaches

\footnotetext{
${ }^{251}$ See Secretariat of the Convention on Biological Diversity, Ecosystem Approach (CBD Guidelines)

${ }^{252}$ See Hugo Tremblay, 'A Clash of Paradigms in the Water Sector? Tensions and Synergies Between Integrated Water Resources Management and the Human Rights- Based Approach to Development' (2011) 51 Natural Resources Journal 307

${ }^{253}$ J. B. Ruhl and James E. Salzman, 'The Law and Policy Beginnings of Ecosystem Services' (2007) 22 Journal of Land Use \& Environmental Law P. 157
} 
Realising the Right to Water and Sanitation in Nigeria

respectively. Clearly, the approaches share certain principles in common such as the principles of participation, accountability and equity ${ }^{254}$ which aimed at ensuring human rights realisation and sustainable utilisation of the natural environment. These similarities provide the basis and framework for their integration and joint pursuit in such a way that their combined application reinforces each other.

\subsection{Structure of the Research}

This research consists of ten chapters. Chapter one provides the general introduction to the research context including country background and water and sanitation situation. Chapter two examines the international legal obligations under the right to water and sanitation. Chapter three analyses Nigeria's human rights environment including institutions for the protection of human rights and those relevant to water and sanitation. Chapter four assesses Nigeria's compliance with the obligations under the right to water and sanitation by examining relevant laws and policies as well as indicators obtained from the empirical study conducted in this research. The chapter provides response to research question one. Chapter five examines the extent of Nigerians' awareness of the existence of the right to water and sanitation as response to research question two. This will be done through empirical study through which responses from duty-bearers and rights-holders will be examined. Chapter six contains findings and observations of political, economic, social, cultural and environmental factors contributing to or sustaining poor water and sanitation coverage in Nigeria. The chapter provide answers to research question three. Chapters seven, eight and nine responds to research question four. In chapter seven principles of interpretation, specifically purposive, liberal and integrated approaches will be examined in relations to how these approaches have influenced the transformation of non-justiciable rights in other jurisdictions around the world. This is important in order to provide an insight on how the Nigerian judiciary can approach the problems of non-justiciability of ESC rights (which includes the right to water and sanitation) in Nigeria. Chapter eight examines the concept of a human rights-based approach and its principles in order to assess its potentials in addressing some of the challenges identified in the research. Similarly, chapter nine analyses the concept of an ecosystems approach and its principles with a view to suggesting how the approach can be utilised in Nigeria in order to ensure environmental sustainability in the context of water generation and management. Chapters 7, 8 and 9 provide response to research question four. Chapter ten summarises the findings on the research questions and provides recommendations.

\subsection{Limitation of the Study}

This is a single-country study, context-specific and limited to Nigeria. It does not attempt to generalise the result to other countries. However, while the analysis is grounded in the context of Nigeria, some of the issues identified could account and are relevant in understanding the larger context of how developing countries are struggling with the realisation of ESC rights as well as the conditions and settings under which deprivations take

\footnotetext{
${ }^{254}$ Refer to chapter 8 in this thesis on the principles of ecosystems approach as developed by the Secretariat of the Convention on Biological Diversity.
} 


\section{Chapter One}

place. As such, the findings are capable of deconstructing other countries' situations and may provide the same or similar results. Realisation of ESC rights takes place across a wide range of issues involving economic, social, cultural and political conditions. An in-depth singlecountry study focussing on these myriad issues could be a better approach to addressing the fundamental issues associated with the non-realisation of these rights.

It also needs to be added that the case study is merely illustrative and does not generally prove similar position in other regions of the country. This is because in some cases, differences exist in other regions especially on rights-holders' behaviour, awareness and willingness to assert human rights claims. Some of these differences have been noted in the research. 


\section{Chapter Two}

\section{Analysis of Legal Obligations Under the Human Right TO Water AND SANitation}

\subsection{Introduction}

The focus of this chapter is analysing the concept of human rights to water and sanitation; its recognition and its legal and normative contents. It discussed how water and sanitation were recognised as human rights, what this recognition entails and the contents of the right in terms of sufficiency, (availability and quantity), quality (safety of water), accessibility and affordability. In this chapter, only doctrinal sources were utilised, ${ }^{255}$ and where appropriate, the databases and publication of Waterlex ${ }^{256}$ and ESCR-Net ${ }^{257}$ which documents cases on water and sanitation from various jurisdictions were used.

\subsection{The Right to Water and Sanitation: United Nations Committee on ESCR, HRC and UNGA}

Clean water and sanitation are the most basic and compelling human need. The debate on human right to water started in the mid-1970s. ${ }^{258}$ The concept 'right to water' has been traced first to the proclamations of international conferences and then to the jurisprudential interpretation of treaties ${ }^{259}$ which define its contents and obligations.

The human right to water had been recognised notably by the UN Committee on ESC rights first in its General Comment 6 of 12 August $1995^{260}$ and later in General Comment 15 of $11-29$ November 2002. ${ }^{261}$ It was expressly recognised in the latter that the right to water is a human right which "entitles everyone to sufficient, safe, acceptable, physically accessible

\footnotetext{
${ }^{255}$ It is acknowledged that a strict legal analysis can only provide a hint as to whether rights are respected and protected and that assessing the obligation to 'facilitate and fulfil' the rights require adopting a different methodological approach such as those available in social science. Other chapters to follow will address these issues using such social science tools.

${ }^{256}$ WaterLex and WASH United, The Human Rights to Water and Sanitation in Courts Worldwide: A Selection of National, Regional and International Case Law (WaterLex 2014) See also Waterlex, 'The Human Rights to Water and Sanitation in Courts Worldwide: A Selection of National, Regional and International Case Law' https://www.waterlex.org/publications/the-human-rights-to-water-and-sanitation-in-courts-worldwide/

${ }^{257}$ See ESCR-Net, 'Caselaw Database' https://www.escr-net.org/caselaw.

${ }^{258}$ From Mar Del Plata Action Plan of 1977 which was the first instrument to make reference to right to water; see also Salman M.A. Salman, 'The Human Right to Water - Challenges of Implementation' (2012) 106 American Society of International Law Proceedings P. 44.

${ }^{259}$ Antonio E. Irujo, 'The Right to Water' (June, 2007) 23 International Journal of Water Resources Development 267 (p. 271-274) making reference to among others, Declaration of Dublin on Water 1992; International Decade of Action, Water for Life, 2005-2015 and; Ministerial Declaration of the Third World Water Forum in Kyoto, 22-23 March 2003.

${ }^{260}$ UNCESCR, General Comment No. 6: The Economic, Social and Cultural Rights of Older Persons (1995) Paras. 5 and 32.

${ }^{261}$ UNCESCR, General Comment No. 15: The Right to Water (Arts. 11 and 12 of the Covenant)
} 
Realising the Right to Water and Sanitation in Nigeria

and affordable water for personal and domestic uses."262 Sanitation on the other hand has been defined by the Independent Expert on the issue of human rights obligations related to access to safe drinking water and sanitation "as a system for the collection, transport, treatment and disposal or reuse of human excreta and associated hygiene." 263 The Independent Expert considered that "States must ensure without discrimination that everyone has physical and economic access to sanitation, in all spheres of life, which is safe, hygienic, secure, socially and culturally acceptable, provides privacy and ensures dignity." 264 These definitions were a jurisprudential interpretation derived from several international legal instruments and documents. ${ }^{265}$ There were several other documents recognising this right; however, the year 2010 was instructive. It was the year that the United Nations General Assembly (UNGA) formally, through resolution A/RES/64/292 recognised the right to clean water and sanitation as a human right "essential to the full enjoyment of life and all other human rights". 266

The right to water, at least before its formal recognition by the UNGA could at best be described an 'implied right' or "derivative right". ${ }^{267}$ It was derived from the interpretation of articles 11 and 12 of the ICESCR and right to life and human dignity. This procedure is a well-recognised method in legal interpretation and in human rights context. ${ }^{268}$ As such, the

\footnotetext{
262 Ibid. Para. 2.

${ }^{263}$ UN Human Rights Council, Report of the Independent Expert on the Issue of Human Rights Obligations Related to Access to Safe Drinking Water and Sanitation, Catarina de Albuquerque (UN Doc A/HRC/12/24 1 July 2009)UN Human Rights Council, Report of the Independent Expert on the Issue of Human Rights Obligations Related to Access to Safe Drinking Water and Sanitation, Catarina de Albuquerque (UN Doc A/HRC/12/24, 1 July 2009) Para. 63.

${ }^{264}$ UN Human Rights Council, Report of the Independent Expert on the Issue of Human Rights Obligations Related to Access to Safe Drinking Water and Sanitation, Catarina de Albuquerque UN Human Rights Council, Report of the Independent Expert on the Issue of Human Rights Obligations Related to Access to Safe Drinking Water and Sanitation, Catarina de AlbuquerqueThis definition seemed to have been accepted by the UN Committee on ESC rights in its Statement on the Right to Sanitation. See UNCESCR, Statement on the Right to Sanitation (19 November 2010)

${ }^{265}$ See art. 14, Para. 2 (h), Convention on the Elimination of All Forms of Discrimination Against Women; art. 24, para. 2 (c), Convention on the Rights of the Child; arts. 20, 26, 29 and 46 of the Geneva Convention relative to the Treatment of Prisoners of War, of 1949; arts. 85, 89 and 127 of the Geneva Convention relative to the Treatment of Civilian Persons in Time of War, of 1949; arts. 54 and 55 of Additional Protocol I thereto of 1977; arts. 5 and 14 Additional Protocol II of 1977; preamble, Mar Del Plata Action Plan of the United Nations Water Conference; see para. 18.47 of Agenda 21, Report of the United Nations Conference on Environment and Development, Rio de Janeiro, 3-14 June 1992 (A/CONF.151/26/Rev.1 (Vol. I and Vol. I/Corr.1, Vol. II, Vol. III and Vol. III/Corr.1) (United Nations publication, Sales No. E.93.I.8), vol. I: Resolutions adopted by the Conference, resolution 1, annex II; Principle No. 3, The Dublin Statement on Water and Sustainable Development, International Conference on Water and the Environment (A/CONF.151/PC/112); Principle No. 2, Programme of Action, Report of the United Nations International Conference on Population and Development, Cairo, 5-13 September 1994 (United Nations publication, Sales No. E.95.XIII.18), chap. I, resolution 1, annex; paras. 5 and 19, Recommendation (2001) 14 of the Committee of Ministers to Member States on the European Charter on Water Resources; resolution 2002/6 of the United Nations Sub-Commission on the Promotion and Protection of Human Rights on the promotion of the realization of the right to drinking water. the report on the relationship between the enjoyment of economic, social and cultural rights and the promotion of the realization of the right to drinking water supply and sanitation (E/CN.4/Sub.2/2002/10) submitted by the Special Rapporteur of the Sub-Commission on the right to drinking water supply and sanitation, Mr. El Hadji Guissé (as contained in General Comment 15).

${ }^{266}$ United Nations General Assembly, The Human Right to Water and Sanitation (United Nations 28 July, 2010)

${ }^{267}$ Peter Gleick, 'The Human Right to Water' (1999) 1 Water Policy

${ }^{268}$ Antonio E. Irujo, 'The Right to Water'p. 267-283); Salman M.A. Salman, 'The Human Right to Water Challenges of Implementation' P. 45)
} 
right to water and sanitation is not strongly disputed. ${ }^{269}$ In fact, not a single vote was casted against it at the UNGA. ${ }^{270}$ The abstention of 41 out of 163 nations was not on the basis of a strong opposition to the recognition of the right in principle but essentially on the manner in which the text of the resolution was introduced and the surrounding circumstances in respect of water and sanitation. ${ }^{271}$ The overwhelming support enjoyed by the resolution indicates that, the right to water and sanitation enjoys no strong opposition from States. Differences of opinion between States seemed to have centred on whether the recognition of the right to water and sanitation introduced new human right or confirms an existing independent human right, or it is merely a component of other human rights. ${ }^{272}$

The recognition of water and sanitation as human rights was of course a three-decade long activity which the resolution clearly outlined. Reference can be made to the United Nations Mar Del Plata Conference on Water 1977. Although at this Conference, water was not, on its own, specifically recognised as a human right, access to it by the people, whatever their economic or social status was considered to be a right. ${ }^{273}$ The availability of water was essentially linked to life and man's full development ${ }^{274}$ and it was unambiguously realised that there is an inextricable link between accelerated and orderly administration of water and improvement of economic and social condition of mankind. ${ }^{275}$ Instructively, it was appreciated that ensuring a better quality of life and promotion of human dignity and happiness will not be possible unless solutions to the issue are found and applied at the domestic, regional and international levels. ${ }^{276}$ Better quality of life and human dignity are

\footnotetext{
${ }^{269}$ See Jonathan Verschuuren, 'The Right to Water as a Human Right or a Bird's Right: Does Cooperative Governance offer a Way Out of a Conflict of Interest and Legal Complexity?' Pp. 359-387.

${ }^{270}$ Interestingly, Nigeria was among the States voted in favour of the resolution.

${ }^{271}$ It was a period when the Geneva-based Human Rights Council was working on the issue and an independent expert was appointed. The abstention by the United States for example was on the basis that voting on the right by the General Assembly would undermine a similar process then taking place at the Geneva-based Human Rights Council because of its description of the right as being not in accordance with the way it is reflected in existing international law and the manner in which the text was drafted (the view of undermining the Geneva led process was shared by Turkey). The US had hoped that the legal implication of such recognition is first considered. Other delegates had wanted a consensus first to be reached before a vote on the text is tabled. None of the delegates however disputed the significance of water and sanitation and the inextricable link with other human rights (see United Nations, 'General Assembly Adopts Resolution Recognizing Access to Clean Water, Sanitation as Human Right, by Recorded Vote of 122 in Favour, None against, 41 Abstentions' 28 July, 2010) <http://www.un.org/press/en/2010/ga10967.doc.htm> accessed 17 August, 2013

${ }^{272}$ During the adoption of resolution 64/292 some States found it necessary to state their understanding although supporting the text as adopted. Brazil was of the view that the right is intrinsically connected to right to life, food and adequate housing, Egypt understood the resolution as not creating new or sub-categories of right other than those contained in international human rights documents, New Zealand appreciated that access to water and sanitation was related to development and realization of the MDGs, Australia positioned that access to water and sanitation is linked to a range of civil rights, Costa Rica considered it as inalienable right, Netherlands and Mexico considered it as a right, Ethiopia and Yemen understood it as a natural right, Liechtenstein understood it to be a component of other human rights, for Cuba it was merely an affirmation of the right, Nicaragua viewed the adoption as a recognition of a new right after 15 years of discussion at the global level and Palestine as observer welcomed its adoption as a universal right. See United Nations General Assembly, Sixty-Fourth Session: 108th Plenary Meeting 28 July 2010)

${ }^{273}$ United Nations, Report of the United Nations Water Conference (United Nations 14-25 March 1977). Resolutions, P. 66

${ }^{274}$ Ibid., Resolutions. P. 67.

275 Ibid. Chap. 1, P. 3.

${ }^{276}$ Ibid.
} 
Realising the Right to Water and Sanitation in Nigeria

rights recognised in various international human rights instruments, documents and several States constitution.

During the discussion on the text of resolution 64/292 tabled by Bolivia for voting, the UNGA official record of speeches of the plenary ${ }^{277}$ showed that several States voiced concern of lack of consensus and the opportunity to critically analysed the contents of text before calling for voting. The concern basically was not on the existence of several references to the right to water and sanitation in many international legal instruments and documents or that water and sanitation are not fundamental components of other recognised rights but on the manner in which the text was introduced for voting before prior negotiations. Several States had wanted, because of the significance of the subject that a consensus is first reached before a resolution is tabled for voting. ${ }^{278}$ This according to them would provide a common ground for understanding and its relationship with the Human Rights Council led process and the work of the Independent Expert on the issue are clearly explained.

Only United States and United Kingdom were of the view that the text of the resolution described the right to water and sanitation in a way not in accordance with existing international law. ${ }^{279}$ According to the US, there was no "right to water and sanitation" in an international legal sense. Although the UK was of the view that no sufficient legal basis exists to support the recognition of water and sanitation as "freestanding human right" it had expressly admitted supporting the resolution establishing the independent expert on the issue as well as the text on human rights and access to water and sanitation adopted in 2009. The view that under existing international law no right to water and sanitation exist is however, not tenable in view of several international documents alluding to the right.

Even among those who abstained from voting, Netherlands and Ethiopia for example, have recognised the existence of the right. Netherlands had wanted sufficient responsibility placed on national governments and redress mechanisms made available to citizens while Ethiopia considered right of access to clean water as a natural right, but the concern was that the text ought to have included the recognition that States had sovereign right to their natural resources. $^{280}$

The General Assembly recognition conferred the right to water and sanitation an important stand within the rank of soft law. The lack of opposition to the right, demonstrated the willingness of the international community to accord it a status close to customary right. It is acknowledged that practice among States differs, but it is also worth noting that no State has so far asserted that water and sanitation can be denied to a community or individual. No State has denied or would be willing to deny the inextricably linked of water and sanitation to right to life and adequate standard of living and that their deprivation would not constitutes a violation of those rights.

\footnotetext{
${ }^{277}$ United Nations General Assembly, Sixty-Fourth Session: 108th Plenary Meeting

${ }^{278}$ States which had wanted a consensus included United States, Spain, Germany, Hungary, Norway, Guatemala, Egypt, Costa Rica, Botswana, United Kingdom, France, Japan, Russian Federation, Belgium, Canada, and Yemen. However, among these, only United States, Botswana, Canada, United Kingdom, and Japan abstained from voting. ${ }^{279}$ United Nations General Assembly, Sixty-Fourth Session: 108th Plenary Meeting

${ }^{280}$ Ibid.
} 


\section{Chapter Two}

The recognition of the right to water is however restricted to personal and domestic uses. These have been defined to mean water for "drinking, personal sanitation, washing of clothes, food preparation, personal and household hygiene". ${ }^{281}$ This is better understood from the context under which the right exists i.e. its links with right to life and adequate standard of living. Although water is required for several purposes such as washing, cooking, drinking, farming, sanitation, industrialisation etc. ${ }^{282}$ It is only in the context of personal and domestic uses as defined, that the right should be construed. ${ }^{283}$ The right to sanitation was equally derived from the rights to adequate standard of living, health, housing and the right to water. ${ }^{284}$ Sanitation was considered essential requirement for leading a life in dignity. ${ }^{285}$ While inextricable link exists between water and sanitation, there are some features of right to sanitation which are independent and specific and which require separate treatment. ${ }^{286}$ One of the issues is the gender dimension of the right to sanitation. ${ }^{287}$

Additionally, important development on the recognition given to access to water and sanitation from the UNGA perspective is their incorporation in both the MDG and SDG goals. Goal 7 of the MDG and Goal 6 of the SDG were dedicated to the promotion of access to water and sanitation and targets and indicators were provided. ${ }^{288}$ SDG Goal 6 is dedicated to achieving universal and equitable access to safe and affordable water and sanitation for all by the year 2030. Water quality is expected to equally be improved and the proportion of untreated water is halved by the same year through the elimination of dumping and minimisation of hazardous chemicals and materials. Other areas addressed by the Goal 6 of the SDG include implementation of integrated water resources management at all levels, restoration of water-related ecosystems, expansion of international cooperation and capacitybuilding support to developing countries on water and sanitation related activities and programmes, as well as supporting and strengthening the participation of local communities in improving water and sanitation management. Goal 17 of the SDG is dedicated to implementation mechanisms and strategies in reaching the goals.

Other important international actors that contribute to the promotion and realisation of the right to water and sanitation include the Special Rapporteur on the human right to safe drinking water and sanitation. Through studies and reports, the Special Rapporteur identified several issues positively and negatively impacting on the realisation of the right to water and sanitation. In the reports submitted to the General Assembly, the Special Rapporteur has assessed for example, the roles development cooperation can and should play in the

\footnotetext{
${ }^{281}$ UNCESCR, General Comment No. 15: The Right to Water (Arts. 11 and 12 of the Covenant)

${ }^{282}$ J. O. Ayoade, 'Water Resources and their Development in Nigeria'. P. 581.

${ }^{283}$ See UNCESCR, General Comment No. 15: The Right to Water (Arts. 11 and 12 of the Covenant)

${ }^{284}$ UNCESCR, Statement on the Right to Sanitation Para. 7.

${ }^{285}$ Ibid. See also UN Human Rights Council, Report of the Independent Expert on the Issue of Human Rights Obligations Related to Access to Safe Drinking Water and Sanitation, Catarina de Albuquerque

${ }^{286}$ UN Human Rights Council, Report of the Independent Expert on the Issue of Human Rights Obligations Related to Access to Safe Drinking Water and Sanitation, Catarina de Albuquerque Para. 55. The Independent Expert noted that "Sanitation, more than many other human rights issue, evokes the concept of human dignity; consider the vulnerability and shame that so many people experience every day when, again, they are forced to defecate in the open, in a bucket or a plastic bag. It is the indignity of this situation that causes the embarrassment."

${ }^{287}$ See Sections 2.5.4 and 2.6.

${ }^{288}$ See Table 4.16 for the targets and indicators of SDG Goal 6.
} 
Realising the Right to Water and Sanitation in Nigeria

realisation of the right and their obligations under human rights law with specific reference to article 2(1) ICESCR. ${ }^{289}$ The report identified the human rights obligations of the less developed States to develop plans, strategies and programmes consistent with their human rights obligations and the develop States to render cooperation assistance in line with their human rights obligations. Multilateral and non-governmental organisation equally have human rights responsibilities in the context of realising the right to water and sanitation to ensure that their activities and programmes are consistent with human rights principles. ${ }^{290} \mathrm{In}$ a report to the $72^{\text {nd }}$ Session of the General Assembly, after examining case studies on how funders contribute to the realisation of the right to water and sanitation through the incorporation of the normative contents of the right to water and sanitation and human rights principles in their policies, strategies and operational tool, the Special Rapporteur proposed a the concept of a "human rights development cycle" to serve as a framework for funders in order to safeguard and implement the human rights to water and sanitation in their development cooperation activities. ${ }^{291}$ The proposed human rights development cycle identified stages "where funders can place guarantees and safeguards to ensure that their development cooperation will fully incorporate human rights."292

In a report to the $33^{\text {rd }}$ session of the UN Human Right Council, the Special Rapporteur focused on gender equality in the realisation of the right to water and sanitation. ${ }^{293}$ The report noted the inequalities between men and women which translate into unequal opportunities in the content of human rights. The United Nations General Assembly has clearly voiced this concern in resolution 70/169 in which it reiterated its concern on the barriers women and girls faced concerning access to water and sanitation and the various risks which women are exposed to including attacks, sexual and gender-based violence, harassment and other threats and how these impact on their enjoyment of human rights. The General Assembly resolution called upon States to ensure progressive realisation of the right to water and sanitation in a non-discriminatory manner and eliminating inequalities in access. ${ }^{294}$ To address inequalities in the context of realising the right to water and sanitation, the Special Rapporteur recommended the adoption of a transformative approach in addressing gender inequalities in the context of water and sanitation. The approach challenges social norms, stereotypes and intra-household patterns, which produce negative effects on women and girls. The approach promote gender-responsive interventions that prioritise the implementation of women's specific needs.

In another report to the $36^{\text {th }}$ session of the UN Human Rights Council, the Special Rapporteur focussed on service regulation and its role in the progressive realisation of the

\footnotetext{
${ }^{289}$ See United Nations General Assembly, Report of the Special Rapporteur on the Human Right to Safe Drinking Water and Sanitation (UN Doc A/71/302, 5 August 2016).

${ }^{290}$ Ibid. Para. 13.

${ }^{291}$ United Nations General Assembly, Report of the Special Rapporteur on the Human Rights to Safe Drinking Water and Sanitation (UN Doc A/72/127, 13 July 2017) UN Doc. A/72/127.

292 Ibid. Para. 8.

${ }^{293}$ UN Human Rights Council, Report of the Special Rapporteur on the Human Right to Safe Drinking Water and Sanitation (UN Doc A/HRC/33/49, 27 July 2016)

${ }^{294}$ United Nations General Assembly, Resolution 70/169: The Human Rights to Safe Drinking Water and Sanitation (UN Doc A/RES/70/169, 22 February 2016)
} 
right to water and sanitation. ${ }^{295}$ The report noted the important role of national and regulatory frameworks in the realisation of the right for example by monitoring how duty-bearers comply with their human rights obligations relating to water and sanitation and ensuring accountability as well as the role of regulatory actors in supporting and influencing policy changes to promote human rights. The report examined different types of regulatory frameworks and how they relate to the human rights standards, the Special Rapporteur recommended the adoption of a more nuanced approach regarding the concept of independence of regulatory bodies. Additional recommendations include adoption of policies and strategies on water and sanitation that incorporate human rights standards; clearly defining necessary procedures and measures in the regulatory framework in order for the State to meets its human rights obligation on water and sanitation; ensuring that the mission, mandate and objectives of regulatory bodies incorporate the principle of non-discriminatory progressive realisation of the right to water and sanitation among others. ${ }^{296}$

\subsection{General Obligations in Human Rights Law}

In the literature, some authors have attempted to distinguish CP rights and ESC rights. ${ }^{297}$ The distinction centred on three major arguments concerning ESC-rights:

1. Alleged focus on positive interventions;

2. Alleged lack of precision; and

3. Alleged lack of judicial enforceability. ${ }^{298}$

These distinctions if taken would have propound effect on States obligations on ESC rights in general and the right to water and sanitation in particular as they seek to suggest that ESC rights are not binding in the same way $\mathrm{CP}$ rights are.

On the first argument, it was alleged that ESC rights do not impose legally binding obligations but are merely programmatic clauses, aspirations or goals ${ }^{299}$ and are promotional. ${ }^{300}$ That the rights entail "resource-intensive obligations requiring resource allocations that are political rather than legal in nature" ${ }^{301}$ unlike CP rights which require nothing but non-interference. This therefore does not connote legal obligation of binding nature on States. Accordingly, in the context of the right to water and sanitation, latitude or margin of appreciation is given to States to determine when and the extent to which they can guarantee the right. ${ }^{302}$ The above argument however has been criticised as "illusory" in that "all types of human rights entail different types of States obligations" and that in many cases,

\footnotetext{
${ }^{295}$ UN Human Rights Council, Report of the Special Rapporteur on the Human Rights to Safe Drinking Water and Sanitation (UN Doc A/HRC/36/45, 19 July 2017)

${ }^{296}$ Ibid. Paras. 87-90.

${ }^{297}$ See E. W. Vierdag, 'The Legal Nature of the Rights Granted by the International Covenant on Economic, Social and Cultural Rights' (1978) 9 Netherlands Yearbook of International Law P. 69.

${ }^{298}$ Inga T. Winkler, The Human Right to Water: Significance, Legal Status and Implications for Water Allocationp. Pp. 102-106.

${ }^{299}$ E. W. Vierdag, 'The Legal Nature of the Rights Granted by the International Covenant on Economic, Social and Cultural Rights' P. 69.

${ }^{300}$ I. Brownlie, Principles of Public International Law (6 edn, Oxford University Press 2003) P. 539.

${ }^{301}$ Inga T. Winkler, The Human Right to Water: Significance, Legal Status and Implications for Water Allocation P. 101.

${ }^{302}$ Ibid. P. 101
} 
Realising the Right to Water and Sanitation in Nigeria

certain CP rights also require States positive action ${ }^{303}$ and some ESC rights can equally be realised without State's interference. ${ }^{304}$

On the second argument, it was alleged that ESC rights lack precision and they are vague in nature. ${ }^{305}$ The lack of precision makes the rights not legally binding. While it is true that some ESC rights are vague compared to their CP counter-part, clarity in the latter only came due to the considerable attention paid to them in legal literatures over time. ${ }^{306}$ ESC rights are equally receiving increasing attention in recent literatures and in the work of Committee on ESC rights through general comments although more work is required. ${ }^{307}$ Additionally, the degree of precision is only relevant to question whether the rights are directly applicable and not on whether they are legally-binding. ${ }^{308}$

On the third argument, it was alleged that ESC rights lacked possibility for judicial or quasi-judicial enforcement. ${ }^{309}$ That there are no necessary mechanisms in place to enforce them. ESC rights and hence the right to water among others may be non-judicially enforceable. This view is considered untenable because of its incompatibility with the fundamental features of international law. International law is horizontally structured and "mechanisms comparable to national courts are the exception rather than the rule." ${ }^{310}$ Even at the national level, it is possible to find this situation. This is more so at the international level where the structures are generally weak, and margin of appreciation is usually given to States. In legal context, this does not mean that such has abolished or extinguished the right.

While it is acknowledged that enforcement of ESC rights may sometimes be fraught with difficulties and in certain instances is country specific (as may be dependent on available resources and the complicated legal structure), this does not by and in itself means that such rights are not legally enforceable or justiciable. ${ }^{311}$ Even in circumstances where some countries' constitution has considered ESC rights as non-justiciable, courts have interpreted such rights as legally enforceable due to their connection with other justiciable rights. This, as noted has been the practice of Indian courts and recently, the Nigerian court in Jonah Gbemre v. Shell, NNPC and $A G F^{312}$ on the right to a healthy environment. ESC rights are therefore binding.

\footnotetext{
${ }^{303}$ For example, the right to fair trial requires the establishment of a judicial system; the right to vote requires expenditure to hold periodic election and freedom of expression requires Police protection. See ibid. p. 102

${ }^{304}$ For example, in the case of right to housing by refraining from forced eviction and the right to food by not depriving people of the land use in food cultivation. See ibid. P. 103.

${ }^{305}$ M. Cranston, 'Human Rights, Real and Supposed' in D. D. Raphael (ed), Political Theory and the Rights of Man (Political Theory and the Rights of Man, Macmillan 1967) P. 47.

${ }^{306}$ Inga T. Winkler, The Human Right to Water: Significance, Legal Status and Implications for Water Allocation p. 104

${ }^{307}$ Ibid. P. 104

${ }^{308}$ Ibid. P. 105; GJH. van Hoof, 'The Legal Nature of Economic, Social and Cultural Rights: A Rebuttal of Some Traditional Views' in P. Alston and K. Tomasevski (eds), The Right to Food (The Right to Food, Martinus Nijhoff 1984) P. 101

${ }^{309}$ See E. W. Vierdag, 'The Legal Nature of the Rights Granted by the International Covenant on Economic, Social and Cultural Rights' P. 73.

${ }^{310}$ Inga T. Winkler, The Human Right to Water: Significance, Legal Status and Implications for Water Allocation p. 105 relying among others on GJH. van Hoof, "The Legal Nature of Economic, Social and Cultural Rights: A Rebuttal of Some Traditional Views' P. 101

${ }^{311}$ The use of the word 'justiciability' here is purely descriptive as opposed to narrative.

${ }^{312}$ Suit No. FHC/B/CS/53/05
} 
In human rights law, the generally recognised obligations separate from those which are specific in particular treaties are the obligations to respect, protect, and fulfil. ${ }^{313}$ These obligations imposed both positive and negative duties on States, ${ }^{314}$ as well as different levels of obligations namely, primary, secondary and tertiary. ${ }^{315}$

\section{The Obligation to Respect}

This obligation imposes a duty on a State to directly or indirectly refrain from interfering with the enjoyment of rights protected by a human rights instrument. ${ }^{316}$ States must not directly or indirectly infringe or restrict the enjoyment of legally established human rights. ${ }^{317}$ This obligation prohibits State from taking actions or measures which deprive individuals of the enjoyment of guaranteed human rights. Specific to the right to water, the obligation includes "refraining from engaging in any practice or activity that denies or limits equal access to adequate water; arbitrarily interfering with customary or traditional arrangements for water allocation; unlawfully diminishing or polluting water, ... limiting access to, or destroying, water services and infrastructure as a punitive measure..."318 contrary to human rights standards. ${ }^{319}$

In Ibrahim Sangor Osman v. Minister of State for Provincial Administration \& Internal Security e-KLR $R^{320}$ a Kenyan Court found in favour of petitioners evicted from informal settlement by Kenya which cut them off from access to water and sanitation. The Court not only allowed for the return of the settlers to the demolished settlements but also ordered Kenya to reconstruct reasonable residences with all the amenities present on the land before the demolition and it issued a permanent injunction against any future eviction. In Beja and Others v. Premier of the Western Cape and Others, ${ }^{321}$ the South African High Court has held it to be a violation if there is failure to take account of the needs of vulnerable group. The African Commission on Human Rights in Sudan Human Rights Organisation and Centre on Housing Rights and Evictions v. Sudan ${ }^{322}$ has found Sudan liable for violation of obligations to respect and protect when Sudan, among others, poisoned water sources and denied access to water done in a discriminatory manner against people of Black African origin in the Darfur region.

\footnotetext{
${ }^{313}$ UNCESCR, General Comment No. 15: The Right to Water (Arts. 11 and 12 of the Covenant): See also The African Commission on Human Rights, Social and Economic Rights Action Center and the Center for Economic and Social Rights v. Nigeria, vol Comm. No. 155/96 (2001) Para 44.

${ }^{314}$ The African Commission on Human Rights, Social and Economic Rights Action Center and the Center for Economic and Social Rights v. Nigeria Para 44.

${ }^{315}$ See ibid. Paras 45-47.

${ }^{316}$ UNCESCR, General Comment No. 15: The Right to Water (Arts. 11 and 12 of the Covenant), para. 21; see also Malcolm Langford (ed), Social Rights Jurisprudence: Emerging Trends in International and Comparative Law (Cambridge University Press 2008). Pp.14-17.

${ }^{317}$ See Mathew Craven, The International Covenant on Economic, Social and Cultural Rights: A Perspective on its Development (Oxford University Press 1995). P. 109.

${ }^{318}$ UNCESCR, General Comment No. 15: The Right to Water (Arts. 11 and 12 of the Covenant), Para. 21.

${ }^{319}$ Inga T. Winkler, The Human Right to Water: Significance, Legal Status and Implications for Water Allocation. P. 108

${ }^{320}$ (2011) High Court (Embu) Constitutional Petition no 2 of 2011

321 (2011) High Court (Western Cape) 21332/10, (2011) ZAWCHC 97

322 [2009] African Commission on Human and Peoples' Rights 279/03 and 296/05
} 
Realising the Right to Water and Sanitation in Nigeria

In elaborating this obligation, it has been posited that "where sufficient resources are already set aside to satisfy all people's basic needs for water, the State must respect this allocation and must not reallocate these resources for other purposes such as industrial uses." 323 Similarly, the obligation extends to prohibiting arbitrary disconnection of water because of inability to pay by those being supplied. ${ }^{324}$

\section{The Obligation to Protect}

This obligation requires preventing third parties from interfering with the enjoyment of human right. ${ }^{325}$ States are required to adopt legislative and other measures to prevent third parties in any way from interfering with a right including as example "denying equal access to adequate water; and polluting and inequitably extracting from water resources, including natural sources, wells and other water distribution systems." 326 This also includes adopting measures which prevent others from detrimentally extracting unreasonable amount of water. ${ }^{327}$ Obligation to protect obliges States to adopt measures to protect individuals from water pollution by third parties. ${ }^{328}$ States must also adopt measures to ensure equitable access to water by all people without discrimination. This includes the poor, the vulnerable and marginalised groups ${ }^{329}$ mostly in the rural areas.

\section{The Obligation to Fulfil}

This obligation requires a State to adopt measures aiming at the full realisation of the right. ${ }^{330}$ It essentially imposes the obligation to provide the necessary opportunity for each individual to realise the right in question. ${ }^{331}$ This obligation has been disaggregated into obligations to facilitate, promote and provide ${ }^{332}$ Obligation to facilitate requires the adoption of positive measures aiming at assisting individuals and groups to enjoy the right. ${ }^{333}$ The obligation to promote on the other hand obliges States to take steps in the context of the right to water to "ensure that there is appropriate education concerning the hygienic use of water,

\footnotetext{
${ }^{323}$ Inga T. Winkler, The Human Right to Water: Significance, Legal Status and Implications for Water Allocation p. 108

${ }^{324}$ See Malcolm Langford, 'The United Nations Concept of Water as a Human Right: A New Paradigm for Old Problems?' (2005) 21 International Journal of Water Resources Development P. 277.

${ }^{325}$ UNCESCR, General Comment No. 15: The Right to Water (Arts. 11 and 12 of the Covenant), Para. 23; see also Malcolm Langford (ed), Social Rights Jurisprudence: Emerging Trends in International and Comparative Law Pp.17-21.

${ }^{326}$ UNCESCR, General Comment No. 15: The Right to Water (Arts. 11 and 12 of the Covenant), Para. 23.

${ }^{327}$ Ibid.

${ }^{328}$ Malcolm Langford, 'The United Nations Concept of Water as a Human Right: A New Paradigm for Old Problems?' P. 278.

${ }^{329}$ Inga T. Winkler, The Human Right to Water: Significance, Legal Status and Implications for Water Allocation. P. 108 .

${ }^{330}$ UNCESCR, General Comment No. 15: The Right to Water (Arts. 11 and 12 of the Covenant), para. 26; see also Malcolm Langford (ed), Social Rights Jurisprudence: Emerging Trends in International and Comparative Law. Pp. 21-24.

${ }^{331}$ See Asbjørn Eide, 'Economic, Social and Cultural Righs As Human Rights' in Asbjørn Eide, Catarina Krause and Allan Rosas (eds), Economic, Social and Cultural Rights (Economic, Social and Cultural Rights, 2nd edn, Martinus Nijhoff Publishers 2001). P. 24.

${ }^{332}$ UNCESCR, General Comment No. 15: The Right to Water (Arts. 11 and 12 of the Covenant), Para. 25

${ }^{333}$ Ibid., Para. 25.
} 


\section{Chapter Two}

protection of water sources and methods to minimize water wastage." 334 Lastly, the obligation to fulfil operates where individuals or groups by reasons beyond their control are unable to realise the right themselves. ${ }^{335}$ It requires the State to fulfil (provide) the right through the adoption of measures aiming at enabling and assisting the affected individuals. ${ }^{336}$

Several cases manifested the requirements of the obligation to fulfil. Waterlex and WASH have documented and translated selected cases on water and sanitation issues around the world which are utilised in this thesis. ${ }^{337}$ The utilisation of cases from courts in other States in this research is considered appropriate or even desirable for three reasons. Firstly, the recognition of the right to water and sanitation is a recent phenomenon at the international level and as such limited jurisprudence exists from international judicial and quasi-judicial bodies that attempt to define the legal implications of the right. Secondly, judges especially in common law jurisdiction learn or borrow from other judges when they are considering issues of similar nature. Thirdly, obligations in human rights law are generally the same with limited exception only on issues which centred on national and local circumstances where peculiarity may be noted. In the light of these therefore, an analysis of how courts in other States have dealt with issues surrounding water and sanitation and the legal implications flowing from certain conducts will provide an insight to the Nigerian courts and other quasijudicial bodies on how to proceed when confronted with issues of similar nature.

In the Argentinian case of Defensor del Pueblo de la Nación c/ Estado Nacional y Provincia del Chaco, ${ }^{338}$ the Supreme Court ordered the National State of Argentina and the Province of Chaco to provide drinking water to impoverished indigenous communities and the implementation of several protection measures and programmes related to water supply. In Asociación Civil por la Igualdad y la Justicia c/ Gobierno de la Ciudad de Buenos Aires, ${ }^{339}$ the court referred to several human rights treaties and documents including General Comments 3 and 15 of Committee on ESC rights to establish human rights obligation of State specific to water and sanitation. The court was of the view that this obligation exist where an individual or group of individuals by reason of their special circumstances cannot enjoy the right of access to potable water, a duty exist on the part of the State to adopt relevant measures to provide basic levels of its enjoyment. ${ }^{340}$ In Usuarios y Consumidores en Defensa de sus Derechos Asociación Civil c/ Aguas del Gran Buenos Aires $S A^{341}$ water supply of several

\footnotetext{
${ }^{334}$ Ibid.

${ }^{335}$ For example, during emergency situations and also in the context of extreme poverty (see Inga T. Winkler, The Human Right to Water: Significance, Legal Status and Implications for Water Allocation). P. 111.

${ }^{336}$ UNCESCR, General Comment No. 15: The Right to Water (Arts. 11 and 12 of the Covenant), Para. 25; An Indonesian Constitutional Court in Judicial Review of the Law of the Republic of Indonesia no 7 Year 2004 regarding Water Resources [2005] Constitutional Court 058-, 059-, 060- and 063/PUU-II/2004, and 008/PUU-III/2005, Pp. 26-27, has held the view that the obligation to protect human right to water "is inseparable from the fulfilment of the right".

${ }^{337}$ WaterLex and WASH United, The Human Rights to Water and Sanitation in Courts Worldwide: A Selection of National, Regional and International Case Law See https://www.waterlex.org/publications/the-human-rights-towater-and-sanitation-in-courts-worldwide/.

338 (2007) Suprema Corte D.587.XLIII, http://odhpi.org/wp-content/uploads/2012/07/Fallo-Chaco-defensor-delpueblo.pdf accessed 01 November 2015

${ }^{339}$ Spanish original version available at: www.acij.org.ar/blog/2011/12/13/sentencia-por-aguaen-la-villa-31-bis/

${ }^{340}$ See WaterLex and WASH United, The Human Rights to Water and Sanitation in Courts Worldwide: A Selection of National, Regional and International Case Law. P. 73.

${ }^{341}$ [2002] Juez de paz (Moreno, Buenos Aires) 44.453.
} 
Realising the Right to Water and Sanitation in Nigeria

consumers (including families with children) in Moreno was disconnected by a private company due to non-payment and the population cannot be provided with alternative source (because it was expressly prohibited under the law), the court questioned how the public authorities reconcile the disconnection with their positive obligation to provide clean drinking water to children under the Convention on the Rights of the Child. ${ }^{342}$ Relying on ICESCR in Rabia Bhuiyan v Ministry of LGRD and others ${ }^{343}$ the Bangladesh Court of Appeal reminded the State of its obligations under the Covenant to "ensure access to basic shelter, housing and sanitation, and an adequate supply of safe and potable water". ${ }^{344}$ Similarly, in Government of the Republic of South Africa and Others $v$ Grootboom and Others ${ }^{345}$ the South African Constitutional Court ordered Governmental authorities to provide the children and their parents with shelter. According to the Court "tents, portable latrines and regular supply of water (albeit transported) would constitute the minimum". ${ }^{346}$

However, in Dagoberto Bohórquez Forero c/ EAAB Empresa de Acueducto y Alcantarillado de Bogotá y Otros ${ }^{347}$ the Court in Colombia while recognising that provision of public services are inherent social purpose of the State for which it is obliged to provide to every inhabitant, it distinguished between legalised and non-legalised settlements. According to the Court, the services are to be provided based on legality which includes observing the principles of planning, programming and budgeting which according to the Court are within the discretion of the Executive for which the Judiciary could not intervene except where evidence of arbitrariness, unreasonableness, disproportionality or neglect of public expenditure principles exist. The Court concluded that non-legalised settlements could not invoke collective right to such public services.

While it is appreciated how developing countries are struggling to fulfil ESC rights due to resource constraints and technical know-how, this decision left much to be desired. The Court should have recognised that it is the failure of the State to provide for example, housing to its population which forces the population to resort to in many instances informal settlements or what may be termed illegal accommodation. The Court in this case should have recognised that ESC rights are interdependent for which the State must be held to account. $^{348}$

The process by which obligation to fulfil can be realised has been discussed by Winkler. ${ }^{349}$ This involves developing a national water strategy to ensure sufficient allocation of water resources to satisfy everyone's basic needs, ensuring access to water for personal and domestic use relating to the provision of water and the creation of enabling environment conducive to the realisation of the right to water.

\footnotetext{
${ }^{342}$ See Art. 24(2)(c) of the Convention on the Rights of the Child

${ }^{343}$ Appellate Division (Civil Appeal no 118 of 1999), 27 August 2005.

${ }^{344}$ Ibid, Para. 20.

345 [2000] Constitutional Court CCT11/00, [2000] ZACC 19, Para. 4.

${ }^{346}$ Ibid, Para. 4

${ }^{347}$ [2012] Tribunal Administrativo (Cundinamarca) 11001-33-31-003-2007-00186-01

${ }^{348}$ See Government of the Republic of South Africa and Others v. Grootboom and Others [2000] Constitutional Court CCT11/00, [2000] ZACC 19.

${ }^{349}$ Inga T. Winkler, The Human Right to Water: Significance, Legal Status and Implications for Water Allocation. P. 111.
} 


\subsection{Some Specific Obligations on the Right to Water and Sanitation}

In the absence of a multilateral treaty recognising water and sanitation as a human right and the inability to establish customary nature of the right, ${ }^{350}$ it calls for attention how the legal nature of the right to water and sanitation can be determined. This necessitates linking it to its foundation: the right to adequate standard of living and the right to health. These are ESC rights and the general obligations referred to above are applicable.

Additionally, separate from the general obligations pertaining to human rights instruments, there are specific obligations in the recognition of water and sanitation as human right. The Committee on ESC rights has outlined the following as the general obligations attaching to the right to water:

1. the obligation to guarantee the exercise of the right without discrimination of any kind; 351

2. the obligation of taking deliberate, concrete and targeted steps towards the full realisation of the right; ${ }^{352}$

3. the obligation not to adopt retrogressive measures unless absolutely necessary. ${ }^{353}$

1. The Obligation of Non-Discrimination:

This obligation emanates from several relevant international legal instruments including the ICESCR, ${ }^{354}$ the ICCPR $,{ }^{355} \mathrm{CEDAW},{ }^{356}$ and the CRC. ${ }^{357}$ Discrimination is generally at the heart of many human rights deprivations and essentially "undermines the fulfilment of economic, social and cultural rights for a significant proportion of the world's population." 358 As such several international instruments recognising or promoting human rights required State parties to adopt measures to ensure the guaranteed rights are enjoyed by all without discrimination.

What constitutes discrimination is essentially the same in human rights instruments and its relevance is to protect mostly, marginalised individuals and groups who are usually discriminated against on prohibited grounds. ${ }^{359}$ The Committee on ESC rights noted

\footnotetext{
${ }^{350}$ Winkler has examined the question of customary law nature of the right to water and concluded that although a strong trend tilting towards the recognition of the right may be detected, currently, right to water is yet to acquire such status under customary law. See ibid.. Pp. 65-97.

${ }^{351}$ UNCESCR, General Comment No. 15: The Right to Water (Arts. 11 and 12 of the Covenant). Para. 17.

${ }^{352}$ Ibid., Para. 17.

${ }^{353}$ Ibid., Para. 19; A Brazilian High Court in Santa Casa de Misericórdia de Santa Rosa do Viterbo x Companhiade Saneamento Básico do Estado de São Paulo - SABESP [2007] Superior Tribunal de Justiça REsp no 943.850 considered a disconnection of water supply from a hospital on account of non-payment as contrary to the principle of non-retrogression. See also Asociación Civil por la Igualdad y la Justiciac/ Gobierno de la Ciudad de Buenos Aires Cámara de Apelaciones en lo Contencioso Administrativo y Tributario (Ciudad Autónoma de Buenos Aires) 18 July 2007 where the decision of court of first instance respected the principle of non-retrogression.

${ }^{354}$ See Art. 2(2)

${ }^{355}$ See Arts. 2(1) and 26

${ }^{356}$ See Art. 14(2)(h)

${ }^{357}$ See Art. 2(1)

${ }^{358}$ See UNCESCR, General Comment No. 20: Non-discrimination in Economic, Social and Cultural Rights (Art. 2, Para. 2, of the International Covenant on Economic, Social and Cultural Rights) (2 July, 2009). Para. 1.

359 The prohibited grounds listed under article 2(2) of ICESCR to include "race, colour, sex, language, religion, political or other opinion, national or social origin, property, birth or other status" are merely illustrative and not
} 
Realising the Right to Water and Sanitation in Nigeria

discrimination to "constitutes any distinction, exclusion, restriction or preference or other differential treatment that is directly or indirectly based on the prohibited grounds of discrimination and which has the intention or effect of nullifying or impairing the recognition, enjoyment or exercise, on an equal footing, of Covenant rights." ${ }^{360}$ Discrimination can manifest in several ways: can be formal in the sense of being incorporated formally in legal and policy instruments or substantive as may be reflected in conditions and attitudes which cause or perpetuate discrimination. ${ }^{361}$ As such discrimination can be de jure or de facto, direct or indirect ${ }^{362}$ or a combination of both.

The obligation of non-discrimination in the enjoyment of the right to water and sanitation entails the adoption of measures which eliminate elements and practices of discrimination and specifically focussed on the disadvantaged members of the society, the marginalised and vulnerable groups. ${ }^{363}$ The most vulnerable and disadvantaged members of the society who are usually marginalised in the provision of water and sanitation include women, children, prisoners ${ }^{364}$ and detainees, ${ }^{365}$ people in rural areas, poor people in urban areas, informal settlements, indigenous groups, migrant and seasonal workers, ${ }^{366}$ nomadic, asylum seekers, refugees and internally displaced persons, the elderly, and persons living with HID/AIDS or suffering some disabilities. ${ }^{367}$ In the context of human rights obligations related to access to sanitation, the Independent Expert on the Issue of Human Rights Obligations Related to

exhaustive (Inga T. Winkler, The Human Right to Water: Significance, Legal Status and Implications for Water Allocation. P. 112.

${ }^{360}$ See UNCESCR, General Comment No. 20: Non-discrimination in Economic, Social and Cultural Rights (Art. 2, Para. 2, of the International Covenant on Economic, Social and Cultural Rights) para. 7

${ }^{361}$ See ibid. para. 8

${ }^{362}$ Inga T. Winkler, The Human Right to Water: Significance, Legal Status and Implications for Water Allocation p. 112

${ }^{363}$ See COHRE and others, Manual on the Right to Water and Sanitation (COHRE 2007) P. xxv

${ }^{364}$ See the French case of Section francaise de l'Observatoire International des Prisons c/ Ministere de la Justice [2012] Conseil d'Etat (référés) 364584; See also the ECHR case of Melnik v. Ukraine (App no 72286/2001) ECHR 28 March 2006; See the Inter-American Commission on Human Rights case of Paul Lallion v Grenada [2002] InterAmerican Commission on Human Rights 11.765

${ }^{365}$ In Habeas Corpus Colectivo presentado por Víctor Atencio c/ el Ministerio de Gobierno y Justicia, Director General del Sistema Penitenciario [2011] Corte Suprema de Justicia 928-09 three civil society organisations visited three detention centres in the Province of Colón: The Nueva Esperanza Rehabilitation Centre, (Centro de Rehabilitación Nueva Esperanza), the Women's Rehabilitation Centre (Centro Femenino de Rehabilitación) and the Public Jail. The sanitation condition and drinking water supply system in these places were found to be woefully inadequate. The Plenary Chamber of Panama Supreme Court of Justice held it to be a violation under international human rights law and Panama Constitution and accordingly ordered a number of measures to be taken by the authorities to remedy the situation including fixing wastewater seepage, solving the garbage problem, undertaking periodic garbage collection and pest control measures and securing necessary budgetary provisions to ensure dignified detention conditions. See also the Irish case of Kinsella v Governor of Mountjoy Prison [2011] High Court 20111125 SS, [2011] IEHC 235 relating to condition of detention; See also the Fijian cases of State v. Senijieli Boila and Pita Nainoka [2004] High Court (Suva) HAC032D.04S and Naba v. The State [2001] FJHC 338, [2001] 2 FLR 187; See the African Commission on Human Rights decision in Institute for Human Rights and Development in Africa v Angola [2008] African Commission on Human and Peoples' Rights 292/04; the European Court of Human Rights in Tadevosyan v Armenia (App no 41698/04) ECHR 2 December 2008, Riad and Idiab v. Belgium (App nos 29787/03 and 29810/03) ECHR 24 January 2008, Eugen GabrielRadu v Romania (App no 3036/04) ECHR 13 October 2009.

${ }^{366}$ See for example the French case of Laurent X [2010] Cour de cassation (Crim) 09-84012.

${ }^{367}$ UNCESCR, General Comment No. 15: The Right to Water (Arts. 11 and 12 of the Covenant). Para. 16. See also Inga T. Winkler, The Human Right to Water: Significance, Legal Status and Implications for Water Allocation p. 114; See also Emilie Filmer-Wilson, 'The Human Rights-based Approach to Development: The Right to Water' (2005) 23 Netherlands Quarterly of Human Rights 213. P. 221. 


\section{Chapter Two}

Access to Safe Drinking Water and Sanitation, Catarina De Albuquerque has noted this concern in her report. ${ }^{368}$ The High Court of Kenya has in the case of Ibrahim Sangor Osman v. Minister of State for Provincial Administration \& Internal Security eKLR ${ }^{369}$ held Kenya liable for the unlawful eviction of the petitioners from an informal settlements the effect of which cut off the evicted population from access to water and sanitation.

The obligation of non-discrimination in the enjoyment of the right to water and sanitation obliges States to:

take steps to remove de facto discrimination on prohibited grounds, where individuals and groups are deprived of the means or entitlements necessary for achieving the right to water. States should ensure that the allocation of water resources, and investments in water, facilitate access to water for all members of society. ${ }^{370}$

A clear and locus classicus case of denial of water on ground of discrimination is the United States case of Kennedy v. City of Zanesville ${ }^{371}$ where the residents of Coal Run, Ohio, the only predominantly black neighbourhood in Muskingum County were denied access to uncontaminated water on racial ground for 50 years despite numerous demands from the population while at the same time difficult and costly water projects were implemented in all the neighbourhood areas populated by whites. The US District Court had no difficulty in concluding that " $[\mathrm{t}]$ here is only one explanation for the fifty years of conduct [of the public authorities]: racial discrimination. That discrimination deprived Plaintiffs of a basic human need - access to uncontaminated water". ${ }^{372}$ The Court further observed:

The story of Coal Run is the story of relentless and enduring hardship and needless suffering from the denial of water. This was not merely the denial of the convenience of public water.

The only water available to Coal Run residents was contaminated and unusable. When

Defendants denied Coal Run water service, they denied the residents their only access to usable water. ${ }^{373}$

The Court proceeded to award $\$ 10.8$ million to the affected population. ${ }^{374}$ It must however be observed that not every unequal treatment could amount to discrimination. ${ }^{375} \mathrm{In}$ Dowdell v. City of Apopka Florida ${ }^{376}$ the Court of Appeal (Florida, $11^{\text {th }}$ Circuit) ordered authorities to prioritise access to water for the marginalised groups (black neighbourhoods) for the purposes of remedying the systemic discrimination which hitherto existed before any further provision to any predominantly white areas could be undertaken. To ensure this, the

\footnotetext{
${ }^{368}$ She stated that "States must realize their human rights obligations related to sanitation in a non-discriminatory manner. They are obliged to pay special attention to groups particularly vulnerable to exclusion and discrimination in relation to sanitation, including people living in poverty, sanitation workers, women, children, elderly persons, people with disabilities, people affected by health conditions, refugees and IDPs, and minority groups, among others." See UN Human Rights Council, Report of the Independent Expert on the Issue of Human Rights Obligations Related to Access to Safe Drinking Water and Sanitation, Catarina de Albuquerque . Para. 65.

${ }^{369}$ (2011) High Court (Embu) Constitutional Petition no 2 of 2011 . While it is appreciated that the Kenyan Constitution recognises ESC Rights as enforceable while in Nigeria these are not formally so recognised. The case demonstrated the interdependent and indivisible nature of human rights. The Kenyan High Court demonstrated

${ }^{370}$ UNCESCR, General Comment No. 15: The Right to Water (Arts. 11 and 12 of the Covenant). Para. 14.

${ }^{371}$ [2008] District Court (Southern District of Ohio, Eastern Division) 2:03-cv-1047

372 Ibid. P. 4.

${ }^{373}$ Ibid. P. 8

${ }^{374}$ It must be stated that less than two weeks after the commencement of a discrimination case with the Ohio Civil Rights Commission, the authorities started to take steps to supply water to the residents of the area.

${ }^{375}$ International Commission of Jurists, Maastricht Guidelines on Violations of Economic, Social and Cultural Rights (International Commission of Jurists 26 January, 1997). Para. 14(d).

${ }^{376} 698$ F. 2d 1181, United States Court of Appeals, Eleventh Circuit, 28 February 1983.
} 
Realising the Right to Water and Sanitation in Nigeria

Court equally impounded federal funds to be used for that purpose. In South Africa, the consequence of apartheid regime necessarily requires differential treatment mostly for the discriminated black population to bring them to the same standards of services enjoyed by their white counterparts. Similarly, some situations may require the adoption of certain measures which prima facie may appear discriminatory but which if considered in the light of other factors may not be unfairly discriminatory. In Mazibuko and Others v. City of Johannesburg and Others (Centre on Housing Rights and Evictions, Amicus Curiae) ${ }^{377}$ the South African Constitutional Court have had to consider whether the installation of prepaid meters in the provision of water in black communities (largely considered vulnerable group consequent upon the apartheid policy) as opposed to credit meters in the white neighbourhood is unfairly discriminatory. The Constitutional Court considered the justification that such meters were necessary to reduce water wastage and water unaccounted for which were the major issues in such community. The Court noted:

... the purpose for which the meters are installed is a laudable, indeed necessary, government objective, clearly tailored to its purpose. Moreover, the difference between the pre-paid meter system and a credit meter system is not disadvantageous to the residents of Phiri. In the circumstances, it cannot be said that the introduction of a pre-paid water meter system in Phiri was unfairly discriminatory. ... Furthermore: 'Underlying the preceding consideration of the unfair discrimination argument is the fact that government has the authority to decide how to provide essential services, as long as the mechanism it selects is lawful, reasonable and not unfairly discriminatory. The prohibition on unfair discrimination does not mean that government, in deciding how to provide essential services, must always opt for a uniform system if local circumstances vary. The conception of equality in our Constitution recognises that, at times, differential treatment will not be unfair. Indeed, correcting the deep inequality which characterises our society, as a consequence of apartheid policies, will often require differential treatment. ${ }^{378}$

In terms of sanitation, the Independent Expert on the Issue of Human Rights Obligations Related to Access to Safe Drinking Water and Sanitation, Catarina De Albuquerque after identifying those who are usually vulnerable to discrimination in the provision of access to sanitation stated that priority should be given to meeting the needs of the identified groups and, "where necessary, positive measures should be adopted to redress existing discrimination and to ensure their access to sanitation." ${ }^{379}$ Any step therefore taken to address specific concerns of these individuals and groups and to eliminate disparity on a prohibited ground $^{380}$ will not be regarded as unfair discrimination.

It has been noted that obligation of non-discrimination is not dependent upon availability of resources but it is an obligation which fulfilment may take some time in the context where

\footnotetext{
${ }^{377}$ Constitutional Court of South Africa (CCT 39/09) [2009] ZACC 28; 2010 (3) BCLR 239 (CC); 2010 (4) SA 1 (CC) 8 October 2009

${ }^{378}$ Ibid. Para. 156.

${ }^{379}$ The vulnerable group are people living in poverty, sanitation workers, women, children, elderly persons, people with disabilities, people affected by health conditions, refugees and IDPs, and minority groups, among others. See UN Human Rights Council, Report of the Independent Expert on the Issue of Human Rights Obligations Related to Access to Safe Drinking Water and Sanitation, Catarina de Albuquerque . Para. 65.

${ }^{380}$ In human rights law, the prohibited grounds are race, colour, sex, age, language, religion, political or other opinion, national or social origin, property, birth, physical or mental disability, health status, or any other civil, political, social or other status.
} 
there were inequalities and discriminatory conditions. ${ }^{381}$ The Indian Supreme Court had posited in Municipal Council, Ratlam v. Shri Vardhichand \& Others ${ }^{382}$ that human rights obligations of the State must be respected irrespective of their budgetary provision. ${ }^{383}$ The Court specifically observed that a "responsible Municipal Council constituted for the precise purpose of preserving public health and providing better finances cannot run away from its principal duty by pleading financial inability. Decency and dignity are non-negotiable facets of human rights and are a first charge on local self-governing bodies." 384 The approach of the Court in this case must be applauded otherwise States especially those where human rights are not generally respected will have justification for non-compliance with their human rights obligations. Insofar as obligations of non-discrimination involve the distribution of existing resources, it might not be appropriate to constrain them using criteria of resource availability.

Non-discrimination is a basic human rights concept which in the context of realising the right to water and sanitation means the obligation on States to ensure vulnerable groups are not marginalised or discriminated against. Discrimination in law and in fact on any of the prohibited grounds must hence be eliminated. ${ }^{385}$

\section{The Obligation of Taking Deliberate, Concrete and Targeted Steps}

The obligation of taking deliberate, concrete and targeted steps towards the full realisation of the right requires having a plan aimed at realising the right to water and sanitation especially in the case of vulnerable population. ${ }^{386}$ States must utilise their available resources to ensure the realisation of the right. Both the Committee on ESC rights and the Independent Expert on the Issue of Human Rights Obligations Related to Access to Safe Drinking Water and Sanitation, Catarina De Albuquerque have noted this obligation on water and sanitation issues. The Independent Expert stated that deliberate, concrete and targeted steps towards full realisation of the right to sanitation must be taken in a way that ensures "access to safe, affordable and acceptable sanitation for all, which provides privacy and dignity." 387 Courts have ordered in several cases, the adoption of necessary administrative, financial and budgetary measures to ensure the attainments of the contents of the rights to water. ${ }^{388}$

\footnotetext{
381 See Inga T. Winkler, The Human Right to Water: Significance, Legal Status and Implications for Water Allocation p. 114; See also the Costa Rican case of Ileana Vives Luque c/ Empresa de Servicios Públicos de Heredia [2003] Corte Suprema de Justicia 2003-04654 where the Supreme Court of Justice held the view that public authorities or private entities to whom the provision was delegated to cannot claim a lack of resources as a justification for non-compliance with their obligation.

382 (1981) SCR (1) 97

${ }^{383}$ Ibid, P. 10.

${ }^{384}$ Ibid, Pp. 11-12.

${ }^{385}$ UNCESCR, General Comment No. 15: The Right to Water (Arts. 11 and 12 of the Covenant). Para. 12(c)(iii). See also UN Human Rights Council, Report of the Independent Expert on the Issue of Human Rights Obligations Related to Access to Safe Drinking Water and Sanitation, Catarina de Albuquerque . Para. 65.

${ }^{386}$ See Government of the Republic of South Africa and Others v. Grootboom and Others [2000] Constitutional Court CCT11/00, [2000] ZACC 19

${ }^{387}$ UN Human Rights Council, Report of the Independent Expert on the Issue of Human Rights Obligations Related to Access to Safe Drinking Water and Sanitation, Catarina de Albuquerque . Para. 64.

${ }^{388}$ See for example the case of Jorge Hernán Gómez Ángel c/ Alcalde Municipal de Versalles - Valle del Cauca y el Gerente de la Empresa de Servicios Públicos de Versalles [2003] Corte Constitucional T-410/03 where the Colombian Constitutional Court ordered the local mayor and the public water company to adopt administrative,
} 
Realising the Right to Water and Sanitation in Nigeria

In Government of the Republic of South Africa and Others v. Grootboom and Others ${ }^{389}$ the South African Constitutional Court maintained that in situation where resources are not available, the State must have a reasonable plan of action such that will progressively fulfil the right in question and is equally under obligation to devote reasonable resources capable of implementing the designed plan in a manner that is non-discriminatory. In Ileana Vives Luque c/ Empresa de Servicios Públicos de Heredia ${ }^{390}$ the Constitutional Chamber of the Costa Rican Supreme Court of Justice reiterated the obligation of the State in terms of provision of public services to adopt measures to achieve full realisation of the rights in question.

On provision of water to informal settlements, the Constitutional Court in Colombia in Hernán Galeano Díaz c/ Empresas Públicas de Medellín ESP, y Marco Gómez Otero y Otros c/ Hidropacífico SA ESP y Otros $^{391}$ ordered the local authorities in Buenaventura to plan with a view to guaranteeing in the short-term, a minimum amount of water to these settlements pending the attainment of a permanent solution.

3. The Obligation not to adopt Retrogressive Measures

This obligation is in the context of progressive realisation of ESC rights. Recognising that ESC rights may not be fully realised in a short period of time, an obligation to move as expeditiously and effectively as possible to realise the goal is imposed. ${ }^{392}$ As such, States should not adopt measures which can undermine the objectives of a particular right. General Comment 3 of the Committee on ESC rights stated that "any deliberately retrogressive measures in that regard would require the most careful consideration and would need to be fully justified by reference to the totality of the rights provided for in the Covenant and in the context of the full use of the maximum available resources." 393 There is hence a presumption that retrogressive measures negatively impacting on the realisation of the right to water and sanitation are prohibited. ${ }^{394}$ Any retrogressive measure, according to the Independent Expert on the Issue of Human Rights Obligations Related to Access to Safe Drinking Water and Sanitation, Catarina De Albuquerque must be carefully considered and justified. ${ }^{395}$ In Santa Casa de Misericórdia de Santa Rosa do Viterbo x Companhiade Saneamento Básico do Estado de São Paulo - SABESP ${ }^{396}$ a Brazilian High Court considered a disconnection of

\footnotetext{
financial and budgetary provisions to ensure the provision of water with the required levels of quality, regularity, immediacy and continuity.

${ }^{389}$ [2000] Constitutional Court CCT11/00, [2000] ZACC 19 <http://www.saflii.org/za/cases/ZACC/2000/19. html> accessed 14 April 2016

390 [2003] Corte Suprema de Justicia 2003-04654

391 [2010] Corte Constitucional T-616/10 <http://www.corteconstitucional.gov.co/relatoria/2010/T-616-10.htm>.

392 UNCESCR, General Comment No. 3: The Nature of States Parties' Obligations (Art. 2, Para. 1, of the Covenant) (14 December, 1990). Para. 9.

393 Ibid.

${ }^{394}$ UNCESCR, General Comment No. 15: The Right to Water (Arts. 11 and 12 of the Covenant) Para. 19.

${ }^{395}$ UN Human Rights Council, Report of the Independent Expert on the Issue of Human Rights Obligations Related to Access to Safe Drinking Water and Sanitation, Catarina de Albuquerque . Para. 64.

${ }^{396}$ [2007] Superior Tribunal de Justiça REsp no 943.850. See also Asociación Civil por la Igualdad y la Justiciac/ Gobierno de la Ciudad de Buenos Aires Cámara de Apelaciones en lo Contencioso Administrativo y Tributario (Ciudad Autónoma de Buenos Aires) 18 July 2007 where the decision of court of first instance respected the principle of non-retrogression
} 
water supply from a hospital on account of non-payment as contrary to the principle of nonretrogression.

Other obligations which have been exhaustively discussed elsewhere include obligations to progressive realisation and core obligations. ${ }^{397}$

\subsection{Contents and Scope of the Right to Water and Sanitation}

Academic works have made useful attempts to define the normative contents of the right to water as an implied/derivative right. ${ }^{398}$ As an implied right, some have pointed out the possibility of encountering difficulties in terms of justiciability and implementation. ${ }^{399}$ For example, in the event of violation can one sue on the basis of a violation of the right to water or of the related right such as right to health or adequate standard of living where the right to water was derived from? Similarly, providing water for personal and domestic uses as necessitated by the right to water as well as balancing the competing needs of other water users necessarily requires identifying the exact obligations which States must strive to discharge in the context of progressive realisation. It was this desire which prompted the Committee on ESC rights to draft and adopt General Comment $15 .{ }^{400}$ Through this General Comment, the Committee clarified the normative content of the right to assist States in discharging their obligations. The academic works referred to above have detailed these contents and provided justifiable arguments in relation there to. In the context of sanitation, the Independent Expert on the issue of human rights obligations related to access to safe drinking water and sanitation has discussed the contents. ${ }^{401}$ This section highlights the contents of the right to water and sanitation. The section utilises Waterlex database ${ }^{402}$ in generating relevant cases to clarify the concepts under discussion.

According to Committee on ESC rights "The human right to water entitles everyone to sufficient, safe, acceptable, physically accessible and affordable water for personal and domestic uses." ${ }^{403}$ From this definition, identifiable features of normative contents of the right are: sufficiency; safety; acceptability; accessibility; and affordability. According to the Independent Expert on the issue of human rights obligations related to access to safe drinking water and sanitation, "States must ensure without discrimination that everyone has physical and economic access to sanitation, in all spheres of life, which is safe, hygienic, secure,

\footnotetext{
397 See Inga T. Winkler, The Human Right to Water: Significance, Legal Status and Implications for Water Allocation. Pp. 115-125.

${ }^{398}$ For a detailed academic discussion on the contents of right to water see Amanda Cahill, 'The Human Right to Water - A Right of Unique Status': The Legal Status and Normative Content of the Right to Water'pp. 389-410); Inga T. Winkler, The Human Right to Water: Significance, Legal Status and Implications for Water Allocation. Pp. $125-140$

${ }^{399}$ Amanda Cahill, 'The Human Right to Water - A Right of Unique Status': The Legal Status and Normative Content of the Right to Water'. P. 391.

${ }^{400}$ Ibid. P. 391.

${ }^{401}$ UN Human Rights Council, Report of the Independent Expert on the Issue of Human Rights Obligations Related to Access to Safe Drinking Water and Sanitation, Catarina de Albuquerque.

402 The Database generated and translated cases relevant to the contents of right to water and sanitation from several jurisdictions. The analysis provided in this research was based on the translated cases from the database. See https://www.waterlex.org/publications/the-human-rights-to-water-and-sanitation-in-courts-worldwide/.

${ }^{403}$ UNCESCR, General Comment No. 15: The Right to Water (Arts. 11 and 12 of the Covenant). Para. 2.
} 
Realising the Right to Water and Sanitation in Nigeria

socially and culturally acceptable, provides privacy and ensures dignity." 404 From this, the contents of human rights obligations related to sanitation have been identified as availability, quality, physical accessibility, affordability, and acceptability. ${ }^{405}$ The contents of both rights to water and sanitation will be examined jointly due to their similarities.

\subsubsection{Sufficiency (Availability)}

The human right to water obliges States to provide water in sufficient quantities to meet human basic personal and domestic needs. As examples of different kinds of personal and domestic uses, the Committee noted this to ordinarily include "drinking, personal sanitation, washing of clothes, food preparation, personal and household hygiene." 406

Sufficiency has been framed in terms of making water available. Although adequacy of water required under the right to water varies depending on conditions, ${ }^{407}$ and that determining the exact amount is a matter of debate, ${ }^{408}$ availability of water for personal and domestic uses must be 'sufficient and continuous' in quantity and regularity. ${ }^{409}$ It is required in the case of quantity to correspond to guidelines of the World Health Organisation which depending on climatic conditions, diet and level of activity, for example in the case of drinking ranges from 2 to 4.5 litres per day. ${ }^{410}$

In general, the difficulty of quantifying the amount of water needed for personal and domestic uses is acknowledged. This makes general agreement on the issue doubtful especially in the light of growing population, industrialisation and other factors posing challenges to the available water resources. Gleick and World Health Organisation considered 50 litres a day to be sufficient in meeting most basic consumption and hygiene needs in the promotion of health. ${ }^{411}$ According to Gleick five litres for drinking, 20 for sanitation and hygiene, 15 for hygiene and 10 for cooking. ${ }^{412}$ However, the Committee's reference to some works in its General Comment 15 suggested a minimum of 20 litres a day

\footnotetext{
${ }^{404}$ UN Human Rights Council, Report of the Independent Expert on the Issue of Human Rights Obligations Related to Access to Safe Drinking Water and Sanitation, Catarina de Albuquerque. Para. 63.

405 Ibid. Paras. 70-80.

${ }^{406}$ UNCESCR, General Comment No. 15: The Right to Water (Arts. 11 and 12 of the Covenant). Para. 12(a)

407 This includes climatic conditions, circumstances, cultural and individual requirements. This necessarily requires the adoption of a contextualized approach to determining the amount required in particular circumstances (see Inga T. Winkler, The Human Right to Water: Significance, Legal Status and Implications for Water Allocation P. 131.

${ }^{408}$ John Scanlon, Angela Cassar and Noemi Nemes, Water as a Human Right? P. 30.

${ }^{409}$ UNCESCR, General Comment No. 15: The Right to Water (Arts. 11 and 12 of the Covenant), Para. 12

${ }^{410}$ Ibid., para. 12(a); see also Guy Howard and Jamie Bartram, Domestic Water Quantity, Service Level and Health; Peter H. Gleick, 'Basic Water Requirements for Human Activities: Meeting Basic Needs' (1996) 21 Water International Pp. 83-92.

${ }^{411}$ Guy Howard and Jamie Bartram, Domestic Water Quantity, Service Level and Health

${ }^{412}$ Peter H. Gleick, 'Basic Water Requirements for Human Activities: Meeting Basic Needs'pp. 88-89); A minimum supply of 50 litres per household per day was considered insufficient by a Court in Argentina and 200 litres per household were ordered to be supplied in Quevedo, Miguel Ángel y Otros c/Aguas Cordobesas SA [2002] Juez Sustituta de Primera Instancia Civil y Comercial (Ciudad de Córdoba) <http://www.cedha.org.ar/docs/doc220spa.doc>.
} 


\section{Chapter Two}

to be sufficient. ${ }^{413}$ Some States have legislations providing for the minimum to be supplied to individuals. ${ }^{414}$

Courts jurisprudence on the number of litres to be supplied varies. In Children of the Paynemil Community c/ Acción de amparo ${ }^{415}$ an Argentinian court ordered the supply of 250 litres of drinking water per person per day. In Marchisio José Bautista y Otros c/ Superior Gobierno de la Provincia de Córdoba y Otros $^{416}$ a court in Argentina ordered the Province of Córdoba to guarantee the supply of minimum of 200 litres of drinking water to each household when the only source of water for the population in the area was contaminated until necessary repairs allowing full access to public water service is done. In Asociación Civil por la Igualdad y la Justicia c/ Gobierno de la Ciudad de Buenos Aires ${ }^{417}$ the residents of four areas in Villa 31 vis, an informal settlement in Buenos Aires were not connected to water supply network and have had to rely on cistern trucks but which was interrupted by the City. The Court ordered the City to supply portable water in cistern trucks to the affected population every day of the week including Sundays and in sufficient quantities and as much as necessary including filling up of reserved tanks for their personal and domestic uses. Instructively, the Court considered this as the minimum which the State is obliged to provide. The obligation of providing sufficient water includes even in situations where water was disconnected due to non-payment based on lack of means. In Quevedo, Miguel Ángel y Otros c/Aguas Cordobesas $S A^{\mathbf{4 1 8}}$ the Court ordered the respondent to guarantee a daily supply of 200 litres per household as minimum to the applicants for the duration of the disconnection.

In the Colombian case of Hernán Galeano Díaz c/ Empresas Públicas de Medellín ESP, y Marco Gómez Otero y Otros c/ Hidropacífico SA ESP y Otros ${ }^{419}$ failure to connect a property to water and sanitation network as well as to supply daily minimum was considered a violation of human rights arising from the Colombian Constitution and international human rights law. The Constitutional Court was of the view that the State is obliged to guarantee the minimum essential level of availability of water and that the refusal to connect a property to water was a threat to human dignity. That even in situations where inhabitants of informal settlements have had to illegally connect their premises, the local authorities are responsible for failure to adopt necessary measures to avoid water loss. In this case, several orders were made including the provision of a daily supply of water to the applicants' houses through any technological system available and the adoption of a plan by the local authorities with a view to guaranteeing minimum supply of water to informal settlements. ${ }^{420}$

\footnotetext{
${ }^{413}$ Inga T. Winkler, The Human Right to Water: Significance, Legal Status and Implications for Water Allocation P. 133.

414 The Rural Code of France, Arts. R. 716-20, 21, 24 for example stipulated a minimum of 100 litres per day to be supplied to a worker in a farm if such farm is not connected to water supply network.

415 2nd Chamber of Appeals for Civil Matters of the Province of Neuquén, File 311-CA - 199719 May 1997

${ }^{416}$ [2004] Juzgado de Primera Instancia Civil y Comercial (Ciudad de Córdoba) 500003/36 <http://wp.cedha.net/wpcontent/uploads/2011/06/Sentencia-Chacras.pdf>. accessed 15 April 2016

${ }^{417}$ Cámara de Apelaciones en lo Contencioso Administrativo y Tributario (Ciudad Autónoma de Buenos Aires) 18 July 2007

418 [2002] Juez Sustituta de Primera Instancia Civil y Comercial (Ciudad de Córdoba) $<$ http://www.cedha.org.ar/docs/doc220-spa.doc>.

${ }^{419}$ [2010] Corte Constitucional T-616/10 <http://www.corteconstitucional.gov.co/relatoria/2010/T-616-10.htm>.

${ }^{420}$ See also Ileana Vives Luque c/ Empresa de Servicios Públicos de Heredia [2003] Corte Suprema de Justicia 2003-04654 where refusal to connect private property to public water supply was considered by the Court as a
} 
Realising the Right to Water and Sanitation in Nigeria

Due to inextricable link between water and human dignity, some States consider it a criminal offence to subject for example a vulnerable individual to working or living conditions which are incompatible with human dignity. ${ }^{421}$ Claims for water availability and connection are however limited to natural persons and legal or juristic persons may not be able to succeed except where such are acting on behalf of natural persons. ${ }^{422}$

To ensure availability of water for personal and domestic uses, adoption of all necessary measures may be needed including declaring a state of emergency where availability is threatened by, for example, natural disaster. ${ }^{423}$ Similarly, a company may be restrained from over extraction of groundwater if such extraction has the tendency of affecting on the availability of drinking water in the area. In Perumatty Grama Panchayat v. State of Kerala ${ }^{424}$ the High Court of Kerala, India ordered a company to stop extracting groundwater for its business because its excessive nature not only creates ecological imbalance and impacts on sustainability but also produces scarcity of drinking water in the area. A similar decision was earlier reached by the same court in Attakoya Thangal v Union of India (Availability - Water resources management $)^{425}$ and the High Court of Pakistan in Nestle Milkpak Limited $v$ Sindh Institute of Urology and Transplantation and Others. ${ }^{426}$ The obligation to make water and necessary sanitary materials applies to detainees and prisoners. ${ }^{427}$

violation of the right to water under the Costa Rican Constitution. The Court ordered the property to be connected at the risk of imprisonment or fine.

${ }^{421}$ The Criminal Chamber of the France Cour de Cassation in Laurent X [2010] Cour de cassation (Crim) 09-84012, found Laurent $\mathrm{X}$ guilty for subjecting seasonal workers to working and living conditions (lack of adequate housing, water sometimes not suitable for human consumption) incompatible to human dignity. In Madame X c/ Commune d'Amiens [2004] Cour de Cassation (Civ 3) 02-20614, the Court of Cassation held that the obligation of the landlord to provide adequate housing under the French Civil Code included the obligation to connect the residential property to water supply service.

${ }^{422}$ See the Colombian case of Carlos Alfonso Rojas Rodríguez c/ ACUAVENORTE y Otros [1992] Corte Constitucional T-578/92

${ }^{423}$ See for example Caso no 0006-10-EE [2010] Corte Constitucional 0010-10-SEE-CC; See also Inter-American Court of Human Rights case of Xakmok Kasek Indigenous Community v Paraguay Inter-American Court of Human Rights Series C no 21 (26 August 2010)

${ }^{424}$ [2003] High Court (Kerala, Ernakulam) Writ Petition no 34292 of 2003, (2004) (1) KLT 731

425 [1990] High Court (Kerala) <http://www.indiankanoon.org/doc/1980528/>.

${ }^{426}$ [2006] High Court (Sindh, Karachi) HCA 271 (2004); See also Frente Amplio Opositor a Minera San Xavier c/ Minera San Xavier SA de CV y Otros [2007] Tribunal Latinoamericano del Agua; Grupo de Formacion e Intervencion para el Desarrollo (Gufides) y Plataforma Interinstitutcional Celendina (PIC) c/ Estado Peruano y Minera Yanacocha SRL [2012] Tribunal Latinoamericano del Agua.

${ }^{427}$ Habeas Corpus Colectivo presentado por Víctor Atencio c/ el Ministerio de Gobierno y Justicia, Director General del Sistema Penitenciario [2011] Corte Suprema de Justicia 928-09; See also the Irish case of Kinsella v Governor of Mountjoy Prison [2011] High Court2011 1125 SS, [2011] IEHC 235 relating to condition of detention; See also the Fijian cases of State v. Senijieli Boila and Pita Nainoka [2004] High Court (Suva) HAC032D.04S and Naba v. The State [2001] FJHC 338, [2001] 2 FLR 187; See the African Commission on Human Rights decision in Institute for Human Rights and Development in Africa v. Angola [2008] African Commission on Human and Peoples' Rights 292/04; the European Court of Human Rights in Tadevosyan v Armenia (App no 41698/04) ECHR 2 December 2008, Riad and Idiab v. Belgium (App nos 29787/03 and 29810/03) ECHR 24 January 2008, Eugen Gabriel Radu v. Romania (App no 3036/04) ECHR 13 October 2009, Fedotov v. Russia (App no 5140/02) ECHR 25 October 2005; Inter-American Commission on Human Rights case of Paul Lallion v Grenada [2002] Inter-American Commission on Human Rights 11.765 and Inter-American Court of Human Rights case of Velez Loor v Panama Inter-American Court of Human Rights Series C no 218 (23 November 2010) 
Availability in the context of sanitation requires the existence of sufficient number of sanitation facilities in all spheres of life. ${ }^{428}$ Case law demonstrated the connection between water and sanitation and the rights to education and housing. In the Environment \& Consumer Protection Foundation v. Delhi Administration and others ${ }^{429}$ the Indian Supreme Court ordered for, among others, the provisions of sanitation at the schools for the purposes of realising the right to education. The Court stated that:

It is imperative that all the schools must provide toilet facilities. Empirical researches have indicated that wherever toilet facilities are not provided in the schools, parents do not send their children (particularly girls) to schools. It clearly violates the right to free and compulsory education of children guaranteed under Article 21-A of the Constitution. ${ }^{430}$

The UN Committee on ESC rights has also noted this connection in its Statement on the Right to Sanitation in 2010. The Committee noted lack of adequate sanitation as one of the reasons for girls and boys not attending school. ${ }^{431}$ In Beja and Others v. Premier of the Western Cape and Others, ${ }^{432}$ a South African High Court considered lack of adequate and appropriate sanitation facilities as a violation of the rights to housing, privacy and dignity. Unlike water however, there is no minimum number of sanitation facilities required to be constructed in a household, educational, workplace or public places except that the facilities should be sufficient. ${ }^{433}$

\subsubsection{Quality}

Under this normative content, water must equally be safe from contamination and other health hazards. General Comment 15 requires water for personal and domestic use to "be safe ... free from micro-organisms, chemical substances and radiological hazards that constitute a threat to a person's health" and that "water should be of an acceptable colour, odour and taste for each personal or domestic use." ${ }^{434}$ Lack of basic sanitation is directly linked to water contamination mostly in developing world where sources of water mainly are direct from surface (rivers, ponds, streams etc.) and underground (wells and boreholes). To ensure safety of drinking water supplies, World Health Organisation in 1993 recommended that States develop national standards for drinking water quality to eliminate or reduce to a minimum, concentration of constituents of water known to constitute hazards to health. ${ }^{435}$ Nigeria is one of such countries which had developed these Standards. ${ }^{436}$

\footnotetext{
${ }^{428}$ These include households, schools, health facilities, public places and workplaces. See UN Human Rights Council, Report of the Independent Expert on the Issue of Human Rights Obligations Related to Access to Safe Drinking Water and Sanitation, Catarina de Albuquerque. Para. 70.

4293 October 2012. See WaterAid, 'Court Cases' <http://www.righttowater.info/rights-in-practice/legal-approachcase-studies/court-cases/> accessed 13 March 2018

${ }^{430}$ See ibid.

${ }^{431}$ UNCESCR, Statement on the Right to Sanitation. Paras. 5-6.

${ }^{432}$ Case No: 21332/10 decision of 29 April 2011. See WaterAid, 'Court Cases'the Court specifically stated that "Any housing development which does not provide for toilets with adequate privacy and safety would be inconsistent with s 26 of the Constitution and would be in violation of the constitutional rights to privacy and dignity".

${ }^{433}$ UN Human Rights Council, Report of the Special Rapporteur on the Human Right to Safe Drinking Water and Sanitation, Catarina de Albuquerque (UN Doc A/HRC/18/33, 2011). Para. 71.

${ }^{434}$ UNCESCR, General Comment No. 15: The Right to Water (Arts. 11 and 12 of the Covenant). Para. 12(b)

${ }^{435}$ World Health Organisation, Guidelines for Drinking-Water Quality (4th edn, World Health Organisation 2011)

${ }^{436}$ See Standards Organisation of Nigeria, Nigerian Standard for Drinking Water Quality (Standards Organisation of Nigeria 2007)
} 
Realising the Right to Water and Sanitation in Nigeria

Jurisprudence of courts from around the world indicated the legal responsibility of States to ensure water safety in areas under their control or jurisdiction. ${ }^{437}$ In order words, a State is under obligation to protect its people from polluted or contaminated water. ${ }^{438}$ The European Court of Human Rights in Dubetska and Others $v$ Ukraine ${ }^{439}$ held Ukraine responsible for violation of article 8 of European Convention on Human Rights (right to private and family life) when it failed to protect the applicants from immediate environmental pollution impacting on drinking water quality resulting from industrial activities. Marchisio José Bautista y Otros c/ Superior Gobierno de la Provincia de Córdoba y Otros ${ }^{440}$ where the applicant alleged a violation of their right to health, healthy environment and a decent quality of life as a result of the operation of wastewater management plant by the Córdoba province which contaminated the river from which the applicants source their drinking water. The court granted an injunction against the Province and ordered the Municipality to take all necessary measures regarding the operation of the plant aiming at minimizing its environmental effects until when a definitive solution is found.

In conformity with judicial approach to interpretation of right to life, the Supreme Court of Pakistan in General Secretary, West Pakistan Salt Miners Labour Union v. The Director, Industries and Mineral Development ${ }^{441}$ required the word "life" to be given an extended meaning under the Constitution and not to be "restricted to vegetative life or mere animal existence." ${ }^{442}$ Specifically, the Court maintained that:

In hilly areas where access to water is scarce, difficult or limited, the right to have water free from pollution and contamination is a right to life itself. This does not mean that persons residing in other parts of the country where water is available in abundance do not have such right. The right to have unpolluted water is the right of every person wherever he lives. ${ }^{443}$

The obligation to protect imposes liability and holds States accountable in situations not only where the State was responsible for water contamination but also in cases of actions of private water companies. A State will be held responsible if no measures are taken to ensure or protect water safety. In Quevedo, Miguel Ángel y Otros c/Aguas Cordobesas $S A^{444}$ the Civil and Commercial first instance Court in Argentina was of the view that where public

\footnotetext{
${ }^{437}$ It is important to note that the obligation is that of result except where the situation was affected by force majeure or negligence of the victim. See the French case of Madame X c/ Commune de Saint-Hilaire-de-Lavit [2012] Cour de cassation (Civ 1) 11-26814; See also Monsieur X c/ Syndicat d'Adduction d'Eau du Tregor [2006] Cour de cassation (Civ 1) 03-16335 where the French Court of Cassation did not consider pollution resulting from agricultural runoff as amounting to force majeure since steps can be taken to render the water safe for human consumption.

${ }^{438}$ See Red de Vigilancia y Exigibilidad de los Derechos Económicos, Sociales y Culturales Región Junín c/ Municipalidad Provincial de Huancayo [2005] Corte Superior de Justicia (Junín) 1230-2005 the High of Justice in Peru ordered the Provincial Municipality to Huancayo to take certain measures in order to fulfil its obligation to protect populations' right to life, health and environment in areas where a public water company was supplying contaminated water. See also the Nepal case of Advocate Prakash Mani Sharma and Others v Nepal Water Supply Corporation and Others [2001] Supreme Court WP2237/1990 <http://www.elaw.org/node/1383>.

439 (App no 30499/03) ECHR 10 February 2011

${ }^{440}$ Marchisio Jose Bautista y Otros c/ Superior Gobierno de la Provincia de Cordoba y Otros [2004] Juzgado de Primera Instancia Civil y Comercial (Ciudad de Córdoba) 500003/36 <http://wp.cedha.net/wpcontent/uploads/2011/06/Sentencia-Chacras.pdf>. accessed 15 April 2016

${ }^{441}$ [1994] Supreme Court Human Rights Case 120 of 1993 <http://ceej.pk/cms/ docs/sc/1994SCMR2061.pdf>

442 Ibid. P. 9.

443 Ibid.

444 [2002] Juez Sustituta de Primera Instancia Civil y Comercial (Ciudad de Córdoba)
} <http://www.cedha.org.ar/docs/doc220-spa.doc>. 


\section{Chapter Two}

service had been privatised such as in the case of provision of water, the State continues to retain the obligation of regulating and controlling private service providers' activities. That the State being the ultimate holder of such public services, it matters not whether the States choses to provide such services directly or indirectly. In Asociación para la Protección del Medio Ambiente y Educación Ecológica '18 de Octubre' c/ Aguas Argentinas SA y Otros ${ }^{445}$ the Province of Buenos Aires (a body responsible for public service) and the Municipality of Quilmes (who delegated the public water service through a concession to a private company) were held directly responsible for the contamination of water by the private company. The Court of Appeal specifically held that the Municipality of Quilmes has the "essential duty to prevent and eliminate the pollution of the environment and of water courses and to ensure the conservation of natural resources". ${ }^{446}$

The obligation equally extends to even where a community provides and manages water for itself, but which is contaminated by the action of a private individual. In María de Jesús Medina Pérez y otros v. Alvaro Vásquez ${ }^{447}$ the Community provided and managed water for its inhabitant for over 20 years. The water was considered safe for human consumption until when a private individual built a pig farm nearer and was collecting and using pig manure as fertilizer, but which runoff carried to the water sources and thereby contaminating the water. While the private individual was restrained, the Court also ordered the State authority to be informed about the decision to be able to make necessary arrangements regarding the rights of the people to participate in decision making on matters which affect their lives especially as it relates to water and sanitation. ${ }^{448}$ Instructive is equally the recognition by the Court that the contamination puts the ecological balance at risk for present and future generations.

In Marian Stoicescu v. Romania ${ }^{449}$ the European Court of Human Rights found Romania to have violated article 3 of the European Convention on Human Rights by reason of detaining the applicants under conditions which among others do not provide access to water fit for human consumption.

There is similarly, a duty to promptly adopt measures safeguarding the health of the affected population where water source is contaminated. In Children of the Paynemil Community c/ Acción de amparo $^{450}$ where some indigenous communities in Neuquén, Argentina realised their groundwater source for drinking and domestic uses was contaminated by a private oil company and which affected the health of children in area, the court granted a number of remedies including injunction, provision of portable water through alternative means to the affected population, procedure to determine whether the polluted water had damaged the community members' health and provision of adequate environmental remedies if necessary. Of relevance is equally the recognition by the court that

\footnotetext{
445 [2003] Cámara Federal de Apelaciones (La Plata) 3156/02, RDAmb 2004-0-193.

446 Ibid. Para. 19.

${ }^{447}$ Sala Séptima de Revisión de la Corte Constitucional 22 November 1994

${ }^{448}$ See also Carlos Alfonso Rojas Rodríguez c/ ACUAVENORTE y Otros [1992] Corte Constitucional T-578/92 where the Colombian Constitutional Court held that whether the public services are being provided by the State directly, indirectly or by organised groups, "in any case, the State will maintain the regulation, control and monitoring of these services" (para. 4, legal grounds).

${ }^{449}$ (App no 12934/02) ECHR 16 July 2009

$4502^{\text {nd }}$ Chamber of Appeals for Civil Matters of the Province of Neuquén, File 311-CA - 199719 May 1997
} 
Realising the Right to Water and Sanitation in Nigeria

the provincial delays in the adoption of measures safeguarding the right to health of children was a clear indication of denial of the right. ${ }^{451}$ In Jorge Hernán Gómez Ángel c/ Alcalde Municipal de Versalles - Valle del Cauca y el Gerente de la Empresa de Servicios Públicos de Versalles ${ }^{452}$ the Constitutional Court of Colombia held it a violation of fundamental rights to life, health and healthy environment where water supply is contaminated and found to be unfit for human consumption. In Rabia Bhuiyan v. Ministry of LGRD and Others ${ }^{453}$ a Bangladesh Court of Appeal ordered the adoption of several measures regarding the contamination of groundwater being used widely as a source of water for personal and domestic uses, but which contains arsenic contamination to safeguard the lives and health of the population. ${ }^{454}$

The quality content of the right to sanitation is in relations to the following: hygienic safety of sanitation facilities in a way that would ensure the prevention of human, animal and insect contact with human excreta; access to water for washing and cleansing, mechanisms for hygienic disposal of menstrual products, technical safety of the facilities, and adequate hygiene promotion and education. ${ }^{455}$ In Beja and Others v. Premier of the Western Cape and Others, ${ }^{456}$ the Court considered that construction of unenclosed toilet facilities fell short of the reasonableness requirement of the South African Constitution and an infraction of human dignity.

\subsubsection{Accessibility}

Another constituent element of the normative contents of the right to water is 'accessibility'. General Comment 15 outlined accessibility to encompassed physical accessibility, economic accessibility, non-discrimination and information accessibility. ${ }^{457}$

1. Physical Accessibility

Undoubtedly, distance from water sources impacts on water quantity secured by individuals and households such that the greater the distance, the limited quantity of water

\footnotetext{
${ }^{451}$ See also the Costa Rican case of Comité Pro-No Construcción de la Urbanización Linda Vista, San Juan Sur de Poás cl Ministerio de Ambiente y Energía y Otros [2004] Corte Suprema de Justicia 2004-01923 <http://www.ernestojinesta.com/ernesto\%20jinesta/Sentencias\%20E.\%20Jinesta/04-01923.HTM>. where the Constitutional Chamber of the Supreme Court of Justice revoked the permit granted for the construction of a housing project which could impact on the quality of groundwater in the area. 452 [2003] Corte Constitucional T-410/03 <http://www.corteconstitucional.gov.co/relatoria/2003/T-410-03.htm>. 453 Appellate Division (Civil Appeal no 118 of 1999), 27 August 2005. Available at: http://www.globalhealthrights.org/wp-content/uploads/2013/02/SC-2007-Rabia-Bhuiyan-v.-LGRD.pdf.

${ }^{454}$ These measures included the taking of necessary and effective steps to implement existing plans and policies against arsenic contamination; expediting the testing of tube wells across the country for arsenic; undertaking a phase-by-phase programme for sealing tube wells identified as being arsenic contaminated and for continuing to screen tube wells; ensuring that no further damage to human health is caused through the use of arsenic contaminated tube wells; and providing a yearly report to the Court regarding steps taken to implement the arsenic policies and plans. See also the Pakistan case of General Secretary, West Pakistan Salt Miners Labour Union v The Director, Industries and Mineral Development [1994] Supreme Court Human Rights Case 120 of 1993 <http://ceej.pk/cms/docs/sc/1994SCMR2061.pdf>.

${ }^{455}$ UN Human Rights Council, Report of the Special Rapporteur on the Human Right to Safe Drinking Water and Sanitation, Catarina de Albuquerque Paras. 72-4.

${ }^{456}$ Case No. 21332/10.

${ }^{457}$ UNCESCR, General Comment No. 15: The Right to Water (Arts. 11 and 12 of the Covenant), Para. 12(c)
} 
an individual or household is likely to have per day. ${ }^{458}$ Distance to water sources in the developing world is known to be significantly impacting on children's school enrolment and attendance. It is equally one of the major causes of sexual and gender-based violence to vulnerable groups such as refugees and displaced persons.

Physical accessibility connotes that "water infrastructure, including distribution networks, individual household connections, public stand-pipes or other means of distribution is required" to be physically accessible including services to "educational institutions, work places, hospitals and healthcare facilities, as well as public institutions and places." 459 Where water and water facilities are not physically accessible, the capacity of vulnerable groups such as the elderly, physically challenged and women to secure sufficient amount of water on daily basis is severely limited. In discharging the right to water obligation therefore, "water, and adequate water facilities and services, must be within safe physical reach for all sections of the population" 460 and it is suggested not to exceed 1000 metres $^{461}$ and collection time should not exceed 30 minutes. ${ }^{462}$ The Israeli case of Abadallah Abu Massad and others $v$. Water Commissioner and Israel Lands Administration ${ }^{463}$ concerned the discriminatory denial of access to water supply for Bedouins living in the unrecognised villages in the Negev desert under the policy of Israeli Water Authority. Under this Policy, water connection is only provided to houses with building permits granted under the law which effectively cut off the residents of the unrecognised villages. The Policy is intended to coerce the Bedouins to move to townships planned by the State. The only option for the Bedouins is either to purchase water and transport to their houses from a water centre near a legal village or on special humanitarian consideration obtained permission from Israeli Water Authority's Committee to establish a private access point to the water pipes. Each option puts a considerable cost higher than what other Israelis pay for direct connection. The Israeli Supreme Court relying among others on General Comment 15 concluded that "the implementation of the state planning policy on the level of accessibility of residents of the unrecognized Bedouin villages to water sources involves a violation of their right to water, which is afforded them as a human right". ${ }^{464}$ However, the Court juxtaposed the right against orderly planning interest of the State and applied proportionality principle. It then determined that:

$[\mathrm{P}]$ roportionality is obtained, therefore, as long as a person's basic right to accessibility to water sources is maintained, even if this involves inconvenience and the bearing of certain monetary costs. To be noted that, in light of the phenomenon of illegal settlements, this is not an optimal system for water consumption, but a minimal arrangement, which intends to uphold the basic right to water, even though its realization involves effort and cost. The

\footnotetext{
${ }^{458}$ See Guy Howard and Jamie Bartram, Domestic Water Quantity, Service Level and Health. P. 18.

${ }^{459}$ Inga T. Winkler, The Human Right to Water: Significance, Legal Status and Implications for Water Allocation p. 135

${ }^{460}$ UNCESCR, General Comment No. 15: The Right to Water (Arts. 11 and 12 of the Covenant). Para. 12(c)(i)

${ }^{461}$ Guy Howard and Jamie Bartram, Domestic Water Quantity, Service Level and Health. P. 21.

${ }^{462}$ Inga T. Winkler, The Human Right to Water: Significance, Legal Status and Implications for Water Allocation. P. 136.

463 [2011] Supreme Court Civil Appeal 9535/06

${ }^{464}$ Ibid. Para. 44.
} 
Realising the Right to Water and Sanitation in Nigeria

realization of the full right to water requires the legal arrangement of settlements, and this is

contingent on the residents' choice, and open to their decision ${ }^{465}$

While the need for proper town planning is appreciated but this left much to be desired for human rights realisation especially relating to a very important resource such as water which is necessary for sustaining human lives especially if the people affected are also economically disadvantaged. Although the Court did require minimum provision of water to the applicant, the Court should have ordered the State to adopt other approaches which may compel the residents to move and not in the context of denial of water connection. A somewhat similar case was considered by the French Council of State (Conseil d'Etat) in Madame Sandra A c/ Commune de Gouvernes ${ }^{466}$ where the Council was equally confronted with situation of refusal by the Municipality of Gouvernes to connect the property of the applicant to drinking water supply network on account that the caravans which the applicant uses in her property constituted an "irregularly established building for residential purposes" in an area where the use of such caravan was prohibited under the law. The Council applying the principle of proportionality held that while such refusal may be justified by the legitimate aim of respecting urban planning, safety rules and respect for the environment, consideration should be on case by case basis for which the administration is to ensure and the court to verify whether refusal to connect is proportionate to the aim. Of significant interest in the instant case was the holding by the Council that such refusal constituted an interference on the right to respect for private and family life.

Physical accessibility in the context of the right to sanitation requires sanitation facilities to be "within or in the immediate vicinity of each household, health or educational institution, public institutions and places, and the workplace." ${ }^{467}$ Location of sanitation facilities must ensure safety and be convenient for all users. ${ }^{468}$ The construction of unenclosed toilets where users have had to cover themselves when using the facilities is clearly below the requirement of physical safety. ${ }^{469}$

\section{Economic Accessibility}

Water may be available through service provided by the State or private providers but may not necessarily be accessible for consumers in terms of the cost associated with its purchase. ${ }^{470}$ Economic accessibility therefore relates to the costs and charges associated with securing water. This therefore encompasses elements of affordability. A World Health Organisation study revealed that the poor "who receive the lowest levels and least reliability of service and water of inferior quality" on average pay " 12 times more per litre of water than their counterparts with a municipal supply." ${ }^{471}$ General Comment 15 requires water and water

\footnotetext{
465 Ibid, Para. 45

${ }^{466}$ [2010] Conseil d'Etat 323250

${ }^{467}$ UN Human Rights Council, Report of the Special Rapporteur on the Human Right to Safe Drinking Water and Sanitation, Catarina de Albuquerque . Para. 75.

${ }^{468}$ Ibid. Paras. 75-76.

${ }^{469}$ See Beja and Others v. Premier of the Western Cape and Others (Supra).

${ }^{470}$ Availability and economic accessibility are considered different in the context in which the two were used by the Committee on ESC rights in its General Comment 15.

${ }^{471}$ World Health Organisation, Right to Water P. 16.
} 


\section{Chapter Two}

facilities and services to be affordable to all and the "direct and indirect costs and charges ... must not compromise or threaten the realisation of other covenant rights." 472 This obligation extends beyond where the government is the service provider to encompass the duty to protect. Practically, therefore, States must intervene to regulate costs and charges where water and water services are provided by private service providers. States must equally intervene in the event where supply of water is cut off against those who cannot afford the cost, to ensure minimum supply is guaranteed. ${ }^{473}$ Failure to pay for water in most cases is associated with inability of the affected persons to afford the costs.

States are under obligation to make water available to resident and to intervene in the context where water is disconnected from the population by a private service provider. A South African High Court in Highveldridge Residents Concerned Party v Highveldridge TLC and Others ${ }^{474}$ ordered a water company to reinstate water supply which was disconnected from several households in the Lebohang Township which as was argued was on account of non-payment. The Court was of the view that a "well-grounded apprehension of irreparable harm" 475 existed in this situation if the interim order of reinstatement of supply was refused. On the basis of balance of convenience, the Court was of the opinion that "any pecuniary losses which the respondent might suffer cannot outweigh human need (and possibly human suffering) which will probably occur due to a lack of fresh water". ${ }^{476}$

In Quevedo, Miguel Ángel y Otros c/Aguas Cordobesas $S A^{477}$ where water was disconnected from an impoverished population on account of non-payment due to lack of means, the court granted an injunction and ordered the authorities to guarantee a minimum daily supply of 200 litres per household. The reasoning of the court was based on the essential nature of water service being public which should be guaranteed to all citizens. In Usuarios y Consumidores en Defensa de sus Derechos Asociación Civil c/ Aguas del Gran Buenos Aires $S A^{478}$ the court emphasised the obligation of the State to provide access to portable water as of right to all the inhabitants irrespective of their capacity to pay for the supply. In this case an injunction was issued against disconnection of water supply in Moreno, Argentina on account of lack of means to pay. A restoration order of the supply to the premises disconnected was equally issued. The High Court of Brazil in Ademar Manoel Pereira $x$ Companhia Catarinense de Agua e Saneamento - CASAN ${ }^{479}$ considered disconnection of water supply on account of lack of means to pay as illegal and inhuman which subjects a consumer to ridicule and embarrassment.

A higher obligation to provide continuous supply to essential services such as hospitals is confirmed by a High Court in Brazil. In Santa Casa de Misericórdia de Santa Rosa do

\footnotetext{
${ }^{472}$ UNCESCR, General Comment No. 15: The Right to Water (Arts. 11 and 12 of the Covenant), para. 12(c)(ii)

${ }^{473}$ John Scanlon, Angela Cassar and Noemi Nemes, Water as a Human Right? P. 29.

474 [2002] High Court (Transvaal Provincial Division) 28521, (2002) (6) SA 66.

475 Ibid. Para. 32.

${ }^{476}$ Ibid. Para. 33.

477 [2002] Juez Sustituta de Primera Instancia Civil y Comercial (Ciudad de Córdoba) <http://www.cedha.org.ar/docs/doc220-spa.doc>.

478 [2002] Juez de paz $\quad$ (Moreno, $\quad$ Buenos $\quad$ Aires) 44.453 <http://www.legalmania.com.ar/derecho/fallo_asociacion_consumidor.htm>.

${ }^{479}$ [1999] Superior Tribunal de Justiça Resp no 201.112.
} 
Realising the Right to Water and Sanitation in Nigeria

Viterbo x Companhiade Saneamento Básico do Estado de São Paulo - SABESP ${ }^{480}$ water supply to a hospital was disconnected on account of non-payment of water rates. The Court held that water supply as an indispensable public service, when it comes to essential services the principle of non-interruption applies and the supply must be continuous whether it is undertaken by the State or a private company under concession contract. The court considered such a disconnection as not only illegal but also an abusive act. This position extent to persons whose health or living condition requires continuous supply of water. In Flor Enid Jiménez de Correa c/ Empresas Públicas de Medellín ${ }^{481}$ a Colombian Court ordered the reconnection of water supply to a 56-year old woman suffering from chronic kidney failure and requiring four daily sessions of dialysis at home which puts access to water indispensable but which the woman due to her financial position cannot afford. The Court considered her vulnerable position and concluded that her health position not only is protected by the constitution, but her health condition entitles her to a special protection from the State in relation to her inability to pay her water bills. ${ }^{482}$

Where affordability to pay water bills exist, the legality for disconnection seemed to be whether disconnection is proportionate to the sufferings which the disconnection will cause or whether the disconnection is in accordance with the principle of reasonableness and fairness. In Condominio del Conjunto Residencial Parque Choroní II c/ Compañía Anónima Hidrológica del Centro (Hidrocentro) ${ }^{483}$ concerning disconnection on non-payment of excessive water bills due to malfunctioned meters installed, the affected residents were willing to pay if the anomaly is addressed by the water company. The Venezuelan First Court of Administrative Litigation reasoned with the applicants and considered whether the measure of disconnection was in accordance with proportionality principle. The Court considered it disproportionate as it would cause greater damage to the affected population in relation to the interest of the water company. In the Netherlands case of $H D 200.018 .358,484$ the Dutch Court of Appeal noted that the right to suspend services under the Dutch Civil Code requires respecting the principle of reasonableness and fairness which necessarily requires the provider of such services (water company, in the instant case) to "do so with severe caution and constraint" 485 . The principle, according to the Court requires water company before becoming entitled to disconnect, to undertake reasonable efforts to persuade the defaulter to pay and notify such defaulter of intention to disconnect if refusal to pay endure. ${ }^{486}$

In exercising the right of disconnection where it exists, however, adopting a coercive measure will be deemed illegal. This for example was considered in the Portuguese case of A $x$ EPAL - Empresa Publica das Aguas de Lisboa ${ }^{487}$ where the Regulations for Water Services allowed disconnection of water services from not only premises in default of

\footnotetext{
${ }^{480}$ [2007] Superior Tribunal de Justiça Resp no 943.850

481 [2007] Corte Constitucional T-270/07

${ }^{482}$ Ibid. Para. II-6.1.

483 [2005] Tribunal Supremo de Justicia AP42-N-000628

${ }^{484}$ [2010] Gerechtshof ('s-Hertogenbosch) LJN BL6583, PRG (2010) 70

${ }^{485}$ Ibid. Para. 4.8.

${ }^{486} \mathrm{Ibid}$

${ }^{487}$ [2004] Tribunal Constitucional 685/2004
} 
payment but other premises of the same user even if such other premises are not in default in order to coerce and accelerate payment. The Court not only invalidated the law, it held that such coercive means go beyond the strict enforceability of contract but also maintained that "the values associated with the access to water for human consumption prevail over the economic importance of coercive means against non-paying users, in such a way, that they expose the disproportionality of the use of such means in the framework of contracts regularly complied with by the same users." ${ }^{488}$ A somewhat similar decision was reached by the Constitutional Court of Slovenia in Ruling No Up-156/98 ${ }^{489}$ where water was disconnected from an entire building due to the non-payment by $1 / 4$ of the residents. ${ }^{490}$

It appears that in certain extreme cases and in some few jurisdictions court may legitimise disconnection when evidence is shown that the defaulting party has the means to pay for water bills. Even in such situations however, the courts interpret such situations strictly narrowly such as not to create the blanket right of the water service company to disconnect. ${ }^{491}$ The obligation to supply the minimum even in the event of disconnection continues. In the Belgium case of Juge de Paix Fontaine-l'Evêque ${ }^{492}$ the Court noted that "[e]ven a chronic failure of the user to his obligation to pay could not deprive him from his basic right to respect of his dignity" as such maintained that the remedy for the supplier is to reduce the quantity but must maintain minimum supply such that could preserve human dignity. ${ }^{493}$

In situations where non-payment relates to lack of means, it appears the only possible option is to have recourse to judicial protection for the recovery of the debt. ${ }^{494}$ This was emphasised in Ademar Manoel Pereira x Companhia Catarinense de Agua e Saneamento $C A S A N^{495}$ where the High Court of Brazil frowned at self-help in the form of disconnection under the rule of law. However, the Colombian Constitutional Court in Carolina Murcia Otálora c/Empresas Públicas de Neiva ESP ${ }^{496}$ while recognising disconnection as legitimate it requires the service providers to consider the reason for non-payment, the fundamental

\footnotetext{
${ }^{488}$ Ibid. Para. 6 as translated in Waterlex database.

${ }^{489}$ [1999] Constitutional Court Official Gazette RS, no 17/99; OdIUS VIII, 118

490 There was a single meter for the entire building. The justification for disconnection was that it would be easier for the water company to recover its debts from the defaulting residents. The court considered it a disproportionate and excessive measure and violates the right to private property under the Slovenian Constitution. The Court however, recognises that disconnection of water supply is permissible if such complies with the principle of proportionality.

${ }^{491}$ See for example the Malaysian case of Rajah Ramachandran v Perbadanan Bekalan Air Pulau Pinang Sdn Bhd [2004] High Court (Malaya) 22-716-2003 which involved a disconnection on account of non-payment in a contentious issue relating to meter reading. The applicant has the means to pay but was contesting the exorbitant bill without proper explanation as to the cause. The Malaysian High Court in para. 13 was of the opinion that "The draconian act of cutting off supply was too harsh in the circumstances of this case. If the [respondent] is entitled to only cut off water supply for non-payment the Act would not have provided for the lesser alternative cause of action the [respondent] could have resorted to. It must be understood that a public body endowed with a statutory discretion in enforcing its rights must exercise such discretion as would impose the least inconvenience to the public. It ought not to act arbitrary or capriciously or unjustly. Nevertheless, it must not hesitate to act appropriately where drastic action is warranted like when a consumer without any rhyme or reason refuses to settle his bill".

492 [2009], JJP [2012] 306

493 Ibid. P. 309.

${ }^{494}$ In some States, the law prescribes circumstances under which the court may authorise disconnection. This is for example the case in Belgium under Décret relatif au Livre II du Code de l'Environnement constituant le Code de l'Eau, 27 mai 2004 (Région wallonne).

495 [1999] Superior Tribunal de Justiça Resp no 201.112

${ }^{496}$ [2009] Corte Constitucional T-546/09
} 
Realising the Right to Water and Sanitation in Nigeria

rights which may be undermined, or the affected peoples' living conditions. ${ }^{497}$ In other words, the principle of proportionality must be observed. The court proceeded to provide the criteria as follows:

$[\mathrm{N}]$ ot all cases of non-payment legitimise the disconnection of water and sanitation services. If the non-payment is involuntary or due to insurmountable reasons; if it is related to groups entitled to constitutional special protection; if the service is indispensable to guarantee other constitutionally protected fundamental rights such as the rights to life, equality, dignity and health; and if, finally, the legal conditions for disconnection are met, what must be changed is the way in which the public service is provided. Rather than disconnecting the water supply, basic and indispensable, minimum quantities of water must be provided to the final user. ${ }^{498}$

Although the Court in this case recognised disconnection as a violation of fundamental human rights to drinking water, life, and health of children but refused to provide protection to the applicant because the applicant had resorted to an unauthorised water connection. In order words, the applicant had resorted to self-help.

Ensuring affordability of water is an obligation which extends to adopting all the necessary measures to make it accessible including for example adopting appropriate pricing policies "such as free or low-cost water". ${ }^{499}$

Affordability of sanitation facilities and services is equally a component of the right to sanitation according to the Special Rapporteur's report. ${ }^{500}$ This relates to the price to be paid for among others, construction, emptying and maintenance of the facilities. ${ }^{501}$

\section{Information Accessibility}

Information accessibility is a procedural guarantee, a necessity in the implementation of the human right to water. ${ }^{502}$ This encompasses "the right to seek, receive and impart information concerning water issues." 503 A detailed explanation of the core procedural right accompanying the right to water has been discussed by Scanlon et al which includes individuals right to information relating to State's activities concerning water, right of individuals to fair and just administrative action, and right of individuals to participate in decision-making concerning water. ${ }^{504}$ These rights have been observed to be civil and political which are necessary in the realisation of the right to water. ${ }^{505}$ On sanitation, the Independent Expert on the Issue of Human Rights Obligations Related to Access to Safe Drinking Water and Sanitation, Catarina De Albuquerque reiterated the obligation of States "to ensure that concerned individuals and communities are informed and have access to

\footnotetext{
${ }^{497}$ Ibid. Para. 4.5.

${ }^{498}$ Ibid, para. 5.1 (Waterlex translation).

${ }^{499}$ See Flor Enid Jiménez de Correa c/ Empresas Públicas de Medellín [2007] Corte Constitucional

T-270/07 <http://www.corteconstitucional.gov.co/relatoria/2007/T-270-07.htm>.

${ }^{500}$ UN Human Rights Council, Report of the Special Rapporteur on the Human Right to Safe Drinking Water and Sanitation, Catarina de Albuquerque Paras. 77-9.

${ }^{501}$ Ibid. Para. 77.

502 John Scanlon, Angela Cassar and Noemi Nemes, Water as a Human Right? P. 29.

${ }^{503}$ UNCESCR, General Comment No. 15: The Right to Water (Arts. 11 and 12 of the Covenant). Para. 12(c)(iv)

${ }^{504}$ John Scanlon, Angela Cassar and Noemi Nemes, Water as a Human Right? p.30; See also the French case of Federation Departementale des Syndicats d'Exploitants Agricoles du Finistere [2012] Conseil constitutionnel $2012-$ 270 QPC

505 Amanda Cahill, 'The Human Right to Water - A Right of Unique Status': The Legal Status and Normative Content of the Right to Water'. P. 393.
} 
information about sanitation and hygiene and are enabled to participate in all processes related to the planning, construction, maintenance and monitoring of sanitation services."506 Full participation is hence required and this should consists of all the representatives of the concerned groups. ${ }^{507}$

Judicial authorities firmly established the obligation to inform and allow the participation of the affected population in matters concerning quality and availability of water supply in their areas. In Halalt First Nation v British Columbia (Environment) ${ }^{508}$ which concerns the construction and operation of a well field designed to extract groundwater as a substitute to surface water in order to guarantee the provision of drinking water in the area but which project would impact on the rights of an indigenous people, the Canadian Supreme Court (British Columbia) emphasised the right of the indigenous people to be consulted and to be informed about the actual scope of the project as well as to the "reasonable interim accommodation for the potential infringements of its interests posed by the project". ${ }^{509} \mathrm{In}$ Gad Amit Kaufman y Otros c/ Municipalidad de Carrillo y Otros ${ }^{510}$ the Costa Rican Supreme Court of Justice maintained that when a project would impacts on the environment and by extension water availability, impact assessment must be done and the results must be shared with the affected population which must participate in decision-making. The Peruvian High Court of Justice in Red de Vigilancia y Exigibilidad de los Derechos Económicos, Sociales y Culturales Región Junín c/ Municipalidad Provincial de Huancayo ${ }^{511}$ ordered the local authorities to inform the population through mass media of the dangers associated with the consumption of water being supplied by public water company without boiling it. ${ }^{512}$ In Rabia Bhuiyan v Ministry of LGRD and others ${ }^{513}$ the Bangladesh Court of Appeal required the State to "raise mass awareness of the dangers of drinking water from arsenic contaminated tube wells and of alternative sources of safe drinking water". ${ }^{514}$ In Beja and Others vs. Premier of the Western Cape and Others ${ }^{515}$ the Court found that there has been failure to ensure that the affected community genuinely participate in the planning, designing and execution of sanitation facilities as required by law.

States are to make information accessible through various available media in all the relevant languages to ensure widest possible circulation. ${ }^{516}$ Information accessibility and participation are important for several reasons. For example, on sanitation, it will ensure that sanitation solutions are consistent with the needs of the beneficiaries, are culturally

\footnotetext{
${ }^{506}$ UN Human Rights Council, Report of the Independent Expert on the Issue of Human Rights Obligations Related to Access to Safe Drinking Water and Sanitation, Catarina de Albuquerque . Para. 66.

${ }^{507}$ Ibid.

${ }^{508}$ [2011] Supreme Court (British Columbia) S098232, 2011 BCSC 945

${ }^{509}$ Ibid. Para. 750.

${ }^{510}$ [2009] Corte Suprema de Justicia 2009-000262

511 [2005] Corte Superior de Justicia (Junín) 1230-2005

512 This is in addition to the adoption of necessary measures to regularise water quality being supplied by the Company.

513 Appellate Division (Civil Appeal no 118 of 1999), 27 August 2005. Available at: http://www.globalhealthrights.org/wp-content/uploads/2013/02/SC-2007-Rabia-Bhuiyan-v.-LGRD.pdf.

514 Ibid. Para. 29.

${ }^{515}$ Supra.

${ }^{516}$ UN Human Rights Council, Report of the Independent Expert on the Issue of Human Rights Obligations Related to Access to Safe Drinking Water and Sanitation, Catarina de Albuquerque . Para. 66.
} 
Realising the Right to Water and Sanitation in Nigeria

acceptable, affordable and technically feasible. ${ }^{517}$ Additionally, it will enable the attainment of community ownership as well as dedication designed to bring "the required behavioural changes." 518

\subsubsection{Acceptability}

This content is in relations to the right to sanitation. It requires sanitation facilities to be culturally acceptable to the population. ${ }^{519}$ The designing, positioning and condition of use of the facilities should be culturally sensitive and ensure privacy in accordance with the need of the users. ${ }^{520}$ Additionally, cultural sensitivity in terms of separating toilets on gender basis should be respected and should have necessary facilities such as water for washing and cleansing. In Mendoza Beatriz Silva et al vs. State of Argentina et al on damages (damages resulting from environmental pollution of Matanza/Riachuelo river) ${ }^{521}$ the Court ordered the adoption of specific sanitation programmes to meet the needs of the population. Though not specifically mentioned, religious consideration is to be added in terms of the structure, construction, positioning of toilet facilities as well as availability of water and sanitary materials.

\subsection{Distinct Nature of Sanitation as Human Right and its Gender Dimension}

While water and sanitation are connected and invariably the absence of one impacts tremendously on the other, the two can conveniently be separated on other grounds. ${ }^{522}$ It is true that water and sanitation are necessary for living a dignified life and ensuring adequate housing, health and standard of living, sanitation deserves special attention in the context of human dignity and its dimensions. In the words of Independent Expert on the Issue of Human Rights Obligations Related to Access to Safe Drinking Water and Sanitation, Catarina De Albuquerque

Sanitation is not just about health, housing, education, work, gender equality, and the ability to survive. Sanitation, more than many other human rights issue, evokes the concept of human dignity; consider the vulnerability and shame that so many people experience every day when, again, they are forced to defecate in the open, in a bucket or a plastic bag. It is the indignity of this situation that causes the embarrassment. ${ }^{523}$

Nothing could be truer than the above statement especially in circumstances where cultural issues where self-respect is an important consideration. The Independent Expert further stated that "[d]ignity closely relates to self-respect, which is difficult to maintain when being forced to squat down in the open, with no respect for privacy, not having the opportunity to clean oneself after defecating and facing the constant threat of assault in such a vulnerable moment." ${ }^{24}$ The Independent Expert has noted momentum currently being generated towards recognising sanitation as an independent human right without the

\footnotetext{
${ }^{517}$ Ibid..

518 Ibid.

${ }^{519}$ UN Human Rights Council, Report of the Special Rapporteur on the Human Right to Safe Drinking Water and Sanitation, Catarina de Albuquerque . Para. 80.

${ }^{520}$ Ibid.

${ }^{521}$ File M. 1569. XL (see WaterAid, 'Court Cases')

${ }^{522}$ This research is not advocating for such but is merely indicating the possibility of doing so at some level with a view to ensuring that specific attention is paid to sanitation because of its special impact on human dignity.

${ }^{523}$ UN Human Rights Council, Report of the Independent Expert on the Issue of Human Rights Obligations Related to Access to Safe Drinking Water and Sanitation, Catarina de Albuquerque . Para. 55.

${ }^{524}$ Ibid. Para. 57.
} 


\section{Chapter Two}

necessity of having to link it with water or housing or adequate standard of living and some States have even provided for its in their domestic laws. ${ }^{525}$

While gender should both be considered in the provision of water and sanitation because in some cases women and girls suffer more in accessing them, the impact of lack of sanitation seems to be more felt by women and girls because of their unique nature. ${ }^{526}$ There is disparity in the way lack of access to sanitation facilities affects men and women. CEDAW requires the elimination of discrimination against women in rural areas in among others, the enjoyment of "adequate living conditions particularly in relation to housing, sanitation, electricity and water supply".527 The Special Rapporteur stated that "Because of their domestic roles and responsibilities, women are in greatest physical contact with contaminated water and human waste." 528 Disparities can be seen in the context of enjoyment of other rights.

There is a link between sanitation and the enjoyment of other human rights and these have negative impacts on women. For example, regarding the right to health, women are more likely not to access hospitals which do not provide for gender-segregated toilet facilities. ${ }^{529}$ Additionally, women and girls who hold urine for a longer period are likely to have a higher risk of bladder and kidney infections. ${ }^{530}$ The right to work of women is equally affected by lack of access to sanitation. Workplaces without sanitation facilities or with prohibitively long waiting time can impact on ability to keep jobs. ${ }^{531}$ This affects women during menstruation and pregnancy. ${ }^{532}$ The UNGA resolution 70/169 has expressed these concerns. ${ }^{533}$ Furthermore, the right physical security is also impacted as women and girls are more vulnerable to physical attacks when they have walk a long way to access sanitation facilities or defecate in the open. ${ }^{534}$ The Report of the Special Rapporteur on the Human Right to Safe Drinking Water and Sanitation have shown that women "fear violence by men in public toilets and open defecation sites, and along the routes leading to both. Some women and girls looking for a place to defecate have reportedly been exposed to rude remarks, brickthrowing, stabbing and rape." ${ }^{535}$ The UNGA resolution 70/169 has equally expressed concern on this issue. ${ }^{536}$ Women suffer harassment and stigmatisation when they defecate in the open.

The specific impact of lack of access to sanitation has been noted to affect girls' education. Schools without sanitation facilities can make girls drop out of school during their

\footnotetext{
525 The Independent Expert noted Bolivia, Uruguay and Kenya.

${ }^{526}$ UN Human Rights Council, Report of the Independent Expert on the Issue of Human Rights Obligations Related to Access to Safe Drinking Water and Sanitation, Catarina de Albuquerque . Para. 6.

${ }^{527}$ Art. 14(2)(h).

${ }^{528}$ UN Human Rights Council, Report of the Special Rapporteur on the Human Right to Safe Drinking Water and Sanitation. Para. 32.

${ }^{529}$ UN Human Rights Council, Report of the Independent Expert on the Issue of Human Rights Obligations Related to Access to Safe Drinking Water and Sanitation, Catarina de Albuquerque . Para. 23.

${ }^{530}$ UN Human Rights Council, Report of the Special Rapporteur on the Human Right to Safe Drinking Water and Sanitation. Para. 32.

${ }^{531}$ UN Human Rights Council, Report of the Independent Expert on the Issue of Human Rights Obligations Related to Access to Safe Drinking Water and Sanitation, Catarina de Albuquerque . Para. 38.

532 Ibid.

${ }^{533}$ United Nations General Assembly, Resolution 70/169: The Human Rights to Safe Drinking Water and Sanitation. Preamble 13-14.

${ }^{534}$ UN Human Rights Council, Report of the Independent Expert on the Issue of Human Rights Obligations Related to Access to Safe Drinking Water and Sanitation, Catarina de Albuquerque . Para. 43.

${ }^{535}$ UN Human Rights Council, Report of the Special Rapporteur on the Human Right to Safe Drinking Water and Sanitation. Paras. 27-29.

${ }^{536}$ United Nations General Assembly, Resolution 70/169: The Human Rights to Safe Drinking Water and Sanitation. Preamble 15.
} 
Realising the Right to Water and Sanitation in Nigeria

menstrual periods. ${ }^{537}$ GC 15 of the Committee on ESC rights, as such required that in the provision of water and sanitation specific needs of women should be considered. ${ }^{538}$

The contents on the right to sanitation therefore specifically in terms of physical accessibility should be such that minimises the risk of attacks on women and girls, ${ }^{539}$ makes it possible for pregnant women to access them. ${ }^{540}$ On affordability, women and girls can equally be vulnerable especially in situation of poverty or lack of means to afford for example sanitary pads. ${ }^{541}$ Affordability is a huge concern for women and girls especially in developing countries where there is disparity in terms of purchasing power on gender basis. The way in which men access public sanitation facilities can be different from women. While in many instances urinals for men is free, same is not case for women and compared to their economic position, this can be a challenge. ${ }^{542}$

In the context of acceptability stated that "[I]n most cultures, acceptability will require separate facilities for women and men in public places, and for girls and boys in schools. Women's toilets need to accommodate menstruation needs." 543

To address the special impacts on lack of access to water and sanitation on women and girls, UNGA resolution 70/169 calls on States:

To promote both women's leadership and their full, effective and equal participation in decision-making on water and sanitation management and to ensure that a gender-based approach is adopted in relation to water and sanitation programmes, including measures, inter alia, to reduce the time spent by women and girls in collecting household water, in order to address the negative impact of inadequate water and sanitation services on the access of girls to education and to protect women and girls from being physically threatened or assaulted, including from sexual violence, while collecting household water and when accessing sanitation facilities outside of their home or practising open defecation. ${ }^{544}$

Similar calls were made by the Special Rapporteur and Independent Expert on the Human Right to Safe Drinking Water and Sanitation. ${ }^{545}$ Lastly, SDG Goal 6 target 6.2 is aimed at achieving access to adequate and equitable sanitation and hygiene for all and end open defecation, paying special attention to the needs of women and girls and those in vulnerable situations by 2030 .

\footnotetext{
${ }^{537}$ UN Human Rights Council, Report of the Independent Expert on the Issue of Human Rights Obligations Related to Access to Safe Drinking Water and Sanitation, Catarina de Albuquerque Para. 51. See also UN Human Rights Council, Report of the Special Rapporteur on Torture and other Cruel, Inhuman or Degrading Treatment or Punishment, Manfred Nowak (UN Doc A/HRC/7/3 15 January 2008). Para. 41. See also UN Commission on Human Rights, Report submitted by the Special Rapporteur on the Right to Education, Mr. V. Muñoz Villalobos (UN Doc E/CN4/2006/45, 8 February 2006). Paras. 129-130.

${ }^{538}$ UNCESCR, General Comment No. 15: The Right to Water (Arts. 11 and 12 of the Covenant). Para. 41.

${ }^{539}$ UN Human Rights Council, Report of the Independent Expert on the Issue of Human Rights Obligations Related to Access to Safe Drinking Water and Sanitation, Catarina de Albuquerque . Para. 75.

${ }^{540}$ Ibid. Para. 76.

${ }^{541}$ Ibid. Para. 79. See also UN Human Rights Council, Report of the Special Rapporteur on the Human Right to Safe Drinking Water and Sanitation. Para. 39.

${ }^{542}$ UN Human Rights Council, Report of the Special Rapporteur on the Human Right to Safe Drinking Water and Sanitation. Para. 37.

${ }^{543}$ UN Human Rights Council, Report of the Independent Expert on the Issue of Human Rights Obligations Related to Access to Safe Drinking Water and Sanitation, Catarina de Albuquerque . Para. 80.

${ }^{544}$ United Nations General Assembly, Resolution 70/169: The Human Rights to Safe Drinking Water and Sanitation. Para. 5(e).

${ }^{545}$ UN Human Rights Council, Report of the Special Rapporteur on the Human Right to Safe Drinking Water and Sanitation. Paras. 54-62. See also UN Human Rights Council, Report of the Independent Expert on the Issue of Human Rights Obligations Related to Access to Safe Drinking Water and Sanitation, Catarina de Albuquerque. Para. 81(h).
} 


\subsection{Freedoms and Entitlements in the Right to Water}

Chapter Two

Recognition of a right implies freedoms and entitlements. ${ }^{546}$ Freedom is in the context of non-interference while entitlement connotes having a right to receive something. The Committee on ESC right in General Comment 15 acknowledged the existence of these freedoms and entitlements in the human right to water and framed them in the form of rights. The freedoms and entitlements connote the positive and negative aspects of the right to water ${ }^{547}$ which are generally linked to the general obligations of respect and protect discussed above.

The freedoms identified by the Committee "include the right to maintain access to existing water supplies necessary for the right to water, and the right to be free from interference, such as the right to be free from arbitrary disconnections or contamination of water supplies." 548 These were contrasted with entitlements which "include the right to a system of water supply and management that provides equality of opportunity for people to enjoy the right to water." 549

\subsection{Obligations of Non-State Actors as Service Providers}

Increasingly in recent time, provision of access to water and sanitation is being privatised by States to non-state actors since from the 2000 Hague World Water Forum. ${ }^{550}$ This has created a paradigm shift from water as social good to water as economic good with all the attendant consequences which put the requirement of equitable and affordable access under threat. ${ }^{551}$ This is equally the case on sanitation especially with regard to waste disposal. Under this arrangement, in many countries, the poor who could not afford are cut off from supply.

Recognising water and sanitation as human rights imposes an obligation on both States and non-state actors to first give preference to human needs and ensures access to quality and affordable water to all over and above any economic consideration such as profits. ${ }^{552}$ On sanitation, States are required to adopt all necessary measures including administrative and legislative to prevent negative impacts of non-state actors concerning enjoyment of sanitation. ${ }^{553}$ Judicial decisions referred to above have demonstrated the duty of States to ensure appropriate regulatory mechanisms are in place to check and ensure that people are not unnecessarily deprived of access to water for their inability to pay. The obligation of State to protect individuals from interfering with access to water continues even when the State privatises in good faith. As such, the State must ensure that contents of the right to water are respected when water provision and management is handed over to the private sector through concession or any other arrangement entered into by the State. This is equally the case on

\footnotetext{
${ }^{546}$ John G. Merrils, 'Environmental Rights'. P. 665.

${ }^{547}$ Amanda Cahill, 'The Human Right to Water - A Right of Unique Status': The Legal Status and Normative Content of the Right to Water' P. 393.

${ }^{548}$ UNCESCR, General Comment No. 15: The Right to Water (Arts. 11 and 12 of the Covenant). Para. 10

${ }^{549}$ Ibid.. Para. 10.

${ }^{550}$ Emilie Filmer-Wilson, 'The Human Rights-based Approach to Development: The Right to Water'At P. 229.

${ }^{551}$ Ibid. P. 229

552 Ibid. P. 232.

${ }^{553}$ UN Human Rights Council, Report of the Independent Expert on the Issue of Human Rights Obligations Related to Access to Safe Drinking Water and Sanitation, Catarina de Albuquerque . Para. 64.
} 
Realising the Right to Water and Sanitation in Nigeria

sanitation. ${ }^{554}$ The United Nations General Assembly in resolution 70/169 had called on nonState actors including business enterprises to comply with their human rights obligations including those on water and sanitation such as availability, quality, accessibility and affordability. ${ }^{555}$ The State and private service providers may be held jointly responsible for any act that interferes with the enjoyment of this right. The Special Rapporteur on the human right to safe drinking water and sanitation in a report to Human Rights Council has reiterated the obligation of ensuring affordability of water and sanitation services especially to those who cannot afford by reason of their special circumstances such as women and girls. ${ }^{556}$ However, recognising water as economic good equally has its advantages such as ensuring the wastage is removed and regular supply is ensured.

\subsection{Conclusions}

Generally, the key obligations in human rights law are the obligation to respect, protect and fulfil human rights by every State. In terms of the right to water and sanitation, the obligation to respect obliges States to refrain from practices which denies or limits equal access to adequate water and sanitation or interfering in an arbitrary manner with traditional arrangement on water allocation or deliberately polluting water. The obligation to protect requires preventing third parties from interfering with the enjoyment of the right through the adoption of relevant measures to protect the population. The obligation to fulfil obliges States to adopt measures to enable full realisation of the right to water and sanitation. In the context of ESC right, it may be added that there is also the obligation to cooperate and seek international assistance where a State is unable to realise the rights by itself and the obligation to provide assistance by those who are in the position to do so.

The recognition of water and sanitation as human rights according to General Comment 15 of the Committee on ESC rights entailed that States must ensure the provision of safe water in sufficient quantity in a manner which guarantees non-discrimination. These have been referred to as the contents of the right. Jurisprudence from domestic courts around the world have helped in explaining some of these contents and have indicated some of the instances in which a State may be in violation of its legal obligations. Currently, there is also the proposed Second Optional to International Covenant on Economic, Social and Cultural Rights signed by States which defines binding norms and States' obligations to achieve the right to water at minimum level in order to guarantee the dignity of the life. The proposed Optional Protocol contains among others provisions relating to quantification of the right to water and the duty of the States to guarantee it; the strengthening of local communities; the recognition of community based water systems managing the water services; the introduction

\footnotetext{
${ }^{554}$ According to the Independent Expert "When sanitation services are operated by a private provider, the State must establish an effective regulatory framework.". See ibid.. Paras. 64 and 67. In Para. 67 it is stated that "States may decide to privatize sanitation services, but in that case must ensure - through adequate regulation, including effective and accessible complaints procedures - that private actors do not adopt approaches which result in human rights violations."

${ }^{555}$ United Nations General Assembly, Resolution 70/169: The Human Rights to Safe Drinking Water and Sanitation. Para. 6

${ }^{556}$ UN Human Rights Council, Report of the Special Rapporteur on the Human Right to Safe Drinking Water and Sanitation. Paras. 37-42.
} 
of a scale of the amount of water per person per day; and the definition of a pricing policy that respect the right of people who cannot pay to have access to the minimum quantity guaranteed for life. 


\section{Chapter Three}

\section{Human Rights Protection in Nigeria and the Right to Water and Sanitation: Perspectives and InSTITUTIONAL STRUCTURES}

\subsection{Introduction}

Uuman rights promotion and protection is circumscribed by several factors. Some of the 1 pillars through which human rights are protected and promoted include existence of appropriate legal frameworks, functional institutional structures, human and sometimes material resources. General Comment 15 of the UN Committee on ESC rights requires States to adopt comprehensive as well as integrated strategies to ensure supply of safe and sufficient water for the present and future generation. ${ }^{557}$ According to the Committee these strategies and programmes include the establishment of competent institutions and appropriate institutional arrangements designed to carry out these strategies and programmes. ${ }^{558}$ However, the existence of the above is not a guarantee that human rights will be realised or promoted as these need to be complemented by other factors. As such it is usual in a particular State to find the existence of legal and policy instruments (which by reasonable standards are compatible with human rights obligations), institutional structures established to promote human rights including availability of resources but yet, realisation of human rights continues to be a challenge. Several reasons may account for these challenges such as for example the legal instruments are not adequately implemented; lack of capacity hampering the operation of the institutional structures; absence of necessary political will; lack of interest on the part of rights-holders or absence of strong civil society organisations putting pressure on dutybearers. This chapter analyses the general human rights environment in Nigeria. It highlighted human rights struggles during the military periods and the current human rights position. The chapter further examined the general institutional structures in human rights protection in Nigeria and those relevant to the provision of water and sanitation. This will help in understanding the challenges associated with human rights protection and realisation in general and the right to water and sanitation in particular. The chapter concludes with identification of problems associated with the operation of these institutions which impact negatively on the realisation of the right to water and sanitation in Nigeria.

\footnotetext{
${ }^{557}$ UNCESCR, General Comment No. 15: The Right to Water (Arts. 11 and 12 of the Covenant) Paras. 28, 47 and 50.

${ }^{558}$ Ibid. Para. 28(i).
} 
Realising the Right to Water and Sanitation in Nigeria

\subsection{Nigeria's Human Rights Environment: Power Politics and Judicial Struggles}

Human right is a generic term which embraces quite a number of rights including civil, political, economic, social, cultural ${ }^{559}$ and environmental rights. The growing number of international legal instruments protecting various aspects of human rights has led commentators and citizens to take for granted the meaning and contents of human rights, ${ }^{560}$ including the idea that the existence of these instruments will guarantee human rights realisation and protection. It has been rightly observed that "[m] ost political activists and commentators are content just to look at the United Nations' ever-growing body of human rights agreements as proof that these rights exist universally and therefore have to be respected by everyone." 561 The reality however is not always the case.

While it is not the intention of this research to address meaning and contents of human rights (except in the context of the right to water and sanitation), it suffices to state that human rights are "[a]ll those rights which are essential for the protection and maintenance of dignity of individuals and create conditions in which every human being can develop his personality to the fullest extent". 562

Human right as an object of inquiry demands a better and critical understanding of the context in which claims are made for its realisation. To understand this, assessment should be country or jurisdiction specific as this will provide deeper understanding on how human rights realisation are fought and won or lost. No doubt, international and domestic legal instruments and human rights institutions are important in human rights realisation, but their mere existence is not a conclusive indication that human rights are enjoyed in a State. A State may be a party to several international human rights instruments and might have even established local structures to protect and promote the rights, but the success of the instruments and structures can be hampered by many factors including the State itself. In certain cases, the State' participation and ratification of international legal instruments may be symbolic in order to find acceptance with other States, and or to avoid pressure from the international community and human rights organisations. A State can equally establish institutional structures to demonstrate its commitment to human right protection formerly but in reality, the structures are mere sham with little or no practical value because the proper functioning of the institutions has been crippled by lack of funding, capacity building or the political will to allow them to fully and independently function. Additionally, a State may be bound internationally by its consent to be a party to a treaty, but its legal system requires it to first domesticate the treaty before powers of domestic courts can be activated to enforce its provisions. As such, steps taken by a State, closer analysis of the working of legal instruments including examination of the operation of domestic institutional structures may be necessary to establish the extent to which a State is committed to ensuring the realisation

\footnotetext{
${ }^{559}$ Chintamani Rout, 'Voices for Human Rights' (2014) 2 IMPACT: International Journal of Research in Humanities, Arts and Literature . P. 34.

${ }^{560}$ Todd Landman, 'Social Science Methods and Human Rights' in Fons Coomans, Fred Grünfeld and Menno T. Kamminga (eds), Methods of Human Rights Research (Methods of Human Rights Research, Intersentia 2009). Pp. 21-22.

561 Andrew Heard, 'Human Rights: Chimeras in Sheep's Clothing?' (Simon Fraser University 1997) <http://www.sfu.ca/ aheard/intro.html > accessed 19 February, 2014

${ }^{562}$ Chintamani Rout, 'Voices for Human Rights'
} 


\section{Chapter Three}

of human rights for its citizens and how it had responded to its international legal obligations. It is in these contexts that the Nigeria's human rights environment is examined.

As the giant and most populated black nation on earth, Nigeria is a party to several human rights instruments including the ICCPR and ICESCR which have equally been ratified. However, Nigeria's human rights performance is dismal. ${ }^{563}$ There are many reasons for this including series of military administrations experienced. Military periods are usually characterised by suspension of constitution, passing of draconian decrees ${ }^{564}$ and sometimes ousting the jurisdiction of courts from entertaining cases challenging the decrees. In certain instances, decrees have been passed with retrospective effects and were used to convict individuals or deprived them of their rights. A review of the formulas used to oust courts' jurisdiction has been published by Nwabueze. The typical characteristics include barring of any civil proceedings on any matter under a decree; nullification of any judgment given in respect of such proceedings; barring of specific remedies such as quo warranto, certiorari, mandamus, prohibition, injunction or declaration; exclusion of constitutionally guaranteed rights; prohibition of inquiry into possible violation of human rights by decrees ${ }^{565}$ and exoneration from liability of persons who acted under these decrees. ${ }^{566}$

This is not surprising as it is typical with dictatorial regimes which often in the case of Nigerian military leaders in no ambiguous terms made it clear that their militaristic system of government is opposed to democracy. ${ }^{567}$ During these periods, a small clique of senior military officers ${ }^{568}$ exercises both executive and legislative functions. The administration is often arbitrary and the jurisdiction of courts to review validity of decrees and edicts is usually ousted $^{569}$ through ouster clauses. ${ }^{570}$ This makes it difficult if not impossible to challenge

\footnotetext{
${ }^{563}$ Scott Pegg, 'Nigeria' in David P. Forsythe (ed), Encyclopedia of Human Rights, vol 4 (Encyclopedia of Human Rights, Oxfod University Press USA 2009). P. 76.

${ }^{564}$ Such as Supreme Military Council, State Security (Detention of Persons) Decree No. 2 (1984) (This Decree provided for the arrest and indefinite detention without trial of anyone deemed by the government to be a security threat; Civil Disturbances (Special Tribunal) Decree No. 2 of 1987 (which provided for military appointed special tribunals operating outside the framework of constitutional safeguards. (see Scott Pegg, 'Nigeria'. P. 76.

565 Ouster clauses in decrees are numerous, for example section 10(3) of the Robbery and Firearms (Special Provisions) Decree 5 of 1984 reads "The question whether any provision of Chapter VI of the Constitution of the Federal Republic of Nigeria 1979 has been, is being or would be contravened by anything done in pursuance of this Decree shall not be inquired into in ... any Court of Law." Chapter VI of the 1979 provides for fundamental rights. Section 8(1) of the Civil Disturbances (Special Tribunal) Decree 2 of 1987 provides: "The validity of any decision, sentence, judgment, conformation, direction, notice or order given or made as the case may be or any other thing whatsoever done under this Act shall not be inquired into in any court of law." Section 3(1) of Decree 55 of 1992 provides that no "civil proceedings shall lie or be instituted in any court or tribunal for or on account of or in respect of any act, matter or thing done or purported to be done under or pursuant to this Decree by or on behalf of the Military Government."

${ }^{566}$ See Ben O. Nwabueze, The Individual and the State under the New Constitution: Government Powers in Relation to Economic Affairs and the Economy under the Constitution (Nigerian Institute of International Affairs 19 February, 1979).

${ }^{567}$ A. A. Oba, 'The African Charter on Human and Peoples' Rights and Ouster Clauses under the Military Regimes in Nigeria: Before and after September 11' (2004) 4 African Human Rights Law Journal P. 276.

${ }^{568}$ Such as the Supreme Military Council 1966 - 1975, 1983 - 1985, Armed Forces Ruling Council 1985 to 1993 , and Provisional Ruling Council 1993 - 1998

${ }^{569}$ See for example The Federal Military Government (Supremacy and Enforcement of Powers) Decree No. 28 of 1970. Even where courts were bold enough to invalidate military decrees or edicts, the Military would pass subsequent decrees nullifying courts' decisions.

${ }^{570}$ For a discussion on ouster clauses see Gani Fawehinmi, 'Ouster of Court's Jurisdiction by Statutes' in E. Smaranda (ed), Contemporary Issues in the Nigerian Legal System (Contemporary Issues in the Nigerian Legal System GLJ
} 
Realising the Right to Water and Sanitation in Nigeria

military excesses. Hence, during these periods, no effective redress mechanisms for human rights violations exist. ${ }^{571}$ In certain instances, the military had even exercised judicial powers, by appointing itself as the appellate body on matters relating to legal proceedings ${ }^{572}$ Thereby depriving the courts of their powers, ${ }^{573}$ independence and their status as the final arbiters of disputes. This frustration has been conveyed by the Court of Appeal in Wang Ching Yao and 4 Others v. Chief of Staff Supreme Headquarters ${ }^{574}$ that "on the question of civil liberties, the law courts of Nigeria must as of now blow muted trumpets". 575

With the demise of Gen. Sani Abacha and the processes leading to return to democracy, Gen. Abubakar revoked some of these hitherto decrees which violate basic human rights and with the return of democracy in 1999 and steps taken by civilian administrations, many CP rights are in some way respected. ${ }^{576}$ Presently, 19 years into democratic system of governance the general human rights situation is still of concern as demonstrated by reported cases of political witch-hunt, curtailment of freedom of expression, unjustifiable arrest, detention and prosecution/persecution of political opponents. Similarly, there are concerns arising from abuses by police and other security forces, degrading prisons and treatment of prisoners. ${ }^{577}$

Constitutional provisions for the protection of human rights in Nigeria have historically concentrated on $\mathrm{CP}$ rights. In their interpretation especially in relations to military decrees, judges appeared to be conservative at first. In the Nigeria's history, the first era could be said to be the early period of independence when provisions on fundamental rights were made in the constitution and judges were empowered to address human rights violations. Understandably, coming from colonial administration and less respect for human rights issues during the period, the judges would be tilted towards maintaining the status quo but with gradual introduction of human rights protection in their judgment. The second era is during the military administration when substantial powers of the courts to determine human rights violations were taken off by way of ouster clauses, suspension of constitution and assertion of supremacy of military decrees. Although during this period, some heroic judgments have been rendered against military excesses, such judgments were only the exceptions rather than the rule. The third era is the civilian administration where courts are more at liberty to render objective, more purposive and pragmatic interpretation of human rights and fundamental values.

A review of judicial attitude towards the enforcement of constitutionally guaranteed rights from the time of independence to date revealed the gradual abandoning of conservatism

\footnotetext{
General Services, Nigerian Bar Association 1997) P. 67; See also Lakanmi \& Anor v. A. G. Western State (1971) 1 UILR 201

${ }^{571}$ For additional resources on the various dimensions of military rule antithetical to human rights protection see $\mathrm{JJ}$. Nnamdi Aduba, 'The Protection of Human Rights in Nigeria' in A. O. Obilade and C. O. Nwanko (eds), Text for Human Rights Teaching in Schools (Text for Human Rights Teaching in Schools Constitutional Rights Project 1999)

${ }^{572}$ Ese Malemi, Outline of Nigerian Legal System (Grace Publishers 1999) P. 77.

${ }^{573}$ See S. Amadi, 'Access to Justice' (1999) 1 Human Rights Newsletter Pp. 3-5

${ }^{574}$ See Gani Fawehinmi, Nigerian Law of Habeas Corpus (Nigerian Law Publications 1986) P. 437

${ }^{575}$ Ibid. per Ademola CJA at p. 447

${ }^{576}$ Scott Pegg, "Nigeria”, in Scott Pegg, 'Nigeria' P. 76

${ }^{577}$ Ibid. P. 85.
} 


\section{Chapter Three}

or passivism by judges to the adoption of a more "libertarian, radical or active posture." 578 Similarly, "a noticeable change from a declaratory, mechanistic or technistic to a purposive, bold and imaginative approach" to human rights interpretation has been detected. ${ }^{579}$

Judicial attitude to interpretation of human rights in Nigeria has been categorised into three: the evolutionary epoch from 1960-1966; the challenge era from 1966 and; the radical, activist and revolutionary years from 1979 to date with intermittent reversal of the situation. ${ }^{580}$ The first era was the first years of independence where the country can decide on human rights issues free from colonial interference basing on a constitution which incorporated provisions on human rights guarantees. The second era was the first time the military struck and began to interfere in judicial administration and powers of courts. Through decrees and edicts, the Constitution is usually suspended and jurisdiction of court to determine the legality or otherwise of military actions is ousted. This significantly posed challenges to the court and this continues relatively until 1979 when the country was restored to civilian administration for a short period. It was during this period, specifically, 1983 that the ACHPR was domesticated in Nigeria. ${ }^{581}$

Another possible way of categorising human rights protection in Nigeria is on regimetype basis at different times in Nigeria's history. Generally, two types of regimes have been experienced in Nigeria intermittently: Military and Civilian. These regimes are distinct in the way and manner human rights issues and judicial powers are viewed and handled with human rights enjoying relative protection during civilian regimes.

Adjudication of human rights cases in Nigeria largely centred on CP rights and generally relates to right to personal liberty, right to freedom of thought, conscience and religion, right to freedom of association and assembly, right to freedom of movement, right to participate in government and right to property. The concentration on these issues could be justified on the basis of the type of government during the periods and the excesses of military and civilian administrators. The domain of ESC rights recorded little activity and the few cases centred on the right to healthy environment in the context of Niger-Delta and the right to work. Although several international human instruments have been ratified by Nigeria, only the ACHPR has so far been domesticated in line with the constitutional requirement. Nigeria as a dualist State, its Constitution requires internationally ratified treaties to be domesticated by an Act of the National Assembly before such treaties can have the force of law and be invoked before the domestic courts. ${ }^{582}$ Hence, only the ACHPR has been invoked and applied by the domestic courts over the years.

In the mid-80s, Nigerian Courts have had occasions to pronounce on the need for Nigeria to discharge its international obligations. For example, in Reinsurance Corp v. Fantaye ${ }^{583}$, the Supreme Court of Nigeria boldly took the view that Nigeria must give effect to legally

\footnotetext{
578 Muhammed Tawfiq Ladan, Law, Cases and Policies on Energy, Mineral Resources, Climate Change, Environment, Water, Maritime and Human Rights in Nigeria (Ahmadu Bello University Press 2009) P.175.

579 Ibid.

${ }^{580}$ Ibid.

${ }^{581}$ African Charter on Human and Peoples Rights (Ratification and Enforcement) Act

${ }^{582}$ See Constitution of the Federal Republic of Nigeria. S. 12.

583 (1986) 1 NWLR (Pt. 14) 113
} 
Realising the Right to Water and Sanitation in Nigeria

binding treaties while in Chief JE Oshevire v. British Caledonia ${ }^{584}$, the Court of Appeal of Nigeria relying on Aeroflex v. Air Cargo Egypt $t^{585}$ held the view that any domestic legislation which is in conflict with an international convention binding on Nigeria is void.

From 1966 onwards, Nigerian courts have been requested to pronounce on ouster clauses, supremacy of military decrees over the constitution, and the applicability and uniqueness of the ACHPR. The usual military practice upon coup d'état is the promulgation of a decree suspending the entire or some parts of the constitution and proclamation of decrees' supremacy over the unsuspended part of the constitution (if any). ${ }^{586}$ The attitude of the courts on the validity of such suspension and the supremacy of decrees was at first controversial. In the case of Lakanmi and Another v. the Attorney-General (Western State) and others ${ }^{587}$ which among others, the issue was whether the enabling decree which suspended some parts of the constitution is supreme in relation to the unsuspended parts. The Supreme Court per Ademola CJN decided in favour of the appellants, upheld the supremacy of the unsuspended parts of the constitution and held that "[t]he Decree is nothing short of legislative judgment, an exercise of judicial power. It is in our view ultra vires and invalid." 588

The reaction of the military to this judgment was draconian. A new decree was immediately promulgated which not only asserted in strong terms the supremacy of the decree over the constitution but also nullified the effects of Lakanmi's judgment. ${ }^{589}$ From this period onwards, Lakanmi's judgment never served as precedent. ${ }^{590}$ Subsequent cases did not venture into questioning the validity of ouster clauses ${ }^{591}$ except that the new approach was to construe the clauses very strictly and narrowly as put by Justice Onalaja (as he then was) in The Registered Trustees of the Constitutional Rights Project (CRP) v. The President of the Federal Republic of Nigeria and Others ${ }^{592}$ to wit: "any decree, edict, act or law, which ousts the jurisdiction of courts, is construed strictly and narrowly' and "where the interpretation is capable of two meanings, the decree is to be interpreted in the manner which retains or preserves the jurisdiction of the court". 593

In the absence of constitutional provisions protecting human rights, individuals whose rights have been trampled upon have resorted to challenging State's action by relying on the ACHPR. This approach however was fraught with difficulties as the court would have to determine the relationship of ACHPR with military decrees suspending the constitution and,

\footnotetext{
${ }^{584}$ See (1990) 7 NWLR (Pt. 163) 489

${ }^{585}$ A decision of Paris Court of Appeal of 25 March 1986 and reported in the Uniform Law Review Biannual 1987 Vol. 2 669, published by (UNIDROT) International Institute for the Unification of Private Law in Rome.

${ }^{586}$ See for example section 6 Constitution (Suspension and Modification) Decree No. 1 of 1966 and section 2 Constitution (Suspension and Modification) Decree No 1 of 1984.

587 (1971) UILR 201

588 at P. 222

${ }^{589}$ See Federal Military Government (Supremacy and Enforcement of Powers) Decree No. 28 of 1970

${ }^{590}$ A. A. Oba, 'The African Charter on Human and Peoples' Rights and Ouster Clauses under the Military Regimes in Nigeria: Before and after September 11'. P. 281.

${ }^{591}$ For example Osadebay v. AG Bendel State (1991) 1 NWLR (Pt. 169) 533; Okeke v. AG Anambra State (1992) 1 NWLR (Pt. 215) 60; Zamani Lekwot \& Others v Judicial Tribunal on Civil Disturbances in Kaduna State \& Another (1993) 2 NWLR (Pt. 276) 410 and Okoroafor v. Miscellaneous Offences Tribunal (1995) 4 NWLR (Pt 387 ) 59 (see ibid. P. 281.

${ }^{592}$ Contained in Journal of Human Rights Law and Practice 4/1 (1994). P. 243.

593 Ibid. P. 245.
} 
in some instances, the unsuspended part of the constitution. The Nigerian Supreme Court in Labiyi v. Anretiola ${ }^{594}$ had determined the hierarchy of laws in Nigeria upon military takeover on $31^{\text {st }}$ December 1983.

1. The Constitution (Suspension and Modification) Decree 1984;

2. Decrees of the Federal Military Government;

3. Unsuspended provisions of the Constitution 1979;

4. Laws made by the National Assembly before $31^{\text {st }}$ December 1983;

5. Edicts of the Governor of a State;

6. Laws enacted before $31^{\text {st }}$ December 1983 by the House of Assembly of a State. ${ }^{595}$

The ACHPR was domesticated in 1983 before the military takeover which effectively ranked it as a law passed by the National Assembly hence the supremacy of military decrees over the Act. This was also enunciated by the Supreme Court in General Sani Abacha and Others v. Chief Gani Fawehinmi. ${ }^{596}$

However, the unique status of ACHPR as a treaty and domestic law was taken into consideration by a High Court in 1990 in Mohammed Garuba and Others v. Lagos State Attorney General and Others. ${ }^{597}$ The Court observed that the ACHPR as a domesticated treaty in Nigeria "[e]ven if its aspect in our Constitution is suspended or ousted by any provision of our local law, the international aspect of it cannot be unilaterally abrogated. . . As [Justice Eso warned us], by signing international treaties, we have put ourselves on the window of the world, we cannot unilaterally breach any of the terms without incurring some frowning of our international friends." This position was reinforced in The Registered Trustees of the Constitutional Rights Project (CRP) v. The President of the Federal Republic of Nigeria and Others ${ }^{598}$ that as a ratified OAU treaty, an organisation which Nigeria continues to be a member, ACHPR is binding on the Military Government. ${ }^{599}$ According to this view the obligation to observe its provision is however at the international level; its domestic applicability and status under ouster clauses was a matter for the Supreme Court consideration in General Sani Abacha \& Others v. Chief Gani Fawehinmi ${ }^{600}$

At the Court of Appeal, ${ }^{601}$ the Court subscribed to the view that although ACHPR is a local enactment by virtue of its domestication, it is not ranked the same with local legislations that "the provisions of the Charter are in a class of their own and do not fall within the classification of the hierarchy of laws in Nigeria in order of superiority as enunciated in Labiyi v. Anretiola". ${ }^{602}$ The Court proceeded to determine that notwithstanding the promulgation of ACHPR by the National Assembly, the legislation's international flavour

\footnotetext{
594 (1992) 8 NWLR (Pt. 258) 139

595 A. A. Oba, 'The African Charter on Human and Peoples' Rights and Ouster Clauses under the Military Regimes in Nigeria: Before and after September 11' P. 282.

596 (2000) 4 SCNJ 401. At the Court of Appeal level, the Court had taken the view that because of the Act international flavour, it is ranked higher than the Constitution see (Chief Gani Fawehinmi v. General Sani Abacha \& Others (1996) 9 NWLR (Pt. 475) 710. This position was however reversed by the Supreme Court.

${ }^{597}$ Contained in Journal of Human Rights Law and Practice 4 (1994), p. 205

598 Ibid. P. 243

599 Ibid. P. 244.

${ }^{600}$ (2000) 4 SCNJ 401

${ }^{601}$ Chief Gani Fawehinmi v. General Sani Abacha \& Others (1996) 9 NWLR (Pt. 475) 710

${ }^{602}$ Ibid. Pp. 746-7.
} 
Realising the Right to Water and Sanitation in Nigeria

meant that "the ouster clauses contained in Decree No. 107 of 1993 or No. 12 of 1994 cannot affect its operation in Nigeria." 603

The Supreme Court, on appeal by a majority opinion reversed this position and held the ACHPR not to be superior to the Constitution and that the domestication of ACHPR as an Act of National Assembly positioned it as a local legislation which should be ranked as such in line with its decision in Labiyi v. Anretiola. ${ }^{604}$

As noted above, human rights cases in Nigeria largely centred on $\mathrm{CP}$ rights. Examples of these cases are: Otunba Oyewole Fashawe v. Attorney-General of the Federation \& 3 Others ${ }^{605}$ a case on the right to personal liberty; Adamu v. Attorney-General of Borno State, ${ }^{606}$ Theresa Onwo v. Oko, ${ }^{607}$ and Agbai v. Okogbue ${ }^{608}$ on the right to freedom of conscience and religion; Anigboro v. Sea Trucks Ltd ${ }^{609}$ and Egri v. Uperi ${ }^{610}$ on the right to freedom of association and assembly; Director of SSS v. Olisa Agbakoba ${ }^{611}$ on the right to freedom of movement; Abubakar v. INEC, ${ }^{612}$ Ngige v. Peter Obi and Others ${ }^{613}$ and Atiku and Action Congress and Others $v$. INEC ${ }^{614}$ on the right to participate in government.

The prolonged military administration in Nigeria's history, their draconian decrees and ouster clauses including judicial approach to constitutional human rights provisions have had impacts on the attitude of human rights claims. As such, very limited human rights cases are instituted by citizens. Instances where such cases were instituted mainly involved influential individuals or those accused of committing criminal offences and human rights issues were incidentally raised at the trial.

With the return of democracy there has been noticeable progress in human rights in Nigeria. Chapter four of the 1999 Constitution (the "Constitution") provided for fundamental human rights which are essentially $\mathrm{CP}$ rights. ${ }^{615}$ The Constitution however recognised that in the interest of defence, public safety, public order, public morality or public health and for the purpose of protecting the rights and freedoms of others, some of the rights can be derogated from by any law that is reasonably justifiable in a democratic society. ${ }^{616}$ Similarly, during periods of emergency, legislative measures may be taken by the National Assembly which may derogate from some of the rights. ${ }^{617}$ However, no derogation from right to life is permitted except to death resulting from acts of war. ${ }^{618}$ Significant steps are currently being taken to address some human rights concerns in the country. The $6^{\text {th }}$ Periodic Country Report

\footnotetext{
${ }^{603}$ Ibid. Pp. 746-7.

604 (1992) NWLR (Pt. 258) 1392

605 (2007) CHR 890

${ }^{606}$ (1996) 8 NWLR 203

607 (1996) 6 NWLR (Pt. 456) 584

608 (1991) 7 NWLR (Pt.204) 391

${ }^{609}$ (1995) 6 NWLR (Pt. 399) 35

${ }^{610}$ (1973) 11 SC 299

611 (1999) All N.L.R 110; (1999) 3 NWLR (Pt.595) 340; (1999) 3 SC 59

612 (2004) 1 NWLR (Pt. 854) 207

${ }^{613}$ (2006) 14 NWLR (Pt. 999) 1

${ }^{614}$ (2007) All FWLR (Pt. 353) 3

${ }^{615}$ Constitution of the Federal Republic of Nigeria Sections 33. 34, 35, 36, 37, 38, 39, 40, 41, 42, 43, 44 and 46

${ }^{616}$ See ibid. S. 45(1)

${ }^{617}$ See ibid. S. 45(2)

${ }^{618}$ See ibid.
} 
Chapter Three $\mid$

on the implementation of the African Charter on Human and People Rights ${ }^{619}$ detailed some of the measures taken to address concerns raised in the $5^{\text {th }}$ Country reports. Several administrative, legislative and judicial measures have been adopted. Some of the noticeable human rights progress legislatively on various issues include the enactment of Act on the Prohibition of Violence Against Persons in 2015; National Health Act 2014; Trafficking in Persons (Prohibition) Law Enforcement and Administration Acts, 2015; HIV/AIDS (AntiDiscrimination) Act 2014; Pension Reform Act, 2014; The National Human Rights Commission (Amendment) Act, 2011; Universal Basic Education (UBE) Act 2003 (Amended in 2005); The 2009 Fundamental Rights (Enforcement Procedure) Rules which abolishes the locus standing and statutes of limitations in fundamental rights enforcement in Nigeria. Administratively, policies have been adopted to improve human rights situations in certain areas including on the environment (National Policy on Environment, 2016); gender dimension in agriculture (National Policy on Gender in Agriculture, 2016); food related issues (National Agriculture Promotion Policy 2016-2020); gender-based violence (National Guidelines and Referral Standards on gender-Based Violence in Nigeria, 2014/15); education (National Policy on Education, 2013); human rights (The National Human Rights Commission Action Plan for the Promotion and Protection of Human Rights in Nigeria 20172021) among others. Additionally,

Economic and social rights have not been recognised as human rights under the constitution. Notwithstanding constitutional provisions on human rights, the current Nigeria's human rights environment is characterised by frequent cases of extra-judicial killings,${ }^{620}$ torture of detainees by security forces, ${ }^{621}$ infringement of freedom of speech and press, ${ }^{622}$ politically motivated arrests and detention as well as disobedience to court orders. However, numerous measures are being taken to address these concerns.

\subsection{Nigeria's Human Rights Environment in Relations to Economic, Social and Cultural Rights}

If realisation of ESC rights is dependent only upon availability of resources, Nigeria would be among States most likely to achieve it. Undoubtedly, Nigeria possesses abundant natural and human resources which if properly utilised could address its socio-economic challenges. Similarly, the water resources potentials of the State if properly developed and utilised, could address the extant water poverty in the country.

There exist abundant natural resources in Nigeria spread in several parts of the country. However, the resources largely remain undeveloped. This situation rendered many States in the country vulnerable and had to rely on oil revenue. It is without doubt that poor economic

\footnotetext{
${ }^{619}$ Federal Republic of Nigeria, Nigeria's 6th Periodic Country Report: 2015-2016 on the Implementation of the African Charter on Human and Peoples Rights in Nigeria (Federal Ministry of Justice, Abuja, August 2017)

${ }^{620}$ Police and armed forces kill extra-judicially with impunity especially against armed robbery suspects and in the context of insurgency.

${ }^{621}$ Currently the Anti-Torture Bill presented by the National Civil Society Organisation Coalition is receiving attention at the National Assembly and the $6^{\text {th }}$ ACHPR Country Report indicated that security officials are being trained on human rights, torture and other related issues.

${ }^{622}$ Newspapers deemed critical of government are harassed and copies confiscated.
} 
Realising the Right to Water and Sanitation in Nigeria

performance of Nigeria in the context of "multisector growths and distribution of wealth directly impacts its abilities to fulfil economic and social right". ${ }^{623}$

The current Nigeria's socio-economic state is partly due to political and economic situations of the country and partly, due to prolonged neglect and inadequate advocacy. ${ }^{624}$ Realisation of ESC rights requires an enabling environment within which claims are pursued and projects are implemented. With history of political disturbances and military dictatorship, and suppression of human rights, Nigeria for a long time has not had an enabling environment where ESC rights can strive. The concern during military dictatorship's periods was the protection of $\mathrm{CP}$ rights. This was because military regimes at various times were associated with arbitrariness, unlawful/extra-judicial killings, mass arrest and detention, torture, enforced disappearance, harassments, curtailment of freedom of expression and press, crackdown and closure of media houses and absence of fair trial. Hence, activists' and international community's main interests was how to secure and protect fundamental human rights such as the right to life, the right to dignity of human person, the right to fair hearing, freedom from torture, and freedom of expression and press. ${ }^{625}$ The domain of ESC rights was either ignored in the pursuit of 'higher ideals/appeals' or not given adequate attention. Either way, negative consequence was hence created.

The legal framework governing ESC rights in Nigeria is the 1999 Constitution. The Constitution apparently adopted the dichotomy between CP rights and ESC rights. It chose to confer justiciability status on the former but not the latter. ${ }^{626}$ The nearest articulation of ESC rights in the Constitution is contained in chapter two which is titled "Fundamental Objectives and Directive Principles of State Policy". It contained provisions relevant to health, education, protection of the environment, suitable and adequate food, shelter, suitable employment, social, religious and cultural life, securing of adequate means of livelihood etc. As fundamental objectives, these were not considered as rights but duties on the Nigerian State.

According to the Constitution, Nigeria is supposedly "based on the principles of democracy and social justice". ${ }^{627}$ Sovereignty belongs to the people and government derives all its powers and authority from the citizens. ${ }^{628}$ Previous constitutions after independence have provisions on fundamental human rights. ${ }^{629}$ This was a significant departure from the colonial period. It must however be recalled that human rights provisions and sometimes the entire constitution are/is suspended during military takeover. In situations where the rights operate, however, the recognised justiciable rights are mainly the so-called first generation: $\mathrm{CP}$ rights. Currently, these rights are contained in chapter four of the Constitution titled

\footnotetext{
${ }^{623}$ Scott Pegg, 'Nigeria' P. 78.

${ }^{624}$ See Jacob Abiodun Dada, 'Impediments to Human Rights Protection in Nigeria ' P. 85.

${ }^{625}$ See Dejo Olowu, 'Human Development Challenges in Africa: A Rights-Based Approach' (2004) 5 San Diego Int'1 LJ 179

${ }^{626}$ See chapters two and four of the 1999 Constitution.

${ }^{627}$ See Constitution of the Federal Republic of Nigeria. S. 14 (1)

${ }^{628}$ See ibid. S. 14 (2)(a)

${ }^{629}$ See Chapter II, 1960 Constitution; Chapter II, 1963 Constitution from section 18 to 40; Chapter IV, 1979 Constitution from section 30 to 39 and chapters 2 and 4, 1999 Constitution. Chapter II of the 1999 Constitution deals with the fundamental objectives and directive principles of state policy which are non-justiciable.
} 


\section{Chapter Three}

"Fundamental Rights". ${ }^{630}$ The second generation rights: ESC rights and the third generation rights: environmental rights have continued to remain as fundamental objectives only and non-justiciable. ${ }^{631}$ In the light of its Preamble, the 1999 Constitution was designed to promote the good government and welfare of all persons in Nigeria "on the principles of freedom, equality and justice". ${ }^{632}$ The second and third generations' right are contained under chapter two of the constitution. These are objectives which the State shall strive to progressively realise if and when resources become available. In their current form and status, they are hence mere State's aspirations.

The Constitution requires the organs and government at all levels, all institutions and persons exercising legislative, executive or judicial powers to, in the performance of their duties, conform, observe and apply the provisions of the chapter. ${ }^{633}$ The Nigerian Supreme Court had in Attorney-General of Ondo State v. Attorney-General of the Federation \& 35 ors ${ }^{634}$ interpreted the personal scope of application of section 13 of the Constitution to include private individuals. In the opinion of the Court, limiting the scope of application to only organs of government, "does not take account of the undeniable fact that those organs do not operate entirely within their official cocoons. They do not, in performance of their duties act in isolation of the public". ${ }^{635}$

The social objectives are set out in section 17 . The section interestingly observed the social order of the State to have been founded on the basis of freedom, equality and justice. By the Constitution, every citizen shall have equality of rights, obligations and opportunities. ${ }^{636}$ Governmental actions shall be humane; ${ }^{637}$ natural resources shall only be exploited for the good of the community, ${ }^{638}$ and easy accessibility to impartial and independent courts of law shall be secured and maintained. ${ }^{639}$ The State shall, without discrimination, direct its policies towards ensuring all citizens "have the opportunity for securing adequate means of livelihood", 640 "adequate facilities for leisure, and for social, religious and cultural life." ${ }^{641}$ Ensuring suitable and adequate shelter and food requires access to adequate and quality water supply and basic sanitation. ${ }^{642}$ Under political objective, the State is obliged to abolish all corrupt practices and abuse of power. ${ }^{643}$ On economic objectives, the State is obligated to direct its policy towards ensuring that all citizens are

\footnotetext{
${ }^{630}$ These are right to life, right to dignity of human person, right to personal liberty, right to fair hearing, right to private and family life, right to freedom of thought, conscience and religion, right to freedom of expression and press, right to peaceful assembly and association, right to freedom of movement, right to freedom from discrimination, and right to acquire and own immovable property anywhere in Nigeria.

${ }^{631}$ Constitution of the Federal Republic of Nigeria S. 6(6)(c)

${ }^{632}$ Ibid. Para. 4 of the Preamble

${ }^{633}$ Ibid. S. 13

634 (2002) 9 NWLR (part 772) 222 S.C

${ }^{635}$ Ibid per Uwaifo, JSC at 381

${ }^{636}$ Constitution of the Federal Republic of Nigeria S. 17(2)(a)

${ }^{637}$ Ibid. S. 17(2)(c)

${ }^{638}$ Ibid. S. 17(2)(d)

${ }^{639}$ Ibid. S. 17(2)(e)

${ }^{640}$ Ibid. S. 17(3)(a)

${ }^{641}$ Ibid. S. 17(3)(b)

${ }^{642}$ See UNHCHR, 'The Right to Water: Fact Sheet No. 35'. P. 13.

${ }^{643}$ Constitution of the Federal Republic of Nigeria. S. 15(5)
} 
Realising the Right to Water and Sanitation in Nigeria

provided with suitable and adequate shelter, suitable and adequate food. ${ }^{644}$ Protecting and improving the environment and safeguarding water air, land, forest and wild life are the environmental objectives under section $20{ }^{645}$

It needs to be stated that human rights are better protected in constitutional provisions than any legislation. This does not however render legislations irrelevant but where a constitution contains a provision which may limit the operation of legislation, the supremacy of the constitution will undermine the effect of such a law. The primary and fundamental problem associated with chapter two provisions is its non-justiciable character. As important as the provisions might be, no court in Nigeria can entertain any question as to whether any act or omission of any authority or person or any law or judicial decision is in conformity with chapter two. ${ }^{646}$ Joseph Vining's observation in this context holds water when he said "[t]hat which evokes no sense of obligation is not law. It is only the appearance of law." 647

The approach of courts in some countries having similar Nigerian constitutional position on ESC rights is to mainstream ESC rights in the interpretation of justiciable CP rights. This has equally been anchored by some authors in justifying the interconnectivity, indivisibility of human rights and justiciability of ESC rights. For example, the Constitution did not expressly provide for the right to health, but it was argued forcefully, that the right is implied through a combine reading of section 17 (social objectives of the Nigerian State), section 33 (right to life) and section 34 (right to dignity of human person). ${ }^{648}$ According to this view, section 17 obligates the State to direct its policies to ensure the provision of adequate medical and health facilities for all persons and to ensure that the health, safety and welfare of all persons in employment are not endangered or abused. That since section 33 and section 35 recognised right to life and right to dignity of human person respectively, "sanctity of the human person and dignity are necessarily connected to physical and mental health of persons." ${ }^{649}$ The combined provisions therefore implicitly, include "the provision of affordable, available, adequate, qualitative and accessible health care facilities and services by all". 650

This interpretation is recognised in the context of human rights. ${ }^{651}$ Instructively, the right to water and sanitation was itself, derived implicitly from this type of interpretation. The Nigerian courts have similarly, recognised and adopted this approach in the context of enforcement of environmental law and in the recognition of right to healthy environment. In the case of Jonah Gbemre v. Shell, NNPC and $A G F^{652}$ a claim for the enforcement of fundamental right arising from gas flaring in oil exploration activities in the Niger-Delta, the

\footnotetext{
${ }^{644}$ Ibid. S. 16(2)(d)

${ }^{645}$ Ibid. See S. 20

${ }^{646}$ Ibid. S. 6(6)(c)

${ }^{647}$ Joseph Vining, From Newton's Sleep (Princeton University Press 1995) p. 34 quoted in Itzchak E. Kornfeld,

'Water: A Public Good or a Commodity?' (2012) American Society of International Law Proceedings P. 50.

${ }^{648}$ Muhammed Tawfiq Ladan, Law, Cases and Policies on Energy, Mineral Resources, Climate Change, Environment, Water, Maritime and Human Rights in Nigeria P. 170.

${ }^{649}$ Ibid.

${ }^{650}$ Ibid.

${ }^{651}$ Antonio E. Irujo, 'The Right to Water' Salman M.A. Salman, 'The Human Right to Water - Challenges of Implementation'. P. 45.

${ }^{652}$ Suit No. FHC/B/CS/53/05
} 


\section{Chapter Three |}

Nigerian Federal High Court recognised and accepted the claim of the plaintiff that the constitutionally guaranteed fundamental right to life and dignity of human person under sections 33 (right to life) and 34(1) (right to dignity of human person) of the Constitution reinforced by articles 4, 16 and 24 (right to respect for lives and the dignity of human person; right to enjoy the best attainable state of physical and mental health; and the right to a general satisfactory environment favourable to their development) of the ACHPR Act inevitably includes the right to clean, poison-free, pollution-free and healthy environment. Additionally, that gas flaring of the defendants in oil exploration and producing activities in the applicant's community is a violation of the right to life (including healthy environment) and dignity of human person guaranteed by the Constitution and the ACHPR.

The Indian courts, arguably, are the most active and visible utilisers of this approach. The courts have "generated the largest volume of jurisprudence regarding the environmental aspects of the constitutional right to life." ${ }^{653}$ Some of the Indian cases where this approach was utilised include the Supreme Court decision in Charan Lal Sahu where the right to life guaranteed by the constitution was interpreted to include the right to a wholesome environment; the case of Virendra Gaur and Others v. The State of Haryana ${ }^{654}$ where "[e]nvironmental, ecological, air and water pollution" have been construed to be a violation of the right to life and the High Court decision in L.K. Koolwal v. State of Rajasthan and Others ${ }^{655}$ where "maintenance of health, preservation of the sanitation and environment" was interpreted to "fall within the purview of article 21 " which provided for the right to life. ${ }^{656}$

One of the many reasons for the failure to address non-justiciable nature of ESC rights under the constitution is the manner in which the Constitution came into existence. The drafting process of the Constitution was shrouded with secrecy by the ruling military elite. No constitutional conference was convened to determine important constitutional issues. Rather, the constitutional drafting committee's tour excluded important stakeholders in their consultations and conferred only with the ruling elites. The Constitution was not released until after the 1998/1999 elections which transferred power to the civilian administration. Currently, the Constitution is facing legitimacy challenges and its claim in the Preamble "We the people of the Federal Republic of Nigeria" 657 is untenable. Chapter two lacked mechanisms to monitor its compliance.

Under international Bill of Rights, States are to pursue programmes "for the benefit of their own citizens and to participate in international efforts to foster social welfare throughout the world. These obligations apply equally to all states, regardless of their economic systems, political arrangements, or level of economic development." ${ }^{658}$ A government deriving its power and authority from the citizenry should consider their well-being as a top priority. Ensuring their well-being necessarily requires establishing and putting the necessary

\footnotetext{
${ }^{653}$ John Scanlon, Angela Cassar and Noemi Nemes, Water as a Human Right? P. 47.

${ }^{654}$ (1995) 2 SCC 577

${ }^{655}$ AIR 1988 Raj 2, 1987 (1) WLN 134

${ }^{656}$ See John Scanlon, Angela Cassar and Noemi Nemes, Water as a Human Right? Pp. 47-48.

${ }^{657}$ Constitution of the Federal Republic of Nigeria Para. 1 of the Preamble

${ }^{658}$ David M. Trubek, 'Economic, Social, and Cultural Rights in the Third World: Human Rights Law and Human Needs Programs' in Theodor Meron (ed), Human Rights in International Law: Legal and Policy Issues (Human Rights in International Law: Legal and Policy Issues, Oxford University Press 1986). P. 207.
} 
Realising the Right to Water and Sanitation in Nigeria

mechanisms to adequately monitor excessiveness, inadvertence, measure the responsiveness and conformity of governmental, institutional and personal actions on matters of fundamental importance to the lives and well-beings of the citizens. Indeed, no harm will be done to government by empowering the judiciary to address questions of excessiveness, inadvertence and lack of responsible leadership. No government would desire to be seen as unresponsive or its policies, programmes and projects as anti-people. The Judiciary is not an agent of destruction but rather a concrete building block in the establishment of an egalitarian society. Moreover, courts do not operate in isolation. Their decisions are in accord with the economic, social and cultural realities of the localities they operate.

The indivisible and interconnected nature of human rights should guide States' actions and adoption of measures in the field of human rights. States are in the same way responsible for violation of ESC rights as they are on CP rights. ${ }^{659}$ States can no longer rely on the phrase "progressive realisation" to continue to deprive their citizens the necessary and basic amenities for survival, well-being and progress. ${ }^{660}$ Democracy as a social system is a tool for good governance and an important weapon for the protection of peoples' human rights. Accountability and responsiveness are important principles of democracy without which the aims of democracy may not be realised.

Other relevant legislative measures in the context of ESC rights are the Labour Act which regulate the regimes of employment; the Factories Act which provides for health and safety in employment; Workmen's and Compensation Act which regulates remuneration and compensation in employment; the Maritime Labour Act which regulates seafarers activities' employers, stevedoring companies, dock workers and other maritime workers; the Pension Reform Act which protects employees it covered in ensuring the receipt of their benefits and: Social Insurance Trust Fund Act which regulates social security system of assistance to the less privilege. Noticeable progress has also been made in the context of education and health with the adoption of the Universal Basic Education Act and National Health Act.

Similarly, there are other legal and policy instruments for the protection of vulnerable groups such as women, children, refugees and internally displaced persons, trafficked victims, persons living with HIV-AIDS, the elderly and victims of war. These instruments include the Child Rights Act, the National Commission for Refugees Act, the Geneva Conventions Act, the National Agency for the Prohibition of Traffic in Person Act, the National Policy and Guidelines on Malaria Control, National Policy on Child and Maternal Health, National Child Policy, National Strategic Framework and Plan of Action for VVF Eradication in Nigeria, National Policy on Education, National Policy on HIV-AIDs, National Policy on Health, National Policy on the Elimination of FGM, National Policy on Food and Nutrition, National Policy and Guidelines on Gender in Basic Education etc.

\footnotetext{
${ }^{659}$ International Commission of Jurists, Maastricht Guidelines on Violations of Economic, Social and Cultural Rights. Para. 4.

${ }^{660}$ International Commission of Jurists, The Limburg Principles on the Implementation of the International Covenant on Economic, Social and Cultural Rights (International Commission of Jurists 1986)
} 


\section{Chapter Three}

Through these instruments, Nigeria has demonstrated its commitment to protect the rights of vulnerable people in the country. ${ }^{661}$

\subsection{Institutional Structures on Human Rights Protection in Nigeria}

United Nations General Assembly Resolution A/RES/48/134 ${ }^{662}$ encourages member States to establish effective national institutions for the protection and promotion of human rights. Pursuant to this, such institutions have been established in Nigeria. However, looking at the state of human rights in some States including Nigeria, it is opined that it is not solely the existence of these institutions and even judicial structures at the domestic level that can single-handedly ensure human rights protection. The Nigerian situation provides a classical example of the power politics, clashes and struggles involved in human rights realisation and protection.

An institution is "organisations, working rules or establishment founded for a specific purpose of public interest based on an accepted custom, law or relationship in a society or community". ${ }^{663}$ This may be organisations established by governments, international and private entities, and may include non-governmental organisations. ${ }^{664}$

National Human Rights Institutions (NHRIs) are generally established as commissions or ombudsman offices and their main function is the protection and promotion of human rights where they operate by relying on the country's human rights instruments and its international obligations. However, the functions of NHRIs have been accepted differently by different scholars. They have been understood to serve as "fundamental building block of human rights protection" $" 665$ and fundamental freedoms in places where they operate. This is true in relations to developed democratic countries where institutions can operate without interference. Some scholars have however viewed the institutions with much suspicion since the institutions are "state sponsored, state funded entity and government agencies". ${ }^{666}$ This is also true in relations to underdeveloped and not fully democratic countries where institutions suffer political interference notwithstanding that their enabling laws mentioned their independent status.

Human rights institutions in Nigeria include National Human Rights Commission, Public Complaint Commission, and Legal Aid Council. Some specific ministries, departments and agencies of governments at the Federal and States levels have been established to regulate, facilitate and operate certain areas of human endeavours concerning human rights issues. Additionally, there are other supervising or oversight mechanisms to monitor and ensure human rights protection. These consist of Human Rights Committee of the Senate, Human

\footnotetext{
661 Muhammed Tawfiq Ladan, Law, Cases and Policies on Energy, Mineral Resources, Climate Change, Environment, Water, Maritime and Human Rights in Nigeria. P. 173.

${ }^{662}$ United Nations General Assembly, National Institutions for the Promotion and Protection of Human Rights (20 December 1993)

${ }^{663}$ Webster Dictionary

${ }^{664}$ D. Adenle, 'Institutional Issues in Water Supply \& Sanitation (WSS) and their Role in the Attainment of Millennium Development Goals' Targets in Nigeria' (Federal Ministry of Water Resources, <www.fmwr.gov.ng> accessed 1 September, 2013

${ }^{665}$ Chintamani Rout, 'Voices for Human Rights'. P. 35.

${ }^{666}$ Ibid.
} 
Realising the Right to Water and Sanitation in Nigeria

Rights Committee of the House of Representatives and similar committees at the State Houses of Assembly. Below is the overview of NHRIs in Nigeria.

\subsubsection{National Human Rights Commission}

The National Human Rights Commission (NHRC) was established in 1995 by the National Human Rights Commission Act ${ }^{667}$ pursuant to the resolution of the United Nations General Assembly which encourages member States to establish human rights institutions for the promotion and protection of human rights. ${ }^{668}$ It is an extra-judicial mechanism designed to enhance the enjoyment of human rights in Nigeria. It is to provide the necessary avenues for public enlightenment, conduct research and dialogue for the purposes of raising awareness on human rights issues. Under its enabling law, the NHRC is designed to be the cornerstone of human rights promotion and protection in Nigeria. It is autonomous (administratively and financially) and has been empowered to deal with all matters concerning the promotion and protection of human rights including but not limited to the UDHR, ICCPR, ICESCR, CEDAW, CRC, ACHPR and other international and regional human rights instruments binding on Nigeria. ${ }^{669}$ It is to undertake studies on all matters concerning human rights and to assist in the formulation of policies by the Federal, States and Local Government where appropriate. ${ }^{670}$ It can examine any legislation or policy with a view to ascertaining its consistency with human rights obligations ${ }^{671}$ and is equally required to publish and submit reports on the state of human rights promotion and protection in Nigeria. ${ }^{672}$ NHRC can equally among others, refer any matter relating to human rights which requires prosecution to the Attorney-General of the Federation or the State, ${ }^{673}$ and has the power to institute any civil action, ${ }^{674}$ determine damages or compensation payable. ${ }^{675}$ The decision of NHRC is enforceable in the same way as the orders of a High Court in Nigeria. ${ }^{676}$

The thematic focus areas of NHRC are women and gender matters, children, corruption and good governance, police, prison and other detention centres, environment and NigerDelta, education, freedom of religion and belief, torture, extra-judicial, summary \& arbitrary executions, law reform and law review, independence of the judiciary and access to justice, labour, food and shelter, communal conflict and other related violence, health, freedom of expression and the media, and people with disabilities. ${ }^{677}$

Until recently, the performance of NHRC was however minimal and its impact was not largely felt by the population especially in the field of ESC rights as much of its work

\footnotetext{
${ }^{667}$ National Human Rights Commission Act, Cap N46 Laws of the Federation of Nigeria, 2004 amended by the National Human Rights Commission (Amendment) Act 2010.

${ }^{668}$ United Nations General Assembly, National Institutions for the Promotion and Protection of Human Rights.

${ }^{669}$ National Human Rights Commission (Amendment) Act 2010. S. 6(a).

${ }^{670}$ Ibid. S. 6(b).

${ }^{671}$ Ibid. S. 6(k).

${ }^{672}$ Ibid. S. 6(c).

${ }^{673}$ Ibid. S. 6(p).

${ }^{674}$ Ibid. S. 7(b)

${ }^{675}$ Ibid. S. 7(e)

${ }^{676}$ Federal Republic of Nigeria, Nigeria's 6th Periodic Country Report: 2015-2016 on the Implementation of the African Charter on Human and Peoples Rights in Nigeria. P. 23.

677 National Human Rights Commission, 'Thematic Focus' (National Human Rights Commission,
} <http://www.nigeriarights.gov.ng/> accessed 25 May 2018. 


\title{
Chapter Three
}

concentrated on $\mathrm{CP}$ rights notwithstanding its other thematic focus areas. Recently however, noticeable progress is being made in both CP and ESC rights and also on water and sanitation issues through programmes including community outreach and sustained advocacy. ${ }^{678}$ Additionally, NHRC has worked out modalities relating to how complaints concerning human rights violations including ESC rights are to be handled. ${ }^{679}$ The Commission is currently appropriately poised to discharge its mandate. Nigeria has also developed the 20172021 National Action Plan for the Promotion and Protection of Human which is a strategic framework for:

\begin{abstract}
an audit of human rights situation in Nigeria; a commitment to concrete measures that need to be adopted to build and entrench a culture of human rights in Nigeria; sustained and coordinated ways to monitor, promote and protect human rights and investigate and redress for violations of human rights in Nigeria. ${ }^{680}$
\end{abstract}

\subsubsection{Public Complaint Commission}

Public Complaint Commission ("PCC") was established by Decree 31 of 16 October, $1975^{681}$ as an effort by the then government to uplift the standard of living of Nigerians. It was to investigate cases of maladministration by public officers and ensure that administrative action of all corporate bodies does not result in the commission of acts of injustice against citizens or residents. In providing free service to all, the PCC has the power to among others, investigate administrative actions which are or appear to be contrary to laid down laws and regulations and those considered to be unreasonable, unfair, or oppressive, etc. ${ }^{62}$ The PCC reaches out to the public through newspaper articles, town hall meetings, visit to opinion leaders and through awareness campaigns. The major advantage of PCC is that it is the only administrative agency in Nigeria with structure and mandate to address peoples' grievances. ${ }^{683}$ Most of the complaints received by PCC from the public consisted of non-payment of workers benefits, wrongful terminations and dismissals from employment.

Notwithstanding that PCC has power to investigate cases of maladministration by public officers, there is no single investigation conducted concerning water and sanitation and the extent through which local or urban population are denied access to this right. This arguably is connected to the docility of the population in challenging public officers discharge of their mandates.

Like other administrative institutions in Nigeria, PCC shares challenges of capacity and funding. ${ }^{684}$ It impact was curtailed from 1999 to 2011 by the non-appointment of a Chief Commissioner and other commissioners to oversee its activities.

\footnotetext{
${ }^{678}$ National Human Rights Commission, Annual Report 2016, (2017)

${ }^{679}$ See National Human Rights Commission, Implementation of Presidential Executive Orders, (2017)

${ }^{680}$ Federal Republic of Nigeria, Nigeria's 6th Periodic Country Report: 2015-2016 on the Implementation of the African Charter on Human and Peoples Rights in Nigeria. P. 23.

${ }^{681}$ Now Public Complaint Commission Act, Cap P37 Laws of the Federation of Nigeria 2004

${ }^{682}$ See Ibid, Sections 5, 8, and 9; See also Public Complaint Commission, 'Public Complaint Commission Handbook' <http://www1.businessindex.com.ng/WSWeb/WAND_attachment.asp?mfg_code=50651332\&iFile_ID=1348 > accessed 28 May, 2014

${ }^{683}$ Ibid.

${ }^{684}$ Ibid.
} 
Realising the Right to Water and Sanitation in Nigeria

\subsubsection{The Legal Aid Council}

The Legal Aid Council was established by the Legal Aid Act No. 56 of $1976 .{ }^{685}$ The Council is to provide free legal aid services to indigents in Nigeria. ${ }^{666}$ The contemplated legal aid consists of assistance and representation in courts or tribunals by a legal practitioner and provision of legal advice. ${ }^{687}$ Legal Aid Act provided for the establishment of a legal aid and access to justice fund. This was to make it possible for financial assistance to be provided to the Council on behalf of indigent citizens for the prosecution of claims in accordance with the Constitution. Much of the services provided centred on assisting indigents in criminal cases.

\subsubsection{Committees of the National Assembly}

The National Assembly consist of two chambers: The Senate and the House of Representatives. Each of the chambers has human rights committee which exercises oversight functions on human rights issues. At the Senate, there is the Committee on Judiciary, Human Rights and Legal Matters. This Committee oversees issues relating to human rights and policies, judicial matters, administration of justice, and legal aid. It also exercises oversight function on the National Human Rights Commission.

At the House of Representative there is the Committee on Human Rights. This Committee has jurisdiction covering all human right issues including petitions of rights' violation, coordination of Child Rights Act and supervision of National Human Rights Commission, National Commission for Refugees and National Agency for Prohibition of Trafficking in Persons.

The main goal of these committees is to ensure effective human rights protection consistent with Nigeria's international obligations. ${ }^{688}$ Pursuant to their mandates, the committees have over the years undertaken certain activities designed to promote human rights in Nigeria. These included promoting the ratification of international human rights instruments, development of National Action Plan on Human Rights Project, the passing of Child Rights Act and Freedom of Information Act, National Working Group on Prison Decongestion, interaction with human rights NGOs and monitoring of ESC rights. ${ }^{69}$ The active cooperation of the committees have produced relevant ESC rights legislations such as Universal Basic Education Commission Act 2003/4, National Health Act 2014, Pensions Reform Act 2014, Anti-Human Trafficking Act 2015 etc. the committees however need to strive to promote the domestication of ICCPR and ICESCR.

\footnotetext{
${ }^{685}$ Now as Legal Aid Act, Cap L9 Laws of the Federation of Nigeria 2004 amended in 2011

${ }^{686}$ Ibid. S. 7.

${ }^{687}$ Ibid. S. 7(4)

688 Muhammed Tawfiq Ladan, Law, Cases and Policies on Energy, Mineral Resources, Climate Change, Environment, Water, Maritime and Human Rights in Nigeria. P. 181.

${ }^{689}$ Ibid.
} 


\subsection{Administration and Management of Water and Sanitation: Institutional Structures in Nigeria}

Nigeria's water resources consist of rainfall, surface and groundwater. The annual water resources potential stands at 319 billion cubic metres consisting of 267 billion cubic metres of surface water and 52 billion cubic metres of groundwater. ${ }^{690}$ African Development Bank research pointed out that only $15 \%$ of the surface water has been utilised. ${ }^{691}$ The annual rainfall varies regionally. In the extreme north, a semi-arid area, it ranges from $500 \mathrm{~mm}$ to $1000 \mathrm{~mm}$ while in the south, a humid area, it ranges from $1,500 \mathrm{~mm}$ to $4,000 \mathrm{~mm}$. ${ }^{62}$ Nigeria's hydrology has been divided into eight, ${ }^{693}$ drained and dominated by River Niger and River Benue ${ }^{694}$ and Lake Chad. ${ }^{695}$ These major rivers have several tributaries. Unlike in the perennial South, rivers in the North largely depend on annual rainfall. ${ }^{696}$ The annual surface runoff at the Lokoja gauging station was recorded to be up to 165.80 billion cubic metres while the volume of groundwater is equally considerably large especially in large sedimentary basins (Sokoto and Chad) ${ }^{697}$ It had been estimated that the total water bodies in Nigeria account for about $15.9 \%$ of Nigeria's total area. ${ }^{698}$

From the above, it may be argued that the problem with Nigeria, is not water availability but capacity to manage and effectively distribute the available water using modern techniques and approaches in a manner that caters for human beings and the environment. Regrettably, these have led to low coverage in terms of providing access to the population and is undermining the health of the environment through unsustainable extraction and consumption. Realising the right to water and sanitation for present and future generations requires adopting a holistic approach, efficient management techniques and technology in order to enhance accessibility "through controlling their movement both through space (by capturing, conveying and transferring water), and through time (by storing water during surplus seasons and years)." ${ }^{699}$ Effective institutional structures are therefore necessary. General Comment 15 of the Committee on ESC rights requires States to establish competent institutions and put in place appropriate institutional arrangement to enable the realisation of the right to water and sanitation. ${ }^{700}$ In the absence of adequate, effective and efficient

\footnotetext{
${ }^{690}$ See I. J. Goldface-Irokalibe, 'Water Management in Federal and Federal - Type Countries: Nigerian Perspectives' (Forum of Federations, 2009) <http://www.forumfed.org/library/water-management-in-federal-and-federal-typecountries-nigerian-perspectives/> accessed 14 September, 2013.See also Hon. Minister of Water Resources, MidTerm Report on Water Sector Transformation (2011 - 2013) (June, 2013), slide 5; See also Federal Republic of Nigeria, National Water Resources Master Plan (Federal Ministry of Water Resources 1995)

${ }^{691}$ African Development Bank, Nigeria: Rural Water Supply and Sanitation Sub-programmes in Yobe and Osun States, Appraisal Report, May, 2007)

${ }^{692}$ See E. Ita, Inland Fishery Resources of Nigeria (Food and Agriculture Organisation 1993), paragraph 2.1. See also Federal Republic of Nigeria, 'National Water Policy' (2004) Para. 1.0.

${ }^{693}$ I. J. Goldface-Irokalibe, 'Water Management in Federal and Federal - Type Countries: Nigerian Perspectives'.

${ }^{694}$ Ibid.

${ }^{695}$ E. Ita, Inland Fishery Resources of Nigeria. Paragraph 2.1

${ }^{696}$ Olawale Ajai, 'Law, Water and Sustainable Development: Framework of Nigerian Law' (2012) 8 Law, Environment and Development Journal P. 92.

${ }^{697}$ Federal Republic of Nigeria, 'National Water Policy'. Para. 1.0.

${ }^{698}$ E. Ita, Inland Fishery Resources of Nigeria. Paragraph 2.1.

${ }^{699}$ Malin Falkenmark, 'Fresh Water-Time for a Modified Approach' (1986) 15 Ambio 192 at P. 193.

${ }^{700}$ UNCESCR, General Comment No. 15: The Right to Water (Arts. 11 and 12 of the Covenant). Paras. 28, 47, and 50 .
} 
Realising the Right to Water and Sanitation in Nigeria

administrative structures in place, no meaningful programme, project or policy implementation can take place.

In realising human rights, specifically, ESC rights, all spheres of government are generally required to integrate and work towards creating an enabling environment for the progressive realisation of the rights in line with the international obligations of the State. As such, no sphere of government can escape in one way or the another, general responsibility. ${ }^{701}$ The complexity and the politics involved in water management require strong and functional institution properly positioned to balance the competing interests in water management and allocation and capable of withstanding the test of time. ${ }^{702}$ It is largely, the inadequate way in which water is managed that leads to conflict and not the lack of the resource in itself. ${ }^{703}$ Water management fails for reasons associated with inadequate institutions, "inadequate administrative capacity, lack of transparency, ambiguous jurisdictions, overlapping functions, fragmented institutional structures, and lack of necessary infrastructure."704

Efficient institutional arrangements should have, among others, a reliable database which should include meteorological, hydrological, and socio-economic data as "fundamental tool for deliberate and farsighted management of water resources."705 This will enable proper planning and assist in the prioritisation process where resources are limited. It is equally essential that appropriate frameworks are put in place to enable proper discharge of institutions' responsibilities. Unfortunately, however, it is common to find in several countries (including Nigeria) water management characterised by "overlapping and competing responsibilities among government bodies." "706 This unhealthy arrangement and culture often lead to disaggregated decision-making which "produces divergent management approaches that serve contradictory objectives and lead to competing claims from different sectors. And such claims are even more likely to contribute to disputes in countries where there is no formal system of water-use permits, or where enforcement and monitoring are inadequate." 707 It is the above concerns which characterised the current institutional and regulatory framework in water governance in Nigeria. ${ }^{708}$

The institutional structure which centred on the provision of Water Resources Act is devoid of detailed regulations, it is outdated, and clearly "not complemented by sufficient administrative structures, processes and institutions for its administration"709 for reasons associated with inadequate resources and weak law enforcement among others. ${ }^{710}$

As mentioned, administration and management of water resources in Nigeria is not the responsibility of a single tier of government or institution. The responsibility is divided.

\footnotetext{
701 Jaap de Visser, Edward Cottle and Johann Mettler, 'Realising the Right of Access to Water: Pipe Dream or Watershed?' (2003) 7 Law, Democracy \& Development , P. 2.

${ }^{702}$ Alexander Carius, Geoffrey D. Dabelko and Aaron T. Wolf, Water, Conflict, and Cooperation (ECSP Report, 2004). P. 61.

703 Ibid.

${ }^{704}$ Ibid.

705 Ibid.

${ }^{706}$ Ibid.

${ }^{707}$ Ibid.

${ }^{708}$ Olawale Ajai, 'Law, Water and Sustainable Development: Framework of Nigerian Law'. P. 98.

${ }^{709}$ Ibid.

${ }^{710}$ Ibid.
} 


\section{Chapter Three $\mid$}

Provision of municipal and domestic water supply is the responsibility of the States and Local Governments while the Federal Government provides counter-part funding, generates data and provides policy directives. In line with this arrangement, there are institutions and organs responsible for the administration and management of water and sanitation in Nigeria.

At the Federal level, several institutions and administrative agencies exist including the Federal Ministry of Water Resources, the River Basin Development Authorities, the National Water Resources Institute, and the Utilities Charges Commission. At the State level, there is the Ministry responsible for Water Resources, ${ }^{711}$ State Water Agency, and State Rural Water and Sanitation Agencies. At the local government level, similar local agencies and units exist. There are also non-governmental organisations and external support agencies that work with Federal, State and Local Government structures. ${ }^{712}$

In sanitation sector, responsibility is also shared among the three tiers of government. ${ }^{713}$ There however, appears to be overlap and at some point, competition between agencies at the Federal and to some extent, the State levels. At the Federal level, there is the Federal Ministry of Environment and the Federal Ministry of Water Resources. For example, the Federal Ministry of Environment has a section which functions duplicate that of Federal Ministry of Water Resources. ${ }^{714}$

It is not unusual in Nigeria to find ministries and agencies competing and sometimes fighting or scrambling for mandates. This usually arose due to lack of clarifications in agencies' enabling law or where lacunae in the laws exist. Ministries/agencies engaged in unnecessary competition and duplication of efforts and waste of valuable public resources. This unhealthy development hampers the efficiency and effectiveness of the agencies, inhibits effective coordination, and negatively affects service delivery. It demonstrated the urgent need for identifying and delineating institutional powers of agencies in order to isolate duplications of powers and functions. ${ }^{715}$ To avoid unhealthy competition and further create synergy and coordination, the National Environmental Sanitation Policy of 2005 established vertical and horizontal arrangements between relevant agencies. This was aimed at creating avenues to enable interaction between government and public agencies. ${ }^{716}$

However, no matter how lofty laws and policies are, realising their objectives depends on the implementation capacity and willingness of the agencies. Political economy suggests that implementation matters as it connects legal provisions with successes of an institution. Implementation has the potential of realising or watering down the goals of laws and policies. It is this recognition that calls for an assessment of public agencies responsible for the implementation of laws and policies.

\footnotetext{
${ }^{711}$ It is not uncommon in Nigeria to find responsibility shared among ministries such as Ministry of Water Resources, Ministry for Environment, Ministry for Lands and Housing etc.

${ }^{712}$ D. Adenle, 'Institutional Issues in Water Supply \& Sanitation (WSS) and their Role in the Attainment of Millennium Development Goals' Targets in Nigeria'

${ }^{713}$ Federal Republic of Nigeria, National Water Supply and Sanitation Policy (Federal Government Printing Press 2000)

${ }^{714}$ D. Adenle, 'Institutional Issues in Water Supply \& Sanitation (WSS) and their Role in the Attainment of Millennium Development Goals' Targets in Nigeria'

${ }^{715}$ Lekan Oyebande, 'Overview of Water Sector Development in Nigeria' (Water Meetup). Slide 19.

${ }^{716}$ D. Adenle, 'Institutional Issues in Water Supply \& Sanitation (WSS) and their Role in the Attainment of Millennium Development Goals' Targets in Nigeria'
} 
Realising the Right to Water and Sanitation in Nigeria

Reviewing institutions' legal and policy implementation is fraught with difficulties. Courts prefer in many respects to accord margin of appreciation to the executive arm on implementation issues. As a matter of practice, courts do not usually substitute executive arm's judgments with their own except in situations where non-compliance is clearly obvious or fundamental or where serious case of abuse of discretion exist. It is therefore of utmost importance that capacity of management staff is built in terms of knowledge and skills necessary to discharge their obligations. ${ }^{717}$ The following are the relevant Nigerian institutional structures on water and sanitation.

\subsubsection{Institutions at the Federal Level}

The relevant institutions at the Federal level are:

\section{National Council on Water Resources}

The National Council on Water Resources ("NCWR") was established in 1980 as the highest policy making body on water resources in Nigeria. Membership of NCWR is drawn from the FMWR, Federal Ministry of Environment ("FME"), representatives of States and the Federal Capital Territory (all commissioners on water resources, permanent secretaries and desk officers). NCWR' functions include overall policy planning on water for Nigeria. It guides the Government on water related legislation, policies and strategies and serves as a coordinating body between the tiers of government. It meets annually to consider issues affecting water resources and make necessary recommendations to the Federal Executive Council. ${ }^{718}$

\section{2. $\quad$ Federal Ministry of Water Resources}

FMWR has a history of merger and demerger in its four decades of existence. It was first created in 1976 and having only one operational department in order to formulate water resources development policies for the Federal Government and to coordinate their development. ${ }^{719}$ A year later, in 1977, the Ministry was merged with that of Agriculture and in 1979 it was recreated and later in 1984 was again merged with Agriculture which continued until 1989 when it was re-created with additional departments. ${ }^{720}$ This practice of merging and demerging between FMWR and Ministry of Agriculture continued until 2010. ${ }^{721}$ This practice has had a damaging effect on its performance in general and a neglect of water sector in particular. During the period of merger water was only seen as an aspect of providing food security in the country and was not viewed independently. With its recent re-creation, the FMWR now has five technical departments, four common services departments, 10 units, four agencies and 12 River Basin Development Authorities (RBDAs). ${ }^{722}$

\footnotetext{
${ }^{717}$ United Nations, 'Agenda 21' Chapter 18, Para. 18.19.

718 The Federal Executive Council is the highest decision-making body in Nigeria. It comprises of the President, the Vice President and members of the Federal Cabinet.

${ }^{719}$ Federal Ministry of Water Resources, 'History of the Ministry' (Federal Ministry of Water Resources, <http://www.waterresources.gov.ng/about/history-of-the-ministry> accessed 29 May 2014.

${ }^{720}$ Ibid.

${ }^{721}$ Ibid.

${ }^{722}$ Hon. Minister of Water Resources, Mid-Term Report on Water Sector Transformation (2011 - 2013), Slide 7.
} 


\section{Chapter Three}

FMWR is the most important agency in portable water provision and management. It is responsible for the setting of legal framework and policy formulation necessary for the development and management of water resources in the following areas: ${ }^{723}$

i. Portable water supply and sanitation

ii. Dams development and reservoir operation for flood control, bulk raw water supply, hydropower generation, irrigation, fisheries development etc.

iii. Construction and operation of irrigation infrastructure, land reclamation and drainage

iv. Enhancement of ecosystem balance through regular monitoring and dissemination of hydrological data.

Ministerial Reforms and Programmes: The FMWR is currently pursuing reforms and programmes designed to improve its technical capacity in ensuring access to improved water supply and sanitation. Pursuant to this, Nigeria is currently pursuing a Road Map on water sector, undertaking legislative and policy reforms, undertaking reforms on the financing and investment in water sector, and improving its relationship with relevant stakeholders.

i. Water Sector Road Map

This programme was launched in 2016 and was designed to provide direction in the sector from 2016 - 2030.

\section{ii. Public Private Partnership}

The FMWR now has a Unit dedicated to enhancing corporate financing of water sector among the three tiers of government and is poised to attract private sector and the expertise, investment and participation of relevant development partners. At the Presidential Summit in 2013 an MOU was signed between the FMWR and Bank of Industries in Nigeria wherein the Bank undertook to provide opportunities for potential private sector operators to access loans for water projects from the Bank. ${ }^{724}$

\section{iii. Relationship with other Stakeholders}

Several international institutions, international development partners, governmental and non-governmental organisations have been working with FMWR in its areas of mandate and specifically assisting in the provision of water around the country. These institutions and organisations include the World Bank, European Union, Japan International Cooperation Agency (JICA), African Development Bank (AfDB), United Nations International Children's Emergency Fund (UNICEF), United Kingdom Department for International Development (DFID), Islamic Development Bank, French Development Agency and Chinese Government. This relationship has between 2009 and 2013 generated over a billiondollar investment for Nigeria in areas of water supply, sanitation and irrigation. ${ }^{725}$

\footnotetext{
${ }^{723}$ Ibid., slide 6 .

${ }^{724}$ WaterAid, 'Presidential Summit on Water 2013' <http://www.wateraid.org/ /media/Publications/PresidentialWater-Summit-final.pdf $>$ accessed 29 May 2014

${ }^{725}$ Hon. Minister of Water Resources, Mid-Term Report on Water Sector Transformation (2011 - 2013), Slide 26. 


\section{National Water Resources Institute}

National Water Resources Institute ("NWRI") is a parastatal of the Federal Government under the supervision of FMWR. It was established in 1979 first as a Project under the Federal Department of Water Resources and was only given legislative backing in 1985 by the National Water Resources Institute Decree No. 3 of 1985. The NWRI is the only Institute in Nigeria dedicated to the research on water issues. Its mandate is to among others: promote and develop training courses in water resources; advise the water resources minister on the training needs and priorities; perform applied research functions in all aspects of water resources development and management of domestic and industrial water supply, sanitation and hygiene practice, sewage and sewerage treatment. ${ }^{726}$

\section{River Basin Development Authorities}

The idea of establishing River Basin Development Authorities ("RBDAs") was mooted by the grossly uncoordinated approach to the management of water resources in Nigeria in the early 1970s. ${ }^{727}$ During the period, Federal and States agencies on water resources were acting independently without appropriate coordination or interaction amongst them. ${ }^{728}$ It was not until the effects of Sahelian drought between 1968 and 1974 with its attendant consequences on food security, water supply and health complications that recognition was brought to bear of the need to coordinate and integrate approaches to water management. ${ }^{729}$ It was the recognition that a comprehensive development strategy which transcends boundary is needed in order to address the crises that necessitated the adoption of river basin development concept. ${ }^{730}$ Pursuant to this, two river basins development authorities were established by decrees of the Federal Government: Chad Basin Development Authority (Decree 32 of 14 August, 1973) and Sokoto-Rima Basin Development Authority (Decree 33 of 14 August 1973). There are currently 12 RBDAs in Nigeria established by the River Basins Development Authority Act: ${ }^{731}$ Anambra-Imo River Basin Authority, Benin-Owena River Basin Authority, Chad River Basin Authority, Cross-River River Basin Authority, HadejiaJamaare River Basin Authority, Lower Benue River Basin Authority, Upper Benue, Upper Niger River Basin Authority, Lower Niger River Basin Authority, Niger-Delta River Basin Authority, Ogun-Osun River Basin Authority, Sokoto-Rima River Basin Authority.

The main functions of the RBDAs under the Act are the comprehensive development of surface and underground water, water supply, construction, operation and maintenance of dams, and boreholes etc., development and updating of comprehensive water resources master plan through adequate collection and collation of water resources, socio-economic and environmental data. ${ }^{732}$ RBDAs activities are coordinated and monitored by the

\footnotetext{
${ }^{726}$ National Water Resources Institute <www.nwri.gov.ng>

${ }^{727}$ Lekan Oyebande, 'Overview of Water Sector Development in Nigeria', Slide 9.

${ }^{728}$ Ibid.

${ }^{729}$ Ibid.

${ }^{730}$ Ibid

${ }^{731}$ River Basins Development Authority Act, Cap R9, Laws of the Federation of Nigeria 2004

${ }^{732}$ Ibid.
} 


\section{Chapter Three}

Department of River Basins Operations and Inspectorates of the FMWR. RBDAs are important agencies in integrated water resources management, generation of water supply and protection of the ecosystems environment.

Like many other public utility institutions in Nigeria, the success of RBDAs is minimal. The interim report of the National Water Resources Master Plan noted that "the RBDAs have fallen short of the high expectations of the FGN as vital instruments for attainment of selfsufficiency in food production". Particularly it was noted that "the RBDAs have been below par in their primary function of hydrological and water resources data generation through sustainable monitoring and information systems." ${ }^{733}$ The main causes of RBDAs dismal performance were inconsistent and Government policy reversals. ${ }^{734}$ These rendered the RBDAs unable to optimally perform leading to discontinuation of series of "laudable peopleoriented programmes" leaving several projects either abandoned or incomplete. ${ }^{735}$

\section{National Council on Environment}

The National Council on Environment ("NCE") is the highest policy-making body on environment in Nigeria. The body was established to provide a platform under which interaction and harmonisation of environmental management issues can be discussed across the nation. Membership of NCE are drawn from ministries, government departments and agencies, the private sector, NGOs, community-based organisations, development partners, academia, and individuals interested in environmental issues. NCE meets annually to review Nigerian state of the environment and adopt appropriate policies to address environmental challenges across the country.

\section{Federal Ministry of Environment}

The Federal Ministry of Environment ("FME") was established first as Federal Environmental Protection Agency (FEPA) in $1988^{736}$ as a Federal Government's response to the growing need for environmental protection in the wake of the dumping of toxic and hazardous waste in Nigeria. This most notably after the discovery of an Italian ship in 1988 importation of some toxic chemical wastes. ${ }^{737}$ FEPA was to protect, restore and preserve the Nigeria's ecosystem through among others, the establishment of environmental guidelines and standards to abate and control all forms of pollution. Similar agencies were established in States and Local Governments around the Country. ${ }^{738}$ FEPA's environmental priority at the time of its establishment was industrial pollution. Pursuant to this the National Guidelines and Standards for Environmental Pollution Control was adopted. With concentration placed

\footnotetext{
${ }^{733}$ Lekan Oyebande, 'Overview of Water Sector Development in Nigeria', Slide 16.

${ }^{734}$ Hon. Minister of Water Resources, Mid-Term Report on Water Sector Transformation (2011 - 2013). Slide 8

735 Ibid., Slide 8.

${ }^{736}$ By Decree 58 of 1988

${ }^{737}$ Joseph Akinkugbe Adelegan, 'The History of Environmental Policy and Pollution of Water Sources in Nigeria (1960-2004): The Way Forward' <http://nigerianlawguru.com/articles/environmental\%20law/THE\%20HISTORY\%20OF\%20ENVIRONMENTAL $\% 20$ POLICY\%20AND\%20POLLUTION\%20OF\%20WATER\%20SOURCES\%20IN\%20NIGERIA.pdf> accessed 29 September, 2013

${ }^{738}$ State Environmental Protection Agencies and Local Government Environmental Protection Agencies 
Realising the Right to Water and Sanitation in Nigeria

on industrial pollution few references were made to surface impoundments, land treatments, waste piles, landfills, incineration and hazardous and toxic wastes. ${ }^{739}$

FEPA was renamed Federal Ministry of Environment, Housing and Urban Development in June 1999 and in 2008 was given a full-fledge status as FME designed to ensure the effective coordination of all environmental matters. Among its mandates, FME is to "prescribe standards and make regulations on water quality, effluent limitations, air quality, atmospheric protection, ozone protection, noise control as well as the removal and control of hazardous substances, and monitor and enforce environmental protection measures."740

Implementation of its mandates is pursued in several ways including through securing a quality environment conducive for good health and well-being of fauna and flora; the promotion of sustainable use of natural environment; raising awareness and maintenance of ecosystem, ecological processes and the preservation of biodiversity as well as raising public awareness and the promotion of understanding of linkages of the environment. ${ }^{741}$

\subsubsection{Institutions at the States and Local Governments Levels}

Pursuant to the sharing of responsibility under the National Water Supply and Sanitation Policy, 2000, States through the State Water Supply Agencies are "responsible for the establishment, operation, quality control and maintenance of urban and semi-urban water supply systems"; "licensing and monitoring of private water supply and monitor the quality of water supply to the public" and provision of technical assistance to the Local Government rural water supply units. ${ }^{742}$ The responsibility of the Local Governments is in the area of establishment, operation and maintenance of rural water supply schemes, in conjunction with the benefiting communities. ${ }^{743}$

In making water available, the bulk of the work is with the States. However, in many parts of the country, Water Supply Agencies have not been able to discharge the tasks of making water available. Several factors are associated with this development including the following: ${ }^{744}$

i. Underinvestment in water supply and sanitation infrastructure

ii. Poor capacity utilisation of the existing infrastructure

iii. High level of unaccounted for water

iv. Billing and water rates collection problems

v. Poor application of subsidy to the domestic consumers

vi. Un-served urban population problem

The functioning of these agencies depends largely on the resources made available and the enabling environment created for them to make effective impacts on the lives of the population. In this respect, Government's role should include appropriate mobilisation of

\footnotetext{
${ }^{739}$ Joseph Akinkugbe Adelegan, 'The History of Environmental Policy and Pollution of Water Sources in Nigeria (1960-2004): The Way Forward'

${ }^{740}$ Federal Ministry of Environment, 'About the Ministry' <http://www.environment.gov.ng/about.html> accessed

11 February, 2017

${ }^{741}$ See ibid.

${ }^{742}$ See Federal Republic of Nigeria, National Water Supply and Sanitation Policy. Para. 29.

${ }^{743}$ See ibid. Para. 30.

${ }^{744}$ See Mohammed Iliyas, 'State of Urban Water Supply in Nigeria' (National Water and Sanitation Forum)
} 


\section{Chapter Three}

financial resources, implementable legislation, creating opportunities for public participation and putting in place monitoring and assessment mechanisms. ${ }^{745}$ In Nigeria, several factors negatively impact on these institutions.

\subsection{Problems Associated with the Operation and Functioning of Institutional Structures on Water and Sanitation in Nigeria}

Although several factors could explain the dismal performance of institutional structures in Nigeria, over reliance on natural resources, specifically oil is one of the major factors. ${ }^{746}$ Nigeria's heavy reliance on oil revenue is responsible for many of the current woes. This account for the heavy toll corruption is taking and its consequential effects on the operations of public institutions in including those responsible for the provision of water and sanitation. Nigeria is the largest producer of oil in Africa and $12^{\text {th }}$ largest in the World ${ }^{747}$ and eighth largest exporter of crude oil. For over 50 years, oil has been the most dominant factor in the Nigerian economy. It accounts for $95 \%$ of Nigeria's foreign exchange earnings and $80 \%$ of budget revenue. ${ }^{748}$

Pegg has pointed out that "oil wealth ... contributes to corruption and has a corrosive effect on the quality of public institutions." $" 749$ Oil wealth is sometimes a curse and affects countries which before the oil do not have well-established and functioning public institutions. ${ }^{750}$ The Federal Government has power over land and natural resources in Nigeria although the federating units share revenue from natural resources on an agreed formula. Nigeria's history and struggles for resource control and revenue accruing therefrom have led to factional competition for the control of the Federal Government. ${ }^{751}$ These struggles have resulted to successive revenue sharing arrangements "accompanied by distrust, inadequate information flows, a lack of transparency, and uncertain accountability". ${ }^{752}$ These ultimately led to political instability, undermining policy-makers' autonomy and negatively impacted on the capacities of bureaucracies. ${ }^{753}$

The sharing of responsibility between the three tiers of government on water and sanitation requires effective and efficient coordination between and among them. Similarly, reliable and effective institutional framework, inter-sectoral coordination, and integrated policy approach are integral aspects which agencies under the tiers must have for a proper discharge of their responsibilities. Unfortunately, these issues are the major concerns hampering on their performance. In terms of human rights, although there are human rights institutions in Nigeria, regrettably, these institutions are not strong enough to ensure

\footnotetext{
745 See United Nations, 'Agenda 21' Chapter 18. Paras. 18.22.

${ }^{746}$ Scott Pegg, 'Nigeria'. P. 78.

${ }^{747}$ Central Intelligence Agency, 'The World Factbook' May 2001) <https://www.cia.gov/library/publications/theworld-factbook/geos/ni.html> accessed 30 December 2016

${ }^{748}$ Central Intelligence Agency, 'Nigeria'

${ }^{749}$ Scott Pegg, 'Nigeria'. P. 78.

${ }^{750}$ Benjamin Smith, Hard Times in the Lands of Plenty: Oil Politics in Iran and Indonesia (Cornell University Press 2007) cited in Scott Pegg, 'Nigeria'. P. 76.

${ }^{751}$ Scott Pegg, 'Nigeria'. P. 78.

${ }^{752}$ Ehtisham Ahmad and Raju Singh, 'Political Economy of Oil-Revenue Sharing in a Developing Country: Illustrations from Nigeria' (2003) IMF Working Paper WP/03/16 . P. 3.

${ }^{753}$ Scott Pegg, 'Nigeria'. P. 78.
} 
Realising the Right to Water and Sanitation in Nigeria

maximum impacts in the promotion and protection of human rights due largely to their lack of independence, financial autonomy, and logistical capability. ${ }^{754}$ Some of the institutional issues in the realisation of human rights to water and sanitation in Nigeria include:

\subsubsection{Technical Capacity}

Capacity is prerequisite to good governance and discharge of responsibility. Indeed, "best water management strategies, best institutional arrangements and best enabling environment" "will be meaningless if those charged with their administration and enforcement are deficient in their roles". ${ }^{755}$ Enhancing capacity requires periodic training on general and technical management issues. Water managers at all levels are to be trained to enable them to develop appropriate understanding of elements necessary in their decision making. ${ }^{756}$ A periodic review on institutional capacity in the implementation of integrated water management is also essential when there is a clear demand for it. ${ }^{757}$

In Nigeria, the NWRI was established to provide capacity building trainings on water resources generally and for the staff of FMWR. This formal setting is complemented by additional tertiary institutions collaborative mechanism established through the NWRI: National Water Resources Capacity Building Network to ensure that water managers in Nigeria acquire adequate capacity to discharge their responsibilities. Under this arrangement, six universities drawn from the six geo-political zones participate in a network of collaborative research and training on water resources. Despite this arrangement however, water institutions and water managers are still battling with technical capacity issues. Several respondents from duty-bearers have identified lack of capacity as one of the major challenges affecting their institutions. Respondents have equally indicated apparent lack of periodic trainings in all water institutions examined in the geographical areas of this study. Results of empirical study indicated that not every public institution in Nigeria has a policy on staff training. Roughly half of respondents (duty-bearers) (51.56\%) indicated that their institutions have training policy while $28.13 \%$ said they do not have and $20.31 \%$ do not know. In terms of training provided to improve staff capacity, the empirical study investigated the number and frequency of trainings provided to the respondents between 2013 and 2015. Table 3.1 indicated the responses.

From the table, it does not appear that regular or continuous capacity building training is considered of critical importance. Staff do not appear to have been adequately exposed to types of training that will empower them to tackle newer challenges or be exposed to new approaches, standards, and techniques. The problem is generally not lack of available experts to provide training, but funding is inadequate, and corruption further complicated the situation. ${ }^{758}$ The resultant effect is that water managers and administrators are left untrained.

\footnotetext{
754 Jacob Abiodun Dada, 'Impediments to Human Rights Protection in Nigeria '. P. 87.

${ }^{755}$ I. J. Goldface-Irokalibe, 'Enabling Environment and Institutions' (Regional Training of Trainers Workshop), Slide 20.

${ }^{756}$ See United Nations, 'Agenda 21' Chapter 18. Paras. 18.20 (b)(d).

${ }^{757}$ See ibid. Chapter 18. Para. 18.21.

${ }^{758}$ The Minister of Water Resources had noted this issue in her mid-term review presentation. See Hon. Minister of Water Resources, Mid-Term Report on Water Sector Transformation (2011 - 2013)
} 


\section{Chapter Three}

Additionally, familiarity with job description by duty-bearers is important in internalising their mandate. Of concern is the finding that only $57.81 \%$ of the respondents have stated that their institutions have job description for every staff. When further requested to indicate if at the time of appointment or posting respondents have been availed with detail description of their duties, only $50.79 \%$ responded in the affirmative demonstrating that about half of the respondent were not informed about their schedule of duty.

\subsubsection{Infrastructural Capacity and Operational Challenges}

While periodic trainings are important, relevant infrastructures should complement. Regular training without necessary working tools can hamper institutional performance. This research investigated the infrastructural capacity of the institutions and other operations challenges. Respondents from duty-bearers were asked to rate the efficiency of their equipment on a scale of 1-6 (inefficient - very efficient). Their responses indicated in Table 3.2 showed that only $33.33 \%$ considered them efficient, another $33.33 \%$ indicated somewhat efficient. When they were further asked to state challenges hampering the sector, several respondents identified obsolete equipment, lack of infrastructural capacity, lack of proper maintenance of equipment and lack of capacity to operate the equipment as some of the challenges. Other operational problems identified are vandalization of facilities, blockage of pipes in the distribution networks, insufficient supply of chemicals for water treatment, frequent breakdown of machineries, diesel, lack of wide area coverage by distribution main, and sabotage by some staff.

\subsubsection{Weak Institutional Framework}

In Nigeria, presently, there is no effective water resources management policy while the current "water laws lack proper provisions and mechanisms for inter-sectoral coordination, tariff setting and conflict resolution." "759 It should be stated that the National Water and Sanitation Policy 2000 made a provision for inter-agency coordination where the Federal Government is to formulate National Policy and coordinate the activities of all the States Water Supply Agencies and the FMWR is to give policy advice to States on quality and quantity of water, "standards for equipment and materials, guidelines on loan sourcing and other technical information necessary for planning and effective operation". ${ }^{760}$ The States through State Water Agencies are to "provide all basic information on their existing and proposed projects" to the FMWR. Such information should include "water supply sources, volume of water pumped, quantity of chemicals, data on water quality, pipe types, sizes and lengths: and such other information FMWR may require. ${ }^{761}$ Similarly, the State Water Agencies are to provide technical support to the local governments "in the areas of planning, design and supervision of their water supply schemes"762 while local governments are to

\footnotetext{
${ }^{759}$ A. J. Ajiboye, A. O Olaniyi and B. A. Adegbite, 'A Review of the Challenges of Sustainable Water Resources Management in Nigeria' (2012) 1 Int J Life Sc Bt \& Pharm Res . P. 1.

${ }^{760}$ See Federal Republic of Nigeria, National Water Supply and Sanitation Policy. Para. 43.

${ }^{761}$ See ibid. Para. 46.

${ }^{762}$ See ibid. Para. 46.
} 
Realising the Right to Water and Sanitation in Nigeria

provide records of their water supply activities to the State Supervisory Outfit on a bi-annual basis. ${ }^{763}$

Similarly, the National Water Sanitation Policy ${ }^{764}$ provided for the establishment of a steering committee at the Federal, States and local governments levels consisting of line ministries and other stakeholder especially at the local governments level which are to include religious and traditional leaders, youth, and women groups. The Policy further requires that a division in Water Supply Department of the FMWR is to be established to coordinate and facilitate the implementation of the Policy. The Federal Government in consultation with stakeholder is to lead in policy development on sanitation, enact appropriate laws and implementation strategies, provides technical assistance to the States and Local Governments and conduct monitoring and evaluation of sanitation improvements. The States are to establish appropriate legislations, develop sanitation programmes among others while the local governments are to make appropriate bye-laws, ensures timely release of funds annually for sanitation activities. Roles have also been created for the households, individuals, private sector, NGOs and development partners.

On environmental sanitation, the National Policy on Environmental Sanitation has established Steering Committees on Environmental Sanitation at the National, States and Local Governments level. The National Committee is to coordinate the implementation strategies of the Policy, monitor and evaluate national environmental sanitation activities. Similar responsibilities at the State and Local Governments levels have been apportioned respectively. ${ }^{765}$ These arrangements however are hardly followed and leave water and water sanitation activities in the country uncoordinated. ${ }^{766}$ The framework does not have mechanism for its implementation. Weak or inadequate institutional framework also exists on environmental management. At present, there appears to be no clear formulated policies designed to coordinate and monitor the relationship between environmental management and sustainable development. ${ }^{767}$ As such agencies working in these fields are not effectively coordinating their activities. Even where environmental laws and policies exist, the provisions are poorly enforced.

\subsubsection{Fragmented and Inadequate Data and Statistics}

In the words of Chino, "sound data represent a key weapon in the battle against poverty". ${ }^{768}$ Data and statistics are important if not fundamental requirements in the measurement of progressive realisation of ESC rights. Effective management and utilisation of the limited resources require availability of data and statistics for planning, ${ }^{769}$ utilisation

\footnotetext{
${ }^{763}$ See ibid. Para. 47.

${ }^{764}$ See Federal Republic of Nigeria, National Water Sanitation Policy. Para. 4.1 - 4.2.

${ }^{765}$ See generally Federal Republic of Nigeria, National Environmental Sanitation Policy. Para. 7.

${ }^{766}$ See ibid. Para. 3.0.

767 Joseph Akinkugbe Adelegan, 'The History of Environmental Policy and Pollution of Water Sources in Nigeria (1960-2004): The Way Forward'

${ }^{768}$ Tadao Chino, President, Asian Development Bank, quoted in Paris21 Secretariat, 'Making the Case: National Strategy for the Development of Statistics (NSDS)' November, 2004) <http://www.paris21.org/sites/default/files/1406_0.pdf> accessed 9 June, 2014 P. 2.

${ }^{769}$ Ibid.
} 


\section{Chapter Three}

of limited resources and concentration of programmes to address deprivations while "good statistics allied to appropriate government policies can change things radically for the better." 770 Through statistics, social indicators for intra - and international comparisons of quality of life of a particular place and people are computed. Data and statistics are important in monitoring progress and the implementation of developmental programmes. They are useful for planning, research, decision making and are basic components of transparency and accountability.

In order to assess community's water supply situation and state of well-being, reliable statistical information at regular intervals is needed. This provides information not only on coverage, but it informs policy and decision makers and stakeholders on the work required in the attainment of targets and goals. Statistics is also important on the sources of water supply and how individuals and groups access water. This is against the background where because of States' failure to provide access to quality water, a large portion of the population has resorted to borehole and wells construction either independently or use those constructed by private organisations accessible upon payment of fees. In order to monitor water quality and ensure compliance with the minimum standard, regulatory bodies must generate data on the locations of water points, water quality and treatment and how population access water. Even where water source is from rivers and ponds, it should be State's obligation to protect individuals from contaminated or un-qualitative water for personal and domestic uses and to assess the rate at which these sources are depleted and discharge for sustainability. This becomes necessary in the light of empirical evidence from Ibadan, Nigeria suggesting that the level of quality of both river water and adjacent dug wells along the Ogunpa stream fall far below established standards as determined by several quality parameters. ${ }^{771}$ Lack of data on water quality has particularly been identified as one of the reasons responsible for the widespread abuse of the right to water in the Niger-Delta. ${ }^{772}$

Nigeria has a statistical and data generating agency: The National Bureau of Statistics ("NBS"). However, under the legal and administrative frameworks in Nigeria, the major source of data on water is the NWRI, a parastatal of FMWR. Some of the main functions of NWRI in this regard are the harmonisation of all system of water data in the country and designing and developing of a data bank system for water sector across all primary and secondary stations in Nigeria. At the moment, NWRI does not seem to be performing well on these aspects. For over a decade now, "no single-pan Nigerian hydrological yearbook has been published." 773 There is the lack of assessment impacts on Decision Support System (DSS) which are "models necessary for understanding the impact of abstraction and groundwater aquifers.",774

\footnotetext{
${ }^{770}$ Clare Short, former Secretary of State for International Development

${ }^{771}$ See A. Y. Sangodoyin, 'Fundamentals and Trends of Water Services in a Nigerian Urban Settlement' (1990) 9 Int J Environ Educ Inform 181

${ }_{772}$ Audrey Gaughran, 'Business and Human Right and the Right to Water' (2012) American Society of International Law Proceedings P. 54.

${ }^{773}$ A. J. Ajiboye, A. O Olaniyi and B. A. Adegbite, 'A Review of the Challenges of Sustainable Water Resources Management in Nigeria'. P. 3.

${ }^{774}$ Ibid.
} 
Realising the Right to Water and Sanitation in Nigeria

Additionally, Statistics on water coverage are hardly harmonised or accurately obtained. As a result, different agencies, individuals and organisations have their own set of data determined by their major interests, the methodology used, the source of funding and their objectives. There is currently, no effective data management system on water resources in Nigeria. ${ }^{775}$ The major issue hampering the effective functioning of many institutions in Nigeria is funding. Agencies like NWRI are underfunded, have dilapidated infrastructure and suffer from other vices including corruption.

The NBS as a data and statistics generating agency generates statistics using the National Integrated Survey of Households (NISH) and the National Integrated Survey of Establishments (NISE) through asking questions on access to different sources of water. The NBS has been relatively conducting periodic household surveys including on access to water and sanitation but it is also an institution suffering similar predicaments like the NWRI.

In addition to institutional problems, another problem associated with data and statistics in Nigeria is the lack of a reporting system for water supply statistics. Generally, data on water supply are fragmented and available only "in bits and pieces, in hard copies in files and occasional reports of water corporations and summaries of activities at water treatment plants and pumping stations which have the ability to keep such records. Hence, retrieval and transfer follow the same pattern of hard copies of data storage."776 The impact of lack of a reliable and efficient data is enormous. It will be difficult to achieve economic and social emancipation where statistics are difficult to come by. Without adequate data, it will be difficult to understand the extent of deprivations or whether the project is achieving its purposes or whether even it is in line with the expectations of the local community. This situation has resulted to instances where projects are at variance with the situations on the ground and consequently, suffer neglect or abandonment after huge resources have been invested. ${ }^{777}$ It is however of a relief to note that these issues are receiving increasing attention in the adopted water and sanitation policy strategies 2016-2030 and the National Policy on the Environment 2017.

\subsubsection{Weak Synergy among Stakeholders}

Management of water resources has suffered uncoordinated approach among the relevant agencies in the Federal, States and Local Governments. This has led the tiers of government and their agencies to pursue fragmented approach and agendas independently. ${ }^{778}$ Even the FMWR in the context of rural water supply had admitted the lack of a comprehensive national rural water supply and sanitation programme framework which focussed on ensuring coordination, streamlining and lending of focus and thrust to all the previous initiatives in water

\footnotetext{
775 Ibid

${ }^{776}$ National Bureau of Statistics, 'Water Supply Statistics' <http://nigerianstat.gov.ng/pages/NBS\%20eLibrary> accessed 6 June, 2014

${ }^{777}$ This is generally one of the biggest challenges in development discourse in many African States. In many cases, projects are developed without obtaining adequate data, contextualizing it with the local circumstances and implemented without consulting those who are to benefit from it. See Dejo Olowu, 'Human Development Challenges in Africa: A Rights-Based Approach'. Pp. 220-222.

${ }^{778}$ A. J. Ajiboye, A. O Olaniyi and B. A. Adegbite, 'A Review of the Challenges of Sustainable Water Resources Management in Nigeria'. P. 1.
} 


\section{Chapter Three}

and sanitation sector. ${ }^{779}$ Some respondents among duty-bearers have equally voiced concern on lack of coordination among related agencies. This leads to duplication of efforts and waste of resources and failure to discharge core obligations relating to availability, access, affordability and quality of water for personal and domestic uses.

There is no effective water monitoring system, no enforcement measures, water polluters are not sanctioned, no remedies to population affected by water pollution and the "overall responsibility for the quality of surface and groundwater in Nigeria remains unclear." 780 The recently adopted National Policy on the Environment 2017 and the 2016-2030 National Water Resources and Sanitation Policy Strategy are designed to address these issues.

\subsubsection{Bureaucracy}

In the empirical study both respondents (duty-bearers and rights-holders) have indicated that government bureaucracy is one of the challenges in the way duty-bearers discharge their duties and rights-holders claim their rights respectively.

\subsubsection{Lack of Cost-Recovery Mechanism}

Except in few States, mostly in the Southern part of Nigeria, generally in the North water is viewed as a social resource which is to be provided free or at a relatively cheaper price. As a result, where water is provided by the State, the rate chargeable is low. Notwithstanding this, large number of consumers do not pay for water. Several respondents among the dutybearers have indicated their concerns on this problem. This has led to poor management of water resources infrastructures. There is no efficient way of cost recovery. It was suggested that due to poor cost-recovery, water should be recognised as an economic good designed to enhance financial viability of the sector and ensures steady supply. ${ }^{781}$

The National Water Policy attempted to address this situation wherein while advocating for this approach puts some caveat for the protection of the poor and cost-sharing arrangement between the beneficiaries and government. ${ }^{782}$ While access to water may not be free, in countries with limited financial capacity, access to water as human right requires balancing the need for cost-recovery and steady supply especially to the vulnerable population who could not financially afford it.

\subsubsection{Lack of Motivation}

Motivation is an important tool that has impacts on employee performance. In the words of Lisa McQuerrey:

Everyone has motivators that trigger them to excel. Although the things that motivate one person may not work for another, finding out what spurs your staffers to action can help you

\footnotetext{
${ }^{779}$ Department of Water Supply and Quality Control, National Rural Water Supply and Sanitation Programme: A Strategic Framework. Pp. 7 - 8.

${ }^{780}$ A. J. Ajiboye, A. O Olaniyi and B. A. Adegbite, 'A Review of the Challenges of Sustainable Water Resources Management in Nigeria'. P. 3.

${ }^{781}$ Kevin Ejike Chukwu, 'Water Supply Management Policy in Nigeria: Challenges in the Wetland Area of Niger Delta ' 11 European Scientific Journal 303)

${ }^{782}$ Federal Republic of Nigeria, 'National Water Policy'
} 
Realising the Right to Water and Sanitation in Nigeria

urge them to higher levels of performance. In addition to being more productive employees,

motivated staffers are also more likely to have high job satisfaction and better morale. ${ }^{783}$

There is no blanket list of factors which motivate employees as these may largely depend on individual needs, and goals. However, several factors have been identified. These include: money; personal satisfaction; professional goals; loyalty; and recognition. ${ }^{784}$ Each of these plays a fundamental role in the way in which an employee discharges his duties towards the employer. As example, employees who are well paid and feel properly compensated will have a sense of job satisfaction which may propel them to put more into the organisation compared to those who feel not well appreciated in terms of payment and other incentives. Professional goals are linked to employees with interest in attaining certain positions within the ranks of the organisation. Existence of possibility for growth and increasing level of responsibility given to such employees are likely to push them further for success. Loyalty in the form of being with the organisation for a long time may give a sense of what the author called 'vested interest in the continued success of the organisation' thereby making them to continue to perform at the optimum levels. Accordingly, fear for job security may equally push others to put extra effort in securing their jobs. Some employees are motivated by their desire for recognition. Awards, commendations, and mention in public can impact on their performance. Similarly, appreciation of employee contributions in the operations of the institution may serve as incentive to many employees.

It is in this context that this research investigated whether there exists any motivation mechanism in the institutions capable of impacting on the duty-bearers' performance. In the Civil Service, there is no general practice of rewarding employees or providing some kinds of incentives when achievements are recorded. In some few organisations, motivation is usually management initiative and the practice is not consistent. Additionally, the condition of service in terms of salary, the amount is not encouraging, and, in some States, payment is irregular and characterised by delays and deductions. These create general apathy in civil servants thereby rendering the service to be a last option. The study investigated whether there exist any reward or incentive for excellence at the duty-bearers' institutions. The results indicated that only $20.31 \%$ responded in the affirmative. Respondents were further asked if their contributions are appreciated in decision making and actions as another form of motivation. Responses indicated that $42.86 \%$ of duty-bearers admitted that their contributions are always considered, $44.44 \%$ indicated that their contribution is sometimes considered while $12.70 \%$ are in the negative. In the light of these figures, it does not appear that duty-bearers in water and sanitation sector are adequately and appropriately motivated. This may have some negative impact on their performance

\subsubsection{Lack of Consultation and Participation of Beneficiaries}

Another dimension of the problem of access to water and sanitation linked to the operation of the institutions is lack of consultation and participation of beneficiaries.

\footnotetext{
783 Lisa McQuerrey, 'Assessing the Role of Motivation on the Employees Performance' <http://work.chron.com/assessing-role-motivation-employees-performance-21649.html> accessed 14 December, 2016

${ }^{784}$ Ibid.
} 
Programmes are often commenced and, in some instances, completed without the participation of beneficiaries. In many instances, this resulted to the projects not serving the intended purposes or objectives. Both the National Water Policy 2004 and the Report of the European Community reiterated this concern. The Policy for example stated:

In most cases, stakeholders are not consulted or otherwise involved in planning, development and management of the nation's water resources. The result has been a vicious cycle of unreliable projects that provide services that do not meet consumer needs and for which the consumers are unwilling to pay. ${ }^{785}$

Participation of right-holders is a principle of human right. The right can only be effectively realised when the beneficiaries are part of all the processes concerning it. ${ }^{786}$ The scope of participation must as a requirement go beyond "information and superficial consultation and involve people in decision-making; providing real opportunities to influence the planning process." $" 787$ It must equally include all segments of the society including the civil society, non-governmental organisations, women, the marginalised, the disadvantaged and vulnerable groups who may be represented. ${ }^{788}$ In Beja and Others v. Premier of the Western Cape and Others ${ }^{789}$ the South African High Court has held it to be a violation if there is failure to provide for the meaningful participation of the community as well as the failure to take account of the needs of vulnerable groups. The Court provided criteria (minimum requirements) under which consultation and participation of community can be held to be effective or discharged. The criteria are that any agreement purporting to have been reached arising from consultation should satisfy the following: ${ }^{790}$

i. it must be concluded with duly authorised representatives of the community;

ii. it must be concluded at meetings held with adequate notice for those representatives to get a proper mandate from their constituencies;

iii. it must be properly minuted and publicised;

iv. it must be preceded by some process of information sharing and where necessary technical support so that the community is properly assisted in concluding such an agreement.

The National Water Policy in Nigeria recognises the critical role of water users' participation in the planning and management of water resources, unfortunately, this is hardly followed as confirmed by the empirical study.

\subsubsection{Low Involvement of Private Corporate Actors}

Private Corporate Actors are important stakeholders in the provisions of access to water and sanitation especially in circumstances where the State is not adequately in the position to undertake the duties itself. Even in developed States, more and more public services are being outsourced to private corporate actors for efficient service delivery. The human rights

\footnotetext{
${ }^{785}$ National Water Policy, Federal Republic of Nigeria, 2004 at 5

${ }^{786}$ WaterLex and WASH United, The Human Rights to Water and Sanitation in Courts Worldwide: A Selection of National, Regional and International Case Law. P. 14.

${ }^{787}$ Ibid.

${ }^{788}$ Ibid. Pp. 14-5.

${ }^{789}$ (2011) High Court (Western Cape) 21332/10, (2011) ZAWCHC 97

${ }^{790}$ Ibid. Para. 98.
} 
Realising the Right to Water and Sanitation in Nigeria

obligation in relations to provisions of ESC rights entail adopting any administrative measure designed to ensure the progressive realisation of the rights. Achieving goal 6 of the SDGs obviously requires active participation of the private sector in water and sanitation issues and this is in line with the global partnership advocated by goal 17 of the SDGs which recognises private sector as a key player in achieving SDG targets. ${ }^{791}$

The necessity of involving private sector in the provisions of access to water and sanitation can be seen in Target 6.1 of SDG 6 which is "to achieve universal and equitable access to safe and affordable drinking water for all" by 2030, target 6.2 which is "to achieve adequate and equitable sanitation and hygiene for all and to end open defecation, paying special attention to the needs of women and girls and those in vulnerable situations" by 2030 and target 6.3 which is "to improve water quality by reducing pollution, eliminating dumping and minimizing release of hazardous chemicals and materials, halving the proportion of untreated wastewater and substantially increasing recycling and safe reuse globally" by 2030 . These targets may be hard to achieve in some developing countries with challenges of resources, technology and capacity without necessary participation of the private sector. In the call to action on sanitation, the United Nations Deputy Secretary General highlighted the role of business as a key partner. The Deputy Secretary General stated:

Tackling sanitation challenges is key to advancing human development. The Deputy

Secretary General is aiming to bring together key partners from government, civil society, business and international organizations to commit to action. The aim is to mobilize resources to rapidly increase access to basic sanitation, with a focus on improving hygiene, changing social norms and better managing human waste and waste-water and ending open defecation. By 2025, the practice of open defecation must be totally eliminated. ${ }^{792}$

The private sector is an important partner in the provision of goods and services in improving access to water and sanitation, it can play a significant role in other areas such as "finance; technology; capacity-building; trade; policy and institutional coherence; multistakeholder partnerships; and data, monitoring and accountability." 793 These are issues which are at the heart of access to water and sanitation crisis in Nigeria.

Although various relevant policies have recognised the important roles of public-private partnership and have clearly indicated the private sector as an important partner, limited implementation has been achieved in this context and mostly in relations to sanitation. It is hoped that the relevant provisions in National Policy on Water, the National Policy on the Environment and the Water and Sanitation Roadmap will be pursued as intended to implement this aspect.

\footnotetext{
${ }^{791}$ Sustainable Development Goal 6, "Ensure availability and sustainable management of water and sanitation for all" and Goal 17, "Strengthen the means of implementation and revitalize the global partnership for sustainable development".

792 United Nations, 'Call to Action on Sanitation' (United Nations, 21 March 2013) <http://www.un.org/millenniumgoals/pdf/DSG\%20sanitation\%20two-pager\%20FINAL.pdf> accessed 29 May 2018.

${ }^{793}$ Nathaniel Mason, Mariana Matoso and William Smith, Private Sector and Water Supply, Sanitation and Hygiene (ODI, October 2015)
} 


\subsection{Conclusions}

Chapter Three

Multiple factors have shaped and redefined the Nigeria's human rights environment. The prolonged period of military administration with its attendant consequences on the polity has impacted in the way in which human rights issues are viewed by the population. Until very recently, human rights protection concentrated only on CP rights while the domain of ESC rights received little or no attention from both governments and rights-holders. The concern was generally on CP rights because of the arbitrariness of military system of government. With the return to democracy, the Constitution failed to recognise the indivisibility and interconnectedness of human rights and separated CP rights from ESC rights and decided to confer justiciability status to the former only while the latter was left to the domain of fundamental objectives and directive principles of state policy which are non-justiciable. This separation has affected the way in which human rights are viewed by the government and population. Institutional structures for the protection of human rights equally seemed to be concentrating more on $\mathrm{CP}$ rights with limited emphasis on ESC rights. Reasons for the limited progress in ESC rights hence can be traced to multiple factors including legal and policy frameworks, political, economic, social and cultural situations in the country.

There is no paucity of institutional structures in the protection of human rights and realisation of the right to water and sanitation in Nigeria. The formal structures of the established institutions seemed to be in conformity with the UNGA resolution A/RES/48/134 and General Comment 15 of the Committee on ESC rights. However, operationally, there are challenges hampering their efficiency and effectiveness. These challenges include inadequate funding, lack of capacity, lack of sufficient political will, and lack of synergy among relevant institutions, bureaucracy, lack of motivation and lack of consultation and participation of relevant stakeholders and low involvement of private corporate actors in the provision of access to water and sanitation. 


\section{Chapter Four}

\section{Nigeria's Compliance with the Legal Obligations Under the Human Right to Water and Sanitation: Legal, Policy and Empirical Perspectives}

\subsection{Introduction}

T egal bases for the recognition of water and sanitation as human right are embodied in several international instruments consisting of treaties and soft laws. As shown in chapter two, the Committee on ESC rights framed the right to water and sanitation within the context of the right to health and the right to an adequate standard of living while the Human Rights Committee analysis was within the context of the right to life and right to dignity of human person contained in the ICCPR. Other relevant binding treaties which made explicit reference to water are CEDAW, CRC and the four Geneva Conventions. There are numerous declarations, resolutions and political commitments ${ }^{794}$ recognising water as human rights, however, these instruments are merely persuasive and do not impose binding obligation on States. This is notwithstanding that, as standards, States do not want to be seen deliberately violating them.

Nigeria has acceded to the ICCPR and ICESCR and is a party to CEDAW and CRC. In most of these human rights treaties and instruments, State Parties are required to adopt measures including legislative, administrative or other measures for the implementation of the rights mentioned therein. ${ }^{795}$ Depending on the character of its legal system, a State can comply with its legal obligations of integrating human rights norms legislatively in a variety of ways including ratification or accession and direct application of these instruments where domestication of treaties is not required. It can equally be done through the adoption of an enabling legislation, or domestication of the treaty in question or even spreading the obligations in a number of relevant legislation in Nigeria. ${ }^{796}$ The ICCPR, ICESCR, CEDAW and CRC have all been ratified. ${ }^{797}$ At the regional level, Nigeria has equally ratified the ACHPR. Regarding domestic enforceability however, only the ACHPR has been domesticated in accordance with article 12 of the Nigeria's 1999 Constitution. Although Nigeria has enacted Child Rights Act which largely follows the CRC, arguably, the Act applies only within the Federal Capital Territory Abuja. ${ }^{798}$ Notwithstanding the non-

\footnotetext{
${ }^{794}$ Such as the Ministerial Declaration of The Hague on Water Security in the $21^{\text {st }}$ Century, $22^{\text {nd }}$ March 2000 , the International Round Table on Trans-Boundary Water Management, Berlin, Germany, 27 ${ }^{\text {th }}$ September 1998; the Third World Water Forum, Kyoto, Japan, 2003 etc.

${ }^{795}$ See for example Art. 2(2) of the ICCPR; Art. 2(1) of the ICESCR; and Art. 2(a) and 18(1) of CEDAW.

796 Nadine Perrault, Erica Hall and Christine Lundy, Assessing Compliance of National Legislation with International Human Rights Norms and Standards, November 2008). Pp. 5-6.

${ }^{797}$ ICCPR and ICESCR were ratified on 29 July 1993, CEDAW was ratified on 13 June 1985 and CRC was ratified on 19 April 1991.

${ }^{798}$ This is because issues relating to children is not within the exclusive legislative list of the constitution
} 
Realising the Right to Water and Sanitation in Nigeria

domestication however, at the international level, Nigeria is still bound to respect, protect and fulfil the rights guaranteed by these instruments. Except with ACHPR, Nigeria has not been consistent in submitting its periodic reports to the treaty bodies which makes monitoring compliance a challenge by the treaty bodies. ${ }^{799}$

Compliance with legal obligations is a requirement in all human rights treaties. Noncompliance is therefore considered as a breach of obligation. Various definitions of the notion of compliance abound. In one sense, it implies the degree to which behaviour of a particular State is in conformity with a particular agreement prescribed or proscribed. ${ }^{800}$ In this context it is the way in which a State is acting or behaving that would be assessed in line with its legal obligation in order to determine whether or not such a behaviour is consistent with the binding obligations. The more a State's behaviour is closer to the obligations prescribed the more it would be deemed to be complying. In another sense, it has been defined as "the process by which an organisation ensures that it observes and complies with the external statutory laws and regulations." 801 This latter definition goes beyond mere behaviour. It encompasses all the steps taken by an organisation consistent with binding laws and regulations. In the context of international legal obligations and the requirement of taken measures including legislative, administrative and other measures, the latter definition seems to be more in line with the requirement of various treaties. In the context of this research, compliance is limited to assessing legislative and policy measures and their conformity with relevant international legal obligations concerning the right to water and sanitation. Additionally, attempt will be made to assess, through the use of empirical data obtained in this research whether there is an indication that Nigeria is complying with its legal obligations under the right to water. The assessment of the empirical data in the light of the contents of the right to water may enable the duty-bearers to reassess the existing water access situation and the impacts of their decisions in water connection and allocation.

In the light of the discussion on the obligations and contents of the right to water and sanitation in chapter two, this chapter assesses the extent to which Nigeria, through legal and policy instruments as well as empirical indicators has directly or indirectly, responded to such obligations. Essentially, the chapter seeks to examine firstly, the position of the Nigerian constitution on the right to water and sanitation within the broader perspective of ESC rights. Secondly, the compatibility of Nigeria's legal and policy instruments concerning water and sanitation with international legal obligations and the identification of problems associated with the legal and policy instruments. Thirdly, through empirical indicators from the field study conducted in this research the extent to which Nigeria, according to the respondents,

\footnotetext{
${ }^{799}$ As at March 2018 Nigeria had submitted a report to the Committee on the Rights of the Child four times: 1995 (CRC/C/8/Add.26), 2004 (CRC/C/70/Add.24) and 2008 (CRC/C/NGA/3-4). Eight reports were submitted to the Committee on the Elimination of all forms of Discrimination against Women (only five available on OHCHR's website): 1987 (CEDAW/C/5/Add.49), 1997 (CEDAW/C/NGA/2-3), 2003 (CEDAW/C/NGA/4-5), 2006 (CEDAW/C/NGA/6), and (CEDAW/C/NGA/7-8). One report was submitted to Human Rights Council, 1996 (CCPR/C/92/Add.1) and one to the Committee on ESCR, 1996 (E/1990/5/Add.31).

${ }^{800}$ Jana von Stein, 'Compliance With International Law' (2017) Oxford Research Encyclopedia of International Studies P. 3. See also O. Young, Compliance and Public Authority (Johns Hopkins Press 1979)

801 Lee's Compliance Portal, 'The Importance of Legal Compliance' <http://www.compliancetools.co.za/ComplianceInABox/ImportanceOfLegalCompliance.aspx> accessed 13 March 2018
} 


\section{Chapter Four}

has complied with the contents of the right to water and sanitation, and fourthly from legal, policy and empirical perspectives, the identification of obstacles to the realisation of the right in Nigeria. This chapter is a response to research question one.

\subsection{Constitutional Regulation of Water Resources and the Right to Water and Sanitation}

By section 20 of the Constitution, it is the fundamental but non-justiciable obligation of the Federal Government to safeguard among others, water, air, forest and wildlife. ${ }^{802}$ The National Assembly has the exclusive jurisdiction to legislate on water from sources affecting more than one States as may have been declared by the same National Assembly. ${ }^{803}$ The distribution of power by the Constitution among the Federal and State Assemblies left other issues on water to fall under concurrent legislative powers for which both the Federal and States can legislate. Although, the Constitution obliges the Government to protect water; this was not conceived from the perspective of human rights. Even if the interpretation can be extended to it, the Government is yet to adopt legislative measures towards that. Save the provisions above, water was not recognised as human right.

In human rights context, the obligation to protect involves adopting measures to ensure that third parties do not interfere with the enjoyment of the right in question. Indeed, there are laws prohibiting polluting water, environment etc., but such laws were not adopted from the context of protecting human rights although the incidental rights may be protected indirectly. On this basis, it may be opined that neither substantive nor procedural provision exists on protecting the rights to water under the Constitution. Rather, the Constitution unambiguously restricted the pursuance of procedural judicial guarantees which an individual may explore in relations to the right to water or obliging the government to make available sufficient water for personal and domestic uses. Procedural guarantees exist only in relation to CP rights. It needs to be mentioned that the ICCPR and ICESCR are yet to acquire the status of domestic laws in Nigeria notwithstanding their ratification several years ago. Combined with the operation of section 12 which restricted the application of international treaties except when domesticated, in relations to ESC rights including the right to water, the Judiciary has been rendered powerless in a fashion reminiscent of military administrative styles. Currently, no court in Nigeria has the power to declare water as an independent human right except to the extent such can be incorporated into other treaties like the ACHPR through expansive interpretation. The position of sanitation is not any way different. By the same section 20, the Government is mandated to protect and improve the environment. By merging the protection of environment, safeguarding water, air and land, the Constitution undoubtedly recognises the inextricable link between these elements.

In relations to international legal obligations and commitments, it appears the Constitution has not done much to realise the objectives of relevant instruments on the right to water and sanitation. Human rights instruments recognised the interdependence of human rights, but the Nigerian Constitution failed to ensure this. Although it holds certain promises,

\footnotetext{
${ }^{802}$ This is by the combined effect of SS. 20 and 6(6)(c) of the Constitution.

${ }^{803}$ Constitution of the Federal Republic of Nigeria Item 64, part 1 of the Second Schedule
} 
Realising the Right to Water and Sanitation in Nigeria

it falls short of a fully people-oriented document because the provisions for strengthening human security and welfare are weak and generally not enforceable.

\subsection{Legislative Measures on Water}

A myriad of legislations or provisions scattered in many legislations relevant to water exist in Nigeria. Some are relevant in the realisation of the right while some are obstacles. Some exist long before the right to water was conceived while some were adopted with the international obligations of Nigeria in mind. It must be stated at the outset, that these legislations were not specifically adopted with the right to water in mind. Rather, some of them have provisions relating to water right which concern different issue altogether. Their discussion here is only to the extent that they are necessarily relevant and for which attention must be given to enable realisation of the right.

The laws comprised those regulating the protection, management, administration of water resources, licensing and operations of water service providers, River Basins developments, inland waterways, navigable waterways, shipping, port administration, exploration of petroleum in territorial waters, generation of hydro-electrical power supply and criminal law provisions protecting water. Most of these laws, however, do not provide for or are not connected to the assessment of the human right to water or water for personal and domestic uses. It suffices to state that at best, some of the laws tilted toward providing for and/or regulating water rights. Water right has been distinguished and is not in any way connected to the recently recognised human right to water. ${ }^{804}$ Water right involves "the removal (and subsequent use) of water from the natural environment or its use in that environment." 805 It is a right "to abstract or divert and use a specified quantity of water from a natural source; to impound or store a specified quantity of water in a natural source behind a dam or other hydraulic structure; or to use water in a natural source." ${ }^{806}$ Water right has nothing to do with providing access to water of sufficient quantity, quality and accessibility for personal and domestic uses.

Notwithstanding the difference between water right and the right to water, some of the laws can contextually be utilised in making a case for the human right to water. In this regard, the analysis on water resources laws in this section is limited to those laws which are relevant to the assessment of Nigeria's response to its obligation on the human right to water. It does not therefore discuss issues relating to water ways, fishing rights, navigable ways, shipping, control of ports and harbours, generation of hydro-electrical energy, oil exploration on territorial waters, etc. Under this section, the following laws shall be examined: Water Resources Act, River Basin Development Authorities Act, Natural Resources Conservation Council Act, The Mines and Mineral Act, and The National Agency for Food and Drug Administration and Control Act, The Federal Environmental Protection Agency, some State Water Supply and Sanitation Agencies Law and some Local Government Water and Sanitation bylaws.

\footnotetext{
${ }^{804}$ S. Hodgson, Land and Water - The Right Interface (Food and Agricultural Organisation 2004) P. 13.

${ }^{805}$ Ibid. P. 14.

${ }^{806}$ Ibid.
} 
Chapter Four

\subsubsection{Water Resources Act}

Water Resources Act ${ }^{807}$ was passed as a decree in 1993. The objective of the Act is "to promote the optimum planning, development and use of Nigeria's water resources". 808 Section 1 vested the right to the use and control of all surface and groundwater and water courses affecting more than one State in the Federal Government through the Federal Ministry of Water Resources. The vesting of the rights was in order to: ${ }^{809}$ promote the optimum planning, development and use of water resources in Nigeria; ensure coordination of activities likely to influence water quality, quantity, distribution use and management; ensure "the application of appropriate standards and techniques for the investigation, use, control, protection, management and administration of water resources" and; to facilitate technical assistance as well as rehabilitation of water supplies.

The Act ensures among others, free access for individuals to watercourses which the public has free access, for domestic uses ${ }^{810}$ and watering of livestock. ${ }^{811}$ The watercourse includes natural or artificially constructed rivers, creeks, streams, spring, lake, lagoon, swamp, marsh or any other course for water in which water flows. ${ }^{812}$ Persons with statutory or customary right of occupancy to land are free to generate and use without charges, water from underground sources where the land is located for domestic uses, livestock watering and irrigation schemes. ${ }^{813}$ The generating of water from underground courses may for example be in the form of borehole and well constructions. In accordance with the Act and other regulations made pursuant to, any person or public authority ${ }^{814}$ may, for any purpose, acquire a right to use or take water from any watercourse or any groundwater described in the schedule to the Act. ${ }^{815}$ Taking and use of groundwater is however subject to the power and control of the Minister responsible for water resources. ${ }^{816}$

In administering the Act, the Minister is obliged "to have regards to the need to make proper provisions" for the adequate supplies of water for domestic and non-domestic use, watering of animals and irrigation, "the supply of water for the drainage, the safe disposal of sewage, effluent and water-borne wastes and the control and prevention of pollution" among

\footnotetext{
${ }^{807}$ No. 101 of 1993 and now Cap W2, Laws of the Federation of Nigeria, 2004

${ }^{808}$ Long title of the Act.

${ }^{809}$ Water Resources Act, S. 1(1)(a-d)

${ }^{810}$ Domestic use was defined under section 20 to mean the use for drinking, washing, bathing, cooking, gardening or for any other domestic purpose in any residential premises utilised for non-profit motives

${ }^{811}$ Water Resources Act, S. 2(1)

812 Ibid. S. 20.

${ }^{813}$ Ibid. S. 2(3).

${ }^{814}$ Public authority was defined by section 20 to include "Minister or any member of the civil service of the Federation, State or Local Government or of any Commission, Authority or Statutory Corporation established by the Government of the Federation, State or Local Government".

${ }^{815}$ Water Resources Act, S. 3.

${ }^{816}$ Under S. 4, the control of groundwater has been vested in the Minister responsible for water resources. The Minister has wide powers in this regard and they include the power to define the places, the manner in which and the time at which such water may be taken or used; the amount which may be taken in times of actual or anticipated shortage; prohibition of taking of water when it will be hazardous to health; revocation of the right to use or take water when it overrides public interest and; the times which water may be taken from boreholes or wells (generally section 4(a-g) of Water Resources Act.
} 
Realising the Right to Water and Sanitation in Nigeria

others. ${ }^{817}$ The Minister has a duty to periodically develop a master plan "for the development, use, control, protection, management and administration of all water resources" and to undertake a periodic review guided by "prevailing economic, financial or technological conditions, activities, plans and proposals of public authorities exercising powers relating to water resources." 818 The Act puts some control mechanisms in the generation and use of water. The Minister's regulatory role extends to prohibiting or regulating the carrying out of any activities whether on land or water which are likely to interfere with the quantity or quality of any water in any watercourse or groundwater. ${ }^{819}$ A license shall be obtained from the Minister ${ }^{820}$ when water is to be diverted, stored, pumped or used on a commercial scale or the construction, maintenance, operation, repair of any borehole. ${ }^{821}$ Failure to obtain the requisite licence is an offence under the Act. ${ }^{822}$

In considering an application for a licence, the Minister shall be guided by a consideration of allocation of useable water in the watercourse or groundwater in the area and the anticipated shortage of water. Licence may be refused if the carrying out of any activity on water would in his consideration interfere with the quality and quantity of water in the watercourse or groundwater. ${ }^{823}$ Fees, rates, or charges may be imposed by an authority if authorised by the Minister in connection with the provision of services prescribed by the Act or regulations made thereunder. ${ }^{824}$

\subsubsection{River Basins Development Authorities ${ }^{825}$}

The Act repealed the River Basins Development Authorities Act 1979 and established 11 River Basins Development Authorities (RBDAs) in Nigeria. ${ }^{826}$ Main functions of RBDAs have been listed under section 4 of the Act. Of relevance is undertaking comprehensive development of surface and underground water resources for multipurpose use with emphasis on irrigation infrastructure and control of floods and erosion and for watershed management. ${ }^{827}$ The River Basins shall similarly supply water from their "completed storage schemes to all users for a fee". Save for reference to "multipurpose use" of water which may include development of surface and underground water for personal and domestic uses as well as ensuring the adequate need of the environment for human and ecosystem survival, and the supply of water to all users, the Act is not essentially designed as a human right

\footnotetext{
${ }^{817}$ Water Resources Act, S. 5.

${ }^{818}$ Ibid. S. 6.

${ }^{819}$ Ibid. S. 8. Other control mechanisms under the section include prohibiting "the storage, diversion, pumping or use of any water or the construction and maintenance, operation, repair or alteration of any borehole" requiring of information relating to water-samples or core-samples by any person who constructs, uses, alters, operates, maintains or repairs any bore-hole"

${ }^{820}$ Ibid. S. 10.

${ }^{821}$ Ibid. S. 9(1).

${ }^{822}$ S. 9(2) of Water Resources Act

${ }^{823}$ Ibid. S. 11(a)

${ }^{824}$ Ibid. S. 14.

${ }^{825}$ No. 35 of 1987 and now Cap R9 Laws of the Federation of Nigeria, 2004

${ }^{826}$ S. 1 of River Basins Development Authorities Act and its first schedule

${ }^{827}$ S. 4(1)(a) of River Basins Development Authorities Act
} 
instrument but may nonetheless be relevant in the human right to water discourse in the context of water availability and accessibility.

\subsubsection{National Agency for Food and Drug Administration and Control Act ${ }^{828}$}

The Act establishes the National Agency for Food and Drug Administration and Control as a body corporate for the regulation, control, importation, exportation, advertisement, distribution, sale and use of bottled water. ${ }^{829}$ The only reference to this Act in this research is its regulation of bottled water for human consumption. In this respect, the Agency is to conduct appropriate test and ensure compliance with designated and approved standard specifications for the effective control of bottled water; ${ }^{830}$ investigate production premises, inspect imported bottled water; ${ }^{831}$ compile standard specification and guidelines of bottled water and registration of bottled water. ${ }^{832}$

The Act establishes a Governing Council with the functions to among others, advise the Federal Government on national policies on the control and quality specification of bottled water; designate, establish and approve quality specifications on bottled water, establishing appropriate programmes for the quality, safety and rational use of bottled water etc. ${ }^{833} \mathrm{An}$ officer of the Agency is empowered to enter into any premises which he reasonably believes any article which the Act regulates is manufactured; ${ }^{834}$ to also open and examine such article. Obstructing an officer in exercising this power shall be an offence under the Act. ${ }^{835}$ This law is relevant in the context of obligation to ensure water quality.

\subsubsection{Drugs and Related Products (Registration, Etc.) Act (As Amended) ${ }^{836}$}

This Act regulates "the manufacture, importation, exportation, advertisement, sale or distribution of processed food, drugs and related products" and their registration. ${ }^{837}$ The Act makes it mandatory for all processed food including water to be registered before importing, exporting, advertisement, selling or distribution in Nigeria. ${ }^{838}$ Pursuant to this Act, the Governing Council of the National Agency for Food and Drug, Administration and Control adopted Regulations titled Pre-Packaged Food (Labelling) Regulations 2005. The Regulation prohibits the selling of pre-package food without labelling. Food was defined by section 24 of the Regulations to include drinking water. The labelling shall bear the name of the food and its accurate nature. ${ }^{839}$ Relevance of this law hence, is centred on water quality.

\footnotetext{
${ }^{828}$ This law was passed as a Decree No. 15 of 1993 and now Cap N1 Laws of the Federation of Nigeria, 2004

${ }^{829}$ Long title of the Act

${ }^{830}$ Ibid. S. 5(b).

${ }^{831}$ Ibid. S. 5(c).

${ }^{832}$ Ibid. S. 5(d).

${ }^{833}$ See generally ibid. S. 6.

${ }^{834}$ Ibid. S. 24(1).

${ }^{835}$ Ibid. S. 26.

${ }^{836}$ Decree No. 19 of 1993 now Cap. F33 Laws of the Federation of Nigeria 2004

${ }^{837}$ Long title of the Act

${ }^{838}$ Food, Drugs and Related Products (Registration, Etc.) Act, S. 1(1).

${ }^{839}$ S. 3 of Pre-Packaged Food (Labelling) Regulations 2005
} 
Realising the Right to Water and Sanitation in Nigeria

\subsubsection{Criminal Code Act, ${ }^{840}$ Penal Code Act ${ }^{841}$ and Shariah Penal Code Law}

These laws are relevant in the context of access to water (availability) and protection of water sources from pollution. Criminal Code Act applies in Southern Nigeria while Penal Code Act applies in the North and Shariah Penal Code Law (of States) applies to those States which have adopted Shariah Criminal Justice System. It is an offence under both laws to "corrupts or fouls the water of any spring, stream, well, tank, reservoir, or place, so as to render it less fit for the purpose for which it is ordinarily used". ${ }^{842}$

It is equally an offence for a person employed in the supply of water to maliciously break his contract of service while he knows or have reason to believe that such action either alone or in combination with others, "will be to deprive the community or any part thereof either wholly or to a great extent of the supply of ... water ${ }^{843}$ Committing mischief by a person through the doing of an act which renders or knows likely to render "any installation for the supply or distribution of water, less efficient for its intended purpose" is an offence. ${ }^{844}$ These laws are relevant in the context of obligation to protect.

\subsubsection{Customary Law (Practices) on Water}

In traditional setting, water is mainly used for domestic ${ }^{845}$ and personal purposes which include drinking, washing, bathing, cooking etc. It must be stated that in countries where no legislations on access or usage of water exist, customary law and practices play a very important role. Validity of these customary laws and practices however depend on variety of factors. In Nigeria, they are dependant among others, on their conformity with written legislations. In the absence of incompatibility with a written law and the custom is not repugnant to natural justice, equity and good conscience, customary law plays a controlling role on access and utilisation of water. Similarly, because of the importance of customs in the lives of the people it regulates, new legislations which fail to consider the prevailing cultural practices could lead to tension ${ }^{846}$ and sometimes conflicts.

Among the Nigerian communities, there exist customary practices and methods on the utilisation of environment including natural resources such as water. These practices and methods continue to exist except to the extent to which they have been replaced or modified by legislations. ${ }^{847}$ Notwithstanding the diversity of customs, research has shown that customary practices on water resources in Nigeria are to some extent uniform with the general principle that individuals have the right to use water which passes through their

\footnotetext{
${ }^{840}$ The was a colonial legacy originally adopted in 1916 and now Cap C38 Laws of the Federation of Nigeria 2004

${ }^{841}$ Cap. P3 Laws of the Federation of Nigeria, 2004

${ }^{842}$ Criminal Code Act, S. 245; see also Zamfara State Shariah Penal Code Law. S. 360

${ }^{843}$ Criminal Code Act, S. 305A(1)

${ }^{844}$ Zamfara State Sharia Penal Code Law, S. 382

${ }^{845}$ Paul Kuruk, 'Customary Water Laws and Practices: Nigeria'. P. 2.

${ }^{846}$ Stefano Burchi, 'The Interface Between Customary and Statutory Water Rights - A Statutory Perspective' (International workshop on 'African Water Laws: Plural Legislative Frameworks for Rural Water Management in Africa)" P. 1.

${ }^{847}$ Muhammed Tawfiq Ladan, 'Review of the Regulatory and Policy Frameworks of the Nigerian Water Sector and International Legal Response for Sustainable Management and Protection of Water Resources'. P. 12.
} 


\section{Chapter Four}

community, ${ }^{848}$ most importantly from large water bodies such as streams and rivers. ${ }^{849} \mathrm{~A}$ cursory glance at the practices from several customs in Nigeria revealed that:

1. Access to water from nearby streams or rivers or any large bodies of water, for personal and domestic uses was generally considered a communal right for which no individual can exercise private right over; ${ }^{850}$

2. Water from smaller sources such as well and spring, more particularly in arid areas, an outsider (usually a non-family member) would require permission for access from those who own them (usually family groups) and permission is usually granted; 851

3. For security and religious practices, community leaders determine the necessary restrictions to be imposed on access to water during certain periods e.g. festivals, wars, night etc. Failure to observe this restriction may lead to sanctions by the community; ${ }^{852}$

4. Community leaders determine the divisions of rivers or streams for consumption and for other purposes such as cleaning; ${ }^{853}$

5. Community leaders may impose the requirement of permit or the payment of fees by foreigners for water uses; ${ }^{854}$

6. If certain water sources are used for purposes other than drinking such as bathing or excreting, division is usually made between male section and female section with barriers erected to run over the rivers, ${ }^{855}$

7. Certain practices on water generation by some communities exist, for example among the Iroko community which prohibits entering some streams with shoes or dipping the calabash into the water while fetching, prohibition of stooling or urinating into were meant to preserve the water from pollution; ${ }^{856}$

8. Communities' observance and compliance of the norms are "secured through a system of sanctions that may vary according to the degree of kinship ranging from censure, to fines, to ostracism or even expulsion from the group." ${ }^{857}$ In certain instances penalties will be imposed by the leader or the population may as a punishment stigmatise the violator. ${ }^{858}$ It should be noted that from the practices

\footnotetext{
${ }^{848}$ T.O. Elias, Nigerian Land Law (Sweet \& Maxwell 1971). P. 46.

${ }^{849}$ Paul Kuruk, 'Customary Water Laws and Practices: Nigeria'. P. 4.

${ }^{850}$ This is the customs among the Egbas community (Muhammed Tawfiq Ladan, 'Review of the Regulatory and Policy Frameworks of the Nigerian Water Sector and International Legal Response for Sustainable Management and Protection of Water Resources' P. 13..

${ }^{851}$ Paul Kuruk, 'Customary Water Laws and Practices: Nigeria'. P. 4.

${ }^{852}$ Muhammed Tawfiq Ladan, 'Review of the Regulatory and Policy Frameworks of the Nigerian Water Sector and International Legal Response for Sustainable Management and Protection of Water Resources'. P. 14.

${ }^{853}$ Ibid. P. 13.

${ }^{854}$ Ibid.

${ }^{855}$ Ibid

${ }^{856}$ P. C. Lloyd, Yoruba Land Law (Oxford University Press 1962) P. 126. (cited in Muhammed Tawfiq Ladan, 'Review of the Regulatory and Policy Frameworks of the Nigerian Water Sector and International Legal Response for Sustainable Management and Protection of Water Resources'. P. 14.

${ }^{857}$ Paul Kuruk, 'Customary Water Laws and Practices: Nigeria'. P. 2.

${ }^{858}$ Muhammed Tawfiq Ladan, 'Review of the Regulatory and Policy Frameworks of the Nigerian Water Sector and International Legal Response for Sustainable Management and Protection of Water Resources'. P. 13.
} 
Realising the Right to Water and Sanitation in Nigeria

itemised above, some customary practices were designed to ensure water availability and quality while some could lead to water pollution or contamination.

\subsubsection{National Environmental (Surface and Groundwater Quality Control) Regulations, S. I. No. 22 of 2011}

This Regulations were adopted pursuant to section 34 of the National Environmental Standard and Regulation Enforcement Agency (Establishment) Act. The purpose is the restoration, enhancement and preservation of the physical, chemical and biological integrity of Nigeria's surface and groundwater sources, to maintain existing water uses and regulate the injection of hazardous wastes among others. ${ }^{859}$ The Regulations provide for the protection of surface water from pollutants in order for such water to be used, developed, conserved, managed and controlled through the recognition of the right of citizens to access clean water and sanitation, ensure environmental sustainability of the resources, the protection of aquatic ecosystem, reduction and prevention of pollution and degradation of surface water. ${ }^{860}$ The Regulations apply to all surface water sources in Nigeria. ${ }^{861}$ It equally imposed obligation to maintain surface water in safe and satisfactory condition for among others, the following uses: agricultural, industrial and public water supply; wildlife, fish and other aquatic life, recreation and navigation. ${ }^{862}$ General provisions were made for the protection of surface water from pollution, water quality standards and discharge which would be harmful to public water supply.

The Regulations allow abstraction of groundwater through drilling boreholes for personal domestic purposes and licence is required for any other. ${ }^{863}$ For other purposes permit is required which application must state among others, location and coordinates of the borehole, quantity of water to be taken per day, the purpose of the water, and the sources of supply. ${ }^{864}$ All owners of boreholes and wells are however required to register with relevant authorities. ${ }^{865}$ Relevance of this regulation is in the context of water availability and quality.

\subsection{Legislative Measures on Sanitation and Environment}

Several legislative measures exist on environment and sanitation in Nigeria. These measures range from those designed to counter the effects of drought, industrial waste, effluent emission, pollution to those intended to address the release of harmful toxic waste. Relevant to environmental sanitation however, includes:

\footnotetext{
${ }^{859}$ National Environmental (Surface and Groundwater Quality Control) Regulations, S. I. No. 22 of 2011, Sections 1 and 19.

${ }^{860}$ Ibid.

${ }^{861}$ Ibid. S. 2.

${ }^{862}$ Ibid. S. 3.

${ }^{863}$ Ibid. S. 24(1).

${ }^{864}$ Ibid. S. 24(3).

${ }^{865}$ Ibid. S. 24(2).
} 


\section{Chapter Four \\ 4.4.1 National Environmental Standards and Regulations Enforcement Agency (Establishment) Act, 2007}

The National Environmental Standards and Regulations Enforcement Agency (NESREA) was established by this Act. NESREA was charged with the responsibility of protecting and developing the environment in Nigeria, and the enforcement of all environmental laws, regulations, standards, policies, guidelines and international conventions on the environment which Nigeria is a signatory. ${ }^{866}$ It has the power to submit for the Minister's approval "proposals for the evolution and review of existing guidelines, regulations and standards on environment other than in the oil and gas sector" which includes on air quality, water quality, effluent limitations, waste management and environmental sanitation, flood control, other forms of pollution and sanitation, and control of hazardous substances and removal control methods. ${ }^{867}$

In order to protect public health or welfare and enhancing the quality of water, NESREA in collaboration with other relevant agencies may make necessary regulations. ${ }^{868}$ Violation of these regulations, by individuals is punishable with a fine which may not exceed N50, 000 or imprisonment which may not exceed one year or both. There is additional fine of N5, 000 everyday if the offence subsists. ${ }^{869} \mathrm{With}$ respect to corporate bodies, the fine may not exceed $\mathrm{N} 50,000$ with additional fine of N10, 000 every day if the offence subsists. ${ }^{870}$ NESREA may also make similar regulations on environmental sanitation violations of which would be punished in accordance with the penalties set under such regulations. ${ }^{871}$ Discharging of harmful quantities of any hazardous substance into the air, on the land and waters except where permitted will give rise to a fine, in the case of individual not exceeding N1, 000,000 or to imprisonment for a term not exceeding 5 years while in the case of corporate body every person who at the time the offence was committed was in charge of the body corporate and was aware is to be punished for such offence accordingly. ${ }^{872}$

\subsubsection{Harmful Waste (Special Criminal Provisions, etc.) Act $^{873}$}

This Act prohibits the carrying, depositing and dumping of harmful waste on any land and territorial waters of Nigeria. It provides life sentence to any person who violates the prohibition and the forfeiture of land or anything used in the commissioning of the offence. ${ }^{874}$ Similarly, if the offence is committed by a corporate body, any officer who connive, consent to or is otherwise negligent would be punished. ${ }^{875}$ Additionally, such person would be liable to anyone who suffered injury as a result of the offending act. ${ }^{876}$

\footnotetext{
${ }^{866}$ National Environmental Standards and Regulations Enforcement Agency (Establishment) Act, 2007. S. 7.

${ }^{867}$ Ibid. S. 8(k).

${ }^{868}$ Ibid. S. 23(1).

${ }^{869}$ Ibid. S. 23(3).

${ }^{870}$ Ibid. S. 23(4).

${ }^{871}$ Ibid. S. 25.

${ }^{872}$ Ibid. S. 27(1-4).

${ }^{873}$ Cap H1 Laws of the Federation of Nigeria, 2004

${ }^{874}$ Ibid. S. 6.

${ }^{875}$ Ibid. S. 7

${ }^{876}$ Ibid. S. 12.
} 
Realising the Right to Water and Sanitation in Nigeria

\subsubsection{Nigerian Urban and Regional Planning Act ${ }^{877}$}

The purpose of this Act is to prevent overcrowding and poor environmental conditions and to oversee a realistic and purposeful planning of Nigeria. Some of its relevant provisions include the rejection of an application for land development if such development would harm the environment or would otherwise constitute a nuisance to the community. ${ }^{878}$ Where an ongoing construction has been ordered to stop, failure to comply with the order in the case of an individual will give rise to a fine not exceeding N10, 000 and not exceeding N50, 000 in the case of a corporate body. ${ }^{879}$ In order to ensure environmental conservation, the Act provided for the preservation and planting of trees. ${ }^{880}$

\subsubsection{National Environmental (Sanitation and Wastes Control) Regulations, S. I. No. 28 of 2009}

This Regulation seeks to provide the necessary legal framework for the adoption of sustainable and friendly environmental practices in environmental sanitation and waste management in order to minimize pollution. The Regulations apply to environmental sanitation connected issues such as food, market and industrial sanitation and to all categories of waste they generate. Furthermore, it outlines duties of owners and occupants of properties and premises, citizens' obligations, extended producer's responsibility, and the polluter pays principle.

\subsection{Policy Measures on Water and Sanitation}

Definition of legislation is sufficiently clear and connotes a binding code/law made or passed by the appropriate and legally empowered organ within a domestic arrangement. Definition of a policy on the hand, is not clear. Indeed, for several reasons, it is difficult to define a policy hence there is yet to be a consensus on the issue. ${ }^{881}$ Determining whether and to what extent a document or pronouncement may be regarded as a policy depend on a variety of factors and the perspective of the assessment. Multiple ways of assessing a policy exists including whether it is a substantive and administrative, vertical and horizontal, reactive and proactive, or current and future policy. ${ }^{882}$ Companies and certain individuals have policies about their relationship with outside bodies, scope and focus of business, social and corporate responsibility etc. Discussion on policies here centred on what we may refer to as "Public Policy". Public policies have decisive and sometimes pervasive effect on citizens' lives or members of a community. Public policies, in variety of ways, determine for example, the quality of air we breathe, the water we drink, the food we eat, the safety of our means of

\footnotetext{
${ }^{877}$ Cap N138, Laws of the Federation of Nigeria, 2004

${ }^{878}$ Ibid. S. 39(7).

${ }^{879}$ Ibid. S. 59.

${ }^{880}$ Ibid. S. 72.

${ }^{881}$ Thomas A. Birkland, An Introduction to the Policy Process: Theories, Concepts, and Models of Public Policy Making (3rd edn, M.E Sharpe 2010)

${ }^{882}$ Sherri Torjman, 'What is Policy?' (The Caledon Institute of Social Policy, 2005) <http://www.caledoninst.org/publications/pdf/544eng.pdf> accessed 23 April 2014. P. 1.
} 


\section{Chapter Four}

transportation etc. ${ }^{883}$ Public policies can be regulatory or distributive, material or symbolic, substantive or procedural. ${ }^{884}$

As a demonstration of lack of consensus on the definition of public policy, the following definitions from Birkland may be observed: ${ }^{885}$ According to Clarke E. Cochran, et al.: "The term public policy always refers to the actions of government and the intentions that determine those actions". The same author also posited that "Public policy is the outcome of the struggle in government over who gets what". For Thomas Dye: Public policy is "Whatever governments choose to do or not do" while according to Charles L. Cochran and Eloise F. Malone: "Public policy consists of political decisions for implementing programs to achieve societal goals". According to Guy Peters "public policy is the sum of government activities, whether acting directly or through agents, as it has an influence on the life of citizens". A Policy is a "course of action intended to be followed by government with a view to achieving certain objectives." 886 Birkland was however able to indicate the essential elements common to the definitions and these serve the basis of our understanding of policies in the context of this research. The common elements are: The policy is made in the name of the "public", it is generally made or initiated by government, it is interpreted and implemented by public and private actors, it is what the government intends to do and what the government chooses not to do.

Myriad of reasons may prompt the adoption of policies by governments. Most common include the promotion of socio-economic objectives, human welfare, environmental sustainability, equitable distribution of government resources etc. As opposed to legislative measures which impose binding obligations on mentioned institutions and individuals, a policy is merely a declaration of intent on the course of actions a government proclaim itself to follow. Notwithstanding its non-binding character however, policies have potentials and are catalyst of institutional and societal transformation.

In Nigeria, there is no paucity of policy measures on water, environmental sanitation, environmental protection and public health. In addition to legislative and regulatory measures, there exist several policies adopted by governments designed to promote access to water, environmental sanitation and the wider environmental protection. In this section, analysis is limited to those policies which bear direct relevance to water and sanitation.

It also needs to be noted that although responsibility for water and sanitation has been shared between the three tiers of government, it is the responsibility of the Federal Government to develop relevant policies. ${ }^{887}$ Prior to year 2000 , there is no national policy on

\footnotetext{
${ }^{883}$ Ibid.

${ }^{884}$ A general discussion on these issues can be seen in Dipak K. Gupta, Analyzing Public Policy: Concepts, Tools and Techniques (2nd edn, CQ Press 2011)

${ }_{885}$ Thomas A. Birkland, An Introduction to the Policy Process: Theories, Concepts, and Models of Public Policy Making. P. 8 following

886 G. C. Nwaobi, 'Oil Policy in Nigeria: A Critical Assessment (1958-1992)' <http://128.118.178.162/eps/pe/papers/0501/0501001.pdf> accessed 29 April 2014

${ }^{887}$ Olusegun Adeoti, 'Challenges to Managing Water Resources along the Hydrological Boundaries in Nigeria' (January, 2007) 9 Water Policy . Pp. 105-118.
} 
Realising the Right to Water and Sanitation in Nigeria

water and sanitation with clearly defined objectives, guidelines and targets in Nigeria. ${ }^{888} \mathrm{~A}$ review of relevant policies and issues covered is undertaken below.

\subsubsection{National Water Supply and Sanitation Policy, 2000}

The main objective of the Policy is to ensure the provision of sufficient portable water and adequate sanitation to all Nigerians through participatory investment by the Federal, States, Local Governments, the private sector and the beneficiaries in a sustainable and affordable manner. ${ }^{889}$ It sought to achieve $100 \%$ water supply and wastewater services coverage of the population by the year $2011 .{ }^{890}$

The Policy divided water supply to the population into rural water supply, semi-urban (small towns) water supply and urban water supply with consumption standards set for each. ${ }^{891}$ In the case of rural water supply which consist of 150 to 5000 people, the Policy guaranteed minimum level of service 30 litres per capita per day within 250 meters of the community and serving about 250-500 persons per water point. For semi-urban or small towns consisting of settlements with population between 5000 and 20,000 and a fair measure of social infrastructure and economic activity, minimum supply standard was put at 60 litres per capita per day "with reticulation and limited or full house connections as determined by the beneficiaries / Government." Lastly, urban water supply consisting of cities with population greater than 20,000, and who are to be "served by full reticulation and consumer premises connection" the minimum supply shall be 120 litres per capita per day.

Some of the components of the policy objective include:

i. Increase service coverage for water supply and sanitation nationwide to meet the level of socio-economic demand of the nation in the sector.

ii. Ensure good water quality standards are maintained by water supply undertakings.

iii. Ensure affordability of water supply and sanitation services for the citizens.

iv. Guarantee affordable access for the poor to basic human need level of water supply and sanitation services.

v. Enhance national capacity in the operation and management of water supply and sanitation undertaking.

vi. Privatise water supply and wastewater services (where feasible) with adequate protection for the poor.

Some of the strategies to be adopted in order to achieve the policy objectives included increasing service coverage for both water supply and sanitation nationwide in order to meet the level of the nation's socio- economic demand; ensuring the maintenance of good water quality standards; ensuring affordability of water supply and sanitation services; guaranteeing of affordable access for the poor; enhancing national capacity; privatising water supply and wastewater services (where feasible) with adequate protection for the poor; and

\footnotetext{
${ }^{888}$ See Department of Water Supply and Quality Control, National Rural Water Supply and Sanitation Programme: A Strategic Framework. P. 7.

${ }^{889}$ See Federal Republic of Nigeria, National Water Supply and Sanitation Policy. Para. 17.

${ }^{890}$ See ibid. Para. 17(iii)-(iv).

${ }^{891}$ See ibid. Para. 18.
} 


\section{Chapter Four}

reforming water supply and sanitation sector to attain and maintain internationally acceptable standards. ${ }^{892}$

The Policy recognises water as an economic good which provision shall also be ensured in equitable manner between the rich and the poor. Similarly, the strategy of the Policy is that delivery of water supply and sanitation can be most efficient and effective if service providers operate as businesses and therefore, water and sanitation "utilities, whether public or private, should be autonomous and free from political interference." 893 The importance and role of private sector participation including communities and NGOs was acknowledged in order to enhance financing, transparency, efficiency, accountability and self-sufficiency. In order to achieve the objectives of the Policy, funding was apportioned to the three tiers of government ${ }^{894}$ and a provision was made for peri-urban areas. ${ }^{895}$ The Federal and States Government are to provide basic water supply facilities (water sources and storage) while the distribution network is to be provided by the benefiting communities in association with NGOs and external support agencies. ${ }^{896}$ In brief, the Policy addresses issues relating to water availability (sufficiency), quality, accessibility and affordability.

\subsubsection{National Water Policy, 2004}

The central objective of this Policy is the proper management and conservation of water in Nigeria as a result of lack of adequate attention to these issues in the previous development and management plans as well as issues associated with lack of adequate consultation with stakeholders and underutilisation of resources. ${ }^{897}$ Other objectives included the eradication of poverty and improving public health through optimal use of water resources for development in addition to prevention of periodic water crisis occurrence. ${ }^{898}$ The Policy recognises the central role of water in sustaining life and civilisation and its interconnectedness with life, health, food and peace. ${ }^{899}$ Some of the principles of the Policy include participation of water users in the planning and management of water resources, ensuring equitable access of water to all users, the interconnectedness of water quality and quantity, protection of the environment, water quality management through economic incentives and penalties to reduce pollution, the protection of aquatic and associated ecosystems. The Policy is therefore relevant in the context of water availability, quality, and information accessibility.

\subsubsection{National Water Resources Roadmap 2016-2030}

The main objective of this Roadmap is the attainment of $100 \%$ coverage in the provision of water and sanitation in Nigeria, by 2030 (the SDG target). ${ }^{900}$ Some of the issues covered

\footnotetext{
${ }^{892}$ See ibid. Para. 20.

${ }^{893}$ See ibid. Para. 20(I)(ii)(c).

${ }^{894}$ See ibid. S. 1.11.7.

895 These are unplanned urban slums where marginalized urban poor live.

${ }^{896}$ Federal Republic of Nigeria, National Water Supply and Sanitation Policy. Para. 39

${ }^{897}$ Federal Republic of Nigeria, 'National Water Policy'. Para. 5.3.2.

${ }^{898}$ Ibid.

${ }^{899}$ Ibid. Para. 1.0.

${ }^{900}$ Federal Ministry of Water Resources, Immediate and Longterm Strategies for the Water Sector 2016-2030. P. 9. 
Realising the Right to Water and Sanitation in Nigeria

by the Roadmap include repositioning of the FMWR for efficient service delivery; identifying alternative sources of funding projects; strengthening of river basin operations; and enhancing monitoring and evaluations. ${ }^{901}$ Relevant to this research, is the goal of developing and implementing a National Water Supply and Sanitation Programme in order to attain the SDG target. ${ }^{902}$ The document has prioritised certain projects and the funding requirements towards the attainment of this goal. The document also contains provisions for partnership for expanded water, sanitation and hygiene (PEWASH) for the period. ${ }^{903}$ This focusses on a national multi-sector collaboration which is aimed at improving water supply with special attention to rural and small towns as well as sanitation in public places with special emphasis on eradicating open defecation. A collaborative intervention model has been developed between major stakeholders (Federal, States, Local Governments, Communities, Donor Agencies/Development Partners, and private sector in Nigeria. In this arrangement, the partnership cost sharing formula on both water and sanitation has been apportioned which is shown in Table 4.1.

The Roadmap envisage the following programme implementation: ${ }^{904}$

Water Supply: Annual Installation of an average of 2,623 water supply systems

- 2016 - 2020: Average target of 13,110 water supply systems

- 2021 - 2025: Average target of 13,110 water supply systems

- 2026 - 2030: Average target of 13,110 water supply systems

Sanitation: Annual Installation of an average of 2,020 public toilets

- 2016-2020: Average target of 10,100 toilets

- $2021-2025$ : Average target of 10,100 toilets

- 2026 - 2030: Average target of 10,100 toilets

The Roadmap is therefore relevant in the context of water and sanitation availability.

\subsubsection{National Water Sanitation Policy 2004}

This Policy was a response to growing health threats which Nigeria was facing from inadequate sanitary facilities ${ }^{905}$ and in order to address the gaps left by the National Water Supply and Sanitation Policy 2000 in the areas of "health and hygiene education, relevant operational research, efficient and affordable sanitation systems, roles of government and all other stakeholders including funding arrangement and relevant legislation."906

The Policy detailed the impact of poor sanitation on many health-related issues in Nigeria including the mortality rate which had been approximated to be between $5-20 \%$ as at 2004 . This Policy recognises the nexus between sanitation, effective hygiene practices and portable water in the promotion of good health and quality of life. ${ }^{907}$ As at 2002, it was estimated that every year, about 150,000 to 200,000 diarrhoea related deaths occur among children below the age of five years and between 1999 and 2002, 41.58\% increase was recorded in the case

\footnotetext{
${ }^{901}$ Ibid. P. 16.

902 Ibid. P. 17.

${ }^{903}$ Ibid. P. 28

${ }^{904}$ Ibid. P. 29

${ }^{905}$ Federal Republic of Nigeria, National Water Sanitation Policy. Para.1.5.

${ }^{906}$ Ibid. Para.1.6.

907 Muhammed Tawfiq Ladan, Law, Cases and Policies on Energy, Mineral Resources, Climate Change, Environment, Water, Maritime and Human Rights in Nigeria. P. 838.
} 
of cholera while typhoid and paratyphoid incidence rate increased from $22.28 \%$ in 1994 to $77.48 \%$ in $2002 . .^{908}$

The main objective of the Policy is for all Nigerians to have access to adequate, ${ }^{909}$ affordable $^{910}$ and sustainable ${ }^{911}$ sanitation, by the active participation of all tiers of government, Development Partners, NGOs, Communities, households ${ }^{912}$ and individuals. ${ }^{913}$ The target of the Policy is to achieve $80 \%$ water sanitation coverage by $2015,90 \%$ by 2020 and $100 \%$ by 2025 . To achieve these, the tiers of government were required to "appropriate and release a separate vote for water sanitation an amount equivalent to $15 \%$ of their annual appropriation for water supply to implement sanitation programmes." 914

Following the tradition of the 2000 Policy, the 2004 Policy maintained the classification of service level: rural, semi-urban and urban. ${ }^{915}$ In the rural service level, each household "must own and have access to safe sanitary facility with at least minor improvements that would reduce flies, odour, etc." (at least upgraded pit latrine).” In the semi-urban, households "must own and have access to safe sanitary facility that is easily adaptable to existing traditional pit latrine and uses superstructures which blends very well with other buildings within the community (at least sanplat latrine) and households in the urban areas "must own and have access to safe sanitary facility that uses suitable and affordable water conveyance systems (at least pour-flush toilet)."

The Policy recognises that sanitation development is multi-sectoral which essentially requires an integrated approach. As such it is aimed at promoting safe sanitation, hygiene education and promotion and safe water supply. In the same vein, the Policy considers stakeholders involvement from pre-planning stage, through implementation to monitoring and evaluation stages as essential. ${ }^{916}$ Other areas the Policy considered crucial include consideration of gender as it affect women, the poor and most deprived segment of the society, private sector and NGOs participation, and social acceptance by the communities. ${ }^{917}$ The strategies of the Policy included advocacy, ${ }^{918}$ mobilisation (of schools, promotion of health education, adoption of gender sensitive approach, representation of the voice of the

\footnotetext{
908 Ibid. P. 838.

${ }^{909}$ Adequate sanitation means "access to safe excreta disposal facilities, services to households, public facilities, and disposal of liquid and solid waste without contamination of water sources, health hazards to people or deterioration of the environment." Furthermore, "adequate sanitation facility must meet social, cultural, technology, user satisfaction and environment friendly criteria." (see Federal Republic of Nigeria, National Water Sanitation Policy. Para.1.3.

${ }^{910}$ Affordable means "The ability of households to own, operate and maintain sanitation facilities, without a major disruption in their expenditure pattern." (see ibid.Para.1.3)

${ }^{911}$ Sustainable means "The ability of a sanitation delivery facility or system to continuously ensure user satisfaction at all times without jeopardizing the ability of future use." (see ibid. Para.1.3)

${ }^{912}$ The Policy considered "The average household size in Nigeria is 5 persons. The household size is slightly higher in rural areas than in urban areas. It is also higher in the North than South. For the purpose of this policy a family unit shall be 8 persons living in the same compound."

${ }^{913}$ Federal Republic of Nigeria, National Water Sanitation Policy. Para.2.1.

${ }^{914}$ Ibid. Para.2.2.

${ }^{915}$ Ibid. Para.2.2.1.

${ }^{916}$ Ibid. Para.2.3.5

${ }^{917}$ See generally Paras. 2.3.6. to 2.3.15.

${ }^{918}$ Para.3.1
} 
Realising the Right to Water and Sanitation in Nigeria

poor and disadvantaged etc.), ${ }^{919}$ capacity building, ${ }^{920}$ and community ownership and management. ${ }^{921}$ The Policy is therefore relevant in the areas of sanitation availability, quality, accessibility, affordability, accessibility and sustainability. It is equally relevant in the context of human rights approach for its emphasis on participation.

\subsubsection{National Environmental Sanitation Policy, 2005}

This Policy was adopted in 2005. It was intended to serve as a veritable instrument for sustainable development in order to secure quality environment for good health and social well-being for the present and future generations ${ }^{922}$ The overall objective is for all Nigerians to have access to adequate and affordable sanitation through the active participation of all the tiers of government, private sector, development partners, NGOs, communities and individuals. Some of the objectives of this Policy are:

i. to coordinate the activities of all Stakeholders involved in Environmental Sanitation and streamline their roles;

ii. to strengthen the capacity of all institutions and Agencies involved in Environmental Sanitation programmes;

iii. to develop healthy human habitation and reduce the incidence of Environmental Sanitation related diseases;

iv. to achieve positive attitudinal changes in people towards sound Environmental Sanitation;

v. to encourage research and development, define local standards and establish database on Environmental Sanitation; and

vi. to identify local funding mechanisms for Environmental Sanitation in Nigeria.

This Policy covers a wide range of areas including solid waste; medical waste management; excreta and sewage management; food sanitation; sanitary inspection of premises; market and abattoir management; adequate potable water supply; school sanitation; pest and vector control; management of urban drainage; control of reared and stray animals; disposal of the dead (humans and animals); weed and vegetation control and hygiene education and promotion.

Some of the targets are: increasing sanitary management of sewage and excreta; increasing access to toilet facilities; instituting schools' sanitation programmes; extending of water supply and waste water services coverage; improving the knowledge, attitude, behaviour and practice of the general population to sound environmental sanitation and; empowering women and youths on income generating environmental sanitation activities. ${ }^{923}$ The Nigerian sanitation target is shown in Table 4.2:924

\footnotetext{
${ }^{919}$ Para.3.2

${ }^{920}$ Para.3.3

${ }^{921}$ Para.3.4

${ }_{922}$ Federal Republic of Nigeria, National Environmental Sanitation Policy, (Policy Declaration).

${ }^{923}$ Ibid. Para.4.4.

${ }^{924}$ WaterAid Nigeria, 'Water and Sanitation in Nigeria: Briefing on National Policy'. P. 10.
} 


\section{Chapter Four}

The overall aim of the Policy is to stimulate, promote and strengthen all government regulations concerned with water supply, sanitation and other related issues such as food security, health etc.

\subsubsection{National Policy on the Environment, 2017}

The goal of this Policy is to "ensure environmental protection and conservation of natural resources for sustainable development" 925 through the following strategic objectives: ${ }^{926}$

i. securing a quality of environment adequate for good health and well-being;

ii. promoting sustainable use of natural resources and the restoration and maintenance of the biological diversity of ecosystems;

iii. promoting an understanding of the essential linkages between the environment, social and economic development issues;

iv. encouraging individual and community participation in environmental improvement initiatives;

v. raising public awareness and engendering a national culture of environmental preservation; and

vi. building partnership among all stakeholders, including government at all levels, international institutions and governments, non-governmental agencies and communities on environmental matters.

The guiding principle central to the attainment of the objectives of the Policy are numerous and all encompassing. These principles are the public trust doctrine; environmental right; environmental offsetting; the polluter pays principle; the user pays principle; the precautionary principle; the subsidiarity principle; the polluter prevention pays principle; the principle of intergenerational equity; the principle of intra-generational equity; the principle of participation; the principle of international cooperation; good environmental governance; and integrated ecosystem approach. ${ }^{927}$

In the context of conservation of natural resources, the areas covered by the Policy which were accompanied by policy statements on the measures the government will take to implement the areas are: Air and Atmospheric Resources; Fresh Water and Wet-land Ecosystems; Coastal and Marine Ecosystem; Montane Ecosystems; Semi- Arid Ecosystems; Forest Ecosystems; Biodiversity and Wildlife Resources; Livestock and Fishery; Land Resources and Land Use; Soil; Oil and Gas; and Minerals. Concerning fresh water and wetland ecosystems, the Policy acknowledged that most of the major rivers in Nigeria have been dammed to supply water for irrigation, power generation, and domestic consumption. This has created, according to the Policy accelerated erosion in the coastal zones. In this context, the Policy specifically noted that:

freshwater availability has become one of the most critical factors in the country's
development. Accessibility to freshwater and its integrated management also remain major
concerns. Inappropriate management of freshwater and competition between user groups limit
efforts by the government to develop the nation's economy and improve the standard of living
of the citizens. There are also concerns over freshwater quality, in terms of pollution from
domestic effluents and industrial wastewater, particularly in the coastal zone of Lagos and the
oil producing Niger-Delta region. Access to good quality drinking water and sanitation has
consequently remained low.

\footnotetext{
${ }^{925}$ Federal Republic of Nigeria, National Policy on the Environment. Para. 31.

${ }^{926}$ Ibid. Para. 3.2.

${ }^{927}$ Ibid. Para. 3.3.

${ }^{928}$ Ibid. Para. 4.2.
} 
Realising the Right to Water and Sanitation in Nigeria

Some of the policy statement through which Government will address these issues include developing and implementing integrated wetland and water resources management strategies and action plans designed to ensure the attainment of Nigeria's water vision of sustainable access to clean and safe water for all; encouraging community participation in the designing, establishment, operation and maintenance of freshwater management programmes and infrastructure; provision of water in adequate quantity and quality to meet domestic, industrial, agricultural, recreational and other needs; and promoting the use of water efficient technology, water user organizations, pricing policies and productivity gains. ${ }^{929}$ To address the problems of oil pollution and its impacts on water and environment, the policy statement provided that the government will among others ensure that baseline studies are conducted before any operations begin; there will be strict environmental and social impact assessments before permits are issued; ensure that biodiversity conservation plans are integrated into the business plans; securing of fragile ecosystems; and will require regular audit throughout the lifespan of the particular fields. ${ }^{930}$

In the context of waste and environmental pollution the Policy covered the following areas accompanied by policy statements: Waste; Environmental Pollution; Industry and Environment; Transboundary Water Resources; Environmental Disasters; Conflicts and Environment; and Genetically Modified Organisms (GMO) \& Biosafety. On waste, the Policy noted that "the total amount of domestic waste per annum in Nigeria is about 63 million tonnes $(0.45 \mathrm{~kg} / \mathrm{capital} / \mathrm{annum}) .{ }^{931}$ " This volume is overwhelming the capacity of urban administrators to plan, execute and dispose the waste. ${ }^{932}$ To address these problems, the Policy stated that the Government will among others not only ensure the enforcement of relevant legislations in this context but will also "setup and enforce standards for sanitary facilities for the disposal of human and solid waste in dwellings, estates, public facilities in both rural and urban areas" and "determine the use of environmentally safe and technological sound techniques for the disposal of toxic, hazardous and radioactive wastes". ${ }^{933}$ On environmental pollution, the policy statement is that the government will develop and implement national strategies on air, water and noise pollution; and will strengthen the capacity and infrastructure in order to monitor environmental pollution..$^{934}$

On cross-sectoral issues, the Policy provided for the Population and Human Settlement; Energy; Infrastructure (Transport, ICT, Housing etc); Trade and Environment; Poverty; Gender; Production and Consumption Patterns; and Environmental Education and Awareness Creation.

It equally need to be stated that the 2017 Policy provided for a much better opportunity for all stakeholders to engage and work together in protecting the environment. This policy is relevant in this research in the context of ensuring adequate sanitation and protection of the ecosystems.

\footnotetext{
929 Ibid. Pp. 15-16.

${ }^{930}$ Ibid. Pp. 28-29.

931 Ibid.

932 Ibid.

${ }^{933}$ Ibid. Pp. 31-32.

${ }^{934}$ Ibid. P. 33.
} 


\subsubsection{Nigeria Standards for Drinking Water Quality 2007}

In line with its international obligations and specifically pursuant to WHO's Guideline for Drinking Water Quality, Nigeria developed these Standards to ensure safety of drinking water supplies. They were designed to speed-up the upgrading of non-protected water systems in the country and to improve drinking water quality. The Standards were a response to the poor reception by stakeholders of the Nigerian Industrial Standard for Potable Water and the National Guidelines and Standards for Water Quality in Nigeria. ${ }^{935}$ The Standard contains mandatory limits relating to constituents and contaminants of water which are of hazard to health. ${ }^{936}$

Material field of application of the Standards covers all drinking water in Nigeria except mineral and packaged water. ${ }^{937}$ Specifically, the standards are applicable to all drinking water supplies from State Water Agencies, community managed drinking water systems, water from vendors and tankers, used in public or privately-owned establishments, those used in food processing by manufacturers, and those from privately owned drinking water system and use solely for the family residence. ${ }^{938}$ All water sources (surface and groundwater) intended for human consumption must meet the Standards and before supply to the population, must receive authorisation from the Ministry of Health. ${ }^{939}$ The Standards provided requirements which are essentially in accordance with WHO Guideline relating to physical/organoleptic parameters, chemical parameters, disinfectants and their bye-products, radioactive constituents, and microbiological requirements. ${ }^{940}$

To ensure the Standards are complied with, a routine monitoring provision is prescribed to be conducted by inspectors in charge of drinking water quality surveillance. ${ }^{941}$ Another essential provision in the protection of the quality of drinking water, the Standards provided for what is called 'Protection Zone'. ${ }^{942}$ By this, water sources must be protected from potential sources of contamination. ${ }^{943}$ In the case of on-site drinking water system, "a minimum distance of 15 meters shall be kept between the water system and potential source of contamination"944 and "for mechanized centralized drinking water systems (high yield), broader protection zones shall be established and enforced by Ministry of Environment."945 The task of declaring special protection zones for chemical elements sensitive areas (such as nitrates and heavy metals) wetlands based on such local peculiarities shall be that of the FME in consultation with States. ${ }^{946}$

\footnotetext{
${ }^{935}$ Standards Organisation of Nigeria, Nigerian Standard for Drinking Water Quality Para.1.2.

${ }^{936}$ Ibid. Para.1.1.

${ }^{937}$ Mineral and packaged water shall comply with Nigerian Industrial Standards for Natural Mineral Water (NIS 345:2003) and Potable Water (NIS 306:2004) and used for regulation and certification by the National Agency for Food and Drug administration and Control and SON respectively (see ibid. para.1.6)

${ }^{938}$ Ibid. Para.1.6.

${ }^{939}$ Ibid. Para.5.1.1.

${ }^{940}$ Ibid. Para.5.1.1 - 5.1.6.

${ }^{941}$ Ibid. Para.5.2.

942 Ibid. Para.5.6.

${ }^{943}$ Ibid. Para.5.6.1.

${ }^{944}$ Ibid. Para.5.6.2.

${ }^{945}$ Ibid. Para.5.6.4.

${ }^{946}$ Ibid. Para.5.6.3.
} 
Realising the Right to Water and Sanitation in Nigeria

The Standards prescribed further that drinking water systems constructions shall comply with the specifications stipulated by the FMWR and materials and equipment in contact with drinking water shall comply with Nigerian Industrial Standards. ${ }^{947}$ State Water Agencies are to forward annual water quality reports to the Federal Surveillance Agency ${ }^{948}$ and all drinking water quality test and sanitary inspections results are to be processed and forwarded to the Federal Ministry of Health domiciled with the National Bureau of Statistic. ${ }^{949}$ General public shall be given access to these water quality reports. ${ }^{950}$

\subsubsection{Other Policies}

There are other policies which more or less embodied similar issues some of which are:

1. The Rural Water Supply and Sanitation Policy, 2000

The main focus of this Policy was the rural communities on water and sanitation issues. The Policy decentralizes more responsibilities to the rural communities. The objective is to assist these communities obtain water supply facilities. It is aimed at ensuring that assistance is directed only to communities which are prepared to maintain the facilities with private sector support. It was further designed among others, to increase the capacity of Federal, States and Local Governments in order to assist the local communities in obtaining water supply facilities and the private sector to construct high quality hand-dug wells, boreholes and latrines and to repair water supply equipment.

\section{Environmental Enforcement Policy}

This is aimed at outlining the relevant actions necessary in the enforcement of environmental legislation, standards, regulations and guidelines in a fair and appropriate manner in order to protect environmental quality and safeguard public health.

3. National Policy on Sanitary Inspection of Premises

This Policy seeks to promote clean and healthy environment for the population. The Policy Guidelines of 2005 was formulated to help in the improvement of quality of life by the application of sound sanitation practices at personal and community levels.

\section{National Policy Guidelines on School Sanitation}

This was issued in 2005. It is aimed at encouraging provision of sanitary facilities and protecting school children from health hazards and attainment of optimal sanitary environment conducive for learning.

5. National Policy Guidelines on Solid Waste Management

This focussed on improving and safeguarding public health and welfare through the adoption of economical and sustainable methods of efficient sanitary solid waste management in order to guarantee sound environmental health.

\footnotetext{
947 Ibid. Para.5.7.

948 Ibid. Para.6.1.

${ }^{949}$ Ibid. Para.6.2.

${ }^{950}$ Ibid. Para.6.4.
} 


\subsection{Compatibility of Legislative and Policy Measures with International Obligations}

Nigeria has been active at the international level in participating, signing and ratifying international human rights treaties. These treaties contain rights and obligations some of which are absolute and require immediate realisation and some are dependent on situations and circumstances but require progressive realisation. ESC rights fall under the latter category. The African Commission on Human Rights had noted in The Social and Economic Rights Action Center and the Center for Economic and Social Rights v. Nigeria that "[d]epending on the type of rights under consideration, the level of emphasis in the application of these duties varies. But sometimes, the need to meaningfully enjoy some of the rights demands a concerted action from the State in terms of more than one of the said duties." 951 Discharging these obligations requires the adoption of appropriate measures consistent with the nature of the obligations in question. The ACHPR for instance, stipulated under Article 2(1) that States "undertake to take steps...by all appropriate means, including particularly the adoption of legislative measures."

Consequently, flowing from its international obligations on water and sanitation, Nigeria as a party to ICESCR, ICCPR, ACHPR, CRC, CEDAW and such other soft law instruments, it is bound to respect, protect and fulfil the rights embodied in these instruments and specifically in relation to water and sanitation. Over the years, Nigeria had adopted legislative and policy measures some of which are consistent with its international obligations and some are not. In assessing compatibility in relation to water and sanitation, the core contents of the right to water and sanitation are juxtaposed with the current instruments in Nigeria. assessment therefore centred on the following issues:

i. Whether water and sanitation are considered human rights in Nigeria;

ii. Whether legislative and policy instruments are consistent with core contents of the right to water; and

iii. Whether Nigeria is currently discharging its core human rights obligations: respecting, protecting and fulfilling the right to water and sanitation.

These issues are examined seriatim.

\subsubsection{Water and Sanitation as Human Right in Nigeria}

One of the major challenges in the realisation of the right to water and sanitation from the legislative context is the absence of a legislation recognising it as a right which would reflect State's international obligation and to elaborate and institutionalise the right. ${ }^{952}$ The concept of right and its advantages have been mentioned previously. It suffices to state that recognising water as a human right in an enforceable domestic legal instrument "guarantees access to safe and affordable water in sufficient quantities without discrimination, and it obliges States to act upon the lack of access." 953 The right empowers people to claim, and

\footnotetext{
${ }^{951}$ African Commission on Human and Peoples' Rights, Comm. No. 155/96 (2001)

952 Salman M.A. Salman, 'The Human Right to Water - Challenges of Implementation'. P. 46.

${ }^{953}$ Inga T. Winkler, The Human Right to Water: Significance, Legal Status and Implications for Water Allocation. P. 8.
} 
Realising the Right to Water and Sanitation in Nigeria

imposes corresponding obligation on the States as duty-bearers. ${ }^{954}$ It ensures accountability and makes governments to live up to the expectations considering that human rights are legally binding and States are held to account for their violation.

The approach of the Nigerian constitution on ESC rights has been discussed above. Under the Constitution, adequate standard of living, health, shelter and protection of the environment are mere objectives which the organs and institutions of government are required to work towards realising and these are not justiciable. Constitutionally, therefore, water and sanitation are not considered human right in Nigeria. Similarly, a review of the laws and policies above did not reveal explicitly access to quality water and basic sanitation as human right which can be legally claimed in court. In the various policies however, water and sanitation as fundamental human needs have been recognised. What came close to an acknowledgement of the need to recognise access to water as a right in official pronouncements was the statement by the Chairman of the Northern Governors Forum and the then Executive Governor of Niger State at the Presidential Summit on Water in February 2013 where the Governor remarked:

Our planning has always been out of sync with the population of Nigeria. The people need to hold government accountable for water supply and we need a legal framework to enforce this.

If government fails to deliver water to its people, the people should have a right to take government to court! $!^{955}$

Although protection of the environment from pollution for example and the promotion of sanitation have been recognised in several instruments, these instruments do not directly provide for a justiciable right to a healthy environment through which individuals and groups could lay legal claims. The instruments merely require that the environment should not be polluted. There is no provision which entitles individuals to assert a legal claim as of right where pollution occurs except to the extent where it is done in their private lands. Internally, the legal frameworks are hence limited in terms of enforcement. This internal limitation restricted the capacity of right-holders to challenge governmental and non-governmental actions having negative impacts on sanitation. The resultant effect is that the legal frameworks are poorly enforced. ${ }^{956}$ It is however recognised that duty-bearers can be held accountable on ESC rights and in some cases, can be instructed to fulfil their obligations by courts through the power of judicial review, ${ }^{957}$ and public law litigation. ${ }^{958}$ In the context of judicial review, the Constitutional Courts of Columbia and South Africa as well as the courts in India and Costa Rica have demonstrated their capacity to make useful impacts in the promotion of ESC rights and in holding public officials accountable to their obligations. ${ }^{959}$

\footnotetext{
954 Ibid.

955 WaterAid, 'Presidential Summit on Water 2013'

${ }^{956}$ Ikelegbe O. Onovughe and Onwuemele Andrew, 'Planning the Nigerian Environment: Laws and Problems of Implementation' <http://www.researchgate.net/publication/252628876_PLANNING_THE_NIGERIAN_ENVIRONMENT_LAWS _AND_PROBLEMS_OF_IMPLEMENTATION> accessed 12 June 2014

${ }^{957}$ César Rodríguez-Garavito, 'Beyond the Courtroom: The Impact of Judicial Activism on Socioeconomic Rights in Latin America' (2011) 89 Tex L Rev 1669

${ }^{958}$ Charles F. Sabel and William H. Simon, 'Destabilization Rights: How Public Law Litigation Succeeds' (2004) 117 Harv L Rev 1015

${ }^{959}$ César Rodríguez-Garavito, 'Beyond the Courtroom: The Impact of Judicial Activism on Socioeconomic Rights in Latin America' Pp. 1669-1674.
} 


\section{Chapter Four}

Through utilisation of judicial activism, the Constitutional Court of Columbia for example has made several pronouncements which impact on the way in which issues relating to ESC rights are viewed or handled by public officials and which positively impact on the justiciability and promotion of ESC rights. ${ }^{960}$ Public law litigation as coined by Chayes ${ }^{961}$ is "a civil rights advocacy" which seeks to restructure public institutions. ${ }^{962}$ In other words, it is aimed at reforming public institutions through the courts ${ }^{963}$ to make them responsive and it is considered as an influential instrument of democratic accountability. ${ }^{964}$ Evidence exists that the use of public law litigation has impacted on several areas including issues relating to schools, mental health, prisons, police abuse, and housing. ${ }^{965}$ In the context of Nigeria, except in few instances such as the one mentioned below, there appears to be limited instances of these approaches being utilised.

In 2005, through liberal approach to judicial interpretation, a Nigerian Federal High Court in Jonah Gbemre v. Shell, NNPC and $A G F^{966}$ which was a claim for the enforcement of fundamental right, has held that the constitutionally guaranteed fundamental right to life and dignity of human person as reinforced by the right to respect for lives and the dignity of human person; right to enjoy the best attainable state of physical and mental health; and the right to a general satisfactory environment favourable to development of the African Charter on Human and Peoples Rights (Ratification and Enforcement) Act inevitably includes the right to clean, poison-free, pollution-free and healthy environment. This interpretation is valid and acceptable and is consistent with international approach as demonstrated by the jurisprudence of both Human Rights Council and Committee on ESC rights as well as cases emanating from other jurisdictions. If reliance is made by the Nigerian courts to the interpretation approach adopted by the Committee on ESC rights and interpretation approach adopted by courts in other countries, it is possible that the right to water and sanitation can equally be derived from the relevant provisions of the African Charter on Human and Peoples Right Act in Nigeria. At the moment, it remains to be seen whether Nigerian courts are willing to further hold other issues such access to water and sanitation as human right due to their inextricable link with recognised justiciable fundamental rights under the Constitution and the ACHPR.

It however needs to be noted that there is a Bill (National Water Resources Bill, 2016) currently before the National Assembly (approved by the Executive) which if adopted and passed as presented will recognise access to water as human right in Nigeria.

\footnotetext{
960 The Court has pronounced itself on the unconstitutional state of affairs relating to issues including "noncompliance with the state's obligation to affiliate numerous public officials to the social security system, massive prison overcrowding, lack of protection for human rights defenders, and failure to announce an open call for public notary nominations." See ibid.

961 Abram Chayes, 'The Role of the Judge in Public Law Litigation' (1976) 89 HARV L REV

${ }_{962}$ Charles F. Sabel and William H. Simon, 'Destabilization Rights: How Public Law Litigation Succeeds'P. 1016).

${ }_{963}$ Peter A. Appel, 'Intervention in Public Law Litigation: The Environmental Paradigm' (2000) 78 Wash U L Q

${ }^{964}$ Charles F. Sabel and William H. Simon, 'Destabilization Rights: How Public Law Litigation Succeeds'

965 Ibid.

${ }^{966}$ Suit No. FHC/B/CS/53/05
} 
Realising the Right to Water and Sanitation in Nigeria

\subsubsection{Compatibility of Legislative and Policy Instruments with Contents of the Right to Water}

The contents of the right to water referred to are: quantity, quality, accessibility and affordability.

\section{Quantity (Availability/Sufficiency)}

There is no limit to the amount of water that can be extracted from surface and groundwater where the population has direct access to them. This has been stated in Water Resources Act. The combined effect of the available provisions in Water Resources Act, River Basin Development Authorities Act and Petroleum Act merely demonstrates that water should be supplied to all users in sufficient quantity. Policy documents which created lines of activities for relevant stakeholders are hardly pursued vigorously and the end result is failure of such policies to achieve the anticipated results.

The National Water Supply and Sanitation Policy has provided for the quantity of water to be supplied per capita per day depending on whether the area is rural, semi-urban or urban with 30, 60 and 120 litres respectively. Although the Policy sought to achieve wider water coverage over a period of time, the current coverage is limited. Compared to the number of population not covered by improved water supply and other factors which impact on water supply such as electricity, infrastructural dilapidation, poor maintenance culture, the attainment of this Policy objective cannot be guaranteed to a significant number of the population. Furthermore, policy implementation in Nigeria has always been a serious issue. While the goals and objectives of a policy may be noble and robust, Nigeria does not seem to have an appreciable record of policy compliance or implementation. Additionally, the Policy is not a binding document from which people can legally assert claims. It may hence be concluded that save for direct access to unimproved surface and groundwater, there are gaps in ensuring supply of water in sufficient quantity and there is no legal instrument guaranteeing minimum supply.

\section{Quality (Safety)}

This is one area where numerous legislative and policy documents exist. Several instruments sought to protect water quality and to regulate water which is to be supplied to the population either by the State or private sector. Criminal legislations and regulations identified above including National Standards on Drinking Water Quality all aimed at protecting both water and the environment. There is therefore no paucity in anti-pollution provisions, but central issue remains the extent of State's willingness to enforce the provisions. In addition to the areas of concern identified under obligation to protect (below), there are no adequate measures to ensure the quality of natural and communities' artificially constructed water sources. This has left individuals entirely at the mercy of all possible hazards contains in water generated from those sources. This is worrisome especially in the context where a large segment of the population relies on those sources for their daily water needs.

\section{Accessibility and Affordability}


Nigerian legislations do not directly contain provisions on physical and economic accessibility. National Water Supply and Sanitation Policy tries to guarantee physical accessibility through its provisions on distance between the population and water sources. The River Basins Development Authorities Act provided that water should be supplied at a fee but did not provide for the criteria of assessing the determination of fees payable. As such in places where there is municipal water supply and other places where vendors supply, there is no legislation regulating the charges. Additionally, there is no legislation protecting such individuals from discriminatory allocations, imposition of high charges or illegal disconnection.

The National Policy on Water Supply and Sanitation was aimed at ensuring physical and economic accessibility for everyone including the vulnerable. However, the Policy conceived water as economic good which should be supplied at a cost. The possibility is that water supply would most likely be dominated by profit motive rather than concern for the sustenance of human lives. In this context, it would be difficult to ensure regular supply of water where the cost of supply is not recovered. The implication is that accessibility and affordability might be compromised. When viewed from the perspective of the number of population without access to quality water and the rate of poverty in the country, the Policy is not well-suited to achieve maximum impact. Hence the need to adopt an appropriate legislation regulating these issues or refining the Policy to provide for a classification of water uses, such as water for personal and domestic uses, water for industrial uses, water for commercial uses and resolve economic accessibility issue.

In terms of sanitation, the National Environmental Sanitation Policy sought to make sanitation affordable to the population, but the central problem is the implementation of the Policy which appears to be a challenge due to a combination of factors including capacity, political will and docility of the population.

Nigeria has in 2011 enacted Freedom of Information Act which obliges ministries, departments and government's agencies to provide information to individuals upon request. This will provide opportunity for individuals, civil society organisation and NGOs to access information concerning water and sanitation issues from the relevant institutional agencies. Additionally, regarding information relating to water quality, the Nigerian Standards for Drinking Water Quality provided for the generation of data and information on water quality which should be made available to the population. Information accessibility hence is not an issue except the extent to which people are willing to utilise these instruments.

\subsubsection{Nigeria and the Obligations to Respect, Protect and Fulfil the Right to Water and Sanitation}

Subject to some concerns expressed below, the enjoyment of water by individuals and groups has generally not been interfered with by the Nigerian authorities through deliberate legislative or policy measures or such measures which by necessary implications could be held to have done so. Access to natural or artificially constructed water sources such as rivers, streams, lakes, creeks, lagoon, ponds, boreholes and wells are generally respected. The Water 
Realising the Right to Water and Sanitation in Nigeria

Resources Act ensures among others, free access for individuals to watercourses if the public has access to them for domestic uses ${ }^{967}$ and watering of livestock. ${ }^{968}$

In certain instances, there are however some control measures noted under the Water Resources Act in the generation and use of water. These come under obligation to protect. The Minister responsible for water resources may prohibits or regulates the carrying out of any activities whether on land or water which are likely to interfere with the quantity or quality of any water in any watercourse or groundwater. ${ }^{969}$ Additionally, if water is to be diverted, stored, pumped, or used on a commercial scale or a borehole is to be constructed, maintained, operated or repaired, ${ }^{970}$ a license shall be obtained from the Minister. ${ }^{971}$ Failure to obtain the requisite licence is an offence under the Act. ${ }^{972}$ These are designed to ensure that the public is protected from activities which may have impact on water availability and accessibility.

However, the following are some of the concerns under the obligation to protect:

1. Absence of legislation prohibiting arbitrary disconnection of water on account of inability to pay by those being supplied. ${ }^{973}$ In a country where about half of the population live below poverty line and where the purchasing power is low, this type of legislation is necessary in order to ensure reasonable survival of individuals who are poor and cannot afford exorbitant utilities payment.

2. In the Niger-Delta area there are issues connected with oil exploration and extraction and their implications on water and sanitation. The Petroleum Act ${ }^{974}$ permits a licensee "to appropriate and use water found in the relevant area and to collect and impound the same". 975 This is however, subject to non-interference with the any right of water enjoyed by any person. ${ }^{976}$ It is hard to contemplate how the power to appropriate and impound can be reconciled with the latter obligation of noninterference with the enjoyment of the right of water by any person. Except such water is not suitable for personal or domestic use, the permit given to licensees would effectively interfere with the right of access and enjoyment since water from natural sources in most cases are considered communal water from which no single individual can assert a private right except in relations to personal borehole and wells etc. In the context of relatively less developed environment such as the Niger-

\footnotetext{
${ }^{967}$ Domestic use was defined under section 20 to mean the use for drinking, washing, bathing, cooling, gardening or for any other domestic purpose in any residential premises utilised for non-profit motives

968 Water Resources Act, S. 2(1)

${ }^{969}$ Ibid. Section 8. Other control mechanisms under the section include prohibiting "the storage, diversion, pumping or use of any water or the construction and maintenance, operation, repair or alteration of any borehole" requiring of information relating to water-samples or core-samples by any person who constructs, uses, alters, operates, maintains or repairs any bore-hole"

${ }^{970}$ Ibid. S. 9(1).

${ }^{971}$ Ibid. S. 10.

972 Ibid. S. 9(2).

973 See Malcolm Langford, 'The United Nations Concept of Water as a Human Right: A New Paradigm for Old Problems?' P. 277.

${ }^{974}$ Cap P10 Laws of the Federation of Nigeria, 2004

${ }^{975}$ Section 15(1)(c), Petroleum (Drilling and Production) Regulations made pursuant to section 9, Petroleum Act, Cap P10 Laws of the Federation of Nigeria, 2004

976 Ibid.
} 


\section{Chapter Four}

Delta where people generally rely on natural water sources and underground waters to meet their daily water needs, ${ }^{977}$ this power under the Petroleum Act interferes with the obligation to respect by the State and to protect against licensees.

3. In terms of environmental pollution, under the Oil Pipelines Act, a holder of a permit is entitled to dig as well as bore into the soil and subsoil and may cut and remove trees and other vegetation which may be an impediment to the holder and may equally do everything necessary for the purpose of ascertaining whether it is suitable to establish an oil pipeline or for ancillary installations. ${ }^{978}$ Although there are some safeguards which are discussed under obligation to protect, the general failure of environmental law enforcement in the country has allowed the pollution of the environment through the exercise of the power granted to oil companies under these Acts. Article 12 of the ICESCR requires State parties to take necessary steps for the improvement of all aspects of environmental and industrial hygiene. Similarly, the right to enjoy the best attainable state of physical and mental health under article 16(1) of the African Charter and article 24 (3) on the right to a general satisfactory environment favourable to development, imposed obligations on governments to desist from directly threatening the health and environment of their citizens.

Indeed, "an environment degraded by pollution and defaced by the destruction of all beauty and variety is as contrary to satisfactory living conditions and the development as the breakdown of the fundamental ecologic equilibria is harmful to physical and moral health." 979 Numerous cases have gone to courts regarding water and environmental pollution in the Niger-Delta area. Laws which interfere with the enjoyment of right to life, right to dignity of human person, and right to health such as the identified sections of Petroleum and Oil Pipelines Acts are certainly incompatible with international obligations embodied in ICCPR, ICESCR, ACHPR.

Regarding the obligation to protect, it should be noted that there are numerous legislative and policy measures relevant to ensuring that individuals' enjoyment of the right to water and sanitation is not deprived by the activities of public and private entities in Nigeria. There are numerous criminal legislations provisions (Criminal Code Act, the Penal Code Act, NESREA, Harmful Water (Special Criminal Provisions) Act, and various States Shariah criminal codes) prohibiting polluting water and dumping of toxic and harmful waste on land and water, activities negatively impacting on the environment, life and health. ${ }^{980}$ The criminalisation of malicious breach of contract of service knowing such would deprive a community of supply of water ${ }^{981}$ and committing of mischief which renders or likely to render installations for the supply of water less efficient ${ }^{982}$ are intended to protect individuals and communities from action capable of depriving them of the right to enjoy access to water.

\footnotetext{
977 Audrey Gaughran, 'Business and Human Right and the Right to Water'. P. 53.

${ }^{978}$ Section 5(1) Oil, Pipelines Act, Cap O7 Laws of the Federation of Nigeria, 2004

${ }^{979}$ Alexander Kiss, 'Concept and Possible Implications of the Right to Environment' in Kathleen E. Mahoney and Paul Mahoney (eds), Human Rights in the Twenty-first Century - A Global Challenge (Human Rights in the Twentyfirst Century - A Global Challenge, Nijhoff 1993) P. 553.

${ }^{980}$ Criminal Code Act, S. 245; see also Zamfara State Shariah Penal Code Law, S. 360.

${ }^{981}$ Criminal Code Act, S. 305A(1).

982 Zamfara State Sharia Penal Code Law, S. 382.
} 
Realising the Right to Water and Sanitation in Nigeria

Similarly, in the context of oil exploration and extraction, the Petroleum Act and Oil Pipelines Acts contain provisions intended to serve as safeguards and designed to protect access and enjoyment of water, environment and the ecosystems.

It is prescribed under the regulations made pursuant to the Petroleum Act, that in order to prevent polluting inland water, rivers and watercourses by oil, mud or other fluid capable of contaminating water or causing harm or destruction to fresh water or marine life, all practical precaution must be adopted by a licensee to avoid such consequences. ${ }^{983}$ Practicable steps must equally be taken by a licensee to prevent escape of petroleum into any water. ${ }^{984}$ Under the Oil Pipelines Act, a holder of a licence shall not, except expressly permitted "construct such works in, under or over, or deposit such material in or make such alteration in the flow of water required for domestic ... use as would diminish or restrict the quantity of water available for such purpose". ${ }^{985}$ Additionally, every licence holder is subject to such other regulations relating to public safety and to avoid interference with the works of public utility as well as the prevention of polluting land or water which may from time to time be in force. ${ }^{986}$

Except under the policies identified above, there is no legislative provision concerning ensuring equal access to water and sanitation. The policies have striven to ensure there is equal equity in the access and enjoyment of water by all individuals including the marginalised and vulnerable. However, policies are hardly implemented, and they do not confer any right to litigate. Indeed, general administrative law provides for measures (ombudsman, courts etc.) to control actions of the Executive and where necessary to grant remedies such as prohibition, mandamus, certiorari, declaration, injunction etc. (judicial remedies). If these remedies are pursued it is possible that duty-bearers can be compelled to act or be held accountable. However, there are problems associated with pursuing this course. The first problem is the grant of these remedies or even the assumption of jurisdiction by the courts is discretionary. ${ }^{987}$ There does not appear to be claims against public officers in this regard and it is difficult to know how courts would act if such claims are brought. The second problem is that although human rights have been defined broadly under the Fundamental Human Rights Enforcement Procedure Rules and not restricted to fundamental rights ${ }^{988}$ but the scope of public interest litigation seemed to be limited to enforcement of fundamental human rights as recognised under the constitution and the African Charter on Human and

\footnotetext{
${ }^{983}$ Petroleum (Drilling and Production) Regulations made pursuant to section 9, Petroleum Act, Cap P10 Laws of the Federation of Nigeria, 2004, S. 25.

${ }^{984}$ Ibid. S. 37(d).

985 Oil Pipelines Act, Cap O7 Laws of the Federation of Nigeria, 2004, S. 14(c).

${ }^{986}$ Ibid. S. 17(4).

${ }^{987}$ In Chief Olusegun Oni v. Attorney-General of the Federation (2012) 3 NMLR, the court per Affen, J., held that "An order of mandamus is not a mechanical relief that slavishly follows the filing of an application; even where a case falls into one of the categories in which judicial review will lie, the court is not bound to grant it because the jurisdiction to make any of the orders available in proceedings for judicial review is discretionary. Whilst the discretion to grant an order of mandamus must be exercised both judicially and judiciously, the court may refuse to make the order unless it has been shown that a distinct demand for performance of the duty has been made and the demand has deliberately not been complied with."; See also Barr. Basil Igwike \& Ors v. Dubem Obaze \& Ors, CA / E/ 162 / 08.

${ }^{988}$ See Fundamental Rights (Enforcement Procedure) Rules, 2009, S. 2.
} 
Peoples Rights. ${ }^{989}$ This is an avenue which may be explored to examine the extent to which courts are willing to entertain cases on issues beyond fundamental rights. The third problem is the undue reliance by the court on the obligation to establish locus standi by any individual challenging the action or omission by a public institution. ${ }^{990}$ The fourth problem is lack of awareness on the part of the population and the civil society organisation appears to be silent on the issue. Civil society organisations seemed to be concentrating on corruption issues and do not seem to be litigating on human rights issues or issues relating to discharge of public obligations. In situations where government officials are rarely held to account, a justiciable instrument is vital and a necessary ingredient in the protection of rights and freedoms.

Legislative provisions in criminal laws in Nigeria empowered only the States to prosecute where for example a case of water pollution has been established. The people do not have direct right to enforce them against the violator. A problem arises where the violator is the State or a transnational corporation for which the State is not willing to prosecute. This is currently the situation in the Niger-Delta region where oil exploration is significantly polluting communities' water. The communities can only institute civil cases for compensation. Another problem associated with criminal law provisions is in the area of penalties. In certain instances, the penalties provided are laughable and cannot guarantee adequate protection. This arises as a result of the outdated nature of the legislation and no proper revision of the laws have been done.

The determination by the court on the obligation to fulfil from a philosophical standpoint has been somewhat controversial. ${ }^{991}$ The doctrine of separation of powers has featured and has played a role in the adjudication of cases by the courts on question concerning fulfilment of social rights. For the purpose of this research however, it suffices to strive to identify if within the legislative and administrative measures adopted by a State, a clear indication can be seen of the desire by the State to fulfil the rights. Whether through these measures individuals especially those marginalised have the opportunity to realise and enjoy the rights. Whether in the context of water and sanitation there are appropriate measures aiming at educating the public concerning hygienic use of water, protection of water sources and methods of improving their sanitation. Whether there are measures designed to enable or

\footnotetext{
${ }^{989}$ See Ibid. Preamble 3(a) and (e).

${ }^{990}$ For example, to request for an order of mandamus from a Nigerian court, the following conditions must be satisfied: (1) The petitioner must establish that he has a clear legal right for enforcement of which the writ is sought. (2) The petitioner must also have the right to compel the performance of some duty upon the respondent. (3) The petitioner should ordinarily be the very person whose right is being infringed. (4) The petitioner must prove that he had made the demand for the performance of the duty relating to his right upon the public official and that the official had refused to perform it. See generally Fawehinmi v. Akilu (1987) NWLR (Pt. 67) 797. It is however interesting to note the decision of ECOWAS Community Court of Justice in Socio-Economic Rights and Accountability Project (SERAP) v. Federal Republic of Nigeria and Universal Basic Education Commission, No. ECW/CCJ/APP/0808 where the court jettisoned the argument of lack of locus standi of SERAP to institute a public interest litigation because of lack of sufficient legal interest. The court stated that "public international law in general, which is by and large in favour of promoting human rights and limiting the impediments against such a promotion, lends credence to the view that in public interest litigation, the plaintiff need not show that he has suffered any personal injury or has a special interest that needs to be protected to have standing." And that the "plaintiff must establish that there is a public right which is worthy of protection which has been allegedly breached and that the matter in question is justiciable."

${ }_{991}$ See Malcolm Langford (ed), Social Rights Jurisprudence: Emerging Trends in International and Comparative Law. Pp.21-24.
} 
Realising the Right to Water and Sanitation in Nigeria

assist those individuals who for reasons beyond their ability cannot realise access to clean water and sanitation. These issues can be answered if it can be shown that a State has developed a national strategy in order to ensure sufficient allocation of water resources to satisfy everyone's basic needs, ensuring access for personal and domestic use and the creation of enabling environment conducive to the realisation of the right to water and sanitation. ${ }^{992}$

The legislative measures available are inadequate and in certain instances not suitable in the fulfilment of this right. For example, legislations on public health are those which have been adopted during colonial periods and no attempt has been made to review or repeal them for the adoption of timely relevant laws. The current water related laws do not have sufficient provisions relevant to discharging the obligation to fulfil. Other administrative measures such as the "Presidential Water Initiative (PWI): Water for People, Water for Life designed to increase access to water supply and sanitation services to $100 \%$ in state capitals, $75 \%$ access in other urban and peri-urban areas, and $66 \%$ access in rural areas yielded limited result.

However, Nigeria indeed has the idea of obligation to fulfil in mind as demonstrated by the National Water Supply and Sanitation Policy, National Water Sanitation Policy, National Policy on Environment, National Environmental Sanitation Policy and such other relevant adopted Standards. These policies aimed at promoting equal access to water and sanitation. They contain provision concerning marginalised groups and vulnerable people. They aimed at creating awareness and promoting individual and public hygiene and in some of them, provisions exist for the participation by the relevant stakeholders including affected individuals and communities.

Notwithstanding the lofty provisions in these policies however, there are concerns. The first concern is in the area of implementation. The framework for interaction among the relevant agencies is generally weak to such an extent that there is lack of adequate coordination of approaches and activities among the implementing agencies. ${ }^{993}$ Secondly, policies are hardly pursued as conceived. There is general lack of continuity of implementation among successive government and in some cases, policies are entirely abandoned. ${ }^{994}$ For example, monthly sanitation exercise used to be practice across the country, but this was stopped by a succeeding government. Thirdly, policies do not give rise to or empower individuals to challenge governmental actions which are not in conformity with the policies. ${ }^{995}$ Fourthly, there is general lack of capacity by the implementing agencies which ultimately rendered the policies only relevant on paper. ${ }^{996}$ Fifthly, although the government has adopted these policies, there is general lack of political will to implement

\footnotetext{
${ }^{992}$ Inga T. Winkler, The Human Right to Water: Significance, Legal Status and Implications for Water Allocation. P. 111.

${ }^{993}$ I. J. Goldface-Irokalibe, 'Water Management in Federal and Federal - Type Countries: Nigerian Perspectives'; Kevin Ejike Chukwu, 'Water Supply Management Policy in Nigeria: Challenges in the Wetland Area of Niger Delta

${ }^{994}$ I. J. Goldface-Irokalibe, 'Water Management in Federal and Federal - Type Countries: Nigerian Perspectives'

${ }^{995}$ Refer to discussion in this section above on judicial review and public interest litigation.

${ }^{996}$ I. J. Goldface-Irokalibe, 'Water Management in Federal and Federal - Type Countries: Nigerian Perspectives'
} 


\section{Chapter Four}

them as exhibited by poor funding and official corruption. ${ }^{997}$ It is in these contexts that recognition of water as human right within justiciable documents becomes very imperative.

It would therefore be fair to state that concerning the obligation to fulfil, it is not generally the lack of adequate measures, but the problem is rooted in implementation and other related factors. This is inconsistent with Nigeria's international obligations as explained in the Maastricht Guidelines on Violations of ESC Rights. ${ }^{998}$

\subsubsection{Observations and Comments on Nigeria's Legal and Policy Frameworks in Relations to Obligations on Water and Sanitation}

In view of the extant deprivation of water and sanitation, the factors responsible and legal and policy measures currently in place, can it be said that Nigeria has adequately responded to its human rights obligations concerning water and sanitation? In other words, could it be said that the measures put in place by Nigeria are compatible to its international legal obligation in respect of the right to water and sanitation? In answering this question, it would be useful to identify mechanisms of monitoring compliance, their approach and the prevailing human rights environment. Generally, in human rights law, three mechanisms are more pronounced: monitoring and observation by human rights treaty bodies, judicial declarations and other quasi-judicial mechanisms. It is through these mechanisms that human rights claims are fought and sometimes enforced.

\section{Human Rights Treaty Bodies}

These bodies essentially rely on States' official reports and shadow reports from civil society and non-governmental organisation in their assessments. The limited reporting by Nigeria and no report after the formal recognition of water and sanitation as human rights have not provided the treaty bodies the opportunity to critically assess and pronounce on Nigeria's compliance with its international obligation on the right to water and sanitation. The only report submitted to the Committee on ESC rights and Human Rights Committee was in 1996. Although measures have been adopted to improve access to water and sanitation since then, the current figure still demonstrated lack of significant progress. In fact, in the context of MDGs goal 7 which is relevant to water and sanitation, Nigeria has been observed to be one of the most off-track countries in Africa. ${ }^{999}$ Similarly, official figures released by the government on the country's coverage ${ }^{1000}$ and reports from human rights, civil society and international organisations are clear indication that much work is required to be done. ${ }^{1001}$

\footnotetext{
${ }^{997}$ Kevin Ejike Chukwu, 'Water Supply Management Policy in Nigeria: Challenges in the Wetland Area of Niger Delta ' P. 315.

${ }^{998}$ See International Commission of Jurists, Maastricht Guidelines on Violations of Economic, Social and Cultural Rights. Para. 15(c).

${ }^{999}$ USAID, 'Nigeria Water and Sanitation Profile'

${ }^{1000}$ See Hon. Minister of Water Resources, Mid-Term Report on Water Sector Transformation (2011 - 2013). Slide 61.

${ }^{1001}$ See for example Water and Sanitation Media Network and Nigeria for Society for Water and Sanitation in Nigeria, 'Nigeria's Progress on High Level WASH Financial Commitments' February, 2013) <www.newsan.org/Files/SWA\%20STUDY\%20REPORT-ANEW.doc> accessed 19 February, 2014; Christian Fellowship and Care Foundation, 'Country Briefing: Nigeria' <http://www.chrifacafinc.org/CFCFnew/pdffiles/NIGERIA1.pdf> accessed 19 February, 2014; WHO and UNICEF, 'Joint Monitoring Programme for Water
} 
Realising the Right to Water and Sanitation in Nigeria

The measures largely failed to produce significant impact because of the influence of multiple factors identified previously: political, economic, social, cultural, institutional and environmental factors. Nigeria needs to be consistent in its periodic report submission to the treaty bodies to enable monitoring of its obligations.

\section{Courts}

The incessant interference by the executive on the powers of the court during military periods (with few exceptions where the courts have been bold to make pronouncements of violations against the military governments), adjudication and judicial pronouncements generally centred on CP rights. The general attitude was that the power to enforce ESC rights has been taken away by the Constitution and as such, individual and groups hardly bring their ESC rights claims before the courts. It was only recently, in the context of environmental issues and concerns that courts have started adopting expansive interpretation approach. Although jurisprudence in this context is extremely limited, if courts continue to utilise the approach it would contribute to the realisation and enjoyment of human rights. Additionally, the approach may open the gate for other opportunities where individuals and groups (pending constitutional or legislative recognition of ESC rights as justiciable rights) could pursue ESC rights claims within the context of fundamental rights.

\section{Quasi-judicial Mechanism}

Although these institutions have been enjoined to address violations of ESC rights as vigorously as they address CP rights violations, ${ }^{1002}$ currently they are yet to fully venture into this and their activities mainly concentrated on CP rights except on employment issues. An opportunity for identifying how these bodies would proceed in the context of ESC Rights is therefore yet to manifest itself.

The Nigerian human rights environment as highlighted, clearly demonstrated concerns in the enjoyment of both CP rights and ESC rights. It had been acknowledged that the system of government under which the country found itself for a considerable length of time has impacted on human rights and has created or promoted a culture of docility in the citizens on prosecuting or asserting human rights claims. This situation continues in the current democratic dispensation as it relates to ESC rights. There are indeed human rights and civil society organisations emerging at the national level and to a significant extent advocating for the realisation of these rights, but except limited adjudication and claims on environmental issues in the Niger-Delta, much of the discourse and activities centred on advocacy.

\subsection{Problems Associated with Legal and Policy Frameworks}

Drawing from the above analysis, it can be said that the Nigeria's response to its international obligation on water and sanitation from legal and policy perspectives has been characterised by non-justiciable nature of ESC rights, non-domestication of human rights

\footnotetext{
Supply and Sanitation: Estimates for the use of Improved Drinking-Water Sources in Nigeria' 2012) <www.wssinfo.org> accessed 15 October 2012

${ }^{1002}$ See International Commission of Jurists, Maastricht Guidelines on Violations of Economic, Social and Cultural Rights. Para. 25
} 


\section{Chapter Four}

instruments, non-recognition of water and sanitation as a human right in legal and policy documents, weak implementation of relevant legislations and policy reversals.

\subsubsection{Non-Justiciability of ESC Rights under the Constitution}

The Nigeria Constitution adopted the 'perceived' dichotomy between CP rights and ESC rights. This gives credence to the distinction between the rights at least within the Nigerian context. It was asserted that the dichotomy was because ESC rights require resources and affirmative governmental actions for their realisation which in essence depends on availability of resources. ${ }^{1003}$ Although after independence, African scholars and leaders have realised the importance of ESC rights wherein the scholars suggested that the realisation of $\mathrm{CP}$ rights should await that of ESC rights, ${ }^{1004}$ majority of constitutions in African States including Nigeria demonstrated otherwise. CP rights were, to a large extent, recognised as enforceable rights while ESC rights received a much lesser recognition. ${ }^{1005}$

The objectives of the 1999 Constitution are the promotion of citizens' welfare, social and economic security and good governance. The Constitution, on the principles of freedom, equality and justice, seeks to promote good governance ensure the welfare of all persons in Nigeria. ${ }^{1006}$ With obligations placed on the arms and tiers of government, ${ }^{1007}$ the Constitution assumes government at all levels will vigorously pursue projects to realise these objectives. It is axiomatic, at the centre of social and economic security; ESC rights serve as the backbone. Ironically, however, section 6(6)(c) of the Constitution seems to block the possibility of ensuring government's compliance with its constitutional obligations under the Chapter. Judicial intervention is a sine qua non to monitoring and ensuring Executive's compliance and a necessary tool in gauging the extent to which actions or inactions comply with the principles of freedom, equality and justice.

Despite the lofty ideals and promises contained in chapter two of the constitution, the provisions when read with section 6(6)(c) are mere rhetoric. This is notwithstanding the apparent economic and social deprivations widely noticeable. The principle of check and balance necessary in democratic governance is weakened, accountability is debilitated, and continuous violations encouraged. The Executive (and Legislative) Arm cannot be entirely trusted and or expected to suo motu religiously adhere to the obligations in the absence of judicial muscle ensuring it to do so. The victims are the population especially the underprivileged, marginalised and vulnerable.

A review of academic and judicial pronouncements on justiciability of ESC rights under the Constitution suggested the existence of two groups:

1. Those who argued on the non-justiciable character of chapter two provisions; and

2. Those who argued in support of a limited justiciability.

\footnotetext{
1003 See Muhammed Tawfiq Ladan, Law, Cases and Policies on Energy, Mineral Resources, Climate Change, Environment, Water, Maritime and Human Rights in Nigeria

1004 See J. Oloka-Onyango, 'Beyond the Rhetoric: Reinvigorating the Struggle for Economic Social and Cultural Rights in Africa' (1995) 26 California Western International Law Journal

1005 Although contained in constitutions but they are recognised as ideals which States hope to or will strive to progressively realise without legal provision obliging them to do so.

${ }^{1006}$ Constitution of the Federal Republic of Nigeria. Para. 4 of the Preamble

${ }^{1007}$ Such as those under chapter two of the Constitution
} 


\section{Non-Justiciable Character of Chapter Two of the Constitution}

This represents the preponderant or majority view among the scholars on ESC rights under the Nigerian Constitution. ${ }^{1008}$ The group derived its strength from the implication of section 6(6)(c) of the Constitution. The powers and limitations of Nigerian Judiciary are contained under section 6 of the Constitution. The limitation relevant here is contained in section $6(6)(c)$ that the powers of the judiciary:

shall not except as otherwise provided by this Constitution, extend to any issue or question as to whether any act of omission by any authority or person or as to whether any law or any judicial decision is in conformity with the Fundamental Objectives and Directive Principles of State Policy set out in Chapter II of this Constitution.

The above provision, it was argued, had expressly ousted courts' jurisdiction to entertain any question on compliance with chapter two of the Constitution. This position is supported by judicial decisions. The Court of Appeal, per Justice Mamman Nasir in Archbishop Okogie v. The Attorney-General of Lagos State ${ }^{1009}$ stated:

While Section $13 \ldots$ makes it a duty and responsibility of the judiciary among other organs of government, to conform to and apply the provisions of Chapter II, Section 6(6)(c) of the same Constitution makes it clear that no court has jurisdiction to pronounce any decision as to whether any organ of government has acted or is acting in conformity with the Fundamental Objectives and Directive Principles. It is clear that section 13 has not made chapter II justiciable. ${ }^{1010}$

Until recently, the preponderant view obstructed possible academic discussion on how such limitations should be interpreted and the inextricable link between ESC rights and CP rights. This made it possible for governments to assume tacit, if not express approval of the non-justiciable nature of ESC rights under the Constitution. Except on gas flaring and environmental pollution in the Niger Delta where attention was given to environmental protection, right to health and its link to right to life, little had so far been written on other ESC rights in Nigeria.

\section{Limited Justiciable Character of Chapter Two of the Constitution}

The minority group argued in favour of limited justiciable character of the chapter. The argument centred on the interpretation of the constitution as a whole and the effect of the

\footnotetext{
1008 See for example M. A. Alabi, 'Fundamental Objectives and Directive Principles Under the Nigerian Constitutional Law' (2006) 11 The Jurist . Pp. 77 - 82; Bamidele Aturu, 'The Legal Profession and Protection of Human Rights <http://bamideleaturuandco.com/THE\%20LEGAL\%20PROFESSION\%20AND\%20HUMAN\%20RIGHTS.pdf> accessed 2 December, 2014; B. Owasanoye, 'Transparency, Accountability and Good Governance Under the 1999 Constitution' in I. A. Ayua, D. A. Guobadia and A. O. Adekunle (eds), Nigeria: Issues in the 1999 Constitution (Nigeria: Issues in the 1999 Constitution, Nigerian Institute of Advanced Legal Studies 2000) P. 235; Dakas C. J. Dakas, 'Judicial Reform of the Legal Framework For Human Rights Litigation in Nigeria: Novelties and Perplexities' in Epiphany Azinge, Dakas C. J. Dakas and Nigerian Institute of Advanced Legal Studies (eds), Judicial Reform and Transformation in Nigeria: A Tribute to Hon Justice Dahiru Musdapher, GCON, FNIALS, Chief Justice of Nigeria (Judicial Reform and Transformation in Nigeria: A Tribute to Hon Justice Dahiru Musdapher, GCON, FNIALS, Chief Justice of Nigeria, Nigerian Institute of Advanced Legal Studies 2012) P. 336; Epiphany Azinge and O. Owasanoye (eds), Justiciability and Constitutionalism: An Economic Analysis of Law (Nigerian Institute of Advanced Legal Studies 2010); and R. Otaru, 'Fundamental Objectives and Directive Principles of State Policy: The Need for Amendment to Ensure their Justiciability' (2006) 11 The Jurist Pp $63-67$

1009 (1981) 2 NCLR 350

1010 Ibid. Paras. 1-2.
} 


\section{Chapter Four}

limitation clause. A combined reading of sections 6(6)(c), 1(1), 13, 224 and item 60(a) of the Exclusive Legislative List, it was argued, suggested that section 6(6)(c) does not entirely foreclosed justiciability of chapter two. Section 1(1) of the Constitution declares the supremacy and the binding nature of the Constitution, section 13 obliges all organs of government, "authorities and persons, exercising legislative, executive or judicial powers, to conform to, observe and apply the provisions of" chapter two, and section 224 makes it mandatory for the aims and objects of political parties to conform to chapter two provisions. It was argued that unlike the Indian Constitution which expressly stated that provisions in Fundamental Objectives and Directive Principles are non-enforceable, the Nigerian limitation clause in section 6(6)(c) did not absolutely exclude justiciability. ${ }^{1011}$ That the phrase "except as otherwise provided by this Constitution" suggested the possibility of justiciability provided provisions are made in the remaining part of the Constitution.

The above interpretation received judicial blessings in Olafisoye v. Federal Republic of Nigeria ${ }^{1012}$ per Justice Niki Tobi where the learned Justice explained that "the nonjusticiability of section 6(6)(c) of the Constitution is neither total nor sacrosanct as the subsection provides a leeway by the use of the words 'except as otherwise provided by this Constitution'. This means that if the Constitution otherwise provides in another section, which makes a section or sections of Chapter II justiciable, it will be so interpreted by the courts." The Supreme Court further considered that:

A community reading of Item 60(a) and section 15(5) results in quite a different package, a package which no more leaves Chapter 2 a toothless dog which could only bark but cannot bite. In my view, by the joint reading of the two provisions, Chapter 2 becomes clearly and obviously justiciable. And if I may fall back on section 6(6)(c) of the Constitution which provided for an exception clause, it is my view that section 6(6)(c) anticipates amongst other possible provisions, the provision of Item 60(a).

The same position was reiterated in Federal Republic of Nigeria v. Alhaji Mika Anache \& Others. ${ }^{1013}$ Even Justice Mamman Nasir seemed to agree with this view when defining the role of the courts in Archbishop Okogie v. The Attorney-General of Lagos State: ${ }^{1014}$

the obligation of the judiciary to observe the provisions of chapter II is limited to interpreting the general provisions of the Constitution or any other statute in such a way that the provisions of the chapter are observed ... subject to the express provision of the Constitution in favour

\footnotetext{
${ }^{1011}$ See for example Y. Akinseye-George, Improving Judicial Protection of Human Rights in Nigeria (Center for Socio-Legal Studies 2012) Pp. 38-39 which according to the author “....it must be understood that the above provision of section $6(6)(\mathrm{c})$ does not mean that the provisions of Chapter II are unenforceable. In other words, the non-justiciability of Chapter II enacted in section 6(6)(c) must not be taken to mean that the provisions of Chapter II are not enforceable. On the contrary, the provisions of chapter II are no less enforceable than any other provision of the constitution. Put in another way, the provisions of Chapter II ARE AS ENFORCEABLE AS ANY OTHER PROVISION OF THE CONSTITUTION. The only difference created by section 6(6)(c) is that, by the reason of that section, the judicial powers of the courts cannot be invoked with respect to any issue or question as to whether any act or omission by any authority or person or as to whether any law or any judicial decision is in conformity with the Fundamental Objectives and Directive Principles of State Policy set out in Chapter II. The implication of this provision is that an action for enforcement of human rights or judicial review cannot be founded solely on the provisions of Chapter II. It also means that judicial power cannot be invoked solely on the basis of Chapter II provisions in order to give effect to the contents of the chapter. However, notwithstanding the so-called provision on non-justiciability, the provisions of Chapter II of the constitution can be enforced by other means including judicial action founded on other legal and constitutional foundations outside Chapter II."

1012 (2004) 4 NWLR (Pt. 864) 580

1013 (2004) 14 WRN 1-90 at p. 61

1014 (1981) 2 NCLR 350
} 
Realising the Right to Water and Sanitation in Nigeria

of limited justiciability of chapter two provisions as may be supported by other provisions of

the Constitution. ${ }^{1015}$

In this regard therefore, it is argued, in interpreting the remaining parts of the Constitution, fundamental rights for example, interpretation of a particular rights necessarily requires the fulfilment of one or some ESC rights. This perforce, renders ESC rights justiciable. The obligations in section 13 and provision of item 6o(a) of the Exclusive Legislative List shall be referred to later. Arguments in this thesis supports the limited justiciability of chapter two specifically, the ESC rights provisions.

Implications of lack of justiciability are many and serious not only on individuals but also on States' accountability in human rights protection. It suffices to note International Commission of Jurists ${ }^{\prime} 1016$ observation anchoring that lack of justiciability: narrows the range of mechanisms available for victims of rights violations to receive remedies and reparations; weakens the accountability of States; undermines deterrence; and fosters impunity for violations. In Nigeria, the above consequences are visible. The majority view regarding ESC rights litigation may have influenced limited human claims. The assumption that courts are powerless on Chapter Two and the official reliance on this view have led to the limited realisation of constitutional objectives. Undoubtedly, this culture promotes impunity and encourages further violation of human rights obligations including those on water and sanitation. The Committee on ESC rights in its General Comment 9 enjoins domestic courts in their judicial review role to, within their limits and where necessary, take account of the rights enshrined in the Covenant in order to ensure that the conduct of the State is consistent with its obligations. ${ }^{1017}$ In the context of Nigeria, nothing could be more necessary. The Committee considered that neglecting this by domestic courts is incompatible with the principle of the rule of law. ${ }^{1018}$ As such, domestic courts need to adopt this approach in order to move from non-justiciability argument if human rights realisation is to be made meaningful

The current legal position of ESC rights under the Nigerian constitution runs against its international obligation as explained by the Committee on ESC rights in General Comment 9. ${ }^{1019}$ A State is required to give effect to the ICESCR in its domestic legal order through the adoption of all appropriate means. ${ }^{1020}$ The General Comment reminded States of the obligations to recognise the norms of the Covenant in appropriate ways, to provide for redress or remedies to aggrieved individuals and ensuring governmental accountability. ${ }^{1021}$ A State cannot use its domestic law as a justification for its failure to observe it's international legal obligations. ${ }^{1022}$ As such, Nigeria cannot use the current constitutional position especially section 6(6)(c) of the Constitution as a reason for the non-justiciable character of ESC rights.

\footnotetext{
1015 Ibid. Paras. 2-3.

${ }^{1016}$ International Commission of Jurists, Courts and the Legal Enforcement of Economic, Social and Cultural Rights: Comparative Experiences of Justiciability (International Commission of Jurists 2008) P. 3.

${ }^{1017}$ UNCESCR, General Comment No. 9: The Domestic Application of the Covenant (1998). Para. 14.

1018 Ibid.

1019 Ibid.

${ }^{1020}$ Ibid. Para. 1.

${ }^{1021}$ Ibid. Para. 2.

1022 Ibid. Para. 3
} 


\section{Chapter Four}

Additionally, justiciability is noted by the Committee as relevant in determining the best way of giving effect to ESC rights. ${ }^{1023}$ The failure by the Nigerian State to recognise the justiciable character of ESC rights in the Constitution is indicative for Nigeria's failure to adequately observe its international legal obligation concerning ESC rights and by extension, the right to water and sanitation.

\subsubsection{Non-domestication of International Human Rights Instruments:}

Domestic application of international instrument is significant in enhancing the scope as well as the effectiveness of remedial measures. ${ }^{1024}$ The African Commission on Human Rights had recognised in The Social and Economic Rights Action Center and the Center for Economic and Social Rights v. Nigeria, ${ }^{1025}$ that, "[w] here a right is not well provided for in domestic law such that no case is likely to be heard, potential conflict does not arise. Similarly, if the right is not well provided for, there cannot be effective remedies or any remedies at all." This statement encapsulated the present position of relevant provisions in chapter two of the 1999 Constitution and by extension the right to water and sanitation which are components of the right to health and adequate standard of living. The supremacy of the Constitution is never in doubt and domestication of human rights instruments before enforceability is a fundamental constitutional requirement. The Nigeria's Supreme Court in Abacha v. Fawehinmi has observed that the:

Constitution is the supreme law of the land; it is the grundnorm. Its supremacy has never been called to question in ordinary circumstance. Thus, any treaty enacted into law in Nigeria by virtue of section 12(1) of the 1979 Constitution (now section 12(1) 1999 Constitution) is circumscribed in its operational scope and extent as may be prescribed by the legislature. ${ }^{1026}$

In the light of constitutional requirement of treaty domestication before enforceability, and the non-domestication of ICCPR and ICESCR, national courts cannot directly enforce their provisions. The Supreme Court of Nigeria in Abacha v. Fawehinmi ${ }^{1027}$ posited that "an international treaty entered into by the government of Nigeria does not become ipso facto binding until enacted into law by the National Assembly and before its enactment, an international treaty has no force of law as to make its provisions actionable in Nigerian law courts." The Court went further to hold that "unincorporated treaties cannot change any aspect of Nigerian law even though Nigeria is a party to those treaties". ${ }^{1028}$

The constitutional position on the non-applicability of undomesticated treaties in the domestic courts has been said to have "the potency to encourage and validate the breach by the Nigerian Government of its international obligation contained in the international human rights instruments to which it is a party". ${ }^{1029}$ This makes a domestic legislation a fundamental requirement. Although domestic courts usually use international standards in the

\footnotetext{
1023 Ibid. Para. 7.

1024 International Commission of Jurists, Maastricht Guidelines on Violations of Economic, Social and Cultural Rights. Para. 26.

1025 African Commission on Human and Peoples' Rights, Comm. No. 155/96 (2001).

${ }^{1026}$ (2000) 6 NWLR at P. 258.

1027 (2000) 6 NWLR 228

1028 (2000) 6 NWLR 228

1029 Jacob Abiodun Dada, 'Human Rights under the Nigerian Constitution: Issues and Problems' (2012) 2 International Journal of Humanities and Social Science
} 
Realising the Right to Water and Sanitation in Nigeria

interpretations of national guarantees, ${ }^{1030}$ the absence of a domestic legislative instrument makes it a difficult exercise. At present therefore, the non-domestication of ICESCR and ICCPR despite their ratification long ago is a challenge in the realisation of ESC rights and the right to water and sanitation in Nigeria.

It must however be noted that Nigeria has domesticated the ACHPR ${ }^{1031}$ which makes it possible for claims on the violation of the rights contained therein to be prosecuted in municipal courts.

\subsubsection{Non-Recognition of Water and Sanitation as Human Rights}

Despite Nigeria's accession to the ICCPR and ICESCR and its voting at the UN General Assembly in support of the recognition of water and sanitation as human rights, there is no legislative or policy document which recognises water and sanitation as human rights. This impacts on the realisation of the right as no undisputed legal claim may be brought against the State on the basis of national legislations. Non-domestication of ICCPR and ICESCR by Nigeria and its consequence has been referred to above.

\subsubsection{Weak Implementation}

Notwithstanding several legislative and policy instruments, especially on the environment, environmental problems relating to poor sanitation coverage is on the increase. The 1990s have seen a spiral of policies to address environmental problems without much success. The issue is not exactly on the efficacy of the adopted measures but on enforcement and implementation by governments successively. This is more pronounced and worrisome in the context of environmental laws. These actions inconsistent with international legal obligations of Nigeria on human rights and environment. ${ }^{1032}$ Internal and external factors are responsible for the poor implementation. These include limitation of the frameworks, institutional bottlenecks, funding, corruption, and ignorance. A combination of these factors hampered the realisation of the ideals promised by the instruments.

\subsubsection{Inconsistencies and Policy Reversals}

Review of legislations and policies revealed inconsistencies and inadequacy of some legislations. While some laws restricted what can be done regarding water and environment, some conferred rights which negated the restriction. This needs to be addressed, as failure to do so amounted to a violation of human rights obligation to remove obstacles to enjoyment of human rights. ${ }^{1033}$ Additionally, the legislations do not usually provide clear-cut regulatory framework among the agencies and departments. ${ }^{1034}$ Previous Minister of Water Resources

\footnotetext{
${ }^{1030}$ Inga T. Winkler, The Human Right to Water: Significance, Legal Status and Implications for Water Allocation. P. 15.

${ }^{1031}$ See African Charter on Human and Peoples' Right (Ratification and Enforcement) Act.

${ }^{1032}$ See International Commission of Jurists, Maastricht Guidelines on Violations of Economic, Social and Cultural Rights Para. 15(c)

1033 Ibid. Para. 15(g)

${ }^{1034}$ Ikelegbe O. Onovughe and Onwuemele Andrew, 'Planning the Nigerian Environment: Laws and Problems of Implementation' P. 8.
} 


\section{Chapter Four}

has equally pointed out as one of the challenges, policy reversals by successive governments over the years. ${ }^{1035}$ As a result, reforms introduced are abandoned when there is a change in political or institutional leadership.

Additionally, addressing water and sanitation problems is not the sole responsibility of one tier of government. As a result, there exist multiple legislations among States and the Federal Government with agencies created to administer the law. Several issues arose in this context including inconsistences between the legislations and multiple agencies and government's departments established or empowered to address same issues. The legislations do not usually provide clear-cut regulatory framework among the agencies and departments $^{1036}$ and most frequently the agencies do not interact and coordinate their activities. This unnecessarily creates institutional bottlenecks in the implementation of the legal frameworks which renders enforcement cumbersome and unsuccessful. ${ }^{1037}$ The State has failed so far to remove these obstacles thereby constituting a breach of its obligations in human rights law. ${ }^{1038}$

\subsection{Empirical Perspective on the Contents of the Right to Water in Nigeria}

SDG Goal 6 is to ensure availability and sustainable management of water and sanitation for all by 2030. A number of targets and indicators have been listed aimed at achieving this goal. ${ }^{1039}$ This section compliments analysis of legislative and policy measures through the assessment of Nigeria's compliance with its international legal obligations concerning the right to water and sanitation. It equally highlights the current situation in the locations of the study with a view to demonstrating what is required to achieve the various targets of SDG Goal 6. Empirical Data obtained from the locations stated in section 1.7 above were assessed. In this section however, only the contents of the right to water specifically were assessed on the basis that generally sanitation facilities except in few places such as schools, hospitals and public places, are constructed by the individuals themselves. Although there is public housing in Nigeria, but the empirical data obtained in this research was not limited to those houses or to those public places. This made it difficult to assess the extent of Nigeria's compliance with the obligation of ensuring the contents of the right to sanitation. It is worthy of note, the report of the Independent Expert on the Issue of Human

Rights Obligations Related to Access to Safe Drinking Water and Sanitation, Catarina De Albuquerque stated in her report to the Human Rights Council, that States are not obliged to provide everyone with access to a sewerage system or provide individual facilities for every home, and they are not obliged to construct toilets, they are only required to create an enabling environment. That it is only "in certain conditions, such as extreme poverty or natural disasters, when people, for reasons beyond their control, are genuinely unable to

\footnotetext{
${ }^{1035}$ Hon. Minister of Water Resources, Mid-Term Report on Water Sector Transformation (2011 - 2013). Slide 8

${ }^{1036}$ Ikelegbe O. Onovughe and Onwuemele Andrew, 'Planning the Nigerian Environment: Laws and Problems of Implementation'. P. 8.

1037 Ibid.

${ }^{1038}$ International Commission of Jurists, Maastricht Guidelines on Violations of Economic, Social and Cultural Rights Para. 15(g)

${ }^{1039}$ These targets and indicators are listed in Table 4.16.
} 
Realising the Right to Water and Sanitation in Nigeria

access sanitation through their own means, is the State obliged to actually provide sanitation services." 1040

However, the non-assessment of the contents of the right to sanitation is therefore recognised as one of the limitations of this research and more work is required in this context especially the gender dimension of sanitation and requirement of privacy.

\subsubsection{Availability (Sufficiency)}

In many developing countries, availability of water is determined by the improved and unimproved sources accessible to the population for their personal and domestic uses. In Nigeria, there is a variety of these sources which consist of surface and groundwater. These include tap water, boreholes, wells, water vendors, private service providers, rivers, ponds, streams, rain etc. ${ }^{1041}$ It needs to be noted that the only treated source is tap water which even in some location its quality is questionable. Availability of these sources varies in terms of time and location. The empirical study investigated the extent (frequency) in which the following sources are utilised by the Nigerian people: personal tap, public tap, personal borehole, public borehole, water vendors, river, pond, well and others (which include rain water). Frequency of responses from the selected rights-holders are shown in Table 4.3.

From the responses it is observed that roughly only $1 / 5$ of the respondents has access to water from personal tap always while a sizable percentage of about $45 \%$ of the respondents utilises public taps often. Public boreholes, water vendors, wells and to some extent, personal boreholes account for the most part, as water access points for the respondents. Limited number of respondents uses rivers and ponds.

Ensuring availability of water is a State obligation. Empirical data from the present case study on water availability in Nigeria clearly demonstrated the failure of the Nigerian State to provide quality water in sufficient quantity to its population. The Majority of respondents have had to rely on other sources most of which the quality is not guaranteed. Similar to diverse communities around the world, water usage among Nigerians is not uniform. As such, requirement of availability varies from community to community or even religion to religion. For example, Islamic religion requires adherents to pray five times daily and each requires water for ablution. Similarly, Muslims are required to perform purity bath upon each sexual or menstrual discharge and before Friday obligatory prayers. Water consumption is equally higher in cities compared to villages. Similarly, consumption may vary depending on climatic conditions and circumstances. Hence it is difficult to determine the amount required by individuals or households on daily basis except where a specific census is conducted on that basis although an estimate had been provided by WHO as mentioned above.

The proportion of respondents using personal taps suggested that $29 \%$ are not connected to public water supply system. This figure increases to $36.36 \%$ if the proportion of those who

\footnotetext{
${ }^{1040}$ UN Human Rights Council, Report of the Independent Expert on the Issue of Human Rights Obligations Related to Access to Safe Drinking Water and Sanitation, Catarina de Albuquerque . Para. 67.

1041 These are the sources from which the population get their water. See Kevin Ejike Chukwu, 'Water Supply Management Policy in Nigeria: Challenges in the Wetland Area of Niger Delta ' P.306 citing National Bureau of Statistics with reference to Niger-Delta area. This is equally applicable to all the regions in Nigeria. See also Alan MacDonald and others, Developing Groundwater: A Guide for Rural Water Supply (ITDG Publishing 2005)
} 


\section{Chapter Four}

almost never use personal taps is added. The non-availability leaves this population with no option but to resort to other sources which potentially put their lives at risk due to possible water contamination. ${ }^{1042}$ The figure demonstrated the severe and acute lack of access to portable drinking water by many Nigerians. Although public taps exist, these are very limited and not widespread. As such even in places where they exist a very limited number gets supply always as shown in the table. Because it is difficult if not impossible to find non-stop water supply in Nigeria, those who could afford, construct boreholes in their houses. The acute shortage of portable drinking water is further evidenced by the proportion of respondents using personal and public boreholes. Notwithstanding that public boreholes are usually constructed by governments the number available are certainly not sufficient and their construction hence does not obviate or discharge the obligation of providing sufficient portable water to the population. Judicial authorities considered above clearly demonstrated the obligation of governments at all levels to ensure availability of sufficient portable water supply through every means possible.

The number of respondents using other water sources such as river, pond/stream and wells is alarming. Not only because these sources are mostly impure as no laboratory assessment is done to determine the quality but also is an indication of the desperate situation of such population. It may be concluded that the obligation of ensuring availability of quality water is an issue in Nigeria and requires urgent and deliberate measures to address the situation. What could possible explain the reason for this situation have been assessed in chapter six.

In terms of compliance with its minimum core obligations on the right to water and sanitation in respect of availability, Nigeria is clearly in violation. Under the Maastricht Guidelines on Violations of ESC Rights, a State would be considered to be in violation where a significant number of the population is deprived of the essential basic necessities of life such as water and sanitation. ${ }^{1043}$ However, in determining which actions or omissions amount to a violation, it is important according to the Guidelines to distinguish between inability and unwillingness of a State. ${ }^{1044}$ This position is equally anchored by GC $15 .{ }^{1045} \mathrm{In}$ applying these provisions to the Nigerian situation, it may be said that the violation arose due to unwillingness of Nigeria to deploy the necessary resources towards ensuring effective utilisation of water sources for the realisation of the right. Although capacity may be an issue, but necessary resources exist which can effectively address this concern. Insufficient expenditure and misallocation of public resources are some of the examples identified by GC 15 as amounting to a violation arising from unwillingness of a State. ${ }^{1046}$ The minimum core

\footnotetext{
1042 This does not however suggest that the public water supply system is free of pollution because the risk is lower due to some level of treatments which such water receive at the treatment plants although there have been instances of public health issues (related to water diseases such as cholera, diarrhoea etc.) associated with public water supply in many parts of Nigeria.

${ }^{1043}$ International Commission of Jurists, Maastricht Guidelines on Violations of Economic, Social and Cultural Rights Para. 9. See also UNCESCR, General Comment No. 3: The Nature of States Parties' Obligations (Art. 2, Para. 1, of the Covenant)

${ }^{1044}$ International Commission of Jurists, Maastricht Guidelines on Violations of Economic, Social and Cultural Rights. Para. 13.

${ }^{1045}$ UNCESCR, General Comment No. 15: The Right to Water (Arts. 11 and 12 of the Covenant) Paras. 39 - 44, specifically Para. 41.

${ }^{1046}$ Ibid. Para. 44(c)(ii).
} 
Realising the Right to Water and Sanitation in Nigeria

obligations apply according to the Guidelines "irrespective of the availability of resources of the country concerned or any other factors and difficulties." 1047 Failure to ensure this is considered a violation. ${ }^{1048}$

\subsubsection{Water Quality: Respondents Perception on Water Quality}

Nigeria's legal and policy measures concerning water quality and observations therefrom have also been made above. Safe water in Nigeria are those which conform to the adopted standards developed by Nigeria in line with WHO's recommendations. This section merely assesses respondents' (general populations) perception of their water quality. It does not contain any laboratory water quality analysis or determines the quality/pollution constituents of water. The responses are shown in Table 4.4 and majority of the respondents seemed to be satisfied with the quality of their water.

Proceeding from subjective to a somewhat objective basis, responses from duty-bearers were examined in relations to whether there exists a mechanism for monitoring water quality and pollution in their areas of jurisdiction and where water is provided by the State. Only about half of the respondents (duty-bearers) seemed to have such a mechanism. While the majority of respondents (general population) are of the opinion that their water is clean enough for their use, and a research has shown that groundwater in Nigeria is generally good, ${ }^{1049}$ these may not be completely true because there are other areas in the country where iron, manganese, nitrate or fluoride concentrations have been noted to be above the recommended WHO Standards. ${ }^{1050}$ Generally, groundwater quality "is controlled by the physical, chemical and biological processes" interacting in the aquifer. ${ }^{1051}$ The population do not have the technical knowledge or the equipment to detect the composition of chemicals contained in the water. And as many Nigerians are relying on other sources of water which are extracted from underground or consumed from the surface, these waters are generally known to have quality issues as no treatment is done to purify them.

Although legal and policy measures on water quality exist in Nigeria, duty-bearers' response on lack of mechanisms to monitor pollution demonstrated the limited enforcement of those measures. With over $40 \%$ of duty-bearers responding that no such mechanisms exist in their areas of operation suggested that even where water is provided by the State there is no assurance that such water is pollution free. The State clearly omitted to provide the necessary resources and facilities to ensure water quality. This is incompatible with Nigeria's international legal obligation. ${ }^{1052}$

\footnotetext{
${ }^{1047}$ International Commission of Jurists, Maastricht Guidelines on Violations of Economic, Social and Cultural Rights. Para. 9.

${ }^{1048}$ UNCESCR, General Comment No. 15: The Right to Water (Arts. 11 and 12 of the Covenant). Para. 44(c)(iv).

1049 G.E Oteze, 'Management Approaches for Nigeria's Water Resources' (2006) 42 Journal of Mining and Geology 15

${ }^{1050}$ H.O Nwankwoala, 'Localizing the Strategy for Achieving Rural Water Supply and Sanitation in Nigeria' (2011) 5 African Journal of Environmental Science and Technology

${ }^{1051}$ National Research Council, Valuing Ground Water: Economic Concepts and Approaches (National Academy Press 1997) P. 41.

${ }^{1052}$ International Commission of Jurists, Maastricht Guidelines on Violations of Economic, Social and Cultural Rights Para. 15(f)
} 


\subsubsection{Accessibility}

Chapter Four

The empirical study generated data from respondents (general population) in respect of physical accessibility, economic accessibility, non-discrimination and information accessibility. Responses on physical accessibility (distance and duration to water access points) are shown in Table 4.5. The response rate generally indicated that accessibility of water is within the legal prescription, with about $4 / 5$ indicating a distance of less than one kilometre and about $90 \%$ accessing within 30 minutes. While this is to be assessed in the light of access points, the State may not generally have been responsible for the provision of ALL the access points as the utilisation of the various sources had indicated above. However, the State is responsible for such provision where water is connected to houses from public sources, public taps and in many cases public boreholes.

Legal obligations require accessibility to be without discrimination on any of the prohibited grounds. Pursuant to this, this study assesses if there exist any disparity between accessibility in terms of gender as an indication. ${ }^{1053}$ The responses were therefore cross tabulated (as shown in Figure 4.1). The finding shows that there is no significant disparity except that females seem to enjoy accessibility slightly more than males on both distance and duration. What could possibly have explained this may not be unconnected with the relative advantage women enjoy in the location where the empirical study was carried out. Most of the women in the region are either married or are otherwise relying on their siblings, brothers, uncles, nephews etc. for the collection of water or purchase from vendors in situations where women are totally independent with no assistance. In terms of compliance with legal obligations under physical accessibility, the findings as indicated by empirical figures suggested that this is not an issue in Nigeria and there does not appear to be discrimination in terms of gender on physical accessibility. Despite this however, there is the need to fast track the provision of water to the population who have had to source their water from a distance of a kilometre or more. This will reduce instances of lateness in school for school children, gender-based violence on women and children and lack of productivity on the part of able-bodied men who have had to spend significant amount of time fetching water for their families.

Another component of accessibility assessed by the empirical study is affordability (also referred to as economic accessibility). Where the State is the service provider, depending on the capacity and technology deployed, the State can use water meters where connection is to houses or a flat rate. In determining cost (water rates), the majority of respondents from dutybearers $(62.90 \%)$ indicated that monthly water rates is assessed by actual consumption and the amount payable to large extent takes economic condition of the people into consideration. Where a flat rate is imposed, the amount from the figure admitted by respondents from rightsholders is generally affordable (N300 per month). However, the position is different and sometimes can be a challenge economically where water vendors are the service providers. As Table 4.6 indicated, daily spending for some rights-holders can go up to N300 per day while those who source water for themselves incur no cost at all. Table 4.7 showed how

\footnotetext{
${ }^{1053}$ Gender is used merely because there are women who are living independently and have had to source water for themselves. Race, religion and for example were not assessed because people are not segregated on this basis.
} 
Realising the Right to Water and Sanitation in Nigeria

different categories of people in this research fare in terms of daily spending on water. Disconnection on account of non-payment indeed takes place but as shown by the empirical figures, $3 / 5$ of respondents disconnects only after a notice is served and about $1 / 5$ do not disconnect at all.

From the above, it can be concluded regarding affordability that, while the fixing of uniform rate to the whole population may not be appropriate in certain instances, in Nigeria the rate is generally fair and goes extremely lower than if water was to be provided by private sector or purchased from water vendors. Water is hence an affordable commodity where the supply is from the State as the economic position of the recipients is generally considered in many States. This may however, not be the case throughout the country. Generally, where water is provided by the State, bills are payable on monthly basis. The major issue however may be where no supply was provided for or where the supply was very limited which sometimes happened when the supply network is faulty, pipes are broken, or simply limited quantity is available at a time. Very few States have installed water metres. It is still of concern, that in some States water is disconnected without considering the extreme economic situation of defaulters especially in situation where duty-bearers do not consider themselves to be under any obligation to provide the basic minimum. This goes against the obligation to take into consideration vulnerable class in the society. While serving of notice is important, it however needs to be taken into consideration whether the non-payment is deliberate or on account of inability to pay in which case the obligation to ensure minimum supply still exist.

Additionally, while the monthly rate is generally affordable, the chargeable uniform rate failed to take into consideration that water is also an economic good which for sustainability reasons needs to account for itself as opposed to merely being a social resource which everyone is entitled to as of right. The fixed low rate failed to consider water as a scarce commodity and hence of economic value. This according to some authors lies at the heart of the problem. ${ }^{1054}$ In an interview with a director of water quality, he pointed out that because of the government approach to water provision and charges, both government and population considered water as a social good which exists in an unlimited quantity. This he said is not only detrimental but unsustainable. There is therefore the need to strike a balance of ensuring that the rate is not unreasonably high and not also economically unsustainable in relation to the cost of provision.

Since in many States public water supply is only available for some few hours daily, it is possible for many areas to be without water for days or weeks. In cities, small towns and villages people purchase from water vendors selling in jerry cans and other small containers. The prices are usually depending on water scarcity at a time, nature of the location, and purchasing power of individuals in an area. The cost of 20 litres can ranges from 10-50 Naira. There is generally no price regulation on products like water. Government agencies such as Consumer Protection Council and Standards Organisation of Nigeria which have mandate to protect individuals from unfair practices of services providers have not been active in this sector. The obligation of the State to protect people from private service providers in this context has not been effective or is generally absent. In the context of general unemployment

${ }^{1054}$ See for example James Winpenny, Managing Water As An Economic Resource (Routledge 1994) 


\section{Chapter Four}

across the country, poverty and socio-economic deprivations, daily spending on water may be too high on especially the unemployed and many civil servants whose monthly salary cannot accommodate their basic necessities. The proportion of respondents not paying for water indicated utilisation of sources not connected to government and private service providers.

In the context of economic accessibility therefore, certain measures need to be put in place to protect consumers from unfair prices, and standards/quality of water. ${ }^{1055}$ Similarly, States must move to protect vulnerable individuals who are relying on the State for the provision of water from being disconnected because of inability to pay. The State must ensure minimum continuous supply especially to this vulnerable class. While policy measures contemplated this situation, implementation seem to be a problem.

In conclusion, two issues must be highlighted regarding water and economic accessibility when the government is the supplier. First, water is under-priced compared to its cost of provision. Both providers and users seemed not to be treating water as a scarce resource which should have components of economic sustainability. As shown by the empirical study, in many instances water seemed to be supplied to users with little or no cost and in most cases at a price less than the cost of treatment and supply. Accessing water from rivers, streams, ponds, wells and boreholes are generally free. While this may be regarded as a social responsibility of the State, sustainability of supply is certainly not guaranteed especially in the context where there is no adequate funding from governments to sustain cost of service delivery.

Second, water is generally considered as a public good which is to be made available to all. ${ }^{1056}$ This is illustrated by unmetered piped water, free construction of wells and boreholes by citizens and free access to rivers, ponds and streams as decisions to consumed more is not accompanied by any financial obligation for payment. While obligation to make water available and accessible exist, the obligation must be balanced with economic consideration.

The consequential effect of the above is that elementary economics suggested that where a commodity is supplied too cheaply, sooner or later such a commodity "need to be rationed by more or less arbitrary means; those who are fortunate to be provided will use the water excessively and wastefully." 1057 Additionally, it had been observed, not treating water as economic good adds to overexpansion of cities as exemplified by Mexico City, Santiago, Beijing, Delhi etc. because users are not charged the actual cost of water used. ${ }^{1058}$ The long term effect of this is, there would be less water to go round.

The next component assessed is information accessibility. This is a necessary procedural right for the realisation and enjoyment of the right to water and sanitation. It encompasses the right to seek, receive and impart information concerning water. Delft Statement on Water Integrity recognises "free and easy public access to relevant, reliable and consistent data and

\footnotetext{
1055 International Commission of Jurists, Maastricht Guidelines on Violations of Economic, Social and Cultural Rights. Para. 15(d).

${ }^{1056}$ The essence of public good is that the good must be made available to everyone and no one should be denied access to it. See James Winpenny, Managing Water As An Economic Resource

${ }^{1057}$ Ibid. P. 15.

${ }^{1058}$ Ibid. P. 17.
} 
Realising the Right to Water and Sanitation in Nigeria

information" as a key requirement of building water integrity and overcoming corruption. ${ }^{1059}$ Judicial decisions have concretised this right in various jurisdictions and individuals can demand duty-bearers to provide information relating to State's or company's activities as they impact on water availability, quality and accessibility etc.

In situation where State is the water provider, information can be accessed only if rightholders are aware of where to access it. It is in this light that this empirical study assessed the following issues:

i. the extent to which Nigerians are aware of the sources of information concerning water and sanitation;

ii. whether rights-holders have ever approached duty-bearers for information concerning water and sanitation; and

iii. the frequency of requests submitted.

These issues are important in assessing whether information is accessible to the population and the extent to which knowledge of the sources could, as part of the larger context, have any impact on the readiness of Nigerians to demand accountability from dutybearers. The first step in empowering disadvantaged individuals is assessing their level of access to information.

In response to the first issue above, about $3 / 5$ of respondents seemed to be aware of sources of information concerning water and sanitation in their areas while $1 / 5$ seemed not to care at all. When responses are cross-tabulated by gender (Table 4.7) males seemed to have a slight advantage.

Concerning the second issue, it appears about $1 / 2$ of the respondents have never bothered to contact duty-bearers for any information concerning access to water and sanitation. When cross-tabulated by gender (Table 4.8), utilisation seemed to be higher on the part of males. This indicated that even among those who are aware of these agencies, a significant proportion has not utilised such knowledge. This is equally an indication of rights-holders' lack of interest in holding duty-bearers accountable.

Third issue was assessed from duty-bearers' perspective in terms of proportion of complaints received from the population consisting of the urban and rural population, civil society organisation, traditional rulers and politicians between 2012 and 2015. Table 4.9 indicated that most complaints emanated from the urban population and to some extent rural population.

Another component of information accessibility is the right to participate in decisionmaking. Legal authorities established the obligation to involve right-holders in matters concerning water and sanitation especially in context where projects are likely to impact on water availability, sufficiency or quality. This can be done through consultation with the local population either directly or through representatives or local administrative structures and civil society organisations. In assessing this component, the empirical study collected data from both duty-bearers and rights-holders to determine whether rights-holders are involved in water and sanitation projects and the extent of their involvement. Table 4.10 contained these responses. There is generally no significant difference between the responses except

${ }^{1059}$ Statement of the First International Water Integrity Forum, 5-7 June 2013, Delft, The Netherlands. 


\section{Chapter Four}

that some duty-bearers seemed to have qualified their responses as indicated in the table. Whether such involvement takes gender into consideration, there appears to be a slight difference in favour of males as shown by Table 4.11. Lastly, regarding the level of involvement, about $1 / 5$ of duty-bearers involve rights-holders as part of decision makers, about $2 / 5$ indicated rights-holders as advisers and about $1 / 5$ as labourers.

When the responses from rights-holders are cross tabulated by gender, there is about $5 \%$ difference between males and females in favour of males as shown by Table 4.9.

Participation of population is important. To a large extent, success of projects depends on the involvement and participation of people with local knowledge and experience and since the projects are meant to serve them. This is more so in the context of Nigeria where due to non-consultation several projects have been abandoned mid-way or where completed, local population do not simply utilise them for reason of non-conformity with needs or local culture. While involvement of local population as workers might bring economic and social benefits to the population, their role as part of decision-makers or their contribution in generating ideas for the successes of such projects is more fundamental.

In terms of likelihood of demanding information from duty-bearers, mechanisms for information accessibility is available in Nigeria but certain measures need to be taken to enlighten the population about their role in ensuring accountability. Relevant State agencies, civil society and non-governmental organisations must play an active role in enlightening the citizens about the existence of these agencies and how they can be accessed. Women for example must be educated to know what it means to be aware of the existence of a right and how information concerning its implementation can be accessed and how such can be used to demand involvement and participation.

As to whether the legal requirement of information accessibility has been complied with, it must be stated that the figures do not show sufficient awareness of the sources of information on water and sanitation and there seems to be limited consultation or involvement by the duty-bearers. It is the duty of the State to enlightens its citizens about their rights and how they can access them and to adequately involve them on matters concerning their rights. The figures have not shown that Nigeria has done well in this context. It must however be mentioned that Nigeria has passed a legislation on freedom of information in 2011 which guarantees access to information except where the release of such information is contrary to public policy. Though the State has a duty to inform its citizens, the citizens equally, especially those who are aware, need to adequately utilise this mechanism to assist themselves in realising their rights and holding duty-bearers accountable to their obligations through accessing the sources, obtaining the relevant information and analysis of the information obtained.

\subsubsection{Non-Discrimination}

According to General Comment 15, discrimination on prohibited grounds must be eliminated in law and in fact in the provision of water and sanitation. From the perspective of duty-bearers and rights-holders, the empirical study investigated whether in the provision of water and sanitation in Nigeria certain individuals, groups or categories of individuals are 
Realising the Right to Water and Sanitation in Nigeria

discriminated against or at least marginalised. The study first considered whether dutybearers and rights-holders are aware of the meanings of 'discrimination' and 'marginalisation' which helps in identifying whether they know any group of people discriminated against or marginalised. Secondly, it ascertained whether awareness of the terms has any impact in the way duty-bearers perform their duties. Thirdly, whether dutybearers, rights-holders and civil society organisations are aware of any group that is discriminated against or at least marginalised in the provision of water and sanitation. Fourthly, the possible reasons for such discrimination or marginalisation ${ }^{1060}$ where it exists and fifthly, what influences duty-bearers' decision in the connection and allocation of water.

On the first issue (awareness of the meaning of the terms), the responses shown in Table 4.12 indicated a significant majority of the respondents understands the meaning of the terms. As to whether this knowledge has impacted on duty-bearers' performance of their duty in response to the second issue, respondents from duty-bearers are evenly divided. On whether there exist a discriminated or marginalised group in the provision of water and sanitation, roughly $1 / 2$ of the respondents from duty-bearers and about $3 / 5$ of respondents from the rightsholders admitted having knowledge of the existence of such groups. Regarding possible reasons advanced in respect of such groups, the responses vary. According to the dutybearers, the reasons for the lack of coverage centred on insufficient funding and resources, population influx in those areas, location or inaccessibility of the areas, technical capacity of duty-bearers, political interference, lack of strict adherence to budgetary provisions, government bureaucracy, and electricity problem. Possible reasons from the rights-holders' perspective are shown in Table 4.13 indicating political consideration, newly constructed area, distance, and accessibility, as possible reasons.

From the civil society perspective, as shown in Table 4.14, economic status of the population was ranked higher than other grounds as the possible reason followed by inaccessibility of the areas and social status of the population.

Regarding what influences duty-bearers in their decision to connect and allocate water to cities and individuals, it needs to be stated that at present, in the States where this empirical study was conducted there is no official policy guiding water connection and allocation. However, from the finding in this research, in their decision-making process concerning areas to be connected, duty-bearers take certain factors into consideration. While there is no exhaustive list of these factors as duty-bearers may be influenced by contextual situations such as affirmative action programmes in favour of disadvantaged areas (if there is any), political promises of elected officials or decision may be part of the larger economic and social development programmes of the State. In certain instances, also, development partners such as UNDP, EU, JICA, DFID etc. involved in some development projects can influence duty-bearers' decisions.

\footnotetext{
${ }^{1060}$ Marginalisation involves the exclusion of a particular group of people from participation mostly because such group(s) cannot be accommodated. Marginalisation becomes discrimination when it is done on any of the prohibited grounds e.g. social status, religion, race, etc.
} 


\section{Chapter Four}

Using GC 15 criteria of non-discrimination ${ }^{1061}$ and violation by States of their obligation to fulfil, ${ }^{1062}$ some factors were identified and used in assessing the extent to which they play a role in water connection and allocation and the extent to which they are in conformity with obligations as defined in GC 15. The factors are distance of the population; number of the population, social status, accessibility of an area, economic status of the population and other factors including political consideration and the area being newly constructed.

While the factors are not exhaustive they can enable identification of a possible trend and the extent to which the States consider or do not consider human rights in their water connection and allocation. Additionally, the assessment will help in identifying possible cases of marginalisation or even discrimination if it falls under any of the prohibited ground such as social or economic status of the people. The empirical indicators of responses from duty-bearers are tabulated in Table 4.15.

It appears the most important or controlling factor among those listed impacting on decision-making is the population of the areas. Areas with high population are more likely to receive authorities' attention on water connection. While this may be justified from utilitarian point of view, there is still an obligation on the State to equally consider less populated areas or at least to provide the required minimum. A possible situation of marginalisation with all the attendant consequences may occur where a population is neglected on the basis of their number.

Distance of areas from water generating plants is the next major consideration. The relative underdevelopment of the country and lack of sufficient infrastructural facilities in place may be a reason behind this. However, while arguments may be advanced to rebut claims of lack of resources, the State may adopt low-cost programmes as required by GC 15 to ensure that these areas are provided for in a way which will ensure that marginalisation does not occur. At present such areas may be regarded as marginalised.

The next after distance is accessibility of an area. Duty-bearers' response indicated remote and isolated areas receive less attention in water connection and allocation decisions. Areas may be considered remote if for example they are inaccessible due to road or geographical conditions. While like distance the claim may be somewhat practically valid but legal obligation willingly assumed suggest that attempts should constantly be made with a view to eliminating the obstacle of ensuing access to water and sanitation. Where no such effort is made, the areas and the people in those locations may be regarded as marginalised.

Presence of economic activities in certain areas equally plays a role. People living in areas with economic activities going on are more likely to be connected with State water services than areas without. This consideration is of course understandable for economic development and revenue generation among others but ensuring equality between individuals irrespective of their location is a human right obligation not susceptible to trade-off.

A possible situation of discrimination exists where a decision to connect people is taken on account of their social and economic status or where political reasons deliberately

\footnotetext{
${ }^{1061}$ UNCESCR, General Comment No. 15: The Right to Water (Arts. 11 and 12 of the Covenant) Para 37 (b)(e) regarding non-discrimination in the provision of access to water facilities and services.

${ }^{1062}$ Ibid. Para 44(c)(iv) regarding violation in respect of inequitable distribution of water facilities and services.
} 
Realising the Right to Water and Sanitation in Nigeria

excluded opposition politician areas. While decisions on these grounds receive less attention than the previous factors, they are by far the most important considerations to be eliminated entirely in decision-making processes. Human rights law considers exclusion of people on the basis of economic or social status as prohibited. There is a consensus in human rights law and a legal obligation under the right to water and obligation that these grounds should not play any role concerning realisation and enjoyment of human rights. Additionally, ability to pay water rates as a factor for water allocation and distribution is inconsistent with the State obligation to provide the basic minimum. While a State will need to recover expenses in the provision of water and sanitation, it could never be accepted that a decision could be taken to deprive water and sanitation to population with inability to pay for such services as reason considering the essential nature of water and sanitation and their requirement in sustaining life and ensuring human dignity. While poverty as indicated by the Colombian Constitutional Court $^{1063}$ is not a defence for refusal to contribute to State public spending, there is still an obligation on the State to provide the basic minimum. In a situation where the majority of the population lives below the poverty line and is struggling to survive on a daily basis, this consideration contributes to making life much harder and not meaningful.

The influence of the above factors calls into account whether duty-bearers consider human rights obligations in their decision-making process. The responses to this question indicated than more than half of duty-bearers considers human rights obligations. This response is however difficult to reconcile with possible cases of marginalisation identified above or even discrimination in the latter case. While deprivation may not be a deliberate State policy, States are to take measures towards ensuring that access to water is guaranteed equally to every citizen in the State.

The possible conclusion to be drawn here is decision-making processes in water connection and allocation by duty-bearers fall short of the legal obligation in human rights law and water and sanitation to ensure equality of access to water for all individuals and removal of all aspects of discrimination in the enjoyment of the right to water and sanitation.

The finding clearly demonstrated the need to adopt certain and urgent measures to enlighten and build the capacity of duty-bearers to appreciate factors necessarily important in considering provision of access to water and sanitation. This validates the relevance of the human right-based approach as it will ensure the removal of all aspects of marginalisation and discrimination, guarantees accountability of duty-bearers and participation of the affected population on matters concerning water and sanitation.

Obligation of non-discrimination is not only a requirement in the provision of access to water and sanitation, it is a general obligation in human rights law embodied in several international legal instruments many of which are binding on Nigeria. These instruments prohibited discrimination in law and in fact if such discrimination is on the basis of any of recognised prohibited grounds. As mentioned above, the grounds are not exhaustive as such the category is open to accommodate other grounds which are not reasonably justifiable in a democratic society.

${ }^{1063}$ See Carolina Murcia Otálora c/ Empresas Públicas de Neiva ESP (Supra) 


\section{Chapter Four}

The obligation of non-discrimination in the context of the right to water and sanitation obliges the States to adopt measures targeted at eliminating practices of discrimination in the provision of access to water and sanitation and specifically having the disadvantaged group in focus. ${ }^{1064}$ From the empirical data, clearly certain individuals and groups are disadvantaged on certain grounds some of which may signify the existence of discrimination. Respondents from the general population, civil society organisations and duty-bearers are unanimous on the existence of some excluded individuals and groups in the provision of water and sanitation services.

While all the parties are aware of the meaning of discrimination, one of the most worrisome findings from the empirical evidence is the admission by half of duty-bearers that awareness of the meaning of discrimination has no relevance in their water connection and allocation. This obviously supported and clarify the findings on the factors guiding water connection and distribution in Nigeria where for example $18.03 \%$ of respondents from dutybearers said they consider economic status of the people very significant, $19.67 \%$ significant, and $14.75 \%$ somewhat significant in their decision to connect individuals and groups to public water supply system. Additionally, $13.11 \%$ of them considers social status very significant, $27.87 \%$ significant and $16.37 \%$ somewhat significant. Provision of access to water and sanitation on the basis of social and economic status only is an indication of discriminatory practices.

Although, possible reasons for the marginalisation vary, of significance is the belief that economic or social class of individuals and political consideration are part of the causes. Although duty-bearers have identified other challenges such as inadequate funding, they have equally pointed out political interference as a reason. Even where only inadequate funding exists as a cause, the obligation of non-discrimination requires equitable distribution of the limited resources in law and in fact to cover all those affected equally. This is more so in the context where more than half of duty-bearers have admitted been aware of individuals and groups not covered by water and sanitation services in their areas of operation. In any case, it had already been addressed that lack of adequate resources may not be cited as justification for discrimination as posited by the Indian Supreme Court in Shri Vardhichand case cited above. A responsible government cannot run away from its responsibility by pleading financial difficulty. If more than $1 / 2$ of duty-bearers are aware of group of people marginalised and budgetary requirements are usually prepared and submitted by them, consideration ought to have been given to this situation.

Reasons such as lack of capacity, lack of strict adherence to budgetary provisions, and electricity only further strengthens the existence of marginalisation. It is usual practice for many years in Nigeria despite the existence of financial regulations, for funds allocated to a particular sector to be unlawfully diverted to another in many cases for political reasons. As such, marginalisation exists in this type of situation not in law but in fact because appropriation laws which might have taken into consideration equitable distribution of resources across sectors and population have been passed into law, but diversion take place

${ }^{1064}$ See UNCESCR, General Comment No. 15: The Right to Water (Arts. 11 and 12 of the Covenant) Para. 37 
Realising the Right to Water and Sanitation in Nigeria

in the context of implementation. This culture is sustained due to lack of capacity to challenge the implementing agency or the offices responsible for such virement. ${ }^{1065}$

\subsubsection{Compliance with Legal Obligations from an Empirical Perspective}

In terms of compliance with its legal obligations under article 2(1) ICESCR, General Comments 3 and 15 of the Committee on ESC rights, Nigeria seems to have several issues which need to be addressed as a matter of priority.

Article 2(1) ICESCR obliges State parties to take steps to the maximum of their resources including through international assistance and cooperation with a view to achieving progressively, the full realisation of the rights enshrined in the Covenant. The obligations are both of conduct and of result including the obligation to ensure that the rights are exercised without discrimination. ${ }^{1066}$ General Comment 3 of the Committee on ESC rights explained the nature of these obligations. The obligation of taking steps is required to be taken within a short time after the Covenant has entered into force with respect to a particular State. "Such steps should be deliberate, concrete and targeted as clearly as possible towards meeting the obligations recognized in the Covenant." 1067 Typical example of the steps to be taken is the adoption of legislative measures which should among others address the problem of discrimination. ${ }^{1068}$ While prohibition of discrimination is a general rule in Nigeria, its implementation by duty-bearers in the context of water connection and allocation is an issue. Additional measures considered appropriate by the Committee include administrative and financial measures. ${ }^{1069}$ In the context of administrative measures, there seems to be compliance by Nigeria in this regard on both human rights in general and water and sanitation in particular. However, the administrative bodies such as the National Human Rights Commission and Public Complaint Commission need to be strengthened to address human rights violations especially relating to ESC rights. There seems to be a lack of compliance in terms of financial measure. Problems of lack of funding, limited release of the allocated funds and delay in their release are actions inconsistent with the obligation under article 2(1) ICESCR. There is equally concern in relation to utilisation of resources and progressive realisation ${ }^{1070}$ of the right to water and sanitation evidenced by the failure to convert other sources of water to an effective use for the benefit of the population and the limited number of the population covered by the State. The limited number of the population covered by the State in water provision for example fell short of the obligation to provide the minimum core. $^{1071}$

\footnotetext{
1065 "Virement is the transfer of budgeted funds from an unspent appropriation category to another, but within one head of appropriation." See Financial Policy Assurance Unit, Guide to Preparing Virements (2011)

${ }^{1066}$ UNCESCR, General Comment No. 3: The Nature of States Parties' Obligations (Art. 2, Para. 1, of the Covenant) Para. 1.

1067 Ibid. Para. 2.

1068 Ibid. Para. 3.

1069 Ibid. Para. 7.

${ }^{1070}$ A State is required to take steps to the maximum of its available resources to ensure progressive realization of the rights in the ICESCR Covenant under article 2(1). See also ibid. Para. 9.

${ }^{1071}$ Ibid. Para. 10.
} 


\section{Chapter Four}

General Comment 15 explains the normative contents of the right to water. ${ }^{1072}$ Some of the entitlements include equal opportunity to enjoy the right to water. ${ }^{1073}$ This seems to be an issue in view of how duty-bearers connect and allocate water to rights-holders which does not seem to be respecting this obligation. While from the empirical study it could generally be said that water is available for the right-holders (notwithstanding the source), the service from the State fell short of the obligation to provide water in sufficient quantity continuously ${ }^{1074}$ as evidenced by the number of right-holders yet to be connected to the service and other factors impacting on continuous supply such as electricity and technical obstacles. Although most respondents have indicated satisfaction with the quality of their water, some respondents from duty bearers have admitted not having facilities for monitoring water quality and pollution. Which means it is possible that the quality of the water may have some issues. The failure to have this facilities in place in an indication that the State has failed to ensure that everything is done to ensure water safety. ${ }^{1075}$ Figures on physical, economic, and information accessibility as indicated by the empirical study generally seemed to be in conformity with the requirement under the General Comment ${ }^{1076}$ except that measures need to be taken to protect the vulnerable population from private service providers who do not seem to have any limitation as to their pricing of water. There are however issues surrounding the obligation of non-discrimination. General Comment 15 requires the elimination of discrimination in the provision of water. ${ }^{1077}$ However, the perception among some rightsholders that political considerations, social and economic status of the population in certain areas underpinned decision to connect them with water is an issue which may fall under discrimination. Additionally, the admission by some respondents from duty-bearers that geographical locations and ability to pay water rates are taken into consideration before decision is made to connect certain areas may come within the prohibited ground of discrimination.

\subsection{Conclusion}

Generally, the key obligations in human rights law are the obligation to respect, protect and fulfil human rights by every State. In terms of the right to water and sanitation, the obligation to respect obliges States to refrain from practices which denies or limits equal access to adequate water and sanitation or interfering in an arbitrary manner with traditional arrangement on water allocation or deliberately polluting water. The obligation to protect requires preventing third parties from interfering with the enjoyment of the right through the adoption of relevant measures to protect the population. The obligation to fulfil obliges States to adopt measures to enable full realisation of the right to water and sanitation.

In Nigeria, generally, the State respect rights of citizens to access and generate water from natural sources: surface and groundwater without much hindrance except where an action is

\footnotetext{
${ }^{1072}$ UNCESCR, General Comment No. 15: The Right to Water (Arts. 11 and 12 of the Covenant) Part II.

${ }^{1073}$ Ibid. Para. 10.

1074 Ibid. Para. 12(a).

1075 Ibid. Para. 12(b).

${ }^{1076}$ Ibid. Para. 12(c)(i)(ii)(iv).

${ }^{1077}$ Ibid. Paras. 12(c)(iii) and 13-16.
} 
Realising the Right to Water and Sanitation in Nigeria

likely to interfere with quality or quantity of water in a particular watercourse. Regarding the obligation to protect, the State has equally adopted several legislations including criminal provisions which prohibit third parties from interfering with access to water or unreasonably extracting water in a manner which jeopardises the people or the environment and prohibition of polluting water or the environment. There are however some inconsistencies in the laws. While some laws restricted what can be done regarding water and environment, some conferred rights which undermined the restriction by permitting what was prohibited. This area needs to be looked at. Additionally, while at the general level these legislations may be adequate in terms of obligation to protect, a critical problem is lack of implementation by the State. Regarding the obligation to fulfil, there is no legislative provision obliging the State to ensure fulfilment of human rights as per as steps to be taken in specific terms except what is contained in the ACHPR. The measures outlining steps to be taken by the State in fulfilling access to water and sanitation are in policy documents which generally do not confer power to litigate. The ICCPR and ICESCR have been ratified by Nigeria but yet to be domesticated as required by the Constitution before they can be applied by domestic courts. Additionally, there are several issues concerning implementation of policies, political will and capacity of implementing agencies.

The legal obligations contained in the right to water and sanitation require that a State must provide water in sufficient quantity, quality and must ensure accessibility both on distance and affordability and the provision must not be on discriminatory basis. Jurisprudence of courts from around the world has established instances where States would be held responsible for failure to meet with their obligation on water and sanitation. There are some policy provisions regarding provision of water in sufficient quantity in Nigeria and several legislative and policy instruments on protecting water quality, accessibility and prohibition of discrimination. However, the problems continue to be lack of political will and capacity to implement and monitor compliance.

Conformity of legislations and policy instruments with Nigeria's obligations is therefore to a varying degree. The three mechanisms of measuring compliance with international legal obligations, have not been of much assistance in terms of ESC rights. Human rights treaty bodies to date have not been able to assess the appropriateness or otherwise of measures adopted by Nigeria on water and sanitation due to failure of the country to submit its periodic reports. Courts jurisprudence concentrated on $\mathrm{CP}$ rights except in few cases concerning environment where some issues of ESC rights were adjudicated. Other quasi-judicial mechanisms seemed also to concentrate on CP rights. Despite these situations however, it is still possible to identify some gaps in this respect. The non-recognition of ESC rights in legislative documents which specifically recognise water and sanitation as human rights is of concern. The non-domestication of ICCPR and ICESCR which would make them to have binding force and applicability at the domestic level, largely left ESC rights at the mercy of the Executive arm. Lack of political will and weak implementation of policy measures further complicated the problem. A combination of these puts doubts into Nigeria's willingness to comply with its international legal obligations.

Regarding the contents of the right to water, empirical figures indicated that Nigeria has not been able to discharge the obligation of making water sufficiently available for personal 


\section{Chapter Four}

and domestic uses. A situation where more than $2 / 3$ of the respondents in the field study are not connected to public water supply system is a clear indication of a severe and acute lack of portable drinking water. This desperate situation forces people to resort to other sources of water of questionable quality and potential risks. The percentage of population relying on boreholes, wells, rivers and wells in the country is alarming.

In terms of water quality, the general perception of the population is that their water is clean. However, no scientific or laboratory test was conducted to confirm this perception. On the contrary, a research ${ }^{1078}$ has pointed out concerns on both surface and groundwater in some areas in Nigeria. Additionally, even where water is provided through State supply system, almost half of duty-bearers in the empirical study have admitted not having any mechanism to monitor water quality or water pollution. On accessibility, water sources are generally physically accessible to the majority of the respondents as most water sources are located within a distance of one kilometre and can be accessed in less than 15 minutes. On economic accessibility, people living close to natural water sources and those with personal boreholes or access water through public boreholes and wells do not pay for water except where purchase is from vendors where quality and affordability issues may be raised. State authorities need to regulate water pricing and quality. Where water is provided by the State, although in some States a uniform rate is used, generally the water rates is affordable.

Regarding information accessibility, while the majority of the respondents from the population are aware of where to access information concerning water and sanitation such awareness does not seem to correlate with demand or request for information from the dutybearers. Few requests/complaints have been submitted to the responsible agencies. Of particular note is the number of respondents who do not know and those who do not care to know about where to obtain information concerning water and sanitation. This could either be due to a lack of confidence in the system or negligence. Either way, it contributes to dutybearers' lack of accountability to the population.

There appears to be limited consultation with relevant stakeholders on projects concerning water and sanitation. Both duty-bearers and rights-holders are unanimous in this regard. Only in few instances, the respondents are involved in decision-making process although in most cases, duty-bearers stated they consult population for advice and equally employ local population as labourers in such projects.

Lastly, a majority of duty-bearers, rights-holders and civil society organisations have admitted the existence of individuals and groups which have never been covered by any water supply system. Although reasons for such non-inclusion vary among the stakeholders, with duty-bearers citing lack of adequate funding and paucity of resources, rights-holders citing political considerations, social and economic status, the recognition that the economic and social status of the people, and political interference are some of the causes suggested that human rights considerations do not seem to influence decision-making process on water and sanitation projects and some discriminatory practices need to be addressed.

In terms of compliance with its legal obligations under article 2(1) ICESCR, General Comment 3 and 9 of the Committee on ESC rights, Nigeria seems to have several issues

${ }^{1078}$ H.O Nwankwoala, 'Localizing the Strategy for Achieving Rural Water Supply and Sanitation in Nigeria' P. 1172. 
Realising the Right to Water and Sanitation in Nigeria

which need to be addressed as a matter of priority. These relate to marginalisation, lack of adequate financial measures, inadequate utilisation of all available resources, provision of the minimum core to the population, issues associated with water connection and allocation, availability and quality of water. 


\section{Chapter Five}

\section{Human Rights Awareness and the Right to Water and Sanitation Among Selected Nigerians}

\section{$5.1 \quad$ Introduction}

7 he empirical figures in the previous chapter regarding the utilisation by respondents of 1 the sources of information concerning water and sanitation in Nigeria have demonstrated a somewhat lack of interest in pushing for positive changes and might have contributed to a lack of accountability of duty-bearers. Additionally, duty-bearers do not seem to be influenced by human rights obligations or to be acting within the international legal requirements in the provision of water and sanitation. These called into question, the extent of respondents' awareness of human rights and the existence of the right to water and sanitation on the one hand and rights-holders' attitude towards human rights claims. This Chapter seeks to assess these issues and the possible reasons behind duty-bearers' inadequacies and rights-holders' attitude. These are considered important in the light of the proposal for the adoption of a human rights-based approach which sought to empower both duty-bearers and rights-holders for the realisation of human rights. The application of the approach has better chance of succeeding if local and national circumstances are assessed and considered. This chapter is therefore a response to research question two which seeks to determine the extent to which duty-bearers and rights-holders from the selected population are aware of the existence of the right to water and sanitation.

\subsection{Composition of the Respondents: Duty-Bearers and Rights-Holders}

It is often said that where there is a right, there is a corresponding obligation. This is specifically true in the context of CP and ESC rights. As such there are people who possess the rights and those whose obligation it is to respect, protect and fulfil the rights. The former is referred to in human rights language as "rights-holders" and the latter, "duty-bearers".

The term duty-bearer connotes an actor who is under an obligation to do or refrain from doing certain acts. In the context of human rights, it is used to refer to any actor who is required to respect, protect and fulfil human rights obligations or refrain from violations of human rights. ${ }^{1079}$ Typically, this refers to States. However, there are certain instances where non-state actors, ${ }^{1080}$ international organisations, private companies etc. can also assume human rights obligations and be properly referred to as duty-bearers. In the context of water and sanitation, duty-bearers refer to authorities directly in charge of providing access to water

\footnotetext{
${ }^{1079}$ See UNICEF, Gender Equality, UN Coherance and You: Glossary See also UNCESCR, General Comment No. 15: The Right to Water (Arts. 11 and 12 of the Covenant) Paras. 18 and 45

${ }^{1080}$ Andrew Clapham, Human Rights Obligations of Non-state Actors (Oxford University Press 2006)
} 
Realising the Right to Water and Sanitation in Nigeria

and sanitation. This refers specifically to the institutions and individuals saddled with the obligation. These institutions have been identified and examined below.

The concept of rights-holder from the perspective of UDHR refers to all human beings, those who have particular entitlements from duty-bearers. ${ }^{1081}$ In water and sanitation, rightsholders are all those who are entitled from a human rights perspective to access sufficient, safe, accessible and affordable water and sanitation. ${ }^{1082}$ In the Nigerian context therefore, these refer to the general population. Respondents that participated in this study consisted of the following:

\subsubsection{Duty-Bearers}

Relevant duty-bearers from the FMWR, States Ministry of Water Resources and Water Boards (consisting of urban and rural water supply departments) in the seven selected States participated in the empirical study. The demographics of the participants were divided in terms of gender, age-group, education, administrative level and duration of service at the institution. (See Table 5.1). A total of 65 responses were collected. The distribution of respondents by gender indicated dominance of males. By age group, 41-50 accounted for about half of the respondents. By educational qualification, those with bachelor's degree are the majority. By administrative level, all respondents are either senior or management staff of their respective institutions with senior staff as the majority. By duration at their institutions, those with minimum of seven years are the significant majority.

\subsubsection{Rights-Holders}

As indicated before, a total of 777 responses from the general population were received. The participants consisted of the population in rural and urban areas with demographics centred on gender, age-group, marital status, religious belief, education and occupation. As shown in Table 5.1, the majority of the respondents by gender are males; by age-group, those with 25-40 years; by marital status they are almost evenly distributed between single and married; by religious belief, Muslims constituted the majority; by educational qualifications, holders of secondary certificate; and by occupation, students of tertiary institutions.

\subsection{Assessment of Human Rights Awareness and the Existence of the Right to Water and Sanitation among Selected Duty-Bearers}

The nexus between water, sanitation and human rights suggested the need for dutybearers in charge of water and sanitation to have some knowledge of human rights relevant to their duties and specifically the existence of the right to water and sanitation. To assess this, it is useful to examine whether human rights trainings, seminars or conferences are organised by the respective institutions to equip staff with technical knowledge (human rights) relevant to their duties. If such exist, whether the trainings have had any impact in the way the respondents discharge their duties. Additionally, whether the respondents have heard

\footnotetext{
${ }^{1081}$ UNICEF, Gender Equality, UN Coherance and You: Glossary

${ }^{1082}$ UNCESCR, General Comment No. 15: The Right to Water (Arts. 11 and 12 of the Covenant) Para. 2
} 
of the existence of the right to water and sanitation and if they have, whether such awareness has any impact on their duty.

From their responses, only one out of 10 respondents has received human rights trainings. Even among those who received the training, only about $20 \%$ of them have indicated that the training had impacted on their duty. However, about $4 / 5$ of respondents are aware of the existence of the right to water and sanitation and about $1 / 2$ of those who are aware have indicated that such awareness had impacted on them.

What these figures suggest is that authorities in these States do not seem to be interested in providing human rights knowledge to their staff. Even where such training is provided, it seems not to be tailored to the manner in which it will enable the recipients to discharge their responsibilities from human rights perspective. Although there appears to be awareness of the recognition of the right to water and sanitation, the institutions do not appear to have taken significant steps toward empowering duty-bearers to appreciate the implication of such recognition. Staff are not exposed to human rights trainings capable of enabling them to understand the extent of their obligations and ways of ensuring their observance.

Provision of access to water and sanitation as a human right requires that those who plan or decide on water management, allocation and distribution receive proper training in a manner that enables the pursuit of appropriate policies and plans to discharge their responsibilities. Although it is commendable that significant majority is aware of the right to water and sanitation but such awareness without fully understanding the extent of corresponding obligation will not make any meaningful positive impact to the right-holders.

\subsection{Assessment of Human Rights Awareness and the Existence of the Right to Water and Sanitation among Selected Rights-Holders in Nigeria}

It is often said that knowledge is power. However, the close relationship between the two is not always appreciated or acknowledged. ${ }^{1083}$ The first step in the empowerment of a disadvantaged population is through awareness creation. When knowledge is acquired, to be beneficial it must be effectively utilised. This research proposes the adoption of a human rights-based approach, however, its successful application to a large extent among others, depends on the extent to which rights-holders are aware of what human rights entails, how to claim the rights and willingness to assert claim. Similar to assessment of awareness of human rights on the part of duty-bearers, this research also assesses whether human rights and the right to water and sanitation are known to the selected rights-holders.

The responses indicated that, generally the language of human rights is known in the locations of the study and across different genders, age-groups, ${ }^{1084}$ educational qualifications and occupations with slight variations (see Table 5.2). Additionally, $3 / 4$ of the respondents seemed to be aware of the existence of the right to water of sanitation. In the context of human rights discourse and the adoption of a human rights-based approach this is important as it

\footnotetext{
${ }^{1083}$ Gill Shepherd (ed), Ecosystem Approach: Learning from Experience

${ }^{1084}$ The proportion of those above 51 years of age is however lower compared to the rest.
} 
Realising the Right to Water and Sanitation in Nigeria

would provide a good basis upon which awareness creation and capacity-building can build on.

Although significant number of the respondent is aware of the existence of the right to water and sanitation, it must be stated that this does not suggest that the respondents are determined or are willing to demand for the realisation of the right. From the Nigerian context and arguably many other developing countries, there is a gap between knowledge and determination by the population to put the knowledge into use through meaningful ways. The extent to which respondents are likely to assert a legal claim in water and sanitation will be examined later.

Having examined the proportion of respondents who are aware of the existence of the right to water and sanitation, the next section examined the relative position of this right in the wider context of some critical ESC rights specifically in relations to likelihood of asserting legal claim in court and whether respondents are aware of how to claim ESC rights. This is intended to assess, among others, how respondents view the right to water and sanitation and some of the obstacles which are hampering ESC rights claims in Nigeria. It will also assist in tailoring the appropriate awareness creation to be provided to the population.

\subsection{The Human Right to Water and Sanitation in Relationship to Other Critical ESC Rights and Likelihood of Asserting Legal Claim}

As previously mentioned, the right to water and sanitation was linked to the rights to health and adequate standard of living all of which are ESC rights. With the recognition of water and sanitation by the UN as (arguably) a right on its own, a question arose as to whether water and sanitation can be claimed independently or need to be connected to the rights from which the rights to water and sanitation were derived from. This is important especially in States where the right has not been recognised in a legally enforceable legislation like Nigeria. Additionally, examining the extent to which rights-holders are aware of how to claim ESC rights is important in determining the appropriate level of intervention for the purposes of awareness creation and capacity building which are relevant in a human rights-based approach. Since, asserting or demanding legal rights requires knowledge of both substantive rights and procedural steps, it needs to be established whether those in whose benefits the rights exist are aware of how to claim them, legally; whether there is likelihood that such claim may be asserted; and whether there is awareness of the duty-bearers against whom claims can be made. In this section therefore, four issues will be assessed:

1. Relative position of the right to water and sanitation in the context of other ESC right regarding likelihood of asserting legal claims by the respondents;

2. Awareness of the respondents of how to claim ESC rights in Nigeria (of which water and sanitation is part of), if the rights are denied. This is in the light of the position of Nigerian constitution on justiciability of ESC rights. Data will equally be segregated by gender, age-group, education level and occupation;

3. Likelihood that respondents will assert legal claim if the right to water and sanitation is recognised in a legally enforceable domestic instrument. Responses will be also 


\section{Chapter Five}

segregated by gender, age group, marital status, religious belief, education and occupation; and

4. Respondents perception of who has the duty to provide water and sanitation in Nigeria.

On the first issue, critical ESC rights considered in this context are the rights to food, the right to housing, the right to water, the right to clean environment, the right to work, and the right to health. Responses in Table 5.3 showed that right to health was ranked higher and is considered more important on the scale of likelihood of asserting legal claim. This was followed by the right to food, the right to water, the right to housing, the right to clean environment and the right to work respectively. The right to water is ranked third most important ESC rights by the respondents. Figure 5.1 has illustrated this relative position. The finding suggested that, in order to prompt more response and assertiveness of the respondents, in empowering them to claim the right to water it would receive more attention and possibly action, if the right is connected to the right to health.

The ranking does not however, informed us about whether laying legal claim is definite when the rights are denied. Asserting legal claims, especially through justice system mechanisms like courts or ombudsman, is circumscribed by internal and external factors including legal, economic, social, cultural and even personal circumstances. For example, introvert people and those that abhor publicity are less likely to utilise a medium capable of bringing their human rights issues to the public domain. Additionally, in traditional African societies, especially within the Hausa community in northern Nigeria where extended family system operates, members of extended family are likely to influence individuals' choice of litigating against others. In some societies, cultural factors such as those which despise litigating against the elders or persons in recognised authority could impact on readiness to litigate. The influence level of some of these factors will be examined later.

On the second issue regarding awareness on how to claim ESC rights if the rights are denied, from information contained in Table 5.4 majority of respondents comprising of $72.87 \%$ are aware of how to claim ESC rights. When segregated to examine the relativity of this awareness, the table indicated that by gender males appear to be more aware of how to claim ESC rights compared to women. In terms of groups, those within the ages of 41-50 have the highest percentage with $78.99 \%$. Consistent with awareness of human rights, awareness of how to claim ESC rights increases with additional educational qualification except between diploma and bachelor holders where the percentage dropped slightly. From postgraduate diploma to masters and $\mathrm{PhD}$, awareness increases progressively. The possible justification for the decline could be that at this stage, those with bachelor's degrees are more exposed to the intricacies, difficulties and challenges involved in ESC rights claim thereby creating some confusion or lack of clarity to the individuals involved. Retirees ranked higher in terms of occupation followed by civil servants then students of higher institutions. Farmers in the rural areas accounted for the least percentage with $35.48 \%$ and having the highest number of those who do not care to know.

Overall, the figures demonstrated that significant number of respondent seemed to be aware. However, as indicated in Table 5.3, about $20 \%$ of the respondent are not aware. While this may be negligible, the figure is statistically significant if it is to be generalised and 
Realising the Right to Water and Sanitation in Nigeria

applied to the general population. Similarly, while acquiring knowledge may be a personal choice, it is equally of concern the percentage of respondent who do not care to know. The implication is duty-bearers may be tacitly encouraged to not also care to account.

It must equally be mentioned that positive response of awareness does not suggest that rights-holders have technical knowledge about the legal frameworks governing ESC rights or the technicalities involved in ESC rights litigation. The response merely indicated, according to rights-holders, accessing normal courts for litigation.

On the third issue relating to the likelihood that respondents will litigate if water and sanitation are recognised as human rights in an enforceable instrument in Nigeria, about $65 \%$ of the respondents are likely to litigate (if the three levels of likelihood are combined) see (Table 5.5 and Figure 5.3). Combining the three levels of likely: somewhat likely, likely and very likely is done in order to assess likelihood as a whole. However, it is recognised that 'very likely' indicates a significant possibility than 'likely' which in turn also is more probable than 'somewhat likely'. In certain instances, 'very likely' responses have been highlighted in order to show where greater likelihood exist.

The data demonstrated that on the general level, more than half of the population indicated the likelihood of litigating for the realisation of the right to water and sanitation if the right is recognised in a legally binding document in Nigeria. Likelihood was further segregated by gender, age group, marital status, religious belief, education and occupation.

By gender, men and women seem to be on the same level regarding likelihood of litigating for the right to water and sanitation. There appears to be no significant difference between men and women when the figures are segregated except when it is intended to show which among the two the 'very likely' level is greater where men have $4 \%$ difference. This suggested that while it is possible for the two to ligate at the general level, men are more likely to do than women which in the context of northern Nigeria is understandable because of the position of women. However, of notice is that men are more on the side of undecided by $2.5 \%$ than women. This figure can swing either side. If it tilts towards the three levels of likely, the difference between men and women will be noticeably higher but if it goes to the side of unlikely, the position of men and women regarding possibility remains.

By age-group, rights-holders between the ages of 41-50 are more likely to litigate than the rest of the groups. This is then followed by rights-holders within the ages of 25-40 and 18-24. The last group is that of 51+. The group with the lowest figure on the scale of very unlikely is that of 25-40 which incidentally also has the highest of those who are undecided. Under age group category, possibility increases with age until the age of 50 when it begins to decline. The possibility, as the statistics show is higher among those within the age of 41 - 50 years. This age group is generally considered in Islam to be when a human being is functioning in his full capacity. The second group is that of 25-40 years. According to CIA, ${ }^{1085} 30.65 \%$ of Nigerians are within the age group of $25-54$. If the two age groups (2540 and 41-50) are combined the average possibility response will be $68.6 \%$. While this figure may appear impressive in pushing the duty-bearers to action, it must be noted that likelihood does not connote actual reality especially when compared with the actual

${ }^{1085}$ Central Intelligence Agency, 'The World Factbook' 


\section{Chapter Five}

demands/complaints on water and sanitation submitted by the respondents to the dutybearers. This issue is examined in the section below.

By marital status, it is to investigate the extent to which additional responsibility created by marital status could impact on likelihood of litigating for the realisation of a right. The responses indicated that by about $11 \%$, married respondents are more likely to litigate for water and sanitation than respondents who are single. There is equally about $2 \%$ difference between them on the scale of those who are very unlikely to litigate. By about $8 \%$, single respondents are more undecided than married respondents. Marital responsibilities seem to impact on likelihood for litigating for realising access to water and sanitation. The more than $10 \%$ difference between married respondents and respondents who are single and married being more resolved in litigating than respondents who are indicated the correlation between marital responsibilities and the right to water and sanitation claims.

By religious belief, Christians are more likely to litigate than Muslim. Whether there is any relationship between religious belief and litigation will be examined later.

By educational qualifications, $\mathrm{PhD}$ holders are more likely to litigate than the rest of the groups. The group is followed by holders of postgraduate diploma, master's certificate, bachelor degree, secondary certificate, diploma, and lastly primary certificate. By educational qualifications, possibility increases with additional qualifications with a slight difference in the case of holders of master's degree. The implication is that highly educated people are more likely to litigate for their rights than less educated. The challenge in the Nigerian context however, is that, the national adult literacy level is $59.6 \%$ with diverse variation among the States ranging from $92 \%$ in Lagos to $14.5 \%$ in Borno. ${ }^{1086}$ Nigeria accounts for about $10 \%$ of the world's out-of-school-children. ${ }^{1087}$ At the rural level, literacy rate is even low with average standing at $48.7 \% .{ }^{1088}$ By the Word Bank data, as at 2015, $52.2 \%$ of the Nigerian population live in the rural areas. ${ }^{1089}$ This suggested that very few adults have higher academic qualifications in Nigeria with Northern Nigeria at a significant disadvantage. The corollary is that few individuals could be able to effectively claim their rights. This underscores the advocacy role of human rights organisations for the right to education which appears to be a vehicle for the claim of all other rights.

Segregating responses by occupation, civil servants have the highest percentage of those who are more likely to litigate. The group is followed by the private sector employees, retired individuals, Self-employed, housewives, students then farmers. Conversely, farmers have the highest percentage of those who are 'very unlikely' to litigate and retirees have the lowest. Although the percentage of likelihood is higher with civil servants, when compared to the percentage of people in the civil service, the number of people is significantly low. As at December 2015, the total number of civil servants at the Federal level was 89, 511. ${ }^{1090}$ At the

\footnotetext{
${ }^{1086}$ UNESCO, High level International Round Table on Literacy: National Literacy Action Plan for 2012 - 2015 , Nigeria (Reaching the 2015 Literacy Target: Delivering on the Promise, 6-7 September, 2012)

1087 Ibid.

1088 Ibid.

1089 The World Bank, 'Rural Population (\% of Total Population)' 2016) <http://data.worldbank.org/indicator/SP.RUR.TOTL.ZS> accessed 3rd January, 2017

${ }^{1090}$ This was the figure released by the Director General of Bureau of Public Civil Service Dr Joe Abah on 11 December 2015.
} 
Realising the Right to Water and Sanitation in Nigeria

States level, the figure is a fraction of the Federal. With $42.79 \%$ of the total population within the age group of $0-14,{ }^{1091}$ which effectively takes them out of the civil service group or any type of occupation except schooling, and the percentage of those in the civil service being low, it puts the figure of the civil servants likely to litigate significantly low. The National Bureau of Statistics does not have statistics of the number of private sector employees. At the rural level, majority of the population are farmers, self-employed or unemployed. As at the end of third quarter of 2016, the National Bureau of Statistics indicated that among the 108.03 million economically active population or working age population in Nigeria, there are currently $13.9 \%$ of unemployed people in the country.

Recognising that the above likelihood statistics was on the basis of combination of three levels of possibility, to make it a bit more certain, if 'somewhat likely' level is eliminated the statistics will become lower and taking other factors likely to influence litigation or demand for human rights realisation into consideration, the number of those likely to demand respect or realisation of their rights from duty-bearers will be further reduced. This takes away the possibility of putting the much-needed pressure on the duty-bearers to discharge their obligations.

On the fourth issue regarding awareness of the respondents on who has the duty to provide water and sanitation, Figure 5.3 demonstrated that a large majority of respondents (89\%) identified government as the duty-bearer, the rest either identifying themselves, private service providers or water vendors.

\subsection{Human Rights Complaints and Claims}

The previous section has largely focussed on personal issues (subjective criteria) such as awareness, likelihood, and perception. In this section, attitudes of respondents regarding human rights claims/complaints will be assessed (objective criteria). The aim is to assess if there is any material difference between the subjective and objectives issues. Assessment in this section will also help in drawing additional insights on whether there exists passiveness on the part of rights-holders in holding duty-bearers accountable and the kind of intervention required to remedy the situation. It is often said that the price of freedom is constant vigilance. Human rights can best be realised if rights-holders are holding duty-bearers accountable. Accountability and participation are important principles of a human rights-based approach. Accountability can be promoted if rights-holders are playing their roles of monitoring and demanding actions and explanations from the duty-bearers.

Furthermore, information in this section will shed light on not only the existing dispute resolution or grievance complaint mechanisms use by rights-holders but also their most trusted one with a view to recommending how such complaint mechanism can be utilised in facilitating accountability and in securing access to water and sanitation. Additionally, it will assist, possibly in gauging peoples' confidence level in the formal and informal mechanisms in their disputes or grievance resolution. Assessment was based on the data collected from the empirical field research in this study. In examining the issue, various complaints

${ }^{1091}$ UNESCO, High level International Round Table on Literacy: National Literacy Action Plan for 2012 - 2015, Nigeria 


\section{Chapter Five}

mechanisms in Nigeria including those on water and sanitation and their rates of utilisation have been highlighted. The section will therefore examine three issues, namely:

1. General complaint mechanisms and respondents' rate of utilisation;

2. Water and sanitation complaint mechanisms in Nigeria and respondents' rate of utilisation;

3. Attitude of respondents regarding complaints about water and sanitation and will draw conclusion between the subjective issues in section 5.5 and objective issues in this section.

On the first issue, there are various formal and informal complaints mechanisms in Nigeria, however, the under-listed are the most commonly utilised by the respondents. Consistently, the grading relied on the three often utilised levels: 'fairly often', 'very often' and 'always' in order to concentrate more on the most utilised. Where necessary, the extent to which a particular mechanism has never been utilised by rights-holders will be pointed out. Table 5.6 contained tabulation of rights-holders' responses. From the data, the most frequently utilised mechanism is the media followed by traditional rulers, civil society organisations, the police, human rights institutions, and lastly the courts.

Respondents seemed more comfortable approaching the media to air their complaints over and above any other complaint mechanism. This was considered the most effective means of having their complaints heard and communicated to the relevant offices concerned which in certain instances were followed by response or action from duty-bearers. In many States, the most utilised media channel is the radio especially by people from the rural areas, through which complaints are aired. In the cities, rights-holders in addition to radio stations also utilised televisions and print media. Social media in the recent past is equally playing a fundamental role through which complaints or problems are shared with the public and which equally have been generating actions from duty-bearers.

In rural areas, the most accessible complaint mechanism is the traditional rulers or traditional title holders. These individuals command a degree of respect and play important roles in the maintenance of peace and security and respect for human rights. Government offices may be far away from certain villages, as such traditional rulers are considered mechanisms through which complaints are conveyed.

The Civil Society Organisations (CSOs) is equally trusted by many individuals. These organisations have links with the population and depending on their areas of operations and programmes, also work with the population. Through these interactions, the concerns of the population are communicated to the CSOs which equally communicate to the appropriate authorities and in some cases, work towards alleviating those concerns depending on mandate, capacity and resources.

The Police is largely utilised in disputes settlement, human rights violation, violence against person or property and pecuniary claims. Human rights institutions such as the NHRC, PCC, Human Rights Committees of National and States assemblies are used in channelling human rights complaints of all kinds such as unfair dismissal from work, illegal or unlawful eviction, and compensation claims etc. The courts are the last in the hierarchy of complaints and redress mechanisms commonly utilised by Nigerians especially in the North. Courts are known to be bureaucratic, expensive (due to filing and lawyers' fees) and not 
Realising the Right to Water and Sanitation in Nigeria

always time effective. Except in extreme situations, and where other avenues do not seem effective, average northerner hardly prosecute claims in courts.

On the second issue regarding complaints mechanisms specific to water and sanitation, those listed in Table 5.7 are the mechanisms identified through interactions with some rightsholders during the empirical study and incorporated in the questionnaire to determine their rate of utilisation. Generally, peoples' complaints or concerns on water and sanitation are channelled through some or all the following mechanisms: political representatives; CSOs; traditional rulers; and courts. Table 5.7 indicated that while about $2 / 5$ of the respondents have never used any of these mechanisms for water and sanitation, politicians are the most utilised. The second mechanism is the CSOs, third is traditional rulers and lastly the court.

On the third issue relating to attitude of respondents in relations to water and sanitation claim, two questions were utilised: one addressed to the rights-holders and another one to the duty-bearers. from the rights-holders perspective, respondents were requested to state if they have ever approached any government agency regarding water and sanitation and from the duty-bearers perspective, respondents were requested to indicate the frequency of complaints on water and sanitation received from rights-holders over a period of two years. The responses indicated that more than half of the respondents have never submitted any complaints to duty-bearers. It would be recalled that Table 4.8 above has indicated rate of complaints received by respondents from duty-bearers. The table has shown that most of the complaints received emanated from the urban population in a more frequent manner followed by politicians. Local population seemed to have approached duty-bearers only in somewhat frequent manner. While this seemed to correlate with likelihood that water and sanitation may be claimed by duty-bearers, empirical indicators in Table 5.7 do not suggest that such claims would be asserted through courts. Complaints are generally through politicians and civil society organisations. There is no single situation where respondents in this research have used court to specifically make a claim on water and sanitation. The $0.52 \%$ relating to courts in is connection to claims where water was part of the issues (as clarified by the respondents) and not specifically on requiring the court to intervene between rights-holders and duty-bearers in the provision of water. Admittedly, water and sanitation are yet to be recognised as human rights in Nigeria however, rights-holders have identified government as the major duty-bearer in providing access to water and sanitation. It will therefore be expected that proactive measures are taken by the respondents to hold government accountable. No doubt, politicians and traditional leaders play an important role in connecting their communities with relevant duty-bearers on socio-economic and development issues. However, they do not have the necessary authority to compel performance of duties. As such their level of influence is largely limited.

To draw conclusion therefore, at the general level, rather than claiming through courts, respondents seemed more comfortable channelling their complaints and concerns through media outlets than direct contacts with government authorities. While there is nothing wrong in using the media, the problem is media outlets also have their interests and challenges. In Nigeria, government's own media is hardly critical of government's actions. Additionally, opinions which are critical of government's interest are hardly aired. It is to be noted that there is growing rate of private media outlets in the recent past, however, these are equally 


\section{Chapter Five |}

shaped by politics and interests of their proprietors though in certain instances views on government's failures have been broadcasted. In developing countries like Nigeria, the capacity of CSOs is limited in many respects. They are challenged by human and material resources. There is therefore the need to tailor awareness creation on the role and relevance of courts in human rights claims. The population need to be aware of the importance of this mechanism and how they can effectively utilise it in the realisation of human rights including on water and sanitation.

\subsection{Influence of Some Formal and Informal Factors on Human Rights Claims}

The general human rights environment in Nigeria and human rights claims as discussed in chapter three and indicators of claims through courts or even demand for information by rights-holders in the preceding section, indicated evidence of passivity on the part of the population especially in relations to ESC rights. This is more so when viewed from the context that there is wide spread deprivation of many basic rights. This raises the question as to what could have been the possible reasons of the passivity of the population. Based on literatures, ${ }^{1092}$ prior discussion with some rights-holders and CSOs, it was observed that some people do not feel comfortable approaching courts and also that other formal and informal obstacles such as money (poverty), family influence, religious belief, bureaucracy, distance, traditional rulers and culture and traditions could be having some influence on rights-holder. In this section, therefore two issues will be investigated, namely:

1. The extent to which respondents are comfortable in approaching courts for human rights claims. Responses will be segregated by gender, age-group, marital status, religious belief, education, and occupation to determine possible variation in terms of these grounds;

2. The influence of culture and tradition, religious belief, family, financial situation, traditional rulers, government bureaucracy and distance from relevant government agencies in human rights claims through courts.

On the first issue, Table 5.8 contained the responses first at the general level and crosstabulated as mentioned above. At the general level, the data shows that roughly $3 / 5$ of respondents said they feel comfortable. Though the response rate is somewhat high, but the rate of those not comfortable is also an indicator of important number of people not willing to be assertive in human rights claims. This indicated one of the challenges in human rights protection, promotion and fulfilment. Rights-holders have fundamental roles to play in ensuring that their rights are respected and where necessary, promoted and fulfilled. In the context where rights are deprived, rights-holders must be willing to be assertive and vigilant. Passiveness of rights-holders is an obstacle to the realisation of human rights, whatever the category of such rights. It should however be noted that level of comfortability is much higher in the South than in the North as most of human rights cases decided in Nigeria were litigated

\footnotetext{
${ }^{1092}$ See for example Nlerum S. Okogbule, 'Access to Justice and Human Rights Protection in Nigeria: Problems and Prospects' (2005) 2 Sur Revista Internacional de Direitos Humanos 100; Eva Brems and Charles Olufemi Adekoya, 'Human Rights Enforcement by People Living in Poverty: Access to Justice in Nigeria' (2010) 54 Journal of African Law 258; Jacob Abiodun Dada, 'Impediments to Human Rights Protection in Nigeria '; The Observatory - Front Line, NIGERIA: Defending Human Rights: Not Everywhere Not Every Right, 2010)
} 
Realising the Right to Water and Sanitation in Nigeria

by the Southerners this may be due to cultural and attitudinal differences between the regions. The Hausas traditionally prefer to settle their differences through the traditional system of dispute resolution rather than formal litigation. ${ }^{1093}$

By gender, the percentage of males is about $10 \%$ higher than females. Notwithstanding that there is a slight difference between men and women on awareness of the meaning of human rights in favour of women, women feel less comfortable litigating than men. Except women who are household leaders, elderly and spinsters, majority of women live under the control of men: parents, husbands or children. This circumscribed the exercise of choice in public by majority of women in northern Nigeria. Additionally, cultural factor significantly impacts on women's freedom to litigate. Among the Hausa community, litigation even by men is generally abhorred because of its attendant effects such as public scrutiny, perception and characterisation which may impact on reputation and interest of family as a whole. Additionally, litigation tends to destroy trust, love, respect and confidence between the parties thereby increasing suspicion and bitterness. ${ }^{1094}$ Generally Hausa people though in certain cases can have recourse to formal and sharia courts as a last resort, they prefer "sulh" (mediation, reconciliation or arbitration) in settling their disputes. ${ }^{1095}$ Except on matrimonial issues, ${ }^{1096}$ women hardly institute legal actions involving disputes or conflict with authorities.

By age group, there is no significant difference noted. Although the percentage of those within the ages of 41-50 is slightly higher with $64.96 \%$ and the age group of 51+ with the lowest having $59.26 \%$, the difference is not far beyond the margin of error. By age-group, comfortability increases with age until the age of 51 where then it begins to drop. The decline may perhaps be associated with lack of convenience associated with litigation. In a country where the life expectancy rate is $53.4,{ }^{1097}$ due to demand of time, litigation by individuals above 51 may be a challenge. By age structure, the second largest group in Nigeria is within the ages of 25-54 years. This group constituted $30.65 \%$ of the total population. ${ }^{1098}$ Within this category, the statistics demonstrated that more than half indicated they are comfortable litigating human rights claims.

By marital status, widows and widowers seemed more comfortable. This may be due the limited family control over the group. Except young widows/widowers, this category of

\footnotetext{
${ }^{1093}$ This is done through the use of traditional and religious leaders from the ward to the state level. See for example I.O. Albert and others, Informal Channels for Conflict Resolution in Ibadan, Nigeria (Institut français de recherche en Afrique 2013) Chap. 2, Paras. 44-46. The Hausa people have been described as "conservative, reserved, calculating, and feudalistic ... predominantly Muslim with uncritical loyalty to the emirs who believe that their authority was divine ... was antagonistic to the embrace of modernity, modernization, scientific revolution and Western ideas including education." (see Monica Emmanuel, Federalism in Nigeria: Between Divisions in Conflict and Stability in Diversity (Globethicsnet Theses, Globethics.net 2016) P. 136.

${ }^{1094}$ Monica Emmanuel, Federalism in Nigeria: Between Divisions in Conflict and Stability in Diversity. P. 67.

1095 An empirical study conducted in Jigawa State (one of the Hausa controlled States) found that more people use the "sulh forum much more extensively than the courts". The Study further found that "majority of the participants were afraid of the courts and never used them, and they had negative impressions about the formal forum, based on the perception that courts wasted time, were expensive and susceptible to manipulation by the rich." see Ali Ahmad, Jummai Audi and Ibrahim N. Sada, Resolution of Civil Disputes in Jigawa State (Nigeria) (Access to Justice Programme - Research Report, June-August 2003) Available on the internet at <http://www.gsdrc.org/docs/open/ssaj131.pdf> accessed 27 July, 2017

${ }^{1096}$ Ibid. Courts in most cases serve as a last resort where the issue failed to be settled through family mediation.

${ }^{1097}$ Central Intelligence Agency, 'The World Factbook'

1098 Ibid.
} 


\section{Chapter Five |}

individuals is less likely to be dominated by their parents or relatives. As such, their degree of freedom may be higher than the married or single individuals. Comfortability is less among the married individuals as the decision is generally, not that of one of the couples. Consultation may be required between the couples and possibly, interest of children may equally need to be considered. Similar to married couples, single individuals may be under parental or family influence when question dealing with litigation arises.

There is no significant difference in terms of religious belief. It had been mentioned before that Muslims constitute at least $50 \%$ of Nigeria' population. ${ }^{1099}$ More than $80 \%$ of the population in the North are Muslims and more than $90 \%$ in the North-West. Nigeria has had and continues to have series of ethnic and religious crises. These crises have impacted on the relationship between different religious sects and organisations in the country. Significantly, it had created situations of suspicion and mistrust between the majority Muslims and minority Christians not only in the North but throughout Nigeria. The less comfortable position of Christians in the North in asserting claims for human rights in Muslims' dominated community where leadership is largely by Muslims may hence be understood.

By education level, consistent with previous findings on the impact of educational qualifications, comfortability equally increases with additional qualification except in the case of holders of bachelor certificates where a slight decline is noticeable. The figure then rises on holders of postgraduate diploma and slightly fall on Masters and significantly lower among the holders of $\mathrm{PhD}$ who appeared to have a percentage less than that of primary certificate holders. Comfortability increases with educational qualifications except in the case of Bachelor and PhD holders. Explanation on bachelor certificate holders remain the same while in the case of $\mathrm{PhD}$ holders, the decline could be on the basis of the fewer number of $\mathrm{PhD}$ holders interviewed. It is likely that if the number increases there will be an increase in the percentage of those who feel more comfortable asserting legal claims.

In term of occupation, there is also consistency. The table shows that civil servants feel more comfortable followed by the retirees, those working for the private sector, students, the unemployed, self-employed, housewives, and lastly farmers. In the case of civil servants, it may be connected to the advantage they enjoy in being exposed to the law and it's working. Conversely, farmers in the rural areas are the least among the groups which may be due to the disadvantage they experienced compared to the rest of the groups in terms of education and information.

Observable from the figures in relations to awareness of human rights, how to claim ESC rights and comfortability, the statistics indicated that about $88 \%$ of the population indicated they are aware of the meaning of human rights, about $73 \%$ are aware of how to claim ESC rights, about $75 \%$ are actually aware of the existence of the right to water and sanitation, about $89 \%$ are aware that it is the responsibility of government to provide access to water and sanitation, only $62 \%$ feel comfortable asserting or seeking for legal redress in court when their rights are violated or denied. There appears to be a slope from awareness of human rights to awareness of how to claim and to comfortability in asserting a legal claim in courts (see Figure 5.4). This is reflected in the statistics above. 
Realising the Right to Water and Sanitation in Nigeria

The slope not only provided a clue as to why there are limited number of cases on human rights claims but also highlighted some of the challenges associated with personal interest and convenience in human rights promotion. ${ }^{1100}$ Additionally, it can further be seen that, in the Nigerian situation it is not necessarily true that awareness of the existence of right could automatically catapult to legal claims when such rights are deprived or violated. The correlation if any, is not always strong.

On the second issue, on a scale of 1-7 from 'very unlikely' to 'very likely', the analysis here combined the three categories of 'likely' (somewhat likely, likely and very likely) to identify the percentage of respondents that feels the identified factors could influence their decision in litigating. Table 5.9 demonstrated that financial situation of rights-holders occupies the highest position as being likely to influence respondents' decision not to litigate human rights claims. Family influence came second, religious belief is third, government bureaucracy is fourth, distance is the fifth, influence of traditional rulers is the sixth and lastly, the influence of culture and tradition. See Figure 5.5 for graphical illustration.

From the above, although these factors have varying degree of influence on decisions to litigate it may be said that they are contributing factors to low level of human rights claim. The factors can be grouped into the following: Poverty (finance); Religious and cultural practices (religious belief, culture and tradition, traditional rulers); Institutional (bureaucracy); Personal (comfortability, family); and Environmental (distance).

\subsection{Conclusions}

There is sufficient awareness of human rights and the existence of the human right to water and sanitation among the respondents in the locations of the empirical study. There is however the need for capacity building among the duty-bearers on human rights to appreciate the extent of their obligations. Similarly, a good proportion of the respondents among the rights-holders are aware of human rights and existence of the right to water and sanitation. However, this awareness does not seem to have had much impact when compared with the level of human rights claims among the Nigerian population. Although respondents have indicated readiness to assert legal claims if water and sanitation are recognised as human rights in Nigeria, awareness creation is required to empower the population on their role in the realisation of not only the right to water and sanitation but all other human rights and on the need to hold duty-bearers accountable through positive actions. Possible factors which might have influenced low record of human rights claims especially in Northwest Nigeria include poverty, religious and cultural practices, institutional requirements, personal and geographical circumstances.

\footnotetext{
${ }^{1100}$ Although comfortability level can impact on human rights claim, it is still possible for the rights to be claimed notwithstanding.
} 


\section{Chapter Six}

\section{Political, Economic, Social, Cultural and Environmental Factors Contributing to Poor Water and Sanitation Coverage in Nigeria}

\subsection{Introduction}

Drevious chapters have identified some of the problems associated with or impacting on access to water and sanitation in Nigeria. As shown, access to water and sanitation is a human right but 'technological, economic, financial or political reasons can be invoked to prevent its realisation' ${ }^{1101}$ Additionally, water availability can be impacted by several factors including population growth, disturbed terrain, climate change, water management projects, geopolitical borders, cultural beliefs and perceptions and power relations. ${ }^{1102}$ Human rights violation usually takes place in complex, political, economic, social and cultural settings. ${ }^{1103}$ As such, violations of human rights or failure by a State to observe its human rights obligations is not only connected to problems associated with legislations or policies but also could be connected to other non-legal factors. From the findings in the previous chapters, in Nigeria, several factors have impacted on or contributed to the present poor water and sanitation coverage. The empirical study has further identified other challenges with their varying degrees of impact. These challenges include poor funding, delay in the release of funds, lack of capacity, bureaucracy, corruption, poverty, religious and cultural practices, institutional issues, passiveness of rights-holders and geographical conditions.

In this chapter, these challenges and others identified from literatures will be examined. In doing this, the challenges have been grouped into the following and shall be examined accordingly:

1. Political factors;

2. Economic factors;

3. Social factors; and

4. Natural and Environmental factors.

\subsection{Political Factors}

Political factors here include the following:

\footnotetext{
${ }^{1101}$ See Henri Smets, 'The Right to Water as a Human Right' (2000) 30 Environmental Policy and Law P. 249.

${ }^{1102}$ Barbara Rose Johnston and John M. Donahue, 'Introduction' in John M. Donahue and Barbara Rose Johnston (eds), Water, Culture, and Power: Struggles in a Global Context (Water, Culture, and Power: Struggles in a Global Context, Island Press 1998) P. 2.

${ }^{1103}$ See for example Manisuli Ssenyonjo, 'Reflections on State Obligations with Respect to Economic, Social and Cultural Rights in International Human Rights Law' (2011) 15 The International Journal of Human Rights P. 973.
} 
Realising the Right to Water and Sanitation in Nigeria

\subsubsection{Prolonged Military System of Governance}

The almost 30 years of military administration has impacted heavily on the functions of public service and utility institutions in Nigeria and the realisation of human rights in general. ${ }^{104}$ Characteristically, not only the military lacked elements of constitutionalism but are autocratic and totalitarian. As such, evidence exists for their apparent lack of respect for the rule of law and constitutionalism. This has led performance of public duty to be generally seen as a favour to the population and leaders are not held accountable for failure to perform their public duties. The non-observance of rule of law during these periods have impacted on the general attitude of the population. It created situations of helplessness and passivity where majority of the population are not interested in taking steps to enforce their human rights.

\subsubsection{Inept and Corrupt Leadership}

During military periods, corruption became institutionalised. Successive military governments starved States and Local governments of necessary funds to function. ${ }^{1105}$ Although economic situations of States and the Local Governments have improved now, corruption has not been adequately addressed and rights-holders do not seem to be demanding accountability and transparency from duty-bearers. Corrupt leadership is not unique to Nigeria or to African Continent; however, African leaders (Nigeria inclusive) have been noted to "have had corrupt governments that exploited their own people as viciously as any outsiders have ever done." 1106 More so, their system of administration is characterised by adoption of pro-rich policies for personal gains and rejection of those designed to enhance development and promote ESC rights. ${ }^{1107}$ This has affected the performance of human rights obligations in general and water and sanitation in particular.

\subsubsection{Cost of Governance}

Nigeria arguably operates one of the most expensive systems of government. With the return of democracy, the 1999 Constitution adopted, at the twilight of military administration, a Presidential System with three arms of Government. The Executive headed by the President, the Legislature operating bicameral parliamentary/legislative system consisting of two houses: The Senate and House of Representative headed by the Senate President and Speaker of the House respectively. The Judiciary is headed by the Chief Justice of Nigeria. By the provision of the Constitution, at least one Minister must be selected from each of the 36 Nigerian States. In practice, usually 40 or more ministers (each with a retinue of aids and assistants) are appointed in addition to numerous Special Advisers and Assistants to the President and Vice-President. The Senate consists of 109 Senators each State being

\footnotetext{
${ }^{1104}$ For a clear demonstration of the gravity of the impact see Osita C. Eze, Human Rights in Africa: Some Selected Problems (Nigerian Institute of International Affairs 1984)

1105 Human Rights Watch, 'Chop Fine: The Human Rights Impact of Local Government Corruption and Mismanagement in Rivers State, Nigeria' (January, 2007) 19 Human Rights Watch . P. 18.

${ }^{1106}$ See Shedrack C. Agbakwa, 'Reclaiming Humanity: Economic, Social and Cultural Rights as the Cornerstone of African Human Rights' (2002) 5 Yale Human Rights \& Development Law Journal P. 195 quoting George Kent, Globalization and Food Security in Africa.)

${ }^{1107}$ Ibid. P. 195
} 


\section{Chapter Six}

represented by three senators and one from the Federal Capital Territory. The House of Representatives consists of 360 members.

The budget of the National Assembly and members' numerous allowances ${ }^{1108}$ take a decisive impact on the Nigerian economy. A Senator is expected to gulp 44 million Naira monthly and 528 million Naira annually while each member of the House of Representative will take 10.7 million Naira monthly and 128.4 million Naira annually. These put the total figure salaries and allowances accruable to the members of the National Assembly per annum at 149.46 billion Naira (over $\$ 918$ million) annually. ${ }^{109}$ This does not include the allowances accruing to the principal officers of the National Assembly and committee leaders.

The civilian administration has not much helped the situation. Rather the politicians are in some ways contributing to the already existing problems. For example, in the National Assembly, there is what is termed 'Constituency Projects'. The idea of Constituency Projects was conceived by politicians at the National Assembly level as a response to the yearnings and aspirations of their constituents for development and federal presence. ${ }^{1110}$ In collaboration with the Executive Arm of Government at the early years of return to democracy, members of the National Assembly began to be paid constituency fund (allowance) where a Senator receives five million Naira and members of the House of Representatives receives three million Naira each. ${ }^{1111}$ Subsequently, constituency projects were included in the Nigerian budgets where legislators were to identify projects to be sited in their constituencies. ${ }^{1112}$ After the inclusion in the budgets however, contracts award, supervision and payments are left with the appropriate executive agencies of government. ${ }^{1113}$ The idea of constituency projects and its intended objective of ensuring minimum presence of Federal Government and equitable distribution of infrastructure in the various constituencies may be laudable but the appropriation has been found to be unsustainable. ${ }^{1114}$

The cost of governance is replicated also at the States and Local Governments levels with several commissioners, advisers and aids to the State Governors, members of State Houses of Assembly, Chairmen of Local Governments and members of legislative councils. These large amounts of money serving as cost of governance has taken away significant amount which could be channelled for developmental projects including improving access to water and sanitation.

\footnotetext{
1108 These allowances include accommodation allowance, medical allowance, transport allowances, leave grant, furniture allowance, security allowance, drivers allowance, domestic servant allowance drivers allowance, security allowances, motor vehicle loan/maintenance allowance, duty tour allowance, entertainment allowance, constituency allowance, monitoring and field allowance, hardship allowance, outfit/robe allowance and sitting allowance, and newspapers/periodicals allowance.

1109 Proshare, 'National Assembly: The Biggest Democracy Cost Centre <http://www.proshareng.com/articles/1823> accessed 2nd June 2014

${ }^{1110}$ P. N. Udenfuna, F. Jumare and F. O. Adebayo, 'Legislative Constituency Project in Nigeria: Implication for National Development ' (July, 2013) 4 Mediterranean Journal of Social Sciences , P. 647.

1111 Ibid.

1112 Ibid., P. 648.

1113 Ibid.

${ }^{1114}$ Hon. Minister of Water Resources, Mid-Term Report on Water Sector Transformation (2011 - 2013), Slide 62.
} 
Realising the Right to Water and Sanitation in Nigeria

\subsubsection{Lack of Political Will}

Despite financial and political commitments of governments at various levels to improve access to water and sanitation, over the years governments at various levels have exhibited low political will. This is demonstrated by the annual appropriations allocated to water and sanitation projects and lack of vigorous pursuit of the implementation of the few projects to which funds were appropriated. It is considered a violation if a "State pursues by actions or omission, a policy or practice which deliberately contravenes or ignores" its human rights obligations. ${ }^{1115}$ Governments have equally exhibited low political will in the way corrupt officials are prosecuted. It is however worthy of note that the 2017 budget contains significant improvement in terms of allocation to the sector. Additionally, the Executive has indicated its willingness to recognise access to water as human rights in the National Water Resources Bill 2016 currently before the National Assembly. If passed, the Bill will significantly lessen the problem in the sector and will provided the much-needed legal backing for the judiciary to enforce the human right to water where it is denied.

\subsubsection{Politicisation of Development}

Development projects in many States are usually undertaken in areas considered favourable or friendly by the Government of the day to the detriment of those perceived to be political opponents. In the empirical study shown in Table 3.12 above has shown that $55.95 \%$ of the respondents from the population strongly agree, $11.62 \%$ agree that other reasons (defined to mean politics and area being a new site) are the reasons behind exclusion of certain areas in water supply and sanitation.

\subsection{Economic Factors}

Several issues may be cited here including:

\subsubsection{Inadequate Budgetary Provision}

Historically, the financing of water supply in Nigeria has not been the sole responsibility of the Federal Government. The colonial administration established the first modern water supply scheme in 1915 . With the expansion of these schemes, the financial responsibility was shared between the central government and what was then called the Native Authorities and in 1953 when there were 27 waterworks only a few were wholly financed by the colonial government. ${ }^{1116}$

From independence to date, financial appropriation for water resources development has been experiencing curves and far less than what is required. After independence, the first development plan covered 1962 to 1968 . Under this plan, the sum of N48.6 million was allocated to water supply which accounted for about $3.6 \%$ of the total planned capital expenditure in the public sector. ${ }^{1117}$ After the civil war, the second National Development Plan covering the period 1970 - 1975, allocated N103.4 million Naira (5\%) of the total

\footnotetext{
1115 International Commission of Jurists, Maastricht Guidelines on Violations of Economic, Social and Cultural Rights. Para 11.

${ }^{1116}$ J. O. Ayoade, 'Water Resources and their Development in Nigeria'. P. 588.

1117 Ibid. P. 589.
} 
Chapter Six

expenditure for the period to water supply including provision of modern sewerage systems for Ibadan and Lagos. ${ }^{111}$ There was however a decrease in percentage in the Third National Development Plan (1975-1980) where N930.038 Million representing 2.8\% of the total planned expenditure in the public sector was earmarked for water supply schemes. ${ }^{1119}$ Against the background of this decrease, an author remarked:

The drop in the proportion of total expenditure earmarked for water supply schemes is to be decried, in view of the fact that Nigeria's per capita expenditure on this important resource is still very low, and compares unfavourably with the situation even in advanced countries where pipe-borne water is already an ubiquitous amenity. ${ }^{1120}$

Since responsibility for water and sanitation is shared historically between the tiers of government, variations exist in the proportion of total expenditure earmarked for water resources development from State to State. A research revealed that "the figures range from $20 \%$ in North Central States to $6.9 \%$ in the South-Eastern States."1121

With return of democracy, from 1999 to 2005, the budgetary allocations on water resources rose from Three Billion Naira to 70 Billion Naira. ${ }^{1122}$ However, despite the increase in funding, the budget is inadequate when compared with the rate of population growth. At the Presidential Water Summit 2013 former Ghanaian President remarked "The problem is in the political prioritisation and commensurate funding of the water sector." 1123 The Federal Government through the Minister of Finance at the High-Level Meeting of Water and Sanitation for All in April, in Washington, 2012 had acknowledged the huge funding gap in the sector.

Prior to the adoption of National Water Supply and Sanitation Policy, 2000 the funding arrangement was that the State Government will fund water supply schemes through the State Water Agency allocations which are to be used for capital projects, operation and maintenance. The expectation was that the funds, at least for operation and maintenance would be generated through water rates collection and through loans (local or international sources) while rural water supply are partly funded by Federal Government and other donor agencies. The Policy however, in the case of capital investment put the funding arrangement as shown in the table below:

Similar arrangement was adopted for water sanitation under the National Water Sanitation Policy 2004. ${ }^{1124}$ For operation and maintenance cost, the arrangement is as shown by the table below:

From 2011 to 2013 a total of 225,616,723,264 Naira (about \$1.387 Billion) was appropriated to the Federal Ministry of Water Resources for capital projects. The breakdown shows that in 2011 the sum of $62,052,000,885$ Naira (\$382 million) was appropriated, in 2012 the sum of 79,336,556,014 Naira (\$487.5 million), and in 2013 the sum of $84,228,166,365$ Naira (\$517.5 million) was appropriated. While the appropriated sum cannot

\footnotetext{
1118 Ibid.

1119 Ibid.

${ }^{1120}$ Ibid.

${ }^{1121}$ Ibid.

1122 Address by the Hon. Minister of Water Resources at the National Forum on Water Resources, $29^{\text {th }}$ August $-1^{\text {st }}$ September 2006.

${ }^{1123}$ WaterAid, 'Presidential Summit on Water 2013'

${ }^{1124}$ See Federal Republic of Nigeria, National Water Sanitation Policy. Para.3.5(e)
} 
Realising the Right to Water and Sanitation in Nigeria

counter and address the current problems in the water sector, the problem was further compounded by the non-release of the appropriated sum. In 2011 only $66 \%$ of the appropriated sum was released and in 2012 only 55\% was released. Coupled with other factors such as corruption and mismanagement, the limited sum directed towards capital projects were not able to make positive impacts. The situation is similar at the States level.

A study, ${ }^{1125}$ (relying on estimate of 50.8 billion Naira annually of capital investment required to achieve target in rural areas of $66 \%$ developed by the former Minister of Water Resources and WaterAid), revealed that going by the sharing formula under the National Policy on Water and Sanitation, it would mean that the Federal Government would contribute 25.4 billion Naira, the States, 12.7 billion Naira and Local Governments 10.16 billion Naira. However, a pilot study in three local governments in 2004 and 2005, the average was found to be 6.6 and 7.5 million Naira respectively. If the average is taken throughout the 774 local governments in Nigeria, the total would be 5.8 billion Naira. ${ }^{1126}$ This is just $11.4 \%$ of the amount required. Similarly, the same period, local governments are required to spend at least 10.16 billion in order to meet the $66 \%$ target in the rural areas on sanitation but if the allocation from the three local governments considered is to be taken as the average, the amount would be 5.8 billion which falls far below the minimum required. ${ }^{127}$ There has not been any drastic change since.

In the numerous commitments undertaken by Nigeria over the years, the relatively low budget allocation has militated against the realisation of set targets in water and sanitation sector. ${ }^{1128}$ It is axiomatic that realisation of all rights has budgetary implications hence budgets have direct bearing on which rights are realised and for whom. ${ }^{1129}$ There appears to be a disconnect between Nigeria's legal and policy frameworks on water and sanitation and the budgetary provisions made over the years. According to a research, for countries in SubSaharan Africa including Nigeria to meet the MDG target, at least $1 \%$ of their GDP must be dedicated to sanitation and $2.5 \%$ to water. ${ }^{1130}$ In 2010, the Nigeria's expenditure on water and sanitation stood at $0.18 \%$ of the GDP. ${ }^{1131}$

Investment in water and sanitation sector has been and continues to be low over the years in Nigeria. Several duty-bearers have pointed out lack of or inadequate funding as one of the biggest challenges facing the sector. This has hampered the equitable coverage of communities with water network system thereby indirectly creating situation of discrimination. The little attention paid to the sector over the years in terms of funding which was further impacted by corruption, mismanagement and diversion of fund ${ }^{1132}$ has exacerbated the condition of acute shortage of access to water throughout the country.

\footnotetext{
${ }^{1125}$ WaterAid Nigeria, 'Water and Sanitation in Nigeria: Briefing on National Policy'. P. 6.

1126 Ibid.

${ }^{1127}$ Ibid. P. 7.

${ }^{1128}$ Hon. Minister of Water Resources, Mid-Term Report on Water Sector Transformation (2011 - 2013)

${ }^{1129}$ HRBA Portal, 'United Nations Practitioner's Portal on Human Rights Based Approaches to Programming' <http://hrbaportal.org/faq> accessed 25 July 2016

${ }^{1130}$ Society for Water and Sanitation, 'Newsletter'. P. 2.

${ }^{1131}$ WaterAid, Off Track, off Target: Why Investment in Water, Sanitation and Hygiene is not Reaching Those Who Need it Most

${ }^{1132}$ In the sense in which monies meant for capacity building for example are stolen, mismanaged or diverted for other purposes.
} 


\section{Chapter Six}

Attempt has been made the access documents or information relating to funding of the institutions, but no response was received during the period of the empirical study. In circumstances where appropriation laws do not determine the actual release to institution, no meaningful conclusion can be drawn from those appropriation laws as to whether adequate funding has been provided. However, it is a matter of public knowledge as admitted at several fora by duty-bearers that water and sanitation sector has not been receiving adequate attention in the yearly appropriation laws from the Federal and State Governments. ${ }^{1133}$

Over the years, poor or inadequate funding has been at the heart of access to water and sanitation problems. Successive governments have failed to realise or deliberately refused to recognise the importance of adequate budgetary provision in water and sanitation sector. Where such admission is made, the claim has consistently been the lack of money/resources. However, when compared to other issues such as the emoluments of legislators and executives, this claim cannot be valid. It is submitted here that the problem is more of lack of political will, prioritisation, corruption, and misapplication of funds. ${ }^{134}$ For any meaningful progress to be made in this area, Nigerian government must realise that judicious appropriation of fund is necessary as much as their mobilisation. ${ }^{1135}$ Government must necessarily prioritise the welfare of the general population and focus on ways to improve their lots and this requires significant shift from political elite concentrated welfare approach (top-down approach) to population's consideration (bottom-up approach). ${ }^{1136}$ Legitimacy of the government and its organs will be put to question when the significant number of the country's population are in abject penury and are experiencing human rights deprivations.

It is therefore not out of place to conclude that in the light of many complexities, water and sanitation has not been receiving adequate budgetary provisions needed for the realisation of access to water and sanitation. This underscores the importance of the UNGA resolution for adequate attention to be paid into budgetary provisions on water and sanitation as fundamental components of human rights.

From the empirical study, 59.68\% of the respondents from duty-bearers strongly agree and $27.42 \%$ agree that funding is an obstacle to the realisation of access to water and sanitation.

\subsubsection{Untimely and Limited Appropriation Releases}

Despite inadequate budgetary provisions to water and sanitation sector, the problem is compounded by untimely release (delay) of the appropriated funds. ${ }^{1137}$ It is further worsened by the non-full released of the appropriated sum. In 2011 and 2012 for example, only 66\% and $55 \%$ of the budget were released to the FMWR respectively. ${ }^{1138}$ This culture leads to

\footnotetext{
${ }^{1133}$ See for example WaterAid, 'Presidential Summit on Water 2013'Hon. Minister of Water Resources, Mid-Term Report on Water Sector Transformation $(2011$ - 2013) ; and Society for Water and Sanitation, 'Newsletter'

${ }^{1134}$ See for example Human Rights Watch, 'Chop Fine: The Human Rights Impact of Local Government Corruption and Mismanagement in Rivers State, Nigeria' ; Proshare, 'National Assembly: The Biggest Democracy Cost Centre

${ }^{1135}$ See Dejo Olowu, 'Human Development Challenges in Africa: A Rights-Based Approach'. P. 209.

1136 Ibid.

${ }^{1137}$ Funds releases are done from the office of Accountants-General of the Federation or the State respectively.

${ }^{1138}$ Hon. Minister of Water Resources, Mid-Term Report on Water Sector Transformation (2011 - 2013 ). Slide 41.
} 
Realising the Right to Water and Sanitation in Nigeria

abandonment of projects, impacts on the capacity of agencies and institutions to discharge their duties and perpetuates the culture of deprivations and marginalisation. From the empirical study, $47.62 \%$ of respondents among the duty-bearers strongly agree and $31.75 \%$ agree that delay in the release of funds for projects and running of their offices is an obstacle to the realisation of access to water and sanitation. Delay in the release of budgetary funds is the second most inhibiting factors affecting progress in water and sanitation according to respondents among the duty-bearers.

\subsubsection{Impact of Business Activities: Oil Extraction and Oil Companies}

Business activities though unrelated to water could have significant impacts on water. ${ }^{1139}$ Reference is made here to the impact of oil extraction for economic reasons in the NigerDelta of Nigeria which housed about 31 million people. Several research findings have detailed how oil extraction in the region is violating ESC rights of the people. Oil extraction has been responsible for the cause of pollution of water sources where a large population of the people derive their means of livelihood including water for drinking and domestic purposes. ${ }^{1140}$ Currently, the Niger Delta people have limited access to clean water and sanitation. Referring to the impacts of oil extraction on the Niger Delta, Audrey Gaughran observed that not only that the majority of the population in the Niger Delta lives in poverty but also:

They do not have adequate access to clean water. Some rely on boreholes, but many rely on the rivers and streams for water both for drinking and domestic use. In light of this, one of the most disturbing findings of Amnesty International's research was that the water system--the rivers, streams, and ponds--have for decades been the receiving bodies for oil spills and waste discharge, including waste water and dumped drilling waste. Rivers and creeks have also been subjected to dredging and canalization. The combined and cumulative impact of these practices by oil companies has significantly undermined the rights to water, food, and health. ${ }^{1141}$

Oil extraction in the Niger Delta is not only polluting surface water but also groundwater. A 2011 UNEP study established empirical evidence demonstrating oil extraction has also polluted the groundwater in the Ogoniland. ${ }^{1142}$ This invariably established that even where the population avoided surface water (rivers, lakes and ponds) and resort to groundwater (boreholes and wells) they remain vulnerable.

It is common in developing countries desirous of economic progress to compromise human rights of citizens in favour of businesses. This usually comes where companies (notably multinational) are given enormous powers, leeway and incentives to the detriment of local population. It is usual to find environmental laws relaxed or not adequately or sometimes selectively enforced. In circumstances where ESC rights are not adequately protected or not even considered as justiciable rights while at the same time oil companies appear to have enormous powers in oil exploration and extraction (which in many instances

\footnotetext{
1139 Audrey Gaughran, 'Business and Human Right and the Right to Water'. P. 52.

${ }^{1140}$ Amnesty International in its yearly reports since 2008 has consistently been reporting the impact of oil spill from the activities of oil companies on human rights.

${ }^{1141}$ Audrey Gaughran, 'Business and Human Right and the Right to Water'. P. 53.

${ }^{1142}$ UNEP, Environmental Assessment of Ogoniland
} 
Chapter Six

violates ESC rights), the resulting effects would be constant violations of some of these rights, like the right to health, clean environment, quality water and basic sanitation.

The oil companies in Nigeria under the Petroleum Act and Oil Pipelines Act have the permit to among others "dig, and bore into the soil and subsoil ... to cut and remove such trees and other vegetation as may impede the purposes ... and to do all other acts necessary to ascertain the suitability of establishment of an oil pipeline or ancillary installations". If environmental laws are applied as they should, the problems would be less, ${ }^{1143}$ but there is the problem of poor enforcement. In the absence of intervention from other relevant institutions such as the Ministry of Health, the result would be violation of human rights. ${ }^{1144}$ Water pollution has been identified as one of the factors with "enormous bearing on the available quantity of water for (safe) human use." 1145 The recently adopted National Policy on the Environment 2017 contains provision relevant to addressing oil pollution and gas flaring. It however remains to be seen the extent to which the Government is committed to enforcing the relevant provisions.

\subsubsection{Corruption and Corrupt Practices}

Over the years, Nigeria has acquired a reputation of being among the most corrupt countries in the world. The 2009 CPI puts Nigeria last or second to the last. Nigeria was ranked $144 / 177$ by the 2013 Transparency International Corruption Perception Index (CPI) with a score of 25/100. ${ }^{1146}$ With a long history of corruption, it is impossible to provide exact figure of the amount stolen from Nigeria. In 2006, the former head of Economic and Financial Crimes Commission (EFCC) Nuhu Ribadu was reported to have estimated that from 1960 to 1999 about $\$ 380$ billion was either stolen or wasted by the Nigerian Government. ${ }^{1147}$ It was also estimated that with the return of civilian administration from 1999 to 2007, at least 4 to 8 billion dollars is lost to corruption annually. ${ }^{1148}$ These are monies meant for the transformations of the lives of average Nigerians, through the provision of healthcare, education, water, roads constructions etc. Cases of corruption range from stealing/embezzlement by public officers of funds meant for developmental projects, misappropriation and bribery. ${ }^{1149}$ In what was considered the biggest corruption in the life of the country, recently it was revealed by the former Governor of Central Bank that in 18 months about 20 billion dollars' oil revenue have not been remitted to the Federal Government account by the Nigerian National Petroleum Corporation. ${ }^{1150}$

\footnotetext{
${ }^{1143}$ Audrey Gaughran, 'Business and Human Right and the Right to Water'. P. 54.

1144 Ibid.

${ }^{1145}$ Inga T. Winkler, The Human Right to Water: Significance, Legal Status and Implications for Water Allocation P. 25.

1146 Transparency International, 'Corruption Perceptions Index 2013: Nigeria' 2013) <http://www.transparency.org/country\#NGA> accessed 24 May 2014

1147 BBC News, 'Nigeria Leaders 'stole' \$380bn' (BBC, 2006) <http://news.bbc.co.uk/2/hi/africa/6069230.stm> accessed 24 May 2014

${ }^{1148}$ Human Rights Watch, Everyone's in on the Game: Corruption and Human Rights Abuses by the Nigerian Police August, 2010) P. 20.

1149 Ibid.

${ }^{1150}$ William Wallis, 'Nigeria's Central Bank and State Clash over 'missing billions" Financial Times (4 May) <https://www.ft.com/content/57d43418-bb14-11e3-948c-00144feabdc0>
} 
Realising the Right to Water and Sanitation in Nigeria

The effect of corruption on the lives of average citizens and in the realisation of ESC rights can be seen in the inability of governments at all levels to provide basic services such as health care, education, water, food security and other human needs. The heavy toll corruption is taking on governance has been highlighted by a Human Rights Watch report. According to the report, the four leading oil-producing States in Nigeria where one State budgets exceeds "the total central government budgets of many West African countries, the state and local governments have grossly failed to progressively realize the basic health and education needs of their citizens." 1151 Although annually appropriations are made for these services in the budgets, the monies are siphoned off by the ruling elite. ${ }^{1152}$ Despite the huge revenue accruing from oil and other products, large percentage of Nigerians totalling more than half, lives on less than a dollar a day. In 2008, it was estimated that the Federal Government's revenue totalled $\$ 45.4$ billion but $64 \%$ of Nigerians lives on less than $\$ 1.25$ a day while the maternal and infant mortality rates is among the largest in the world. ${ }^{1153}$ Corruption in Nigeria takes the form of stealing by public officers, illegal diversion of State's revenue for private gains, and abuse of office. These are acts considered abominable by several international legal and non-legal instruments. ${ }^{1154}$

In the early 2000s, in attempting to address corruption and other financial crimes, Nigeria established two supposedly independent agencies: The Independent Corrupt Practices Commission (ICPC) and the EFCC. Although some convictions have been secured by these agencies, their performance is minimal and are seen by many as only persecuting political opponents.

There are legislations to tackle corruption in Nigeria however the political commitment and corruption within the Judiciary undermine appropriate prosecution or in cases where prosecutions were carried out, lighter sentences are awarded. The prosecution of the former Inspector-General of Police Tafa Balogun, the former Governor of Edo State Lucky Igbinedion, ${ }^{1155}$ and the former Governor Bayelsa State are typical examples. Others like the former Governors of Jigawa, Nasarawa and Sokoto States their trials have been stalled several years after commencement and no significant progress visibly seen. In October 2006, the anti-corruption czar and the head of EFCC announced that 31 out of 36 governors have corruption cases to answer after leaving office. ${ }^{1156}$ At the local government level, the situation is the same. The head of ICPC in an interview with Human Rights Watch in August 2006 remarked that corruption at the local government level is "rampant". ${ }^{1157}$

\footnotetext{
${ }^{1151}$ Human Rights Watch, Everyone's in on the Game: Corruption and Human Rights Abuses by the Nigerian Police 1152 Ibid.

1153 Ibid. P. 21.

${ }^{1154}$ For example, the United Nations Convention against Corruption. UN Doc. A/58/422, adopted October 31, 2003, entered into force December 14, 2005, ratified by Nigeria December 14, 2004 and the African Union Convention on Preventing and Combating Corruption, adopted July 11, 2003, in Maputo, Mozambique, entered into force August 5, 2008, ratified by Nigeria September 26, 2006.

${ }^{1155}$ Who was charged in 2008 with embezzling $\$ 2.9$ billion (approximately $\$ 24.2$ million) of State funds and who a year later in a plea bargain pleaded guilty to one charge of failing to disclose his assets was fined $¥ 3.5$ million $(\$ 29,167)$ and released without any jail time.

1156 ThisDay, 'Ribadu in Senate: 31 Governors under Investigation'(28 September)

1157 Chris Albin-Lackey, Chop Fine: The Human Rights Impact of Local Government Corruption and Mismanagement in Rivers State, Nigeria, vol 19 (2A) (Human Rights Watch: A Sub-Saharan Africa, Human Rights Watch 2007) P. 19.
} 
Chapter Six

The impacts of corruption in Nigeria is not only on its economy or realisation of human rights but has pervaded all areas of human endeavours including politics through fuelling political violence, human rights abuse and subversion of democratic processes. Politicians including those in power utilise the wealth and other resources at their disposal to intimidate, rig elections, "mobilise violence and graft to support their bid for office."1158

Corruption undermines accountability, takes a heavy toll on the poor, the disadvantaged and the marginalised individuals and groups and perpetuates poverty. Through revenues accruable to the governments at various levels and the annual appropriations, citizens expect basic services to be provided. States are expected to appropriately fund public service institutions to among others fulfil obligations on education, health, human and food security. In Nigeria, corruption "has crippled the government's capacity to invest in its people" 1159 and to progressively provide for the realisation of their basic human rights. Public institutions appropriations are not released but siphoned off, monies meant for capacity building are diverted for private gains, developmental projects are poorly, if at all, executed and judicial officers are compromised. As a result, public utility service agencies such as those providing water for example, are performing below expectations/standards and in some instances nonfunctional and basic infrastructures are dilapidated.

In the empirical study, $53 \%$ of respondents among duty-bearers have identified corruption as an obstacle to realising access to water and sanitation in Nigeria.

\subsubsection{Economic Activities}

This has been found to be of important consideration in the decisions of duty-bearers to connect and allocate water to certain location. See Table 3.1 which indicated that about $70 \%$ of duty-bearers considers this issue to be significant. Technically, areas with little or no economic activities would be affected by low water and sanitation coverage.

\subsection{Social Factors}

As the social context pointed out, there are several social issues impeding progress in human rights in general and the right to water and sanitation in particular. Some of these issues include:

\subsubsection{Population Explosion}

The impact of population growth on water availability and access has been highlighted above. It suffices to mention that an uncontrolled population growth impacts significantly on the available resources. The growth rate of Nigeria's population is $2.54 \% .{ }^{1160}$ In about seven years, from 2006 when the official census was conducted to 2013 the Nigerian population increased by more than 30 million people. It will be difficult if not impossible to achieve sustainability unless resource carrying capacity matches with the demands. Nigeria has a population policy which acknowledges the concept of sustainable development as its

\footnotetext{
${ }^{1158}$ See for example ibid. P. 10.

${ }^{1159}$ Ibid. P. 18.

${ }^{1160}$ Central Intelligence Agency, 'Nigeria'
} 
Realising the Right to Water and Sanitation in Nigeria

underlying strategy. It recognises the importance of regulating population growth for meeting government's obligations to citizens and ensuring sustainable development. The Policy mentioned that " $\mathrm{t}] \mathrm{o}$ achieve sustainable development and a higher quality of life for all people, Nigeria shall promote appropriate policies including population-related policies, to meet the needs of current generations, without compromising the ability of future generation to meet their own needs." ${ }^{1161}$ However, at present, there does not appear to be any effective programme in place to check population explosion for sustainable development.

When combined with other factors such as inadequate budgetary provision to meet growing demands, lack of maintenance of existing infrastructures, technical obstacles and corruption the effect would be as population increases, available water would be overstretched, and deprivation would increase. In the empirical study, respondents among the duty-bearers have identified population growth as a challenge to the water and sanitation sector. For example, as part of the difficulties in the sector, a respondent mentioned that "population growth with respect to the water being produce" is one of the issues hampering progress. Another said, "increase in population" to be served is a challenge.

\subsubsection{Rural-Urban Migratory Movement and Informal Settlements}

Closely connected to population explosion is the migratory movement from rural areas to urban centres (urbanisation) in search of better social and economic fortunes due to underdevelopment in Nigeria's rural areas. Worldwide, only 14\% of the world population was living in the urban areas in 1900 but this figure more than doubled by $1950 .{ }^{1162}$ By 2008 more than $50 \%$ of the population are known to be living in urban areas. ${ }^{1163}$ Urbanisation is more common and rapid in developing countries as pointed out by the United Nations Human Settlements Programme. ${ }^{1164}$ This is true in the Nigerian situation. Rural-urban migration in Nigeria is currently assuming a disproportionate level. ${ }^{1165}$ Nigeria undoubtedly is one of the "countries in the world with very high rural-urban dichotomy." 1166 Both push and pull factors are responsible for this rural-urban migration. Rural areas are generally characterised by lack of basic socio-economic facilities such as pipe borne water, electricity, motor able roads, and industries. ${ }^{1167}$ These services and facilities are better in the cities because urbanisation is closely linked to modernisation, industrialisation and improved social and economic living conditions.

\footnotetext{
${ }^{1161}$ Federal Republic of Nigeria, National Policy on Population for Sustainable Development (2004)

1162 Asit K. Biswas, 'Water Management for Major Urban Centres' (2006) 22 International Journal of Water Resources Development . P. 185.

${ }^{1163}$ Inga T. Winkler, The Human Right to Water: Significance, Legal Status and Implications for Water Allocation. P. 21.

1164 United Nations Human Settlements Programme, State of the World's Cities 2008/2009: Harmonious Cities (Earthscan 2008) P. iv.

${ }^{1165}$ Adejumoke Afolayan and IOM's Research Division, Migration in Nigeria: A Country Profile 2009 (International Organization for Migration 2009). P. 81.

${ }^{1166}$ Ezebunwa E. Nwokocha, 'Engaging the Burden of Rural-Urban Migration in a Non-regulatory System: The Case of Nigeria' <http://www.irmgard-coninx-stiftung.de/fileadmin/user_upload/pdf/urbanplanet/Nwokocha.pdf> accessed 15 June 2014

${ }^{1167}$ Omonigho T. Okhankhuele, 'Causes and Consequences of Rural-Urban Migration Nigeria: A Case Study of Ogun Waterside Local Government Area of Ogun State, Nigeria' (2013) 16 British Journal of Arts and Social Sciences P. 188 .
} 


\section{Chapter Six}

With life becoming more unbearable, economic and social conditions worsening in the rural areas, peasants are forced out of rural areas to cities for wage labour and other lumpenproletarian works. ${ }^{168}$ Major cities in Nigeria such as Lagos, Kano, Port Harcourt, and Onitsha are some of the cities heavily impacted by this trend. As the population of urban centres increases, the cities' social and economic challenges also increase. This impact on the available water, and increases pollution and poor living condition. A study has demonstrated the impacts of rapid and unplanned urbanisation on water. ${ }^{169}$ For example, in urban Indian cities affected by unplanned urbanisation, regular supply of clean drinking water was affected. ${ }^{1170}$ Usually governments are not inclined to provide services to informal settlements for fear of legitimising or encouraging their growth. ${ }^{1171}$ Environmental Sanitation Policy noted this concern especially in the context that the neighbourhoods where these people live are usually without legal tenure of land as such they often remain officially invisible with the consequence that "they are often not taken into account in municipal programmes to improve or extend services such as water supply, basic sanitation, garbage collection, flood protection, health care, etc." 1172 Conversely, the poor who live in informal settlements have to spend large share of their meagre income in the purchase of water from private service providers or walk long distances to an illegal or common water source with all the attendant social and economic consequences. ${ }^{1173}$

One reason which could explain the declining socio-economic facilities and services in the urban centres is rural-urban migration. Rural-urban drifts and unplanned social services necessitate the increasing population to negotiate ways of providing for themselves in terms of housing, food, water and other basic human needs. These could be done in any manner considered necessary by the population. According to the National Policy on Environmental Sanitation, rapid urbanisation and uncontrolled population growth unaccompanied by expansion of sanitation facilities made environmental sanitation more acute. ${ }^{1174}$ Except the periodic census conducted in general, there is currently, no programme documenting informal settlers, their locations and social services required. With limited facilities put in place in the cities, frequent arrival of unplanned for population exerts pressure on the available resources. Rural-urban migration is a factor impacting on access to water and sanitation.

\subsubsection{Discrimination and Marginalisation}

Available statistics from the government and private sectors indicated disparities on access to water and sanitation coverage between regions, and between rural and urban areas.

\footnotetext{
${ }^{1168}$ Isah Mohammed Abbas, 'Trends of Rural-Urban Migration Nigeria' (2012) 8 European Scientific Journal p. 100 ${ }^{1169}$ For example, in the Indian cities where similar challenges exist: intense socio-spatial, cultural, political and ecological conflicts over the limited supply of water were noted. See Deya Roy, 'Negotiating Marginalities: Right to Water in Delhi' (2013) 10 Urban Water Journal 97

${ }^{1170}$ Ibid.

1171 Malin Falkenmark and C. Widstrand, 'Population and Water Resources: A Delicate Balance' (1992) 47 Population Bulletin P. 22.

${ }^{1172}$ Federal Republic of Nigeria, National Environmental Sanitation Policy. Para. 2.5.1.

${ }^{1173}$ Deya Roy, 'Negotiating Marginalities: Right to Water in Delhi'. P. 97.

${ }^{1174}$ Federal Republic of Nigeria, National Environmental Sanitation Policy. Para. 2.5.1. 
Realising the Right to Water and Sanitation in Nigeria

Development activities seem to have concentrated in the urban centres to the disadvantage of rural areas. Notwithstanding the constitutional averment to promote good government and welfare of all persons on the principles of freedom, equality and justice, in practice the rich and socially placed, seemed to be favoured. An eminent Judged had once remarked that "in actual practice one sees that it is the powerful, the rich and the dominant class that seem to have all the rights, while the only right left to the poor, the weak and the down-trodden seems to be their rights to suffer in silence, to be patient and wait for their reward in heaven (if they are believers)." 1175 Through this practice, the poor and the rural people get marginalised or discriminated against for their apparent lack of voice and representation.

Additionally, water supply and distribution by duty-bearers are determined by many factors. For example, while duty-bearers try to avoid deliberate discrimination on the basis of economic position of individuals in water supply, some of the determining factors indirectly lead to marginalisation and sometimes discrimination. According to duty-bearers, water supply is more likely to be provided in areas with socio-economic activities, large population, accessible roads and reachable locations than areas which suffer absence of these considerations. Hence the latter areas and people are marginalised or discriminated against incidentally. In the empirical study, when asked to comment on the reasons why certain areas were not covered by water and sanitation programmes some respondents among the dutybearers identified political interference and neglect. Tables 4.12 and 4.13 above have identified the percentages of respondents among the rights-holders and CSOs who believe certain reasons such as social and economic status of the people in certain locations are among the reason why such areas and people are not covered by water and sanitation programmes.

\subsubsection{Sanitation Practices and Lack of Awareness}

Knowledge and awareness are key ingredients in human emancipation, security and in addressing deprivations. It is often said knowledge is power. Knowledge guides people actions and enable them to claim their entitlements. Although hygiene is a matter of individual, social and public concern, it is not in all cases that individuals know or recognise the impact of their actions on personal and societal hygiene.

Very little awareness among the population exists on waste pollution. It is not uncommon for the population, especially in the rural areas to tap groundwater through shallow wells which in certain instances are proximate to some excreta dump or to find an extensive use of water downstream of effluent discharge points. ${ }^{1176}$ It was estimated that 34 million Nigerians defecate in the open, ${ }^{1177}$ including those areas where people generate water for personal and domestic uses. It was reported recently, that 440,000 infants die annually due to poor sanitation culture and inability to maintain good personal hygiene at home. ${ }^{1178}$ The

\footnotetext{
1175 C.A. Oputa, Human Rights in the Political and Legal Culture of Nigeria (Nigerian Law Publications 1989) Pp. 67-68.

1176 See Joseph Akinkugbe Adelegan, 'The History of Environmental Policy and Pollution of Water Sources in Nigeria (1960-2004): The Way Forward'

${ }^{1177}$ UNICEF and WHO, 'Progress on Drinking Water and Sanitation: 2012 Update'. P. 20.

1178 , '440,000 Infants' Deaths Annually' Leadership Newspaper (19 April)
} 


\section{Chapter Six}

Registrar/Chief Executive Officer, Environmental Health Officers Registration Council of Nigeria traced the problem "to the failure of the various city authorities to cope with the mounting refuse heaps in various street corners" and it is frequently observed that many houses in villages and urban areas including public places such as motor parks, bus stations, and markets do not have latrines. ${ }^{1179}$

Additionally, in some cases faeces from slaughterhouses and raw sewage from human sources mix with water sources with their attendant effects. ${ }^{180}$ The effect of "uncontrolled disposal system renders surface waters and underground water systems unsafe for human, agricultural and recreational use, destroys biotic life, poisons the natural ecosystems, poses a threat to human life and is therefore against the principles of sustainable development."1181 In this context, the population themselves do not effectively contribute to realising their right to quality water, healthy environment and basic sanitation. ${ }^{1182}$

Interestingly also, awareness of right to clean environment is limited among the Nigerian population. A study by the National Human Rights Commission observed that " $[t]$ he right to clean and secure environment is one area of rights that average Nigerians is not aware of their entitlement to." 1183 The report noted that the lack of awareness "has made government passive in ensuring the protection of this right. ${ }^{1184}$ A study has further revealed a general lack of awareness on environmental litigation among the population has led to slow rate of judicial enforcement. ${ }^{1185}$ In cases where litigation has been resorted to notably on matters of pollution by oil companies, the main motivating factor is financial compensation and not necessarily the protection of the environment. This attitude has been described as "gold digging actions". ${ }^{1186}$ Knowledge and awareness are therefore issues which authorities and civil society organisations must pay adequate attention to on matters relating to the protection of environment and sanitation and in the protection of water quality for the realisation of the right to water and sanitation.

In the empirical study, respondents among the duty-bearers commenting on the problems challenging water and sanitation in Nigeria stated that "the attitude of people toward maintenance of water facilities is very poor", "individual behavioural attitude", open defecation in rural and semi-urban areas, lack of cooperation from the people, and consumer lack of awareness are some of the challenges hampering progress in the sector.

\subsubsection{Lack of Access to Information/Non-Utilisation of Available Sources}

Access to information is a human right principle relevant to the right to water and sanitation. It serves as a safeguard "of particular importance in the realisation of the right to

\footnotetext{
1179 Ibid.

${ }^{1180}$ See Joseph Akinkugbe Adelegan, 'The History of Environmental Policy and Pollution of Water Sources in Nigeria (1960-2004): The Way Forward'

${ }^{1181}$ Ibid. P. 10.

${ }^{1182}$ The National Environmental Policy noted this concern as one of the reasons why several previous efforts failed to achieve success. See Federal Republic of Nigeria, National Environmental Sanitation Policy. Para. 2.0.

${ }^{1183}$ National Human Rights Commission, State of Human Rights in Nigeria, 2007). P. 122.

1184 Ibid.

1185 Muhammed Tawfiq Ladan, Law, Cases and Policies on Energy, Mineral Resources, Climate Change, Environment, Water, Maritime and Human Rights in Nigeria. P. 134.

${ }^{1186}$ Ibid. P. 134
} 
Realising the Right to Water and Sanitation in Nigeria

water and sanitation." 1187 The public is entitled to seek and receive information about laws and policies relating to water. ${ }^{1188}$ The capacity of a population to voice out concerns and demand or hold duty-bearers accountable is curtailed by lack of access to information. ${ }^{1189}$ The reports of the United Nations Special Rapporteur on the Human Right to Safe Drinking Water and Sanitation has highlighted typical information concerning water which must be made available to the public. This includes financial information on public and private water service providers, ${ }^{1190}$ which is to be disseminated through channels easily accessible to the public ${ }^{1191}$ such as "local radio, billboards, newspapers or information centres." 1192

Similarly, information in relation to the right to water has been recognised as an entitlement by the Committee on ESC rights and that people should have information on water sources and environment. ${ }^{193}$ In Nigeria, until the enactment of the Freedom of Information Act (FOI) in 2011, citizens do not have freedom of accessing information on matters relating to governance issues and working of public institutions and agencies except those which were made public by the institutions themselves. Lack of access to information on water programmes and decisions concerning water have left individuals and groups vulnerable to deprivation.

Additionally, with the adoption of FOI people do not seem to be active in utilising and accessing information on matters concerning water and sanitation. This is evidenced by the findings in the empirical study and indicated above. The combined effect of these is that rights-holders tacitly encourage the duty-bearers not to account.

\subsubsection{Poverty}

The fast-economic growth experienced in recent times in Nigeria has not positively impacted on the citizens' economic fortunes and potentials. On the contrary, poverty continues to pervade a large segment of the Nigerian population. A significant number of the Nigerian population are poor or are experiencing some aspects of poverty. Poverty has been defined as "the inability to achieve a certain minimal standard of living" 1194 which is "caused and perpetuated by a diverse set of power relations that deny life-skills, assets and resources to people."1195 Rather than reducing, the level of poverty among the Nigerian citizens is increasing. For example, using a head-count index ${ }^{1196}$ a study revealed that the level of

\footnotetext{
${ }^{1187}$ WaterLex and WASH United, The Human Rights to Water and Sanitation in Courts Worldwide: A Selection of National, Regional and International Case Law. P. 10.

1188 Ibid. P. 14.

1189 Ibid.

${ }^{1190}$ UN Human Rights Council, Report of the Special Rapporteur on the Human Right to Safe Drinking Water and Sanitation, Catarina de Albuquerque

${ }^{1191}$ UN Human Rights Council, Report of the Independent Expert on the Issue of Human Rights Obligations Related to Access to Safe Drinking Water and Sanitation, Catarina de Albuquerque

${ }^{1192}$ WaterLex and WASH United, The Human Rights to Water and Sanitation in Courts Worldwide: A Selection of National, Regional and International Case Law P. 14. (See also UN Human Rights Council, Report of the Special Rapporteur on the Human Right to Safe Drinking Water and Sanitation, Catarina de Albuquerque

${ }^{1193}$ UNCESCR, General Comment No. 15: The Right to Water (Arts. 11 and 12 of the Covenant)

${ }^{1194}$ Ben E. Aigbokhan, 'Poverty, Growth and Inequality in Nigeria: A Case Study' (2000) Working Papers, African Economic Research Consortium

1195 ACTIONAID-Kenya, Country strategy paper, 2002-2005 (ActionAid Kenya 2002) P. i.

${ }^{1196}$ Ben E. Aigbokhan, 'Poverty, Growth and Inequality in Nigeria: A Case Study'
} 


\section{Chapter Six}

poverty in 1985 is 38\%, in 1992 43\%, in 1996 47\%. The Statistician General of Nigeria estimated that about $45 \%$ of Nigerians are living below the poverty line. ${ }^{1197}$ In terms of proportion, the rate of poverty is higher in the rural areas than urban centres ${ }^{1198}$ but with the impact of rural-urban migration, a significant number of poor people are also concentrated in the slums areas of the cities. Regionally, poverty rate is higher in Northern Nigeria than in the South.

Rapid population growth makes the proportion of people living below the poverty line in Nigeria worrisome. These people suffer more disadvantages and are given low priority in development and resource allocation. ${ }^{1199}$ Poverty has been identified to have constituted "a serious problem to the health of women and children in Nigeria" and plausibly "explains the numerous cases of nutritional deficiencies leading to different kind of diseases". ${ }^{1200}$ Similarly, even in the context of justiciable rights: the so-called fundamental rights under chapter four of the Constitution, it had been rightly observed by an eminent jurist that:

The practical actualization of most of the fundamental rights cannot be achieved in a country like ours where millions are living below starvation level... In the circumstances of this nature, fundamental rights provisions enshrined in the constitution are nothing but meaningless jargon to all those of our people living below or just at starvation leve $1 .{ }^{1201}$

Considering water as a social, economic, and cultural resource, overcoming poverty cannot effectively be achieved without realising the right to water. ${ }^{1202}$ Water supply and sanitation have been recognised as important components in the Nigeria's national drive for poverty reduction because of its impact on agriculture, rural infrastructural development, education, industrial development, among others. ${ }^{1203}$ Hence the FMWR was recognised by the National Poverty Elimination Programme as one of the key government agencies in the "elimination of absolute poverty and the reduction or alleviation of relative poverty." 1204

It suffices to mention that several factors including corruption, political instability, lack of good governance, inequality in the distribution of State resources are some of the factors responsible for poverty in Nigeria. Another dimension which does not seem to be receiving much attention is the influence of political and wealthy individuals in the promotion of poverty. Poverty among citizens is sometimes promoted by politicians and wealthy people in order to perpetuate continued dominance and control over the poor. The thinking is, as people become economically self-reliant, their capacity to assert claims on their right increases, and total reliance on the politicians and the wealthy will reduce.

There have been several attempts to alleviate poverty without significant success. For example, Nigeria has pursued the following programmes: the National Accelerated Food

\footnotetext{
${ }^{1197}$ Yemi Kale, 'Measuring Better: Rebasing/Re-benchmarking of Nigeria's Gross Domestic Product ' Slide 22.

${ }^{1198}$ Ben E. Aigbokhan, 'Poverty, Growth and Inequality in Nigeria: A Case Study'

${ }^{1199}$ Inga T. Winkler, The Human Right to Water: Significance, Legal Status and Implications for Water Allocation. P. 4.

${ }^{1200}$ Muhammed Tawfiq Ladan, Law, Cases and Policies on Energy, Mineral Resources, Climate Change, Environment, Water, Maritime and Human Rights in Nigeria. P.189.

${ }^{1201}$ T. Akinola Aguda, 'Judicial Process and Stability in the Third Republic' National Concord Newspaper (Lagos 7 November), at P. 7.

${ }^{1202}$ Antonio E. Irujo, 'The Right to Water' P. 282.

${ }^{1203}$ Department of Water Supply and Quality Control, National Rural Water Supply and Sanitation Programme: A Strategic Framework. P. 5.

1204 Ibid.
} 
Realising the Right to Water and Sanitation in Nigeria

Production Programme and the Nigerian Agricultural and Co-operative Bank in 1972; Operation Feed the Nation which was designed to educate rural farmers how to utilise modern farming tool in 1976; Green Revolution Programme designed to increase local food production and reduce importation of food in 1979; Directorate of Food, Roads and Rural Infrastructure in 1986; Family Support Programme and the Family Economic Advancement Programme in 1993 and; National Poverty Eradication Programme in 2001. The causes of poverty and their continued dominance in the polity are the reasons why programmes aimed at alleviating poverty achieved limited success. From these perspectives, it is clear that poverty is caused and perpetuated by denial of human rights. There is a symbiotic relationship between poverty and human rights violations. When peoples' rights are denied such as the right to effectively participate and voice out opinions on fundamental issues affecting lives and dignity, their power relations diminish leading to diminish in status and self-worth. Poverty and its consequence of inequality are currently among the major sources of insecurity and political instability.

The impacts of poverty on the realisation of access to water and sanitation are numerous. The Human Development Report 2006 pointed out that "the scarcity at the heart of the global water crisis is rooted in power, poverty and inequality". ${ }^{1205}$ The National Environmental Sanitation Policy recognises the impact of poverty and poor living standard on environmental sanitation which is responsible for the high morbidity and mortality from sanitation related diseases. ${ }^{1206}$ Poverty creates unequal bargaining power and, wide social and economic disparity and instability. The perpetuation of poverty subjugates individuals and leads them to compromise their rights due to gaps between the different social classes. The basic issue is how to survive. The unequal bargaining power of the poor makes priority in the allocation of water to them very low. Indeed, "water flows uphill ... toward money." 1207 Findings in the empirical study has demonstrated that poverty is the main reason why people fail to claim human rights (see Table 5.9 and Figure 5.5).

\subsubsection{Low-level Literacy and Lack of Awareness}

This is yet another factor impeding progress in the realisation of ESC rights in general. The 2006 National Bureau for Statistics figures put adult literacy of the country at $65.70 \%$. Low level of literacy affects the capacity of individuals to be aware of their rights and to take progressive steps toward claiming and enforcing them. ${ }^{1208}$ In the empirical study, the findings indicated that several respondents are not aware of how to claim their rights or even the existence of the right to water and sanitation. Additionally, respondents among the dutybearers have voiced out concern as part of the challenges that people are not aware of the hazards of using untreated water and keeping sanitation standards. While it is not definite that awareness will automatically catapult action, action only takes place when awareness

\footnotetext{
${ }^{1205}$ UNDP, Beyond Scarcity: Power, Poverty and Global Water Crisis (Human Development Report 2006, Palgrave Macmillan 2006). P. 2.

${ }^{1206}$ See Federal Republic of Nigeria, National Environmental Sanitation Policy. Para. 1.2.1

${ }^{1207}$ See A. Markels, 'Sin City's Continuous Flow' US News (27 May) (cited by Inga T. Winkler, The Human Right to Water: Significance, Legal Status and Implications for Water Allocation) P. 7.

${ }^{1208}$ See also Federal Republic of Nigeria, National Environmental Sanitation Policy Para. 2.0.
} 


\section{Chapter Six}

exists. Additionally, people who are not educated are not likely to prompt or require dutybearers to act towards discharging their obligations. The existence of about $34 \%$ of illiterates in the country is a source of concern.

\subsubsection{Culture and Traditions, Religious Beliefs and Practices and Family Influence}

Some cultural and religious beliefs and practices are obstacles to the progressive realisation of the right to water and sanitation around the country. Practices of open defecation mostly in the rural areas and the belief that such provides manure to the farms and crops, the belief that water impurities are not considered dangerous and hence consumed without caution, the practice by farmers at work of eating without washing before and after meals, ${ }^{1209}$ are some of the most disturbing cultural issues affecting water sanitation and personal hygiene. Culture and traditions, religious, family and traditional rulers' influences equally impact on some rights-holders regarding litigation and or holding duty-bearers accountable. Findings in the empirical study have shown the extent to which these issues count in decisions to litigate on human rights.

\subsubsection{Population Passivity}

There seems to be awareness of human rights and the existence of the right to water and sanitation by the population. However, this awareness does not seem to correspond with the population's willingness to demand accountability from duty-bearers. Limited number of people have ever complained or sought for information on water and sanitation related issue from duty-bearers as established by the empirical study. This passivity has contributed to duty-bearers not considering accountability as an important requirement in the discharge of their duties.

\subsection{Natural and Environmental Factors}

It is acknowledged that the term "environment" carries as many meanings as the people who use it for different purposes and the contexts under which discussions are sustained. As such the term 'environment' has become susceptible to different interpretations and connotes the different contexts in which we utilise it as well as its importance to us. For some, the word environment "means reporting the garbage in to biodegradable and non-biodegradable items to others it means saving on electricity or saving water. The term environment may be associated with restoring the vitality of tropical rain forest maintaining biodiversity and arresting desertification." 1210 Environment has been defined as "the outer physical and biological system in which man and other organisms live - is a whole albeit, a complicated one with many interacting components." ${ }^{1211}$ From this perspective, environment includes the rocks, minerals, soils, waters, lands including their vegetation, animals and climate. ${ }^{1212}$

\footnotetext{
${ }^{1209}$ WaterAid, Nigeria: Country Strategy 2010-2015) P. 29.

${ }^{1210}$ Om Dutt, 'Relation Between Environment and Human Rights with Special Reference to India' (August, 2013) 3 Indian Streams Research Journal , P. 2.

${ }^{1211}$ See United Nations Environment Programme, UNEP Annual Review, 1980 (UNEP 1981) P. 6

1212 Ibid.
} 
Realising the Right to Water and Sanitation in Nigeria

Environment has also been defined to mean "the total planetary inheritance and the totality of all resources. It includes all the biotic and abiotic factors that influence each other."1213

The importance of environment to the growth and survival of human beings and societies cannot be overemphasised. Environmental health determines the health of a nation and its people. Environment impact on lives in unimaginable ways which because of it complex nature and the importance, clearly it "demands positive and realistic planning that balances human needs against the potential the environment has for meeting them." ${ }^{1214}$ In this context, appropriate planning which ensures reduction or elimination of pollution, gas flaring, unsustainable extraction of natural resources and harmful industrial emissions are required in order to sustain human lives, promote sustainable development and preserve the surrounding ecosystems. If our activities causing environmental degradation exceeds the carrying capacity of the environment, the lives of human beings and organisms would be at risk and may lead to extinction. ${ }^{1215}$

There is a direct relationship between the realisation of human rights and the nature of the environment. A cleaner and healthier environment is necessary for the realisation of human rights, ${ }^{1216}$ much more ESC rights. A good environment is necessary for human beings to develop and harness their potentials, and to promote progress in the society. Conducive environment is therefore a sine qua non for the realisation of human rights.

The obligation to protect the environment and the promotion of ESC rights cannot be ensured in an environment which is constantly polluted by human and industrial activities and in the absence of environmental data and statistic for planning, monitoring and implementation of programmes and policies. The Nigerian Government has acknowledged that "[a]lmost all socio-economic activities of man affect the environment" 1217 but certain environmental conditions negating human security and development have continued to be allowed occasioned by urbanisation and industrialisation. It is in this context that realisation of ESC rights and specifically right to quality water and environmental sanitation is proving difficult.

Notwithstanding the establishment of environmental protection agencies at the Federal and State levels, these agencies have not recorded much success in the protection of Nigerian environment and in encountering environmental and natural threats. There are no adequate proactive measures to tackle environmental degradation issues in place. This has led some regions like the Niger-Delta to experience restiveness. ${ }^{1218}$ The poor performance of agencies and lack of adequate measures have allowed the situation to worsen when other natural and environmental factors come into play. In many instances governments would only intervene "when serious environmental problems are reported." 1219 Natural and environmental factors including climate change and geographical location and the impact of oils extraction in some

\footnotetext{
${ }^{1213}$ Om Dutt, 'Relation Between Environment and Human Rights with Special Reference to India'. P. 2.

${ }^{1214}$ United Nations Environment Programme, UNEP Annual Review, 1980. P. 6.

${ }^{1215}$ Om Dutt, 'Relation Between Environment and Human Rights with Special Reference to India'. P. 2.

${ }^{1216}$ See ibid. P. 1.

1217 National of Bureau Statistics, 'Environmental $\quad$ Statistics'

<http://www.nigerianstat.gov.ng/pdfuploads/ENVIRONMENT\%20STATISTICS.pdf> accessed 28 June, 2014

${ }^{1218}$ National Human Rights Commission, State of Human Rights in Nigeria. P. 122.

1219 Ibid.
} 


\section{Chapter Six}

areas have contributed to water and sanitation problems. The impact of climate change is equally posing challenges on the available water and a change in the hydrological cycle. While controlling natural factors may be beyond governmental authorities, there is the need to adopt mitigatory measures to ensure that the impact is reduced. The National Policy on the Environment has noted this need and has outlined measures which the Government needs to take. ${ }^{1220}$ Some of these measures include developing and implementing a national strategic roadmap for responding to climate change; domesticating relevant climate change treaties and instruments including the Paris Agreement; and implementing the National Climate Change Policy and Response Strategy and mainstreaming climate change into all sectors of the national economy. The natural and environmental factors are:

\subsubsection{Climate Change}

Climate change is a serious issue affecting freshwater availability worldwide. It is indeed, a fundamental global phenomenon which does not recognise borders or sovereignty. ${ }^{1221}$ Global climatic changes effect on freshwater systems is not uniformly experienced or evenly distributed while the rate of precipitation is also different. ${ }^{1222}$ This means that some places will be wetter while others dryer. ${ }^{1223}$ Certain areas of the African continent are among those which the Intergovernmental Panel on Climate Change (IPCC) expected to be dryer. ${ }^{1224}$ The impacts will results to many of the world's most populated areas experiencing protracted drought with its resulting consequences on "agricultural production, economic development, the environment, human health, population growth, and power generation." 1225 The IPCC stated that the "[o]bservational records and climate projections provide abundant evidence that freshwater resources are vulnerable and have the potential to be strongly impacted by climate change, with wide-ranging consequences on human societies and ecosystems."1226 Nigeria is one of those countries experiencing the effects. Lake Chad is one of the major sources of water in Nigeria which at some point in history was the $3^{\text {rd }}$ largest in Africa but in 40 years, the Lake has decreased in volume by $95 \%$ due to among others, the impact of climate change. This has led to food insecurity, water scarcity and drought. ${ }^{1227}$

The impact of climate change is more severe in the developing world due to underdevelopment. It is stated that "[i]n the developing world, even a relatively small

\footnotetext{
${ }^{1220}$ Federal Republic of Nigeria, National Policy on the Environment. Para. 6.1.

1221 Eckstein Gabriel, 'Water Scarcity, Conflict, and Security in a Climate Change World: Challenges and Opportunities for International Law and Policy' (2009-2010) 27 Wis Int'l LJ . P. 414.

${ }^{1222}$ Ibid. P. 410.

${ }^{1223}$ Ibid.

${ }^{1224}$ Intergovernmental Panel on Climate Change, Technical Paper on Climate Change and Water, 2008) P. 32.

1225 Eckstein Gabriel, 'Water Scarcity, Conflict, and Security in a Climate Change World: Challenges and Opportunities for International Law and Policy' P. 411; See also O.B. Akpor and M. Muchie, 'Challenges in Meeting the MDGs: The Nigerian Drinking Water Supply and Distribution Sector' (2011) 5 Journal of Environmental Science and Technology Pp.480-489.

${ }^{1226}$ Intergovernmental Panel on Climate Change, Technical Paper on Climate Change and Water. P. 4. 1227 Arrianna Marie, 'Preventing Water Wars in Northern Nigeria' 2011) <http://aconerlycoleman.wordpress.com/2011/01/17/article-preventing-water-wars-in-northern-nigeria/> accessed 19 October, 2013
} 
Realising the Right to Water and Sanitation in Nigeria

climatic shift can trigger or exacerbate food shortages, water scarcity, destructive weather events, the spread of disease, human migration, and natural resource competition."1228

The impact of climatic changes on agriculture and food security is unquantifiable. In northern Nigeria (which produces a significant percentage of staple food for the country), food production exclusively or largely depends on how regular the hydrologic cycle is and its reliance by the people. ${ }^{1229}$ Majority of northern States rely on rainfall for agricultural production. The rates of rainfall per year determines the year's production. Changes in climatic conditions are currently causing changes in the hydrologic cycle leading to irregularity in the period coupled with the continued reduction in the amount of rain per given year.

Additionally, climate change is increasing desertification and drought in the northern States. These not only impact on food production and condition of life but also challenges water supply which also has consequences on sanitation and hygiene. In the coastal areas like Lagos where a significant number of the population rely on groundwater (boreholes), the rising sea level occasioned by climatic changes is increasing saltwater intrusion into groundwater making water unsuitable and unhealthy for human consumption. Furthermore, Nigeria has been, especially of recent, experiencing worst cases of flooding. Not only flood destroys farms and houses but also increases the cost of rehabilitating the damaged water infrastructures and construction of new systems in drought prone areas thereby causing additional expenditure on governments at various levels. ${ }^{1230}$ Flood has been known to be a major threat to the safety of water for human consumption. ${ }^{1231}$

In tackling and or mitigating the effects or impacts of climate change, Nigeria is under obligation where necessary to seek for international assistance and cooperation in line with article 2(1) of the ICESCR from technologically advanced nations. GC 15 of the UN Committee on ESC rights, ${ }^{1232}$ resolution $70 / 169$ of the $\mathrm{UNGA}^{1233}$ and the report of the Special Rapporteur on human rights to safe drinking water and sanitation ${ }^{1234}$ have all reiterated this obligation.

\subsubsection{Geographical Location: Inaccessibility and Distance}

Another factor accounting for poor coverage in water supply and sanitation and in the isolation or marginalisation of certain areas is the geographical location of those areas. This is connected to broader social and development issues and the effectiveness of Nigeria's governance system. Developmental programmes largely concentrated in the urban areas.

\footnotetext{
${ }^{1228}$ Kurt M. Campbell and others, The Age of Consequences: The Foreign Policy and National Security Implications of Global Climate Change, November, 2007) P. 56.

${ }^{1229}$ UNESCO, Water in A Changing World (2009) P. 112.

${ }^{1230}$ See Hon. Minister of Water Resources, Mid-Term Report on Water Sector Transformation (2011 - 2013), Slide 63.

${ }^{1231}$ Inga T. Winkler, The Human Right to Water: Significance, Legal Status and Implications for Water Allocation p. 26

${ }_{1232}$ UNCESCR, General Comment No. 15: The Right to Water (Arts. 11 and 12 of the Covenant). Paras. 30-36.

1233 United Nations General Assembly, Resolution 70/169: The Human Rights to Safe Drinking Water and Sanitation. Preamble 19 and Paras. 7 and 10.

${ }^{1234}$ United Nations General Assembly, Report of the Special Rapporteur on the Human Right to Safe Drinking Water and Sanitation. Para. 11.
} 
Chapter Six

Several towns and villages are not connected to power and good transportation networks. Provision of water in Nigeria is affected by power supply and transportation of water through trucks can also be affected by poor road networks. These leave the areas vulnerable and record low (if any) socio-economic developments. Duty-bearers have identified inaccessibility of certain areas or their geographical locations as a consideration in determining access to water and allocation.

\subsection{Assessment of Human Rights Obligations and Political, Economic, Social and Environmental Factors Contributing to Poor Water and Sanitation Coverage in Nigeria}

The impacts of the factors identified above on human rights realisation and enjoyment in Nigeria have been shown. As to whether the presence of these factors in the light of Nigeria's human rights obligations amounted to a breach, it needs to be established whether failure to address them is connected to inability or unwillingness of Nigeria as mentioned in both General Comment 15 of the Committee on ESC rights ${ }^{1235}$ and Maastricht Guidelines on Violation of ESC rights. ${ }^{1236}$

The political factors identified above demonstrated Nigeria's failure to adopt sound good governance principles that would enable it to comply with its international and domestic legal obligations such as those related to human rights in general and the right to water and sanitation in particular. Nigeria cannot claim inability in this context. Though the impacts of the military style of governance may take long to address, real possibilities of addressing the problems exist under democratic administration. Nigeria has failed to address leadership problems and corruption and has failed to generate the necessary political will to discharge its obligations to its citizens. This is not a problem of inability, but unwillingness as there exist manpower and resources to address the challenges associated with these problems.

The problems associated with the economic factors are equally problems demonstrating Nigeria's unwillingness to respond to its human rights obligations. As the biggest economy on the continent with adequate revenues accruing to the State, Nigeria has failed to ensure adequate funding of institutions saddled with responsibility to address human rights challenges. The limited and untimely releases of budgetary provisions and corruption are equally issues which are within the capacity of the State to address. Although much is currently being done to address corruption issues but there are still possibilities for improvement.

The problems on social and cultural issues demonstrated Nigeria's failure to take measures to adequately address the problem of population explosion and migratory movement. While there is a policy on population which is aimed at curbing population growth, there is a failure to implement the content of the policy by the duty-bearers. Additionally, while there is freedom of movement and residence in the country, no adequate steps seemed to have been taken to address imbalances created by migratory movements such

\footnotetext{
${ }^{1235}$ UNCESCR, General Comment No. 15: The Right to Water (Arts. 11 and 12 of the Covenant) Paras. 39-44.

${ }^{1236}$ International Commission of Jurists, Maastricht Guidelines on Violations of Economic, Social and Cultural Rights Para. 13.
} 
Realising the Right to Water and Sanitation in Nigeria

as expansion of services in areas susceptible to internal migration or such other measures which may discourage migratory movements such as development of rural areas or improving economic activities in such areas. There has equally been a failure to eliminate discriminatory practices in the provision of water and sanitation by Nigeria. This is an obligation which is not subject to availability of resources. Lack of awareness and access to information by the population indicate a failure by Nigeria to ensure adequate enlightenment of its population about human rights and the impact of its population practices on the realisation of human rights. The National Orientation Agency has been established to undertake among others this function, there seems to be a general failure to achieve this objective. There is equally a failure to adopt requisite strategies for the elimination of poverty. The current position demonstrated that human rights obligations do not seem to be guiding duty-bearers' effort to eradicate poverty.

The problems associated with institutional factors are problems on good governance issues and the failure to ensure that relevant human rights institutions are equipped with necessary capacity to discharge their functions. Problems of resources cannot be a justification in this context as the State has adequate resources capable of addressing institutional challenges.

In terms of Natural factors such as climate change and its impact on water availability, Nigeria may not be in the position to control climate change, but it is certainly in the position to adopt relevant measures to cushion the effect. While measures such as dam construction are currently being adopted, this must be done in the context of sound environmental management such that in an effort to provide water for human and agricultural needs, no damage is caused to the environment. The duty-bearers' response on environmental consideration in their decision to connect certain areas with State water supply is a failure of the State to ensure elimination of discriminatory practices in the provision of water and the obligation to ensure availability of a minimum supply to the vulnerable population. It is important to recall that ensuring the availability of the core minimum is an obligation irrespective of availability of resources. ${ }^{1237}$

\subsection{Conclusions}

Nigeria has water potentials capable of addressing its water scarcity and poor coverage. Several institutional structures exist to manage water, sanitation and environmental issues. However, institutional performance and coverage are hampered by multiple factors including political factors, economic factors, social factors, and natural and environmental conditions. Their continued presence in democratic dispensation period indicate Nigeria's failure to adopt relevant measures consistent with its human rights obligations. How legal and policy issues can be addressed will be the focus of next chapter while remaining issues would be covered in chapters eight and nine.

\footnotetext{
${ }^{1237}$ UNCESCR, General Comment No. 15: The Right to Water (Arts. 11 and 12 of the Covenant) Para. 37(a) and (h); International Commission of Jurists, The Limburg Principles on the Implementation of the International Covenant on Economic, Social and Cultural Rights Principles 25-28; International Commission of Jurists, Maastricht Guidelines on Violations of Economic, Social and Cultural Rights. Paras. 9 and 10.
} 


\section{Chapter Seven}

\section{Potentials of Liberal (Dynamic, Progressive) Legal Interpretation Approaches in the Promotion of Non-JUSTiCiable Rights}

\subsection{Introduction}

Chapter four has pointed out the problems associated with justiciability of ESC rights in Nigeria especially in relations to the constitutional provisions and non-domestication of relevant international conventions including ICCPR and ICESCR. Possibilities exists through which these problems can be addressed including through the use of principles of interpretation as demonstrated by the jurisprudence of courts from various jurisdictions. This chapter examines how the problem of non-justiciability can be approached in Nigeria. it draws from the potentials of liberal or progressive legal interpretation approaches utilised in some jurisdictions. Liberal interpretation involves the enlargement of the meaning of a statute or a provision in a statute for the purposes of bringing it in line with its spirit. ${ }^{1238}$ It equally means giving a meaning that would enable the attainment of the statute's objectives which is not inconsistent with the wordings used in the statute. ${ }^{1239}$ Dynamic or progressive interpretation is an interpretation approach which sees a legislation from the perspective of the present rather than the past. ${ }^{1240}$ In other words, it seeks to interpret legislations by taking into consideration new developments in the areas affected by the law and brings the legislation to be a living document by making it relevant to the new situations.

The chapter will first examine the concept of and arguments on justiciability of ESC rights, why justiciability of ESC rights is relevant to the realisation of the right to water and sanitation; how ESC rights can be realised in Nigeria through the African Charter Act; and the approaches to legal interpretation. This sets the pace to how relevant constitutional provisions are to be interpreted in order to promote ESC rights and by extension, the right to water and sanitation in Nigeria. The chapter will then examine the relevance of principles of a human rights-based approach in legal interpretation and will conclude with a possible option opened to the judiciary in transforming ESC rights in Nigeria. This chapter answers research question four in relations to the role of liberal legal interpretation in the realisation of the right to water and sanitation in Nigeria

\footnotetext{
${ }^{1238}$ Sreya B., 'Literal Interpretation Versus Liberal Interpretation' 8 July 2013) <https://ssrn.com/abstract=2290872> accessed 13 March 2018 P. 3.

1239 Ibid.

${ }^{1240}$ Mariamah Crona, 'The Principle of Dynamic Interpretation - A Matter of Legitimacy: The ECHR Principle of Dynamic Interpretation from a Constitutional Perspective', University of Oslo 2009) Pp. 35-7.
} 
Realising the Right to Water and Sanitation in Nigeria

\subsection{The Concept and Arguments on the Justiciability of ESC Rights}

Judicial decisions seem to suggest 'justiciability' is not a legal concept that has "a fixed content or susceptible of scientific verification." 1241 It is merely a convenient term signifying whether or not a court can consider, settle and award a remedy on an issue. Broadly, the term connotes "the extent to which a matter is suitable for determination." 1242 Essentially, it is a term that operates within the context of enforcement of rights. It has been defined as:

[A]bility to claim a remedy before an independent and impartial body when a violation of a right has occurred or is likely to occur. Justiciability implies access to mechanisms that guarantee recognized rights. Justiciable rights grant right-holders a legal course of action to enforce them, whenever the duty-bearer does not comply with his or her duties. ${ }^{1243}$

From the above insights, descriptively, a right is said to be justiciable if the holder of the right has a legal procedural right to access a judicial or quasi-judicial mechanism for its enforcement and entitles the right-holder to a remedy if the right is compromised. The concept of justiciability therefore is only meaningful, and a right is said to be 'justiciable' if there exist either an impartial court, administrative tribunal or other independent bodies with the power to determine the violation of a right and with authority to remedy or prevent a violation in a manner considered fair and acceptable in human rights law. As observed, the enforcement of a legal right is in the broad sense and has not been limited or restricted to the courts alone. Depending on internal arrangements in a State, rights can be adjudicated in domestic courts, administrative tribunals or other bodies provided those bodies are impartial, have sufficient degree of independence, ${ }^{1244}$ are capable of imposing order and can award remedies for which the State will respect and enforce. In the protection and enforcement of rights, States have different mechanisms. ${ }^{1245}$ Justiciability of a right essentially implies two important issues:

1. The right is recognised as a legal right for which the law guarantees and protect; and

2. Violation of the right entails the grant of a legal remedy or redress. ${ }^{1246}$

\footnotetext{
${ }^{1241}$ See Sehindemi \& Ors. v. Governor of Lagos State \& Ors. (2006) 10 NWLR (Pt.987) 1 Per SALAMI, J.C.A. (Pp.57-58, Paras. D-D) relying on Poe v. Ullman (1961) 367 US 497, 506 and Flast v. Cohen (1942) 392 US 83,95 where Chief Justice of United States Warren said- "Justiciability is itself a concept of uncertain meaning and scope. Its reach is illustrated by the various grounds upon which questions sought to be adjudicated in Federal Courts have been held not to be justiciable. Thus, no justiciable controversy is presented when the parties seek adjudication of only a political question, when the parties are asking for an advisory opinion when the question sought to be adjudicated had been mooted by subsequent development and when there is no standing to maintain the action."

${ }^{1242}$ Craig Scott and Patrick Macklem, 'Constitutional Ropes of Sand or Justiciable Guarantees? Social Rights in a New South African Constitution' (November, 1992) 141 University of Pennsylvania Law Review P. 17 relying on D. J. Galligan, Discretionary Powers: A Legal Study of Official Discretion (Clarendon Press 1990)

${ }^{1243}$ International Commission of Jurists, Courts and the Legal Enforcement of Economic, Social and Cultural Rights: Comparative Experiences of Justiciability P. 6

${ }_{1244}$ The International Commission of Jurists, International Principles on the Independence and Accountability of Judges, Lawyers and Prosecutors: Practitioners Guide No. 1 (International Commission of Jurists 2007) has provided guidance on the concept of independence and impartiality of judicial and quasi-judicial bodies. In terms of independence, such body should be free from control or influence of authorities and in terms of impartiality, the body should be one capable of making decisions on the basis of law and facts without bias.

1245 This may be for example the High Court, the Constitutional Court or the office of an Ombudsman as courts of first instance in laying a claim for the protection of a right or remedy for a violation.

${ }^{1246}$ Availability of remedy has been recognized by the Committee on ESC Rights in General Comment 9 and Human Rights Committee General Comment 29 as one of the most essential rights in human rights protection available even during period of State of Emergency. (See UNCESCR, General Comment No. 9: The Domestic Application of the Covenant; UN Human Rights Committee, General Comment No. 29: States of Emergency (article 4) (UN Doc CCPR/C/21/Rev1/Add11, 2001)
} 


\section{Chapter Seven}

Provision of a legal remedy or redress is a necessary component of justiciability. Article 2(3)(a) ICCPR obliges States to provide effective remedy to those whose rights have been violated. The ICESCR contains no such provision, however, the Committee on ESC rights in General Comment 9 is of the opinion that:

a State party seeking to justify its failure to provide any domestic legal remedies for violations of economic, social and cultural rights would need to show either that such remedies are not "appropriate means" within the terms of article 2.1 of the Covenant or that, in view of the other means used, they are unnecessary. ${ }^{1247}$

Although justiciability as a term implies legal protection of a right or the procedural right to approach a judicial or quasi-judicial mechanism, in the context of rights especially in Nigeria, it is often associated with CP rights. Constitutionally, CP rights have been provided for; their scope defined and procedural steps for enforcement clearly outlined. For example, in the 1999 Constitution, anyone who alleges any of the fundamental rights under chapter four of the constitution 1248 "has been, is being or likely to be contravened" may approach a High Court for redress. ${ }^{1249}$ Additionally, other quasi-judicial bodies such as the National Human Rights Commission, Public Complaints Commission and Committees of the National Assembly have been empowered to entertain complaints from individuals and groups on rights recognised under the Constitution.

Flowing from the above therefore, a right is said to be non-justiciable if by the operation of a constitution or other laws, an individual is expressly not permitted to challenge governmental actions (or individuals acting on State's behalf) for the violation of a right. Chapter Two of the Nigerian Constitution is widely believed to be non-justiciable. ${ }^{1250}$

There are two arguments concerning justiciability of ESC rights: the first one is that ESC rights are justiciable, and the second argument is that they are non-justiciable. ${ }^{1251}$ Those in support of justiciability demonstrated how realisation of CP rights is circumscribed by the presence of ESC rights. It was for example argued that in the developing world freedom of expression or assembly would mean nothing to a population struggling with insufficient food and those who are homeless. ${ }^{1252}$ The legitimacy of constitution in these countries, it was argued, depended on the extent to which ESC rights have been recognised. This consideration obviously informed the inclusion of ESC rights in the bill of rights of the South African Constitution. The other side of the divide however, argued that ESC rights are programmatic, polycentric and requiring positive obligations. This argument considered judges ill-equipped to adjudicate on issues essentially within the domestic jurisdiction of Legislative and Executive arms. The suitability and competence of judges to determine national budget allocations, for example, was questioned. That the Judiciary, unlike the Legislative and

\footnotetext{
${ }^{1247}$ UNCESCR, General Comment No. 9: The Domestic Application of the Covenant Para. 3

${ }^{1248}$ Chapter Four is titled "Fundamental Rights" and contains rights similar to those provided for in International Covenant on Civil and Political Rights, 1966.

${ }^{1249}$ Constitution of the Federal Republic of Nigeria S. 46

${ }^{1250}$ Because of S. 6(6)(c) of the Constitution

${ }^{1251}$ For more information about the debate on this issue see: Stanley Ibe, 'Beyond Justiciability: Realising the Promise of Socio-economic Rights in Nigeria' (2007) 7 African Human Rights Law Journal 225 Pp. 230-233)

${ }^{1252}$ Justice Richard J. Goldstone referred to this in his foreword in Varun Gauri and Daniel M. Brinks, Courting Social Justice: Judicial Enforcement of Social and Economic Rights in the Developing World (Cambridge University Press 2008) P. vii.
} 
Realising the Right to Water and Sanitation in Nigeria

Executive arms, lacked the requisite information or training to determine and adjudicate budgetary allocations issues.

\subsection{Justiciability of ESC Rights and its Relevance to Water and Sanitation in Nigeria}

The foundation of CP rights and ESC rights is traceable to the Universal Declaration of Human Rights (UDHR), but for historical reasons, namely, cold war among others (the West rejecting ESC rights and East refuting CP rights), ${ }^{1253}$ less attention is paid to justiciability of ESC rights compared to $\mathrm{CP}$ rights. As an implied right, justiciability or enforcement of the right to water and sanitation is circumscribed by the broader justiciability of ESC rights except the extent to which it can be linked to CP rights. Both ESC rights and CP rights are formal rights. By Formal it means the rights have been formally recognised by a State in a legally binding document such as the constitution, legislation or arising from ratification of or accession to a treaty or contained in a judicial decision. ${ }^{1254}$ Strictly, the right to water and sanitation is not an independent formal right. However, as an implied right, it is impacted and enforced if one of the formal rights from which the right was derived from is made justiciable.

In many countries, constitutions guaranteed CP rights, provided mechanisms for their enforcement and effective remedies where the rights have been violated while ESC rights are considered as mere objectives which the States are to pursue subject to availability of resources. This generated academic debates on the justiciability of ESC rights.

The approach of African States to ESC rights in constitutional arrangement can be categorised into three:

1. States with Justiciable ESC Rights: ${ }^{1255}$ The South African Constitution, 1996 in chapter 2 provided for Bill of Rights which recognises ESC rights such as right to healthy environment, right to housing, right to health care, food, water and social security, right to education, right to language and culture as justiciable rights. Pursuant to this recognition a number of cases have been decided by South African courts on ESC rights and in particular those which are relevant to the right to water

\footnotetext{
${ }^{1253}$ Although in the end both the Western and the Eastern blocs have contributed to the separation of ESC Rights from civil and political rights. The West being responsible for the partitioning of the rights, the East for depriving the ESC Rights of expert monitoring and individual communication procedures (see Ioana Cismas, 'The Intersection of Economic, Social, and Cultural Rights and Civil and Political Rights' in Eibe Riedel, Gilles Giacca and Christophe Golay (eds), Economic, Social, and Cultural Rights in International Law: Contemporary Issues and Challenges (Economic, Social, and Cultural Rights in International Law: Contemporary Issues and Challenges Oxford University Press 2014) p. 454; see also Asbjørn Eide, 'Economic, Social and Cultural Righs As Human Rights' See also Barbara Stark, 'Urban Despair and Nietzsche's "Eternal Return": From the Municipal Rhetoric of Economic Justice to the International Law of Economic Rights' (1995) 28 Vand J Transn'l L See also Kitty Arambulo, Strengthening the Supervision of the International Covenant on Economic, Social and Cultural Rights: Theoretical and Procedural Aspects (Intersentia 1999)

${ }^{1254}$ Varun Gauri and Daniel M. Brinks, Courting Social Justice: Judicial Enforcement of Social and Economic Rights in the Developing World. P. 7.

${ }^{1255}$ An example being the Constitution of the Republic of South Africa, 1996 and Libya which had enacted a legislation recognising economic and social rights (The Great Green Charter of Human Rights in the Jamahiriyan Era, adopted 12 June 1988).
} 
Chapter Seven

and sanitation. ${ }^{1256}$ The Namibian Constitution ${ }^{1257}$ does not require domestication of international treaties ratified by the State before being enforced by the domestic courts. This makes it possible and easier for citizens to lay claims before domestic courts on all human rights issues covered by international treaties binding on the State.

2. States with Limited Justiciable ESC Rights in the Constitution and others under National Objectives and Directive Principles of State Policy: ${ }^{1258}$ Under the Ugandan Constitution for example, the only ESC rights included in the Constitution are protection from deprivation of property, the right to education, the right to work and participate in trade union activity, and the right to a clean and healthy environment. Other ESC issues such as health, water and food are contained in the preamble under the National Objectives and Directive Principles of State Policy. As to whether these are justiciable is open to debate. Courts and administrative tribunals' jurisprudence on this issue is limited. ${ }^{1259}$

3. States with ESC provisions as Non-Justiciable Fundamental Objectives and Directive Principles of State Policy. Nigeria is in the third category. The Nigerian Constitution considered ESC rights as non-justiciable. Except the right to free and compulsory basic education, there are no other legally binding instruments under which ESC rights were made justiciable. The ICCPR and ICESCR are yet to be domesticated for the treaties to directly apply in domestic courts.

However, it needs to be pointed out that a possible instrument through which ESC rights can be adjudicated upon in Nigeria is the provision of ACHPR which had been domesticated as an Act of the National Assembly. In the next section, this issue will be examined.

\footnotetext{
${ }^{1256}$ See for example the following cases: Federation for Sustainable Environment and Others $v$. Minister of Water Affairs and Others [2012] High Court (North Gauteng, Pretoria) 35672/12, [2012] ZAGPPHC 128 <http://www.saflii.org/za/cases/ZAGPPHC/2012/128.html>; City of Cape Town v. Strumpher [2012] Supreme Court of Appeal 104/2011, [2012] ZASCA 54 <http://www.saflii.org/za/cases/ZASCA/2012/54.html>; Mandla Bushula v. Ukhahlamba District Municipality [2012] High Court (Eastern Cape Division) 2200/09, [2012] ZAECGHC 1 <http://www.saflii.org/za/cases/ZAECGHC/2012/1.html>; Beja and Others v. Premier of the Western Cape and Others [2011] High Court (Western Cape) 21332/10, [2011] ZAWCHC 97 <http://www.saflii.org/za/cases/ZAWCHC/2011/97.html>; Johnson Matotoba Nokotyana and Others v. Ekurhuleni Metropolitan Municipality and Others [2009] Constitutional Court CCT31/09, [2009] ZACC 33 <http://www.saflii.org/za/cases/ZACC/2009/33.pdf>; Mazibuko and Others v. City of Johannesburg and Others (Centre on Housing Rights and Evictions, Amicus Curiae) Constitutional Court of South Africa (CCT 39/09) [2009] ZACC 28; 2010 (3) BCLR 239 (CC); 2010 (4) SA 1 (CC) 8 October 2009; Highveldridge Residents Concerned Party v. Highveldridge Transitional Local Council and Others [2002] High Court (Transvaal Provincial Division) 28521, (2002) (6) SA 66; Government of the Republic of South Africa and Others v. Grootboom and Others [2000] Constitutional Court CCT11/00, [2000] ZACC 19 <http://www.saflii.org/za/cases/ZACC/2000/19.html〉.

${ }^{1257}$ Republic of Namibia, The Constitution of the Republic of Namibia (Ministry of Information and Broadcasting 1990) Art. 144 which provides "Unless otherwise provided by this Constitution or Act of Parliament, the general rules of public international law and international agreements binding upon Namibia under this Constitution shall form part of the law of Namibia".

${ }^{1258}$ For example, the Constitution of the Republic of Ugandan, 1995.

${ }^{1259}$ Some of the cases decided by the courts and Ugandan Human Rights Commission included: Byabazaire Grace v. Mukwano Industries, Miscellaneous Application No 909 of 2000; Joseph Eryau v. Environmental Action Network, Miscellaneous Application No 39 of 2001; Dimanche Sharon v. Makerere University, Constitutional Cause No 01 of 2003; Emmanuel Mpondi v. The Chairman, Board of Governors, Ngwana High School and Others, Complaint No. 210 of 1998; Kalyango Mutesasira v. Kunsa Kiwanuka and Others, Complaint No 501 of 2000.
} 
Realising the Right to Water and Sanitation in Nigeria

\subsection{Enforcement of ESC Rights through the African Charter Act}

ACHPR was ratified by Nigeria in 1983, ${ }^{1260}$ and in accordance with section 12(1) of the Constitution, ${ }^{1261}$ ACHPR was equally domesticated. ${ }^{1262}$ The domestication guarantees justiciability of its provisions at the domestic level as confirmed by the Nigeria's Supreme Court in Abacha v. Fawehinmi: ${ }^{1263}$

where an international treaty entered into by Nigeria is enacted into law by the National Assembly, as was the case with the African Charter on Human and Peoples' Rights which is incorporated into our domestic law by the African Charter on Human and Peoples' Rights (Ratification and Enforcement) Act, it becomes binding and our courts must give effect to it like all other laws falling within the judicial powers of the court.

Similarly, the Supreme Court has held in Ogugu v. State ${ }^{1264}$ that the ACHPR: like all other laws fall within the judicial powers of the courts ... Thus, by virtue of the provisions of sections 6(6)(b), 236 and 230 of the 1979 Constitution, ... it is apparent that the human and peoples' rights are enforceable by the several high courts depending on the circumstances of each case and in accordance with the rules and practice of each court.

As an important human rights instrument in Africa and specifically, Nigeria, the ACHPR contains binding obligations on the promotion and protection of $\mathrm{CP}$ and $\mathrm{ESC}$ rights. Relevant to our discussion, the following ESC rights have been expressly recognised in the ACHPR: Right to work, ${ }^{1265}$ right to health, ${ }^{1266}$ right to education, ${ }^{1267}$ right to economic, social and cultural development, ${ }^{1268}$ and right to general satisfactory environment. ${ }^{1269}$ Although the ACHPR has its own shortcomings, ${ }^{1270}$ it is nevertheless important to note its certain fundamental features such as omnibus provision, ${ }^{1271}$ absence of derogation clause and the fact that ESC rights are not subject to progressive realisation. In the ACHPR, ESC rights enjoy the same status with CP rights. Additionally, the obligation to respect, protect and fulfil is of immediate effect and not dependent upon resource availability. ${ }^{1272}$ All the rights provided for under the ACHPR are justiciable before the African Commission on Human and Peoples Rights subject to the exhaustion of local remedies where necessary and available. ${ }^{1273}$ These rights are equally justiciable at the domestic level.

\footnotetext{
${ }^{1260}$ Nigeria signed the African Charter on 31/08/1982, ratified on 22/06/1983 and deposited the instrument of ratification on $22 / 07 / 1983$

${ }^{1261}$ S. 12(1) of the Constitution provides that no treaty between the Federation and any other country shall have the force of law to the extent to which any such treaty has been enacted into law by the National Assembly.

1262 African Charter on Human and Peoples Rights (Ratification and Enforcement) Act. Cap. A9 Laws of the Federation of Nigeria, 2004

1263 (2000) 6 NWLR (Pt.660) 228 at P. 299.

1264 (1994) 9 NWLR Part 366 P. 1.

1265 Art. 15.

1266 Art. 16.

1267 Art. 17.

1268 Art. 22.

1269 Art. 24.

${ }^{1270}$ For example, it does not provide for all the ESC Rights and some rights like right to property is limited in context because it can be encroached upon in the interest of public needs or general community (Art. 14)

${ }^{1271}$ The African Commission on Human and Peoples Rights can draw inspiration from other human rights treaties including the UN Charter, Universal Declaration of Human Rights and other agreements binding on Africa and the specific States and instruments adopted by UN Agencies of which a particular State is a member (see Art. 60 of the African Charter).

${ }^{1272}$ Stanley Ibe, 'Beyond Justiciability: Realising the Promise of Socio-economic Rights in Nigeria' P. 227.

${ }^{1273}$ See Art. 45 of the African Charter
} 


\section{Chapter Seven}

Domestic courts have applied and pronounced judgments pursuant to ACHPR's provisions including during most repressive military periods when the whole or parts of the constitution was/were suspended, or the jurisdiction of courts to adjudicate human rights violations under the constitution was ousted. In 1990, a High Court in Mohammed Garuba and Others v. Lagos State Attorney General and Others ${ }^{1274}$ observed that the ACHPR as a domesticated treaty in Nigeria:

[e]ven if its aspect in our Constitution is suspended or ousted by any provision of our local law, the international aspect of it cannot be unilaterally abrogated. . . As [Justice Eso warned us], by signing international treaties, we have put ourselves on the window of the world, we cannot unilaterally breach any of the terms without incurring some frowning of our international friends.

This position was reinforced in The Registered Trustees of the Constitutional Rights Project (CRP) v. The President of the Federal Republic of Nigeria and Others ${ }^{1275}$ that as a ratified OAU treaty, an organisation which Nigeria continues to be a member, the ACHPR is binding on the Military Government. ${ }^{1276}$ Judicial decisions have confirmed ACHPR's justiciability in Nigeria. This survives notwithstanding section 6(6)(c). As shall be shown, arguments by some writers ${ }^{1277}$ that section 6(6)(c) had foreclosed justiciability of ACHPR's ESC rights provision is untenable. Admittedly, ACHPR ranked below the Constitution but its justiciability is in conformity with the Constitution and its enforcement is exempted by the Constitution under the phrase in section 6(6)(c) 'shall not except as otherwise provided by this Constitution'. ${ }^{1278}$ (Emphasis added).

Clearly, the cloak on judicial powers is limited to those chapter two provisions yet to receive additional recognition as enforceable under the Constitution or other laws. Where additional mention is made, and a specific authority is empowered to enforce, such issues are justiciable before courts.

Currently therefore, the judicial powers extend to entertaining questions arising from recognised constitutional rights (fundamental rights) and the aims and objectives of political parties provided for under section 224 of the Constitution. ${ }^{1279}$ This also includes such other provisions and laws (including treaties) adopted in conformity with constitutional requirements. These with respect, include ESC rights under ACHPR as a treaty and as national law domesticated pursuant to section 12 of the Constitution. To suggest that ESC rights in the ACHPR (both as a treaty and domestic law) are non-justiciable is not only disturbing but also amounted to overstretching the constitution and flying in the face of international legal obligations. With the domestication of the ACHPR long before the Constitution, it is untenable to assert the constitutional ousting of its justiciability. Importantly, it is instructive to note that under international law, a State may not be allowed

\footnotetext{
12744 Journal of Human Rights Law and Practice (1994) P. 205.

1275 Ibid. P. 243.

1276 Ibid. P. 244.

1277 See for example Onyekachi Wisdom Ceazar Duru, 'The Justiciability of the Fundamental Objectives and Directive Principles of State Policy Under Nigerian Law' 2012) <http://ssrn.com/abstract=2140361> accessed 1 December, 2014

${ }^{1278}$ Emphasis added

1279 The Supreme Court referred to this provision in Attorney-General of the Federation v. Atiku \& Ors. 2 CLC 218 at P.275
} 
Realising the Right to Water and Sanitation in Nigeria

to invoke its domestic law in order to justify its failure to comply with its treaty obligations. ${ }^{1280}$

As a valid, enforceable and constitution compliant domestic law, ACHPR provides ample opportunity for the Nigerian population to promote the realisation of ESC rights and to hold political leaders accountable. It is important to note the following regarding the ACHPR:

1. As a legally binding justiciable and constitutionally recognised domestic instrument, its applicability and enforcement are not subject to the limitation imposed by section 6(6)(c) of the constitution;

2. Not enforcing ESC rights under ACHPR is not only disrespect to the constitution, and a violation of international responsibility but also is capable of invoking the rebuke of the international community especially parties to the ACHPR;

3. Failure to enforce ACHPR and or provide effective remedy in the event of its violation could lead to submission of a communication by the injured party to the African Commission on Human Rights/African Court of Human Rights;

4. The wide applicability of ACHPR within the African Continent, the jurisprudence of the African Commission and those of other States within the region and provide opportunity for judges to borrow regarding the extent to which the ACHPR had been interpreted and enforced by courts. This may enrich judicial approach, promotes human rights enforcement, and address economic and social deprivations.

Notwithstanding its promises and judicial disposition to enforce it, limited attention has so far been paid to the ACHPR. To date few ESC rights cases have been brought before the domestic courts and African Commission on Human Rights from Nigeria. ${ }^{1281}$ This may have been as a result of general lack of awareness or other multiple factors such as poverty and its impact on litigation and other technicalities including the amount of time required to successfully pursue a claim to its logical conclusion.

\subsection{Approaches to Legal Interpretation}

In providing meanings to legal provisions, judges are assisted by several principles or rules of interpretation. Some of these rules are ancient while some are fairly recent. Some assist judges in discovering the intention of the draftsman while others serve mechanical purposes such as the filling of legislative gaps. The principles may be classified into two, though this classification is not watertight because some principles fall outside it: ${ }^{1282}$

1. Those which derived meaning from the statute itself; and

2. Those which use extrinsic aids.

The first group are principles used to derive meaning of the words used from the statute itself through deconstructing the statute as a whole. These include ejusdem generis rule; noscitur a sociis; expression unius est exclusio alterius; and casus omissus. In the second

\footnotetext{
${ }^{1280}$ Article 27 of the Vienna Convention on the Law of Treaties. This provision is however without prejudice to article 46 of the Treaty which may invalidate a treaty.

${ }^{1281}$ Such as the Social and Economic Rights Action Centre (SERAC) and Another v. Nigeria (2001) AHRLR 60 (ACHPR 2001)

${ }^{1282}$ See Quintin Johnstone, 'An Evaluation of the Rules of Statutory Interpretation' (1954-1955) 3 Kansas Law Review P. 2.
} 


\section{Chapter Seven}

group are those rules which resort to outside materials or information to clarify or discover legislative meanings and or intention. This category includes mischief rule, golden rule and statute in pari materia. Those falling outside the categorisation include instances of judicial activism. ${ }^{1283}$ The adoption of one or more of these principles is determined by facts and circumstances and or the disposition of a judge in a given case, though which principle is applied however, is significant. A principle which utilises extrinsic aid for example can lead to a result fundamentally different from a principle which only derived meanings from the statute itself. Extrinsic aids provide valuable insights into legislative intent and purpose. ${ }^{1284}$

In Nigeria, academic writers and judicial decisions (with few exceptions) appeared to have adopted principles in the first group in their interpretation of chapter two constitutional provisions. This approach impacted on the manner in which ESC provisions have been construed.

Nigeria is not the only country with non-justiciable constitutional ESC provisions. Within the common law system for example, Ireland and India were known to have constitutional provision limiting the powers of courts from enforcing Fundamental Objectives and Directive Principles of State Policy (which contain ESC Provisions). However, courts (even in India which at some point has had stricter constitutional limitation on Fundamental Objectives provisions) have played active roles in transforming non-justiciable ESC provisions through interpretations. Various judicial approaches have therefore demonstrated the important role of interpretation ${ }^{1285}$ in this endeavour. Arguably, adjudication of contentious legal issues involving meanings and import of phrases, wording and provisions, principles of interpretation impact on the results arrived at by courts. Through interpretation approaches, judges have transformed and protected otherwise non-justiciable ESC rights/provisions. How courts have used these may be said to have been assisted by judicial activism. Through judicial activism, judges have adopted liberal, integrated and purposive approaches to interpretation to transform the character of non-justiciable ESC rights. Next subsection focusses on the concept of judicial activism in legal interpretation.

\subsubsection{Judicial Activism in Legal Interpretation}

The utilisation of a liberal, integrated and purposive interpretation approaches appeared to be entirely the discretion of courts and quasi-judicial bodies. Its adoption is similar to the use of a precedent by a judge in circumstance where a judge has discretion to adopt or strive to distinguish the cases. Those who adopt the approach are often termed liberal judges or judicial activists. Judicial activism is a practice which judges adopt in determining and resolving issues in judicial proceedings. ${ }^{1286}$ This practice goes beyond traditional conservative approach to judicial decision-making where judges feel bound to adopt a particular restricted approach. It is an approach which opposes conservatism within and

\footnotetext{
${ }^{1283}$ Where courts may be said to be "legislating" in the way and manner in which they interpret statutory provisions. ${ }^{1284}$ See for example De Sloovere, 'Extrinsic Aids in the Interpretation of Statutes' (1940) 88 PA L Rev ; H. W. Jones, 'The Plain Meaning Rule and Extrinsic Aids in the Interpretation of Federal Statutes' (1939) 25 Wash, ULQ

${ }^{1285}$ In this thesis, principles of interpretation, rules of interpretation and canons of interpretation have been used interchangeably.

${ }^{1286}$ Clifford Brown, 'Judicial Activism' (1986) 13 Ohio Northern University Law Review . P. 157. 
Realising the Right to Water and Sanitation in Nigeria

among the judicial circle. Conservatism relates to the "tendency or disposition to maintain the existing views, methods, conditions or institutions" 1287 and a conservative is considered as "traditional, moderate and cautious." 1288 Flowing from this, conservative judges are orthodox judges with the tendency to maintain status quo and resist innovative techniques or approaches which extend the known boundaries in their judicial decisions. A liberal is "one who is open-minded or not strict in the observance of orthodox, traditional or established forms or ways, is an advocate or adherent of liberalism, especially in individual rights."1289 Arguments against judicial activism usually centred on doctrine of separation of powers that judges by using this, are usurping the legislative powers of the Legislature.

Expounding his ideas as a "liberal judge" former Ohio Supreme Court Justice Clifford Brown considered that the description of a liberal as "an advocate or adherent of liberalism, especially in individual rights" is quite apt and which in judicial context and layman's language connotes promotion of equal justice for the common man away from the conservative view. ${ }^{1290}$

It is difficult if not impossible to compose a constitution or a statute which is free from all interpretation problems. ${ }^{1291}$ Usually constitutions are drafted broadly and "a search for the 'intention of the framers' cannot resolve all, nor even a substantial proportion, of the problems of interpretation." 1292 However, it is through an attempt to address interpretation problems that judges are often accused of legislating or resorting to judicial activism. Conservative judges view liberals or judicial activists as judges who legislate and who arrogate to themselves the power to introduce new rules into the law which may sometimes be contrary to the laid down letters of the law. Indeed, the task of interpretation is substantial and can be too decisive as to create or lead to a creation of certain fundamental rules with enormous impact or implication on the existing laws. However, it must be noted that the broad and open-ended language in constitutions "is an invitation to subjectivity and activism"1293 and from which judges may find themselves incapable of escaping. Liberal judges have over the years adopted an innovative approach free from constitutional limitations to interpret sections of the constitution in ways considered revolutionary.

Arguments against judicial activism in the enforcement of constitutional ESC provisions seemed to have been anchored on doctrine of separation of powers. It is asserted that as the function of the judiciary is to interpret and apply laws, questions as to how budgetary allocations, prioritisation and decision on the measures to implement ESC rights are to be left to the executive and legislative arms of government as they belong more to the political sphere unlike their CP counterpart which "offer a better legal foundation as a basis for judicial adjudication." 1294 This argument has been challenged by other writers and commentators

\footnotetext{
1287 Ibid.

1288 Ibid.

1289 Webster's New Collegiate Dictionary (1979)

${ }^{1290}$ Clifford Brown, 'Judicial Activism'. P. 158.

${ }^{1291}$ Charles B. Blackmar, 'Judicial Activism' (1997-1998) 42 Saint Louis University Law Journal P. 771.

1292 Ibid. P. 772.

1293 Ibid.

${ }^{1294}$ International Commission of Jurists, Courts and the Legal Enforcement of Economic, Social and Cultural Rights: Comparative Experiences of Justiciability p.73. for a discussion on the issue, refer to Pp. 74-88.
} 
including the International Commission of Jurists (ICJ). The ICJ has demonstrated the hazy nature of this argument and the imprecise distinction between the political and legal spheres. In 1959, the ICJ in its Rule of Law Conference held at New Delhi, India had underscored the point on the subordination of the Executive to the rule of law in its decisions and actions. The Jurists noted that "... the acts of the executive which directly and injuriously affect the person or property, or rights of the individual should be subject to review by the courts..." 1295

Regarding the encroachment of separation of power doctrine, the South African Constitutional Court when confronted with this issue held that:

It is true that the inclusion of socio-economic rights may result in courts making orders which have direct implications for budgetary matters. However, even when a court enforces civil and political rights such as equality, freedom of speech and the right to a fair trial, the order it makes will often have such implications. A court may require the provision of legal aid, or the extension of state benefits to a class of people who formerly were not beneficiaries of such benefits. In our view, it cannot be said that by including socio-economic rights within a bill of rights, a task is conferred upon the courts so different from that ordinarily conferred upon them by a bill of rights that it results in a breach of the separation of powers. ${ }^{1296}$

Indeed, the Judiciary as an important organ in the promotion and protection of human rights is at the centre of legal enforcement of ESC rights and by extension the right to water and sanitation. In several countries, Judiciary serves the role of a watchdog guarding against Executive excesses and laxity and supplementing legislative gaps. To have legitimacy and respect however, judges must strive to ascertain precisely the circumstances under which their judicial activism and decisions can be enforced under a political situation. It has rightly been observed by Gauri and Brinks that "[c]ourts can advance social and economic rights under the right conditions precisely because they are never fully independent of political pressures." 1297 This is true especially when viewed from the context of judicial reliance on the Executive for funding and enforcement of judicial decisions.

One of the criticisms against the justiciability of ESC rights is their vagueness. Whether this is true will be determined by courts through judicial pronouncement. The courts however, would need to be activated by a complaint, a request for a declaratory pronouncement and or enforcement of a legal right. Courts do not as a matter of practice serve Father Christmas functions. To determine the contents of the right to water and sanitation under the extant Nigerian laws for example, and the extent to which it can be judicially enforced would require individual or group's action.

The propensity of adoption of liberal, integrated and purposive approach by Nigerian courts appeared positive. The Nigerian Federal High Court has issued quite recently a revolutionary judgment recognising right to a healthy environment as a human right in the context of environmental pollution and protection in Niger Delta area. This is notwithstanding that right to health and healthy environments are contained in the nonenforceable Fundamental Objectives provisions of the Constitution.

\footnotetext{
1295 International Commission of Jurists, The Rule of Law and Human Rights: Principles and Definitions as Elaborated at the Congresses and Conferences Held Under the Auspices of the International Commission of Jurists, 1955-1966 (International Commission of Jurists 1966) Pp. 11-12.

${ }^{1296}$ Case CCT 23/96, Certification of the Constitution of the Republic of South Africa, September 6, 1996, Para. 77

1297 Varun Gauri and Daniel M. Brinks, Courting Social Justice: Judicial Enforcement of Social and Economic Rights in the Developing World. P. 6.
} 
Realising the Right to Water and Sanitation in Nigeria

Courts sometimes borrow or draw inspirations from international legal standards, interpretation of treaty bodies and legal experts on the contents and obligations of States in the implementation of their international legal obligations and in the interpretation of domestic constitutional and legal obligations. Judges have been invited to consider this possibility by the Bangalore Declaration and Action Plan.

Judges should apply domestically international human rights norms in the field of economic, social and cultural rights. Where there is an ambiguity in a local constitution or statute or an apparent gap in the law, or inconsistency with international standards, judges should resolve the ambiguity or inconsistency or fill the gap by reference to the jurisprudence of international human rights bodies. ${ }^{1298}$

\subsubsection{Purposive, Liberal and Integrated Interpretation Approaches}

These approaches are utilised in legislative, constitutional and treaty interpretation. Purposive interpretation seeks to ascertain the purpose of a legislation before words in the legislation are interpreted. This approach was explained by Lord Simon in Maunsell $v$. Olins $^{1299}$ that "The first task of a court of construction is to put itself in the shoes of the draftsman - to consider what knowledge he had and, importantly, what statutory objective he had ...being thus placed...the court proceeds to ascertain the meaning of the statutory language." Liberal interpretation involves equitable enlargement of statutory words in order to accomplish the intended purpose of the legislation or promotes justice. ${ }^{1300}$ The enlargement however, does not extend to situations where the legislation is clear or unambiguous and free from doubts. ${ }^{1301}$ It merely seeks to expand the meaning to meet cases which are clearly within the spirit, reason or intent of the legislation or to avoid the evils which the legislation was designed to remedy. ${ }^{1302}$ In the case of integrated approach (also called unified contextual approach), the actual wordings are respected by the court but are interpreted in the context they appear together with the underlying purpose of the legislation. Sir Rupert Cross has demonstrated how this approach is applied: first consider the words' ordinary meaning in the general context of the legislation, then one takes a broad view of what constitutes the "context", and then one considers other possibilities where the ordinary meaning leads to an absurd result. ${ }^{1303}$ There is a nexus between these approaches as all of them provide flexibility to judges to develop the law in accordance with their perception of the intention of the draftsman. These approaches are important in the interpretation of constitutions because of their unique and broad language and the purposes they are designed to achieve.

\subsubsection{Interpretation of Constitution}

A national constitution is a unique legal document and superior to any other written law. The validity or otherwise of any law is usually assessed in the light of its conformity with constitution. As the foundation of governance structure in a State, a constitution serves

\footnotetext{
${ }^{1298}$ International Commission of Jurists, Bangalore Declaration and Plan of Action (1995), Para. 18.5.4

${ }^{1299}$ [1975] AC 373

${ }^{1300}$ Causey v. Guilford Country, 135 S.E. 40

${ }^{1301}$ R.E. Agpalo, Statutory Construction' 2003 Ed (Rex Book Store 2003) P. 286

${ }^{1302}$ Crescent City v. Griffin, 87 P2d 414

${ }^{1303}$ R. Cross, J. Bell and G. Engle, Statutory Interpretation (Butterworths 1995)
} 


\section{Chapter Seven}

numerous functions including ensuring and maintaining the coherent existence of a State, bringing together several and diverse interests on common terms. To serve these purposes, it is usually drafted broadly. Judicial approach to constitutional interpretation has to necessarily be liberal, broad and encompassing. The Nigerian Supreme Court per Ogwuegbu JSC in Attorney-General, Ondo State v. Attorney-General of the Federation ${ }^{1304}$ observed that:

[a] Constitution is an instrument of government under which laws are made and are not mere Acts or law and the construction which the court will give to a constitutional provision must be such that will serve the interest of the Constitution and best carry out the subject and purpose and give effect to the intention of the framers.

Similarly, in Attorney-General, Lagos State v. Attorney-General of the Federation ${ }^{1305}$ the Supreme Court per Kalgo JSC held that:

[i]n the interpretation of any provision of the Constitution, it has been well established by this court in its various decisions that a wider and liberal interpretation must be applied unless there is express provision to the contrary and this must be done in order to carry out or give effect to the intention of the makers of the Constitution.

Quoting with approval, its decision in Nafiu Rabiu v. State, ${ }^{1306}$ the Supreme Court per Uwais CJN considered it "trite canon that in interpreting the Constitution narrow meaning should not be given to it unless it becomes necessary to do so". Furthermore, in Ekeochav. Civil Service Commission, Imo State \& Ors. ${ }^{1307}$ Oputa, J. (as he then was) held that "in all cases of interpretation of the Constitution, the courts should adopt such a construction as will promote the general legislative purpose underlying the Constitution, which is to put the Federal Legislature in such a position that it can legislate for the general interest of the whole country."

Similarly, the difficulty and stringent conditions usually associated with constitutional amendments necessitate its liberal, broad and purposive interpretation in order for the constitution to be in line with changing circumstances. Changes in social, economic, technological circumstances and other factors bear direct relationship with statutory interpretation $^{1308}$ including constitution particularly where changes are fundamental and affect attainment of constitutional objectives. This essentially requires broad interpretation not only to achieve the objectives but to equally address new and important issues which human nature failed to address or anticipate during the drafting process. It is in this light and the tradition set in other jurisdictions that a purposive interpretation of the Nigerian Constitution is proposed. The Judiciary must be progressive and innovative in the promotion and attainment of constitutional ideals. Judges must set themselves free from the cocoon of literal interpretation. Identifying and balancing all processes which controlled drafting of a constitution are sine qua non to achieving constitutional objectives.

Constitutions inter alia must first and foremost be seen as important human emancipation legal documents and not just documents outlining States' structures. In some jurisdictions, ${ }^{1309}$

\footnotetext{
1304 (2002) 6 S.C (Pt.I) 1 (2002) 9 NWLR (Pt.772)

1305 (2003) 12 NWLR (Pt.833) (2003) 6 S.C (Pt.I) 24

1306 (1981) 2 NCLR 293; (1980) 8 - 11 SC 130

1307 (1981) 1 NCLR 154 at 165

${ }^{1308}$ See F.A.R. Bennion, Understanding Common Law Legislation: Drafting and Interpretation (Oxford University Press 2009) Pp. 53-55

${ }^{1309}$ Such as India
} 
Realising the Right to Water and Sanitation in Nigeria

courts have used interpretation powers to promote and protect citizens' rights using constitutional provisions. Trends in judicial decisions have established the transformation of non-justiciable ESC right through integrated, liberal and purposive interpretation. Courts' functions are many, but it suffices to state that as the arbiter in dispute resolution, a mechanism for human rights protection, and last hope of the common man, courts must avoid narrow interpretation of human rights provisions except in circumstances where derogation is permitted. The Nigerian Supreme Court had at some point recognised implications flowing from narrow interpretation of the constitution. In Attorney-General of Ondo State $v$. Attorney-General of the Federation ${ }^{1310}$ the Supreme Court per Uwais CJN stated:

It has been argued that the fundamental objectives and the directive principles of state policy are meant for authorities that exercise legislative, executive and judicial powers only and therefore any enactment to enforce their observance can apply only to such persons in authority and should not be extended to private persons, companies or private organisations. This may well be so, if narrow interpretation is to be given to the provisions, but it must be remembered that we are here concerned not with the interpretation of a statute but the constitution which is our organic law or grundnorm. Any narrow interpretation of its provisions will do violence to it and will fail to achieve the goal set by the constitution.

It is not however intended that the adoption of a liberal, integrated and purposive interpretation which sometimes assist in filling certain legislative gaps, should entitle courts to usurp Executive and Legislative functions. Courts are duty-bound to give effect to constitutional provisions except in circumstances where doing so will occasioned injustice not intended by the constitution. The courts are not to supplant but supplement, hence the obligation to observe separation of power principle under the extant laws.

In this thesis, the application of these approaches is in two ways which will be examined below:

1. Application of purposive interpretation to fundamental objectives and directive principles of state policy;

2. Liberal and integrated approach to ESC rights through fundamental (justiciable) rights provisions.

\subsubsection{Purposive Interpretation Approach to Fundamental Objectives and Directive Principles of State Policy}

In the context of Nigeria, applying purposive interpretation approach requires identifying the intendment of the Chapter Two provisions. It requires investigating the constitutional drafting process and how the provisions found themselves in the Constitution. In this context, the pertinent question requiring investigation is what was the intention of framers of Fundamental Objectives provisions? Without a doubt, Nigeria had operated other constitutions previously, which advertently or inadvertently failed to incorporate enforceable ESC rights. The 1999 Constitution similar to its predecessor, 1979 Constitution, suffered haphazard preparation and enormous political interference. It was drafted at the tail end of military administration. Pre-determined issues drafted by the military were hurriedly put to public debate which lasted for less than two months wherein the Constitution was presented

${ }^{1310}$ (2002) 6 S.C (Pt.I) 1 (2002) 9 NWLR (Pt.772) 
to the general public as adopted. The Constitution hence could best be described as a 'received document'.

The 1999 Constitution has its roots in the 1979 Constitution $^{1311}$ and was heavily influenced by it. ${ }^{1312}$ The 1979 Constitution was a major attempt to break-away from the colonial type constitutions and British system of governance in post-colonial Nigeria after civil war. The process was intended to give Nigeria a truly indigenous constitution which addresses the country's political problems on the basis of true and realistic representations, devolution of power, and the establishment and strengthening of viable political institutions. ${ }^{1313}$ The inclusion of national policy objectives which constitutes the core ESC rights in the 1979 Constitution (and those of other African States) was done at the time when African States were "grappling with the formulation of coherent constitutional agenda for nation building as well as human and national development". ${ }^{1314}$ The provisions were then termed as "Fundamental Objectives" or "Directive Principles". ${ }^{1315}$ Within the common law States, Ireland pioneered having a non-justiciable constitutional provision on Directives of State Policy. ${ }^{1316}$ However, the Nigerian provisions were heavily influenced by the Indian experience. ${ }^{1317}$

The history of Fundamental Objectives and Directive Principles of the Indian Constitution demonstrated no intention to distinguish, in terms of justiciability, between the $\mathrm{CP}$ rights and ESC rights. According to Glanville Austin ${ }^{1318}$ supported by other writers: ${ }^{1319}$

Although the Fundamental Rights and Directive Principles appear in the Constitution as distinct entities, it was the (Constituent) Assembly that separated them; the leaders of the Independence Movement had drawn no distinction between the positive and negative obligation of the state. Both types of rights have developed as a common demand, product of the national and social revolutions, of their almost inseparable intertwining, and of the character of Indian politics itself. ${ }^{1320}$

\footnotetext{
${ }^{1311}$ Constitution of the Federal Republic of Nigeria (CFRN), promulgated into law by the CFRN Decree 104 of 1979 , entered into force $1^{\text {st }}$ October 1979.

1312 John Simpkins, 'The Role of Constitution-Building Processes in Democratization' (International IDEA Democracy-building \& Conflict Management (DCM), 2004) <http://www.idea.int/cbp/upload/CBP-NigeriaExternal.pdf> accessed 20 November, 2014 P. 3.

${ }^{1313}$ This was reflected in the speech delivered by the then Head of State Gen. Murtala Mohammed to the Constitution Drafting Committee (see Oyele Oyediran (ed), The Nigerian 1979 Elections (MacMillan Nigeria 1981) P. 22.

${ }^{1314}$ Dejo Olowu, An Integrative Rights-based Approach to Human Development in Africa (Pretoria University Law Press 2009) P. 90.

1315 There are however, other States outside Africa with similar constitutional provisions. See for example the Constitution of India

${ }^{1316}$ Article 45 of the Irish Constitution, 1937 (as amended) provides: The principles of social policy set forth in this Article are intended for the general guidance of the Oireachtas. The application of those principles in the making of laws shall be the care of the Oireachtas exclusively, and shall not be cognisable by any Court under any of the provisions of this Constitution.

${ }^{1317}$ Dejo Olowu, An Integrative Rights-based Approach to Human Development in Africa. P. 94.

1318 A Constitutional Historian and a leading authority on Indian Constitution

1319 V. Z. Narively, Conflict: Right to Property and Directive Principles of the Indian Constitution (Sterling Publishers 1988) P. 39. A somewhat similar opinion was also shared by Seervai (see H. M. Seervai, Constitutional Law of India: A Critical Commentary, with Supplement (N.M. Tripathi 1967) p. 759 that "The principal object in enacting the directive principles was to set standards of achievement before the legislature and the executive, the local and other authorities, by which their success or failure could be judged. It was also hoped that those failing to implement the directives might receive a rude awakening at the polls."

${ }^{1320}$ G. Austin, The Indian Constitution: Cornerstone of a Nation (2nd edn, South Asia Books 1999) P. 52.
} 
Realising the Right to Water and Sanitation in Nigeria

The drafting process of 1979 Constitution indeed involved participation of representatives and consultations after the first draft, however, little evidence can be adduced to prove the Constitution truly reflected 'the act of the people' or the true desires and aspirations of the Nigerian people. ${ }^{1321}$ The process was closely monitored at the very beginning and interfered with by the then military administration which made the final document "primarily the result of a constitution building process dominated by the government and engineered to deliver a result that the outgoing regime would find acceptable." 1322 The Constitution Drafting Committee $^{1323}$ considered it necessary to provide for a national ideology within the Constitution $^{1324}$ and the intention (upon which a recommendation was also made to the Government) was to make Fundamental Objectives ${ }^{1325}$ justiciable while the Directive Principles of State Policy ${ }^{1326}$ non-justiciable. ${ }^{1327}$ However, the final document released by the Military contained the two provisions lumped together ${ }^{1328}$ and made them 'nonjusticiable'. 1329

Although with defects, the fact that the Constitution was considered as first indigenous coupled with several measures which were more inclusive than past democratisation efforts (such as the holding of local governments elections as the beginning of democratisation, as well as the public participation in its making), the Constitution was received notwithstanding that the final document did not exactly incorporates citizens' yearnings and aspirations. Arguably, the main concerns, at the time, were restoration of civilian administration and respect for CP rights. The non-justiciability of ESC right was not thought to be of significant implication. With the expectation that government would be proactive and pro-people, it was assumed developmental programmes leading to the realisation of ESC rights would be actively pursued without a need to require enforcement through judicial process. This was

\footnotetext{
${ }^{1321}$ John Simpkins, 'The Role of Constitution-Building Processes in Democratization'. P. 6.

1322 Ibid.

${ }^{1323}$ The Constitution Drafting Committee consisted of 49 experts who were considered as "wise men" chaired by a Constitutional Law expert Prof. Ben O. Nwabueze.

${ }^{1324}$ Muhammadu Lawal Uwais, 'Fundamental Objectives and Directive principles of State Policy in Modern Constitutions: Possibilities and Prospects' in C. C. Nwaeze (ed), Justice in the Judicial process: Essays in Honour of Honourable Justice Eugene Ubaezeonu JCA (Justice in the Judicial process: Essays in Honour of Honourable Justice Eugene Ubaezeonu JCA, Fourth Dimension Publishers 2002) P. 166.

${ }^{1325}$ Fundamental Objectives, according to the Constitution Drafting Committee mean the ultimate objectives of the nation i.e. the hall mark of a nation.

${ }^{1326}$ Directive Principles of State Policy indicate the roadmap leading to the attainment of the Fundamental Objectives.

${ }^{1327}$ A. J. Maidin and others, 'Sustaining Development through Socio-Economic Rights: Prospect and Challenges in Selected African Countries' (2011) 7 Journal of Applied Sciences Research P. 2367.

1328 Ibid.

${ }^{1329}$ Another justification for the inclusion of Fundamental Objectives provisions according to a writer was that the Objectives "[R]efer to a set of social ideals which are semi-justiciable and designed as targets towards which the country must aim. They define a goal for the Nation without which this country would drift as it appeared to have done in the past. In a country as vast and heterogeneous as Nigeria where we still have primacy of local interests and where the people have ... different historical, cultural and religious backgrounds, it has become necessary to spell out in detail the basic principles of the state for the guidance of government" (see E. U. Emovon, 'Fundamental Objectives and Directive Principles and Public Accountability' in Suleimanu Kumo and Abubakar Aliyu (eds), Issues in the Nigerian Draft Constitution: The Report of the Conference on Issues in the Draft Constitution, Held at the Institute of Administration, Ahmadu Bello University, Zaria, 21st - 24th March, 1977 (Issues in the Nigerian Draft Constitution: The Report of the Conference on Issues in the Draft Constitution, Held at the Institute of Administration, Ahmadu Bello University, Zaria, 21st - 24th March, 1977, Dept. of Research and Consultancy, Institute of Administration, Ahmadu Bello University 1977) P. 29.
} 


\section{Chapter Seven}

because seemingly, the general consensus on chapter two provisions is for the purpose of benefiting majority of the population especially the poor and the vulnerable ${ }^{1330}$ and governments at all levels will work towards addressing issues and imbalances. Lack of resources was never the reason behind their non-justiciable nature.

The events leading to the adoption of the 1999 Constitution were decisive. Nigeria was struggling to cope with political, ethnic and religious disturbances resulting from the failure to truly articulate the Nigerian reality. ${ }^{1331}$ With political scenes changing rapidly following the demise of General Sani Abacha, no adequate arrangements were made to usher in acceptable constitutional arrangements and provisions. The 1999 Constitution suffered political interference by the ruling military elites. Several criticisms were labelled against the entire constitutional drafting procedure which commenced with the appointment of a 25member Constitutional Debate Coordinating Committee ${ }^{1332}$ by the Military Government. The process was considered as not people oriented or driven. ${ }^{1333}$ The 1979 Constitution was adopted as a working document in the drafting of the 1999 Constitution because it "had been tried and tested and, therefore, provides a better point of departure in the quest for constitutionalism in Nigeria." 1334

The substance of the Constitution was itself subjected to criticisms as it failed to respond to series of demands by various groups in Nigeria. Substantively, the non-inclusion of ESC rights in fundamental rights provision, the over-concentration of power in the hands of Executive especially the subjection of the Judiciary and Police to Executive's control were heavily criticised. ${ }^{1335}$ The 1999 Constitution was described as a "fraudulent document" by the 1979 Constitution Drafting Committee Chair. ${ }^{1336}$ The Constitution witnessed little public consultation. Even when the draft was circulated, recommendations made were largely ignored. ${ }^{1337}$ The claim by the Preamble of the Constitution 'We the people' was described as a 'lie'. ${ }^{1338}$ According to a Senior Advocate of Nigeria it "is not the Constitution of the People of Nigeria. It is no more, no less, than a Constitution for Nigeria designed by the Military. It is nothing, but a Military Constitution imposed on Nigeria by force of guns." 1339 The 1999 Constitution was never a reflection of Nigerians' aspirations. Additionally, in order to force it on the people, the ruling military elite kept the country in suspense. Although it claimed

\footnotetext{
${ }^{1330}$ Onyekachi Wisdom Ceazar Duru, 'The Justiciability of the Fundamental Objectives and Directive Principles of State Policy Under Nigerian Law' Pp. 1-2.

${ }^{1331}$ John Simpkins, 'The Role of Constitution-Building Processes in Democratization' P.8.

1332 Consisting of academics, lawyers, and retired officers.

${ }^{1333}$ John Simpkins, 'The Role of Constitution-Building Processes in Democratization' P. 8.

${ }^{1334}$ Constitution Debate Coordinating Committee, Report of the Constitution Debate Coordinating Committee (CDCC): Main Report, vol 1 (Government Printer, December 1999) P. 56.

1335 Economist Intelligence Unit, 'Nigeria: Constitutions and Institutions' 15 June, 2004) <http://country.eiu.com/Nigeria> accessed cited in John Simpkins, 'The Role of Constitution-Building Processes in Democratization'p.8. See also A.A.O. Ismail, 'Towards the People's Constitution in Nigeria' (2010) 7 Journal of Law and Diplomacy

${ }^{1336}$ Taiwo Osipitan, 'An Autochthonous Constitution for Nigeria: Myth or Reality?' (An Inaugural Lecture Delivered at University of Lagos Main Auditorium on Wednesday, 24 November, 2004)

${ }^{1337}$ John Simpkins, 'The Role of Constitution-Building Processes in Democratization' P. 8.

${ }^{1338}$ Taiwo Osipitan, 'An Autochthonous Constitution for Nigeria: Myth or Reality?'

${ }^{1339}$ Chief Tanimose Abioye Bankole-Oke, 'Lawyers' Challenge and Burden of 1999 Constitution' Guardian (Lagos 28 April)
} 
Realising the Right to Water and Sanitation in Nigeria

the Constitution will substantially be similar to that of 1979 , details of amendments made were never made public until a day to the formal handing over to civilian administration. ${ }^{1340}$

From the foregoing, it appears the framers from 1979 onward never intended the Fundamental Objectives provisions to be merely non-justiciable ideals. This then call to question the intention of the Military Government for refusing to allow justiciable ESC rights. This is a question which is yet to be answered. In both 1979 and 1999, the Military leaders were surrendering political administration with little or no legal obligations to ensure realisation of ESC rights. In the light of political and legal impediments to constitutional amendments or pending when such is done, purposive interpretation is a useful judicial approach to restore framers' intention in the best interest of citizens.

Additionally, flowing from the examination of obligations imposed by chapter two of the constitutions, it appears the Nigerian judiciary has obligation to work towards ensuring the realisation of the chapter's provisions. The opening section of chapter two of the Constitution unambiguously stated that "[i]t shall be the duty and responsibility of all organs of government, and of all authorities and persons, exercising legislative, executive or judicial powers, to conform to, observe and apply the provisions of this Chapter of this Constitution." 1341 This effectively imposes obligations on all governmental organs, agencies, and individuals (and arguably the private sector and individuals) to observe, conform and apply the provisions of the chapter. Similarly, in imposing specific obligations, the chapter uses mandatory operative word 'shall' to denote such obligations on duty-bearers to actively pursue the political, economic, and social objectives of the constitution. ${ }^{1342}$ However, this appeared contradictory when jointly read with section $6(6)(c) .{ }^{1343}$ The limitation of judicial powers on chapter two provisions made a caricature of the obligations imposed by section 13. ${ }^{1344}$ What then is the nature of the obligation?

It is argued here that the Constitution could not, after imposing obligations, becomes an obstacle to courts whose duty include addressing questions on whether constitutional provisions are complied with in any governmental actions. To assume this is to render the obligations hollow, providing free ride for organs of government saddled with those responsibilities. This runs against common sense and normal cause of events which suggest

\footnotetext{
1340 See Constitution Writing and Conflict Resolution, 'Nigeria 1999' (Princeton University, <https://www.princeton.edu/ pcwcr/reports/nigeria1999.html> accessed 20 November, 2014

${ }^{1341}$ Constitution of the Federal Republic of Nigeria S. 13.

${ }^{1342}$ See for example S. 16. (1) The State shall, within the context of the ideals and objectives for which provisions are made in this Constitution. (a) harness the resources of the nation and promote national prosperity and an efficient, a dynamic and self-reliant economy; (2) The State shall direct its policy towards ensuring: (d) that suitable and adequate shelter, suitable and adequate food, reasonable national minimum living wage, old age care and pensions, and unemployment, sick benefits and welfare of the disabled are provided for all citizens; S. 18. (1) Government shall direct its policy towards ensuring that there are equal and adequate educational opportunities at all levels; 20. The State shall protect and improve the environment and safeguard the water, air and land, forest and wild life of Nigeria; S. 21. The State shall - (a) protect, preserve and promote the Nigerian cultures which enhance human dignity and are consistent with the fundamental objectives as provided in this Chapter; etc.

${ }^{1343}$ See Onyekachi Wisdom Ceazar Duru, 'The Justiciability of the Fundamental Objectives and Directive Principles of State Policy Under Nigerian Law'p.6. See also M. A. Alabi, 'Fundamental Objectives and Directive Principles Under the Nigerian Constitutional Law' Pp. $77-82$.

${ }^{1344}$ Dakas C. J. Dakas, 'Judicial Reform of the Legal Framework For Human Rights Litigation in Nigeria: Novelties and Perplexities' P. 336.
} 


\section{Chapter Seven}

duty and accountability run concurrently. The reproduced Akinseye-George's comment is plausible.

...it must be understood that the ... provision of section 6(6)(c) does not mean that the provisions of Chapter II are unenforceable. In other words, the non-justiciability of Chapter II enacted in section 6(6)(c) must not be taken to mean that the provisions of Chapter II are not enforceable. On the contrary, the provisions of chapter II are no less enforceable than any other provision of the constitution. Put in another way, the provisions of Chapter II ARE AS ENFORCEABLE AS ANY OTHER PROVISION OF THE CONSTITUTION. The only difference created by section $6(6)(c)$ is that, by the reason of that section, the judicial powers of the courts cannot be invoked with respect to any issue or question as to whether any act or omission by any authority or person or as to whether any law or any judicial decision is in conformity with the Fundamental Objectives and Directive Principles of State Policy set out in Chapter II. The implication of this provision is that an action for enforcement of human rights or judicial review cannot be founded solely on the provisions of Chapter II. It also means that judicial power cannot be invoked solely on the basis of Chapter II provisions in order to give effect to the contents of the chapter. However, notwithstanding the so-called provision on non-justiciability, the provisions of Chapter II of the constitution can be enforced by other means including judicial action founded on other legal and constitutional foundations outside Chapter II. ${ }^{1345}$

Assuming section 6(6)(c) did indeed block judicial powers from the ambit of chapter two, laws are and should be applied contemporaneous with changing circumstances. The relevance of laws is determined by the extent to which they respond or move with societal changes as well as their role in the promotion of economic, social, cultural and political developments. There is a symbiotic relationship between law and society. Law influences and is influenced by changes and developments. Societies look up to their laws in addressing issues such as poverty, national security, immigration, environment, gender, sexuality and healthcare. Technological and political advancements have rendered the world of the 50s radically different from that of the 90s much more the present day. Societal focus and attention have equally advanced to addressing issues which hitherto were neglected or considered non-debatable. Point of reference here is acceptance of gay rights and same-sex marriage. Gender issues are being mainstreamed in daily developmental programmes and projects. There have equally been significant advances in technology, medicine, science and information management. These and many more are regulated by law.

In human rights discourse, so-called first-generation rights are no longer debatable issues and the next agenda centred on post millennium development goals. The UDHR is no longer considered mere declaration but a reflection of customary international law. The adoption of treaties in various fields recognises the growing need for relevant legal instruments to deal with new developments and inevitable changes. The symbiotic relationship between law and society requires amending certain redundant laws to accommodate changes and developments. Legislative or Executive measures are sometimes required by reason of necessity. The Legislature which has the duty to provide for or amend laws, is not always prompt. Urgent and newer issues are often left with or taken to courts for judicial determination. The relevance of courts in this endeavour largely depend on how well they are able to articulate and apply the law to provide workable solutions to legal, political and

${ }^{1345}$ Y. Akinseye-George, Improving Judicial Protection of Human Rights in Nigeria Pp. 38-39. 
Realising the Right to Water and Sanitation in Nigeria

social issues. Courts utilise various mechanisms in addressing these concerns and it is in this light judicial activism becomes more relevant. Pending legislative actions, it is courts' duty to adapt and suit existing laws to the changing circumstances. The era of 'our hands are tight' is long gone by.

Additionally, the end of justice which judges must pursue foresees the positive role of judges in making laws (through judicial interpretations) when gaps exist concerning the position of the law in matters before them. The common law tradition which Nigeria subscribes to, recognises that the legal system could not effectively operate without judges filling in gaps through interpretation. This is reflected in several law fields including contract, criminal law, constitutional law, company law etc. No valid argument has been canvassed against doing the same on ESC rights. It had long been advocated that judges should decide cases in accordance with the general welfare ${ }^{1346}$ of the people and to strive in achieving the basic democratic values. ${ }^{1347}$ The Nigerian Constitution underscores "sovereignty belongs to the people of Nigeria from whom government through this Constitution derives all its powers and authority" that "the security and welfare of the people shall be the primary purpose of government."1348 This recognition suggests that actions and inactions by all organs and arms of government should be measured on the basis of how they have advanced or prevented promotion of general welfare of the people.

In the light of changing circumstances, courts are to adopt measures including interpretation techniques adequate to make constitutional provisions meaningful, salvage as well as promote peoples' welfare which the constitution seeks to achieve. Purposive interpretation is a 'usual device' employed to do away with contrary results realisable if other rules of interpretation were employed. ${ }^{1349}$ In the Indian case of Mohini Jain v. State of Karnataka and $\operatorname{Ors}^{1350}$ the Supreme Court while interpreting the right to life demonstrated "[a]lthough a citizen cannot enforce the directive principles contained in Chapter IV of the Constitution, but these were not intended to be mere pious declarations." In Transbridge Trading Company Limited $v$. Surrvey International Limited, ${ }^{1351}$ one of the most erudite judges, Justice Kayode Esho was of the opinion that:

It would be tragic to reduce Judges to a sterile role and make an automation of them. I believe
it is the function of Judges to keep the law alive, in motion, and to make it progressive for the
purpose of arriving at the end of justice, without being inhibited by technicalities, to find
every conceivable, but acceptable way of avoiding narrowness that spells injustice. Short of
being a legislator, a Judge, to my mind, must possess an aggressive stance in interpreting the
law.

Adopting literal rule of interpretation to chapter two of the Constitution and section 6(6)(c) will occasion more harm than good. In several decisions of the United States courts, the courts have often observed that rules of interpretation are mere guides and do not have binding obligation. In other words, the courts are at liberty to decide which rule to employ

\footnotetext{
${ }^{1346}$ A. H. Pekelis, 'The Case for a Jurisprudence of Welfare' (1950) Law and Social Action

${ }^{1347}$ Harrold D. Lasswell and Myres S. McDougal, 'Legal Education and Public Policy: Professional Training in Public Interests' (1943) 52 The Yale LJ

${ }^{1348}$ Constitution of the Federal Republic of Nigeria S. 14(2)(a) and (b)

${ }^{1349}$ Quintin Johnstone, 'An Evaluation of the Rules of Statutory Interpretation' P. 15.

1350 (1992) AIR 1858; (1992) SCR (3) 658

1351 (1996) 4 NWLR (Part 37) 576 at 596-597
} 


\section{Chapter Seven}

and for what reason. The controlling idea is to, as much as possible interpret and apply the law in accordance with legislative intent or to give certainty to the legislative provisions in a manner which do not negate human welfare. Judges should be at the forefront of democratic values enthronement and promotion of citizens' welfare. Judges role in contemporary democratic governance and human rights promotion and protection has progressed beyond resolving disputes or reconciling parties. Current practice showed courts, especially in common law system, as active agent in what may be described as 'judicial law making' in the effort to promote human rights and welfare of citizens.

The inherent power of courts to remedy certain situations is widely recognised. Black's Law dictionary defines 'inherent power' to mean "powers over and beyond those explicitly granted in the Constitution or reasonably to be implied from express grants." The United States Supreme Court has defined inherent powers as those powers which "cannot be dispensed with ... because they are necessary to the exercise of all others." ${ }^{1352}$ Some examples drawn from courts' jurisprudence on inherent or implied powers includes the management of litigation, imposing of sanctions, and supervising the administration of criminal justice. Admittedly also, the inherent powers extend to other issues such as regulating the conduct of counsels in court, punishing contempt, and ensuring the interest of justice and due process and supervisory powers. In some jurisdictions, courts have utilised inherent powers in deciding wide range of issues. Admittedly, the inherent powers of Nigeria courts under the Constitution are wide and far reaching. ${ }^{1353}$ This power can be utilised for the common good of mankind and promotion of human rights in situations where there are no express provisions prohibiting doing so. It is suggested that this power should be utilised in the context of promoting the realisation and enjoyment of all human rights and freedoms.

\subsubsection{Liberal and Integrated Interpretation Approach to ESC Rights through Fundamental (Justiciable) Rights}

These approaches in the context of constitutional interpretation explored the interaction/relationship between CP rights and ESC rights and the relevance of ESC rights in the attainment and enjoyment of CP rights. The adoption of the approaches in some countries which have restrictions on ESC rights, has to a significant extent transformed the character of the so-called non-enforceable ESC constitutional provisions, and strengthened the protection, promotion and enjoyment of these rights. CP rights intersect with ESC rights at both normative-theoretical as well as practical levels which often reinforce the realisation of ESC rights and vice-versa. ${ }^{1354}$ At the normative-theoretical level, the interdependence, indivisibility and intersectionality of human rights have demonstrated, as illustrated by courts, quasi-judicial bodies and academic writers, how ESC rights impacted on the realisation of $\mathrm{CP}$ rights and vice-versa. Human rights instruments, treaty bodies, soft laws and commentators have reiterated the inseparability of all human rights. As such, the

\footnotetext{
${ }^{1352}$ United States $v$. Hudson \& Goodwin 7 Cranch 321812

${ }^{1353}$ See Constitution of the Federal Republic of Nigeria S. 6

${ }^{1354}$ See for example Ioana Cismas, 'The Intersection of Economic, Social, and Cultural Rights and Civil and Political Rights'
} 
Realising the Right to Water and Sanitation in Nigeria

protection and promotion of both $\mathrm{CP}$ rights and ESC rights was reiterated. The Vienna Declaration and Programme of Action of 1993 for example provided:

All human rights are universal, indivisible and interdependent and interrelated. The international community must treat human rights globally in a fair and equal manner, on the same footing, and with the same emphasis...[I]t is the duty of States, regardless of their political, economic and cultural systems, to promote and protect all human rights and fundamental freedoms. ${ }^{1355}$

At the regional level both political and judicial bodies have had occasions to demonstrate either in their opinion or judicial decisions this important link. The Economic and Social Committee on the Citizens' Europe confirmed that the ESC rights are "indissolubly linked to civil and political rights: Together these citizens' rights and accompanying duties constitute the cornerstone of a free, democratic society founded on respect for human rights." ${ }^{1356}$ At the African level, the African Commission on Human Rights has been consistent in its interpretation of the ACHPR adopting an expansive interpretation to the rights, and demonstrating the nexus and interaction between them. At the practical level, eminent judges have equally concurred with this approach as demonstrated by Justice Bhagwati:

There is a close inter-linkage between the two categories of human rights because all human rights and fundamental freedoms are indivisible and interdependent and each category of human rights is indispensable for the enjoyment of the other. Hence, it is axiomatic that the promotion of respect for and enjoyment of one category of human rights cannot justify the denial of the other category of human rights. ${ }^{1357}$

It had become a recognised approach within the judicial circle in both developed and developing countries (including those with similar constitutional standing on ESC rights as Nigeria) to enforce ESC rights through CP rights. This method is known as indirect approach to justiciability, ${ }^{1358}$ or integrative approach which usually is through the interpretation power of courts. In series of decisions, courts have established duties of States in fulfilling ESC rights and have, in certain cases enforced these rights through $\mathrm{CP}$ rights provisions in context where the rights are regarded as non-justiciable. For example, in Germany, the German Federal Constitutional Court and German Federal Administrative Court have developed the doctrine of vital minimum ${ }^{1359}$ which obliges the State to provide assistance to those in needs in order to lead a dignified life through the interpretation of the right to dignity. ${ }^{1360}$ The Colombian Constitutional Court in Hernán Galeano Díaz c/ Empresas Públicas de Medellín ESP, y Marco Gómez Otero y Otros c/ Hidropacífico SA ESP y Otros ${ }^{1361}$ had demonstrated the clear nexus between deprivation of water for personal and domestic uses and the rights

\footnotetext{
${ }^{1355}$ World Conference on Human Rights, Vienna Declaration and Programme of Action, 25 June 1993, Art. 5.

1356 Opinion adopted on 23 September 1992

${ }^{1357}$ Quoted in Jacob Abiodun Dada, 'Human Rights under the Nigerian Constitution: Issues and Problems'p. 40). A cautious approach on indivisibility has however been suggested as not all rights have the same quality of implementation. See James W. Nickel, 'Rethinking Indivisibility: Towards A Theory of Supporting Relations between Human Rights' (2008) 30 Human Rights Quarterly 984

1358 See C. C. Nweze, 'Evolution of the Concept of Socio-Economic Rights in Human Rights Jurisprudence: International and National Perspectives' in C. C. Nweze (ed), Justice in the Judicial Process (Justice in the Judicial Process, Fourth Dimension Publishers 2002) P. 521.

${ }^{1359}$ Which comprises access to food, housing and social assistance

${ }^{1360}$ International Commission of Jurists, Courts and the Legal Enforcement of Economic, Social and Cultural Rights: Comparative Experiences of Justiciability Pp. 24-25.
}

1361 (2010) Corte Constitucional T-616/10 
to dignity, life, and health. The Indian jurisprudence is particularly rich on these issues. Some of the cases have been referred to before.

Judicial interpretation of Fundamental Objectives and Directive Principles of States Policy demonstrated divergent approach. The Indian approach is particularly interesting and worth noting. In the early years of Indian constitution, the Indian Supreme Court has held the view that "the Directive Principles have to conform to and run subsidiary to the chapter on fundamental rights". ${ }^{1362}$ However, subsequent judicial approach appeared to be nothing short of radical, proactive ${ }^{1363}$ and pragmatic. In Olowu's words, "Indian courts have found a veritable juridical pedestal in the Directive Principles to address the plight of India's underprivileged masses, to challenge poverty and deprivation, and to question governmental acts that are capable of fettering the very life, capabilities and fulfilment of ordinary Indians." 1364 Indian jurisprudence is particularly important in Nigeria. India has similar ESC provisions contained in the Fundamental Objectives and Directive Principles of State Policy like Nigeria. In the Indian case, however, those provisions were expressly stated to be nonenforceable. ${ }^{1365}$ Indian judicial approach was however, revolutionary, innovative and instructive. One of the most striking statements made by the Indian Supreme Court regarding the directive principles is worth noting. The Court in Mohini Jain v. State of Karnataka and Ors $^{1366}$ stated:

The directive principles which are fundamental in the governance of the country cannot be isolated from the fundamental rights guaranteed .... These principles have to be read into the fundamental rights. Both are supplementary to each other. The State is under a constitutional mandate to create conditions in which the fundamental rights guaranteed to the individuals ... could be enjoyed by all.

The Indian interpretation of justiciable constitutional rights is anchored on integrative or expansive approach. through this, several ESC rights were made enforceable and justiciable. Right to life was interpreted in several cases to incorporate series of ESC rights such as the right to food, housing, livelihood, healthy environment, education etc. In Francis Coralie Mullin v. The Administrator, Union Territory of Delhi \& Ors, ${ }^{1367}$ the Indian Supreme Court per Bhagwati, J., held that the right to life "cannot be restricted to mere animal existence. It means something much more than just physical survival" and it "includes the right to live with human dignity and all that goes along with it, namely, the bare necessaries of life such as adequate nutrition, clothing and shelter and facilities for reading, writing and expressing oneself in diverse form ..." In M/S. Shantistar Builders v. Narayan Khimalal Totame \& Ors ${ }^{1368}$ the Indian Supreme Court further confirmed the right to life "take within its sweep the right to food, the right to clothing, the right to decent environment and a reasonable

\footnotetext{
1362 See State of Madras v. Champakam Dorairajan (1951) SCR 226525

${ }^{1363}$ See Dejo Olowu, An Integrative Rights-based Approach to Human Development in Africa. P. 93.

1364 Ibid.

${ }^{1365}$ Article 37 of the Indian Constitution provides "The provisions contained in this Part shall not be enforceable by any court, but the principles therein laid down are nevertheless fundamental in the governance of the country and it shall be the duty of the State to apply these principles in making laws."

1366 (1992) AIR 1858; (1992) SCR (3) 658

1367 (1981) AIR 746, (1981) SCR (2) 516

1368 (1990) AIR SC 630, (1990) 92 BOMLR 145, (1990) JT (1) SC 106, (1990) (1) SCALE 86, (1990) 1 SCC 520, (1990) (1) UJ 379 SC
} 
Realising the Right to Water and Sanitation in Nigeria

accommodation to live in." In Olga Tellis \& Ors v. Bombay Municipal Corporation \& Ors, ${ }^{1369}$ the Court held that an important facet of the right to life includes the right to livelihood on the basis that "no person can live without the means of living". The right to food was confirmed to be part of the right to life in Peoples Union for Civil Liberties (PUCL) v. Union of India \& others ${ }^{1370}$ and series of orders were made directing the State to ensure regular supply of food and the implementation of several schemes. ${ }^{1371}$ Similarly, in Mohini Jain v. State of Karnataka and Ors ${ }^{1372}$ the Supreme Court while interpreting the right to life demonstrated the interconnectivity between the right and the right to education. The Court maintained that:

The right to education flows directly from right to life. The right to life under Article 21 and the dignity of an individual cannot be assured unless it is accompanied by the right to education. The State Government is under an obligation to make endeavour to provide educational facilities at all levels to its citizens.

According to the Court, education is fundamental to the enjoyment of those rights guaranteed under the constitution that if 'right to education' is not made a reality the guaranteed fundamental rights "shall remain beyond the reach of large majority which is illiterate." The State is therefore under constitutional mandate to provide educational institutions to its citizens at all levels. The Court considered a charge of capitation fee ${ }^{1373}$ as a patent denial of the right to education under the Indian Constitution. The interconnectivity and interdependence of the right to life and the right to health was equally demonstrated by the Court in Bandhua Mukti Morcha v. Union of India Ors. ${ }^{1374}$ where the Court was of the view that the right to live with human dignity under article 21 of the Indian Constitution:

must include protection of the health and strength of workers, men and women, and of the tender age of children against abuse, opportunities and facilities for children to develop in a healthy manner and in conditions of freedom and dignity, educational facilities, just and humane conditions of work and maternity relief. These are the minimum requirements which must exist in order to enable a person to live with human dignity and no State - neither the Central Government nor any State Government - has the right to take any action which will deprive a person of the enjoyment of these basic essential."

It had been noted before, that India has "generated the largest volume of jurisprudence regarding the environmental aspects of the constitutional right to life."1375 The Indian Supreme Court in Charan Lal Sahu held that the right to life guaranteed by the constitution include the right to a wholesome environment. In Virendra Gaur and Others v. The State of Haryana "[e]nvironmental, ecological, air and water pollution" have been construed to be a violation of the right to life. At the Indian High Court level in L.K. Koolwal v. State of

\footnotetext{
1369 (1986) AIR 180, (1985) SCR Supl. (2) 51

${ }^{1370}$ Writ Petition (Civil) No. 196 of 2001

1371 The Employment Assurance Scheme, Mid-day Meal Scheme, Integrated Child Development Scheme, National Benefit Maternity Scheme for BPL pregnant women, National Old Age Pension Scheme for destitute persons of over 65 years, Annapurna Scheme, Antyodaya Anna Yojana, National Family Benefit Scheme and Public Distribution Scheme for BPL \& APL families.

1372 (1992) AIR 1858; (1992) SCR (3) 658

${ }^{1373}$ Uniform fee being charged by educational bodies not advertised in the prospectus of the institution, usually in exchange for admission to the institution.

1374 (1984) 2 SCR 67

1375 John Scanlon, Angela Cassar and Noemi Nemes, Water as a Human Right? P. 47.
} 
Rajasthan and Others "maintenance of health, preservation of the sanitation and environment" was interpreted to be part of right to life. ${ }^{1376}$

The International Commission of Jurists ${ }^{1377}$ had acknowledged that rights to health, food, water and education can be protected through interpretation of right to life. The right to health and right to housing can further be protected through the right to freedom from torture, degrading treatment and right to private and family life. The right to social security, housing, collective right to ancestral land of indigenous people can be protected under the right to property. Freedom of association can be used to protect right to form and join trade unions and right to collective bargaining, while the right to work and to fair conditions of work can be protected through the right to freedom from forced or compulsory labour. This interpretation is not only consistent and recognised in the context of human rights, ${ }^{1378}$ but also the most preferred in the context of providing the greatest opportunity for human beings to realise their potentials.

In Nigeria, some writers have already opined the existence of some constitutional justiciable ESC rights. It had been argued for example that right to health is implied through a combined reading of section 17 (social objectives of the Nigerian State), section 33 (right to life) and section 34 (right to dignity of human person). ${ }^{1379}$ This was justified on the basis that section 17 obligates the State to direct its policies to ensure the provision of adequate medical and health facilities for all persons and to ensure that the health, safety and welfare of all persons in employment are not endangered or abused and that since sections 33 and 35 recognised right to life and right to dignity of human person respectively, it was argued that "sanctity of the human person and dignity are necessarily connected to physical and mental health of persons." 1380 The combined provisions therefore implicitly, include "the provision of affordable, available, adequate, qualitative and accessible health care facilities and services by all". 1381

In limited contexts, the Nigerian courts have utilised this approach to transform the ESC rights from non-justiciable to justiciable. In the context of right to education, the cases of Archbishop Olubunmi Okogie v. The Attorney General of Lagos State ${ }^{1382}$ and Adewole v. Alhaji Jakande, have been referred to above. Similarly, In Jonah Gbemre v. Shell, NNPC and $A G F^{1383}$ a claim for the enforcement of fundamental right arising from gas flaring in the extraction of oil activities in the Niger-Delta, the Federal High Court recognised and accepted the claim of the plaintiff that the constitutionally guaranteed fundamental right to life and dignity of human person under sections 33 (right to life) and 34(1) (right to dignity of human person) of the Constitution reinforced by articles 34, 16 and 24 (right to respect for lives and

\footnotetext{
1376 See ibid. Pp. 47-48

${ }^{1377}$ See International Commission of Jurists, Courts and the Legal Enforcement of Economic, Social and Cultural Rights: Comparative Experiences of Justiciability. P. 72.

1378 Antonio E. Irujo, 'The Right to Water'p. 267-283); Salman M.A. Salman, 'The Human Right to Water Challenges of Implementation'. P. 45.

1379 Muhammed Tawfiq Ladan, Law, Cases and Policies on Energy, Mineral Resources, Climate Change, Environment, Water, Maritime and Human Rights in Nigeria. P. 170.

${ }^{1380}$ Ibid.

${ }^{1381}$ Ibid.

1382 Supra

${ }^{1383}$ Suit No. FHC/B/CS/53/05
} 
Realising the Right to Water and Sanitation in Nigeria

the dignity of human person; right to enjoy the best attainable state of physical and mental health; and the right to a general satisfactory environment favourable to their development) of the ACHPR (Ratification and Enforcement) Act inevitably includes the right to clean, poison-free, pollution-free and healthy environment and that gas flaring of the defendants in oil exploration and producing activities in the applicant's community is a violation of the right to life (including healthy environment) and dignity of human person guaranteed by the Constitution and the ACHPR.

As commendable as this limited acceptance by Nigerian courts, the courts would need to go further and demonstrate their capacity to protect citizens' rights through the adoption of among others, this well-established practice. This is justified by the extent of economic and social deprivations and the clear unwillingness of the Executive Arm to adopt progressive measures to realise ESC rights in Nigeria or the Legislature to domesticate ICESCR. The courts may draw inspiration from the Colombian Constitutional Court which has held in the context of justiciability of ESC rights that even in situations where an ESC right in question is such that can be subjected to progressive realisation as opposed to immediate, it will become justiciable where the State has over a reasonable period of time failed to take or adopt appropriate measures to realise the right. ${ }^{1384}$ The Nigerian Government having failed to domesticate the ICESCR since its ratification in 1993 (a duty which was suggested to be of immediate effect) ${ }^{1385}$ the power of the court in justifying the justiciability of the rights contained therein may have since materialised and should be invoked. Through this method of interpretation and enforcement of ESC rights, certain positive unintended consequences may be achieved: Government may be prevented from enacting legislations which significantly allows the infringement of ESC rights as well as challenging cases on ESC rights litigations.

If the Indian Judiciary, with all the economic and social challenges could adopt such proactive, pragmatic and purposive interpretation technique through which effect is given to fundamental objectives and constitutional ESC provisions made enforceable, a useful though non-binding precedent exist which the Nigerian courts can borrow from.

\subsection{Accountability in the Case of Omission}

As the mechanism for ensuring justice and fairness, the arbiter of disputes and the decider of rights and wrong, the courts are strongly placed to protect human rights and fundamental freedoms. Enjoyment of rights and freedoms cannot be guaranteed where violators are not held to account or their compliance is not assessed vis-à-vis the rules and legal obligations. Indeed, the constitution has imposed duties on all arms of Government to ensure compliance with fundamental objectives and directive principles of state policy. However, it is anomalous for the same constitution to place a cloak in the wheel of justice by preventing adjudicating or the ascertainment of the extent to which these obligations have been complied with by duty-bearers. Be that as it may, the courts are not completely enclaved. As demonstrated

\footnotetext{
${ }^{1384}$ Colombian Constitutional Court, decision T-595/2002, August 1, 2002, Para. 5.3.

${ }^{1385}$ International Commission of Jurists, Courts and the Legal Enforcement of Economic, Social and Cultural Rights: Comparative Experiences of Justiciability. P. 26.
} 
Chapter Seven

above, courts have developed innovative approaches to circumnavigate the cloak. Courts have questioned governmental actions and compliance, determined violations and they have granted remedies in appropriate cases. These innovative approaches have helped boost human rights promotion and protection and guarded against continued deprivations.

The Constitution anticipated faithful adherence to its terms and the pursuit of projects by the relevant governmental arms in the realisation of the fundamental objectives. What then happens where there is fundamental omission? It has been asserted quite correctly that " $[\mathrm{t}] \mathrm{he}$ Judiciary has an important role to play where there exists a sufficiently gross failure to uphold basic socio-economic rights. Where the other two branches have comprehensively failed to fulfil their responsibilities, "the least dangerous branch" has a duty to intervene." 1386 In democratic governance, "[t]he supervision of State power has always been integral to the theory of democracy, and is deeply enshrined in the idea of the rule of law." 1387 Rule of law principle recognises judicial review of executive and legislative actions to, not only determine conformity with the laws of the land, but also the protection of rights and freedom, and ensuring fairness, equality and equity. In other words, the principle of checks and balances is integral to effective operation of democratic system. The power of courts to hold governmental authorities and agencies accountable is hence fundamental. In this context, accountability is in two folds: accountability to conform to international legal obligations and accountability to the population.

On accountability in terms of international legal obligations, participation in bilateral and multilateral agreements is usually the function of the Executive. The process of ratification is in accordance with domestic system and compliance with domestic laws. However, at the international level, once violation is determined responsibility is on the State as a whole, it matters less which arm of government fails to perform its functions. This obliges the Judiciary to be proactive in ensuring domestic compliance of international legal obligations. In its General Comment 9, ${ }^{1388}$ the Committee on ESC rights is of the view that:

Questions relating to the domestic application of the Covenant must be considered in the light of two principles of international law. The first, as reflected in article 27 of the Vienna Convention on the Law of Treaties of 1969 , is that "[A] party may not invoke the provisions of its internal law as justification for its failure to perform a treaty". In other words, States should modify the domestic legal order as necessary in order to give effect to their treaty obligations. This issue is considered further by the Committee in its General Comment No. 12 (1998). The second principle is reflected in article 8 of the Universal Declaration of Human Rights, according to which "Everyone has the right to an effective remedy by the competent national tribunals for acts violating the fundamental rights granted him by the constitution or by law."

Undoubtedly, the then military government and the membership of constitution drafting committee could not have been unaware of the international legal obligations under UDHR

\footnotetext{
${ }^{1386}$ Lord Lester of Herne Hill QC and Colm O'Cinneide, 'The Effective Protection of Socio-economic Rights' in Yash Ghai and Jill Cottrell (eds), Economic, Social and Cultural Rights in Practice: The Role of Judges in Implementing Economic, Social and Cultural Rights (Economic, Social and Cultural Rights in Practice: The Role of Judges in Implementing Economic, Social and Cultural Rights, Interights 2004) P. 19.

${ }^{1387}$ International Commission of Jurists, Courts and the Legal Enforcement of Economic, Social and Cultural Rights: Comparative Experiences of Justiciability. P. 82.

${ }^{1388}$ UNCESCR, General Comment No. 9: The Domestic Application of the Covenant
} 
Realising the Right to Water and Sanitation in Nigeria

(as a reflection of customary international law), ICCPR, ICESCR and domesticated ACHPR. This leads to the consequential necessity for all domestic laws (including the Constitution) to be in conformity with the obligations contained in the above instruments. ${ }^{1389}$ The judicial attitude on accountability and compliance seems to suggest the courts in Nigeria are in agreement. The Nigerian Judiciary had shown the tendency of abandoning conservatism or passivism and demonstrated their willingness to adopt, in the context of human rights protection a "libertarian, radical or active posture." 1390 Courts' judgments have in the recent past proceeded from being "declaratory, mechanistic or technistic to a purposive, bold and imaginative approach." ${ }^{1391}$ Even during the military administration periods, Nigerian courts have reiterated the need for Nigeria to discharge its international obligations. The Supreme Court in Reinsurance Corp v. Fantaye ${ }^{1392}$ boldly stated that Nigeria must give effect to legally binding treaties. In Chief JE Oshevire v. British Caledonia, ${ }^{1393}$ the Nigerian Court of Appeal relying on Aeroflex v. Air Cargo Egypt ${ }^{1394}$ held that any domestic legislation which is in conflict with an international convention binding on Nigeria is void. The courts as the guardian of the law and the protector of human rights should proceed in this line.

The question however is whether in the light of section 12 of the Constitution, the courts are in the position to require compliance with international obligations contained in undomesticated treaties. Arguably, substantive provisions of undomesticated treaties may not be directly enforceable. However, accountability argument may be deployed to draw Government's attention to the implications of flying in the face of its international legal obligations and the image of the State among its peers at the international level. As a party to several human rights instruments, courts may draw Executive's attention to Nigeria's international responsibility. Nigeria is accountable to the rest of State parties to the treaties it had ratified and failed to enforce at the domestic level. This leads to the broader issue of State responsibility and the repercussions following from other States willing to ensure the observance of the treaties' obligations. Judicial pronouncement on the issue will lend weight to the need for possible constitutional, legislative and other administrative measures to forestall further violations and the setting up of effective mechanisms to comply with legal obligations.

The establishment of the United Nations, the progressive development and adoption of democracy around the world, the adoption of many human rights instruments and the establishment of various mechanisms for human rights enforcement all pointed to the need for governments (understood to involve all its arms and organs) to work actively and collectively for the realisation of the goals and objectives of those various instruments they have willingly signed and ratified. The Judiciary as an important watchdog, considered as the last hope of the common man and alpha and omega in law interpretation and protection of

\footnotetext{
${ }^{1389}$ See for example Article 27 of the Vienna Convention on the Law of Treaties, 1969.

1390 Muhammed Tawfiq Ladan, Law, Cases and Policies on Energy, Mineral Resources, Climate Change, Environment, Water, Maritime and Human Rights in Nigeria P. 175.

1391 Ibid.

1392 (1986) 1 NWLR (Pt. 14) 113

${ }^{1393}$ See (1990) 7 NWLR (Pt. 163) 489

${ }^{1394}$ A decision of Paris Court of Appeal of 25 March 1986 and reported in the Uniform Law Review Biannual 1987 Vol. 2 669, published by (UNIDROT) International Institute for the Unification of Private Law in Rome.
} 


\section{Chapter Seven}

human rights should not be cowed and docile in the face of human rights deprivations. They should not advance a lame argument that treaties, duly ratified and binding at the international level, have not been domesticated. The Judiciary should be proactive not only in resolving conflicts but also in the protection of State's integrity and helping it to comply with its international legal obligations. When a State is held to be in violation of its international legal obligations, it is not only the executive arm for failure to introduce or adopt appropriate administrative or policy measures, the legislature for failure to adopt legislative measures that will be condemned, it is the State in its entirety that is blamed or blacklisted. ${ }^{1395}$

In the context of those laws which serve as stumbling blocks to the realisation of ESC rights, courts are not expected to enforce oppressive laws. Hence judicial review necessitates juxtaposing pros and cons of every legislation and its operation. If the end result is such that will grossly violate citizens' rights or significantly deprived them of means of living normal, decent and honourable life, the courts should be bold enough to point that out to the legislative and executive's arms for possible amendment.

In another context, the making of bogus promises by governments at all levels appeared to be the order of the day in Nigeria. In some cases, the promises were followed by assessment and projects commencement but which at a later time are abandoned. This culture not only leaves the promised population depressed, deprived and without remedy but also perpetuates wastage of resources and promotes lack of trust. Governments are held accountable even in contexts where a law allows Executive's margin of appreciation in choosing methods of compliance with duties. ${ }^{1396}$ Courts have shown their readiness to hold governments/agencies accountable, enforce promises and commitments made by a State to its population. In the UK for example, judicial decisions confirmed that where the authorities have assessed the circumstance of an individual and found such individual to be in need under the law, such authorities are under legal obligation to fulfil the need, an appeal to lack of resources is irrelevant. ${ }^{1397}$ Nigerian courts should be at the forefront of ensuring that governments at all levels conform to their obligations under the law: international and domestic. They should be the watchdog in ensuring accountability in the fulfilment of promises. This will enable Nigeria to remedy violations and give effects to its obligations.

\subsection{Downside of Judicial Activism}

No doubt judicial activism especially as seen from the perspective of Indian courts had played an important role in the transformation of some ESC rights, had prompted legislative actions, and in some cases balanced existing laws. However, its adoption or practice by judges must be approached with caution to avoid circumstances where judges will be

\footnotetext{
${ }^{1395}$ As far as the implementation of chapter II is concerned, the Nigerian Supreme Court per Uwais JSC has held in Attorney-General of Ondo state v. Attorney-General of the Federation (2002) FWLR (pt. 111) P. 1972, that the 'State' include all the tiers of government.

${ }^{1396}$ International Commission of Jurists, Courts and the Legal Enforcement of Economic, Social and Cultural Rights: Comparative Experiences of Justiciability. P. 21.

${ }^{1397}$ See R. v. Sefton Metropolitan Borough Council, ex parte Help the Aged (1997) 4 All ER 532. Similar decision was reached in other cases such as R. v. Birmingham City Council, ex parte Mohammed (1998) 3 All ER 161; R. (on the application of Batantu) v. Islington Local Borough Council (2001) 4 CLR 445; $R$ v. North and East Devon Health Authority, ex parte Coughlan (2001) QB 213.
} 
Realising the Right to Water and Sanitation in Nigeria

substituting legislative provisions with their own personal or political feelings or affinity. Judicial activism is a concept that can easily be abused. Where caution is not applied, there is the tendency for judges to constitute themselves as the legislative arm of government where for example the following problems might crop in: refusal to apply any law as intended by the parliament; personal and political leanings of the judge substituting the written law and judges' rulings eventually becoming final and binding. ${ }^{1398}$ Additionally, the doctrine of separation of powers may be diluted in the struggle by a judge to do what they think is appropriate in certain circumstances without regard to their limitations. ${ }^{1399}$ Justice Jackson of the US Supreme Court was for example quoted to have said "The doctrine of judicial activism which justifies easy and constant readiness to set aside decisions of other branches of Government is wholly incompatible with a faith in democracy and in so far it encourages a belief that judges should be left to correct the result of public indifference it is a vicious teaching." 1400

\subsection{Relevance of Interpretation Approaches to the Realisation of the Right to Water and Sanitation}

Several advantages flow from the adoption of an expansive interpretation and a human rights-based approach. It suffices to mention that recognising ESC rights or at least some of them such as right to health, right to adequate standard of living, right to healthy environment and right to food as justiciable will provide a gateway to the recognition and enforcement of all other human rights derivable from CP rights and ESC rights.

The right to water and sanitation, which though in some countries has acquired an independent human right status, ${ }^{1401}$ in Nigeria will ultimately become justiciable as the rights from which the right to water and sanitation was derived from cannot be fully realised without water as an important component. Similarly, if the expansive interpretation continues to be adopted more liberally by Nigerian courts, the Judiciary will properly station itself as a more effective organ in the discharge of its obligations. It will be seen as a liberal organisation that promotes and protects human rights of citizens including the marginalised, vulnerable, downtrodden and less privileged. Adopting an expansive approach serves as a mechanism for holding political leaders accountable to their constitutional duties without violating the provision of the Constitution. In this manner, the fundamental objectives of the Constitution would be realised as leaders would be more responsive to the needs of the population. Government' legitimacy would be enhanced, and population would be able to realise their rights and fulfil their basic needs.

An effective utilisation of these mechanisms will obviate the need for constitutional amendment or going through law making process. Although these are most desirable, but are

\footnotetext{
${ }^{1398}$ See Connect US, '11 Principal Pros and Cons of Judicial Activism' < https://connectusfund.org/11-principal-prosand-cons-of-judicial-activism> accessed 20 February 2018

1399 See T. R. Andhyarujina, 'Disturbing Trends in Judicial Activism' (The Hindu, 6 August 2012) <http://www.thehindu.com/opinion/lead/Disturbing-trends-in-judicial-activism/article12680891.ece> accessed 20 February 2018

${ }^{1400}$ Ibid.

${ }^{1401}$ For example, South Africa and Brazil
} 
tedious, time and resource consuming processes. As these are avoided, the resources would be effectively utilised in addressing other social and economic deprivations in the country.

\subsection{Conclusions}

Purposive, liberal and integrated interpretation approaches are useful mechanisms which have proved relevant in the promotion of non-justiciable rights especially those regarded as fundamental objectives and directive principles of state policy like in Nigeria. Courts in relevant jurisdictions such as India have demonstrated how these principles of interpretation come to the aid of citizens in matters of human rights without undermining rule of law or principles of separation of powers. They are used to fill in gaps which for certain reasons letters of the law failed to address. This dynamic approach is relevant in Nigeria due to the constitutional position of ESC rights. If adopted by the Nigerian judiciary several benefits would flow from it including rendering ESC rights justiciable; making the Judiciary to be seen as a more effective organ of Government in the protection of human rights with positive impacts on its legitimacy; political duty-bearers would be more made accountable; and it would enable Nigeria to discharge its human rights obligations. However, its application must be approach with caution to avoid a situation where the Judiciary will ignore separation of power requirements and existing written laws are not respected by judges as intended by the Parliament. 


\section{Chapter Eight}

\section{Potentials of a Human Rights-based Approach to the Realisation Of the Right to Water and SANitation in Nigeria}

\subsection{Introduction}

The dawn of the new millennium brought with it a shift in development discourse and 1 relations between development and human rights. The beginning of the 90s firmly strengthened the interconnectedness of human rights and development. This was brought about by variety of factors including the end of cold war, the shift in the way aid is delivered, and the distancing of discourse from the right to development through the tacit assurance to rich governments that such language of 'rights' does not connote ideologically, the baggage of the Right to Development (such as imposing duties on those States to ensure the realisation of rights). ${ }^{1402}$ The emphasis of the integration of rights at the Vienna Conference on Human Rights was a significant milestone in connecting ESC rights to mainstream CP rights and soon work in the area of integrating development and human rights began to take shape. This was further promoted by multilateral organisations such as the United Nations. The then UN Secretary-General in 1997 called for reorientation of UN mission to reflect realisation of human rights as part of the UN reforms. ${ }^{1403}$ Since then, development issues are mostly being seen from the lenses of human rights. Interestingly also, in many important respects human rights considerations seem to be controlling to a growing and varying degree, projects and interventions whether by civil society, NGOs or development agencies. This was pursuant to the political support the integration of human rights into policy-making received at the international level. For example, at the World Summit in September 2005, 170 Heads of States and Governments affirmed and resolved to integrate the promotion and protection of human rights into their national policies and to further support the mainstreaming of human rights at the UN level. ${ }^{1404}$

The interconnectedness of human rights has led to a series of discussions. Human rights framework has witnessed expansions, interpretations and repositioning. It is no longer considered taboo for the subjects of women, sexuality, marginalisation and children to be openly discussed and opinions shared whether at the individuals, community, national or international levels. It has, by these, created new opportunities for a whole range of ideas and solutions. The adoption of a human rights-based approach to development is one of them with its varying degrees of success, lessons and experience gathered and at the same time,

\footnotetext{
1402 Andrea Cornwall and Celestine Nyamu-Musembi, 'Putting the 'Rights-Based Approach' to Development into Perspective' (2004) 25 Third World Quarterly 1415 Pp. 1423-4.

${ }^{1403}$ André Frankovits, The Human Rights Based Approach and the United Nations System (UNESCO 2006) P. 17.

${ }^{1404}$ United Nations, '2005 World Summit Outcome' (2005) A/RES/60/1
} 
Realising the Right to Water and Sanitation in Nigeria

real and concrete solutions provided to certain pressing issues of concern. Issues such as poverty, discrimination, gender equality and conflicts are being addressed from the lenses of a human rights-based approaches. These approaches equally receive varying degree of support from the local levels to the UN level. The UN for example, affirmed and gave unprecedented political support to addressing security and development issues together with human rights promotion and protection. ${ }^{1405}$

Introductory remarks and justifications for the adoption of the approach in this research have been provided in chapter one. This chapter focusses more on the approach, its principles and how it can be utilised in the Nigerian situation in realising access to water and sanitation. It draws insights from local and national circumstances and will suggest how the approach can provide solutions to the myriad problems associated with access to water and sanitation in Nigeria. The chapter is a response to research question three regarding a human rightsbased approach and its potentials in the realisation of the right to water and sanitation in Nigeria.

\subsection{The Concept of a Human Rights-Based Approach}

Shift in development discourse and how development can be achieved in a rather more effective way brought into limelight, the discourse on the applicability of a human rightsbased approach to development in the first half of the 90s. It demonstrated the need to shift from the consideration of economic growth ${ }^{1406}$ which hitherto was considered to be the basis for development to a more principled approach which takes into consideration sustainable human development. Through this approach, the interconnectedness of human rights and development was clearly outlined. It was appreciated that development and social progress are required for the realisation of human rights as shown by article 28 of UDHR. ${ }^{1407}$ These and other reasons call for reorientation of development policy.

In the context of development, various justifications have been advanced for the adoption of a human rights-based approach. These have been grouped into three: normative, pragmatic and ethical. ${ }^{1408}$ Normative, justifies that "rights put values and politics at the very heart of development practice", in that it works by setting out a vision of what ought to be, which in turn brings an ethical as well as moral dimension to development assistance. Specifically, by stipulating an internationally agreed set of norms backed by international law, it provides a stronger basis for citizens to make claims on their States and for holding States to account for their duties. Pragmatic suggests that "the current architecture of aid makes new demand for ensuring accountability on the part of recipient states" which will increase the likelihood of adopting and implementing relevant policy measures in practice. Ethical in that it "it can serve as an opportunity to reflect more broadly on the power dynamics inherent in the practice

\footnotetext{
1405 Ibid.

${ }^{1406}$ Economic growth from decades was considered to be the basis of development from which it will trickle down to the poor through which their situation can be made better.

${ }^{1407}$ See Brigitte I. Hamm, 'A Human Rights Approach to Development' (2001) 23 Human Rights Quarterly

${ }^{1408}$ Celestine Nyamu-Musembi and Andrea Cornwall, What is the "Rights-Based Approach" all about? Perspectives from International Development Agencies (Institute of Development Studies 2004) Pp. 2-4.
} 


\section{Chapter Eight}

of international development and on questions of ethics." ${ }^{1409}$ In that to speak of rights, is to speak about power as well the obligation of those who are engaged in development assistance. Ever since this paradigm change, several international, bilateral, national and nongovernmental organisations and agencies have been transiting to this approach with UN in mid 90s bringing in reforms to integrate human rights in its development agenda.

At the heart of a human rights-based approach is the idea of empowerment of relevant stakeholders including duty-bearers and rights-holders to be able to discharge legal obligations and claim legal (and ethical) rights. Before delving into this issue, the basic idea and principles of the approach deserves critical attention.

At the outset, there is no universally adopted definition of a human rights-based approach. There is even, as has been noted, a subtle difference between the phrases "human rightsbased approach" and "rights-based approach". ${ }^{1410}$ In this work, these two phrases are used interchangeably.

International and development agencies have provided series of definitions and understandings of what a human rights-based approach entails. A review of these revealed that the definitions are generally contextual in nature and limited in scope. The definitions suggest how the organisations' interventions are shaped or framed. ${ }^{1411}$ Cornwall and NyamuMusembi have outlined how the concept have been defined by some international and bilateral agencies. ${ }^{1412}$ In some cases the definitions are broad and in some, are restrictive. The difference centred more on the normative contents than its relevance in addressing injustices, deprivations and inequality. The lack of uniform definition with sufficient clarity led some authors to conclude that it supported "the suspicion that the rights-based approach is nothing more than a sexy new term to dress up old-style development, and one that will last only a couple of years before being cast aside for the next bit of fashionable jargon." ${ }^{1413}$ However, what appeared to be common in the utilisation of the approach are reference to human rights treaties, emphasis on legal obligations, and the benefits resulting from its adoption in addressing marginalisation and deprivations, improving accountability and empowerment, among others.

At the general level, it is acknowledged to be a catalyst through which the needs of marginalised or poor people are met and through which this category of people is enabled to recognise and to be able to claim their rights from duty-bearers using human rights norms. ${ }^{1414}$ In other words, at the macro-level, a human rights-based approach may be a conduit for achieving development through respect for human rights and at the micro-level it eliminates or addresses situations responsible for marginalisation and deprivation. To realise the benefits of the approach, its application at the micro-level requires analysis and deeper

\footnotetext{
1409 Ibid.

${ }^{1410}$ Ibid.

${ }^{1411}$ For the various definitions given to the concept see ibid. P.13.

${ }^{1412}$ See Table 6.1 for what rights-based approach means to some of these agencies (lifted from ibid. P.13)

1413 Ibid. P. 14.

${ }^{1414}$ Andrea Cornwall and Celestine Nyamu-Musembi, 'Putting the 'Rights-Based Approach' to Development into Perspective'. P. 1430.
} 
Realising the Right to Water and Sanitation in Nigeria

understanding of each situation and circumstance in which it is sought to apply and for particularities to be carefully assessed. ${ }^{1415}$

Analysis of how human rights have been deployed in developments contexts has been done elsewhere. ${ }^{1416}$ From this, four dimensions of a human rights-based approach in development context have been noted: ${ }^{1417}$

1. As a set of normative principles to guide the way in which development is done ...;

2. As a set of instruments with which to develop assessments, checklists and indicators against which interventions might be judged ...;

3. As a component to be integrated into programming ...;

4. As the underlying justification for interventions aimed at strengthening institutions, whether to develop the advocacy skills of organisations representing marginalised people... ${ }^{1418}$

The main goal behind a human rights-based approach is the attainment of human rights which enables individuals and groups to fulfil their desires and aspirations. A human rightsbased approach provides the necessary framework through which this goal could be achieved. The delineating common factors in the approach are: ${ }^{1419}$

1. Reference to human rights treaties;

2. Non-discrimination, with special focus on the marginalised;

3. Participation and empowerment of rights-holders; and

4. Good governance (which ensures responsibility and accountability)

From these, a human rights-based approach is a process which emphasises the idea of good governance, ensures participation and empowerment of marginalised groups in a nondiscriminatory manner through emphasis and application of legally (and ethically) binding instruments and which enables duty-bearers and rights-holders to responsibly and accountably undertake their legal (and ethical) commitments and claim of rights respectively. It addresses underlying causes of poverty, injustices and marginalisation. It enables the discriminated and marginalised individuals and groups to have voices in matters concerning their rights. It "requires that special attention be given to disadvantaged individuals and communities; the active and informed participation of individuals and communities in policy

\footnotetext{
${ }^{1415}$ HRBA Portal, 'United Nations Practitioner's Portal on Human Rights Based Approaches to Programming'

${ }^{1416}$ Andrea Cornwall and Celestine Nyamu-Musembi, 'Putting the 'Rights-Based Approach' to Development into Perspective'. P. 1431.

${ }^{1417}$ This as had been argued, each of the dimensions has its limitation through which certain difficulties might be encountered if taken in isolation. See ibid. P. 1432.

${ }^{1418}$ Ibid. 1431. See also John Farrington, 'Sustainable Livelihoods, Rights and the New Architecture of Aid', Natural Resource Perspectives, vol 69 (Natural Resource Perspectives, Overseas Development Institute 2001) P. 3 which highlighted the purpose of rights-based approaches to include: Strengthening organisations of the poor; Rights information and education for the poor; Participatory planning that allows people to define their own priorities; Training for officials responsible for service delivery to ensure equity of treatment; Reform of laws and policies, in relation to, for instance, land tenure; Legal representation to enable people to claim their rights; Monitoring by civil society organisations of the performance of public institutions and the budget process (i.e. enhancing downward accountability); and Strengthening the capabilities of police and the courts.

${ }^{1419}$ See Brigitte I. Hamm, 'A Human Rights Approach to Development'. P.1011.
} 


\section{Chapter Eight}

decisions that affect them; and effective, transparent and accessible monitoring and accountability measures." 1420

At the heart of a human rights-based approach is the idea of using legal norms derived from internationally agreed human rights instruments as a potentially more powerful approach to development. ${ }^{1421}$ This serves as the basis of accountability and empowerment. The use of legal norms introduces a significant shift in the way development works are carried out which hitherto were shaped by purely political and economic interests. Reference to human rights instruments makes it easier due to the universal nature of human rights and arguments become less political. Notwithstanding, it had also been argued, that "invoking distant international human rights standards" has its own problems such as for example "that most poor people have little access to the institutions that might enforce their rights, and that the interface between legal systems governing their access to entitlements makes the process of recognising and claiming rights complex." ${ }^{1422}$ It was also argued that finite resources demand prioritisation and ultimately contravenes the principle of indivisibility of human rights and at the same time highlights the dilemma to be encountered when dealing with competing rights. ${ }^{1423}$

While these may be valid arguments, it is however, submitted, that prioritisation does not by and in itself violates the principle of indivisibility of human rights. Although legal obligation exists to fulfil all human rights, the law does not compel the impossible. Prioritisation becomes necessary considering it is to some extent impossible especially in developing countries for all the country's problems to be addressed at once. States' actions will be adjudged based on how reasonable their prioritisation was. As such in certain instances, especially regarding ESC rights prioritisation is consistent with the principle of progressive realisation ${ }^{1424}$ as the realisation of some rights is dependents on the attainment of others. For example, rights to education may only be effectively realised if right to food and adequate shelter are in existence. Similarly, rights to housing may not be adequately enjoyed if the environment is constantly polluted. Although the rights are interconnected, regarding putting measures in place to secure and safeguard them, some take priority.

\subsection{A Human Rights-Based Approach in Relations to other Approaches}

With above in mind, what then distinguishes a human rights-based approach from other development approaches such as need-based and utilitarian-driven approaches? Human

\footnotetext{
${ }^{1420}$ Paul Hunt and Gillian MacNaughton, 'A Human Rights-Based Approach to Health Indicators' in Mashood A. Baderin and Robert McCorquodale (eds), Economic, Social and Cultural Rights in Action (Economic, Social and Cultural Rights in Action, Oxford University Press 2007)

${ }^{1421}$ Andrea Cornwall and Celestine Nyamu-Musembi, 'Putting the 'Rights-Based Approach' to Development into Perspective'p. 1418). See also Dejo Olowu, 'Human Development Challenges in Africa: A Rights-Based Approach' (Pp. 192-196)

${ }^{1422}$ Celestine Nyamu-Musembi and Andrea Cornwall, What is the "Rights-Based Approach" all about? Perspectives from International Development Agencies P. 4 citing Celestine Nyamu-Musembi, Towards an Actor-Oriented Perspective on Human Rights (Institute of Development Studies 2002) And Caroline Moser and others, To Claim Our Rights: Livelihood Security, Human Rights and Sustainable Development (Overseas Development Institute 2001)

${ }^{1423}$ John Farrington, 'Sustainable Livelihoods, Rights and the New Architecture of Aid'

${ }^{1424}$ HRBA Portal, 'United Nations Practitioner's Portal on Human Rights Based Approaches to Programming'
} 
Realising the Right to Water and Sanitation in Nigeria

rights-based approach is different from need-based approach in terms of goal, individuals and responsibilities, ${ }^{1425}$ as well as norms, methodology, process and results. In need-based, the focus is to secure additional resources to certain groups based on need. Primarily, the focus is the provision of assistance to those who do not have and usually is carried out by charitable organisations. The approach is not controlled by the obligation to provide, there is no question of accountability to the population. Although the process may be participatory in some cases, ${ }^{1426}$ there is no question relating to dialogue between the providers and recipients. No legal claim can be made by the beneficiaries and the end result mostly is that of satisfying need and not building the capacity of the marginalised to provide for themselves in the future. If carried by charitable organisations, the approach focusses on the marginalised which allows the duty-bearers to escape their responsibilities. A human rights-based approach shifts focus from needs to right and these created certain consequences. The use of the language of 'right' confers certain advantages in development context. Some of the advantages include shifting thinking from assistance to entitlement and from meeting needs to enabling people to identify and claim rights. It equally helps or ensures governments recognition of priorities and further increases the moral weight and political commitment necessary to fulfil the priorities. ${ }^{1427}$ Emphasising 'right' in discourse and in the context of deprivation has the potential of strengthening local communities' position in their relationship with authorities and in providing them with additional bargaining power. ${ }^{1428}$ Needs are generally contextual while human rights are universal and with certain standards of measurement. Charitable organisation may be obligated to account but only to the donors and not to the beneficiaries and since it is more or less a 'charity' there is no demand for legal enforcement or protection from deprivation. Beneficiaries cannot equally demand for involvement in the designing and implementation phases of the projects.

The "utilitarian-driven approach such as "low cost high impact" project approach and cost-benefits analysis, ${ }^{1429}$ on the other hand, the target is to achieve greater coverage in terms of number of beneficiaries as opposed to removal of obstacles or severe deprivations affecting few marginalised individuals. ${ }^{1430}$ This approach may perhaps be desired in the short term where severe deprivation exist but may leave the beneficiaries in the long run dependent on assistance with little capacity to fend for themselves and to demand accountability from duty-bearers. According to Ferguson, the use of 'right' is a "vehicle for increasing the accountability of government organisations to their citizens and consequently increasing the likelihood that policy measures will be implemented in practice". ${ }^{1431}$

\footnotetext{
${ }^{1425}$ Hisayo Katsui, Downside of the Human Rights-Based Approach to Disability in Development (Institute of Development Studies, Helsinki University 2008)

${ }^{1426}$ For example, in identifying what a particular community needs and how such provisions can be undertaken in a manner which ensure success of the process.

${ }^{1427}$ Frances Stewart, 'Basic Needs, Strategies, Human Rights and the Right to Development' (1989) 11 Human Rights Quarterly 347

${ }^{1428}$ Emilie Filmer-Wilson, 'The Human Rights-based Approach to Development: The Right to Water'p. 230)

${ }^{1429}$ Andrea Cornwall and Celestine Nyamu-Musembi, 'Putting the 'Rights-Based Approach' to Development into Perspective' P. 1417.

1430 Ibid.

${ }^{1431}$ C. (Clare) Ferguson, Global Social Policy Principles: Human Rights and Social Justice (DFID, SDD 1999) P. 23.
} 


\section{Chapter Eight}

In the above two approaches although the aim is to ensure that marginalised are provided, the focus is, primarily that of assistance and the marginalised as stakeholders are generally not always involved in designing the processes. Unlike human rights-based approach, these approaches are not grounded in legal (or sometimes ethical) obligation which imposes duty to provide. Since there is no obligation, the marginalised may go back to their initial position as soon as the assistance ceases because the procedural capacity may be lacking. In addition to lack of accountability to the beneficiaries, the two approaches have little to do in balancing power relations between providers and recipients and in ensuring equality between different individuals in the society. Relying on experience, Care International UK noted that "a rightsbased approach does enable a deeper understanding of the causes of poverty and social injustice and therefore opens up the possibility of longer term changes than more conventional development approaches."1432

\subsection{Arguments against a Human Rights-Based Approach}

Notwithstanding its benefits, there are arguments against a human rights-based approach. The first centred on cultural imperialism. While human rights are universal, and majority of States are parties to major human rights treaties, concerns have been expressed regarding some of these rights especially taking into consideration and as some have argued, their Eurocentric nature. There is some resistance for example in the Middle-East and Africa on some human rights norms as being 'foreign' to culture and or religion notwithstanding that legal binding instruments relating to them have been ratified by some of these countries. This criticism may be a valid claim in certain quarters as regard some social rights. On this some might feel their religious or cultural beliefs would be eroded by the use of rights language emanating from the global north. Some communities and religious organisations are sceptical about accepting approaches or interventions from the West on this basis and acceptance by government is viewed with suspicion and sometimes may suffer peoples' non-cooperation.

The second argument centred on operationalisation challenges of human rights. It was argued that human rights are in conflict with one another, they are vague and with exceptions. ${ }^{1433}$ That a human rights-based approach does not have the transformative power of the real thing. ${ }^{1434}$ This argument has been categorised into three: irresponsibility for intervention, priority making and vagueness of human rights and cultural insensitivity. ${ }^{1435}$

On irresponsibility for intervention, it was stated that while human rights language is absolute and there is no rejection of it, ${ }^{1436}$ there is no operational guidance to achieved the

\footnotetext{
1432 Care International UK, Principles into Practice: Learning from Innovative Rights-Based Programmes (September 2005) P. 2.

${ }^{1433}$ David Kennedy, The Dark Sides of Virtue: Reassessing International Humanitarianism (Princeton University Press 2004) Pp- 21-22.

${ }^{1434}$ Srilatha Batliwala, Engaging with Empowerment: An Intellectual and Experiential Journey (Women Unlimited 2015)

${ }^{1435}$ Hisayo Katsui, Downside of the Human Rights-Based Approach to Disability in Development Pp. 8-12

${ }^{1436}$ Samuli Seppänen and Erik Castrén-instituutti, Possibilities and Challenges of the Human Rights-based Approach to Development (Erik Castrén Institute of International Law and Human Rights, University of Helsinki 2005) P. 85 
Realising the Right to Water and Sanitation in Nigeria

change aimed at. ${ }^{1437}$ That mechanism for operationalisation is weak. ${ }^{1438}$ This was evidenced by the vagueness of human rights treaties such as the ICESCR which only requires appropriate measures to be taken with available resources thereby leaving a room for interpretation "without practical implications." ${ }^{1439}$ Hence a human rights-based approach at most will remain in the "high moral ground" without practical implementation tools. ${ }^{1440}$

On priority making, it was argued that while a human rights-based approach requires priority to be given to the most marginalised in the society, ${ }^{1441}$ in reality, it is a case of 'tradeoffs' at the expense of less privileged most of the times. ${ }^{1442}$

On vagueness of human rights and cultural insensitivity, it was argued that although cultural sensitivity is required in operationalising a human rights-based approach, ${ }^{1443}$ the practice is contrary to this requirement as it is often a top-down approach ${ }^{1444}$ without taken into consideration specific circumstances of situations. ${ }^{1445}$

\subsection{Principles of a Human Rights-Based Approach}

Principles in human rights-based approach were derived from international human rights instruments and serve to oblige State parties to observe them in all aspects relating to human rights realisation and most especially in development programming. These principles are equality and non-discrimination, empowerment, participation, and responsibility and accountability.

\subsubsection{Principle of Equality and Non-Discrimination}

Equality and non-discrimination are fundamental principles of human rights law enshrined in various international and regional human rights instruments notably the bill of rights, ACHPR, European Convention on Human Rights, etc. It enshrined that all human beings are equal and entitled to the enjoyment of human rights without discrimination of any kind on the basis of race, religion, sex, ethnicity, language, political opinion, age, national or

\footnotetext{
${ }^{1437}$ Peter Uvin, Human Rights and Development (Kumarian Press 2004) Pp. 30-31 cited in Hisayo Katsui, Downside of the Human Rights-Based Approach to Disability in Development P. 9.

${ }^{1438}$ Samuli Seppänen and Erik Castrén-instituutti, Possibilities and Challenges of the Human Rights-based Approach to Development P. 34.

${ }^{1439}$ Hisayo Katsui, Downside of the Human Rights-Based Approach to Disability in Development P. 10.

${ }^{1440}$ Peter Uvin, Human Rights and Development See also Hisayo Katsui, Downside of the Human Rights-Based Approach to Disability in Development P. 10.

${ }^{1441}$ HRBA Portal, 'United Nations Practitioner's Portal on Human Rights Based Approaches to Programming'

1442 David Kennedy, The Dark Sides of Virtue: Reassessing International Humanitarianism P. 17. See also Philip Alston, 'Ships Passing in the Night: The Current State of the Human Rights and Development Debate seen through the Lens of the Millennium Development Goals' (2005) 27 Human Rights Quarterly P. 806; Katarina Frostell, Human Rights of Women (KIOS 2006); Samuli Seppänen and Erik Castrén-instituutti, Possibilities and Challenges of the Human Rights-based Approach to Development. P. 93.

${ }^{1443}$ HRBA Portal, 'United Nations Practitioner's Portal on Human Rights Based Approaches to Programming'

${ }^{1444}$ Philip Alston, 'Ships Passing in the Night: The Current State of the Human Rights and Development Debate seen through the Lens of the Millennium Development Goals'. P. 767.

${ }^{1445}$ David Kennedy, The Dark Sides of Virtue: Reassessing International Humanitarianism P. 12; Srilatha Batliwala, 'When Rights Go Wrong' (2007) Seminar P. 89.
} 
Chapter Eight

social origin, disability or other prohibited grounds. ${ }^{1446}$ Discrimination disempowers and denies the discriminated individuals and groups their freedoms. ${ }^{1447}$

\subsubsection{Principle of Empowerment}

Empowerment which relates to power within, confidence, identity and self-worth and it is critical in encouraging marginalised individuals to act. ${ }^{1448}$ It involves transformation of power relations, "creating new relationships based on values of solidarity, equity and common good", ${ }^{1449}$ and critical in boosting self-esteem of poor people. ${ }^{1450}$ In the words of Batliwala:

The term empowerment refers to a range of activities from individual self-assertion to collective resistance, protest and mobilization that challenge basic power relations. For individuals and groups where class, caste, ethnicity and gender determine their access to resources and power, their empowerment begins when they not only recognize the systemic forces that oppress them, but act to change existing power relationships. Empowerment, therefore, is a process aimed at changing the nature and direction of systemic forces that marginalize women and other disadvantaged sectors in a given context. ${ }^{1451}$

The use of human rights in discourse is empowering as it comes with the potentials of empowering those at the grassroots level to believe in the existence of their rights contained in international legal documents. ${ }^{1452}$ Empowerment, as a participatory process, enables people to reflect, engage, and ask questions. ${ }^{1453}$ It can be done at individual (and group) and organisational level. At the individual level, it enables working with others, learning decision-making skills and managing resources. ${ }^{1454}$ At the organisational level, it involves sharing of responsibility and leadership and participation in decision-making processes. ${ }^{1455}$

\footnotetext{
${ }^{1446}$ Relevant international instruments prohibiting discrimination includes: Arts. 2.1, 3, 24.1, 26 of ICCPR; General Comment No. 28 (2000) of Human Rights Committee; Arts. 2.2, and 3 ICESCR; General Comment No. 16 (2005) and General Comment No. 3 (1990) of Committee on ESC Rights; CEDAW and general recommendations adopted by the Committee on the Elimination of Discrimination against Women; International Convention on the Elimination of All Forms of Racial Discrimination and general recommendations adopted by the Committee on the Elimination of Racial Discrimination; Art. 2 of CRC; Art. 7 of International Convention on the Protection of the Rights of All Migrant Workers and Members of Their Families; United Nations Educational, Scientific and Cultural Organization (UNESCO) Convention against Discrimination in Education; and International Labour Organization (ILO) Convention No. 111 on Discrimination (Employment and Occupation).

${ }^{1447}$ Joel E. Oestreich, 'The United Nations and the Rights-based Approach to Development in India' (2014) 20 Global Governance 77 At P. 84.

${ }^{1448}$ Care International UK, Principles into Practice: Learning from Innovative Rights-Based Programmes p. 38

${ }^{1449}$ Valerie Miller, Lisa VeneKlasen and Cindy Clark, 'Rights-based Development: Linking Rights and Participation - Challenges in Thinking and Action' (2005) 36 IDS Bulletin 31.

${ }^{1450}$ Emilie Filmer-Wilson, 'The Human Rights-based Approach to Development: The Right to Water'

${ }^{1451}$ Quoted in Valerie Miller, Lisa VeneKlasen and Cindy Clark, 'Rights-based Development: Linking Rights and Participation - Challenges in Thinking and Action' P. 34.

${ }^{1452}$ Philip Alston, 'The Rights Framework and Development Assistance' (1995) 34 Development Bulletin (Australia) 9

${ }^{1453}$ Lisa VeneKlasen and others, Rights-Based Approaches and Beyond: Challenges of Linking Rights and Participation (Institute of Development Studies 2004) P. 34.

1454 A. J. Schulz and others, 'Empowerment as a Multi-level Construct: Perceived Control at the Individual, Organizational, and Community Levels' (1995) 10 Health Education Research 309 See also M. A. Zimmerman, 'Empowerment Theory: Psychological, Organizational, and Community Levels of Analysis' in J. Rappaport and E. Seidman (eds), Handbook of Community Psychology (Handbook of Community Psychology, Kluwer Academic 2000)

1455 A. J. Schulz and others, 'Empowerment as a Multi-level Construct: Perceived Control at the Individual, Organizational, and Community Levels'See also M. A. Zimmerman, 'Empowerment Theory: Psychological, Organizational, and Community Levels of Analysis'
} 
Realising the Right to Water and Sanitation in Nigeria

There is no meaningful empowerment when individuals and groups are not capable of participating in the process, carrying out the work and taking decisions in a way which demonstrates control of the process. ${ }^{1456}$ Some of the advantages of this principle are the raising of voice for the marginalised, it increases self-confidence or self-identity, promotes ability to engage in collective action in the resolution of problems, or claim of rights and influencing duty-bearers to support the rights of the marginalised. ${ }^{1457}$

Empowering individuals and groups requires first a clear appreciation of the sociocultural and economic factors responsible for their lack of voice, exclusion and or passivity. A successful application of a human rights-based approach hence requires contextualisation and utilisation of local knowledge, experience and resources.

\subsubsection{Principle of Participation}

Participation ${ }^{1458}$ is seen from varying perspectives. It is seen as a methodology through which people's project performance is improved and as "a process fostering critical consciousness and decision making". ${ }^{1459}$ According to DFID it refers to "enabling people to realise their right to participate in, and access information relating to, the decision-making process which affect their lives". ${ }^{1460}$ It enables addressing contextual challenges creating exclusion and perpetuating poverty or other deprivations and promotes sensitivities which impact on behaviour changing. ${ }^{1461}$ Participation provides the opportunity of ensuring ownership of the entire processes regarding a particular project by the relevant stakeholders. $^{1462}$

Stakeholders' participation benefits projects in several ways including raising the efficiency of resources allocation, utilising the local knowledge and exposing needs and preferences and ensures greater sustainability. ${ }^{1463}$

Genuine participation must go beyond mere sharing of information or even consultation where agenda had already been set. It must go beyond "perfunctory consultations" and should, for example, involve the participation of local groups in "agenda-setting, decision making and structures to hold government and donors accountable." 1464 Participation must remove apparent and hidden power relations which reinforce peoples' feelings of privilege or inferiority which impact on their potential to act. ${ }^{1465}$

\footnotetext{
${ }^{1456}$ R. L. Miller and R. Campbell, 'Taking Stock of Empowerment Evaluation: An Empirical Review. ' (2006) 27 American Journal of Evaluation 296

${ }^{1457}$ Care International UK, Principles into Practice: Learning from Innovative Rights-Based Programmes P. 3.

${ }^{1458}$ Relevant international instrument relating to participation are: Arts. 19, 21, 22.1, and 25 of ICCPR; General Comment 25 (1996) of the Human Rights Committee; Art. 15(1) ICESCR; Arts. 7 and 8 of CEDAW; Arts. 13, 15, 31 of CRC.

${ }^{1459}$ Valerie Miller, Lisa VeneKlasen and Cindy Clark, 'Rights-based Development: Linking Rights and Participation - Challenges in Thinking and Action' P. 32.

${ }^{1460}$ DFID, Realising Human Rights for Poor People (DFID 2000) P. 7.

${ }^{1461}$ Valerie Miller, Lisa VeneKlasen and Cindy Clark, 'Rights-based Development: Linking Rights and Participation - Challenges in Thinking and Action' P. 32.

${ }^{1462}$ HRBA Portal, 'United Nations Practitioner's Portal on Human Rights Based Approaches to Programming'

${ }^{1463}$ See Emilie Filmer-Wilson, 'The Human Rights-based Approach to Development: The Right to Water'p. 219)

${ }^{1464}$ Valerie Miller, Lisa VeneKlasen and Cindy Clark, 'Rights-based Development: Linking Rights and Participation — Challenges in Thinking and Action' P. 32.

1465 Ibid.
} 
Chapter Eight

To achieve these objectives, human rights standards must guide the participation process. This means that the process should be inclusive and specifically ensures that all those who are to be affected are involved including women, children, traditional rulers, civil society organisation, the poor, the elderly and people living with disabilities. Participation must be genuine, free, dynamic, proactive and beyond mere consultation. ${ }^{1466}$ In this, participation should be ensured in all the programme circle including planning, implementation, and monitoring and evaluation.

Success of project is better ensured when there are genuine participation of local structures and people and when projects are people-owned and people-controlled. ${ }^{1467}$ The adoption of policies and implementation of projects without necessary consultations and direct link with local structures is a recipe for projects' failure and resources wastage. Dutybearers must never assume the incapacity or irrelevance of local structures and should consider their peculiarities in projects development, monitoring and implementation.

\subsubsection{Principle of Responsibility and Accountability}

Accountability relates to taking responsibility for one's action and behaviour and being able to account for it. ${ }^{1468}$ Accountability is an important principle of human right-based approach under which roles of duty-bearers and NGOs are stressed ${ }^{1469}$ and monitored which overall, improved effectiveness and efficiency of duty-bearers. ${ }^{1470}$ Promoters of a human rights-based approach considers requirement of accountability of relevant actors as one of the most added value of the approach because of its impact on the rights of people. This is on the basis that "[r]ights imply duties, and duties demand accountability." 1471

Accountability however, should be seen more in the context of relations between the citizens and State as there is little accountability between State and donor or international agencies, or between recipients and these agencies as there is no legal obligations binding on the agencies notwithstanding their work being termed human rights-based. ${ }^{1472}$ Strategies to ensure accountability are contextual. This means what is to be done and how it should be done largely depend on each situation or circumstance. These may be supportive or

\footnotetext{
${ }^{1466}$ HRBA Portal, 'United Nations Practitioner's Portal on Human Rights Based Approaches to Programming'

${ }^{1467}$ See James C. Scott, Seeing Like a State: How Certain Schemes to Improve the Human Condition Have Failed (Yale University Press 1998)

${ }^{1468}$ See Peter Laban, 'Accountability and Rights in Right-based Approaches for Local Water Governance' (2007) 23 International Journal of Water Resources Development 355 See also Care International UK, Principles into Practice: Learning from Innovative Rights-Based Programmes P. 25.

${ }^{1469}$ Care International UK, Principles into Practice: Learning from Innovative Rights-Based Programmes

${ }^{1470}$ Emilie Filmer-Wilson, 'The Human Rights-based Approach to Development: The Right to Water' P. 218.

${ }^{1471}$ UNHCHR, Principles and Guidelines for a Human Rights Approach to Poverty Reduction Strategies Para. 24

1472 Andrea Cornwall and Celestine Nyamu-Musembi, 'Putting the 'Rights-Based Approach' to Development into Perspective' P. 1433.
} 
Realising the Right to Water and Sanitation in Nigeria

confrontational. ${ }^{1473}$ In some cases, focus is on the rights-holders ${ }^{1474}$ while in others it is on duty-bearers ${ }^{1475}$ and yet in other situations it can be a combination of the two. ${ }^{1476}$

Holding duty-bearers accountable requires removal of obstacles which duty-bearers face in the performance of their obligations. A number of these obstacles have been identified including budgetary provisions, delay in budgetary releases, corruption, lack of capacity, politicisation at the level of implementation etc. Framing obligations in the context of human rights provide the necessary legal framework through which obstacles to realisation of human rights could be removed and rights-holders could demand performance and explanations from duty-bearers. Applying the principles of transparency, accountability, nondiscrimination and participation are some of the important mechanisms through which obstacles could be eliminated. Demand by rights-holders is the most effective way of ensuring accountability. ${ }^{1477}$ Capacity of rights-holders to identify and claim their rights is hence an essential requirement of ensuring accountability. A human rights-based approach hence focuses on assessment of capacity gaps not only of duty-bearers but equally of those who are essentially to identify their rights and demand accountability for their realisation. Where weak institutional structures and unwillingness to assert claim exist, achieving accountability is difficult if not impossible. ${ }^{1478}$

Additionally, ensuring accountability requires the use of qualitative and quantitative data to periodically monitor how policies are achieving the desired target, and sharing of such data with relevant stakeholders. ${ }^{1479}$ As such, mechanisms must be in place to monitor and measure on periodic basis, series of targets and compliance with plans (which incorporated human rights obligations of the State) at all levels of project implementation. ${ }^{1480}$ Ratifying international human rights treaties such as those relevant here by Nigeria or any other States makes it necessary for Nigeria to accept the creation of credible platforms for accountability. ${ }^{1481}$ A human rights-based approach provided the needed methodology for its attainment.

\subsection{Potentials of a Human Rights-Based Approach to Nigeria's Water and Sanitation Sector}

Exclusion, poverty or injustice do not exist on their own. They are products of processes taking place in a society. These processes may be political, economic, social, cultural or even environmental. A holistic analysis of these issues is necessary before the deployment of a human rights-based approach. Structures, systems, and social norms or traditions must be

\footnotetext{
${ }^{1473}$ HRBA Portal, 'United Nations Practitioner's Portal on Human Rights Based Approaches to Programming'

${ }^{1474}$ Such as raising of awareness and educating rights-holders about their rights and building their capacity to assert claims against duty-bearers.

${ }^{1475}$ Such as developing duty-bearers' capacity at all levels, strengthening of accountability mechanisms (judicial, quasi-judicial, administrative and informal justice mechanisms).

${ }^{1476}$ Such as building relationships between duty-bearers and rights-holders to work together.

${ }^{1477}$ HRBA Portal, 'United Nations Practitioner's Portal on Human Rights Based Approaches to Programming'

1478 Ibid.

1479 Ibid.

${ }^{1480}$ Emilie Filmer-Wilson, 'The Human Rights-based Approach to Development: The Right to Water'.P. 222

${ }^{1481}$ Dejo Olowu, 'Human Development Challenges in Africa: A Rights-Based Approach'. P. 214.
} 


$$
\text { Chapter Eight }
$$

examined to uncover the root causes of poverty, exclusion or marginalisation. ${ }^{1482}$ According to the United Nations Development Group's guidelines for Common Country Assessment and United Nations Development Assistance Framework, ${ }^{1483}$ human rights standards reinforce situation analysis in the following levels:

1. Causality analysis;

2. Role/obligation analysis; and

3. Identifying the interventions needed to build rights-holders capacity and dutybearers performance.

In identifying the required intervention in building rights-holders' capacity and improving duty-bearers' performance, causality and role/obligation analysis are necessary. Causality analysis draws attention to the root causes of the problems as well as the systemic pattern of discrimination while role/obligation analysis defines those under obligations to act and those who are to benefit from the performance of such obligations. ${ }^{1484}$

The problems responsible for lack of access to water and sanitation in Nigeria and those whose duty it is to provide access have been discussed before. A critical observation of the Nigerian situation suggested that it is the combined actions and inactions of the Nigerian duty-bearers and rights-holders which are contributing to water and sanitation poverty in Nigeria. Indeed, there are certain factors beyond their control such as climatic or environmental factors, but equally legal, political, economic, social cultural and institutional factors can be traced to the existing gaps among the duty-bearers and rights-holders. Problems traceable to duty-bearers include failure to domesticate ratified international human rights instruments and to develop necessary policies in line with the legal obligations of Nigeria, poor institutional governance; technical and infrastructural capacity which are responsible for poor data gathering, lack of coordination and data sharing; poor maintenance culture; leadership and corruption; cost of governance; inadequate budgetary provisions and releases; politicisation and lack of professionalism and low-cost recovery. On the part of rights-holders, low-level literacy; cultural beliefs and practices; attitudinal approach to governances and accountability and lack of capacity or willingness to assert claims are some of the problems. Additionally, the root causes of marginalisation are equally traceable to certain environmental and social factors including accessibility of location, presence of economic activities in an area, socio-economic position of communities and number of population in a given area. Proper appreciation of how these impact on the attainment of the human right to water and sanitation and the role both duty-bearers and rights-holders could play will assist in defining how duty-bearers' capacity could be improved and rights-holders could be empowered.

In view of the problems impacting on the realisation of the right to water and sanitation in Nigeria, a proper application of a human rights-based approach will enable Nigeria to address these problems especially from the context of equality and non-discrimination, empowerment, participation, and responsibility and accountability.

${ }_{1482}$ Care International UK, Principles into Practice: Learning from Innovative Rights-Based Programmes
United Nations Development Group, 'UNDAF/Programming Guidance' <https://undg.org/home/guidance-policies/common-country-programmingundaf/> accessed 29 July, 2016 2016) ${ }^{1484}$ HRBA Portal, 'United Nations Practitioner's Portal on Human Rights Based Approaches to Programming' 
Realising the Right to Water and Sanitation in Nigeria

A successful application of the principles of equality and non-discrimination will assist in addressing problems of marginalisation on access to water and sanitation which seemed to be an issue in Nigeria. Problems associated with lack of awareness, lack of access to information, passivity of the population, and institutional factors can be addressed through a successful application of the principles of empowerment and participation. Principles of responsibility and accountability can assist in addressing political and economic factors such as inept and corrupt leaders, lack of political will, politicisation of development, inadequate budgetary provisions and untimely releases, and corrupt practices.

Attention should hence be focused on the necessary intervention to enable both dutybearers and rights-holders undertake their obligations and claim their rights respectively. Issues to concentrate on are:

1. Strengthening the capacity of duty-bearers and relevant non-state actors to fulfil their obligations and

2. Building the capacity of rights-holders to claim their rights. ${ }^{1485}$

\subsubsection{Use of Language of 'Right' in the Nigerian Context}

The language of 'rights' is important in strengthening duty-bearers' capacity and awareness as well as empowering rights-holders to assert claims. UDHR is binding on Nigeria as a reflection of customary law on human rights and Nigeria has acceded to the ICCPR, ICESCR, the Geneva Conventions and is a party to CEDAW and CRC. These instruments have all been ratified. ${ }^{1486}$ At the regional level, Nigeria has ratified and domesticated the ACHPR. The Nigerian Constitution provided for what mostly is referred to as $\mathrm{CP}$ rights. These instruments contain the positive legal obligations of Nigeria which it must work towards realising their ideals in all its legislative, administrative and judicial measures. The instruments provided the needed platform through which advocacy could be launched, duty-bearers could be required to conform to and rights-holders could be empowered to claim. ${ }^{1487}$ Similarly, the provisions of Islamic law drawn from Qur'anic verses and Prophetic traditions which set the rights of individuals against the State and the general obligations of State to work towards the promotion of the general welfare of its citizens could be used in areas where Islamic law apply.

As demonstrated, the measures hitherto adopted, from the context of contents of the right to water, the Nigerian State is currently below the minimum standard. The availability, quality, and accessibility are issues deserving urgent attention legislatively, administratively and judicially. These international, regional and domestic human rights instruments provided the necessary and appropriate platforms for advocacy campaign and demand for action

\footnotetext{
1485 Andrea Cornwall and Celestine Nyamu-Musembi, 'Putting the 'Rights-Based Approach' to Development into Perspective'. P. 1430.

${ }^{1486}$ ICCPR and ICESCR were ratified on 29 July 1993, CEDAW was ratified on 13 June 1985 and CRC was ratified on 19 April 1991.

${ }^{1487}$ Activating the powers of local courts however requires relevant international instruments to be domesticated. At the moment, only the African Charter on Human and Peoples Rights has been domesticated. This however, does not make the issue of utilising the instruments moot. Nigeria has ratified the instruments and hence bound to conform to their established standards including the adoption of legislative, judicial and administrative measures to implement the embodied obligations.
} 
Chapter Eight

against the Nigerian State. They are tools to be used in awareness creation. The central and germane questions however are:

1. How can these instruments be used?

2. Who can utilise them in the context of advocacy?

3. In what manner could the utilisation be monitored?

In the Nigerian context, the language of rights is to be drawn firstly, from the justiciable rights constitutional provisions which link directly to the right to water and sanitation such as the right to life and the right to dignity of human person. The ACHPR as domesticated and tested in several cases as discussed, provided the international legal flavour in human rights claims. Islamic law provisions equally supplemented rights claim especially at the State level where certain elements of Sharia law are applicable. Advocacy should therefore be centred on drawing the attention of duty-bearers to legal obligations the State has willingly assented to.

Although there is the general idea about what human rights is and that majority of Nigerians considered water and sanitation as human rights, there is no adequate understanding regarding the existence of these legal instruments and their relationship with practical human rights issues in the State. In improving capacity therefore, the first step is the creation of an environment through which people could get to know about the instruments, how the instruments relate to fundamental human rights issues and the obligations embedded therein. Sustain advocacy is therefore needed not only in bringing peoples' attention to the existence of these instruments and their binding nature, but efforts must also be geared towards interpreting the instruments in a meaningful manner by bringing their contents to bear on concrete human rights issues affecting the society. Considering low-literacy level, advocacy should not be centred on the abstract provisions in the instruments. Discussions should be contextualised and tailored towards issues relating to poverty, hunger, housing and water and sanitation and how these instruments relate to them.

Empirical figures suggested that majority of Nigerians considered water and sanitation as human right issue. This makes it easier to link it to legal instruments which enables individuals to demand respect, protection and fulfilment from duty-bearers. When language of right was used in relations to water, rights-holders indicated their willingness to assert its claim.

Equally, understanding the contents of the right and the manner in which they relate to fundamental issues of concern to the population create an opportunity to assess not only the substance of the right (the provision of quality water and sanitation) but also the procedural rights flowing therefrom including the right to participate on matters concerning water and sanitation and the right to request and receive information. Methodology on how the instruments can be used and answers to the questions, who can utilise them in advocacy and how such can be monitored will be combined under the methodology for the application of a human rights-based approach and the role of civil society organisations respectively in the later sections. 
Realising the Right to Water and Sanitation in Nigeria

\subsubsection{Relevance of Principles of Human Rights-Based Approach to Challenges in Water and Sanitation Sector}

The problems contributing to poor water and sanitation coverage in Nigeria have been identified. In this section, relevance and potentials of a human rights-based approach in addressing some of the challenges would be highlighted. A close analysis of the political, economic, social and institutional factors as they impact on water and sanitation coverage demonstrated failure of governance. This failure of governance can be attributed to both dutybearers and rights-holders because of the way in which each discharges their obligations. What therefore is required is the existence of good governance structure. Observance of human rights-based principles by the duty-bearers and by extension, rights-holders, is important in imbibing the culture of good governance. This would promote not only the realisation of the human right to water and sanitation but also all other human rights.

Good governance is a concept which appeared in public discourse in the late 1980s as response to failures in development policies linked to concerns in governance. ${ }^{1488}$ Governance simply refers to "mechanisms, institutions and processes through which authority is exercised in the conduct of public affairs". ${ }^{1489}$ It is a decision-making process and how such decisions are implemented or not implemented. ${ }^{1490}$ It involves several formal and informal actors. The roles these actors play is dependent upon their level and the extent to which they participate in decision-making and implementation processes. At all times, government is a key to governance. Good or bad government facilitate good or bad governance respectively. The main characteristics of good governance are accountability, transparency, rule of law, responsiveness, equity, inclusiveness, efficiency, effectiveness and participation. ${ }^{1491}$ There is increasing demand from donors and international financial institutions in the context of aid, loans and development discourse for reforms to be in line with good governance. ${ }^{1492}$ Through its characteristics, good governance ensures the removal of obstacles to enjoyment of human rights and facilitates development. Vices such as corruption, discrimination, lack of accountability and lack of capacity are all addressed when tools provided by the concept are effectively utilised.

There exists close relationship between good governance and a human rights-based approach and the two are mutually reinforcing as both have been built on the principles of transparency, accountability, non-discrimination and participation. ${ }^{1493}$ Observance of human rights strengthens good governance through, not only ratification of human rights instruments but equally domesticating them, putting the necessary structures in place which ensure observance of rule of law and access to justice, accountability, checks and balances and provision of effective remedies. A human rights-based approach promotes good governance

\footnotetext{
${ }^{1488}$ HRBA Portal, 'United Nations Practitioner's Portal on Human Rights Based Approaches to Programming'

1489 Ibid.

${ }^{1490}$ United Nations Economic and Social Commission for Asia and the Pacific, 'What is Good Governance? ' <http://www.unescap.org/sites/default/files/good-governance.pdf> accessed 28 August, 2016

1491 Municipal Association of Victoria and others, 'About Good Governance' 2012) <http://www.goodgovernance.org.au/about-good-governance/what-is-good-governance/> accessed 28 August, 2016

${ }^{1492}$ United Nations Economic and Social Commission for Asia and the Pacific, 'What is Good Governance?

${ }^{1493}$ HRBA Portal, 'United Nations Practitioner's Portal on Human Rights Based Approaches to Programming'
} 


\section{Chapter Eight}

and with good governance corruption, discriminatory tendencies, and marginalisation are minimised or eliminated. ${ }^{1494}$ Additionally, strengthening of duty-bearers' capacity to discharge their responsibilities and empowerment of rights-holders may not be achieved in an environment which does not promote good governance.

In Nigeria, a combination of incapacity, corruption and attitudinal issues is responsible for lack of accountability. Duty-bearers and rights-holders are all complicit in this respect. The common problem which seems to cut across and shared by duty-bearers and rightsholders is the believe that performance of duties by political office holders is a favour to the population. Political office holders failed to see themselves as duty-bearing individuals and rights-holders support this anomaly through validation process wherein duty-bearers are praised many a times in the media for a simple act of duty performance. Rights-holders failed to realise their position as rights-holders who should demand accountability from dutybearers. No mechanisms are used to ensure duty-bearers perform their obligations. No meaningful questions are asked by rights-holders hence no accountability is given. This perception enabled duty-bearers to shy away from their obligations. Political office holders personalise state resources. Development projects are concentrated only in areas where politicians have interests to the detriment of areas where opposition resides. ${ }^{1495}$ It took a very long time before civil society organisation started asking questions on financial allocations to States.

In the context of water and natural resources management, it has been pointed out that the problem in many cases is the local population to assume accountability. That "[i]t is only when people change, individually and collectively, that the organisation changes."1496 Accountability is not only on the part of duty-bearers. It is a term which cut across all the relevant stakeholders including the duty-bearers, the right-holders, the civil society and nogovernmental organisations. Rights-holders rarely request duty-bearers to account and in the context of water and sanitation very limited request was recorded. While power relations may be an issue in this context but when rights are not claimed by those who are expected to do so, marginalisation will be the result. ${ }^{1497}$ Long term water intervention programmes can only succeed where there is a sense of ownership and accountability on the part of right-holders especially at the grassroots level. ${ }^{1498}$ Ensuring grassroots accountability is circumscribed by several pre-conditions relating to the "benefits, knowledge, rights and claim-making power." 1499 Adherence to the principles of accountability, equity and participation has the potential of addressing political, economic, social and institutional factors identified above. It would ensure that governance is in line with national and international obligations of the

\footnotetext{
${ }^{1494}$ United Nations Economic and Social Commission for Asia and the Pacific, 'What is Good Governance?'

${ }^{1495}$ See Dunstan N. Wai, 'Human Rights in Sub-Saharan Africa' in Adamantia Pollis and Peter Schwab (eds), Human Rights: Cultural and Ideological Perspectives (Human Rights: Cultural and Ideological Perspectives, Praeger 1979) See also James C. N. Paul, 'Participatory Approaches to Human Rights in Sub-Saharan Africa' in Abdullahi Ahmed An-naim and Francis Mading Deng (eds), Human Rights in Africa: Cross-Cultural Perspectives (Human Rights in Africa: Cross-Cultural Perspectives, The Brookings Institution 1990)

${ }^{1496}$ Care International UK, Principles into Practice: Learning from Innovative Rights-Based Programmes P. 28.

${ }^{1497}$ Celestine Nyamu-Musembi and Andrea Cornwall, What is the "Rights-Based Approach" all about? Perspectives from International Development Agencies

${ }^{1498}$ See Peter Laban, 'Accountability and Rights in Right-based Approaches for Local Water Governance' P. 356. 1499 Ibid. P. 357
} 
Realising the Right to Water and Sanitation in Nigeria

State. As such issues associated with lack of political will, cost of governance, politicisation of development, funding, lack of transparency and participation would be attended to, eliminated or at least, minimised. Equally, realising its fundamental obligations to the citizens, the State would need to vigorously pursue policies and actions in line with good governance that would address problems of population explosion and uncontrolled migratory movement as proper planning would be done in a way that the needs of citizens are addressed.

To achieve equality and removal of discriminatory practices and marginalisation, in certain instances pragmatic measures such as affirmative action targeting marginalised individuals are necessary. In the context of water, judicial decisions from around the world suggested that duty-bearers are required to give priority to those who are marginalised. A human rights-based approach equally requires prioritisation in favour of marginalised or discriminated group. It requires that in the context of development programming, attention must not only be on those who are easy to reach or national and local elites, ${ }^{1500}$ it must take into consideration the poor and downtrodden and those who have no voice or representations. Programming must ensure the removal of power imbalances and must not directly or indirectly perpetuate discrimination.

Addressing discrimination or marginalisation requires first identifying the victims and adequately understanding the circumstances under which such marginalisation or discrimination takes places as well as conditions which make marginalisation or discrimination occurs or continues. ${ }^{1501}$ In the Nigerian context, theoretical and empirical study revealed that these marginalised groups are the poor, the physically inaccessible including people living in the riverine areas, the internally displaced persons, individuals living in locations with little population and locations with little or no presence of economic activities among others. The way in which water is connected and distributed in Nigeria together with other identified factors have revealed how intended or otherwise, the above categories of individuals and communities are marginalised or discriminated against.

Under a human rights-based approach, strategies must be devised to ensure equality and non-discrimination. Applying the principle of non-discrimination in water connection and distribution has the potential of ensuring the elimination of these problems. This would be achieved if data is collected and analysed, segregated in terms of, for example social and economic conditions/status of the people, their geographical locations etc. in a way that would take into consideration all different categories of people in the country. The data should clearly demonstrate the extent to which people and communities are enjoying the guaranteed rights. To promote accountability and transparency, this information should be made available in accessible formats and minority languages. ${ }^{1502}$

\footnotetext{
${ }^{1500}$ HRBA Portal, 'United Nations Practitioner's Portal on Human Rights Based Approaches to Programming'

${ }^{1501}$ Care International UK, Principles into Practice: Learning from Innovative Rights-Based Programmes. P. 15. see also Emilie Filmer-Wilson, 'The Human Rights-based Approach to Development: The Right to Water' Pp. 221222.

${ }^{1502}$ HRBA Portal, 'United Nations Practitioner's Portal on Human Rights Based Approaches to Programming'
} 
Chapter Eight

The next issue is the problem of poverty. It appears to be the biggest obstacle preventing large number of rights-holders from accessing the justice system. ${ }^{1503}$ Nigerian human rights environment had demonstrated few attempts by rights-holders to challenge State's actions which are incompatible with human rights obligations. The few cases mostly centred on CP rights concerning influential members of the society while ESC rights are largely neglected except recently in the context of labour and environment. Conditions under which poverty results and is perpetuated are associated with disempowerment and exclusion. ${ }^{1504}$ When people are excluded from decision-making processes in which political, economic, social, and cultural issues are discussed, such people are cut-off from information. Their voices are severely fettered and disempowered. A human rights-based approach provides the enabling environment of addressing root causes of poverty through ensuring stakeholders' participation especially the poor and marginalised. It demands that marginalised be identified and prioritised. Additionally, a human rights-based approach emphasises the importance of addressing stigma, discrimination, drawing attention to insecurity and social isolation associated with poverty. ${ }^{1505}$ The salient features of human rights norms such as equality, accountability, interdependence of rights, participation and non-discrimination are instrumental to addressing causes of poverty. ${ }^{1506}$ The compelling norms in the approach reinforced by legal obligations provide the needed standards to be observed by States. These in turn enable the poor and marginalised to effectively participate on issues concerning their rights and lives. When the poor are appropriately empowered their participation will serve as springboard through which their concerns are factored in decision-making, policies and projects.

Addressing poverty in the context of realising the right to water and sanitation requires the following:

1. Recognising poverty is caused and is perpetuated by several factors. The first step is investigating laws, policies and institutions whose covert or overt provisions/actions perpetuate discriminatory tendencies, excludes certain individuals on economic, or social status and compromises institutional obligation of accountability.

2. Recognising the impacts of exclusion and lack of participation. The appropriate strategy to convert these is to develop mechanisms and arrangement from the grassroots level to the federal level which will facilitate interaction and dialogue between duty-bearers and rights-holders in ways which ensure dignity and respect. Through this, the roles of each are defined and stakeholders become

\footnotetext{
${ }^{1503}$ Poverty has been defined to not only mean lack of material goods and opportunities but also "the lack of physical and social goods, such as health, physical integrity, freedom from fear and violence, social belonging, cultural identity, organisation capacity, the ability to exert political influence and the ability to live a life with respect and dignity." See ibid.in the context of human rights, it was equally defined as "the denial of a person's rights to a range of basic capabilities — such as the capability to be adequately nourished, to live in good health, and to take part in decision-making processes and in the social and cultural life of the community." See UNHCHR, Principles and Guidelines for a Human Rights Approach to Poverty Reduction Strategies . Para. 7.

${ }^{1504}$ HRBA Portal, 'United Nations Practitioner's Portal on Human Rights Based Approaches to Programming'

${ }^{1505}$ UNHCHR, Principles and Guidelines for a Human Rights Approach to Poverty Reduction Strategies Para. 15. ${ }^{1506}$ Ibid. Para. 20.
} 
Realising the Right to Water and Sanitation in Nigeria

aware of the relationship between them and how actions of one could impact on the other. This has the effect of bringing governance to the doorsteps of the poor and appropriate concerns can be shared which will inform decisionmaking, programmes and projects. Recognising bureaucracy as an impediment in human rights claims, establishment of these arrangements will provide the needed avenue through which concerns, and violations are attended to and addressed.

3. Recognising the need to provide for appropriate, accessible and poor-friendly complaints mechanisms with power to provide effective remedies. This will help in attending to complaints arising for example, from discriminatory practices in the application of laws and policies and in the ways in which projects are executed.

Success of application of a human rights-based approach that would ensure accountability, non-discrimination, and participation requires empowerment of both dutybearers and rights-holders without which addressing the challenges may not be realised.

\subsubsection{Empowerment of Duty-Bearers and Rights-Holders}

Deployment of a human rights-based approach compels interaction of spectrum of players in the relevant field. Its success depends on or is determined by how relevant stakeholders network, share information and cooperate to address the identified challenges. Line ministries and agencies must share data and statistics and coordinate efforts toward addressing water and sanitation crisis. Government must work with international and bilateral agencies to share experience, standards and best practices. Both will equally have to work with civil society organisations in advocacy and capacity building of rights-holders. The international community, and civil society should forge link between duty-bearers and rights-holders to create enabling environment for dialogue and sharing of information in a mutually respectable manner.

International human rights law establishes direct relationship between a State as the dutybearer and citizens as rights-holders. ${ }^{1507}$ This relationship is crucial in the realisation of human rights. ${ }^{1508}$ Capacity to discharge legal obligations by the State and non-state actors as well as capacity to claim by rights-holders is fundamental. As such, both duty-bearers and rights-holders must be properly enabled to not only become aware of their roles but to also to be able to discharge those roles in a manner that will lead to the realisation and enjoyment of the rights in question. Consequently, their empowerment is crucial. A human rights-based approach essentially considers empowerment as one of its essential principles. How empowerment in the Nigerian situation is to be done is suggested below:

1. Empowerment of Duty-Bearers

The first step in empowering duty-bearers is building and strengthening of responsible institutions. This requires the formulation and adoption of strong legal provisions

\footnotetext{
${ }^{1507}$ Emilie Filmer-Wilson, 'The Human Rights-based Approach to Development: The Right to Water' P. 223. ${ }^{1508}$ Ibid.
} 


\section{Chapter Eight}

empowering institutions responsible for water and sanitation. Necessary political backing will ensure that the legal and policy frameworks are properly adhered to. The objective here is to strengthen the institutions for good governance.

Secondly, the creation of awareness on international and national human rights obligations of the State and applicable instruments. This could be done through trainings and retraining of critical staff responsible for decision making and policy implementation. Dutybearers should be enabled to appreciate the implications of their actions and their impacts on human rights of citizens. They should know the importance of participatory planning, sharing of data and information with all the relevant and affected stakeholders including rightsholders. Capability should be improved towards responsible action and ways through which marginalisation and exclusion could be avoided in decisions and actions. Duty-bearers' approach to considering performance of obligations as a favour needs to be reversed. They need to be empowered to be able to appreciate the position of the population as rights-holders with a range of rights including right to be heard and right to participate in decision-making process concerning their lives.

Thirdly, advocacy by non-state actors including civil society organisations and development agencies is crucial to empowerment process. Strategies could include media campaign, political lobbying, and training of relevant stakeholders on human rights, their indivisibility and interdependence. These will help in creating the necessary awareness and serve as tools in tracking the extent to which the State is keeping to its international legal obligations. ${ }^{1509}$ The role of courts in this context is equally crucial. Judiciary must be prepared to take bold steps in recognising that the dichotomy between CP rights and ESC rights is no longer tenable in the light of developments around the world.

\section{Empowerment of Rights-Holders}

In the first instance, as pointed out by Hugo and anchored by Filmer-Wilson, rightsholders must first see themselves as those possessing rights which they could justifiably demand from power and not victims with needs. ${ }^{1510}$ They must be enabled to first change their perception about themselves and the perception of how they are viewed and treated by duty-bearers.

Empowering local population to claim their rights should include encouraging and supporting them to pursue ESC rights claims either independently (as rights) or through the so-called justiciable rights. The long-term effects of this will generate public attention, discussions, agitation and possibly formal domestication of ICESCR or even recognition in the constitution. These necessarily requires building networking relationships between the civil society organisations, Nigerian Bar Association, traditional institutions, faith-based organisations and youth organisations in Nigeria.

As the empirical study established, local communities are mostly employed as labourers only in the construction of water and sanitation structures. This approach needs to be

\footnotetext{
1509 Ibid. P. 223.

${ }^{1510}$ See Hugo Slim, Making Moral Low Ground: Rights as the Struggle for Justice and the Abolition of Development (Stamford Policy Paper, 2002) See (Emilie Filmer-Wilson, 'The Human Rights-based Approach to Development: The Right to Water' P. 223.
} 
Realising the Right to Water and Sanitation in Nigeria

reversed. As communities are the beneficiaries, their voices, interests and concerns are of critical importance for sense of ownership, maintenance and sustainability. Their active participation is therefore important. Local structures should be linked to the duty-bearers and duty-bearers should be enabled and encouraged to allow local participation in project planning and implementation.

Importantly also, understanding of socio-cultural sensitivity is required. A proper understanding of the local attitude to governance issues and ways of interaction with governmental institutions is required. Rather than engaging the local population with issues relating to corruption or poor governance at the national level, civil society organisations could facilitate discussions with the people at the grassroots level to construct their own understanding of these issues together with suitable and acceptable mechanisms for addressing them. ${ }^{1511}$ Creating spaces for the people to reflect and work towards understanding taking steps in improving their welfare is important. It provides the feeling of ownership of ideas and solutions to the population which are necessary to prompt or promote action in ways which may impact peoples' lives.

Necessary linkages to human rights norms (and instruments, where context so admit) could be made to create awareness and provide needed justification for the acceptance of human rights instruments in peoples' decisions and actions which in turn increases their selfworth (power within). Care International UK adopted this approach in its Sierra Leone Upstream Approach to Human Rights. It connected rural masses to their government's human rights commitments, then strategized and centred discussions on 'principled behaviour at all levels of society' from which issues of concern were incorporated into discussion including governance, traditional cultural practices etc. Similar approach could be utilised in Nigeria in order to counter and possibly avoid the suspicion that peoples' cultures and religious beliefs are the targets. Efforts should be made to find the necessary linkages with culture and religion on issues of concern through the involvement of traditional and religious leaders. This will further enrich discussion, facilitate acceptance and promote compliance by the local population.

Media is an important tool in advocacy, empowerment and creation of awareness processes. Significant number of Nigerians utilises radio, television and social media in accessing and sending information. Carefully controlled and targeted messages could be channelled through these mediums in ways which enable individuals to become aware of their rights and how to claim them. Media may equally be an important tool in the monitoring of duty-bearers' performance and compliance to human rights norms and standards.

Additionally, resorce competition and partnerships between civil society organisations and between rights-holders and civil society organisations proved to be useful. ${ }^{1512}$ Building collaborative mechanisms between local organisations and mainstream civil society on relevant issues could provide an important platform through which the capacity of the former to claim rights could be built and enhanced. ${ }^{1513}$

\footnotetext{
${ }^{1511}$ Similar methodology seemed to have worked in Care International UK Programme in Sierra Leone (see Care International UK, Principles into Practice: Learning from Innovative Rights-Based Programmes P. 10.

${ }^{1512}$ See Emilie Filmer-Wilson, 'The Human Rights-based Approach to Development: The Right to Water'p. 223)

${ }^{1513}$ This methodology has worked for CARE in the Philippines and Concern in Cambodia.
} 


$$
\text { Chapter Eight }
$$

Academic and research community could equally contribute in capacity-building endeavour of both duty-bearers and rights-holder in their research and scholarship. Sustained attention should be paid to ESC rights in their research. As discourse pays more attention to this category of rights, awareness and attention including momentum would be built. This may help in springing up demands for justiciability of the rights or the clamour for the removal of the non-justiciability section in the Constitution.

For the application of a human rights-based approach to be successful, existing situations in the country must be taken into consideration and factored in the process. The next section addresses this issue.

\subsection{Relevance of Local and National Conditions in the Application of a Human Rights-Based Approach in Nigeria}

Human rights-based approach has been criticised as not being responsive to cultural sensitivity in its operationalisation. ${ }^{1514}$ However, the approach is not a model which is to be applied blindly. Examining situational conditions is necessary for its successful application. Its success requires adequate understanding of the local people, circumstances, and challenges. ${ }^{1515}$ Failure to take these issues into consideration, a project, although wellintentioned, may fail. This is more pronounced in circumstances where human rights discourse is viewed suspiciously. As an example, application of an approach which aims at educating people on holding leaders to account in a society which cultural rules prohibit challenging leaders or elders to account may be viewed with reservations. This may be exacerbated by other factors such as ignorance, lack of awareness or access to information.

Additionally, corruption-ridden societies may not easily allow an approach demanding transparency and accountability to succeed. Hence cautions must be exercised in the way in which such approach is to be introduced and applied. In order word, general environmental situation and human rights discourse must be carefully assessed and obstacles identified before an approach is introduced or applied. Conducive human rights environment is essential for the sustenance of the approach. ${ }^{1516}$

As previously mentioned, prolonged military governance in Nigeria has tremendously affected the way in which human rights issues are discussed or handled. Human rights monitoring mechanisms in the country are weak and corruption on the part of duty-bearers has assumed an unquantifiable dimension. Efforts must therefore be geared towards enlightening the public and other relevant stakeholders about the indivisibility and interconnectedness of all human rights and how political, economic, social, cultural and institutional factors impact on human rights realisation. Considering that myriad issues have contributed immensely on human rights enjoyment and realisation of the right to water and sanitation in Nigeria, these issues must be factored in the planning, implementation and monitoring cycles of a human rights-based approach. As an example, removing economic obstacles in the planning process requires the provision of adequate funding and proper

\footnotetext{
${ }^{1514}$ Philip Alston, 'Ships Passing in the Night: The Current State of the Human Rights and Development Debate seen through the Lens of the Millennium Development Goals' P. 767.

${ }^{1515}$ Care International UK, Principles into Practice: Learning from Innovative Rights-Based Programmes

${ }^{1516}$ Dejo Olowu, 'Human Development Challenges in Africa: A Rights-Based Approach' P. 204.
} 
Realising the Right to Water and Sanitation in Nigeria

monitoring of budget disbursement in a way that ensures corruption is tackled and leakages blocked.

Considering that uncovering the root causes of water deprivation is not only desirable but necessary, the empirical part of this study investigated the extent of awareness of the population regarding human rights, their exposure to media outlets, their perception of litigation and willingness to assert claims, other factors which may impact on rights claim such as religion, culture, family, traditional settings, poverty, government bureaucracy, and distance to authorities. This was done in order to identify the extent to which in the process of empowering for example the local population and other important issues of concern to the population are taken into consideration. Similarly, issues relating to participation, access to information, human rights considerations in the allocation and distribution of water and current capacity of duty-bearers are relevant issues impacting on a successful application of human rights-based approaches. Understanding local circumstances determines the necessary strategy to be adopted including the appropriate dialogue mechanisms to be utilised in the introduction of new approaches.

One of the beauties of a human rights-based approach is its emphasis and concentration on local and national circumstances and potentials. In fact, a successful application of a human rights-based approach is dependent upon its contextual perspective. ${ }^{1517}$ Contextual perspective points out in each country, legal and policy issues, binding human rights instruments, relevant institutions and their capacity, existing gaps, local and political culture, human rights awareness, and capacity of civil society organisations. These factors determine to a large extent the success or otherwise of the approach and the challenges it may likely encounter. In context where there is generally low awareness of human rights and perception of human rights as euro-centric, the approach may likely suffer resistance if no proper foundation for its deployment is laid. Relevant principles of a human rights-based approach have to therefore be fully assessed in order to determine the level of intervention required and to appreciate the perspectives which concentration should be centred on. Empowerment cannot, for example, be properly achieved when relevant mechanisms are not present or are fundamentally ineffective. Accountability will face serious challenges where corruption is the order of the day. Achieving adequate participation, will be difficult where the people have no experience of being engaged in such discussions. ${ }^{1518}$ These need to be considered.

Similarly, every community, society or even individual has certain potentials capable of being positively utilised. Instances abound where projects' successes were recorded through ideas and contribution of local community. Care International UK has been one of the leading NGOs in the application of a human rights-based approach to development and in addressing poverty, exclusion, discrimination or marginalisation. It had and continues to record success in the way communities are empowered to make positive impact in their lives and be able to claim their rights. One of the secrets is utilisation of local potentials in its projects. A typical example is Bangladesh SHAHAR project, "which enabled communities to identify their priorities, mobilise, and build network with local support structures to address their needs

\footnotetext{
${ }^{1517}$ Emilie Filmer-Wilson, 'The Human Rights-based Approach to Development: The Right to Water' P. 225.

1518 Ibid. P. 226.
} 


$$
\text { Chapter Eight }
$$

and rights." 1519 Similar approach was used in the Guatemala Promoting Maternal Health (PMH) Project.

National and local potentials which may impact on realisation of the right to water and sanitation are politicians, traditional rulers, rights-based organisations, civil society and nongovernmental organisations, human rights institutions and media. Local knowledge and expertise of local population can assist in water supply and sanitation projects' improvement and sustenance.

In the light of the above, the following are required for a successful application of a human rights-based approach in Nigeria:

1. Review and Enforcement of Legislative and Policy Frameworks

A review of relevant legislations and policies to incorporate human rights obligations of Nigeria on water and sanitation is required. The legislative and policy frameworks should recognise the core contents of the right to water and sanitation and provide for the mechanisms of redress in the event rights-holders are denied or obstacles exist in the enjoyment of the right. It is true that legislative amendment takes time and has to pass through several bureaucratic steps, in the interim, relevant agencies responsible for water and sanitation can adopt or amend existing subsidiary legislations to consider water and sanitation as human right. The existing policy frameworks should be reviewed in the light of human rights obligations of Nigeria which ensures the enjoyment of rights at all levels and free from discrimination or marginalisation. Relevant agencies should be adequately empowered to monitor compliance with the policies and periodically review it in the light of new knowledge and circumstance consistent with human rights obligations of Nigeria.

Policies should as of necessity adopt a bottom-top approach in favour of the marginalised communities and individuals. Specifically, greater attention should be paid to the poor, people living in slum areas, remote villages, internally displaced persons, people living in the riverine areas and areas where their sources of water are contaminated by oil exploration and development activities such as the Niger-Delta region. This positive discrimination has been recognised in several cases discussed under contents of the right to water and sanitation. The aim is to bridge the gaps between the rich and the poor, villages and cities and the haves and the haves-not. States could equally adopt policies consistent with the economic, social, cultural, geographical, and religious conditions and circumstances aiming at ensuring the removal of obstacles to the enjoyment of access to water and sanitation. Advocacy aimed at activating or improving the enforcement of water and sanitation related laws and policies is necessary to remind and draw the attention of relevant responsible agencies on the need to put the mechanisms into action for the benefits of citizenry. In this context, influential individuals, traditional rulers, faith-based organisations, youth organisations, civil society and non-governmental organisations are necessary partners in building a networking arrangement which ensure a multi-faceted and targeted approach and enlightenment.

2. Vigorous Awareness Campaign

${ }^{1519}$ Care International UK, Principles into Practice: Learning from Innovative Rights-Based Programmes P. 2. 
Realising the Right to Water and Sanitation in Nigeria

Attitudinal changes regarding human rights claims in Nigeria is necessary. Nigerians need to see themselves as rights-holders and not merely favour-seeking citizens. Awareness must be raised concerning importance of human rights to attainment of political, economic, social, cultural and even personal objectives. Nigerians must be enlightened to understand the international legal obligation of Nigeria on water and sanitation in a way that pressure could be exerted on the political class to discharge their obligations. Citizens must appreciate the importance of demanding accountability from duty-bearers. Rights-holders must be enabled to know where and how to access information concerning water and sanitation and the mechanism for laying complaints where request for information is denied. Civil society and non-governmental organisations working in this sector must be able to incorporate appropriate strategies in working with the local population in different sections of the country taking into consideration local circumstances. An approach that takes the role of religiocultural circumstances and that of traditional leaders in awareness creation into consideration is necessary.

In adjudicating human rights claims especially in poverty-stricken societies, relevant stakeholders such the Nigerian Bar Association and Legal Aid Council have important roles to play in providing legal advice and assistance to indigents, vulnerable and marginalised individuals. A sustained ESC rights litigation may impact on the judiciary's approach to Chapter Two of the Constitution and could prompt executive and legislative arms into action.

3. Pragmatic Approach in Tackling Corruption

Although under the current administration, positive indicators are emerging regarding accountability, a more pragmatic approach is required which leaves no sacred cows and ensure that internal mechanisms are established which checks and balances that monitor and prevent abuses and official corruption.

4. Capacity-Building

Appropriate capacity-building in water and sanitation, human rights and their interrelationship is necessary to enable duty-bearers to appreciate their responsibilities, accountability requirements and expectations of rights-holders under human rights law.

5. Residing of Ownership in the Local Community

The local community through traditional rulers should take ownership and charge of projects to preserve and ensure their sustainability. In this context, the existing local structures and their roles should be properly understood for proper engagement. Improving access to quality water and basic sanitation condition requires the adoption of approaches developed in conjunction with local communities as opposed to traditional imposition of what the elites or duty-bearers might consider to be good for the beneficiaries. This gives a sense of ownership and accountability.

6. Focus of National Human Rights Institution to be Realigned

National human rights institutions should extent their focus and advocacy to ESC rights issues through mobilisation and sensitisation. Their concern should not be limited to protection of human rights only but should equally extend to promotion and fulfilment.

7. Private Sector Participation

Enhancing private sector participation as envisaged in the National Water Policy and the National Policy on the Environment especially at the rural level with a regulatory body to 


\section{Chapter Eight}

ensure effective performance, supply and protection of water consumers. Additionally, private sector is an important partner that has the capability to provide products and services. It can utilise its resources a successful application of a human rights-based approach.

\subsection{Proposed Methodology for the Application of a Human Rights-Based Approach in Nigeria}

Choice of appropriate methodology impacts on the results or outcome of approach's application. While different methodologies exist and are deployable in context as seen from the works of NGOs and development partners around the world, the choice of parallel and participatory methodology in the application of a human rights-based approach is proposed here.

1. Parallel Approach

In this context, it refers to separating duty-bearers from rights-holders and working towards enabling each of the categories to understand and appreciate its role in realising access to water and sanitation. In the case of duty-bearers, the National Human Rights Commission could organise capacity-building trainings on human rights and work with NWRI, FMWR, States Ministry of Water Resources and Environment, Water Boards and Rural Water Supply Agencies to mainstream human rights issues in water and sanitation periodic trainings. Additionally, while donor agencies, development partners and international organisations have their mandates and specific objectives, most of these organisations have sufficient interest in human rights realisation in areas where their projects are situated. As such, the NHRC could work with them to fine-tune approaches in ways which build the capacity of duty-bearers especially in projects requiring government' participation. Issues concerning accountability, marginalisation and discrimination and participation from human rights perspective are to be factored into projects planning, execution, monitoring and evaluation. Relevant governmental agencies such as FMWR, FME and their States counterparts should equally plan targeted trainings geared towards improving the capacity of staff including on human rights issues and the importance of working with the local population and the civil society organisations on water and sanitation matters.

Dialogues should be initiated towards overcoming resistance to the adoption of a human rights-based approach. This can be done as suggested above where both recipient of the approach and those delivering it will learn from each other. It is usual to expect for example those profiting from the existing situation to resist new approaches especially if such approaches have the possibility of bringing changes which may affect their position, power, and interest. To overcome resistance to change, service designers have developed theories in implementing their projects. Service design has been defined as:

the activity of planning and organizing people, infrastructure, communication and material components of a service to improve its quality and the interaction between the service provider and its customers. The purpose of service design methodologies is to design 
Realising the Right to Water and Sanitation in Nigeria

according to the needs of customers or participants, so that the service is user-friendly,

competitive and relevant. ${ }^{1520}$

Three theories are worth mentioning here: ${ }^{1521}$

i. $\quad$ Frames to overcome symbolic and political obstacles to change; ${ }^{1522}$

ii. Power games; and

iii. Networks of humans and resources.

Frames to overcome symbolic and political obstacles to change refers to taking into consideration, structural, human resources, political and symbolic frames when introducing a change. This is because people view their world from these frames. Structural frame are the bones of the organisation which focus on how to organise and properly structure groups for the purposes of improving performance. Human resources frame denotes individuals and how such individuals interact inter se to realise their needs and desires. Political frame refers to taking into consideration the particular organisation from the perspective of power and conflict and dangers which external factors bring. Lastly, symbolic frame is the culture of an organisation and how meaning is made. ${ }^{1523}$

New changes bring with them new rules, new skills required, new alliances and new uncertainties. These may pose some threats to individuals who feel losing power. These require understanding of what happens to peoples' interests and their power. This is what the theory of power games addresses. ${ }^{1524}$

Actor-network theory focusses attention on social relations which comes into play during change process. ${ }^{1525}$ It refers to the effects of networks (human and objects) which work together to achieve specific objective. Because new changes which new approaches bring on resources affect people who control them, attention must be given to such modifications and their relationship to the rest of the social system.

In the case of rights-holders, the NHRC could equally promote and coordinate the participation of international and non-governmental organisations to work with civil society organisations, opinion, community and religious leaders in discussing about their roles, the general human rights situation, water and sanitation and the role of formal and informal justice systems. These stakeholders will then work with the general population in creating necessary awareness for the success of a human rights-based approach and building their capacity to engage in constructive and fruitful deliberations with duty-bearers at a later stage in the application of the approach.

When duty-bearers are properly trained on their roles and rights-holders enlightened about their rights and how claims can be made, a necessary framework has been created for the deployment of participatory approach.

\footnotetext{
${ }^{1520}$ Ricardo Martins, 'Three Theories to Help Overcome Change Resistance in Service Design Implementation' (Integration and Implementation Insights, 2017) <https://i2insights.org/2017/03/23/overcoming-changeresistance/> accessed 26 March, 2017

${ }^{1521}$ Ricardo Martins, 'Increasing the Success of Service Design Implementation: Bridging the Gap Between Design and Change Management' (2016) 8 Touchpoint

${ }^{1522}$ Lee G. Bolman and Terrance E. Deal, Reframing Organizations (5th edn, Jossey-Bass 2013)

${ }^{1523}$ See generally, ibid.

${ }^{1524}$ See Michel Crozier, On ne change pas la société par décret (Bernard Grasset 1979)

${ }_{1525}$ Bruno Latour, Reassembling the Social: An Introduction to Actor-Network-Theory (Oxford University Press 2005)
} 
Chapter Eight

\section{Participatory Approach}

This refers to duty-bearers and rights-holders including the civil society organisations working together in the development, implementation and monitoring of policies and programmes relating to water and sanitation. At the parallel level, the strengths of both have been built and at the participatory level, discussion will be centred from point of understanding, respect and informed position. Participatory approach gives recognition and voice to the marginalised and provides the opportunity for duty-bearers to discuss their challenges in a mutually respectable manner.

The process on how such methodology should be applied requires painstakingly understanding educational background, experience, cultural background and attitudes relating to human rights discourse. Taking these into consideration, the process must be inclusive, transparent and must ensure respect and consideration of positions and opinions. It must be carefully managed and facilitated.

\subsection{Relevance of Civil Society and International Organisations in a Human Rights- Based Approach}

Across the globe, there is increasing trend in the recognition of the role and active participation of civil society organisations as important partners in good governance, human rights promotion and democratic processes. ${ }^{1526}$ This role also extends to the articulation of connections between substantive rights and peoples' actual experiences and framing of rights where no such exist. ${ }^{1527}$ This recognition has led to the development of a soft law regarding rights and responsibilities of individuals, groups and organs of society in the promotion and protection of human rights and fundamental freedoms. ${ }^{1528}$ The soft law reiterated the right of individuals and groups to know, seek and obtain information on human rights and how those rights are being implemented in domestic setting as well as disseminate information and knowledge on human rights and fundamental freedoms. ${ }^{1529}$ This soft law is a veritable tool through which civil society organisations can work towards empowering rights-holders, demanding accountability from duty-bearers, drawing attention to some impediments and working together to address challenges associated with human rights implementation and enjoyment. ${ }^{1530}$ Through the scrutiny power, civil society organisations can directly and indirectly contribute in the efficient administration of public institutions.

In situations where duty-bearers are deliberately evading responsibility, the success of a human rights-based approach requires the pertinent and important role of the civil society organisations who should be the vehicle through which rights-holders are empowered, effective monitoring of institutions is carried out with necessary pressure maintained on duty-

\footnotetext{
${ }^{1526}$ Dejo Olowu, 'Human Development Challenges in Africa: A Rights-Based Approach' P. 215.

${ }^{1527}$ Jethro Pettit and Joanna Wheeler, 'Developing Rights? Relating Discourse to Context and Practice' (2005) 36 IDS Bulletin 1

${ }^{1528}$ See Declaration on the Rights and Responsibility of Individuals, Groups and Organs of Society to Promote and Protect Universally Recognised Human Rights and fundamental Freedoms, G.A. Res. 53, U.N. GAOR Suppl., $85^{\text {th }}$ mtg., U.N. Doc. A/RES/53/144 (1999).

${ }^{1529}$ See Art. 6

${ }^{1530}$ See also Art. 8
} 
Realising the Right to Water and Sanitation in Nigeria

bearers for accountability and performance. ${ }^{1531}$ In doing these, civil society organisations should work with data drawn from empirical study to engage and support institutions in budgetary processes, planning, execution and monitoring of projects. Civil society should serve as facilitators advocating and building the capacity of rights-holders especially the marginalised and vulnerable to enable their voices to be heard. Civil society and nongovernmental organisations with support from donors could provide strategic trainings on rights awareness to local communities through youth organisations in order to facilitate human rights knowledge, building of capacity, strengthening of social identity, empowerment and self-esteem, improving negotiating power and easing of rights claims.

Participation and monitoring by civil society equally assist in preventing and combatting corruption. Civil society should equally refocus and struggle for the removal of dichotomy between CP rights and ESC rights. With necessary pressure maintained on the relevant arms of government, the struggle for respect and realisation of ESC rights could record a momentum that could prompt changes in the ways judicial arm define rights and popular aspirations.

However, the civil society has its own challenges worthy of note. Many civil society organisations suffer lack of human and material capacity to function effectively. Lack of adequate funding mechanisms limits in many instances, the reach and impact of civil society organisations. To overcome these challenges, civil society should network and collaborate to create momentum and to serve as avenue for empowerment. ${ }^{1532}$ The Nigerian Bar Association collaborating with Legal aid workers may be more suitable to provide legal assistance, guidance, awareness and advocacy programme to the local population about their rights and the mechanisms through which such rights may be claimed. Lastly, the civil society organisations' role in the monitoring and submission of periodic reports to treaty bodies and reports of special rapporteurs is important in keeping State authorities to their duties. ${ }^{1533} \mathrm{In}$ this light, the civil society should become fully aware of the treaties binding on Nigeria and the reports required to be submitted on periodic basis. The monitoring of compliance with concluding observations is equally as important as the reports.

For the civil society to effectively facilitate, certain skill set such as those relating to mediation, facilitation, advocacy, relationship-building, cultural and religious sensitivity are needed.

The international and multilateral organisations equally have a collaborative role to play. As a "formidable pillar" 1534 of a human rights-based approach, collaboration with international and development agencies is important. International organisations such as the World Bank, the UN and its relevant specialised agencies should focus attention to ways in which Nigeria can be supported to fulfil its international human rights obligations. This could be done in the form of Memorandum of Understanding between relevant government

\footnotetext{
1531 A. B. Zack-Williams, 'No Democracy, No Development: Reflections on Democracy \& Development in Africa' (2001) 28 Rev Afr Pol Econ P. 213; see also Dejo Olowu, 'Human Development Challenges in Africa: A RightsBased Approach' P. 210.

${ }^{1532}$ Dejo Olowu, 'Human Development Challenges in Africa: A Rights-Based Approach' P. 221.

${ }^{1533}$ Emilie Filmer-Wilson, 'The Human Rights-based Approach to Development: The Right to Water'p. 224)

${ }^{1534}$ Dejo Olowu, 'Human Development Challenges in Africa: A Rights-Based Approach' P. 210.
} 
institutions and relevant international organisations, for example on capacity-building, participatory budgeting, networking and collaboration, dialogue on water allocation and distribution, enhancing sanitation, etc. This is in line with the obligation of States under article 2(1) of ICESCR and Goal 17 of the SDGs. To assist duty-bearers fulfil their human rights obligations, international organisations should avoid using anecdote or vague moral arguments but rather use data in pointing out areas where improvement are needed. ${ }^{1535}$ International organisations such as the EU, DFID, JICA and WaterAid have been very supportive in this area. However, momentum needs be maintained in this new approach which the aim is to secure the enjoyment of basic human rights for the citizens. International organisation may equally support programmes which target reforms in the legal system, training of judicial officers on ESC rights and their interconnectedness with CP rights and approaches through which ESC rights may be given effect.

In addition to working with State institutions, international and development agencies should have direct link and interact with the affected population and the civil society organisations as essential partners in a bid to ensure the removal of all obstacles to marginalisation and discrimination. ${ }^{1536}$ Programmes which aim at creating awareness of rights at the grassroots level should be supported. Funded projects should reflect the fundamental role of human rights principles and standards and should ensure the active participation of the local structures in order to build trust and ownership which are necessary for infrastructural maintenance.

\subsection{Monitoring the Application of a Human Rights-Based Approach}

Admittedly, adoption of a human rights-based approach may not address all the problems bedevilling water and sanitation sector, but it may go in a long away removing most of the obstacles. As such, making it more effective requires putting in place, a system of tracking progress, coverage and conformity with human rights obligations. Periodic evaluation and reflection with a view to identifying and addressing challenges along lines of implementation are equally important. For these purposes, it is sought to borrow from terminologies in place serving as indicators of measuring human rights compliance. Indicators for the attainment of the right to water and sanitation are to be viewed from contents of the right discussed above. In this light, the following terminology might be referred to: structural, process and outcome. ${ }^{1537}$ By structural, it would be determined whether the necessary and key structures required for the realisation of the right to water and sanitation are in place such as whether the relevant treaties have been ratified and domesticated, whether national legislations and policies have been adopted to give effect to obligations under the right to water and sanitation, and whether there exists proper and efficient institutional mechanisms to implement these obligations. ${ }^{1538}$ Process indicators relate to measuring of efforts put in by the State in terms of programmes, activities and interventions while outcome indicators measure the impact of

\footnotetext{
1535 Joel E. Oestreich, 'The United Nations and the Rights-based Approach to Development in India' P. 89.

${ }^{1536}$ Dejo Olowu, 'Human Development Challenges in Africa: A Rights-Based Approach' P. 212.

${ }^{1537}$ See Paul Hunt and Gillian MacNaughton, 'A Human Rights-Based Approach to Health Indicators' P. 316. ${ }^{1538}$ Ibid.
} 
Realising the Right to Water and Sanitation in Nigeria

such programmes and interventions. ${ }^{1539}$ Specific to water and sanitation and a human rightsbased approach, indicators should demonstrate within a specific timeline, number of individuals and communities identified and have participated in the discussion on access to water and sanitation and this should be segregated in terms of political and socio-economic status and locations. Number of water points constructed. Number of communities covered by water and sanitation coverage etc.

\subsection{Contextual Challenges}

Like any approach, there may be challenges which need to be factored in and considered. In the Nigerian context, the following may be identified:

1. Lack of political will and possible internal resistance from duty-bearers; a human rights-based approach requires the support of governmental authorities in creating the necessary operating space and participation. ${ }^{1540}$ Addressing this requires adoption of a sensitive approach which seeks to create enabling environment for duty-bearers to cooperate. With sustained advocacy, scrutiny from civil society and encouragement from international organisations, a formidable culture will likely be created that will see duty-bearers collaborating with each other and rights-holders in addressing rights and demands. CARE experience in India has shown that dutybearers' initial resistance can be eroded when they are properly enlightened about communities' needs and rights and the latter's capacity and willingness to contribute to finding solutions. ${ }^{1541}$

2. Use of human rights language by international organisations such as the UN Agencies may be viewed with suspicion by duty-bearers and in some cases, may even be seen as interference in domestic affairs in violation of article 2(7) of the UN Charter. ${ }^{1542}$ Addressing this requires the use of certain strategies which do not suggest that the aim is imposition of human rights policy into the duty-bearers' action. Language such as inclusiveness of the excluded groups, or the poor or the disable or women, community-level engagement etc. into planning and programming may secure the cooperation of duty-bearers to collaborate with international organisations. ${ }^{1543}$

3. Suspicion from relevant stakeholders such as religious and traditional rulers: Addressing this requires adopting appreciative inquiry centred on dialogue aimed at suspending judgment and building trust and confidence. ${ }^{1544}$ Religious, traditional, opinion and youth leaders could be dialogued with to address misconceptions and culturally centred assumptions.

\footnotetext{
1539 Ibid.

${ }^{1540}$ Care International UK, Principles into Practice: Learning from Innovative Rights-Based Programmes P. 14.

1541 Jude Rand, CARE's Experience with Adoption of a Rights-Based Approach: Five Case Studies (Care International UK 2002) P. 55.

${ }^{1542}$ Joel E. Oestreich, 'The United Nations and the Rights-based Approach to Development in India' At P. 81.

1543 Ibid.

${ }^{1544}$ This approach seemed to have worked in the context of Care International UK project in Honduras
} 


\section{Chapter Eight}

4. Resource competition and lack of capacity: There may be competing interests in terms of limitation of resources and government plans and priorities; there may be lack of capacity to adequately understand the various dimensions of the approach; and there may be a conflict between those who will want projects with quick impact and those who prefer those with long term benefits.

\subsection{Conclusions}

A Human rights-based approach is an important tool in addressing discrimination, marginalisation, poverty, corruption and lack of accountability. Its deployment in the water and sanitation sector will promote good governance, enhances capacity of duty-bearers to discharge their obligations and enables rights-holders to claim their rights through its principles of equality and non-discrimination, empowerment and participation, responsibility and accountability.

As a concept, its success requires adequate understanding of local circumstances and its methodological application should be consistent with national and local situations. Its deployment in Nigeria is suggested to be a two-prong approach: parallel and participation. Parallel until both duty-bearers and rights-holders' capacity have been improved, their roles properly defined and communicated, and awareness about human rights and implications of duty-bearers and rights-holders' actions on realisation of human rights are communicated. Participatory approach will provide a platform for direct discussion and engagement between the duty-bearers and the rights-holders. In all these, the National Human Rights Commission should spearhead the campaign working closely with relevant institutions, other human rights stakeholders, civil society and representatives of the grassroots.

The application of a rights-based approach is not a magical concept. It requires time, persistence and patience for it to work. When a new concept is brought to bear, and a complete paradigm is introduced there may be challenges. These are however, surmountable depending on the commitment and will of all the stakeholders. 


\section{Chapter Nine}

\section{Potentials of an Ecosystems Approach to the Realisation Of the Right to Water AND Sanitation and Protection of the Environment}

\subsection{Introduction}

$\mathrm{T}$ his chapter concludes the discussions centred on answering research question four. It is dedicated to detailing what ecosystems approach entails and the potentials it holds in the protection of environment as part of the larger context of water generation and management. Human beings need nature for their survival, nature needs human beings' attention for its continued existence. If human beings fail take care of nature, nature will not take care of human beings. Natural and human factors over the years have impacted on the functioning of natural environment with consequential effects. Several researches have pointed out how issues like climate change, deforestation, drought, and unsustainable extraction of natural resources are posing threats to environmental sustainability. These pointed to the need to take deliberate and targeted actions to convert these effects, conserve natural resources and protect biodiversity. SDG Goal 6 in target 6.6 is dedicated to among others protection and restoration of water-related ecosystems by $2020 .{ }^{1545}$ In the last three decades, natural environment has been receiving increasing attention from States and international organisations with varying degrees of success and mixed feelings. Several national and international instruments providing for approaches necessary to achieve or promote environmental protection have been adopted by States. Much of the discussion from these instruments centred on environmental sustainability and importance of planning for the future generations. One of the approaches currently being promoted in this respect, is the Ecosystems Approach.

An Ecosystems Approach "is a strategy for the integrated management of land, water and living resources that promotes conservation and sustainable use in an equitable way." 1546 International organisations such as the International Union for the Conservation of Natural Resources (IUCN) and United Nations Environmental Programme (UNEP) have been promoting its adoption in the last ten years with several case studies conducted to showcase its benefits in environmental protection and conservation of natural resources. It is currently the primary framework for action under the Convention for Biological Diversity. ${ }^{1547}$ The Secretariat of the Convention has provided and defined the principles controlling its application. ${ }^{1548}$ This chapter highlights these principles and how they can be utilised in the context of water and sanitation in Nigeria. In addition to the compatibility of ecosystems

\footnotetext{
1545 These include mountains, forests, wetlands, rivers, aquifers and lakes.

${ }^{1546}$ Gill Shepherd, The Ecosystem Approach: Five Steps to Implementation (IUCN 2004) P. 1.

${ }^{1547}$ Ibid.

${ }^{1548}$ Secretariat of the Convention on Biological Diversity, Ecosystem Approach (CBD Guidelines)
} 
Realising the Right to Water and Sanitation in Nigeria

approach and human rights-based approach shown in section 1.9.5 above, this chapter further illustrates how the two approaches can mutually reinforce each other in the effort to realise the right to water and sanitation.

The chapter first addresses preliminary issues such as the right to a healthy environment and the obligation to ensure that; water as a resource of varying nature and a subject of competitions from multiple users, the imperative of preservation of ecosystems goods and services, and legal basis for the adoption of the approach in Nigeria. The chapter further discusses an ecosystems approach to management of water resources, the concept of integrated water resources management and its relationship with an ecosystems approach. Lastly, the chapter identified possible challenges in the application of the approach in Nigeria.

\subsection{The Right to a Healthy Environment and its Relationship with Ecosystem}

Population growth, natural resources exploitation and technological advancement with their attendant consequences such as deforestation, water pollution, and drained soil fertility have produced tremendous negative impact on the natural environment in the last few decades. ${ }^{1549}$ These have created growing awareness of the need to protect the environment and conserve natural resources for their consequential benefits and in the interest of future generations. These led to the growing interest in the recognition of the right to a healthy environment.

The idea of recognising the right to a healthy environment started in the 1970s with the adoption of soft law documents starting with Stockholm Declaration ${ }^{1550}$ which was a turning point in the context of environmental protection. ${ }^{1551}$ It was in this Declaration that environmental protection was linked to human rights norms. ${ }^{1552}$ Two decades later, another conference was held in Rio de Janeiro which focussed on elaborating the strategies and measures necessary to address the effects of environmental degradation as well as strengthening national and international efforts in promoting sustainable and environmentally sound development. ${ }^{1553}$ In the adopted Declaration, the entitlement of human beings to a healthy and productive life in harmony with nature was recognised. ${ }^{1554}$ While the right to a healthy environment was not explicitly recognised, there was obligation on the part of States to ensure that in the exploitation of natural resources in their countries, damage is not done to the environment. ${ }^{1555}$

\footnotetext{
1549 Human Rights Resource Center, 'The Right to a Healthy Environment' (University of Minnesota, <http://hrlibrary.umn.edu/edumat/IHRIP/circle/modules/module15.htm> accessed 28 May 2018

1550 United Nations, 'Declaration of the United Nations Conference on the Human Environment' 1972) <http://www.un-documents.net/unchedec.htm> accessed 28 May 2018

${ }^{1551}$ The Declaration served as a reference document in many international environmental instruments and institutions in the following decades including the creation of UNEP and World Commission on Environment and Development, and the development of UNCLOS.

${ }^{1552}$ Principle 1 of the Declaration provides: Man has the fundamental right to freedom, equality and adequate conditions of life, in an environment of a quality that permits a life of dignity and well-being, and he bears a solemn responsibility to protect and improve the environment for present and future generations.

${ }^{1553}$ Human Rights Resource Center, 'The Right to a Healthy Environment'

${ }^{1554}$ See United Nations, 'Rio Declaration on Environment and Development'. Principle 1. 1555 Ibid.
} 


\section{Chapter Nine}

At present, there has not been a formal recognition in a binding international instrument of the right to a healthy environment ${ }^{1556}$ notwithstanding that there are references to the obligation to protect the environment in many binding instruments and that several States have provisions in their national constitutions or legislations linking environment with human rights or have explicitly recognised the right to a healthy environment. ${ }^{1557}$ In the ICESCR, article 12(2)(b) States have committed themselves to the taking of steps to achieve the full realisation of ESC rights including those which are necessary for the improvement of all aspects of the environment. In the 1985 Vienna Convention for the Protection of the Ozone Layer, contracting States are under obligation to take appropriate measures "to protect human health and the environment against adverse effects resulting or likely to result from human activities which modify or are likely to modify the ozone layer."1558 In the 1989 Basel Convention on the Control of Transboundary Movements of Hazardous Wastes and their Disposal, the obligation to protect the environment from hazardous wastes were clearly stated and undertaken by States parties. ${ }^{1559}$ Other obligations relating to different aspects of the environment are stated in other international instruments such as the 1992 Framework Convention on Climate Change and the 1992 Convention on Biological Diversity.

In other soft laws at the universal level, the UNGA resolution 45/94 reiterated the need to ensure a healthy environment for the well-being of individuals. ${ }^{1560}$ The resolution recognises that individuals are entitled to live in an environment adequate for their health and well-being. ${ }^{1561}$

At the regional level, the ACHPR contains provision recognising the right of peoples to "a general satisfactory environment favourable to their development." 1562 In relations to women, the Protocol to the African Charter on Human and Peoples' Rights on the Rights of Women in Africa, provided that women "shall have the right to live in a healthy and sustainable environment". ${ }^{1563}$ In the Americas, the Protocol of San Salvador ${ }^{1564}$ explicitly recognised the right to a healthy environment in article 11(1) which provided that "[e]veryone shall have the right to live in a healthy environment and to have access to basic public services." ${ }^{1565}$ In the Middle-East, the 2004 Arab Charter on Human Rights also has a right to a healthy environment as part of the right to an adequate standard of living that ensures wellbeing and a decent life. ${ }^{1566}$ In South-East Asia, , the Human Rights Declaration adopted by

\footnotetext{
${ }^{1556}$ UN Human Rights Council, Report of the Independent Expert on the Issue of Human Rights Obligations Relating to the Enjoyment of a Safe, Clean, Healthy and Sustainable Environment, John H. Knox: Scoring Report (UN Doc A/HRC/22/43, 24 December 2012). Para. 14.

${ }_{1557}$ Marcos Orellana, 'The Case for a Right to a Healthy Environment' (Human Rights Watch, 1 March 2018) <https://www.hrw.org/news/2018/03/01/case-right-healthy-environment> accessed 28 May 2018.

1558 Art. 1.

1559 See Article 4.

${ }^{1560}$ United Nations General Assembly, Resolution 45/94: Need to Ensure a Healthy Environment for the Well-being of Individuals (UN Doc A/RES/45/94, 14 December 1990)

${ }^{1561}$ Ibid. Para. 1.

1562 Art. 24.

1563 Art. 18.

${ }^{1564}$ Additional Protocol to the American Convention on Human Rights in the Area of Economic, Social and Cultural Rights "Protocol of San Salvador".

${ }^{1565}$ Art. 11(1).

1566 Art. 38.
} 
Realising the Right to Water and Sanitation in Nigeria

the Association of Southeast Asian Nations in November 2012 provided for a "right to a safe, clean and sustainable environment" as part of the right to an adequate standard of living. ${ }^{1567}$

In terms of obligations attached to the 'right to a healthy environment, the various reports of the Special Rapporteur on the Issue of Human Rights Obligations Relating to the Enjoyment of a Safe, Clean, Healthy and Sustainable Environment have helped clarified many aspect of the relationship between environment and other human rights, ${ }^{1568}$ and have identified the procedural and substantive obligations on stakeholders as well as obligations in relations members of groups in vulnerable situations. ${ }^{1569}$ The procedural obligations according to the Special Rapporteur include the following duties: ${ }^{1570}$

i. assessing environmental impacts and making environmental information public;

ii. facilitating public participation in environmental decision-making, including by protecting the rights of expression and association; and

iii. providing access to remedies for harm.

The substantive obligations vary from right to right as are provided in human rights treaties. However, the following obligations are general: 1571

i. adopting and implementing legal frameworks to protect against environmental harm that may infringe on enjoyment of human rights; and

ii. regulating private actors to protect against such environmental harm.

Not only that there is indivisibility and interdependence between the right to a healthy environment and other human rights, ${ }^{1572}$ there is equally a nexus between healthy environment and the concept of ecosystem as both are aimed at ensuring the protection of the environment and the enjoyment of environmental and natural resources in a sustainable manner. In the words of Marcos Orellana:

The right to a healthy environment brings together all that humanity has learned about how human rights and the environment interact. It encompasses the environmental dimensions of the rights to life, health, food, water, sanitation, property, private life, culture, and nondiscrimination, among others. ${ }^{1573}$

\subsection{Water Resources and Ecosystem}

Nigerian water resources consisted of rain, surface and groundwater. The varying degree of their availability in regional and spatial terms have been noted. As a unitary resource, ${ }^{1574}$ an action on one of the sources of water has impact on the others. Surface and groundwater

\footnotetext{
${ }^{1567}$ Para. 28(f).

${ }^{1568}$ See for example UN Human Rights Council, Report of the Independent Expert on the Issue of Human Rights Obligations Relating to the Enjoyment of a Safe, Clean, Healthy and Sustainable Environment, John H. Knox: Scoring Report

${ }^{1569}$ UN Human Rights Council, Report of the Independent Expert on the issue of human rights obligations relating to the enjoyment of a safe, clean, healthy and sustainable environment, John H. Knox: Mapping Report (UN Doc A/HRC/25/53, 30 December 2013). Section IV.

${ }^{1570}$ Ibid. Paras. 30-43.

1571 Ibid. Paras. 44-61.

${ }^{1572}$ Such as for example the right to health, the right to food, the right to water, the right to housing, right to education and the right to adequate standard of living.

${ }^{1573}$ Marcos Orellana, 'The Case for a Right to a Healthy Environment'

${ }^{1574}$ Rain, surface and underground water are all part of the same resource.
} 


\section{Chapter Nine}

systems are interrelated. ${ }^{1575}$ For example, unused surface water can recharge groundwater, over extraction of underground water can reduce surface flow and rain can recharge both surface and groundwater. ${ }^{1576}$

Surface and groundwater provide municipal, agricultural and industrial uses ${ }^{1577}$ and other in situ services. The in situ services provided by groundwater include the structure of geologic environment such that if groundwater is extracted, subsidence can occur. ${ }^{1578}$ In coastal areas, groundwater plays a role of avoiding salt water intrusion in addition to acting as a buffer when managed conjunctively with surface water. ${ }^{1579}$ Water resources management should take into cognizance the immediate and remote causes of surface and underground water depletion and the impact such is causing to the population, species and natural environment. Depletion occurs where withdrawal is higher than recharge. ${ }^{1580}$ Water table rises where the extraction is less than the recharge rate and vice-versa. ${ }^{1581}$ This also applies to surface water. Unsustainable consumption and or extraction has impact on the survival of environment, its dependant's aquatic ecosystem and future generations. If the rate of depletion for example of aquifers is higher than recharge, the position is akin to that of mineral reserve. ${ }^{1582}$ In certain instances, depletion of underground water is irreversible. ${ }^{1583}$ Unsustainable extraction has been shown to have significant impact. As example, the Ogallala Aquifer in the United States which originally contained 100 years' supply has been depleted to about 40 years with attendant consequences on some farms relying on its supply. ${ }^{1584}$ Some of the ways in which depletion occurs included natural discharge via seeps and springs, direct uptake by plants (where the water table is within the root zone), and extractions through wells ${ }^{1585}$ (including borehole). Natural recharging of underground water, where it occurs, is low and analogous to situation of mining. ${ }^{1586}$ More so aquifers in arid regions where the rate is between few hundredths of millimetres to perhaps 200 millimetres per year. ${ }^{1587}$

In situations where majority of the population in a country are relying on surface water (rivers, lakes, streams, ponds etc.) and underground water (wells and boreholes) for their water needs: personal and domestic as well as industrial, consideration should be given to the rate of consumption and recharge of these sources. While survival is of important consideration, sustainability is a critical requirement. The effects of extraction or depletion may not be readily known to the population and hence may not be considered. ${ }^{1588}$

\footnotetext{
${ }^{1575}$ National Research Council, Valuing Ground Water: Economic Concepts and Approaches. P. 59.

${ }^{1576}$ Peter Rogers, Comprehensive Water Resources Management: A Concept Paper (World Bank 1992). P. 2.

${ }^{1577}$ National Research Council, Valuing Ground Water: Economic Concepts and Approaches P. 58.

1578 Ibid. P. 60.

1579 Ibid.

${ }^{1580}$ Ibid. P. 110

${ }^{1581}$ Ibid. P. 35.

1582 James Winpenny, Managing Water As An Economic Resource. P. 11.

${ }^{1583}$ National Research Council, Valuing Ground Water: Economic Concepts and Approaches. P. 45.

1584 James Winpenny, Managing Water As An Economic Resource

${ }^{1585}$ National Research Council, Valuing Ground Water: Economic Concepts and Approaches. P. 35.

${ }^{1586}$ Ibid. P. 34.

${ }^{1587}$ Ibid. relying on Ralph C. Heath, Basic Ground-Water Hydrology: U.S . Geological Survey Water-Supply Paper 2220, 1983)

${ }^{1588}$ National Research Council, Valuing Ground Water: Economic Concepts and Approaches P. 57. 
Realising the Right to Water and Sanitation in Nigeria

Water is an essential element in the sustenance of environment. An illustration of function of water on environment has been recounted in a conversation between children and their grandfather. A grandfather asked his grandchildren their view about land and their response alluded to just the use to which the land is put to. The respond of the grandfather was:

Look at yourself. Look at your body, what do you have? You got some parts there, it looks pretty simple on the outside, but on the inside, inside of you as a person you have a soul, you have a heart. You have some blood running through your body to keep your vital organs going. It is the same thing with the land. The land has a soul, the land that we are on has a soul, it has a heart. It also has its own blood. The blood running through it are the streams to keep it alive, to keep us alive. ${ }^{1589}$

The thought expressed couldn't be truer. Land relies on water for its survival and sustenance of all in and on it. The drying or polluting of rivers and streams not only impact on water availability but could affect the cultural and sentimental values of people living in the areas. ${ }^{1590}$ Hence, unsustainable extraction and or utilisation of water has consequences on the environment, its surrounding ecosystem components and their consequential benefits. ${ }^{1591}$

Studies have shown that aquatic biodiversity is significantly affected by degradation of water flows in river networks. ${ }^{1592}$ The 1992 Dublin Principles on water and environment clearly pointed out not only the vulnerability of water but also its essential role in sustaining life, promoting development and safeguarding the environment. ${ }^{1593}$ Ecosystem impact in several ways on the content of the right to water for personal and domestic uses. Issues on availability, quality and affordability are all affected by how ecosystem is treated or valued. There is no doubt water availability is determined by how well ecosystem is safeguarded and quality of water is largely controlled by the health of aquatic ecosystems especially where water is directly sourced/extracted and consumed from natural sources.

Water is a natural, environmental, social, economic, and cultural resource serving multiple purposes. The nature of water and its multiple uses necessitate the adoption of an approach which takes these realities into consideration and balances varrying and competing interests. As an example of the effects resulting from considering water as a social good alone and only for domestic and personal uses, in India, irrigation does not operate because of water diversion to a city with growing population; industries in China are reducing production due to water shortages; in California selenium salts leached by irrigation are killing wildlife etc. ${ }^{1594}$ While it continues to be of concern that significant number of world's population

\footnotetext{
${ }^{1589}$ Quoted in Peter Whiteley and Vernon Masayesva, 'The Use and Abuse of Aquifers: Can the Hopi Indians Survive Multinational Mining?' in John M. Donahue and Barbara Rose Johnston (eds), Water, Culture, and Power: Struggles in a Global Context (Water, Culture, and Power: Struggles in a Global Context, Island Press 1998) P. 24.

${ }^{1590}$ See for example the concerns as narrated, of the local people on a similar situation in Quebec, Canada in Kreg Ettenger, '"A River That Was Once So Strong and Deep": Local Reflections on the Eastmain Diversion, James Bay Hydroelectric Project' in John M. Donahue and Barbara Rose Johnston (eds), Water, Culture, and Power: Struggles in a Global Context (Water, Culture, and Power: Struggles in a Global Context, Island Press 1998)

${ }^{1591}$ See for example Peter Whiteley and Vernon Masayesva, 'The Use and Abuse of Aquifers: Can the Hopi Indians Survive Multinational Mining?' where the unsustainable extraction of aquifers is impacting on springs and creating scarcity and crisis with attendant consequences on lives and environment.

1592 P. Keys, J. Barron and M. Lannerstad, Releasing the Pressure: Water Resource Efficiencies and Gains for Ecosystem Services (United Nations Environment Programme \& Stockholm Environment Institute 2012) P. 6.

${ }^{1593}$ See United Nations, The Dublin Statement on Water and Sustainable Development (31 January, 1992) Principle 1

${ }^{1594}$ Peter Rogers, Comprehensive Water Resources Management: A Concept Paper P. 1.
} 


\section{Chapter Nine}

lacked access to clean water, it was equally of concern that, in part, the syphoning off of water to agriculture and energy is leading to "loss and degradation of aquatic habitats such as wetlands, lakes and river systems". ${ }^{1595}$ The 1992 International Conference on Water and Environment noted the following:

Water is a vital part of the environment and a home for many forms of life on which the wellbeing of humans ultimately depends. Disruption of flows has reduced the productivity of many such ecosystems, devastated fisheries, agriculture and grazing, and marginalized the rural communities which rely on these. Various kinds of pollution, including transboundary pollution, exacerbate these problems, degrade water supplies, require more expensive water treatment, destroy aquatic fauna, and deny recreation opportunities. ${ }^{1596}$

The pressure on limited water resources led to the proposal for the adoption of integrated water resources management as a solution to upstream-downstream water dependant ecosystem services and promotion of human well-being. ${ }^{1597}$ It provides "the opportunity to safeguard aquatic ecosystems and make their benefits available to society on a sustainable basis." 1598

In Nigeria, natural and human factors are contributing to water scarcity, degradation of environment and loss of biodiversity. The case of Lake Chad; complaint from Lagos State Government to the National Council on Water Resources regarding over extraction of groundwater; droughts and desertification in the North are reference points. Additionally, empirical evidence from the previous chapters indicated that majority of Nigerians rely on surface and groundwater for their personal and domestic water needs. The consumption and extraction are not subject to any monitoring mechanism. These portend danger to the ecosystem organisms depending on environmental flows and water from aquifers. Ecosystem provides good and services necessary for the sustenance of human environment. The preservation of these should be a fundamental consideration by all societies.

Management of surface and groundwater in Nigeria is the responsibility of Minister for Water Resources. The Minister has power to regulate water abstraction and use including through hydraulic works, wells and boreholes. ${ }^{1599}$ In principle, construction of these require license from the Minister. ${ }^{1600}$ Similar obligations exist under the National Environmental (Surface and Groundwater Quality Control) Regulations ("Statutory Instrument No. 22") as these issues concern protection of the environment. If the powers prescribed under these legal frameworks are exercised and monitored appropriately, adequate control and management of surface and groundwater would be ensured. However, multiple problems can be pointed out.

Firstly, there are serious flaws in the implementation of legal provisions contained in Water Resources Act and Statutory Instrument No. 22. There seems to be a strong disconnection between the law in the books and the law in practice. While for example, permit is required for the construction of boreholes which are not meant for personal or

\footnotetext{
1595 P. Keys, J. Barron and M. Lannerstad, Releasing the Pressure: Water Resource Efficiencies and Gains for Ecosystem Services P. iii.

${ }^{1596}$ United Nations, The Dublin Statement on Water and Sustainable Development

${ }^{1597}$ See P. Keys, J. Barron and M. Lannerstad, Releasing the Pressure: Water Resource Efficiencies and Gains for Ecosystem Services

${ }^{1598}$ United Nations, The Dublin Statement on Water and Sustainable Development

${ }^{1599}$ Water Resources Act, Ss. 4 and 8.

${ }^{1600}$ Water Resources Act, S. 9.
} 
Realising the Right to Water and Sanitation in Nigeria

domestic purposes, and information regarding the location of the boreholes, quantity of water to be extracted on daily basis, the intended purpose of the water to be provided before a permit is granted and the requirement that all owners of boreholes are to register, the authorities do not seem to be implementing the relevant provisions. There is no register kept in the States visited on these issues. The requirement of reasonable use is neither monitored nor respected. ${ }^{1601}$ Secondly, water managers have no specific mechanism of securing information about the rate, the extent or the magnitude of water extraction by the population where water is not provided by the State. Thirdly, construction of boreholes and wells are not monitored, or permission not sought irrespective of whether the construction is for domestic or commercial use. Fourthly, surface and groundwater uses are not balanced against future use and no measure in place to ensure sustainability. Fifthly, even where boreholes construction is done by government, in most cases, no environmental impact assessment is done to determine the viability or otherwise of situating water points in particular areas

To address these gaps, several measures could be proposed. These include the creation of a unit within the Ministry to be responsible for issuing appropriate licenses for boreholes and wells and enforcement of regulatory frameworks relating to access, extraction, quantity, and environmental consideration. Secondly, the Ministry should adopt statistical approach to surface and groundwater consumption to assess the rate at which water is taken and the rate of recharge over period of time in order to determine sustainability of the rate of consumption. Thirdly, adoption of other measures such as pump taxes or quotas, the objective of which is to only allow safe-yield ${ }^{1602}$ amount such that the depletion does not become irreversible. Furthermore, taking the vulnerability of both surface and groundwater due to multiple factors including over extraction, depletion, climate change etc., managing them in a sustainable manner would require conjunctive use approach. Conjunctive use approach is an integrated plan where surface and groundwater are combined to achieve a greater benefit. ${ }^{1603}$ In consideration of variation of climate and rain water across regions and multiple cases of flooding during rainy season, conserving sufficient water during surplus period to recharge groundwater will address challenges posed to the environment. Engineering mechanism hence is required where water surplus will be stored underground, recharging aquifers and enabling the environment to sustain its capacity to continue to provide its goods and services which are dependent on water availability.

\subsection{Imperative of Preserving Ecosystems Goods and Services}

Human population derive benefits from good and services offers by the ecosystem. For example, goods include food, and services include waste assimilation. ${ }^{1604}$ The services according to Goodstein result from the "physical, chemical and biological activities that

\footnotetext{
${ }^{1601}$ Reasonable use doctrine requires landowners to use groundwater on their land without waste and if the use exceed what is considered reasonable, landowner is liable in damages.

1602 Safe-yield amount refers to "the amount of water that can be safely withdrawn without leading to long-terms aquifer depletion". See National Research Council, Valuing Ground Water: Economic Concepts and Approaches P. 110

1603 Ibid. P. 35.

${ }^{1604}$ Robert Costanza and others, 'The Value of the World's Ecosystem Services and Natural Capital' (1997) 387 Nature P. 253.
} 


\section{Chapter Nine}

influence the flows, storage and transformation of materials and energy within and through ecosystems." 1605 Ecosystems provide important support for human livelihood such as food, fibre, livestock storage etc. and these are dependent on water. ${ }^{1606}$ A very clear illustration of services provided by ecosystem is detailed by UNEP, expanding on four broad categories of Millennium Ecosystem Assessment. ${ }^{167}$ These expanded four categories are: provisioning services, cultural services, regulating services, and supporting services. ${ }^{1608}$ The detail of the services are:

Provisioning services are products obtained from ecosystems, including: bioenergy or biofuels, fisheries, timber, and crops. Provisioning services can often be assigned economic value, since they are easily bought and sold in local and global markets.

Cultural services "are the nonmaterial benefits people obtain from ecosystems through spiritual enrichment, cognitive development, reflection, recreation, and aesthetic experiences." Although these services are 'nonmaterial', e.g. 'beautiful' waterfalls, those nonmaterial benefits can improve livelihoods of nearby people, e.g. incomes from ecotourism. Regulating services "are the benefits obtained from the regulation of ecosystem processes," including: climate regulation, natural hazard regulation, water regulation, water purification $\&$ treatment, and disease regulation.

Supporting services "are necessary for the production of all other ESS. They differ from provisioning, regulating, and cultural services in that their impacts on people are either indirect or occur over a very long time, whereas changes in the other categories have relatively direct and short-term impacts on people." Supporting services are often considered to be free, because beneficiaries are not expected to pay for them. ${ }^{1609}$

There is no gain repeating the significance of the above services in human lives and the environment. However, of concern is that tendency exists to treat water as merely a social resource in abundance ignoring its economic and other values and its scarcity. Additionally, because economic value is hardly attached to services provided by ecosystem, their consideration is hardly factored in management planning and population restraints. Ecosystems does not only affect human lives in the goods and services they provide, their conservation is of significant economic benefits to a State. The trend in assessing the economic value of ecosystem is usually through assessing the cost of replacement of such goods and services, but there is equally another dimension. Development and restoration of ecosystem provide significant economic savings which may be utilised in advancing other issues including human rights. A typical example is that of New York City where \$660 million development and restoration of Cat-Skill watershed from which the City gets its much drinking water provided a saving of over $\$ 4$ billion. ${ }^{1610}$

Population and government in many instances do not seem to appreciate the critical nature of their actions on water withdrawal or depletion either for consumption or other

${ }^{1605}$ David Goodstein, Out of Gas: The End of the Age of Oil (W. W. Norton \& Company 2004) Pp. 32-33

${ }^{1606}$ P. Keys, J. Barron and M. Lannerstad, Releasing the Pressure: Water Resource Efficiencies and Gains for Ecosystem Services P. 7.

${ }^{1607}$ Millennium Ecosystem Assessment, Ecosystems and Human Well-Being: Biodiversity Synthesis (Island Press 2005)

${ }^{1608}$ P. Keys, J. Barron and M. Lannerstad, Releasing the Pressure: Water Resource Efficiencies and Gains for Ecosystem Services P. 4.

1609 Ibid.

1610 James Salzman, 'Valuing Ecosystem Services' (1997) 24 Ecology LQ See also James Salzman, Barton H. Thompson and Gretchen C. Daily, 'Protecting Ecosystem Services: Science, Economics and Law' (2001) 20 Stanford Environmental Law Journal 
Realising the Right to Water and Sanitation in Nigeria

developmental purposes. While ecosystem reliance of water for its survival had been shown, there are significant negative economic externalities when ecosystem is ignored in water generation and allocation by authorities. Not only will over withdrawal can lead to extinction of ecosystem's goods and services, other negative consequences could be hunger, poverty, drought etc. Withdrawal of surface and groundwater creates shift in water flows with consequences on the landscape. ${ }^{1611}$

\subsection{An Ecosystems Approach and Integrated Water Resources Management}

Research has observed that poorest communities are often more dependent on sustainable landscape ecosystems services for their livelihood than their counterpart in the rich world. ${ }^{1612}$ This clearly indicated that they stand to suffer more when the services ceased or are degraded. Additionally, changes in water flows and storage for certain human needs impact on other uses of water and the benefits such water sustain. ${ }^{1613}$ Strategy adopted to counter this problem is integrated water resources management. The strategy combines human and environmental needs and serves as a vehicle for sustainable development.

Integrated water resources management is an approach which aims at managing landscape and basin synergies and trade-offs of water uses ${ }^{1614}$ to achieve among others, sustainable development and to essentially address the necessity of maintaining fresh water flows through the landscape to guarantee environmental water flows. ${ }^{1615}$ As a process, it "promotes the coordinated development and management of water, land and related resources, in order to maximize the resultant economic and social welfare in an equitable manner without compromising the sustainability of vital ecosystems." ${ }^{1616}$ SDG Goal 6 target 6.5 advocated for the implementation of this strategy.

This approach has been at various fora discussed and advocated for in Nigeria. Pursuant to such calls and discussions, a National Bill has been developed. The Bill referred to provision of water for the protection of vital ecosystem without clear explanation of the modalities of how such can be achieved. Management of water must be viewed from the perspective of water as one of the essential components of the ecosystem with potential impact on other ecosystem components. This requires the adoption of an ecosystems approach as a veritable tool that considers the health of all aquatic resources, the needs of the environment and makes provision for the population. While an ecosystems approach generally refers to integrating human and environmental needs in the management of resources and integrated water resources management refers to taking into consideration all water users in the management of water, the two concepts are sometimes interchangeably used to refer to an approach where water resources are managed in a way that takes not only the interest of the population in water allocation but also the environment and its components.

\footnotetext{
1611 P. Keys, J. Barron and M. Lannerstad, Releasing the Pressure: Water Resource Efficiencies and Gains for Ecosystem Services P. 5.

1612 Ibid. P. 7.

1613 Ibid.

1614 Ibid. P. 47.

1615 Ibid.

${ }^{1616}$ Global Water Partnership, 'A Secure World' 2010)accessed 29 January, 2017
} 


\section{Chapter Nine}

As shown in chapter one, the understanding of the term ecosystems and its components varies. However, the common goals when its approach is considered are the same: the integration of human and environmental needs in the management of land, water, and all other environmental resources, living and non-living which are relying on the environment. The approach has been identified as one of the themes in achieving sustainability. ${ }^{1617}$ It focusses on the way resources are valued and allocated. The beauty of ecosystem is its encompassing nature. It encompasses conservation and development concerns and integrate them in a way that makes it possible to see the two in a more complimentary relationship. ${ }^{1618}$ The principles of ecosystems highlighted some overarching issues which include the recognition that land and water are found in the ecosystem and the interaction, influence and impact of one ecosystem process or resources can affect the others. ${ }^{1619}$ Human beings themselves are considered to be part of the ecosystem components and ecosystems approach places and values the active roles of human beings in the management of ecosystem. ${ }^{1620}$

An ecosystems Approach was adopted for the implementation of the Convention on Biological Diversity (CBD) in order to achieve the three objectives of the Convention, to wit: conservation; sustainable use; and the fair and equitable sharing of the benefits from the genetic resources utilisation. ${ }^{1621}$ The main idea is attaining a balance of the objectives. ${ }^{1622}$ The approach was thus defined as "a strategy for the integrated management of land, water and living resources that promotes conservation and sustainable use in an equitable way." 1623 It must however be stressed that like the conception of the ecosystem, the approach also has been perceived in various perspectives from focussing more on the natural science ecosystem components to referring to a more holistic and integrated methodology. ${ }^{1624}$

An Ecosystems Approach is linked to the adoption of appropriate scientific methodologies which focus on levels of biological organisations that encompass, according to the Secretariat of Convention on Biological Diversity, "the essential structure, processes, functions and interactions among organisms and their environment."1625 Within the ecosystem, human beings are an essential component as much as other living and non-living organisms which deserve attention. Ecosystem is complex and arguably, with not much information on how it functions. This complexity requires adaptive management approach capable of responding to the non-linear processes and uncertainties associated with its functioning. ${ }^{1626}$ This suggested that in understanding and responding to the processes taking place within the ecosystem, the approach should be capable of responding to new situations

\footnotetext{
1617 Jonathan Rosenbloom, 'A Framework for Application: Three Concrete Scalable Strategies to Accelerate Sustainability' in Jessica Owley and Keith Hirokawa (eds), Rethinking Sustainability to Meet the Climate Change (Rethinking Sustainability to Meet the Climate Change, Environmental Law Institute 2015) P. 69.

1618 Gill Shepherd (ed), Ecosystem Approach: Learning from Experience. P. 3.

1619 Ibid.

${ }^{1620}$ Ibid. P. 4.

${ }^{1621}$ Secretariat of the Convention on Biological Diversity, Ecosystem Approach (CBD Guidelines)

1622 It should be noted that Nigeria is a party to the Convention on Biodiversity. The Convention was signed by Nigeria on $13^{\text {th }}$ June 1992 and ratified on $29^{\text {th }}$ August 1994.

${ }^{1623}$ Secretariat of the Convention on Biological Diversity, Ecosystem Approach (CBD Guidelines) P. 6.

${ }^{1624}$ Cassandra De Young, Anthony Charles and Antonia Hjort, Human Dimensions of the Ecosystem Approach to Fisheries: An Overview of Context, Concepts, Tools and Methods (FAO 2008) P. 3

${ }^{1625}$ Secretariat of the Convention on Biological Diversity, Ecosystem Approach (CBD Guidelines) P. 6. ${ }^{1626}$ Ibid. P. 6.
} 
Realising the Right to Water and Sanitation in Nigeria

and challenges uncovered or discovered as a result of changes within the ecosystem. In essence, it can be likened to having three eyes: one to the future, another to the past with one focussed on the present. The approach is important in order to avoid damage resulting from unsustainable approach in the management of resources, adopting and applying measures that promote peaceful coexistence and ensuring future sustainability. Analysis of the approach indicated that it is centred on achieving conservation, biodiversity and sustainability.

Humanity has no future unless nature and natural resources are conserved. ${ }^{1627}$ Recognition of limited resources and carrying capacity of ecosystem and the need to consider future generation brought into light the concept of conservation. ${ }^{1628}$ Conservation is "the management of human use of the biosphere so that it may yield the greatest sustainable benefit to present generations while maintaining its potential to meet the needs and aspirations of future generations." 1629 On the other hand, biodiversity is "the variability among living organisms from all sources including, inter alia, terrestrial, marine and other aquatic ecosystems and the ecological complexes of which they are part; this includes diversity within species, between species and of ecosystems." ${ }^{1630}$ It is said to be "the foundation of ecosystem services to which human well-being is intimately linked." 1631 Review of scholarly writings and international discussions on the concept of sustainability indicated that, the emerged definition was designed to address competing interests, differences and to achieve consensus. ${ }^{1632}$ Sustainable development has been defined by the Brundtland Report as "development that meets the needs of the present without compromising the ability of future generations to meet their own needs." 1633 This connotes the idea of intergenerational equity which "ensures our small planet is passed over to future generations in a condition which guarantees a life of human dignity for all." ${ }^{1634}$ Inherent in all these is, environmental protection. ${ }^{1635}$ Sustainability of the ecosystem essentially requires three things: enabling environment; institutional roles; and management instruments. ${ }^{1636}$ The three concepts are interrelated. Conservation is a critical requirement for sustainable development. ${ }^{1637}$

The adoption of an ecosystems approach is not akin to religious adherence which may be strict. It is merely a framework connected to learning by doing considering the complexity of ecosystem processes. As such therefore, its adoption and utilisation depend on factors which may be local, national, regional or even global.

\footnotetext{
${ }^{1627}$ IUCN, World Conservation Strategy: Living Resource Conservation for Sustainable Development

1628 Ibid.

${ }^{1629}$ Ibid. Ch. 1, Para. 4.

${ }^{1630}$ Millennium Ecosystem Assessment, Ecosystems and Human Well-Being: Biodiversity Synthesis P. 18.

1631 Ibid.

1632 Jonathan Rosenbloom, 'A Framework for Application: Three Concrete Scalable Strategies to Accelerate Sustainability'

${ }^{1633}$ U.N World Commission on Environment and Development, Our Common Future, 1987) Pt. 1, Ch. 2. Para 1.

${ }^{1634}$ UNEP, Nairobi Declaration, 1982) Para. 50.

${ }^{1635}$ U.N World Commission on Environment and Development, Our Common Future Ch. 1. Para. 50.

${ }^{1636}$ Anil Agarwal and others, Integrated Water Resources Management (Global Water Partnership 2000)

${ }^{1637}$ IUCN, World Conservation Strategy: Living Resource Conservation for Sustainable Development
} 


\subsection{Principles of an Ecosystems Approach}

Chapter Nine

Ecosystems Approach has 12 principles ${ }^{1638}$ which highlighted its working and focus and provide guidance on its application. The sub-sections below highlighted the principles. It needs to be noted that the principles have been used in several case studies with varying degrees of success. ${ }^{1639}$ These principles are:

\subsubsection{Principle One: The Objectives of Management of Land, Water and Living Resources are a Matter of Societal Choice}

There is no unanimous understanding on the meaning of ecosystem. Different societies have different perceptions about its components. Its constituents are determined by "economic, cultural and societal needs". ${ }^{1640}$ This necessitates that, in the application of any approach aimed at managing ecosystem or any of its constituents, or management approach that will impact on the ecosystem, the peculiar understanding, particular circumstances, and rights and interest of the society are to be critically examined and such particularities are to be factored into the plans. It is then necessary that all relevant stakeholders participate in this process, which necessarily involves negotiations and trade off ${ }^{1641}$ in view of different dimensions of ecosystems and multiple interests which it impacts on. The composition and selection of stakeholders' participants must be equitable and discussions and decisions transparent. ${ }^{1642}$ The approach must equally ensure sustainability, environmental concerns and consideration of the interests of future generations. Case studies demonstrated that principle one and two have been found to be the hardest in implementation due to a complex judgment which they require. ${ }^{1643}$

\subsubsection{Principle Two: Management should be Decentralized to the Lowest Appropriate Level}

The rationale of this principle is to enhance efficiency, effectiveness and equity. ${ }^{1644}$ Under this principle, an ecosystems approach requires that roles and responsibilities are balanced between the local government, central government and wider interests which in turn will serve as the basis of "responsibility, ownership, accountability, participation, and use of local knowledge."1645

\subsubsection{Principle Three: Ecosystem Managers Consider the Effects (Actual or Potential) of their Activities on Adjacent and other Ecosystems}

The rationale of this principle is the protection of other surrounding ecosystems which may be affected unintentionally by management interventions on other ecosystems. ${ }^{1646}$ The

\footnotetext{
${ }^{1638}$ Secretariat of the Convention on Biological Diversity, Ecosystem Approach (CBD Guidelines) for case studies where these principles have been applied see: Gill Shepherd (ed), Ecosystem Approach: Learning from Experience ${ }^{1639}$ See for example, Gill Shepherd (ed), Ecosystem Approach: Learning from Experience

${ }^{1640}$ Secretariat of the Convention on Biological Diversity, Ecosystem Approach (CBD Guidelines) P. 8.

${ }^{1641}$ Ibid. P. 8.

1642 Ibid.

${ }^{1643}$ Gill Shepherd (ed), Ecosystem Approach: Learning from Experience P. 17.

${ }^{1644}$ Secretariat of the Convention on Biological Diversity, Ecosystem Approach (CBD Guidelines) P. 10.

1645 Ibid.

1646 Ibid. P. 12.
} 
Realising the Right to Water and Sanitation in Nigeria

guidelines recognised the unclosed nature of ecosystems and the interconnectedness of one ecosystem to another which intervention or non-intervention on one could impact on the other or others. Land, water, oceans, aquifers, living and non-living organisms are all part of the ecosystem. Intervention or non-intervention in one could impact on the other. For example, actions to divert the floor of water to one direction for extraction, treatment and supply to human beings could impact on the survival of rivers, lakes, aquifers which depend on such floor in such direction and organisms sustaining their lives on these water sources. As such this should be critical part of management systems.

\subsubsection{Principle Four: Need to Understand and Manage the Ecosystem in an Economic Context}

It has been noted that, the replacement by alternative system of land use is the greatest threat to biological diversity which generally, arises out of market distortions. ${ }^{1647}$ In this context, the distortions devalue "natural systems and populations and provide perverse incentives and subsidies to favour the conversion of land to less diverse systems."1648 According to the guidelines:

Often those who benefit from conservation do not pay the costs associated with conservation and, similarly, those who generate environmental costs (e.g. pollution) escape responsibility. Alignment of incentives allows those who control the resource to benefit and ensures that those who generate environmental costs will pay. ${ }^{1649}$

The ecosystems approach hence requires that:

Any such ecosystem-management programme should:

(a) Reduce those market distortions that adversely affect biological diversity;

(b) Align incentives to promote biodiversity conservation and sustainable use;

(c) Internalize costs and benefits in the given ecosystem to the extent feasible. ${ }^{1650}$

\subsubsection{Principle Five: Conservation of Ecosystem Structure and Functioning, for Maintenance of Ecosystem Services as a Priority Target}

This principle recognises the dynamic relationship within, between and among different species of the ecosystem as well as the physical and chemical interaction within the environment, maintenance of which are necessary in order to ensure ecosystems' functioning and resilience. ${ }^{1651}$ Hence it considers conservation, and in the events of distortion, restoration of these interactions and processes as being of greater benefit than merely protecting the species. It is a fact that numerous benefits accrue from goods and services provided by the ecosystem. The 2005 Millennium Ecosystem Assessment has detailed some of these benefits and which have been referred to previously. ${ }^{1652}$ Human wellbeing to a greater extent depends on the wellbeing of the environment and different species of the ecosystem can only exist when they are interacting with other species. This symbiotic relationship is necessary to be maintained for the overall benefits and resilience of both human beings and the environment.

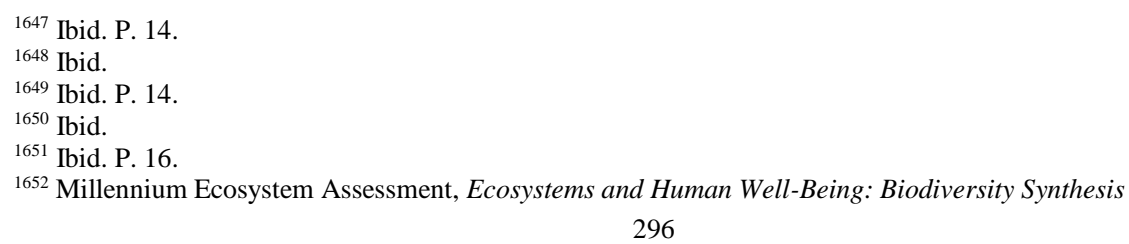




\subsubsection{Principle Six: Ecosystems Must Be Managed Within the Limits of their Functioning}

Recognising the uncertainties surrounding the limits of the ecosystems, this principle requires that attention should be given to "the environmental conditions that limit natural productivity, ecosystem structure, functioning and diversity." 1653 Management must develop necessary precautionary measures by taking into cognizance that, like many other environmental resource and process, ecosystem also is affected by and is responsive to excessive demands. For example, when extraction or withdrawal of surface and groundwater is over stretched, impact could be seen not only on the environment but on the organisms surviving under them including human beings. To continue providing, these waters must either be recharged or at some point will become extinct with all the attendant consequences. Management approach is hence required to be proactive in preventing impacts and must be adaptive in responding to newer challenges which may arise due to uncertainties and mysteries surrounding the working of the ecosystem.

\subsubsection{Principle Seven: The Ecosystem Approach Should Be Undertaken at the Appropriate Spatial and Temporal Scales}

The rationale for this principle is in recognition of the varying functioning nature of ecosystem in terms of time and space and the way in which human activities impact on it. With ecosystem composed of both biotic and abiotic components, their responses are dependents on several factors which are dependent on time and space. Biotic factors such as plants, animals, bacteria, fungi and abiotic factors such as climate, water, soil etc. all function at different times and space. As such the scope of observation should also be dependent on spatial and temporal scales. Availability of water or lack of it, impact on these factors, necessitating that their management should be at more than one scale in order to meet management objectives. ${ }^{1654}$

\subsubsection{Principle Eight: Objectives for Ecosystem Management Should Be Set for the Long Term}

In consideration of the varying temporal scales of ecosystems, in setting objectives for the management of ecosystem or the adoption of an ecosystem approach, managers are to consider long term benefits not only the short terms. In other words, consideration of time in the management plans of the ecosystem is critical to the success of an ecosystems approach. $^{1655}$

\subsubsection{Principle Nine: Management Must Recognize that Change is Inevitable}

It's a common adage, change is the only constant thing in life. Natural processes act and change everything and in some cases, in unpredictable ways. In the application of an ecosystems approach, this principle requires management to recognised not only the

\footnotetext{
${ }^{1653}$ Secretariat of the Convention on Biological Diversity, Ecosystem Approach (CBD Guidelines) P. 18. 1654 Ibid.

1655 Ibid. P. 22.
} 
Realising the Right to Water and Sanitation in Nigeria

uncertainties in the ecosystem but the periodic natural changes impacting on ecosystem's components, composition and population and to factor into their management plans, adaptive management techniques capable of responding to changes and not to foreclose possibility options in their decisions. ${ }^{1656}$ This principle recognises the obvious, and the approach in the management of ecosystem must clearly demonstrate that sound management practices have been or are to be put in place to address inevitable changes especially in the context that the dynamism and functioning of the ecosystem is yet to be fully appreciated.

\subsubsection{Principle 10: The Ecosystem Should Seek the Appropriate Balance Between, and Integration of, Conservation and Use of Biological Diversity}

The main rationale of an ecosystems approach is conservation of biological diversity, for two reasons: firstly, its intrinsic value; and secondly its role to the ecosystem and other services. ${ }^{1657}$ Considering how conservation was approached previously, in the sense of considering some areas as protected and others not, this principle suggested a flexible approach subject to the context. ${ }^{1658}$ The main aims are to achieve sustainability in the use of ecosystem's components and equitable sharing of benefits from biological diversity.

\subsubsection{Principle 11: The Ecosystem Approach Should Consider all Forms of Relevant Information, Including Scientific and Indigenous and Local Knowledge, Innovations and Practices}

This principle considers the critical nature of information gathering in developing ecosystem management strategies. As such, it requires information sharing with all relevant stakeholders and actors. ${ }^{1659}$ Management should not simply presume, all information must be verified from the relevant sources and views of those sources considered ${ }^{1660}$ if the promise hold by the ecosystems approach is to be achieved. While in some cases and due to uncertainties and lack of complete understanding of the functioning of ecosystem components certain issues must be presumed and decisions taken based on such assumptions, efforts must be made to verify and where necessary such assumptions should be on the basis of experience, or best available expertise. The various sources from which information could be sourced can provide unique insights which could prompt development of new ideas and strategies.

Considering information not only from scientific experts, but also from the indigenous and local people who are directly affected by interventions could provide valuable information about the interests of the communities, the functioning of ecosystem components, impacts of interventions and could equally generate a wealth of ideas with which to address environmental concerns of the community in a way that would ensure equity and conservation.

\footnotetext{
1656 Ibid. P. 24.

1657 Ibid. P. 26.

${ }^{1658}$ Ibid. P. 26

${ }^{1659}$ Ibid. P. 28

1660 Ibid.
} 


\subsubsection{Principle 12: The Ecosystem Approach Should Involve all Relevant Sectors of Society and Scientific Disciplines.}

The last principle underscores the importance of involvement and participation of all the relevant actors and consideration of all the relevant sectors of the society. It recognises the complexity in biodiversity management hence requires the participation of all relevant experts, local, national, regional and international stakeholders. ${ }^{1661}$

\subsection{Legal and Institutional Bases for the Adoption of an Ecosystem Approach in Nigeria}

In a federal system, success of an ecosystem approach requires the existence of sound legal basis, administrative policies and institutional structures with mandate to handle application of the approach, to monitor and to respond to challenges in efficient manner. In Nigeria, legal basis, policies and institutional structures exist to facilitate the adoption of the approach. In terms of legal basis, numerous national and international legal instruments imposed a variety of obligations on the Nigerian State on issues relating to conservation of natural resources, biodiversity, sustainability and protection of the environment from degradation. Relevant provisions are spread in several instruments including the Constitution. Under the 1999 Constitution, section 20 obliges the Nigerian State to protect and improve the environment, safeguard the water, air and land, as well as the forest and wild life. Although the provision falls under the famous Chapter Two perceived to be nonjusticiable, obligations exist on the part of all organs exercising governmental functions to work in conformity with the Constitution. These organs therefore, whether executive, legislative or judicial are duty-bound to ensure that their activities do not put Nigerian environment in danger and must work towards protecting the Nigerian ecosystems.

The Nigerian Water Resources Act vested the right to the use and control of water (surface and groundwater) affecting more than one State on the Federal Government. ${ }^{1662}$ The purpose is to ensure optimum planning, development and use of water and to ensure the coordination of activities likely to affect water quality, quantity, distribution and use of water among others. ${ }^{1663}$ The Act imposes a duty on the Minister of Water Resources to, among others, have regard to the need to properly make adequate supply of suitable water for animals, agricultural purposes, fisheries, recreation, the protection of inland and estuarine fisheries, flora and fauna, control and prevention of flooding, soil erosion and damage to watershed areas and ensuring that possible consequences of development proposals on the environment are properly investigated and considered before such proposals are approved. ${ }^{1664}$ The Minister equally can require persons with statutory or customary right of occupancy to a land to construct and maintain works for the conservation of land or water resources. ${ }^{1665}$

Under the RBDAs Act, it is the function of the RBDAs to, among others, develop and to keep an up-to-date, "a comprehensive water resources master plan identifying all water

\footnotetext{
1661 Ibid. P. 30.

1662 Water Resources Act, S. 1.

1663 Ibid.

1664 Ibid. S. 5.

1665 Ibid. S. 8(e).
} 
Realising the Right to Water and Sanitation in Nigeria

resources requirements in the RBDAs' area of operation, through adequate collection and collation of water resources, water use, socio-economic and environmental data of the River Basin." "1666 It is the duty of the National Environmental Standards and Regulations Enforcement Agency (NESREA) to ensure the "protection and development of the environment, biodiversity conservation and sustainable development of Nigeria's natural resources in general and environmental technology". ${ }^{1667}$ NESREA has powers to enforce compliance with all environmental laws in the country including international agreements on matters relating to environment, biodiversity, conservation, desertification, marine and wild life, pollution and sanitation, ecosystem, development of natural resources, among others. ${ }^{1668}$ Additionally, it can conduct public investigation on pollution and degradation of natural resources and in collaboration with the judicial arm establish mobile courts for the prosecution of violators. ${ }^{1669}$ It can equally, in collaboration with other agencies establish programmes in order to set standards and regulations for the purposes of preventing, regulating and eliminating pollution and other forms of environmental degradations affecting the environment and for the restoration and enhancement of natural resources. ${ }^{1670}$

The Environmental Impact Assessment Act was adopted as Decree No. 86 of 1992. The Act requires assessment of environmental impacts of development projects to be undertaken and details to be provided before authorisation for such projects can be given. In this context, it is irrelevant that the project is undertaken by the Federal, State, Local Government nongovernmental organisations or individuals. ${ }^{1671}$ This assessment is mandatory for all activities in all sectors of the Nigerian economy. ${ }^{1672}$ The main objective is to ensure environmental protection, preservation of natural resources and sustainability.

The National Environmental (Surface and Groundwater Quality Control) Regulations provided another legal basis for the adoption of an ecosystem approach on issues relating to both surface and groundwater. ${ }^{1673}$ The main purposes of the Regulations are to "restore, enhance and preserve, the physical, chemical and biological integrity" of the Nigeria's surface $^{1674}$ and protection of groundwater sources by regulating the discharge and underground injection of hazardous wastes and such other substances capable of contaminating water. ${ }^{1675}$ Waters are to be protected, used, developed, conserved, managed and controlled in a manner that takes into account "the protection of the water environment for sustainability of the resources and protection of aquatic ecosystems" among others. Additionally, one of the guiding principles of the National Policy on the Environment is the

\footnotetext{
${ }^{1666}$ River Basins Development Authorities Act, S. 4(1)(e).

${ }^{1667}$ National Environmental Standards and Regulations Enforcement Agency (Establishment) Act, 2007 (Act No.

25), S. 2.

1668 Ibid. S. 7.

1669 Ibid. S. 8.

${ }^{1670}$ Ibid. S. 8(o).

${ }^{1671}$ See Environmental Impact Assessment Act, S. 2.

${ }^{1672}$ See Fatona Pius Olugbenga, Adetayo Olumide and Adesanwo Adeola, 'Environmental Impact Assessment (EIA) Law and Practice in Nigeria: How Far? How Well?' (2015) 1 American Journal of Environmental Policy and Management

1673 The Regulations were adopted as a Statutory Instrument No. 22 of 2011

${ }^{1674}$ The National Environmental (Surface and Groundwater Quality Control) Regulations, S. 1.

1675 Ibid. S. 19.
} 


\section{Chapter Nine}

adoption of integrated ecosystem approach to conserve environmental resources and ensure sustainable development. ${ }^{1676}$

At the international level, several instruments binding on Nigeria and relevant to the adoption of an ecosystems approach could be cited here. These include Convention on Biological Diversity; ${ }^{1677}$ Convention for Cooperation in the Protection and Development of the Marine and Coastal Environment of the West and Central African Region; ${ }^{1678}$ United Nations Convention to Combat Desertification; ${ }^{1679}$ Agreement on the Conservation of African-Eurasian Migratory Waterbirds; ${ }^{1680}$ Convention on Wetlands of International Importance especially as Waterfowl Habitat. ${ }^{1681}$ Although most of these international instruments are yet to be domesticated, yet they provide compelling legal ground for the adoption of measures design to facilitate the execution of Nigeria's international environmental obligations. Nigeria is required to align its activities in line with its international obligations.

Both environmental and water policies alluded to the fundamental ideal of protecting the environment and its surrounding ecosystems. At the Institutional level, the Federal Ministry of Environment was established in 1999 to ensure the effective coordination of all environmental matters in Nigeria. Its mandate includes "securing a quality environment conducive for good health and well-being of fauna and flora, promoting sustainable use of natural resources" and restoration and maintenance of the ecosystem, ecological process and preservation of biodiversity.

From the above, it could be concluded that sound legal, policy and institutional bases exist for the application of an ecosystem approach in Nigeria.

\subsection{Potentials of the Principles of an Ecosystems Approach in Water Resources Management in Nigeria}

When viewed from the perspectives of the imperative of preserving ecosystems goods and services, water as environmental, economic, social and cultural resource, the Nigeria's contextual problems regarding environment and the principles of ecosystems approach, clearly, the approach holds numerous advantages in addressing water and sanitation crisis in Nigeria, guaranteeing the realisation of the right to water and sanitation without undermining the environment and its surrounding ecosystems. As such the subsections following will advise how these principles can be applied in Nigeria.

\subsubsection{Development of Defined Management Objectives of Water}

The first principle recognised that the objectives of managing land, water and living resources is a matter of societal needs. This requires that managers of water and sanitation in Nigeria must first develop clearly defined objectives on how water, land and other living

\footnotetext{
${ }^{1676}$ Federal Republic of Nigeria, National Policy on the Environment. Para. 3.3(xiv).

${ }^{1677}$ Signed on $13^{\text {th }}$ June 1992 and ratified on $29^{\text {th }}$ August 1994

1678 Signed on $23^{\text {rd }}$ March 1981 and ratified on $6^{\text {th }}$ June 1984

${ }^{1679}$ Signed on $31^{\text {st }}$ October 1994 and ratified on $8^{\text {th }}$ July 1997.

${ }^{1680}$ Acceded on $1^{\text {st }}$ July 2004

${ }^{1681}$ Acceded on $2^{\text {nd }}$ October 2000.
} 
Realising the Right to Water and Sanitation in Nigeria

resources, as necessary constituents of the ecosystem, are to be managed for the benefit of all. In developing these objectives, several factors and interests need to be holistically considered. Land, water and living resources are important not only in their own sense or interests but are necessary for both environment and human beings. They are critical in societal development and survival. In this context, water as a cross-cutting resource needed for economic, social and cultural development, is to be managed in accordance with the general interests of the Nigerian people from different sectors of the society, the interests of the environment and organisms living in it for their fundamental role in the survival of human beings and the interests of the future generations.

In the application of this principle, duty-bearers need to have proper understanding of societal interests, different uses of water, interests and rights of local or indigenous people over water and Nigeria's environmental obligations. It is in this context that negotiations and trade-offs are necessary for building a harmonious relationship between competing users and interests. The requirement is that of equitable distribution of the resources in a way that balances different competing interests. The complexity of Nigeria culturally and religiously and the different demands of local and urban population, as well as the impacts which these have on access to and utilisation of water must be taken into consideration by duty-bearers.

Developing a defined and constructive management objectives of water hence require the full and positive participation of all relevant stakeholders selected on equitable basis including but not limited to relevant water and environment managers, welfare officer, forest and maritime managers, agriculture, rural development, health, local and urban population (men and women), indigenous populations, environmental activists water and environment experts, media, traditional leaders, business community, religious and civil society organisations. The discussions and decisions should be appropriate and transparent ${ }^{1682}$ wherein every stakeholder is free to discuss and suggest in a respectable manner, interests and considerations. This way, the concerns, the interests and the various dimensions of issues are shared and discussed. Additionally, workable objectives can be developed and informed decisions can be taken that could lessen conflicts, and roles of each stakeholder will be clearly defined and accountability measures will be put in place. This will equally provide the needed opportunity to develop networks of communication and coordination.

\subsubsection{Decentralisation of Management}

An ecosystem approach envisages decentralization of management for efficiency, effectiveness and equitable distribution of roles and responsibilities. It encourages as much as possible the adoption of bottom-up approach where the closer a stakeholder is to the ecosystem, the greater the role such stakeholder may have over the ecosystem. It is however, recognised that with stakeholders having different capacity, equitable distribution hence is necessary that will ensure those having stakes are allowed to decide and those with capacity are allowed to manage. ${ }^{1683}$

\footnotetext{
${ }^{1682}$ Secretariat of the Convention on Biological Diversity, Ecosystem Approach (CBD Guidelines) P. 8. 1683 Ibid.
} 
Chapter Nine

Ultimately, application of this principle requires that the top-bottom approach currently in operation in the management of water and environment in Nigeria must be reversed. While expertise in management is fundamental, local knowledge, interests and concerns may be residing somewhere distant from the water and environment managers. As such, in the context that water serve different purposes and its extraction impacts on both people and the environment, those who are mostly affected by these and those who have developed expertise in the relevant areas are to be allowed to decide on matters of usage, while management should be with water and environment managers. In this context, local population who are marginalised in the provision of water and sanitation and population whose means of livelihood are affected by over-extraction/withdrawal, their farms lands destroyed, their environment drained and environmental experts with expertise on ecosystem and its benefits are allowed to decide on these issues while government agencies with resources and expertise in management are allowed to manage.

There indeed may be intense competition between groups of different and possibly competing interests. Selecting an appropriate level of management is therefore important in addressing concerns and interests. Management should closely collaborate with various actors to ensure participation, ownership and accountability and to avoid marginalisation. Overall, however, the fundamental legal obligations concerning water and sanitation and those obligations in respect of environment should control decisions and actions.

Consistent with guidelines for the implementation of $\mathrm{CBD}$, where necessary decisions and management functions be subdivided in proportion to the comparative advantage a stakeholder possesses. Decentralisation of management is critical to good governance. It promotes efficiency and accountability in service delivery. The empirical study in this research has demonstrated that majority of Nigerians are aware of who is responsible for the provision of water and sanitation, but little complaint or demands have been submitted for reasons of lack of understanding as to the channel of communication. In many societies, no such channel of communication exists, as such rights-holders find themselves complaining through the media, traditional rulers, and civil society organisations. It is suggested that in each water generating plant, water treatment plant and water distribution plant, a standing committee consisting of relevant stakeholders should be constituted and tasked with these responsibilities. This way, flow and management of information is guaranteed, concerns and interests are addressed before they escalate and become a source of conflicts.

\subsubsection{Consideration of other Ecosystems}

The Technical Committee of the Global Water Partnership observing the dependence of ecosystem on water flows concluded that "Land and water resources management must ensure that vital ecosystems are maintained and that adverse effects on other natural resources are considered and where possible ameliorated when development and management decisions are made" 1684

It's been pointed out, the effect and impact of over extraction of groundwater in Lagos and other areas. The changes other parts of the country are experiencing consequent upon

${ }^{1684}$ Anil Agarwal and others, Integrated Water Resources Management P. 11. 
Realising the Right to Water and Sanitation in Nigeria

climate change, erosion, deforestation and seasonal changes in rains and their impact on the population and the environment. Nigeria does not currently have any mechanism in monitoring borehole constructions, generation of water by vendors and private sector or even industries and companies. ${ }^{1685}$ The system seems to be working without control. These are greatly creating negative consequences on water availability, increasing environmental degradation, lack of food security, loss of biodiversity and increasing drought. The Nigerian population does not seem to appreciate the impact of their surface and groundwater over extraction/withdrawal on other components of the ecosystem.

To address these concerns, the first step is to put in place the necessary mechanism or institutional structure that ensures environmental impact assessment compliance. Water and environmental managers must, as an essential principle of ecosystems approach, design a system that ensures harmonious coexistence of different components of the ecosystem. The mechanism should equally have realistic and workable methods of implementation which should be adequately circulated to ensure compliance. It is the responsibility of FMWR to ensure that surface and groundwater are adequately protected through the provisions of regulatory mechanisms. Environmental regulations, where they exist, are hardly implemented. Sanitation has direct impact on quality of water and contaminated environment directly impact on the health of people living in those areas. The absence of a mechanism (non-intervention) and non-implementation of environmental laws have and continue to have actual and potential impact on many components of the ecosystem.

Public awareness is an important requirement in sustainable water management because it induces changes in behaviour and in fostering political pressure to act. ${ }^{1686}$ The mechanism should create awareness within the different sectors of the population about the actual and potential impacts of their actions on the environment and the future generations. Sharing of knowledge between different stakeholders could create greater equity and more ecosystem benefits. ${ }^{1687}$ Experts are to constantly and consistently monitor and advise on developments, intervention or non-intervention and are to be given opportunity to share their views about how best the effects of such actions can be tackled and how the public can contribute to the protection and sustainability of the environment. All industrial activities and other acts with impact to the environment or any of its species must comply with environmental impact assessment requirements under applicable legislations.

\subsubsection{Understanding and Managing Ecosystems in an Economic Way}

Water as a component of the ecosystem is an economic resource. To realise its full value and to achieve its efficient and equitable use as well as encouraging conservation, it is essential to treat it, in addition to its other nature, as economic good. ${ }^{1688}$ Failure to recognise water as economic good has in the past led to wastages and environmentally damaged

\footnotetext{
1685 This is notwithstanding that Nigerian law provided that license/registration is required in this context. Authorities do not seem to be implementing this requirement.

${ }^{1686}$ Anil Agarwal and others, Integrated Water Resources Management P. 11.

${ }^{1687}$ Gill Shepherd (ed), Ecosystem Approach: Learning from Experience P. 15.

${ }^{1688}$ United Nations, The Dublin Statement on Water and Sustainable Development Principle 4
} 


\section{Chapter Nine}

uses. ${ }^{1689}$ The economic value of ecosystem is often undervalued. The activities of oil companies in the Niger-Delta area and other industrial activities impacting on the surrounding ecosystems contaminating water, depleting fisheries and other valuable organisms were understandably allowed for economic reasons. Governments provide incentives to bigger and influential companies to the detriment of the population and the environment. In many instances, environmental regulations designed to ensure environmental sustainability are selectively implemented or ignored. However, governments at all levels seem to undervalue the impact of such activities on the ecosystems and their effect on the natural environment. It is of fundamental importance that governments appreciate the economic value of the surrounding ecosystems when markets distortions are allowed and to balance the costs and advantages of each action before necessary permits are given. Understanding it this way will provide the necessary protection to the environment and guarantees the health of the ecosystems.

Understanding the value in an economic way inevitably requires collaboration with those who possess the necessary capacity to value and assess them including the local or indigenous population who are benefiting from their goods or services, the knowledge of which may be lacking by government officials. This will address the possibility of marginalisation of local or indigenous communities who may be having little or no political, social or economic influence. $^{1690}$

Government can promote respect for the environment through provision of incentives where necessary for ecosystems conservation while other economic activities are being pursued.

\subsubsection{Prioritising Conservation of Ecosystem Structure and Functioning}

In the extraction, allocation and distribution of water, managers should demonstrate concern and take steps to conserve the ecosystem structure and functioning. With records of how over or unrestricted water extraction, climate change, environmental factors, and attitudinal challenges are hampering on the proper functioning of the ecosystem, efforts should be geared toward conserving and restoring the functioning of the ecosystem. Prioritising necessarily involves taking proactive steps to identify and protect vulnerable species of the ecosystem it involves how these and other components of ecosystems such as lakes, rivers, groundwater are affected with a view to conserving them and preventing their extinction.

Management should strive to understand the working of the ecosystem and its various components, develop conservation objectives as well as strategies to act and to respond to changes on the basis of available and existing knowledge.

\subsubsection{Managing Ecosystems Within the Limits of their Functioning}

Realising that every resource has its limitations and that excessive demand on any particular resource could have a predictable and unpredictable impact on other surrounding

\footnotetext{
1689 Ibid.

${ }^{1690}$ Secretariat of the Convention on Biological Diversity, Ecosystem Approach (CBD Guidelines). P. 14. 
Realising the Right to Water and Sanitation in Nigeria

resources, in the generation, allocation and distribution of water, managers must develop or refine policies in line with environmental obligations of Nigeria including the CBD. An ecosystem approach recognises that the ecosystem is responsive to the limits of disturbance which can be impacted on it. ${ }^{1691}$ While this policy should only serve as a guide, attention should equally be given to challenges recorded and consistently refine the policies to adapt to the situation. Managers must utilise their monitoring and evaluations units to record impacts of their activities on the functioning of ecosystems' components they have been interacting with or which their actions are impacting on. Temporary or permanent conditions sustaining water generation could affect the functioning of the ecosystem such as river flow and fisheries, since no exhaustive knowledge has yet been acquired on the extent of ecosystem functioning. These impacts have been highlighted before. ${ }^{1692}$ Managers must hence be cautious and adaptive. In this sense, active learning was encouraged. ${ }^{1693}$

The guidelines for the implementation of an ecosystem approach recommended identifying unsustainable practices, developing understanding of the limits of ecosystem functioning and the effects of various human use as well as monitoring and assessing ecosystem responses among others. ${ }^{1694}$

\subsubsection{Undertaking Ecosystem Approach at the Appropriate Spatial and Temporal Scales}

This principle underscores the importance of timely management planning and response. Understanding that different species of ecosystems function differently within space and time, management intervention should be properly planned to target such periods as have been observed. In situation where it had been noted that untimely release of budgetary allocation and bureaucratic process have been identified as some of the obstacles hampering on the work of agencies, plans and allocation should target against this obstacle in a way that will make it possible for appropriate interventions to be undertaken. If this is not done, tendency exist that by the time intervention will be taken, the specie of the ecosystem against which protection is sought is already extinct or intervention would amount to waste of resources because not meaningful impact can be made.

There continues to be environmental degradation in many parts of the Nigerian society. Some of these are direct results of deliberate human activities, some are incidental, and others are accidental. In whatever way these result, it is the duty of managers to respond and address the situation before it deteriorates. In the north for example, a semi-arid area, the total water capacity is low and raining season lasted for few months than the southern part, impact of human and natural activities and conditions on the environment are contributing to desertification and other situations impacting on the environment. Surface and groundwater in these areas are only recharged by rain, the rate of which is low from $500 \mathrm{~mm}$ to

\footnotetext{
1691 Ibid. P. 18.

1692 See also Inga T. Winkler, The Human Right to Water: Significance, Legal Status and Implications for Water Allocation. P. 23.

${ }^{1693}$ Secretariat of the Convention on Biological Diversity, Ecosystem Approach (CBD Guidelines) P. 18.

${ }^{1694}$ Ibid. P. 19.
} 
$1000 \mathrm{~mm} .{ }^{1695}$ The unrestricted generation of water at an unsustainable rate is creating environmental conditions unsuitable for both continued existences of human and other aquatic animals as well as leading to dry rivers, desertification etc.

For the management to be able to adopt this approach and respond to the situation, the guidelines recommended enhancing the capacity of managers to understand the spatial and temporal scales of the functioning of ecosystem, the effects of managers' actions on the delivery of ecosystems goods and services and the application of stewardship and intergenerational equity in consideration of temporal scales. ${ }^{1696}$

\subsubsection{Setting of Long-Term Ecosystem Management}

Recognizing the varying temporal scales and lag-effects that characterize ecosystem processes, in setting the objectives, consideration should be given to the effect which are nondetectable in the short term. In most cases, ecological processes take a long time to manifest making any haphazard measure difficult to address or even detect or successfully monitor interventions. Nigeria has experience series of management and policy shifts, hence making observation of responses of ecosystem in most cases difficult because of ad hoc and temporary measures, structures and monitoring mechanisms in place. Duty-bearers should hence be enabled to understand the effect of short term plans on something as complex as the environment.

Implementation guidelines therefore recommended adaptive management process that should include "the development of long-term visions, plans and goals that address intergenerational equity, while taking into account immediate and critical needs (e.g., hunger, poverty, shelter)." ${ }^{1697}$ Equally to factor into consideration are, the trade-offs "between shortterm benefits and long-term goals in decision-making processes", the lag between actions by the management and the outcomes, and the development of monitoring mechanism that observe time scale of the changes in the selected ecosystem, among others. ${ }^{1698}$ The success of this, largely depend on relative continuity which the relevant institutions are to enjoy.

\subsubsection{Recognising and Managing Change in the Ecosystem}

Change is natural and plans to respond to new challenges occasioned by change elements is a requirement in sound management practice. Every manager should have strategies of adapting to predictable and unpredictable changes in the course of discharging their duties. Applying principle nine therefore requires deliberate efforts by the management not only to recognise that change is inevitable but to also have plans capable of attending to such changes in timely and proactive manner. Relevant stakeholders in the management of water, environmental and other aspects of the ecosystem, are to put in place a mechanism dedicated to monitoring changes occurring within the ecosystem whether naturally or resulting from their deliberate actions, but which impacts are not yet known. The mechanism should be able to periodically compare data and figures and observe the adverse effects of changes over time

\footnotetext{
${ }^{1695}$ E. Ita, Inland Fishery Resources of Nigeria

${ }^{1696}$ Secretariat of the Convention on Biological Diversity, Ecosystem Approach (CBD Guidelines) P. 19.

${ }^{1697}$ Ibid. P. 23.

1698 Ibid.
} 
Realising the Right to Water and Sanitation in Nigeria

with a view to assisting the management in adapting and improving on the management techniques in practice. Management should be willing to learn on these new changes and should be willing to make available necessary resources for monitoring and response. This equally requires a periodic joint review by stakeholders to improve learning, awareness of natural and manmade interventions impacting on the ecosystem and avoid being strict in decisions.

Additionally, to be responsive, the working of the mechanism should be subjected to as few bureaucratic procedures as possible for efficiency and effectiveness. The mechanism should be composed of stakeholders with knowledge and expertise including the local population who may be directly affected by the changes and who may equally have direct knowledge about the working, functions and impacts of the components of the ecosystem.

\subsubsection{Ensuring Appropriate Balance Between, and Integration of, Conservation and Use of Biological Diversity}

Within water and environmental management cycles, the concept of integrated management is not new. In the recent past, an integrated water management bill was developed where some of the concerns for the environment were considered. The Bill is important in many respects in the adoption of an ecosystems approach. Before its passage by the National Assembly, the Bill should further be subjected to public debate wherein experts, civil society organisations, interest groups including representations from urban and local communities further consider it in the light of conservation of natural resources, biological diversity and safeguarding human and environmental needs in the generation, management and allocation of water. The law should provide clear provisions on sustainable use of water with criteria as to its measurement.

The Bill when passed, should serve as the basis of water and environmental conservation in the country. It should have a monitoring and evaluation group appropriately empowered to observe not only impacts of interventions by the management but also the deliberate observance of both human rights and ecosystems approaches principles and to advise appropriately.

Alternatively, considering the amount of time required for a Bill to be passed into law, management should consider revising existing water and sanitation policies to incorporate principles of a human rights-based approach and an ecosystem approach with a mechanism of monitoring and evaluating interventions, impacts and changes within the ecosystem and to act appropriately.

\subsubsection{Considering Relevant Information: Scientific, Indigenous, Local Knowledge, Innovations and Practices}

One of the major problems affecting the functioning of government agencies in Nigeria is lack of data. This mostly arises due to lack of investment in data gathering, information sharing and weak or non-communications between and among relevant agencies. It has to be appreciated that no meaningful plans can be developed, and no significant success can be achieved when interventions are not based on evidence. Government policies should be 


\section{Chapter Nine}

evidence-based driven and agencies should be willing to coordinate, gather periodic information, share and compare data and develop interventions on concrete terms and figures.

One important information that seems to be under-valued and, in some cases, not even considered by authorities in their decisions is indigenous and local knowledge. Local communities are hardly consulted. Empirical figures suggested that few consultations are done by agencies when plans are being developed or implemented and in most instances consultations, where done, were not centred on utilising the local knowledge for optimising benefits. In an attempt to somewhat 'modernise' the local people, projects are carried out without their views, inputs or participation and the resulting effect is abandonment by the people which the projects are to serve. ${ }^{1699}$

Large scale resource development affects people living around the project areas especially in relations to the utilisation of the resource. Hence, getting their understanding before embarking on the project is important. ${ }^{1700}$ Central to this, is balancing the power relations between duty-bearers and rights holders especially in the rural areas. The usual tendency is to ignore the local population due to their relative social and economic position in the schemes of the country. As such decisions are taken without consultation or utilisation of their knowledge. Success of an ecosystems approach could be achieved through utilising a human rights-based approach principle of non-discrimination and participation through which power is balanced between duty-bearers and rights-holders. Utilisation of local knowledge further strengthens and provide additional protection to other important human rights such as the protection of cultural values which the local population considers important and which contribute to the cultural diversity of the population in the State. Additionally, experts with scientific knowledge are to be part of decisions making, implementation and evaluation of projects impacting on the ecosystem.

The population is an important stakeholder not only because they are the direct recipient of the negative externalities when ecosystems degradation occurs but also because water is an essential resource in sustaining their livelihood. Success of an ecosystems approach requires active and cooperative efforts of the population. A number of actions are required to be taken by the population. These actions are, first, developing tools through which their water withdrawal can be monitored. While imposition of these tools can be counterproductive, to have a sense of ownership and hence respect for these tools, communities can be enabled to develop the tools in line with their skills, experience and needs. Secondly, they need to strive to understand the role of water in sustaining the ecosystem. Thirdly, they need to appreciate and value the services provided by the ecosystem. Many valuable tools have been developed in this respect. ${ }^{1701}$

\footnotetext{
1699 See for example UNICEF, 'Scaling Up Sanitation and Hygiene Promotion: The Case of Kadadaba' <https://www.unicef.org/wcaro/WCARO_Nigeria_WASH-ScalinUp.pdf> accessed 22 January, 2017

${ }^{1700}$ Kreg Ettenger, '"A River That Was Once So Strong and Deep": Local Reflections on the Eastmain Diversion, James Bay Hydroelectric Project' P. 66.

${ }^{1701}$ See for example P. Kumar and others, Guidance Manual for the Valuation of Regulating Services (United Nations Environment Programme 2010); IUCN, How Much is an Ecosystem Worth? Assessing the Economic Value of Conservation (The World Bank 2004)
} 
Realising the Right to Water and Sanitation in Nigeria

To achieve sustainability, conservation of ecosystem resources and realise maximum benefits of ecosystem resources, information gathering, sharing, evaluation and incorporation into development plans is not only important but critically essential. Relevant agencies should strive to avoid rivalry, unhealthy competition, and refusal to share information that could be of benefit to the working of the entire system. Where possible, agencies should develop channels of interaction that will facilitate speedy sharing of information and willingness to collaborate in addressing challenges. The NWRI could play a fundamental role in this context through the development of database from all sectors in the country through which agencies could consult and make decisions. Additionally, NWRI and NBS should provide capacity building to appropriate agencies not only on the application of an ecosystems approach but also on the utilisation of data in management decisions.

\subsubsection{Involvement and Participation of Relevant Sectors of the Society and Scientific Disciplines}

It is often said that one may go faster when alone but farther with others. No one may be an island and a tree cannot constitute a forest. Evidence showed that management that consult and allows participation of relevant stakeholders achieve better results than those which do not. Involvement and participation of individuals and organisations in the management of any institution or resources is a boost in the development of ideas, strategies and in the way challenges are confronted. Dublin Principles clearly recognises the important role of participatory approach to water development and management. Dublin Principles suggested the involvement of users, planners and policy makers at all levels in water development and management. ${ }^{1702}$

Implementing principle 12 is in line with other principles of ecosystem that require consultation, information gathering and sharing. Working with the local population, scientific experts with knowledge on ecosystems components could provide wealth of knowledge to government through which proper and better management plans could be developed. The local populations which generate direct benefits from the ecosystems and hence understands the values, the experts with technical knowledge and the managers with technical know-how and resources could serve as a viable platform through which understanding and functioning of components of ecosystem could be improved. Relevant scientific experts in this area should include land and spatial experts, agricultural, fisheries, and forestry experts, energy, transport, environmental designers, biodiversity experts, water resources experts, environmental activists, civil society organisations with interests in human rights, water, environmental and biological diversity, urban and local population and judicial officers. Conservation and ecosystems goods and services are better enhanced when all the affected are allowed to participate in decision making and are given roles to implement. Sharing of information between agencies as canvassed under principle 11 is also reiterated here. Integration framework should provide mechanism of cooperation and working among the

\footnotetext{
${ }^{1702}$ See United Nations, The Dublin Statement on Water and Sustainable Development Principle 2
} 
Chapter Nine

different sectors and agencies which will remove unhealthy competition, promote transparency and accountability. ${ }^{1703}$

\subsection{Role of International Community and the Obligation to Seek for International Assistance and Cooperation}

Recognising specific problems of less advanced/developing countries, article 2(1) of the ICESCR imposes an obligation in the context of progressive realisation of the ESC rights to seek for international assistance and cooperation where a State is unable to realise the rights by itself. In elaborating this, GC 15 cited this article and articles 11(1) and 23 of the Covenant demonstrating international obligations of States in the context of realising the right to water and sanitation. ${ }^{1704}$ The obligation of international assistance and cooperation is relevant and connected to obligation to respect and facilitate. In terms of obligation to respect, specifically, the Committee on ESC rights reiterated the obligation of other States to respect the enjoyment of the right to water in other countries. ${ }^{1705}$ Similarly, international cooperation according to the Committee requires States to refrain from actions which directly or indirectly interfere with the enjoyment of the right to water. ${ }^{1706}$ As such measures such as imposition of embargoes on water as well as goods and services necessary for securing the right to water are considered action incompatible with this obligation. ${ }^{1707}$ This obligation is not only where the State is the actor, but the State is also required to prevent its citizens and companies from doing so. ${ }^{1708}$

With respect to obligation to facilitate, the Committee stated that States are to facilitate the realisation of the right in other countries depending on the availability of their resources. ${ }^{1709}$ This can be done through provision of water resources, technological and financial assistance in a manner consistent with human rights standards and cultural environment. ${ }^{1710}$ The Committee reiterated the special responsibility of economically developed States to assist poorer States. ${ }^{1711}$

The United Nations General Assembly affirmed the importance of regional and international cooperation as a means of promoting the progressive realisation of the right to water and sanitation in resolution 70/169. ${ }^{1712}$ The resolution invites regional and international organisation to complement States' efforts to progressively realise the rights ${ }^{1713}$ and stresses the important role of international cooperation and technical assistance provided by States, the UN System, development partners and donor agencies. ${ }^{1714}$ These obligations were

\footnotetext{
${ }^{1703}$ For further discussion on strategies for implementation see Gill Shepherd, The Ecosystem Approach: Five Steps to Implementation

${ }^{1704}$ UNCESCR, General Comment No. 15: The Right to Water (Arts. 11 and 12 of the Covenant). Para. 30.

1705 Ibid. Para.31.

1706 Ibid.

${ }^{1707}$ Ibid. Para. 32.

${ }^{1708}$ Ibid. Para. 33.

${ }^{1709}$ Ibid. Para. 34.

${ }^{1710}$ Ibid.

1711 Ibid.

1712 United Nations General Assembly, Resolution 70/169: The Human Rights to Safe Drinking Water and Sanitation. Preamble 19.

1713 Ibid. Para. 7.

${ }^{1714}$ Ibid. Para. 10.
} 
Realising the Right to Water and Sanitation in Nigeria

reiterated by the Special Rapporteur on the Human Right to Safe Drinking Water and Sanitation in the report to the $71^{\text {st }}$ Session of the UNGA. ${ }^{1715}$

In the context of environmental protection, the Rio Declaration in its Plan of Action

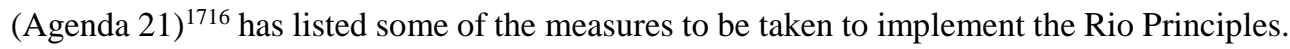
These measures include provision of financial resources and mechanism, transfer of environmentally sound technology, international cooperation and support for capacity building, education and awareness, and information for decision making etc. These measures are relevant to Nigeria and can be sought from States who are in the position to assist. In this context therefore, the international community, more specifically developed and technologically advanced States can assist Nigeria in tackling not only access to water problems, but environmental issues connected therewith. Additionally, Nigeria is under obligation where necessary and seek for this assistance.

\subsection{Ensuring and Monitoring of Minimum Environmental Flow}

Rivers are among the most important sources of freshwater and homes to different organisms and sub-ecosystems. ${ }^{1717}$ From the language of Brisbane Declaration, "Environmental flows describe the quantity, timing, and quality of water flows required to sustain freshwater and estuarine ecosystems and the human livelihoods and well-being that depend on these ecosystems." 1718 Environmental flow allows rivers to complete their hydrological cycles, carry out various ecological and evolutionary process and enables benefitting ecosystem services which are provided by the rivers and their flows. ${ }^{1719}$ Specifically, environmental flow delivers rich nutrients to the sea; sustains fisheries and livelihoods; protects wetlands with their capacity to filter out pollutants; provides habitat for a rich diversity of aquatic life; safeguards fertile deltas; protects water quality; and maintains salt and sediment balances. ${ }^{1720}$ Environmental flow connects the different uses of water e.g. food, water, fishing, farming, navigation, power generation, canal irrigation, industries etc. ${ }^{1721}$ It equally "connects other ecosystems, carries water, transports dissolved materials, sediments and nutrients to maximum places before emptying into its natural outlet." ${ }^{1722}$ River flow is considered the main driver of biodiversity. ${ }^{1723}$ From these perspectives, rivers must be allowed to flow in a way that the goods and services therefrom can be ensured. However, over the years several activities interfere with environmental flow leading to degradation of ecosystems goods and services. Several phrases have been used to connote environmental

\footnotetext{
${ }^{1715}$ United Nations General Assembly, Report of the Special Rapporteur on the Human Right to Safe Drinking Water and Sanitation. Para. 11.

${ }^{1716}$ United Nations, 'Agenda 21'. Section IV

${ }^{1717}$ Latha Anantha and Parineeta Dandekar, Towards Restoring Flows into the Earth's Arteries: A Primer on Environmental Flow (May, 2012) P. 1.

${ }^{1718}$ Brisbane Declaration, The Brisbane Declaration: Environmental Flows Are Essential for Freshwater Ecosystem Health and Human Well-Being (3-6 September 2007)

${ }^{1719}$ Latha Anantha and Parineeta Dandekar, Towards Restoring Flows into the Earth's Arteries: Why, What and How of 'ENVIRONMENTAL FLOWS'. Slide 21.

${ }^{1720}$ Ibid. slide 14

${ }^{1721}$ Latha Anantha and Parineeta Dandekar, Towards Restoring Flows into the Earth's Arteries: A Primer on Environmental Flow P. 5.

1722 Ibid. P. 7.

${ }^{1723}$ Jay O'Keeffe and Tom Le Quesne, Keeping Rivers Alive: A Primer on Environmental Flows (2009). P. 8.
} 


\section{Chapter Nine}

flow including instream flow, ecological flow requirement and environmental allocation. ${ }^{1724}$ As a key element in integrated water resources management, environmental flow is currently being promoted around the world by international organisations such as the IUCN. ${ }^{1725}$

Environmental flow is affected by several factors including total or partial diversion of water, dam construction, mining, deforestation, pollution, and climate change. ${ }^{1726}$ Of significant concern is the effect of dam construction on environmental flow and survival of rivers. Dams are usually constructed for irrigation, power generation, water supply and other purposes. As important as these purposes are, however, it is dam construction that has the most direct and often irreversible modification of environmental/river flows. It makes rivers lose their natural flow patterns with all the attendant consequences on the ecosystem. ${ }^{1727}$ In their preface, Anantha and Dandekar highlighted the effects of dams' construction on river flow. ${ }^{1728}$ That in efforts to extract water for human use, dams have, often irreplaceably, regulated and fragmented river flows. This according to them, is leading to ecological and hydrological death of the rivers. That environmental flow is needed to ensure survival of human and other beings and for the ecosystems to perform their evolutionary and ecological functions.

In Nigeria, presently there are 17 dams ${ }^{1729} 13$ of which are located in northern Nigeria where rainfall is low in order to provide for irrigation, water supply and electricity. Hydroelectric is the main with at least seven power stations around the country ${ }^{1730}$ which centred on river flows. ${ }^{1731}$ While this may be seen as serving important purposes, the major problem is the effects of these dams on environmental flow in an area where water is already a huge challenge and threats from climate change is wrecking the environment. Holding of water by hydro-electric dams for a long period (20-22 hours) a day in order to release it during peak demand hours have been noted to be causing river beds "to go dry for extended periods, playing havoc with riverine and riparian ecosystems and communities along river bank and depending on the river." ${ }^{1732}$ Maintenance of minimum flow is therefore necessary in order not only to guarantee survival of other ecosystems but also to ensure environment remain habitable.

\footnotetext{
${ }^{1724}$ Mike Acreman and Michael J. Dubar, 'Defining Environmental River Flow Requirement - A Review' (2004) 8 Hydrology and Earth System Sciences 861

${ }^{1725}$ Megan Dyson, Ger Bergkamp and John Scanlon (eds), Flow: The Essentials of Environmental Flow (IUCN 2003)

${ }^{1726}$ Latha Anantha and Parineeta Dandekar, Towards Restoring Flows into the Earth's Arteries: Why, What and How of 'ENVIRONMENTAL FLOWS'

${ }^{1727}$ Latha Anantha and Parineeta Dandekar, Towards Restoring Flows into the Earth's Arteries: A Primer on Environmental Flow. P. 5.

1728 Ibid.

${ }^{1729}$ Ede-Erinle Reservoir (Water supply), Asejire Reservoir (Water supply), Bakolori Dam (Irrigation), Challawa Gorge Dam (Water supply), Dadin Kowa Dam (Water supply) Goronyo Dam (Irrigation), Ikere Gorge Dam (Hydroelectric, water supply), Jebba Dam (Hydro-electric power), Jibiya Dam (Water supply, irrigation) Kafin Zaki Dam (Planned - irrigation), Kainji Dam (Hydro-electric), Kiri Dam (Irrigation, plans for hydro-electric), Oyan River Dam (Water supply, irrigation, hydro-electric), Shiroro Dam (Hydro-electric power), Tiga Dam (Irrigation, water supply), Zauro polder project (Irrigation), and Zobe Dam (Water supply).

${ }^{1730}$ Kainji, Jebba, Shiroro, Zamfara, Kano, Kiri, and Mambilla power stations.

${ }^{1731}$ Niger, Kaduna, Bunsuru, Hadejia, Benue, Donga rivers.

${ }^{1732}$ Latha Anantha and Parineeta Dandekar, Towards Restoring Flows into the Earth's Arteries: A Primer on Environmental Flow. P. 6.
} 
Realising the Right to Water and Sanitation in Nigeria

Relevance of maintaining minimum of flow of rivers can be seen from the findings of Brisbane Declaration that due to draining of rivers:

Aquatic species are declining more rapidly than terrestrial and marine species. As freshwater ecosystems degrade, human communities lose important social, cultural, and economic benefits; estuaries lose productivity; invasive plants and animals flourish; and the natural resilience of rivers, lakes, wetlands, and estuaries weaken. The severe cumulative impact is global in scope. ${ }^{1733}$

In addition to dam construction and other human activities interfering with river flow, significant number of Nigerian population rely on rivers, streams and ponds to meet their daily water needs. This puts pressure on the existing rivers and the effect is reflected on daily basis. However, currently, there is no mechanism monitoring the quantity of water extracted on daily or periodic basis. With the rate of recharge being lower than discharge, large rivers are now shrinking and what is left is only a fraction of their original size. This necessitate taking a stock of the problem and ensuring the maintenance of environmental flow.

There are three levels of environmental flow which serve different purposes: high, moderate and low. In the case of high flow, it is "important for channel maintenance, bird breeding, algae control, wetland flooding and maintenance of riparian vegetation." 1734 Moderate flow on the other hand, "may be critical for carrying of organic matter from river banks and for fish migration" and lastly, low flow is "necessary for fish spawning, water quality maintenance, the use of the river by local people, etc." ${ }^{1735}$ Determining which flow should be adopted is a matter for the authorities and other stakeholders to decide depending on what the objectives are. ${ }^{1736}$

While damage to environmental flow cannot be undone, ${ }^{1737}$ ensuring maintenance of minimum environmental flow requires setting clearly defined objectives. This is connected to identified purposes for which the objectives are to be set and which are connected to the goods and services derive from the rivers. Like setting objectives for ecosystem is a matter of societal choice, determining minimum environmental flow is equally a social choice. ${ }^{1738}$ Setting objectives hence requires active participation of all relevant stakeholders including those who are depending on the goods or services from the rivers. ${ }^{1739}$ Methods for quantifying minimum flows are numerous with number exceeding 200. However, these have been grouped into four categories: ${ }^{1740}$

\footnotetext{
${ }^{1733}$ Brisbane Declaration, The Brisbane Declaration: Environmental Flows Are Essential for Freshwater Ecosystem Health and Human Well-Being

${ }^{1734}$ Latha Anantha and Parineeta Dandekar, Towards Restoring Flows into the Earth's Arteries: A Primer on Environmental Flow. P. 7.

${ }^{1735}$ Ibid. See also N. LeRoy Poff and others, 'The Natural Flow Regime: A Paradigm for River Conservation and Restoration' (1997) 47 BioScience

${ }^{1736}$ See Mike Acreman and Michael J. Dubar, 'Defining Environmental River Flow Requirement - A Review'p. 862)

${ }^{1737}$ Latha Anantha and Parineeta Dandekar, Towards Restoring Flows into the Earth's Arteries: A Primer on Environmental Flow. P. 13.

${ }^{1738}$ Jay O'Keeffe and Tom Le Quesne, Keeping Rivers Alive: A Primer on Environmental Flows. P. 4.

${ }^{1739}$ Several methodologies on environmental flow allocation exist. See for example Latha Anantha and Parineeta Dandekar, Towards Restoring Flows into the Earth's Arteries: A Primer on Environmental Flow

${ }^{1740}$ See the following: Megan Dyson, Ger Bergkamp and John Scanlon (eds), Flow: The Essentials of Environmental Flow; Rebecca E. Tharme, 'A Global Perspective on Environmental Flow Assessment: Emerging Trends in the Development and Application of Environmental Flow Methodologies for Rivers' (2003) 19 River Research and Applications 397
} 
1. Hydrological rules;

2. Hydraulic rating methods;

3. Habitat simulation methods; and

4. Holistic methodologies.

Another classifications/categorisation also advanced are: ${ }^{1741}$

1. Look-up tables;

2. Desk top analysis;

3. Functional analysis; and

4. Hydraulic habitat modelling.

Within the holistic methodologies, the best and workable methodology for Nigeria is the Building Block Methodology (BBM) by reason of its encompassing and integrative nature and can be tailored to suit local needs and circumstances. BBM recognises negotiations between various stakeholders and experts in identifying requirement flows for particular needs. ${ }^{1742}$ Under this methodology, relevant stakeholders and local population interact and discuss and issues discussed are shared for review and social assessment are jointly undertaken. ${ }^{1743}$ Rather than developing general objectives for rivers, this methodology defines specific objectives for each river and achievable targets are set in respect of it.

BBM will be useful in Nigeria because of the different roles which rivers serve for different communities. Water and environment managers with scientific experts drawn from the various sectors of human and environmental endeavours together with representative of local population, religious and traditional leaders, environmental flow can be discussed, and objectives can be set regarding each major river serving multiple purposes. Through this, roles will be assigned, and monitoring groups can be established that will ensure compliance and development. Periodic review should be included in the plan that will track and determine the extent to which the set objectives are being achieved.

\subsection{Relevant Stakeholders and Coordination of an Ecosystem Approach Application in Nigeria}

Relevant stakeholder in the application of an ecosystems approach to water management in Nigeria include all agencies dealing with water issues and environment. These include, FMWR, NWRI, RBDAs, States ministries of water, States water boards and rural water supply agencies, FME, NESREA, and National Bureau of Statistics other relevant stakeholders include scientific experts on land, agriculture, forestry, fisheries, energy, climate, transport, environment, biodiversity, human rights, civil society, judiciary, members of the business community and representatives of urban and local population. Recognising however, stakeholders perform different roles for different reasons, grouping them on the basis of roles will be more in line with the ecosystem approach hence the need to identify the

\footnotetext{
${ }^{1741}$ For explanation about these approaches see Mike Acreman and Michael J. Dubar, 'Defining Environmental River Flow Requirement - A Review' Pp. 863-67.

${ }^{1742}$ Latha Anantha and Parineeta Dandekar, Towards Restoring Flows into the Earth's Arteries: A Primer on Environmental Flow. P. 21.

1743 Ibid.
} 
Realising the Right to Water and Sanitation in Nigeria

primary, secondary and tertiary stakeholders. ${ }^{1744}$ However, coordination is to be done by relevant agencies with mandate and comparative advantage. This will ensure compliance with legal obligations of the State and the creation of necessary political will and pooling of required resources for its successful application. Overall coordination should be the function of NESREA because of its expertise and wide mandate on the protection of ecosystem. Coordination in this context refers to playing a leading role in bringing together relevant stakeholders to work towards achieving a common goal. Recognising mandate competition between different agencies in Nigeria, success can only be achieved if agencies work with open-mind and focus is centred on the objectives to be achieved and not who exercises power or control over others. Each agency and stakeholder bring on the table technical expertise, experience and resources and therefore an important contributor in the success of the approach.

It needs to be pointed out at the outset, simple adoption of the approach alone may not guaranty the much-desired result except certain steps are taken to ensure its workability. As such, it has been pointed out that the approach can only succeed when and where the stakeholders are willing and ready to share knowledge and power as well as willingness to invest in the gathering of the knowledge and realignment of management goals and activities. ${ }^{1745}$ These for example have been pointed out as some of the possible challenges which need to be addressed for the successful adoption of the approach.

\subsection{Possible Challenges}

While an ecosystems approach has been applauded as a useful mechanism that provides tools for planning, monitoring and evaluation, ${ }^{1746}$ there are certain challenges. In the case of Nigeria, some of the challenges which need to be factored into the planning and implementation of an ecosystems approach are: resistance to change especially from dutybearers, government bureaucracy, political priorities, technical capacity, lack of ecological database, lack of valid and reliable hydrological database, high direct dependence on river without other possible options, institutional and policy challenges and lack of awareness about flows among the local population.

\subsection{Complementarity of a Human Rights-Based Approach and an Ecosystems Approach}

Section 1.9.5 above has provided for the compatibility of human rights-based and ecosystems approaches. The similarities between the approaches in terms of their objectives and the principles embedded in them have been mentioned. This section highlights how a human rights-based approach reinforces an ecosystems approach and vice-versa; how the two complement each other in the realisation of human rights and how they are relevant in realising the right to water and sanitation.

\footnotetext{
${ }^{1744}$ Gill Shepherd, The Ecosystem Approach: Five Steps to Implementation. P. 6.

${ }^{1745}$ Gill Shepherd (ed), Ecosystem Approach: Learning from Experience P. 20.

${ }^{1746}$ Ibid. P. 19.
} 


\section{Chapter Nine}

Realisation of human rights is circumscribed by the operation and interaction of complex processes and availability of necessary resources (depending on the right in question). Since all human rights are interdependent, interrelated and interconnected, it is easy to see the link between the right to water and right to food as the production and or processing of food involves to a large extent, availability of water. The right to health is equally connected to the right to a healthy environment. An attempt to ignore food, health or a clean environment in the realisation of the right to water for example has the potential of creating more crisis than providing solution to human problems. There exists a symbiotic relationship between an ecosystems approach and a human rights-based approach in the context of realisation of human rights and specifically the right to water and sanitation. For example, failure to apply ecosystems approach in the realisation of rights which are largely if not dominantly connected to the environment will render the realisation a mirage.

According to Morgera, the report of Special Rapporteur on Human Rights and the Environment revealed "that human rights can provide additional argument and means to protect ecosystems." 1747 Indeed, a human rights-based approach reinforces an ecosystems approach in several ways and vice-versa. For example, rural populations who are relying directly for their survival on the surrounding ecosystems services will be supported in the protection of such services by the presence of the right to freedom of expression, ${ }^{1748}$ the principles of participation and non-discrimination. Conversely, the protection of the biodiversity will enable the realisation of many rights in this context such as right to food, health and cultural rights ${ }^{1749}$ where the resources in the environment have cultural values or attachment to the local population. A combination of the two approaches equally enables the identification of rights, roles and responsibilities on the basis of agreed norms. ${ }^{1750}$ A human rights based-approach provides the basis for the protection of ecosystems and biodiversity through the recognition of the right to environmental protection, the right to access information and participation. The Millennium Development Goals and Sustainable Development Goals have all demonstrated how human rights have underpinned ecosystems and biodiversity and how human rights have influence in the fulfilment of goals related to ecosystems and biodiversity. ${ }^{1751}$ The UN in its first report on ecosystems, biodiversity and human rights has specifically recognised the essential role of ecosystems services in the realisation of human rights and the application of human rights obligations to biodiversity related actions. ${ }^{1752}$ From this report, States are required to incorporate biodiversity actions to

\footnotetext{
${ }^{1747}$ Elisa Morgera, 'Healthy Ecosystems Essential for Human Rights' 12 June 2017) <https://www.espa.ac.uk/newsblogs/blog/healthy-ecosystems-essential-human-rights> accessed 26 January 2018

1748 SIDA, 'Human Rights, Biodiversity and Ecosystems' (SIDA, April 2017) <https://www.sida.se/globalassets/sida/eng/partners/green-tool-

box/human_rights__biodiversity_and_ecosystems.pdf $>$ accessed 26 January 2018

1749 Ibid.

${ }^{1750}$ Ibid.

${ }^{1751}$ See Goal 7 of MDGs and Goal 6 of SDGs.

${ }^{1752}$ United Nations General Assembly, Report of the Special Rapporteur on the Issue of Human Rights Obligations Relating to the Enjoyment of a Safe, Clean, Healthy and Sustainable Environment
} 
Realising the Right to Water and Sanitation in Nigeria

those actions which have already been considered for human rights protection. ${ }^{1753}$ The report specifically pointed out the necessity of healthy ecosystems in the realisation of rights to life, health, food, water and participation in cultural life. ${ }^{1754}$ Additionally, it draws attention to the fact that a loss of ecosystems services may violate the right to non-discrimination when it produces disproportionate effects on vulnerable people. ${ }^{1755}$

In the case of the human right to water and sanitation, a combined application of the two approaches is necessary because of the interconnection between water, ecosystems and biodiversity. ${ }^{1756}$ The Committee on ESC rights in its General Comment 15 on the right to water and sanitation has recognised this necessity and as such recommended the adoption of an integrated strategy that takes into consideration among others, concern for the environment in order to guarantee availability for the present and future generation. ${ }^{1757}$

The human rights-based approach has among others, the promise of responding to the human rights needs of the marginalised and vulnerable population. The marginalised and vulnerable include the poor who are generally more prone to the negative effects and impacts of deteriorating ecosystems ${ }^{1758}$ as their lives are largely dependent on the services provided by the system. Several international and national legal instruments while requiring respect, protection and fulfilment of rights contained in them currently require the adoption of a sound and sustainable approach that takes environmental needs into consideration. ${ }^{1759}$ This indicated the need for a State to adopt the two approaches concurrently/jointly.

\subsection{Conclusions}

Water is an environmental, economic, social and cultural resource. This indicates multiple uses of water and mostly between competing interests. Considering water only as a social resource which must be appropriated to satisfy personal and domestic needs has consequences on the very survival of human beings. This has the effect of rendering the environment inhabitable and could lead to extinction of fundamental ecosystem goods and services which human beings depend on. To ensure sustainability, an ecosystems approach is proposed. An ecosystem approach is a tool that facilitates conservation, biodiversity and sustainability of natural resources and the environment. The various threats currently being faced by the natural environment necessitate a shift in the way in which environment is treated.

Several efforts to protect the environment resulted to the adoption of series of international instruments and national laws. These instruments imposed legal obligations to take environmental concerns into consideration when development projects have significant

\footnotetext{
${ }^{1753}$ Elisa Morgera, 'Healthy Ecosystems Essential for Human Rights'; United Nations General Assembly, Report of the Special Rapporteur on the Issue of Human Rights Obligations Relating to the Enjoyment of a Safe, Clean, Healthy and Sustainable Environment Part B.

${ }^{1754}$ United Nations General Assembly, Report of the Special Rapporteur on the Issue of Human Rights Obligations Relating to the Enjoyment of a Safe, Clean, Healthy and Sustainable Environment Paras. 5-21.

1755 Ibid. Paras. 22-25.

${ }^{1756}$ Ibid. Paras. 5, 6, 7, and 21.

${ }^{1757}$ UNCESCR, General Comment No. 15: The Right to Water (Arts. 11 and 12 of the Covenant) Paras. 7 and 28.

${ }^{1758}$ SIDA, 'Human Rights, Biodiversity and Ecosystems'

${ }^{1759}$ See for example Art. 12(2)(b) of ICESCR; Principle 1 of Rio Declaration on Environment and Development; Paras. 8 and 28 of General Comment 15; Goal 7 of MDGs; and Goal 6 of Sustainable Development Goals.
} 


\section{Chapter Nine}

impacts on the environment and its surrounding ecosystems and to ensure vital ecosystems' components are conserve for the present and future generations to guarantee sustainability. Recognising water is part of the environment and plays a fundamental role in not only sustenance of the environment but vital ecosystem components for their goods and services, an ecosystem approach is being canvased around the world mostly by international organisations. Its principles have been clearly defined and their adoption are currently being promoted for adoption in projects. Nigeria is one of the States experiencing shortage in water coverage and have had to rely on natural sources and dam construction in order to satisfy human needs. However, these are posing threats to the natural environment and its surrounding ecosystems. To address these threat, adoption of an ecosystem approach combined with a human rights-based approach is proposed. The manner in which principles of ecosystems approach is to be applied in Nigeria is suggested. If applied, this holds the promise of ensuring sustainability of ecosystems' components, goods and services. Additional to the protection of environment is the idea of ensuring minimum environmental flow and adoption of water trust models in the country to promote conservation, biodiversity and sustainability. 


\section{Chapter Ten}

\section{ConClusions: Findings AND ReCOMmendations}

\subsection{Findings}

This research has the aim of investigating how the recently recognised right to water and 1 sanitation can be realised in Nigeria through the utilisation of a human rights-based and ecosystem approach. It takes into consideration the existing water and sanitation coverage as documented by various sources. The research is specifically centred around answering four questions drawing insights from legal and non-legal sources and in order to identify and recommend the necessary interventions required for the realisation of the right in Nigeria. These research questions are:

1. To what extent are Nigeria's laws, policies and practices in conformity with its obligations under the right to water and sanitation?

2. To what extent are Nigerians aware of the existence of human rights to water and sanitation?

3. What are the factors contributing to or sustaining poor water and sanitation coverage in Nigeria?

4. What do legal interpretation, human rights-based and ecosystems approaches entail and how can these be utilised in the realisation of the right to water and sanitation in Nigeria?

In answering these questions, a combination of normative, qualitative and quantitative research methodologies was used as dictated by the research questions. Through doctrinal/normative legal research relevant national and international legal instruments and scholarly writings were analysed. Through empirical study conducted in the seven States of Nigeria, responses from relevant stakeholders in the water and sanitation sector consisting of duty-bearers, rights-holders and the civil society organisations were collected, analysed and insights from the responses were drawn.

The research is structured and presented in ten chapters. Chapter one provides a general introduction and background to the research contexts. It provides a brief background to the Nigerian situation, water and sanitation coverage and the approaches to be utilised in this research. Chapter two discusses the legal obligations in human rights law and those under the right to water and sanitation through analysis of the contents of the right and its scope. Chapter three analyses Nigeria's human rights environment and the institutional structures for the protection of human rights in general and those relevant to the implementation of the right to water and sanitation. Through this analysis, problems affecting the operations of these institutions were identified. Chapter four analyses the Nigeria's legal and policy frameworks with a view to ascertaining their compatibility with the legal obligations discussed in chapter two. In this analysis, problems associated with these legal and policy frameworks were identified. The chapter further complemented the analysis with the use of empirical figures 
Realising the Right to Water and Sanitation in Nigeria

drawn from the field in showing a reflection of the contents of the right to water in the seven States visited. Chapter four provided response to research question one. With the use of empirical method, chapter five analyses awareness of human rights and the existence of the right to water and sanitation among selected Nigerians in the seven States of the empirical study. Through these, some of the problems affecting human rights realisation and access to water and sanitation were identified. Chapter five answers research question two. Chapters six examines the political, economic, social, cultural and environmental factors contributing to or sustaining poor and sanitation coverage in Nigeria and provided answers to research question three. Research question four was divided into three and was answered in chapters seven, eight and nine. Chapter seven examines interpretation approaches with specific attention to purposive, liberal and integrated approaches and their roles in the transformation of non-justiciable rights. The chapter shows how these interpretation approaches can assist Nigeria in the realisation of ESC rights in general and the right to water and sanitation in particular. Chapter eight discusses the concept of a human rights-based approach and its principles. The chapter then demonstrated how the principles can assist Nigeria in addressing some of the problems contributing to poor access to water and sanitation identified in this research. Chapter nine analyses the concept of ecosystem approach and its principles and the relevance of these principles in the protection of the Nigerian environment and its biodiversity. The chapter provides suggestions on how the principles can be applied in Nigeria and how the approach can reinforce a human rights realisation. Lastly, chapter ten contains findings and recommendations.

The main findings on the research questions are summarised below:

\section{Conformity of Nigeria's Laws, Policies and Practices with Obligations under the Right to Water and Sanitation}

Regarding conformity of Nigeria's laws and policies, the following need to be noted: first, there is no specific legal or policy instrument in Nigeria which recognises water and sanitation as human right. Secondly, although Nigeria is a party to all relevant human rights treaties from which the human rights to water and sanitation was implied, these treaties are yet to be domesticated hence the treaties do not have binding force at the domestic level. Thirdly, the Nigerian Constitution has adopted the dichotomy between CP rights and ESC rights wherein $\mathrm{CP}$ rights have been recognised as fundamental rights with mechanism for their enforcement, while most of the ESC rights have been left as part of the fundamental objectives and directive principles of state policy which are non-justiciable under the Constitution. Fourthly, there is no judicial decision in Nigeria where water and sanitation were recognised as human rights or where access to water was litigated in Nigeria. Majority of human rights cases in Nigeria are on CP rights with limited ESC rights issues litigated under the ACHPR mostly in relation to environmental protection in the Niger-Delta area. Fifthly, most of the complaints coming to human rights institutions in Nigeria centred on $\mathrm{CP}$ rights with limited complaints on ESC rights.

Notwithstanding, there are several legal and policy instruments in Nigeria which are relevant to assessing the level of Nigeria's compliance to its obligations under the right to water and sanitation as well as environmental protection. These instruments are however 


\section{Chapter Ten $\mid$}

scattered and not well coordinated. This is probably because of the recognition that water is a cross-cutting resource. It is on the basis of these instruments that Nigeria's compliance/conformity was assessed.

Human rights law has imposed three types of obligation on States: the obligation to respect, protect, and fulfil. The findings in this research indicated that on the obligation to respect, it may be said that the non-recognition of ESC rights by the Constitution and the lack of justiciability of Chapter Two which contains provisions relevant to the right to water and sanitation, Nigeria has not adequately respected the right to water and sanitation. Additionally, provision in the Petroleum Act which empowers a licensee to appropriate and use water found in the relevant area and to collect and impound water, the law seemed to have interfered with enjoyment of access to water when such water impounded by the licensee under the Petroleum Act is being used by the public. At the general level however, access to natural or artificially constructed water sources such as rivers, streams, lakes, creeks, lagoon, ponds, boreholes and wells are generally respected. Although under the law, construction of boreholes by companies needs permits and private individuals need to register such boreholes, this is only in in the books as no such registration is done and no penalty is imposed for failure to do so. The Water Resources Act ensures among others, free access to individuals to watercourses if the public has access to them for domestic uses and watering of livestock.

Concerning the obligation to protect, control measures have been put in some legislations to ensure that no third party interferes with peoples' enjoyment of access to water. Notwithstanding this, however, some concerns still exist. There is currently no legislation prohibiting arbitrary disconnection of water on account of inability to pay. Although under the policy the poor are to be protected from exorbitant water rates, such provision is not implemented as there are no mechanism so far put in place to ensure compliance. Additional concern is the power granted to holders of permits under Oil Pipeline Act which promotes pollution and interferes with environmental protection as the holders can do anything for the purpose of ascertaining the suitability of establishing an oil pipeline or ancillary installation. Failure to uphold environmental legislations has allowed polluting the environment in the Niger-Delta area. The research found that certain sections of Petroleum and Oil Pipelines Acts are incompatible with international obligations embodied in ICCPR, ICESCR, and ACHPR concerning human rights enjoyment as it relates to right to life, right to the dignity of human person and the right to health.

On the obligation to fulfil, there are no legislative measures concerning enabling the marginalised to realise the right, or measures to enable or assist those individuals who for reasons beyond their ability cannot realise access to clean water and sanitation themselves. Additionally, there are no legislative measures aimed at educating the public concerning hygienic use of water, protection of water sources and methods of improving their sanitation. The available relevant legislative measures are inadequate and in certain instances not suitable in the fulfilment of this right. Some of the examples include legislations on public health which have been adopted during colonial periods and which are no longer relevant. Such laws continue to operate without amendments or repeal. The current water related laws do not have sufficient provisions relevant to discharging the obligation to fulfil. 
Realising the Right to Water and Sanitation in Nigeria

However, national policies have made provisions for water and sanitation coverage in urban areas, towns and villages and have provided strategies by which these are to be achieved. There exist in Nigeria the National Water Supply and Sanitation Policy, the National Water Sanitation Policy, the National Policy on the Environment, the National Environmental Sanitation Policy and such other relevant adopted Standards. These policies are aimed at promoting equal access to water and sanitation. They contain provisions concerning marginalised groups and vulnerable people. They are aimed at creating awareness and promoting individual and public hygiene and in some of them, provisions exist for the participation of relevant stakeholders including affected individuals and communities. Some of the concerns noted in this area include problems associated with implementation of those policy provisions. There exist gaps between provisions of the policies and programmes developed by duty-bearers in the implementation of the policy provisions. The framework for interaction among the relevant agencies is generally weak to such an extent that there is lack of adequate coordination of approaches and activities among the implementing agencies. Secondly, there is general lack of continuity between successive governments and in some cases, policies are entirely abandoned. Thirdly, policies do not give rise to or empower individuals to challenge governmental actions which are not in conformity with the policies. Fourthly, there is general lack of capacity by the implementing agencies which ultimately rendered the policies only relevant on paper. Fifthly, there is general lack of political will on the part of duty-bearers demonstrated by poor funding and official corruption.

The contents of the right to water as interpreted by the Committee on ESC rights indicated that States are under obligation to ensure provision of sufficient, safe, acceptable, physically accessible and affordable water in a non-discriminatory manner for personal and domestic uses. Available legal and policy instruments in Nigeria indicated that in terms of making water available in sufficient quantity, there is no binding instrument which imposes an obligation on the government to make water available in sufficient quantity to the population. Relevant provisions which could be alluded to this requirement merely demonstrated that existing sources of water for the population should not be tempered with in a way which interferes with water availability. These provisions generally relate to water from natural sources and it is considered a crime to temper with such sources. The National Water Supply and Sanitation Policy however has the ambition of making water sufficiently available to the population for their personal and domestic uses. Unfortunately, however, even legal provisions are hardly implemented, much less policies. Concerning water quality, there exist sufficient legislative provisions prohibiting interfering with water quality, water contamination and by extension protecting water quality. These provisions if fully implemented are sufficient to guarantee water quality throughout the country. However, the fundamental problem is implementation. Physical and financial accessibility was addressed in a policy instrument. Under the policy, water points are to be located in accessible locations and prices are to be affordable. However, there is currently no mechanism in place to ensure the attainment of the policy objectives. In terms of non-discrimination, no legal instrument allows discrimination in any form concerning water and sanitation but the unwritten policy of some States in the country directly or indirectly promotes or allows discrimination. This issue is connected to question number two. 


\section{Chapter Ten}

It could be concluded here that Nigeria's legal and policy frameworks have not fully complied with the obligations under the right to water and sanitation and several interventions are required in this respect. While there are issues associated with the implementation of the three general obligations in human rights as stated above, article 2(1) of the ICESCR and General Comment 3 of the Committee on ESC rights ${ }^{1760}$ concerning the nature of State Parties obligations under article 2(1) ICESCR have additionally reiterated the importance of adopting legislative measures under the obligation to take steps. While States have the latitude to take a variety of measures in fulfilling their obligations, the adoption of legislative measures in the case of Nigeria seems to be necessary considering the lack of protection of ESC rights under the Constitution. The lack of judicial remedies generally on ESC rights and specifically on water and sanitation is another area where Nigeria has failed to ensure respect of the right. This is considered necessary under the obligation of a State party to ICESCR. ${ }^{1761}$

In terms of practices, through analysis of 777 responses collected from rights-holders, 65 from duty-bearers and five from civil society organisation, the research found that regarding water availability and sufficiency, the Nigerian population rely on several sources of water for their personal and domestic needs. These sources are taps, boreholes, rivers, ponds, streams, well, and purchasing from water vendors. The responses clearly demonstrated the failure of the Nigerian State to provide quality water in sufficient quantity to its population. Majority of the Nigeria's population have had to rely on other sources most of which the quality is not guaranteed. The proportion of respondents using personal taps suggested that $29 \%$ are not connected to public water supply system. This figure increases to $36.36 \%$ if the proportion of those who almost never use personal taps is added. The non-availability leaves this population, together with million others who are not always getting supply with no option but to resort to other sources which potentially put their lives at risk due to possible water contamination. The figure demonstrated the severe and acute lack of access to portable drinking water by many Nigerians. Although public taps exist, these are very limited and not widespread. As such even in places where they exist only about $16 \%$ are getting supply from them always. The acute shortage of portable drinking water is further evidenced by the figure of $11.16 \%$ of respondents using personal boreholes always, about $5 \%$ very often, $17.66 \%$ using public boreholes always and $13.20 \%$ often using them. The number of respondents using other water sources such as river, pond/stream and wells is alarming. Not only because these sources are mostly impure as no laboratory assessment is conducted to determine their suitability but also it indicated the desperate situation of such population. It may be concluded that the obligation of ensuring availability of quality water is in issue in Nigeria.

In terms of compliance with its minimum core obligations on the right to water and sanitation in respect of availability, Nigeria is clearly in breach of obligations under Article 2(1) ICESCR and General Comments 3 and 15 of the Committee on ESC rights. In line with the Maastricht Guidelines on Violations of ESC Rights ${ }^{1762}$ and General Comment 15 of the

\footnotetext{
${ }^{1760}$ UNCESCR, General Comment No. 3: The Nature of States Parties' Obligations (Art. 2, Para. 1, of the Covenant) Para. 3.

${ }^{1761}$ Ibid. Para. 5.

${ }^{1762}$ International Commission of Jurists, Maastricht Guidelines on Violations of Economic, Social and Cultural Rights Para. 13.
} 
Realising the Right to Water and Sanitation in Nigeria

Committee on $\mathrm{ESCR}^{1763}$ Nigeria has failed to ensure availability of water for its citizens. Both the Guidelines and GC 15 require distinguishing between whether the failure resulted from inability or unwillingness of a State. In the context of Nigeria, the failure resulted from the unwillingness of the State to mobilise the necessary resources, ensure adequate funding and address obstacles impacting on the realisation of access to water and sanitation. These obstacles include corruption, lack of technical capacity and unnecessary policy reversals. Nigeria cannot claim inability in view of the available resources in the country which are capable of addressing the obstacles impacting on ensuring availability of water and sanitation. Additionally, under the Guidelines, a State would be considered to be in violation where a significant number of the population is deprived of the essential basic necessities of life such as water and sanitation. ${ }^{1764}$ The minimum core obligations apply according to the Guidelines "irrespective of the availability of resources of the country concerned or any other factors and difficulties." 1765 Failure to ensure the minimum level of enjoyment of any human right is considered a failure by a State to discharge its legal obligation. ${ }^{1766}$

Regarding water quality, the responses merely indicated the perceptions of rights-holders about the quality of their water. About $73 \%$ of respondents from rights-holders are satisfied with the quality of their water. However, $44 \%$ of respondents from duty-bearers indicated that they do not have mechanisms for monitoring water pollution. This admission seems to suggest that Nigeria has failed to observe its obligation of ensuring water safety under General Comment 15 of the Committee on ESC rights.

In terms of accessibility, generally physical accessibility to water sources is not an issue in Nigeria. A significant number of the respondents accesses water from a distance within the requirement as explained by GC 15. This in turn is connected to the time required within which water is sourced. As such both distance and time are within the requirement of ensuring physical accessibility. Regarding economic accessibility, from the figures obtained from the empirical study in this research, water is generally affordable and water disconnection where the State is the service provider to a large extent occurs only after notice is given. Some concerns which can be raised here is in the areas of ensuring a minimum supply by the State where disconnection is connected to inability to pay and intervention in the context of private service providers who are not subject to any pricing regulation. This will help protect the poor and the vulnerable. On information accessibility, majority of the respondents seemed to be aware of where to access information concerning water and sanitation although more is needed to be done to further enlighten the population on how to utilise such information for the realisation of the right to water and sanitation. In terms of compliance with its obligation under General Comment 15 of the Committee on ESC rights, Nigeria seems to have no fundamental issue concerning physical, economic and information accessibility except in

\footnotetext{
${ }^{1763}$ UNCESCR, General Comment No. 15: The Right to Water (Arts. 11 and 12 of the Covenant) Paras. 39-44

1764 International Commission of Jurists, Maastricht Guidelines on Violations of Economic, Social and Cultural Rights Para. 9. See also UNCESCR, General Comment No. 3: The Nature of States Parties' Obligations (Art. 2, Para. 1, of the Covenant)

${ }^{1765}$ International Commission of Jurists, Maastricht Guidelines on Violations of Economic, Social and Cultural Rights Para. 9.

${ }^{1766}$ UNCESCR, General Comment No. 3: The Nature of States Parties' Obligations (Art. 2, Para. 1, of the Covenant) Para. 10.
} 


\section{Chapter Ten}

relations to pricing regulation of private service providers. Concerning the obligation of nondiscrimination, there appears to be elements of discriminatory practices by the duty-bearers as opined by the respondents from the rights-holders and members of civil society organisation. The view was that certain segments of the society were not connected to State water supply because of their social or economic status. The responses from the duty-bearers however indicated that the failure to connect such people resulted from the lack of adequate resources and poor funding of the sector which in turn impact on their capacity to reach out and cover geographically distant areas. While duty-bearers' response may be valid, it falls short of the requirement of ensuring availability of a minimum supply to everyone irrespective of their position and requirements of taking steps to ensure equality between rights-holders as required by both ICESCR and General Comment 15.

\section{Extent of Nigerians' Awareness of the Existence of the Right to Water and Sanitation}

This question was divided into two for duty-bearers and rights-holders respectively. On the part of duty-bearers, it investigated whether human rights training is provided to the respondents; if yes, whether such training has had any impact in the way they discharge their duties; whether they are aware of the existence of human rights to water and sanitation; and if yes, whether such awareness had any impact in the way respondents discharge their obligations regarding provision of access to water and sanitation. The findings established that only $9.38 \%$ of the respondents indicated having received human rights training, a significant majority consisting of $85.94 \%$ have not and $4.69 \%$ cannot remember. On the second issue, even among those who received such training only $18.52 \%$ indicated that the training impacted on their performance. On the third issue, a large majority of respondents consisting of $83.87 \%$ indicated having heard of the existence of the right to water and sanitation. This suggested that 4 in every 5 of the respondents is at least aware that access to water and sanitation is a human right. When the responses were cross tabulated by administrative level, there is only a slight difference as $84.65 \%$ of management staff and $83.33 \%$ of senior staff are aware. On the last issue, roughly half of the respondents consisting of $50.82 \%$ said that such awareness has impacted on them significantly, $26.23 \%$ very significantly, $13.11 \%$ are indifferent, $8.2 \%$ said the impact was insignificant and $1.64 \%$ said it was very insignificant. However, notwithstanding the significant number of respondents who are aware of the existence and recognition of water and sanitation as human rights, the institutions do not appear to have taken significant steps toward empowering duty-bearers to appreciate the implication of such recognition. Staff are not exposed to human rights trainings capable of enabling them to understand the extent of their obligations and ways of ensuring accountability.

On the part of rights-holders, the study first investigated the proportion of respondents who are aware of the meaning of human rights and the existence of the right to water and sanitation. It then investigated how respondents have ranked the right to water and sanitation in relations to other critical ESC rights such as right to health, food, housing, clean environment, and right to work in relations to likelihood of respondents asserting legal claim for their realisation. The study also investigated whether respondents are aware of how to 
Realising the Right to Water and Sanitation in Nigeria

claim ESC rights if the rights are denied; whether they will assert legal claim if the right to water and sanitation are recognised under a domestic and legally enforceable legislation and respondents' perception of whose duty it is to provide access to water and sanitation. The study found that although responses do not suggest deeper understanding and technicalities associated with human rights and legal claims but there appears to be a somewhat general understanding of these issues.

The responses indicated that $87.95 \%$ are aware of the meaning of human rights, $9.20 \%$ are not and $2.85 \%$ do not care. There is a slight disparity between males and females in favour of female regarding awareness and females seemed to be more concerned about awareness of human rights than males. When cross-tabulated by age-groups, those within the ages of 41-50 seems to slightly be more aware than other age groups. This is followed by the ages of 18-24 and 25-40. The least are those from 51 years and above in all the three options. Additionally, awareness of human rights increases with advancement in educational qualifications except between diploma and bachelor where a slight decrease was noticed though within the margin of error. The curve rises from about $92 \%$ to $100 \%$ as additional educational qualifications are acquired. Responses indicated that awareness of human rights is higher in the category of those who have retired from the civil service (respondents in this category are however few). This was followed by individuals whose occupation does not belong to any of the listed. The third in the hierarchy are individuals working for the private sector which are followed by the civil servants, students, housewives, unemployed and selfemployed respectively. Individuals whose main occupation is farming (mostly in the rural areas) are the least in the hierarchy and accounted for the highest number of those who are not aware and those who do not care to know.

On awareness of the existence of the right to water and sanitation, about $3 / 4$ of the respondents are aware. When this is cross-tabulated, proportion of males is slightly higher compared to females. By age-group, those between the ages of 41-50 seem to have a higher figure as 4 in every 5 of them are aware. This is followed by ages 25-40, 51+, and 18-24 respectively. By educational level, all the respondents with $\mathrm{PhD}$ are aware, followed by those with master's degree, primary certificates, diploma holders, postgraduate diploma, bachelor certificate holders, secondary certificate holders and those having other qualifications respectively. By occupation, all those who have retired from civil service are aware, followed by civil servants, housewives, the unemployed, self-employed, employees of private sectors, students, other employees, and lastly farmers respectively. From the figures, there seems to be general awareness of the existence of the right to water and sanitation by the respondents from both duty-bearers and rights-holders. Exposure to various sources of information especially the social media could be a reasonable explanation as to the way in which respondents became aware. By providing reasonable platforms through which rights-holders could acquire or generate information on human rights, Nigeria seems to have respected its obligation to ensure information accessibility. Although there remains a limited number of respondents who are not aware, this is to be expected especially in the context where literacy is still a challenge.

In terms of ranking of ESC rights in relations to likelihood of asserting legal claim, it was found that right to health was ranked higher and is considered more important on the scale of 


\section{Chapter Ten}

likelihood of asserting a legal claim. This was followed by the right to food, the right to water, the right to housing, the right to clean environment and the right to work respectively. The right to water is therefore ranked the third most important ESC rights by the respondents. Regarding awareness of how to claim ESC rights, it was found that more than $2 / 3$ of the respondents are aware. The awareness however does not necessarily mean the respondents understood the technicalities involved or the current legal status of ESC rights in Nigeria. It simply indicates that the respondents are aware of the role of courts in litigating rights claims. On whether respondent will litigate if the right to water and sanitation is recognised under a domestic law, it was found that more than half of respondents indicated the likelihood of asserting such a legal claim. There is therefore a possibility that if ESC provisions in the constitution are made justiciable or a separate law recognising water and sanitation is adopted in Nigeria, rights-holders may play a role in holding duty-bearers accountable to their obligation of ensuring availability of quality water. Lastly, on assessing respondents' perception of whose duty it is to provide water and sanitation, it was found that $89 \%$ identified government as the duty-bearer, 7.33\% indicated it's their personal responsibility, $2.49 \%$ identified private service providers (water companies) and $1.18 \%$ indicated water vendors. The recognition by most respondents that government is the duty-bearer makes it easier for them to know against whom claims should be made which is relevant in the context of a human rights-based approach.

\section{Factors Contributing to or Sustaining Poor Water and Sanitation Coverage in Nigeria}

Multiple factors are contributing to or are sustaining poor water and sanitation coverage in Nigeria. Identifying these requires analysing legal, political, economic, social, cultural and environmental issues because it is under these conditions that human rights violations take place. A review of Nigerian laws and policies demonstrated inadequacies, lack of consistency, and policy reversals. Additionally, water and sanitation have not been recognised in any legal or policy document as human right in Nigeria thereby curtailing the power of people to assert legal claims for its realisation. The non-domestication of relevant international treaties and the judicial cloak placed on ESC provisions in the Constitution have limited the possibility of litigating for the realisation of the right to water and sanitation or even such other rights from which the right to water and sanitation was derived from. This is contrary to Nigeria's legal obligation under the ICESCR and other relevant binding human rights instruments as expounded in General Comment 9 of the Committee on ESC rights. ${ }^{1767}$ The Committee underscored the need for States to give effect to the norms recognised in the Covenant in their legal order and to ensure appropriate mechanisms for redress or remedies are provided in the event where there is failure to observe the ESC rights. ${ }^{1768}$

Additionally, in the context of treatment of the Covenant rights by domestic courts, while the Committee had noted state practice varies in this context, it underscored the general acceptance of the need to interpret domestic law in the light of its conformity to international

\footnotetext{
${ }^{1767}$ UNCESCR, General Comment No. 9: The Domestic Application of the Covenant

${ }^{1768}$ Ibid. Paras. 1-3.
} 
Realising the Right to Water and Sanitation in Nigeria

legal obligations of a State. ${ }^{1769}$ While other jurisdictions have adopted other approaches such as interpreting ESC rights through CP rights in order to make ESC rights meaningful and justiciable, the Nigeria approach is not rich in this area and the jurisprudence is generally limited. As such, domestic courts in Nigeria in their interpretation and judicial review roles need to actively observe the recommendation of the Committee on ESC rights. Specifically, the courts need to take into account the human rights obligations of Nigeria and to ensure that Nigeria's conduct is consistent with such obligations. Failure to do this, as noted by the Committee is incompatible with the principle of the rule of law. ${ }^{1770}$

Non-legal factors found to be contributing to the problem of acute water and sanitation in Nigeria are political, economic, social, cultural, environmental and institutional. Although non-legal but they impact negatively on the realisation and enjoyment of human rights in Nigeria. Human rights violations take place under complex circumstances. ${ }^{1771}$ To the extent that these non-legal factors negatively impact on human rights realisation in Nigeria and contribute to Nigeria's failure discharge its legal obligation, examining them with a view to identifying possible measures to counter their negative influence is expedient. Their continued presence indicates Nigeria's failure to eliminate all obstacles to the realisation of human rights in Nigeria as part of its human rights obligation. General Comment 3 of the Committee on ESC rights considered administrative, financial and social measures as part of the appropriate measures contemplated under article 2(1) ICESCR. ${ }^{1772}$ These measures are required to be taken for the progressive realisation of the Covenant's rights. Additionally, the continued existence of these factors despite international legal obligations of Nigeria on human rights indicated a tacit if not express approval of retrogressive measures which ICESCR seemed to have prohibited. ${ }^{1773}$ These non-legal factors are:

\section{i. $\quad$ Political Factors}

Firstly, the prolonged military system of governance has destroyed basic good governance structure that could hold duty-bearers accountable to their obligation and allow individuals and groups to claim their rights. The general human rights violations attached to the military style of governance and the lack of adequate human rights protection mechanisms have impacted on the general population leading to situation of docility and hopelessness in the face of human rights violation. Secondly, inept and corrupt leadership which was institutionalised during military periods extend to civilian administration such that leaders no longer strongly feel accountable, public office is seen as avenue for personal enrichment such that financial appropriations for office duties are converted to private pockets. Thirdly, Nigeria operates one of the costliest style of political governance. The cost of maintaining political offices has largely affected appropriations to government institutions

\footnotetext{
1769 Ibid. Para. 15.

${ }^{1770}$ Ibid. Para. 14

${ }^{1771}$ Manisuli Ssenyonjo, 'Reflections on State Obligations with Respect to Economic, Social and Cultural Rights in International Human Rights Law' P. 973.

${ }^{1772}$ UNCESCR, General Comment No. 3: The Nature of States Parties' Obligations (Art. 2, Para. 1, of the Covenant) Para. 7.

${ }^{1773}$ UNCESCR, General Comment No. 15: The Right to Water (Arts. 11 and 12 of the Covenant) Paras. 19 and 42.
} 


\section{Chapter Ten}

for their proper functioning. Fourthly, there is general lack of political will to back legal and political commitments with necessary financial requirements for institutions to discharge their responsibilities. And fifthly, politicisation of development where duty-bearers put political considerations over and above human rights obligations on development issues has affected balancing development concentration and addressing marginalisation or discriminatory practices. These political factors are issues within the control of Nigeria and can be addressed through the adoption of or incorporation of principles of good governance in Nigeria which not only ensures that the country is administered for the benefits of the citizens but also provide necessary framework for the realisation of human rights. The current governance structure is incompatible with human rights protection of Nigeria.

\section{ii. Economic Factors}

Several issues can equally be cited here. First, the problem of inadequate budgetary provision over the years. Despite acknowledgement of the critical nature of water and sanitation by the government and the extent of financial commitment required, governments at various levels are treating the sector with little concern in terms of budgetary provisions in their yearly appropriation laws. Second, despite the limited funds allocated to water and sanitation sector, the problem is further compounded by limited releases of the funds and in most cases after series of delay. This has affected the proper functioning of relevant agencies and has bred culture of projects abandonment. Third, economic incentives given to multinational companies such as oil companies to the detriment of the people has affected their human rights enjoyment and in certain cases has resulted to human rights violation such as the case of the Niger-Delta in the context of environmental pollution. Fourth, the limited funds released by government for the execution of water and sanitation projects is further affected by corruption and corrupt practices. Nigeria has for several years been ranked as one of the most corrupt countries in the world. There is virtually no government agency which has not been affected by corruption. This has affected project implementation throughout the country. Fifth, the unwritten policy of States in Nigeria to connect and allocate water to areas which are vibrant in economic activities has contributed to the marginalisation of areas where no such activities are taking place. This is equally a good governance issue which can be adequately addressed if Nigeria takes into consideration its obligations arising from international and domestic legal instruments especially those relating to human rights. This is an issue demonstrating the unwillingness of Nigeria to conform to its legal obligations.

\section{iii. Social Factors}

Relevant issues here which have impacted on water and sanitation coverage are population explosion in both cities and villages, rural-urban migratory movements in search of greener pasture leading to establishment of informal settlements and their abandonment by government service-providers. Available statistics demonstrated the possible existence of discrimination and or marginalisation in water and sanitation coverage between villages and cities. Services seemed to be concentrated in cities to the detriment of other towns and villages thereby leading to their marginalisation. Sanitation practices and lack of awareness among the population have equally been found to be a contributing social issue. There does 
Realising the Right to Water and Sanitation in Nigeria

not seem to be good awareness on waste pollution and problems associated with accessing water from polluted sources especially in the villages. While generally the population seemed to be aware of human rights, there is limited understanding about the categories, nature and dimensions of these rights. For example, rights to clean environment and environmental litigation are not very much known to the population especially in rural areas. Another social problem is lack of access to information. Until 2011 when Freedom of Information Act was adopted, the population did not have freedom to access information concerning governance and matters connected to financial appropriation of government agencies. The level of poverty combined with low-level literacy rate among the population have affected the capacity of the people to effectively assert or claim human rights. Lastly, evidenced from the empirical study regarding request for information by the population, it may be opined that peoples' passiveness might have contributed to poor water and sanitation coverage. People do not seem to be much interested in holding duty-bearers accountable. Even where known rights are violated, very few rights-holders are willing to litigate for their protection. The Committee on ESC rights has reiterated the importance of accountability in the realisation of human rights. ${ }^{1774}$ According to the Committee, absence of accountability makes human rights to be a mere window dressing. ${ }^{175}$ The problems associated with social factors demonstrated Nigeria's failure to enlighten its citizens about human rights and the consequences of their actions on the realisation of the right to water and sanitation. This has contributed to the docility of the population and the problem of accountability. This failure is connected to unwillingness of Nigeria as there is nothing on the ground to suggest Nigeria's inability to discharge this obligation.

\section{iv. Cultural Factors}

Some cultural practices and beliefs of the people have contributed to poor quality water and sanitation coverage. Practices such as defecating in the open with the belief that it serves as manure, the practice of eating without washing hands and the belief that water impurities are not dangerous are issues concerning water and sanitation quality. Other cultural and religious beliefs relate to the influence of religion and traditional settings on litigation. Several people have indicated how family, culture and traditions as well as religious belief will not allow them to prosecute cases on human rights. Several people do not seem comfortable exposing themselves to the rigours and public scrutiny attached to litigation. The cultural issues identified here equally demonstrated a problem of lack of information and awareness on the part of the population. It's the obligation of Nigeria to promote information awareness and to do everything within its powers to ensure obstacles to the realisation of human rights, specifically the human right to water and sanitation are eliminated. The State through the National Orientation Agency has failed in this context as the Agency which was specifically established to orientate the population does not seem to be adequately discharging this function.

\footnotetext{
${ }^{1774}$ UNCESCR, Substantive Issues Arising in the Implementation of the International Covenant on Economic, Social and Cultural Rights: Poverty and the International Covenant on Economic, Social and Cultural Rights (10 May 2001)

${ }^{1775}$ Ibid. Para. 14. See also UNCESCR, General Comment No. 9: The Domestic Application of the Covenant
} 
v. Natural and Environmental Factors

The research found that water variation and seasonal changes on water availability are affected by some natural and environmental factors including climate change. Previously known large water sources are now depleting due to climate change. Additionally, environmental consideration by duty-bearers in water provision which discriminate against areas which they considered geographically inaccessible or situated far away from the locations of water infrastructures contributed to poor water coverage. While nothing much can be done to control natural factors, a lot can be done to prepare for them especially when their effects are known. In this context, there has been a failure to put necessary structures in place to cushion the effects of natural factors on water availability. In terms of environmental factors such as locations of some villages and towns and the decision to connect them with water services, Nigeria has failed to discharge its obligation on equality and nondiscrimination. In the context of human rights, these types of locations are required to be given specific attention due to their vulnerability. This has not been done by duty-bearers in Nigeria.

\section{vi. Institutional Factors}

This research has found several issues associated with water and sanitation institutions and other relevant or government agencies. First, technical capacity. While there appears to be in existence requisite academic qualifications among duty-bearers, there is generally lack of technical capacity to discharge the obligations. Duty-bearers are hardly trained to attend to new challenges or equip themselves with additional skills to handle their tasks. Several duty-bearers do not have a policy concerning staff training or even motivation mechanisms. Duty-bearers appear not to be utilising to an appreciable level, the NWRI in equipping their staff. Second, institutional framework in water and sanitation is weak as there are no provisions for sectoral coordination, tariff setting and conflict resolution. Even where the national policies provided for coordination between agencies, this is hardly followed. Third, there is the problem of fragmented and inadequate data and statistics in the country. The NBS is the official body responsible for the generation of data and statistics in Nigeria. However, the NWRI has the specific mandate to compile data and statistics concerning water. This institution is not doing well in this area. As such different agencies are generating different data consistent with their interest and this data or statistics is hardly shared among relevant agencies. There is currently, no effective data management system on water resources in Nigeria. This has significantly affected planning and implementation of projects of relevant agencies. Water and sanitation projects are hence not directly from evidenced-informed research. Fourth, there is the problem of weak synergy among relevant stakeholders. There is no clear coordination or cooperative mechanisms between the relevant Federal, States and Local Governments agencies. Even among the Federal Government agencies, the institutions pursue parallel programmes and sometimes duplication of efforts and waste of resources because of lack of synergy. Fifth, duty-bearers in many instances do not consult or involve beneficiaries in the designing, implementation and monitoring of water and sanitation projects. This has led in certain cases to abandonment by the beneficiaries because the 
Realising the Right to Water and Sanitation in Nigeria

projects have no direct connection with their interests. Sixth, there is no cost-recovery mechanism that would ensure people pay for the water provided by public agencies in many States. Several States rely on the goodwill of the people to pay for water rates. This has affected the poor performance of the institutions which in addition to poor funding are not able to sustain cost of providing the service. Lastly, although policies have recognised the important role of private corporate actors, little implementation has been done in this context to facilitate their participation in the provision of access to water and sanitation.

The relevance of effective and efficient institutions in the realisation of human rights cannot be overemphasised. General Comment 15 of the Committee on ESC rights had demonstrated this in its recommendation to State parties to establish "competent institutions and appropriate institutional arrangements" for the implementation of strategies and programmes concerning water and sanitation. ${ }^{1776}$ Having effective and efficient institution is part of good governance. Good governance (which has been said to encompass full realisation of human rights, effective participation, multi-actor cooperation, empowerment of people, equity, transparency, rule of law and accountability) has generally been agreed to relate to political and institutional processes and outcomes which are considered necessary in the attainment of development goals. ${ }^{177}$ Additionally, good governance has been expressly linked to an environment which is conducive to the enjoyment of human rights. ${ }^{1778}$ In the context of ecosystems and biodiversity protection, weak institutions, poor transparency, as well as lack of public access and participation were among the causes which undermine important ecosystems services. ${ }^{179}$ The institutional problems identified above are incompatible with the requirement of General Comment 15, SDG Goal 6, good governance and human rights realisation.

\section{Interpretation Approaches, Human Rights-Based and Ecosystems Approaches and their Potentials in the Realisation of the Human Right to Water and Sanitation in Nigeria}

There are several interpretations approaches which are used by judges and other quasijudicial bodies in deconstructing legal provisions. These include those which use intrinsic aids to derive meaning of a legal provision and those which use external aids. Purposive, liberal and integrated approaches are among the latter and are used to address gaps in legislative provisions or expand their scope to cover situations which have not be provided for in the law. Usually the utilisation of these approaches involves judicial activism. The approaches appeared to be useful in the interpretation of constitutions due the nature of its language although they have been used in other legislations and treaties as well. The approaches hold potentials especially in the context where there is dichotomy between $\mathrm{CP}$ rights on the one hand and ESC rights on the other where only the former have been regarded

\footnotetext{
${ }^{1776}$ UNCESCR, General Comment No. 15: The Right to Water (Arts. 11 and 12 of the Covenant) Para. 28.

1777 UNHCHR, 'Good Governance Human Rights'

<http://www.ohchr.org/EN/Issues/Development/GoodGovernance/Pages/GoodGovernanceIndex.aspx> accessed 25 January 2018

${ }^{1778}$ UNHCHR, The Role of Good Governance in the Promotion of Human Rights (26 April 2000)

${ }^{1779}$ SIDA, 'Human Rights, Biodiversity and Ecosystems'
} 


\section{Chapter Ten}

as justiciable. Jurisprudence in countries with constitutions that regard economic, social and cultural rights as non-justiciable or merely fundamental objectives and directive principles have utilised these approaches in expanding the scope of CP rights to cover relevant ESC rights and by extension render them enforceable. The approaches are important in the context of Nigeria where the Constitution considers ESC rights as non-justiciable. Recognition of the right to water and sanitation in a legislative document or realising the right through legal claims is circumscribed by the broader recognition and justiciability of ESC rights. Through these approaches, judiciary would be in the position to efficiently transform the character of ESC rights in Nigeria and promote realisation of human rights.

A human rights-based approach is a process which emphasises the idea of good governance, ensures participation and empowerment of marginalised groups in a nondiscriminatory manner through emphasis and application of legally (and ethically) binding instruments. It enables duty-bearers and rights-holders to responsibly and accountably undertake their legal (and ethical) commitments and claim of rights respectively. It addresses underlying causes of poverty, injustices and marginalisation. It enables the discriminated and marginalised individuals and groups to have voices in matters concerning their rights. At the heart of a human rights-based approach is the idea of using legal norms derived from internationally agreed human rights instruments as a potentially more powerful approach to development which makes it easier due to the universal nature of human rights and arguments become less political. Human rights-based principles of equality and non-discrimination, empowerment, participation and accountability contain potentials for addressing Nigeria's water and sanitation problems relating to political, economic, social and institutional factors identified in this study. The principles would ensure that good governance is entrenched in the system which will facilitate not only the realisation of the right to water and sanitation but also other human rights. The legal basis for the adoption of the approach exists as Nigeria has ratified all the relevant international instruments on human rights. The approach however would need to be contextualised in order to take local and national circumstances into consideration for it to be successful. These should include appreciation of religious and cultural affiliations of the people in introducing the 'rights' discourse. This will prevent a situation where the population will perceive the adoption of a human rights-based approach as a mechanism through which their religious and cultural beliefs will be eroded or interfered with through the back-door. It is proposed that the methodology for its application in Nigeria should both be parallel and participatory in nature. Parallel until both duty-bearers and rightsholders are properly empowered to meaningfully participate in a useful discussion for the realisation of their rights. This should be spearheaded by the National Human Rights Commission and other relevant international and civil society organisations. However, it is acknowledged that there may be challenges which may include resistance to change from duty-bearers, lack of political will, suspicion or mistrust from some religious or cultural organisations, and resources competition.

An Ecosystems Approach is a strategy for the integrated management of land, water and living resources which promotes conservation and sustainable use in an equitable way. Recognising that water is a cross-cutting resource, its effective utilisation is necessary not only for personal and domestic uses but also for the sustainability of the environment and its 
Realising the Right to Water and Sanitation in Nigeria

surrounding ecosystems for their consequential benefits. It has been shown that unsustainable extraction or consumption of water significantly impact on the life of the environment. The approach ensures that environmental needs and concerns are taken into consideration in the allocation and management of water resources. Several international legal instruments and domestic legislations imposed legal obligations to take environmental concerns into consideration when development projects have significant impacts on the environment and its surrounding ecosystem and to ensure vital ecosystems components are conserve for the present and future generations to guarantee sustainability. It is the approach adopted for the implementation of the Convention on Biological Diversity and twelve principles have been developed as guides to how ecosystems can be safeguarded. These principles hold potentials for Nigeria's water management and allocation. A State where the majority of the population is relying on surface and groundwater, unsustainable collection and extraction have significant impacts on the life of the environment and the ecosystems. There exists sufficient legal basis for the adoption of the approach in Nigeria as Nigeria has ratified several conventions and has adopted domestic legislations relating to environmental protection. The twelve principles can be applied in Nigeria mutatis mutandis to suit local and national circumstances. It is proposed that their application, monitoring and evaluation should be spearheaded by NESREA, an agency of the Federal Government with responsibility for the protection of the environment in conjunction with relevant stakeholders. Some of the challenges which may however be encountered include resistance to change especially from duty-bearers, government bureaucracy, political priorities, technical capacity, lack of ecological database, lack of valid and reliable hydrological database, high direct dependence on river without other possible options, institutional and policy challenges and lack of awareness about flows among the local population.

The combined application of a human rights-based approach and ecosystems approach has been advocated in many quotas including at the United Nations level which considers it an obligation on the part of States due to the nexus between human rights, ecosystems and biodiversity. The two approaches complement each other and provide a framework for the realisation of their promises. Ecosystems and biodiversity are undoubtedly connected to the realisation of several human rights including the rights to water, food, health, nondiscrimination, information, and participation. Human rights on the other hand strengthen protection to the services provided by the ecosystems and protect the rights of people in relations to environment, culture and resources.

\subsection{Recommendations}

Flowing from the findings of the research questions and connected issues several recommendations can be made to the stakeholders. These stakeholders are government, civil society organisations, general population, religious and traditional rulers, media and international and non-governmental organisations. 


\subsubsection{Government}

$$
\text { Chapter Ten }
$$

This is intended to refer to the three arms of government: The Executive, Legislature and the Judiciary. Additionally, it includes all the relevant agencies and institutions under them as pointed out below.

\section{A. Executive Arm}

i. Strengthening of agencies to ensure implementation of laws and policies especially those concerning water and sanitation and environmental protection through the provision of necessary financial resources and political backing. There should be effective prosecution of individuals and companies which violate or interfere with enjoyment of human rights and environmental protection.

ii. The Executive must realise and appropriately reflect the importance and position of water and sanitation in the development of a nation. Government at all levels should provide necessary political backing which will ensure that the legal and policy frameworks are properly adhered to. The most fundamental impediment hampering the performance of government agencies in the discharge of their duties is funding and associated issues. Notwithstanding that this problem is known, government does not seem to be responding appropriately to the need of the sector. As such, as a matter of priority, adequate budgetary provision is necessary to ensure compliance with obligation on the right to water and sanitation.

iii. Since release of funds appropriated has been identified as an impediment, Executive arm needs to adopt a policy of ensuring timely disbursement of funds to its agencies on periodic basis consistent with the nature of an agency to avoid delay in the execution of their mandates and to be able to respond to emergencies where necessary.

iv. While bureaucratic procedures are sometimes necessary to check the relevance and compliance of projects and programmes with government rules and policies, exceptions need to be made to certain critical agencies such as those dealing with lives and safety of the population. Opportunity needs to be given to such agencies as may be required to respond to emergencies without unnecessary bureaucratic delays.

v. Anti-corruption agencies need to be strengthened and removed from Executive interference to allow them to independently conduct investigation and prosecution consistent with their mandate and the rule of law. Closely connected to this is the adoption of a strong regulatory framework meant to deter corrupt practices among officials of government agencies and the adoption of targeted campaigns against corruption and corrupt practices and how these impact on economic and social lives of citizens in the most accessible media. Citizens should also be encouraged to report corrupt practices. Government may equally adopt whistleblowing programmes and incentives to the people who report corrupt practices in government.

vi. The national policies relevant to water and sanitation should be amended to reflect the contents of the right to water and sanitation as interpreted by the Committee on 
Realising the Right to Water and Sanitation in Nigeria

ESC rights with adequate provisions in terms of ensuring minimum daily supply, water pricing to ensure accessibility and affordability as well as protection of vulnerable population. By all means, the policies should not only consider water as an economic resource which must be adequately utilised but also reflect bottom-up approach where local communities are given greater roles to ensure sustainability and success.

vii. The adoption of a national policy to ensure the removal of discrimination and marginalisation in law and in fact in the work of all government agencies.

viii. The adoption of a national policy on the protection of vital ecosystems will boost agencies response and guide the adoption of appropriate measures to ensure that vital ecosystems are protected and preserved for their consequential benefits.

ix. Ensure greater public participation in the formulation and adoption of relevant policies to ensure that all concerns are addressed in a manner that balances competing interest especially on water and sanitation issues. This will help in achieving success in projects implementation.

x. Expand the mandate of Public Complaint Commission to have quasi-judicial powers to enable it address human rights violations including on ESC rights matters.

xi. Vigorously involve private corporate actors in water and sanitation sector and possibly liberalise the sector with adequate regulatory provisions to ensure efficient service delivery and protection of human rights.

xii. Seek international cooperation and assistance consistent with international obligation under the ICESCR where there are capacity and resources gaps.

xiii. Vigorous enforcement of legislation for the protection of endangered species not only for themselves but for their consequential benefits to humans and environment. This will further strengthen the adoption of an ecosystem approach.

Additionally, the following agencies equally need to adopt certain measures as stated below to facilitate realisation of the right to water and sanitation:

\section{Federal Ministry of Water Resources and States Ministry of Water Resources}

i. Adoption of management-oriented research and research-oriented management: there is the need for the Management to incorporate research in its policies and programmes and managers should acquaint themselves with research techniques so that the most urgently needed basic information is generated more quickly. This will address problems arising from implementation of decisions made without adequate data and information available.

ii. To address technical capacity, SWOT (Strengths, Weaknesses, Opportunities and Threats) analysis should to be conducted to identify the strengths and weaknesses of the institutions in order to chart a way for addressing such challenges. In the interim, the institutions should adopt training policy to guide how and when staff are to be trained to acquire additional knowledge and skills in improving their capacity. Institutions should develop appropriate motivation mechanisms consistent with public service rules to boost service delivery and reward outstanding staff. 
iii. Periodic trainings on water and sanitation issues tailored to addressing the needs of the sector should be developed in conjunction with National Water Resources Institute. Since recognition of water and sanitation as human rights requires building the capacity of duty-bearers to appreciate their duties and implications of their actions as may impinge on human rights, relevant periodic training on human rights should be organised in conjunction with National Human Rights Commission and civil society organisations. This will for example facilitate the removal of discrimination in the way and manner in which water and sanitation issues are handled by duty-bearers. Furthermore, clear guidelines on the expectations of each office are to be developed and staff are to be enabled to appreciate their job descriptions with adequate monitoring mechanisms to ensure compliance.

iv. Consistent with its role under the relevant water and sanitation policies, the Federal Ministry of Water Resources should establish an inter-agency standing committee comprising of relevant agencies from the Federal and States Government to address issues relating to coordination and sharing of information. Institutions should work with national and local potentials necessary for the realisation of the right to water and sanitation. These include religious and traditional leaders, youth organisations, civil society, media, human rights institutions and non-governmental organisations.

v. Adoption of a policy on water connection and distribution consistent with human rights obligations and human rights-based and ecosystem approaches.

vi. In order to protect ecosystems; observe strict implementation of Water Resources Act and Statutory Instrument 22 on permit and registration of boreholes; monitoring and enforcement of reasonable use; strict compliance with Environmental Impact Assessment requirements, ministries should consider creating a Unit which should be responsible for issuing appropriate licenses for boreholes and wells and enforcement of regulatory frameworks relating to water access, water extraction, water quality and quantity, and environmental protection.

vii. Ministries should adopt statistical approach to surface and groundwater consumption to assess the rate at which water is taken and the rate of recharge over period of time in order to determine sustainability of the rate of consumption.

viii. Ministries should consider adopting other measures such as pump taxes or quotas, designed to allow only safe-yield amount in order to ensure depletion does not become irreversible. Additionally, considering the vulnerability of both surface and groundwater due to multiple factors including over extraction, depletion, climate change etc., managing them in a sustainable manner would require conjunctive use approach wherein surface and groundwater are combined to achieve a greater benefit. Engineering mechanism should be utilised through which water surplus will be stored underground, recharging aquifers and enabling the environment to sustain its capacity to continue to provide its goods and services which are dependent on water availability.

ix. Ministries should consider licensing water trusts organisation and the adoption of appropriate method of ensuring minimum environmental flow. 
Realising the Right to Water and Sanitation in Nigeria

x. In the implementation and monitoring of water and sanitation projects, ministries are to allow residing ownership of the projects in communities with clearly defined responsibilities and methods of evaluation to ensure maintenance of water and sanitation facilities.

xi. To avoid discrimination in the provision of water and sanitation, ministries are to generate statistics to monitor coverage and assess factors which are likely to negatively impact on certain groups of people.

xii. To address poor cost recovery, institutions should adopt appropriate mechanism working in conjunction with judiciary such as the creation of a quasi-judicial mechanism to be empowered to prosecute defaulters especially those with capacity to pay. This requires the installation of consumption metres to ensure that people are not unfairly prejudiced.

\section{Federal Ministry of Environment, States Ministry of Environment}

i. Through an inter-agency standing committee, coordinate programmes on environmental sanitations throughout the country.

ii. Through NESREA coordinate the adoption of an ecosystems approach and lead an inter-agency standing committee that will monitor the application, monitoring and evaluation of the approach. work with local communities in identifying vital ecosystems to be protected.

iii. Design and disseminate environmental protection awareness campaigns to build support for sanitation and conservation and facilitate campaigns in conjunction with ministries of water resources regarding water safety especially in villages.

3. National Human Rights Commission, Public Complaint Commission and Human Rights Committees of National and States Assemblies

i. Coordinate the adoption of a human rights-based approach to the realisation of the right to water and sanitation.

ii. Provide necessary technical knowledge of human rights to duty-bearers in water and sanitation sector relevant to discharging their obligations. This should be done through training and retraining of relevant staff in water and sanitation ministries and agencies. Dialogues should be initiated towards overcoming resistance to the adoption of the approach. Capability should be improved towards responsible action and ways through which marginalisation and exclusion could be avoided in decisions and actions. Duty-bearers' approach to considering performance of obligations as a favour needs to be reversed. They need to be empowered to be able to appreciate the position of the population as rights-holders with a range of rights including right to be heard and right to participate in decision-making processes concerning their lives and dignity. Efforts should be made to link concrete issues such as water and sanitation to national and legal instruments to enable clear understanding.

iii. Vigorously continue to pursue the creation of necessary awareness of human rights, international and national legal obligations of Nigeria and roles of citizens in the 


$$
\text { Chapter Ten } \mid
$$

realisation of human rights. Awareness creation should include the indivisibility and interconnectivity of all human rights and target remote and marginalised areas. Campaign should include information on procedures for human rights claims and judicial and quasi-judicial mechanisms for human rights redress. In this regard, consider using media outlets including social media in reaching out to the population.

iv. Work with media organisations to strengthen their role in human rights promotion in order to make them more efficient, effective, responsive and to understand the implications of bias reporting on human rights issues.

v. Human rights committees of the national and states assemblies should strengthen their oversight functions on how human rights agencies are handling human rights complaints. They should equally facilitate the allocation of sufficient resources necessary to discharge their duties under the law.

vi. Facilitate the domestication of relevant international human rights instruments in accordance with constitutional requirement.

\section{National Water Resources Institute}

i. Develop necessary training programmes and courses to build the capacity of dutybearers in water sector consistent with existing and possible future impediments in the water and sanitation sector.

ii. Establish real time database with information and statistics on water consistent with their mandate and share with relevant government agencies to facilitate informed decisions.

\section{National Bureau of Statistics}

i. Lead in the generation of data and statistics on water and sanitation coverage and segregate statistics on grounds which will enable identification of discrimination and marginalisation.

ii. Work with relevant agencies from federal and state governments in building their capacity for data generation and interpretation and how to utilise such data in decision-making.

\section{B. Legislative Arm}

i. Immediate domestication of ICCPR and ICESCR to facilitate human rights claims and application of the instruments by domestic courts to guarantee and facilitate human rights realisation.

ii. Fast track the passing of National Water Resources Bill recognising water and sanitation as human rights with clear guidelines on their contents and necessary protection mechanism. The law should equally address issues connected to customary practices which interfere with enjoyment of the right to water and sanitation.

iii. Amend the Constitution to recognise and provide for the justiciability of ESC rights and removal of section $6(6)(\mathrm{c})$ of the Constitution. 
Realising the Right to Water and Sanitation in Nigeria

iv. Amend relevant legislations to empower Public Complaint Commission to have quasi-judicial powers on matters concerning $\mathrm{CP}$ and ESC rights and legal empowerment of human rights committees to entertain human rights complaints and make appropriate recommendations.

v. Amend legislations such as Petroleum Act and Oil Pipeline Act to remove interference with contents of the right to water and sanitation.

vi. Adopt a legislation that will provide religious and traditional leaders legal standing with defined roles including on ensuring human rights protection and promotion. This will provide the necessary mandate to relate with relevant duty-bearers in meeting the rights of their subjects.

\section{Judiciary}

i. Adopt purposive and integrative interpretation approaches to human rights instruments through the recognition of indivisibility and interconnectivity of all human rights. This can be done through borrowing from the jurisprudence of other jurisdictions such as India and Colombia as well as taking the opportunity to expand the scope of the ACHPR to cover other incidental rights including water and sanitation.

ii. Be judicially active in holding duty-bearers accountable to their international and national legal obligations on human rights. Judges should be active in utilising their powers for the betterment and protection of human rights by not strictly restricting themselves to the traditional or conservative approach to human rights issues especially in situations where human dignity is at stake.

iii. Continue to provide regular and appropriate human rights trainings/refreshers programmes to the judges at the States and national levels.

\subsubsection{Civil Society}

i. Advocate for the recognition of ESC rights including water and sanitation in legislative documents of the States.

ii. Obtain necessary knowledge about religious and cultural beliefs and their relationship with human rights issues in order to better appreciate how to advocate and campaign for human rights realisation to the general population.

iii. Through religious and cultural sensitivity, facilitate and conduct human rights awareness campaigns targeting most marginalised especially and linking concrete issues with human rights provisions. Enlighten the population about the human rights obligations of Nigeria, procedures for human rights claims, and mechanisms for the adjudication of human rights. Enlighten the population about human rights claims under the ACHPR and how it will help address critical human rights issues in their domains. Participation and understanding of human rights discourse by women, men, youth, and middle-age individuals will likely be smoother except that special attention be given to the elderly from the ages of 51 and above. In the selection of individuals on occupational basis, farmers (in the rural society), basic 


$$
\text { Chapter Ten }
$$

foundational approach to the understanding of human rights is to be adopted in bringing the level of understanding of the category to that of other occupations in the society.

iv. Create awareness on the recognition of the human right to water and sanitation and detail contents of the right to both duty-bearers and rights-holders.

v. Establish linkages and channels of communication with duty-bearers in water and sanitation sector to advocate the adoption of a human rights-based approach to the realisation of the human rights to water and sanitation. Strategies could include media campaign, political lobbying, and training of relevant stakeholders on human rights.

vi. Facilitate interaction between duty-bearers and rights-holders on water and sanitation issues and on the adoption of human rights-based and ecosystem approaches. Serve as facilitators advocating and building the capacity of rightsholders especially the marginalised and vulnerable to enable their voices to be heard.

vii. Enlighten the population about the role of demanding accountability from dutybearers in human rights realisation. With support from donors provide strategic trainings to build capacity, strengthens social identity, empowerment and selfesteem, improve negotiations power and ease rights claims. The Nigerian Bar Association collaborating with Legal aid workers may be more suitable to provide legal assistance and guidance in human rights claims.

viii. Liaise with duty-bearers and rights-holders to monitor and identify marginalised groups in the provision of water and sanitation and to campaign for their inclusion. This can be done through obtaining data and statistics and information concerning allocation of resources.

ix. Conduct public interest litigation on behalf of marginalised or discriminated groups on human rights issues including on water and sanitation.

x. Work with data drawn from empirical study to engage and support institutions in budgetary processes, planning, execution and monitoring of projects.

xi. Using Freedom of Information Act maintain necessary pressure on duty-bearers in combatting corruption and corrupt practices.

xii. Strengthen the role in monitoring periodic reports to treaty bodies and reports of special rapporteurs in keeping State authorities to their duties. In this light, the civil society should become fully aware of the treaties binding on Nigeria and the reports required to be submitted on periodic basis. The submission of shadow reports and monitoring of compliance with concluding observations is equally as important as the reports.

\subsubsection{General Population}

i. Appreciate and consider that water is not only social but also economic, and environmental resource with significant implications on human, country and the environment. As such wastage should be avoided and water is to be optimally utilised. 
Realising the Right to Water and Sanitation in Nigeria

ii. Learn about the content of the right to water and sanitation with a view to holding duty-bearers accountable to their obligation of compliance.

iii. Utilise the opportunities provided by the domestication of ACHPR in prosecuting ESC rights claims under the Charter and continue to explore the possibility of justiciability of other ESC rights (which have not been provided in other legislations) through claims linking them with justiciable rights under the Constitution.

iv. Strive to understand legal obligations of duty-bearers and demand accountability through direct contacts, media, religious and traditional rulers, civil society, youth leaders etc.

v. Research and academic community to continue to focus on research and writings on ESC rights and their implementation in Nigeria to increase awareness and momentum for their recognition as justiciable rights.

vi. Continue to explore and utilise ECOWAS Community Court of Justice and African Commission on Human Rights under the ACHPR ICCPR and ICESCR for prosecuting ESC rights claims including on access to water and sanitation.

\subsubsection{International and Donor Organisations}

i. International and donor organisations should focus attention to ways in which Nigeria can be supported to fulfil its international human rights obligations. This could be done in the form of Memorandum of Understanding between relevant government institutions and relevant international organisations, for example on capacity-building, participatory budgeting, networking and collaboration, dialogue on water allocation and distribution, enhancing sanitation, etc.

ii. To assist duty-bearers fulfil their human rights obligations, avoid using anecdote or vague moral arguments but rather use data in pointing out areas where improvements are needed.

iii. Support programmes which target reforms in the legal system, training of judicial officers on ESC rights and their interconnectivity with $\mathrm{CP}$ rights and approaches through which ESC rights may be given effect.

iv. Create direct link and interact with the affected population and the civil society organisations as essential partners in a bid to ensure the removal of all obstacles to marginalisation and discrimination. Programmes which aim at creating awareness of rights at the grassroots level should be supported.

v. Funded projects should reflect the fundamental role of human rights principles and standards and should ensure the active participation of the local structures in order to build trust and ownership which are necessary for infrastructural maintenance. 
TABLES AND FIGURES

\begin{tabular}{lll}
\hline States & State Capital & Local Government \\
Jigawa & Dutse & Babura \\
Kaduna & Kaduna & Giwa \\
Kano & Kano & Bunkure \\
Katsina & Katsina & Dutsin-Ma \\
Kebbi & Birnin Kebbi & Maiyama \\
Sokoto & Sokoto & Yabo \\
Zamfara & Gusau & Gummi \\
\hline
\end{tabular}

Table 1.1: Locations of Empirical Study

\begin{tabular}{llccc}
\hline & \multicolumn{3}{c}{ Type of Training } & Number of Training \\
& & $\mathbf{0}$ & $\mathbf{1 - 3}$ & $\mathbf{4 - 6}$ \\
1 & In-House & $60.32 \%$ & $38.10 \%$ & $1.59 \%$ \\
2 & National & $64.62 \%$ & $33.85 \%$ & $1.54 \%$ \\
3 & International & $90.63 \%$ & $9.38 \%$ & $0.00 \%$ \\
\hline
\end{tabular}

Table 3.1: Proportion of Response on Trainings on Water and Sanitation Between 2013-2015

\begin{tabular}{cccccc}
\hline Inefficient & $\begin{array}{c}\text { Somewhat } \\
\text { Inefficient }\end{array}$ & $\begin{array}{c}\text { Neither } \\
\text { Efficient nor } \\
\text { Inefficient } \\
14.29 \%\end{array}$ & $\begin{array}{c}\text { Somewhat } \\
\text { Efficient }\end{array}$ & Efficient & Very Efficient \\
$4.76 \%$ & $7.94 \%$ & $13.33 \%$ & $33.33 \%$ & $6.35 \%$ \\
\hline
\end{tabular}

Table 3.2: Perception of Efficiency of Equipment

\begin{tabular}{lcc}
\hline \multicolumn{1}{c}{ Stakeholders } & Water & Sanitation \\
Federal & $20 \%$ & $20 \%$ \\
States & $20 \%$ & $20 \%$ \\
Local Governments & $10 \%$ & $10 \%$ \\
Private Sector & $5 \%$ & $20 \%$ \\
Development Partners & $40 \%$ & $25 \%$ \\
Communities & $5 \%$ & $5 \%$ \\
\hline
\end{tabular}

Table 4.1: Funding Arrangement for Water and Sanitation in Water and Sanitation Roadmap 2016-2030

\begin{tabular}{cl}
\hline \multicolumn{1}{c}{ Year } & \multicolumn{1}{c}{ Target } \\
2007 & Improve coverage of sanitation to $60 \%$ of the population \\
2010 & Extension of sanitation coverage to $65 \%$ of the population \\
2015 & Extension of sanitation coverage to $80 \%$ of the population \\
2020 & Extension of sanitation coverage to $90 \%$ of the population \\
2025 & Achieve and sustain 100\% sanitation coverage of the population \\
\hline
\end{tabular}

Table 4.2: Sanitation Policy Target 
Realising the Right to Water and Sanitation in Nigeria

\begin{tabular}{llllllll}
\hline S/N & $\begin{array}{c}\text { Water } \\
\text { Sources }\end{array}$ & Never & $\begin{array}{c}\text { Almost } \\
\text { Never }\end{array}$ & Sometimes & $\begin{array}{r}\text { Fairly } \\
\text { Often }\end{array}$ & $\begin{array}{r}\text { Very } \\
\text { Often }\end{array}$ & Always \\
1 & Personal Tap & $29.00 \%$ & $7.36 \%$ & $17.96 \%$ & $9.48 \%$ & $14.14 \%$ & $22.07 \%$ \\
2 & Public Tap & $26.32 \%$ & $9.30 \%$ & $19.46 \%$ & $12.16 \%$ & $16.74 \%$ & $16.02 \%$ \\
3 & $\begin{array}{l}\text { Public } \\
\text { borehole }\end{array}$ & $36.50 \%$ & $5.34 \%$ & $18.55 \%$ & $8.75 \%$ & $13.20 \%$ & $17.66 \%$ \\
4 & $\begin{array}{l}\text { Personal } \\
\text { borehole }\end{array}$ & $74.36 \%$ & $4.07 \%$ & $3.32 \%$ & $2.26 \%$ & $4.83 \%$ & $11.16 \%$ \\
5 & Vendor & $26.54 \%$ & $6.16 \%$ & $29.03 \%$ & $12.90 \%$ & $9.97 \%$ & $15.40 \%$ \\
6 & River & $80.82 \%$ & $8.16 \%$ & $4.68 \%$ & $3.02 \%$ & $1.06 \%$ & $2.27 \%$ \\
7 & Pond & $85.41 \%$ & $6.02 \%$ & $3.91 \%$ & $1.35 \%$ & $0.75 \%$ & $2.56 \%$ \\
8 & Well & $42.88 \%$ & $4.26 \%$ & $14.54 \%$ & $5.73 \%$ & $7.20 \%$ & $25.40 \%$ \\
9 & Other & $89.80 \%$ & $2.72 \%$ & $3.17 \%$ & $0.68 \%$ & $0.68 \%$ & $2.95 \%$ \\
\hline
\end{tabular}

Table 4.3: Water Sources and Frequency of Utilisation in Nigeria

\begin{tabular}{|c|c|}
\hline Perception of Water Quality & Response Rate \\
\hline Yes & $72.86 \%$ \\
\hline No & $5.27 \%$ \\
\hline To some extent & $21.87 \%$ \\
\hline
\end{tabular}

Table 4.4: Respondents (General Population) Perception of Water Quality

\begin{tabular}{lc}
\hline \multicolumn{1}{c}{ Distance } & Response Rate \\
Less than one kilometre & $79.89 \%$ \\
One kilometre & $15.25 \%$ \\
More than one kilometre & $4.86 \%$ \\
& \\
$0-15$ minutes & \\
$15-30$ minutes & $59.63 \%$ \\
30-60 minutes & $31.08 \%$ \\
More than 60 minutes & $6.77 \%$ \\
\hline
\end{tabular}

Table 4.5: Distance and Time to a Water Source

Spending (Naira)

0

$1-100$

$101-200$

201-300

More than 300

\section{Percentage of Respondents}

$30.79 \%$

$35.13 \%$

$19.87 \%$

$8.55 \%$

$5.66 \%$

Table 4.6: Daily Spending on Water Supply from Water Vendors 
Table and Figures

\begin{tabular}{lccccccccc}
\hline $\begin{array}{c}\text { Amount } \\
\text { (Naira) }\end{array}$ & CS & PS & F & SE & HW & R & S & U & Other \\
0 & $30.50 \%$ & $22.97 \%$ & $48.39 \%$ & $31.11 \%$ & $18.60 \%$ & $0.00 \%$ & $34.01 \%$ & $30.95 \%$ & $33.33 \%$ \\
$1-100$ & $39.50 \%$ & $36.49 \%$ & $32.26 \%$ & $37.78 \%$ & $34.88 \%$ & $66.67 \%$ & $33.20 \%$ & $21.43 \%$ & $27.78 \%$ \\
$101-200$ & $20.00 \%$ & $18.92 \%$ & $16.13 \%$ & $16.67 \%$ & $23.26 \%$ & $0.00 \%$ & $19.43 \%$ & $23.81 \%$ & $27.78 \%$ \\
$201-300$ & $6.00 \%$ & $10.81 \%$ & $3.23 \%$ & $7.78 \%$ & $18.60 \%$ & $33.33 \%$ & $7.29 \%$ & $16.67 \%$ & $5.56 \%$ \\
Over & $4.00 \%$ & $10.81 \%$ & $0.00 \%$ & $6.67 \%$ & $4.65 \%$ & $0.00 \%$ & $6.07 \%$ & $7.14 \%$ & $5.56 \%$ \\
300 & & & & & & & & &
\end{tabular}

Table 4.7: Daily Spending on Water by Profession

\begin{tabular}{c|c|c|c|c|c|c|c|c} 
Key & CS & PS & F & SE & HW & R & S & U \\
\hline & Civil & Private & Farmers & Self \\
Servants & Sector & & Housewives & Retired & Students & Unemployed
\end{tabular}

\begin{tabular}{|c|c|c|c|c|c|}
\hline $\begin{array}{c}\text { Source of } \\
\text { Complaint }\end{array}$ & $\begin{array}{c}\text { Not } \\
\text { Frequent }\end{array}$ & $\begin{array}{c}\text { Somewhat not } \\
\text { Frequent }\end{array}$ & $\begin{array}{l}\text { Neither Frequent } \\
\text { nor Infrequent }\end{array}$ & $\begin{array}{c}\text { Somewhat } \\
\text { Frequent }\end{array}$ & Frequent \\
\hline $\begin{array}{l}\text { Rural } \\
\text { Population }\end{array}$ & $6.45 \%$ & $16.13 \%$ & $6.45 \%$ & $51.61 \%$ & $19.35 \%$ \\
\hline $\begin{array}{l}\text { Urban } \\
\text { Population }\end{array}$ & $15.25 \%$ & $20.34 \%$ & $5.08 \%$ & $23.73 \%$ & $35.59 \%$ \\
\hline $\begin{array}{l}\text { Traditional } \\
\text { Rulers }\end{array}$ & $17.24 \%$ & $15.52 \%$ & $13.79 \%$ & $37.93 \%$ & $15.52 \%$ \\
\hline Politicians & $20.69 \%$ & $17.24 \%$ & $12.07 \%$ & $18.97 \%$ & $31.03 \%$ \\
\hline Civil Society & $29.41 \%$ & $13.73 \%$ & $13.73 \%$ & $31.37 \%$ & $11.76 \%$ \\
\hline \multicolumn{6}{|c|}{ Table 4.8: Proportion of Complaints Received by Duty-Bearers on Water and Sanitation from 2012-2015 } \\
\hline \multicolumn{3}{|c|}{ Awareness of the Sources } & Males & \multicolumn{2}{|c|}{ Females } \\
\hline \multicolumn{2}{|c|}{ Yes } & \multicolumn{2}{|r|}{$63.32 \%$} & \multicolumn{2}{|c|}{$53.06 \%$} \\
\hline \multicolumn{2}{|l|}{ No } & \multicolumn{2}{|r|}{$24.90 \%$} & \multicolumn{2}{|c|}{$37.55 \%$} \\
\hline \multicolumn{2}{|c|}{ Do no care } & \multicolumn{2}{|r|}{$11.78 \%$} & \multicolumn{2}{|c|}{$9.39 \%$} \\
\hline \multicolumn{6}{|c|}{ Utilisation of the Sources } \\
\hline \multicolumn{2}{|c|}{ Yes } & \multicolumn{2}{|r|}{$41.62 \%$} & \multicolumn{2}{|c|}{$27.46 \%$} \\
\hline \multicolumn{2}{|l|}{ No } & \multicolumn{2}{|r|}{$48.94 \%$} & \multicolumn{2}{|c|}{$61.07 \%$} \\
\hline \multicolumn{2}{|l|}{ Do not care } & \multicolumn{2}{|r|}{$9.44 \%$} & \multicolumn{2}{|c|}{$11.48 \%$} \\
\hline
\end{tabular}

Table 4.9: Awareness and Utilisation of Sources of Information by Gender

\begin{tabular}{lccc}
\hline & Yes & No & Not Always \\
Duty-Bearers & $39.68 \%$ & $47.62 \%$ & $12.70 \%$ \\
Rights-Holders & $34.05 \%$ & $65.95 \%$ & \\
\hline
\end{tabular}

Table 4.10: Involvement and Participation of Local Population in Water and Sanitation Projects

\begin{tabular}{lcc}
\hline & Yes & No \\
Males & $36.22 \%$ & $63.78 \%$ \\
Females & $29.75 \%$ & $70.25 \%$ \\
\hline
\end{tabular}

Table 4.11: Gender Response on Right-Holders' Involvement and Participation 
Realising the Right to Water and Sanitation in Nigeria

\begin{tabular}{lccc}
\hline \multicolumn{1}{c}{ Discrimination and Marginalisation } & \multicolumn{3}{c}{ Percentage } \\
Awareness of Meaning & Yes & No & Do not know \\
Duty-Bearers & $96.72 \%$ & $3.28 \%$ & \\
Rights-Holders & $79.11 \%$ & $20.89 \%$ & \\
Existence of Marginalised Groups & & & $0 \%$ \\
Duty-Bearers & $53.97 \%$ & $46.03 \%$ & $26.85 \% 0 \%$ \\
Rights-Holders & $57.33 \%$ & $15.82 \%$ & $0 \%$ \\
Civil Society Organisations & $100 \%$ & $0 \%$ & \\
\hline
\end{tabular}

Table 4.12: Discrimination: Awareness of Marginalised Groups and Existence

\begin{tabular}{lrrrrr}
\hline Reason & $\begin{array}{r}\text { Strongly } \\
\text { Agree }\end{array}$ & Agree & $\begin{array}{r}\text { Neither Agree nor } \\
\text { Disagree }\end{array}$ & Disagree & $\begin{array}{r}\text { Strongly } \\
\text { Disagree }\end{array}$ \\
$\begin{array}{l}\text { Distance } \\
\text { Inaccessibility }\end{array}$ & $24.47 \%$ & $19.41 \%$ & $14.00 \%$ & $14.99 \%$ & $21.13 \%$ \\
$\begin{array}{l}\text { Population } \\
\text { Number }\end{array}$ & $11.78 \%$ & $16.49 \%$ & $15.44 \%$ & $18.99 \%$ & $19.75 \%$ \\
Social Status & $14.93 \%$ & $17.16 \%$ & $21.20 \%$ & $25.65 \%$ & $24.87 \%$ \\
Disability & $8.85 \%$ & $10.19 \%$ & $22.89 \%$ & $23.38 \%$ & $21.64 \%$ \\
Gender & $6.34 \%$ & $9.37 \%$ & $26.81 \%$ & $30.83 \%$ & $23.32 \%$ \\
Other & $55.95 \%$ & $11.62 \%$ & $27.82 \%$ & $30.58 \%$ & $25.90 \%$ \\
\hline
\end{tabular}

Table 4.13: Possible Reasons for Discrimination and or Margination (Population)

\begin{tabular}{lccc}
\hline Reasons & Yes & Maybe & No \\
Distance & $50.00 \%$ & $25.00 \%$ & $25.00 \%$ \\
Inaccessibility & $75.00 \%$ & $0.00 \%$ & $25.00 \%$ \\
Number of the Population & $50.00 \%$ & $0.00 \%$ & $50.00 \%$ \\
Social Status & $60.00 \%$ & $20.00 \%$ & $20.00 \%$ \\
Economic Status & $80.00 \%$ & $0.00 \%$ & $20.00 \%$ \\
Other(s) & $66.67 \%$ & $33.33 \%$ & $0.00 \%$ \\
\hline
\end{tabular}

Table 4.14: Possible Reasons for Discrimination and or Marginalisation (CSOs)

\begin{tabular}{|c|c|c|c|c|c|c|c|}
\hline $\mathbf{S} / \mathbf{N}$ & Factor & I & SI & NSNI & SS & $\mathbf{S}$ & VS \\
\hline 1 & Distance & $11.48 \%$ & $4.92 \%$ & $9.84 \%$ & $19.67 \%$ & $31.15 \%$ & $22.95 \%$ \\
\hline 2 & Population Size & $3.28 \%$ & $3.28 \%$ & $3.28 \%$ & $9.84 \%$ & $34.43 \%$ & $45.90 \%$ \\
\hline 3 & Social Status & $26.23 \%$ & $3.28 \%$ & $13.11 \%$ & $16.39 \%$ & $27.87 \%$ & $13.11 \%$ \\
\hline 4 & Accessibility & $8.20 \%$ & $4.92 \%$ & $9.84 \%$ & $29.51 \%$ & $32.79 \%$ & $14.75 \%$ \\
\hline 5 & Economic Activities & $11.48 \%$ & $3.28 \%$ & $11.48 \%$ & $24.59 \%$ & $34.43 \%$ & $14.75 \%$ \\
\hline 6 & Economic Status & $22.95 \%$ & $9.84 \%$ & $14.75 \%$ & $14.75 \%$ & $19.67 \%$ & $18.03 \%$ \\
\hline 7 & Others & $14.63 \%$ & $4.88 \%$ & $39.02 \%$ & $19.51 \%$ & $12.20 \%$ & $9.76 \%$ \\
\hline
\end{tabular}

Table 4.15: Factors Impacting on Water Connection and Allocation

\begin{tabular}{c|c|c|c|c|c|c} 
Key & I & SI & NSNI & SS & S & VS \\
\hline & Insignificant & Somewhat & Neither & Somewhat & Significant & Very \\
& & Insignificant & Significant & Significant & & Significant \\
& & & nor \\
& & & & &
\end{tabular}


Table and Figures

\begin{tabular}{|c|c|c|}
\hline \multirow[t]{9}{*}{ SDG GOAL 6} & TARGETS & INDICATORS \\
\hline & $\begin{array}{l}\text { 6.1 } \\
\text { By 2030, achieve universal and } \\
\text { equitable access to safe and } \\
\text { affordable drinking water for all }\end{array}$ & $\begin{array}{l}\text { 6.1.1 } \\
\text { Proportion of population using } \\
\text { safely managed drinking water } \\
\text { services }\end{array}$ \\
\hline & $\begin{array}{l}6.2 \\
\text { By 2030, achieve access to } \\
\text { adequate and equitable sanitation } \\
\text { and hygiene for all and end open } \\
\text { defecation, paying special attention } \\
\text { to the needs of women and girls and } \\
\text { those in vulnerable situations }\end{array}$ & $\begin{array}{l}\text { 6.2.1 } \\
\text { Proportion of population using } \\
\text { safely managed sanitation services, } \\
\text { including a hand-washing facility } \\
\text { with soap and water }\end{array}$ \\
\hline & $\begin{array}{l}\mathbf{6 . 3} \\
\text { By } 2030 \text {, improve water quality by } \\
\text { reducing pollution, eliminating } \\
\text { dumping and minimizing release of } \\
\text { hazardous chemicals and materials, } \\
\text { halving the proportion of untreated } \\
\text { wastewater and substantially } \\
\text { increasing recycling and safe reuse } \\
\text { globally }\end{array}$ & $\begin{array}{l}\text { 6.3.1 } \\
\text { Proportion of wastewater safely } \\
\text { treated } \\
\text { 6.3.2 } \\
\text { Proportion of bodies of water with } \\
\text { good ambient water quality }\end{array}$ \\
\hline & $\begin{array}{l}\text { 6.4 } \\
\text { By 2030, substantially increase } \\
\text { water-use efficiency across all } \\
\text { sectors and ensure sustainable } \\
\text { withdrawals and supply of } \\
\text { freshwater to address water scarcity } \\
\text { and substantially reduce the number } \\
\text { of people suffering from water } \\
\text { scarcity }\end{array}$ & $\begin{array}{l}\text { 6.4.1 } \\
\text { Change in water-use efficiency over } \\
\text { time } \\
\text { 6.4.2 } \\
\text { Level of water stress: freshwater } \\
\text { withdrawal as a proportion of } \\
\text { available freshwater resources }\end{array}$ \\
\hline & $\begin{array}{l}\mathbf{6 . 5} \\
\text { By 2030, implement integrated } \\
\text { water resources management at all } \\
\text { levels, including through } \\
\text { transboundary cooperation as } \\
\text { appropriate }\end{array}$ & $\begin{array}{l}\text { 6.5.1 } \\
\text { Degree of integrated water } \\
\text { resources management } \\
\text { implementation }(0-100) \\
\text { 6.5.2 } \\
\text { Proportion of transboundary basin } \\
\text { area with an operational } \\
\text { arrangement for water cooperation }\end{array}$ \\
\hline & $\begin{array}{l}\mathbf{6 . 6} \\
\text { By 2020, protect and restore water- } \\
\text { related ecosystems, including } \\
\text { mountains, forests, wetlands, } \\
\text { rivers, aquifers and lakes }\end{array}$ & $\begin{array}{l}\text { 6.6.1 } \\
\text { Change in the extent of water- } \\
\text { related ecosystems over time }\end{array}$ \\
\hline & $\begin{array}{l}\text { 6.A } \\
\text { By 2030, expand international } \\
\text { cooperation and capacity-building } \\
\text { support to developing countries in } \\
\text { water- and sanitation-related } \\
\text { activities and programmes, } \\
\text { including water harvesting, } \\
\text { desalination, water efficiency, } \\
\text { wastewater treatment, recycling } \\
\text { and reuse technologies }\end{array}$ & $\begin{array}{l}\text { 6.A.1 } \\
\text { Amount of water- and sanitation- } \\
\text { related official development } \\
\text { assistance that is part of a } \\
\text { government-coordinated spending } \\
\text { plan }\end{array}$ \\
\hline & $\begin{array}{l}\text { 6.B } \\
\text { Support and strengthen the } \\
\text { participation of local communities } \\
\text { in improving water and sanitation } \\
\text { management }\end{array}$ & $\begin{array}{l}\text { 6.B.1 } \\
\text { Proportion of local administrative } \\
\text { units with established and } \\
\text { operational policies and procedures } \\
\text { for participation of local } \\
\text { communities in water and sanitation } \\
\text { management }\end{array}$ \\
\hline
\end{tabular}


Realising the Right to Water and Sanitation in Nigeria

\begin{tabular}{|c|c|c|c|}
\hline \multicolumn{2}{|c|}{ Duty-Bearers } & \multicolumn{2}{|c|}{ Rights-Holders } \\
\hline Gender & & Gender & \\
\hline Males & $89.23 \%$ & Males & $67.97 \%$ \\
\hline Females & $10.77 \%$ & Females & $32.09 \%$ \\
\hline Age Group & & Age Group & \\
\hline $18-24$ & $1.59 \%$ & $18-24$ & $31.44 \%$ \\
\hline $25-40$ & $15.87 \%$ & $25-40$ & $47.61 \%$ \\
\hline $41-50$ & $47.62 \%$ & $41-50$ & $15.39 \%$ \\
\hline $51+$ & $33.33 \%$ & $51+$ & $3.49 \%$ \\
\hline \multirow[t]{2}{*}{ Not Mentioned } & $1.59 \%$ & Not Known & $1.03 \%$ \\
\hline & & Not Mentioned & $1.03 \%$ \\
\hline Education & & Marital Status & \\
\hline Secondary & $1.56 \%$ & Single & $48.05 \%$ \\
\hline Diploma & $17.19 \%$ & Married & $48.57 \%$ \\
\hline Bachelor & $32.81 \%$ & Widow/Widower & $1.04 \%$ \\
\hline$P G D$ & $25.00 \%$ & Divorced & $1.04 \%$ \\
\hline Masters & $17.19 \%$ & Other & $1.30 \%$ \\
\hline Others & $6.25 \%$ & & \\
\hline Administrative Level & & Religious Belief & \\
\hline Senior Staff & $60.00 \%$ & Islam & $84.42 \%$ \\
\hline \multirow[t]{2}{*}{ Management Staff } & $40.00 \%$ & Christianity & $13.22 \%$ \\
\hline & & Not Mentioned & $2.36 \%$ \\
\hline Duration & & Education & \\
\hline 1.3 Years & $3.08 \%$ & Primary & $7.06 \%$ \\
\hline 4-7 Years & $13.85 \%$ & Secondary & $32.55 \%$ \\
\hline \multirow[t]{16}{*}{$7+$ Years } & $83.08 \%$ & Diploma & $28.63 \%$ \\
\hline & & Bachelor & $17.65 \%$ \\
\hline & & $P G D$ & $2.88 \%$ \\
\hline & & Masters & $1.96 \%$ \\
\hline & & $P h D$ & $0.26 \%$ \\
\hline & & Others & $9.02 \%$ \\
\hline & & Occupation & \\
\hline & & Civil Servants & $27.06 \%$ \\
\hline & & Private Sector & $9.67 \%$ \\
\hline & & Farmers & $4.05 \%$ \\
\hline & & Self-Employed & $11.90 \%$ \\
\hline & & Housewives & $5.75 \%$ \\
\hline & & Retired & $0.39 \%$ \\
\hline & & Students & $33.07 \%$ \\
\hline & & Unemployed & $5.62 \%$ \\
\hline & & Others & $2.48 \%$ \\
\hline
\end{tabular}

Table 5.1: Demographics of the Respondents (Duty-Bearers and Rights-Holders) 
Table and Figures

\begin{tabular}{|c|c|c|c|c|c|}
\hline \multirow[t]{2}{*}{ Variables } & \multicolumn{3}{|c|}{ Awareness of Human Rights } & \multicolumn{2}{|c|}{ Awareness of the Right to Water } \\
\hline & Yes & No & $\begin{array}{c}\text { Do not } \\
\text { care }\end{array}$ & Yes & No \\
\hline General & $87.95 \%$ & $9.20 \%$ & $2.85 \%$ & $74.77 \%$ & $25.23 \%$ \\
\hline \multicolumn{6}{|l|}{ Gender } \\
\hline Males & $87.76 \%$ & $8.60 \%$ & $3.64 \%$ & $76.79 \%$ & $23.21 \%$ \\
\hline Females & $88.31 \%$ & $10.48 \%$ & $1.21 \%$ & $70.78 \%$ & $29.22 \%$ \\
\hline \multicolumn{6}{|l|}{ Age Group } \\
\hline $18-24$ & $89.21 \%$ & $9.54 \%$ & $1.25 \%$ & $68.91 \%$ & $31.09 \%$ \\
\hline $25-40$ & $88.52 \%$ & $7.92 \%$ & $3.56 \%$ & $77.35 \%$ & $22.65 \%$ \\
\hline $41-50$ & $92.37 \%$ & $5.94 \%$ & $1.69 \%$ & $80.87 \%$ & $19.13 \%$ \\
\hline $51+$ & $59.26 \%$ & $29.63 \%$ & $11.11 \%$ & $69.23 \%$ & $30.77 \%$ \\
\hline \multicolumn{6}{|l|}{ Education } \\
\hline Primary & $71.70 \%$ & $18.87 \%$ & $9.43 \%$ & $77.78 \%$ & $22.22 \%$ \\
\hline Secondary & $85.08 \%$ & $13.31 \%$ & $1.61 \%$ & $72.65 \%$ & $27.35 \%$ \\
\hline Diploma & $95.87 \%$ & $3.21 \%$ & $0.92 \%$ & $77.67 \%$ & $22.33 \%$ \\
\hline Bachelor & $91.73 \%$ & $5.26 \%$ & $3.01 \%$ & $76.92 \%$ & $23.08 \%$ \\
\hline$P G D$ & $100.00 \%$ & $0.00 \%$ & $0.00 \%$ & $77.27 \%$ & $22.73 \%$ \\
\hline Masters & $100.00 \%$ & $0.00 \%$ & $0.00 \%$ & $85.71 \%$ & $14.29 \%$ \\
\hline$P h D$ & $100.00 \%$ & $0.00 \%$ & $0.00 \%$ & $100.00 \%$ & $0.00 \%$ \\
\hline Others & $75.36 \%$ & $15.94 \%$ & $8.70 \%$ & $61.19 \%$ & $38.81 \%$ \\
\hline \multicolumn{6}{|l|}{ Occupation } \\
\hline Civil Servants & $91.67 \%$ & $6.37 \%$ & $1.96 \%$ & $81.68 \%$ & $18.32 \%$ \\
\hline Private Sector & $91.89 \%$ & $2.70 \%$ & $5.41 \%$ & $73.97 \%$ & $26.03 \%$ \\
\hline Farming & $61.29 \%$ & $25.81 \%$ & $12.90 \%$ & $58.06 \%$ & $41.94 \%$ \\
\hline Self-Employed & $81.32 \%$ & $14.29 \%$ & $4.40 \%$ & $75.28 \%$ & $24.72 \%$ \\
\hline Housewives & $88.64 \%$ & $11.36 \%$ & $0.00 \%$ & $79.07 \%$ & $20.93 \%$ \\
\hline Retired & $100.00 \%$ & $0.00 \%$ & $0.00 \%$ & $100.00 \%$ & $0.00 \%$ \\
\hline Students & $90.04 \%$ & $8.76 \%$ & $1.20 \%$ & $70.80 \%$ & $29.20 \%$ \\
\hline Unemployed & $81.40 \%$ & $11.63 \%$ & $6.98 \%$ & $76.19 \%$ & $23.81 \%$ \\
\hline Others & $94.74 \%$ & $5.26 \%$ & $0.00 \%$ & $66.67 \%$ & $33.33 \%$ \\
\hline
\end{tabular}

Table 5.2: Awareness of Human Rights and the Right to Water and Sanitation (Rights-Holders)

\begin{tabular}{lccccccc}
\hline \multicolumn{1}{c}{ Rights } & $\begin{array}{c}\text { Very } \\
\text { Unlikely }\end{array}$ & Unlikely & $\begin{array}{c}\text { Response } \\
\text { Somewhat } \\
\text { Unlikely }\end{array}$ & Undecided & $\begin{array}{c}\text { Somewhat } \\
\text { Likely }\end{array}$ & Likely & $\begin{array}{c}\text { Very } \\
\text { Likely }\end{array}$ \\
Food & $9.51 \%$ & $8.32 \%$ & $3.70 \%$ & $11.76 \%$ & $8.06 \%$ & $19.68 \%$ & $38.97 \%$ \\
Housing & $10.23 \%$ & $7.37 \%$ & $3.00 \%$ & $15.42 \%$ & $8.19 \%$ & $21.83 \%$ & $33.97 \%$ \\
Water & $6.90 \%$ & $7.03 \%$ & $4.00 \%$ & $17.10 \%$ & $7.03 \%$ & $20.00 \%$ & $37.93 \%$ \\
Clean & $6.65 \%$ & $7.34 \%$ & $3.60 \%$ & $19.81 \%$ & $9.14 \%$ & $22.44 \%$ & $31.02 \%$ \\
Environment & & & & & & & \\
Work & $7.21 \%$ & $6.53 \%$ & $3.27 \%$ & $19.18 \%$ & $10.61 \%$ & $21.63 \%$ & $31.56 \%$ \\
Health & $5.14 \%$ & $5.28 \%$ & $2.71 \%$ & $15.97 \%$ & $8.53 \%$ & $20.70 \%$ & $41.68 \%$ \\
\hline
\end{tabular}

Table 5.3: Ranking of Critical ESC Rights on Likelihood of Asserting Legal Claim 


\begin{tabular}{|c|c|c|c|}
\hline \multirow[t]{2}{*}{ Variables } & \multicolumn{3}{|c|}{ Awareness } \\
\hline & Yes & No & Do not care \\
\hline General & $72.87 \%$ & $20.45 \%$ & $6.68 \%$ \\
\hline \multicolumn{4}{|l|}{ Gender } \\
\hline Males & $73.60 \%$ & $19.46 \%$ & $6.94 \%$ \\
\hline Females & $71.60 \%$ & $22.22 \%$ & $6.17 \%$ \\
\hline \multicolumn{4}{|l|}{ Age Group } \\
\hline $18-24$ & $71.85 \%$ & $22.27 \%$ & $5.88 \%$ \\
\hline $25-40$ & $72.70 \%$ & $20.33 \%$ & $6.96 \%$ \\
\hline $41-50$ & $78.99 \%$ & $16.81 \%$ & $4.20 \%$ \\
\hline $51+$ & $62.96 \%$ & $25.93 \%$ & $11.11 \%$ \\
\hline \multicolumn{4}{|l|}{ Education } \\
\hline Primary & $59.62 \%$ & $28.85 \%$ & $11.54 \%$ \\
\hline Secondary & $69.51 \%$ & $23.17 \%$ & $7.32 \%$ \\
\hline Diploma & $78.24 \%$ & $16.67 \%$ & $5.09 \%$ \\
\hline Bachelor & $73.08 \%$ & $18.46 \%$ & $8.46 \%$ \\
\hline$P G D$ & $90.91 \%$ & $9.09 \%$ & $0.00 \%$ \\
\hline Masters & $93.33 \%$ & $6.67 \%$ & $0.00 \%$ \\
\hline$P h D$ & $100.00 \%$ & $0.00 \%$ & $0.00 \%$ \\
\hline Others & $69.12 \%$ & $25.00 \%$ & $5.88 \%$ \\
\hline \multicolumn{4}{|l|}{ Occupation } \\
\hline Civil Servants & $78.00 \%$ & $16.50 \%$ & $5.50 \%$ \\
\hline Private Sector & $67.57 \%$ & $20.27 \%$ & $12.16 \%$ \\
\hline Farming & $35.48 \%$ & $32.26 \%$ & $32.26 \%$ \\
\hline Self-Employed & $68.13 \%$ & $23.08 \%$ & $8.79 \%$ \\
\hline Housewives & $72.09 \%$ & $25.58 \%$ & $2.33 \%$ \\
\hline Retired & $100.00 \%$ & $0.00 \%$ & $0.00 \%$ \\
\hline Students & $76.61 \%$ & $18.95 \%$ & $4.44 \%$ \\
\hline Unemployed & $64.29 \%$ & $33.33 \%$ & $2.38 \%$ \\
\hline Others & $78.95 \%$ & $21.05 \%$ & $0.00 \%$ \\
\hline
\end{tabular}

Table 5.4: Awareness of How to Claim ESC Rights 
Table and Figures

\begin{tabular}{|c|c|c|c|c|c|c|c|}
\hline \multirow[t]{2}{*}{ Variables } & \multicolumn{7}{|c|}{ Likelihood of Litigating } \\
\hline & \multirow{2}{*}{$\begin{array}{c}\text { Very } \\
\text { Unlikely } \\
6.90 \%\end{array}$} & Unlikely & Somewhat & Undecided & \multicolumn{2}{|c|}{$\begin{array}{c}\text { Somewhat Lik } \\
\text { Likely }\end{array}$} & \multirow{2}{*}{$\begin{array}{r}\text { Very } \\
\text { Likely } \\
37.93 \%\end{array}$} \\
\hline General & & $7.03 \%$ & $4.00 \%$ & $17.10 \%$ & $7.03 \%$ & $20.00 \%$ & \\
\hline \multicolumn{8}{|l|}{ Gender } \\
\hline Males & $8.03 \%$ & $6.02 \%$ & $3.21 \%$ & $17.87 \%$ & $7.03 \%$ & $18.67 \%$ & $39.17 \%$ \\
\hline Females & $4.42 \%$ & $9.29 \%$ & $5.75 \%$ & $15.49 \%$ & $7.08 \%$ & $22.57 \%$ & $35.40 \%$ \\
\hline \multicolumn{8}{|l|}{ Age Group } \\
\hline $18-24$ & $7.39 \%$ & $7.83 \%$ & $5.65 \%$ & $17.39 \%$ & $5.65 \%$ & $13.91 \%$ & $42.18 \%$ \\
\hline $25-40$ & $5.64 \%$ & $4.75 \%$ & $3.26 \%$ & $18.99 \%$ & $7.42 \%$ & $24.93 \%$ & $35.01 \%$ \\
\hline $41-50$ & $6.90 \%$ & $10.34 \%$ & $2.59 \%$ & $10.34 \%$ & $10.34 \%$ & $18.10 \%$ & $41.39 \%$ \\
\hline $51+$ & $15.38 \%$ & $7.69 \%$ & $3.85 \%$ & $15.38 \%$ & $0.00 \%$ & $26.92 \%$ & $30.78 \%$ \\
\hline \multicolumn{8}{|l|}{ Marital Status } \\
\hline Single & $7.74 \%$ & $7.16 \%$ & $4.30 \%$ & $21.49 \%$ & $4.87 \%$ & $15.76 \%$ & $38.68 \%$ \\
\hline Married & $5.54 \%$ & $6.41 \%$ & $4.08 \%$ & $13.70 \%$ & $8.75 \%$ & $23.91 \%$ & $37.61 \%$ \\
\hline Widow(er) & $0.00 \%$ & $25.00 \%$ & $0.00 \%$ & $0.00 \%$ & $12.50 \%$ & $25.00 \%$ & $37.50 \%$ \\
\hline Divorced & $14.29 \%$ & $0.00 \%$ & $0.00 \%$ & $14.29 \%$ & $14.29 \%$ & $28.57 \%$ & $28.57 \%$ \\
\hline Others & $20.00 \%$ & $10.00 \%$ & $0.00 \%$ & $10.00 \%$ & $10.00 \%$ & $20.00 \%$ & $30.00 \%$ \\
\hline \multicolumn{8}{|l|}{ Religious Belief } \\
\hline Islam & $6.52 \%$ & $7.36 \%$ & $3.51 \%$ & $18.06 \%$ & $7.02 \%$ & $20.40 \%$ & $37.13 \%$ \\
\hline Christianity & $9.28 \%$ & $4.12 \%$ & $8.25 \%$ & $11.34 \%$ & $7.22 \%$ & $18.56 \%$ & $41.23 \%$ \\
\hline Not Mentioned & $5.56 \%$ & $16.67 \%$ & $0.00 \%$ & $22.22 \%$ & $11.11 \%$ & $16.67 \%$ & $27.78 \%$ \\
\hline \multicolumn{8}{|l|}{ Education } \\
\hline Primary & $15.22 \%$ & $15.22 \%$ & $0.00 \%$ & $10.87 \%$ & $13.04 \%$ & $26.09 \%$ & $19.56 \%$ \\
\hline Secondary & $7.69 \%$ & $4.70 \%$ & $4.70 \%$ & $15.81 \%$ & $5.56 \%$ & $17.95 \%$ & $43.59 \%$ \\
\hline Diploma & $5.39 \%$ & $5.88 \%$ & $3.92 \%$ & $23.53 \%$ & $6.37 \%$ & $19.62 \%$ & $35.29 \%$ \\
\hline Bachelor & $3.88 \%$ & $6.20 \%$ & $5.43 \%$ & $13.95 \%$ & $8.53 \%$ & $20.16 \%$ & $41.85 \%$ \\
\hline$P G D$ & $5.26 \%$ & $5.26 \%$ & $0.00 \%$ & $0.00 \%$ & $10.53 \%$ & $26.32 \%$ & $52.63 \%$ \\
\hline Masters & $0.00 \%$ & $0.00 \%$ & $0.00 \%$ & $0.00 \%$ & $20.00 \%$ & $13.13 \%$ & $53.34 \%$ \\
\hline$P h D$ & $0.00 \%$ & $0.00 \%$ & $0.00 \%$ & $0.00 \%$ & $0.00 \%$ & $50.00 \%$ & $50.00 \%$ \\
\hline Others & $8.82 \%$ & $17.65 \%$ & $2.94 \%$ & $19.12 \%$ & $2.94 \%$ & $23.53 \%$ & $25.00 \%$ \\
\hline \multicolumn{8}{|l|}{ Occupation } \\
\hline Civil Servants & $3.65 \%$ & $2.08 \%$ & $1.56 \%$ & $17.19 \%$ & $7.29 \%$ & $19.79 \%$ & $48.44 \%$ \\
\hline Private Sector & $6.94 \%$ & $5.56 \%$ & $4.17 \%$ & $11.11 \%$ & $12.50 \%$ & $16.67 \%$ & $43.06 \%$ \\
\hline Farming & $17.24 \%$ & $17.24 \%$ & $3.45 \%$ & $13.79 \%$ & $10.34 \%$ & $20.69 \%$ & $17.24 \%$ \\
\hline Self-Employed & $5.75 \%$ & $8.05 \%$ & $5.75 \%$ & $19.54 \%$ & $6.90 \%$ & $31.03 \%$ & $22.99 \%$ \\
\hline Housewives & $9,09 \%$ & $9.09 \%$ & $9.09 \%$ & $12.12 \%$ & $12.12 \%$ & $24.24 \%$ & $24.24 \%$ \\
\hline Retired & $0.00 \%$ & $0.00 \%$ & $0.00 \%$ & $33.33 \%$ & $33.33 \%$ & $33.33 \%$ & $0.00 \%$ \\
\hline Students & $8.75 \%$ & $6.67 \%$ & $4.58 \%$ & $20.00 \%$ & $4.58 \%$ & $15.42 \%$ & $40.00 \%$ \\
\hline Unemployed & $7.50 \%$ & $17.50 \%$ & $2.50 \%$ & $15.00 \%$ & $2.50 \%$ & $22.50 \%$ & $32.50 \%$ \\
\hline Others & $5.88 \%$ & $29.41 \%$ & $0.00 \%$ & $11.76 \%$ & $5.88 \%$ & $29.41 \%$ & $17.65 \%$ \\
\hline
\end{tabular}

Table 5.5: Likelihood of Litigating for the Right to Water and Sanitation in Nigeria

\begin{tabular}{lcccccc}
\multicolumn{1}{c}{ Mechanisms } & Never & $\begin{array}{c}\text { Almost } \\
\text { Never }\end{array}$ & Sometimes & $\begin{array}{c}\text { Fairly } \\
\text { Often }\end{array}$ & $\begin{array}{c}\text { Very } \\
\text { Often }\end{array}$ & Always \\
Traditional Rulers & $51.65 \%$ & $7.96 \%$ & $16.48 \%$ & $6.87 \%$ & $8.52 \%$ & $8.52 \%$ \\
Courts & $72.31 \%$ & $9.78 \%$ & $7.13 \%$ & $3.92 \%$ & $2.66 \%$ & $4.20 \%$ \\
Human Rights & $59.66 \%$ & $12.06 \%$ & $12.93 \%$ & $4.83 \%$ & $4.55 \%$ & $5.97 \%$ \\
Institutions & $50.79 \%$ & $10.83 \%$ & $16.02 \%$ & $8.08 \%$ & $7.50 \%$ & $6.78 \%$ \\
Civil Society/NGOs & $45.01 \%$ & $10.55 \%$ & $14.67 \%$ & $8.97 \%$ & $9.40 \%$ & $11.40 \%$ \\
Media & $55.40 \%$ & $8.13 \%$ & $14.31 \%$ & $6.03 \%$ & $4.91 \%$ & $11.22 \%$ \\
Police & & & & & & \\
\hline
\end{tabular}

Table 5.6: Common Complaints Mechanisms and the Rate of Utilisation in Nigeria 


\begin{tabular}{rlc}
\hline $\mathbf{S} / \mathbf{N}$ & \multicolumn{1}{c}{ Mechanism } & Utilisation Rate \\
1. & Politicians & $36.92 \%$ \\
2. & Civil Society Organisations & $12.31 \%$ \\
3. & Traditional Rulers & $7.77 \%$ \\
4. & Courts & $0.52 \%$ \\
5. & None & $42.49 \%$ \\
\hline
\end{tabular}

Table 5.7: Common Complaints Mechanisms on Water and Sanitation and the Rate of Utilisation

\begin{tabular}{|c|c|c|}
\hline \multirow[t]{2}{*}{ Variables } & \multicolumn{2}{|c|}{ Comfortable } \\
\hline & Yes & No \\
\hline General & $62.37 \%$ & $37.63 \%$ \\
\hline \multicolumn{3}{|l|}{ Gender } \\
\hline Males & $65.18 \%$ & $34.82 \%$ \\
\hline Females & $56.36 \%$ & $43.62 \%$ \\
\hline \multicolumn{3}{|l|}{ Age Group } \\
\hline $18-24$ & $60.68 \%$ & $39.32 \%$ \\
\hline $25-40$ & $62.71 \%$ & $37.29 \%$ \\
\hline $41-50$ & $64.96 \%$ & $35.04 \%$ \\
\hline $51+$ & $59.26 \%$ & $40.74 \%$ \\
\hline \multicolumn{3}{|l|}{ Marital Status } \\
\hline Single & $59.94 \%$ & $40.06 \%$ \\
\hline Married & $64.40 \%$ & $35.60 \%$ \\
\hline Widow/Widower & $75.00 \%$ & $25.00 \%$ \\
\hline Divorced & $50.00 \%$ & $50.00 \%$ \\
\hline Others & $60.00 \%$ & $40.00 \%$ \\
\hline \multicolumn{3}{|l|}{ Religious Belief } \\
\hline Islam & $62.50 \%$ & $37.50 \%$ \\
\hline Christianity & $58.16 \%$ & $41.84 \%$ \\
\hline Not Mentioned & $66.67 \%$ & $33.33 \%$ \\
\hline \multicolumn{3}{|l|}{ Education } \\
\hline Primary & $52.83 \%$ & $47.17 \%$ \\
\hline Secondary & $57.85 \%$ & $42.15 \%$ \\
\hline Diploma & $69.91 \%$ & $30.09 \%$ \\
\hline Bachelor & $66.15 \%$ & $33.85 \%$ \\
\hline$P G D$ & $80.95 \%$ & $19.05 \%$ \\
\hline Masters & $80.00 \%$ & $20.00 \%$ \\
\hline$P h D$ & $50.00 \%$ & $50.00 \%$ \\
\hline Others & $46.38 \%$ & $53.62 \%$ \\
\hline \multicolumn{3}{|l|}{ Occupation } \\
\hline Civil Servants & $71.14 \%$ & $28.86 \%$ \\
\hline Private Sector & $66.22 \%$ & $33.78 \%$ \\
\hline Farming & $40.00 \%$ & $60.00 \%$ \\
\hline Self-Employed & $55.68 \%$ & $44.32 \%$ \\
\hline Housewives & $53.49 \%$ & $46.51 \%$ \\
\hline Retired & $66.67 \%$ & $33.33 \%$ \\
\hline Students & $60.48 \%$ & $39.52 \%$ \\
\hline Unemployed & $57.17 \%$ & $42.86 \%$ \\
\hline Others & $57.89 \%$ & $42.11 \%$ \\
\hline
\end{tabular}

Table 5.8: Comfortability of Litigating Human Rights Claims in Northwest Nigeria 
Table and Figures

\begin{tabular}{lcrrrrrr}
\hline \multicolumn{1}{c}{ Factor } & $\begin{array}{c}\text { Very } \\
\text { Unlikely }\end{array}$ & Unlikely & $\begin{array}{c}\text { Somewhat } \\
\text { Unlikely }\end{array}$ & Undecided & $\begin{array}{c}\text { Somewhat } \\
\text { Likely }\end{array}$ & Likely & $\begin{array}{c}\text { Very } \\
\text { Likely }\end{array}$ \\
$\begin{array}{l}\text { Culture and } \\
\text { Tradition }\end{array}$ & $43.83 \%$ & $10.96 \%$ & $3.88 \%$ & $21.09 \%$ & $3.88 \%$ & $4.85 \%$ & $11.51 \%$ \\
$\begin{array}{l}\text { Religious } \\
\text { Belief }\end{array}$ & $38.11 \%$ & $9.60 \%$ & $2.92 \%$ & $18.22 \%$ & $4.59 \%$ & $8.48 \%$ & $18.08 \%$ \\
$\begin{array}{l}\text { Family } \\
\text { Influence }\end{array}$ & $35.25 \%$ & $9.55 \%$ & $4.49 \%$ & $19.25 \%$ & $6.74 \%$ & $10.11 \%$ & $14.61 \%$ \\
$\begin{array}{l}\text { Financial } \\
\text { Situation }\end{array}$ & $27.60 \%$ & $6.12 \%$ & $4.84 \%$ & $19.33 \%$ & $6.69 \%$ & $10.67 \%$ & $24.75 \%$ \\
$\begin{array}{l}\text { Traditional } \\
\text { Ruler }\end{array}$ & $36.48 \%$ & $10.30 \%$ & $6.58 \%$ & $25.90 \%$ & $5.72 \%$ & $7.01 \%$ & $8.01 \%$ \\
$\begin{array}{l}\text { Government } \\
\text { Bureaucracy }\end{array}$ & $31.93 \%$ & $8.44 \%$ & $5.06 \%$ & $25.88 \%$ & $6.75 \%$ & $9.99 \%$ & $11.95 \%$ \\
Distance & $34.16 \%$ & $8.14 \%$ & $5.52 \%$ & $26.31 \%$ & $7.12 \%$ & $7.99 \%$ & $10.76 \%$ \\
\hline
\end{tabular}

Table 5.9: Influence of Some Formal and Informal Factors on Human Rights Claims

\begin{tabular}{lccc}
\hline \multicolumn{1}{c}{ Agency } & Rural Water Supply & $\begin{array}{c}\text { Small Towns Water } \\
\text { Supply }\end{array}$ & Urban Water Supply \\
Federal Government & 0 & 0 & 0 \\
State Government & $10 \%$ & 0 & $100 \%$ Tariff \\
Local Government & $20 \%$ & 0 & 0 \\
Community & $70 \%$ & $100 \%$ & 0 \\
\hline
\end{tabular}

Table 6.2. Funding for Water Sanitation under the NWSP

\begin{tabular}{lccc}
\hline \multicolumn{1}{c}{ Agency } & Rural Water Supply & $\begin{array}{c}\text { Small Towns Water } \\
\text { Supply }\end{array}$ & Urban Water Supply \\
Federal Government & $50 \%$ & $50 \%$ & $30 \%$ \\
State Government & $25 \%$ & $30 \%$ & $60 \%$ \\
Local Government & $20 \%$ & $15 \%$ & $10 \%$ \\
Community & $5 \%$ & $5 \%$ & 0 \\
\hline
\end{tabular}

Table 6.1 Funding Arrangement for Water under the NWSSP 
Realising the Right to Water and Sanitation in Nigeria

A rights-based approach is a conceptual framework for the process of human development that is normatively based on international human rights standards and operationally directed to promoting and protecting human rights.

Mary Robinson, UN High Commissioner for Human Rights 2001

The human rights approach to development means empowering people to take their own decisions, rather than being the passive objects of choices made on their behalf.

DFID

A rights-based approach to development describes situations not simply in terms of human needs, or developmental requirements, but in terms of society's obligations to respond to the inalienable rights of individuals, empowers people to demand justice as a right, not as a charity, and gives communities a moral basis from which to claim international assistance when needed.

UN Secretary-General 1998

The human rights approach brings to the development discourse . . . a conceptual framework from which to begin assessment and analysis, keeping in mind that the overall aim is the realization of all human rights for all people.

Rios-Kohn 2001

A democracy and human-rights approach translates poor people's needs into rights, and recognises individuals as active subjects and stakeholders. It further identifies the obligations of states that are required to take steps for example through legislation, policies and programmes - whose purpose is to respect, promote and fulfil the human rights of all people within their jurisdiction.

SIDA

A rights-based approach affirms that all citizens are entitled to the resources that satisfy their basic needs. Additionally, every citizen - rich and poor - has the right to information and participation in the development process.

\section{ActionAid Kenya}

SCF supports a rights-based approach . . . because: rights imply obligations; . . . rights provide a move from dependency to empowerment; . . . rights can encourage responsibilities.

SCF UK website (www.scf.org.uk) 2002

A rights-based approach deliberately and explicitly focuses on people achieving the minimum conditions for living with dignity. It does so by exposing the root causes of vulnerability and marginalization and expanding the range of responses. It empowers people to claim and exercise their rights and fulfil their responsibilities. A rights-based approach recognises poor people as having inherent rights essential to livelihood security - rights that are validated by international standards and laws.

\section{CARE}

In this $50^{\text {th }}$ anniversary year of the signing of the Universal Declaration of Human Rights, it is important to remind ourselves of the value of a rights-based approach. Christian Aid affirms the equal rights of all people as 'made in the image of God'.

\section{McGee, Robinson and van Diesen}

An ethical approach to globalization can mean nothing less than a rights-based approach to development. We must struggle not only against torture, arbitrary detention and unfair trials, but also against hunger, illiteracy and discrimination if human rights are to be meaningful in developing countries.

Amnesty International

Table 8.1: Definitions of a Human Rights-Based Approach 


\section{NW Nigeria}

Jigawa State

Kaduna State

Kano State

Katsina State

Kebbi State

Sokoto State

\section{Zamfara State}

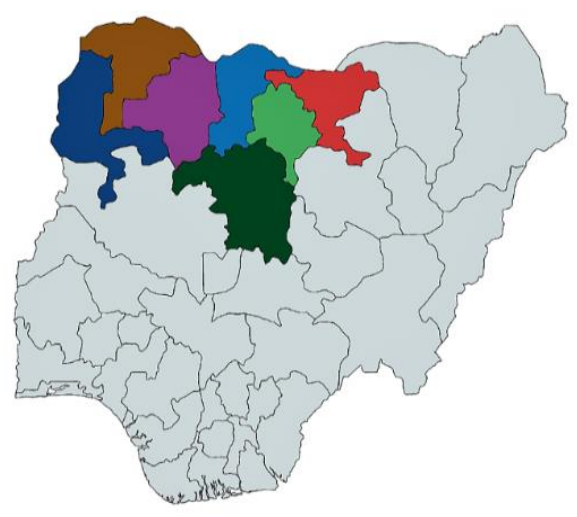

Figure 1.1: North-West Geopolitical Zone of Nigeria

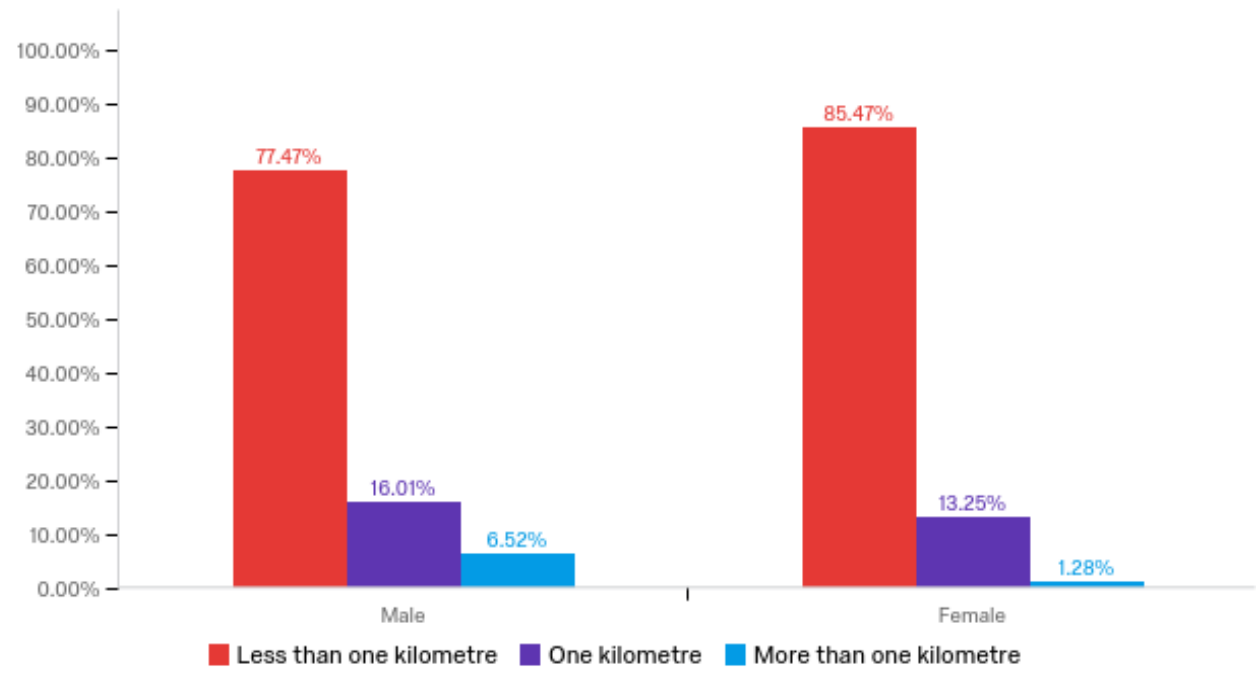

Figure 4.1: Cross Tabulation of Distance to Water Source by Gender 
Realising the Right to Water and Sanitation in Nigeria

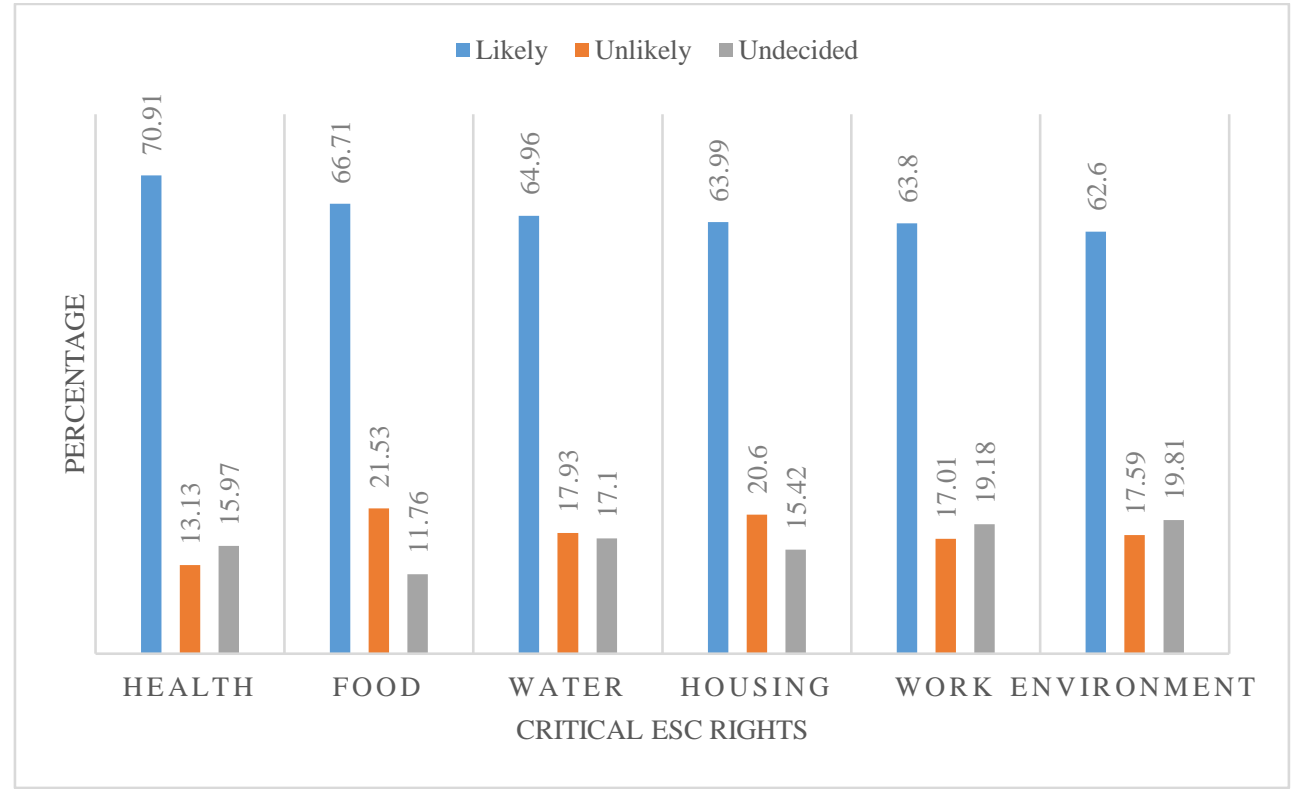

Figure 5.1: Ranking of ESC Rights on Likelihood of Asserting Legal Claim

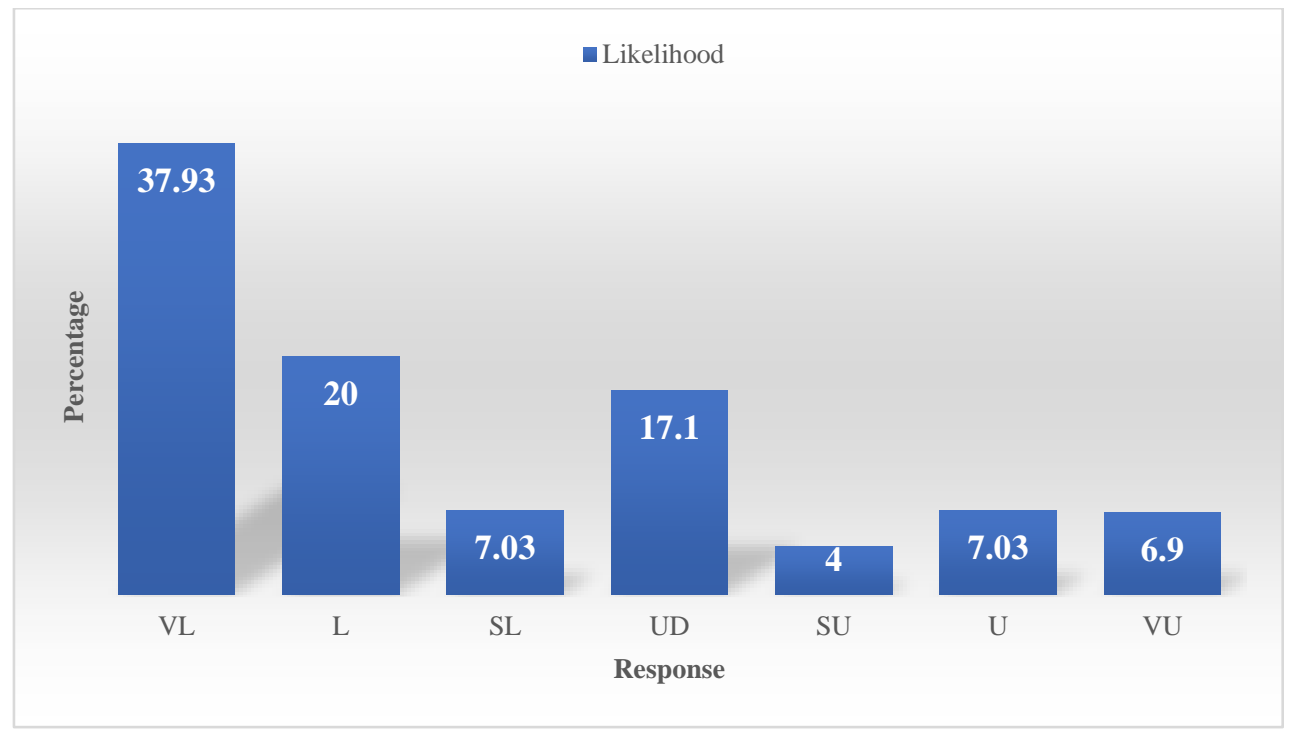

Figure 5.2: Likelihood of Litigating the Right to Water and Sanitation (General)

\begin{tabular}{l|l|l|l|l|l|l|l} 
Key & VL & L & SL & UD & SU & U & VU \\
\hline & Very & Likely & Somewhat & Undecided & Somewhat \\
Likely & & Likely & Unlikely & Very \\
Unlikely
\end{tabular}


Table and Figures

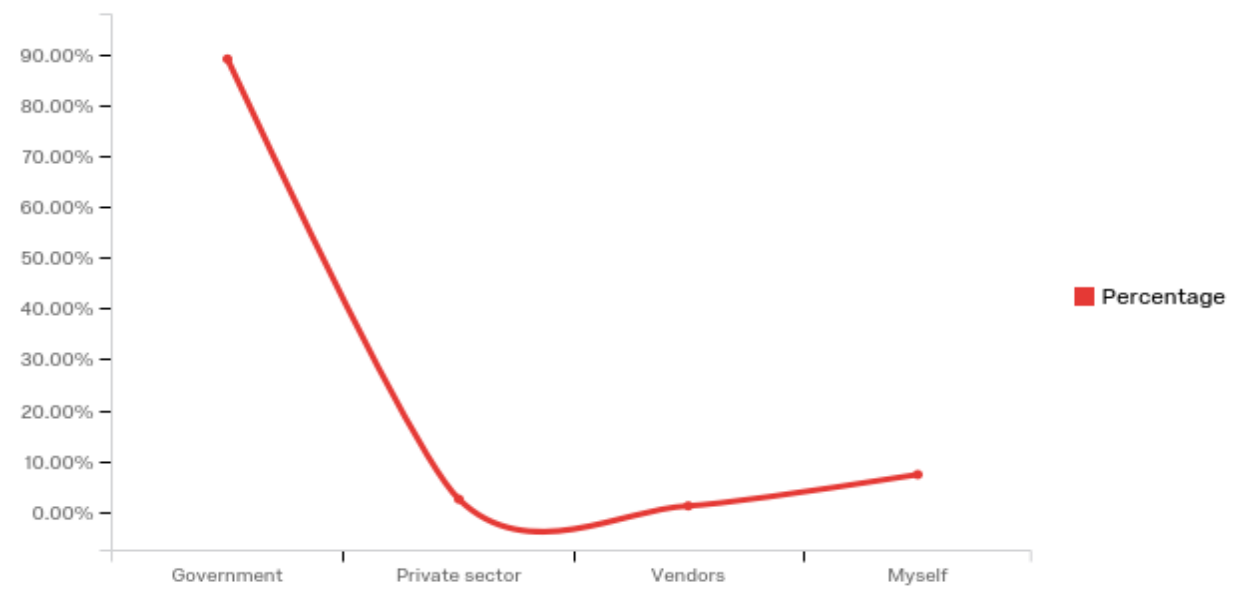

Figure 5.3: Perception of Respondents on Who Has the Duty to Provide Access to Water and Sanitation

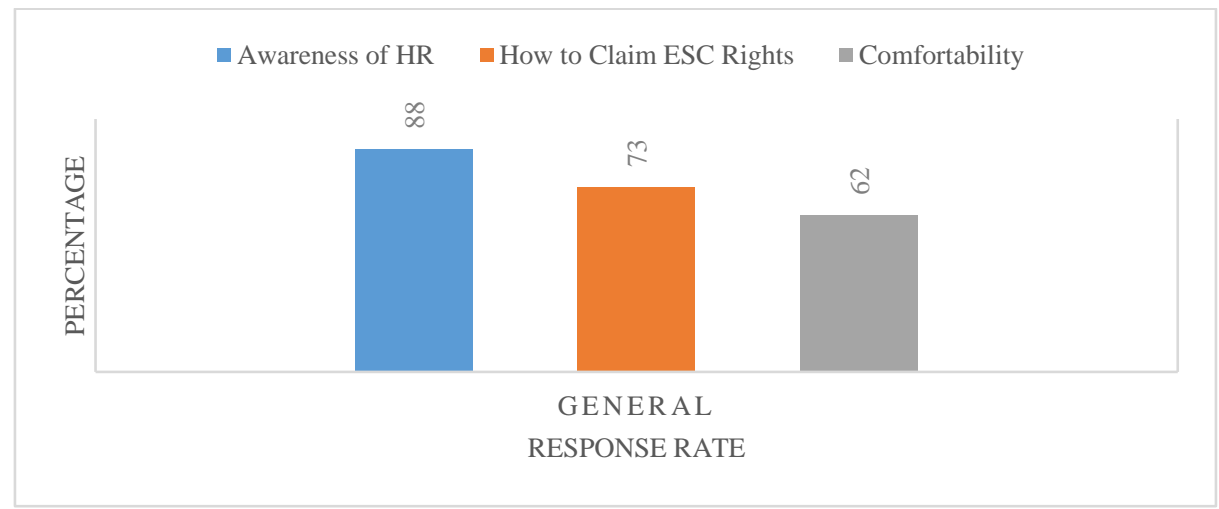

Figure 5.4: Relationship - Awareness and Comfortability (General)

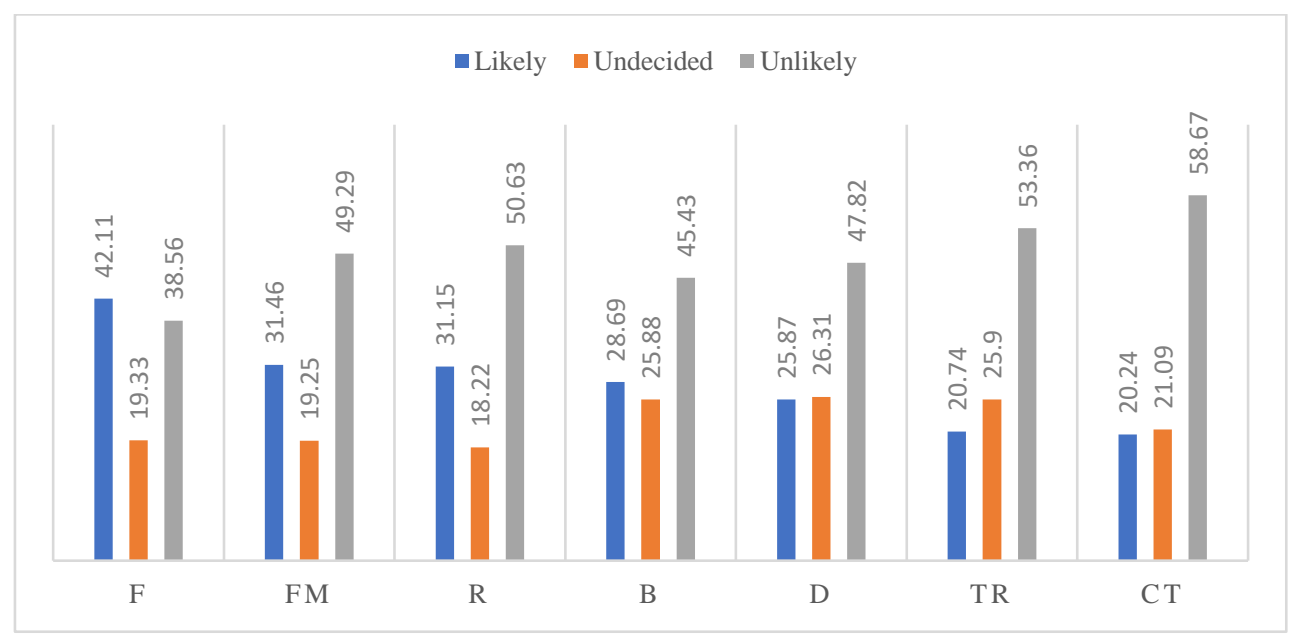

Figure 5.5: Level of Impact of Possible Factors Influencing Human Rights Claims in NW Nigeria 
Realising the Right to Water and Sanitation in Nigeria

\begin{tabular}{c|c|c|c|c|c|c|c} 
Key & $\mathbf{F}$ & $\mathbf{F M}$ & $\mathbf{R}$ & $\mathbf{B}$ & $\mathbf{D}$ & $\mathbf{T R}$ & $\mathbf{C T}$ \\
\hline & Finance & Family & Religion & Bureaucracy & Distance & Traditional & Culture \\
Ruler & and \\
Tradition
\end{tabular}




\section{Appendixes}

\section{QUESTIONNAIRES TYPE A}

\section{GENERAL POPULATION (RIGHTS-HOLDERS)}

Dear Respondent,

This survey is being conducted in pursuance to a $\mathrm{PhD}$ research. The research seeks to identify the factors militating against the realisation of access to quality water and basic sanitation in Nigeria and to recommend best possible options to address the situation.

Your opinion in this project is considered vital and extremely important. You are kindly requested to fill the attached questionnaire honestly and to the best of your ability. Your data will be treated as confidential and all responses are anonymous and would not in any way be used to identify you as a person. Please sign below to indicate your consent to give your opinion on this issue.

Thank you.

Signature and Date 


\section{SECTION ONE}

1. Gender $\square$ Male $\square$ Female

2. Age group $\square$ 18-24 $\square$ 25-40 $\square 41-50 \square 51 \&$ above $\square$ I don't know $\square$ Refused

3. Marital status $\square$ Single $\square$ Married $\square$ Widow/Widower $\square$ Divorced $\square$ Other

4. Religion $\square$ Islam $\square$ Christianity $\square$ Traditional $\square$ Refused

5. Highest qualification $\square$ Primary $\square$ Secondary $\square$ Diploma $\square$ Bachelor $\square$ PGD $\square$ Masters $\square \mathrm{PhD} \square$ Other

6. Current occupation $\square$ Civil Servant $\square$ Private Sector $\square$ Farming $\square$ Self-employed $\square$ Housewife $\square$ Retired $\square$ Student $\square$ Unemployed $\square$ Other

\section{SECTION TWO:}

7. How often do you use any of the following as a source of information? (Circle each one appropriately)

\begin{tabular}{lcccccc}
\hline & Never & $\begin{array}{c}\text { Almost } \\
\text { never }\end{array}$ & Sometimes & $\begin{array}{c}\text { Fairly } \\
\text { often }\end{array}$ & $\begin{array}{c}\text { Very } \\
\text { often }\end{array}$ & Always \\
\hline Radio & $\square$ & $\square$ & $\square$ & $\square$ & $\square$ & $\square$ \\
Television & $\square$ & $\square$ & $\square$ & $\square$ & $\square$ & $\square$ \\
Newspaper/Magazine & $\square$ & $\square$ & $\square$ & $\square$ & $\square$ & $\square$ \\
Internet & $\square$ & $\square$ & $\square$ & $\square$ & $\square$ & $\square$ \\
Books & $\square$ & $\square$ & $\square$ & $\square$ & $\square$ & $\square$ \\
Social media (Facebook, Twitter & $\square$ & $\square$ & $\square$ & $\square$ & $\square$ & $\square$ \\
etc) & $\square$ & $\square$ & $\square$ & $\square$ & $\square$ & $\square$ \\
Other & $\square$ & $\square$ & $\square$
\end{tabular}

8. Are you aware of the meaning of human rights? $\square$ Yes $\square$ No $\square$ I don't care

9. If any of your economic, social or cultural right (e.g. right to education, health, housing, development, clean environment) is denied, are you aware of how to claim it?

$\square$ Yes $\square$ No $\square$ I don't care

10. Do you feel comfortable going to court to claim your rights? $\square$ Yes $\square$ No

11. If you are to know that the following are your human rights but are being denied what is the likelihood that you will claim them? (Please circle each one appropriately) 


\begin{tabular}{|c|c|c|c|c|c|c|c|}
\hline & \multicolumn{7}{|c|}{ Appendixes } \\
\hline & $\begin{array}{c}\text { Very } \\
\text { unlikely }\end{array}$ & Unlikely & $\begin{array}{c}\text { Somewhat } \\
\text { unlikely }\end{array}$ & Neutral & $\begin{array}{c}\text { Somewhat } \\
\text { likely }\end{array}$ & Likely & $\begin{array}{c}\text { Very } \\
\text { likely }\end{array}$ \\
\hline Right to food & $\square$ & $\square$ & $\square$ & $\square$ & $\square$ & $\square$ & $\square$ \\
\hline Right to housing & $\square$ & $\square$ & $\square$ & $\square$ & $\square$ & $\square$ & $\square$ \\
\hline Right to water & $\square$ & $\square$ & $\square$ & $\square$ & $\square$ & $\square$ & $\square$ \\
\hline $\begin{array}{l}\text { Right to clean } \\
\text { environment }\end{array}$ & $\square$ & $\square$ & $\square$ & $\square$ & $\square$ & $\square$ & $\square$ \\
\hline Right to work & $\square$ & $\square$ & $\square$ & $\square$ & $\square$ & $\square$ & $\square$ \\
\hline Right to health & $\square$ & $\square$ & $\square$ & $\square$ & $\square$ & $\square$ & $\square$ \\
\hline
\end{tabular}

12. If you have ever channelled a complaint or grievance, please circle the rate at which you use any of the following: (Please circle each one appropriately)

\begin{tabular}{lcccccc}
\hline & Never & Almost never & Sometimes & Fairly often & Very often & Always \\
\hline Traditional Rulers & $\square$ & $\square$ & $\square$ & $\square$ & $\square$ & $\square$ \\
Courts & $\square$ & $\square$ & $\square$ & $\square$ & $\square$ & $\square$ \\
Human Rights Institution & $\square$ & $\square$ & $\square$ & $\square$ & $\square$ & $\square$ \\
Civil Society/NGOs & $\square$ & $\square$ & $\square$ & $\square$ & $\square$ & $\square$ \\
Media & $\square$ & $\square$ & $\square$ & $\square$ & $\square$ & $\square$ \\
Police & $\square$ & $\square$ & $\square$ & $\square$ & $\square$ & $\square$ \\
\hline
\end{tabular}

\section{SECTION THREE}

13. Please rate the source from which you mostly get your drinking water (please circle each one appropriately)

\begin{tabular}{lcccccc}
\hline & Never & Almost never & Sometimes & Fairly often & Very often & Always \\
\hline Personal Pump & $\square$ & $\square$ & $\square$ & $\square$ & $\square$ & $\square$ \\
Public Pump & $\square$ & $\square$ & $\square$ & $\square$ & $\square$ & $\square$ \\
Public Borehole & $\square$ & $\square$ & $\square$ & $\square$ & $\square$ & $\square$ \\
Personal Borehole & $\square$ & $\square$ & $\square$ & $\square$ & $\square$ & $\square$ \\
Vendor & $\square$ & $\square$ & $\square$ & $\square$ & $\square$ & $\square$ \\
River & $\square$ & $\square$ & $\square$ & $\square$ & $\square$ & $\square$ \\
Pond & $\square$ & $\square$ & $\square$ & $\square$ & $\square$ & $\square$ \\
Well & $\square$ & $\square$ & $\square$ & $\square$ & $\square$ & $\square$ \\
Other & $\square$ & $\square$ & $\square$ & $\square$ & $\square$ & $\square$ \\
\hline
\end{tabular}

14. If your water source is not at home, what is the approximate distance from your house?

$\square$ Less than one kilometre $\square$ One kilometre $\square$ More than one kilometre

15. If your source of water is personal borehole or personal well, is there a need to seek the approval of government before construction? $\square$ Yes $\square$ No

16. Is your water clean? $\square$ Yes $\square$ No $\square$ To some extent

17. On the average, how much do you spend on water daily? $\square$ 0 Naira $\square$ 1-100 Naira $\square$ 101-200 Naira $\square$ 201-300 Naira $\square$ More than 300 Naira

18. How long does it take you to fetch water from your house to the water source?

$\square$ 0-15 Minutes $\square$ 15-30 Minutes $\square$ 30-60 Minutes $\square$ More than 60 Minutes 
Realising the Right to Water and Sanitation in Nigeria

19. In your opinion, who do think is responsible for providing you with water?

\section{$\square$ Government $\square$ Private Sector $\square$ Vendors $\square$ Myself}

20. In your opinion do you think access to water and sanitation is your human right entitlement? $\square$ Yes $\square$ No $\square$ I don't know

21. Do you know where you can get information about water and sanitation?

$\square$ Yes $\square$ No $\square$ I don't care

22. Have you ever approached any office or agency of the government regarding the issue of water or sanitation? $\square$ Yes $\square$ No $\square$ I don't care

23. Have you already heard about the right to water and sanitation? $\square$ Yes $\square$ No

24. In the last two years, which of the following have you approached regarding provision of access to water and sanitation? $\square$ Politician $\square$ Traditional Ruler $\square$ Court $\square$ Civil Society $\square$ None

25. Please rate how any of the following can prevents you from accessing the court to assert a claim to the right to water and sanitation (please circle)

\begin{tabular}{lccccccc}
\hline & $\begin{array}{c}\text { Very } \\
\text { unlikely }\end{array}$ & Unlikely & $\begin{array}{c}\text { Somewhat } \\
\text { unlikely }\end{array}$ & Neutral & $\begin{array}{c}\text { Somewhat } \\
\text { likely }\end{array}$ & Likely & $\begin{array}{c}\text { Very } \\
\text { likely }\end{array}$ \\
\hline Culture/tradition & $\square$ & $\square$ & $\square$ & $\square$ & $\square$ & $\square$ & $\square$ \\
Religious belief & $\square$ & $\square$ & $\square$ & $\square$ & $\square$ & $\square$ & $\square$ \\
Family & $\square$ & $\square$ & $\square$ & $\square$ & $\square$ & $\square$ & $\square$ \\
Money & $\square$ & $\square$ & $\square$ & $\square$ & $\square$ & $\square$ & $\square$ \\
Traditional Ruler & $\square$ & $\square$ & $\square$ & $\square$ & $\square$ & $\square$ & $\square$ \\
Gov't & $\square$ & $\square$ & $\square$ & $\square$ & $\square$ & $\square$ & $\square$ \\
bureaucracy & $\square$ & $\square$ & $\square$ & $\square$ & $\square$ & $\square$ & $\square$ \\
Distance & $\square$ & $\square$
\end{tabular}

\section{SECTION FOUR}

26. Are you aware of the term "marginalisation" or "discrimination"? $\square$ Yes $\square$ No

27. Do you have any marginalised/discriminated group in your area?

$\square$ Yes $\square$ No $\square$ I don't know

28. Are you aware of any group of people that has never been covered by water development projects in Nigeria? $\square$ Yes $\square$ No $\square$ I don't know

29. If yes, rate the extent to which in your opinion is the reason for their non-inclusion. (Please circle each one appropriately) 


\begin{tabular}{|c|c|c|c|c|c|}
\hline & & & & \multicolumn{2}{|c|}{ Appendixes } \\
\hline & $\begin{array}{l}\text { Strongly } \\
\text { agree }\end{array}$ & Agree & $\begin{array}{c}\text { Neither agree nor } \\
\text { disagree }\end{array}$ & Disagree & $\begin{array}{l}\text { Strongly } \\
\text { disagree }\end{array}$ \\
\hline Distance of the area & $\square$ & $\square$ & $\square$ & $\square$ & $\square$ \\
\hline Inaccessibility & $\bar{\square}$ & $\bar{\square}$ & $\bar{\square}$ & $\bar{\square}$ & $\square$ \\
\hline Population is small & $\square$ & $\square$ & $\square$ & $\square$ & $\square$ \\
\hline $\begin{array}{l}\text { Status of the people (minority, } \\
\text { language etc.) }\end{array}$ & $\square$ & $\square$ & $\square$ & $\square$ & $\square$ \\
\hline They are poor) & $\square$ & $\square$ & $\square$ & $\square$ & $\square$ \\
\hline Disability & $\square$ & $\square$ & $\square$ & $\square$ & $\square$ \\
\hline Gender & $\square$ & $\square$ & $\square$ & $\square$ & $\square$ \\
\hline Other & $\bar{\square}$ & $\bar{\square}$ & $\bar{\square}$ & $\bar{\square}$ & $\square$ \\
\hline
\end{tabular}

30. When planning, establishing or constructing water and sanitation projects in your area, have you ever been part of or been consulted by the Government? $\square$ Yes $\square$ No

\section{SECTION FIVE}

31. To what extend do you think the following can influence access to water and sanitation in your area? (Please circle each one appropriately)

\begin{tabular}{lccccccc}
\hline & $\begin{array}{c}\text { Very } \\
\text { unlikely }\end{array}$ & Unlikely & $\begin{array}{c}\text { Somewhat } \\
\text { unlikely }\end{array}$ & $\begin{array}{c}\text { Neither } \\
\text { likely nor } \\
\text { unlikely }\end{array}$ & $\begin{array}{c}\text { Somewhat } \\
\text { likely }\end{array}$ & Likely & $\begin{array}{c}\text { Very } \\
\text { likely }\end{array}$ \\
\hline $\begin{array}{l}\text { Traditional } \\
\text { Rulers } \\
\text { Civil Society/ }\end{array}$ & $\square$ & $\square$ & $\square$ & $\square$ & $\square$ & $\square$ & $\square$ \\
NGOs & $\square$ & $\square$ & $\square$ & $\square$ & $\square$ & $\square$ & $\square$ \\
$\begin{array}{l}\text { Human Rights } \\
\begin{array}{l}\text { Institutions } \\
\text { Politicians }\end{array}\end{array}$ & $\square$ & $\square$ & $\square$ & $\square$ & $\square$ & $\square$ & $\square$ \\
$\begin{array}{l}\text { Faith-based } \\
\text { Organisations }\end{array}$ & $\square$ & $\square$ & $\square$ & $\square$ & $\square$ & $\square$ & $\square$ \\
Media & $\square$ & $\square$ & $\square$ & $\square$ & $\square$ & $\square$ & $\square$ \\
\hline
\end{tabular}

32. Is there any water source in your area that you think can be developed to ensure availability of and access to water in your area? $\square$ Yes $\square$ No $\square$ I don't know

33. Are you aware that the United Nations has recognized water and sanitation as human right? $\square$ Yes $\square$ No

34. Do you have any suggestion(s) on how to improve access to water and sanitation in your area? (Please write below)

\section{THANK YOU FOR YOUR PARTICIPATION. PLEASE WRITE YOUR EMAIL OR PHONE NUMBER IF WE CAN CONTACT YOU FOR FURTHER CLARIFICATIONS}


Malam/Malama,

Wannan binciken anayin shine domin samun bayani akan dalilan da suke kawo matsalar rashin ruwan sha da tsaftace muhalli a Nigeria domin bada shawarwari akan yadda zaa magance matsalar.Wannan binciken baya da wani alaka da Gwamnati.

Raayinku akan wadannan tamboyin yana da amfani sosai. Muna rokon ku da ku karba wadannan tambayoyin da gaskiya a iyakar kokarinku. Duk abinda kuka fada za ayi amfani da shi kuma baza a sanar da sunan wanda ya fada ba.

Idan kun yarda sai kusa hannu a kasa

Sa hannu da kwanan wata

Mungode. 


\section{SASHE NA DAYA}

Appendixes

1. Menene jinsin $\mathrm{ka} / \mathrm{ki}$ ?

Namiji

Mace

2. Menene gurbin shekarun $\mathrm{ka} / \mathrm{ki}$ ?

$18-24$

$25-40$

51 zuwa sama

Ban sani ba

Ban son fada

3. Kana/Kina da aure?

Marar Aure

$\square \quad$ Mai Aure

$\square \quad$ Zaman Takaba

$\square \quad$ Zawara/Gauro

$\square \quad$ Ba Ko Daya

4. Menene addinin ka/ki?

$\square \quad$ Musulunci

Kiristanci

Gargajiya

Bana son fadi

5. Wace babbar takardar shaidar karatu kakelkike dashi?

Firamare

Sakadare

Difloma

Digiri

PGD

$\mathrm{PhD}$

$\square \quad$ Wani daban

6. Wane aiki kake/kike yanzu?

Gwamnati

Masana'anta

Noma

Aikin kai 
Realising the Right to Water and Sanitation in Nigeria

Nayi ritaya

Makaranta

Ban aiki

Wani daban

SASHE NA BIYU

7. Da yaushe da yaushe kuke amfani da wadannan kafafe yada labarai?

\begin{tabular}{llllllll}
\hline & $\begin{array}{l}\text { Sam bama } \\
\text { amfani }\end{array}$ & $\begin{array}{l}\text { Can baa } \\
\text { rasa ba }\end{array}$ & $\begin{array}{l}\text { Wani } \\
\text { lokaci }\end{array}$ & $\begin{array}{l}\text { Lokuta } \\
\text { dama }\end{array}$ & $\begin{array}{l}\text { Kusan } \\
\text { kullum }\end{array}$ & $\begin{array}{l}\text { Koda } \\
\text { yaushe }\end{array}$ \\
\hline Radiyo & 1 & 2 & 3 & 4 & 5 & 6 \\
Talabijin & 1 & 2 & 3 & 4 & 5 & 6 \\
Jarida & 1 & 2 & 3 & 4 & 5 & 6 \\
Yanar gizo & 1 & 2 & 3 & 4 & 5 & 6 \\
Littafai & 1 & 2 & 3 & 4 & 5 & 6 \\
Social media (Facebook, & 1 & 2 & 3 & 4 & 5 & 6 \\
Twitter etc) & 1 & 2 & 3 & 4 & 5 & 6 \\
Wata hanya daban & 1 & & & & 5 & 6 \\
\hline
\end{tabular}

8. Kana/kina da masaniyar abinda ake kira hakkin dan adam?
Na'am
Aa
Ban damu ba

9. Idan aka hana ku wani daga cikin hakkokin ku kamar irin hakkin dan adam akan ilimi, lafiya, mazauni, cigaba ko kyakkyawan gurin zama kunsan hanyar da zaku bi ku nemo hakkinku a hukumance?
Na'am
Aa
Ban damu ba

10. Zaku iya zuwa kotu don nemo hakkinku?

Na'am

Aa

11. Idan kunsan cewa wadannan hakkokin ku ne amma aka hana ku, akwai alamun cewa zaku iya bi ku kwato su? (Zagaye daya)

\begin{tabular}{lllllllll}
\hline & $\begin{array}{l}\text { Ba zai } \\
\text { yiyu ba }\end{array}$ & $\begin{array}{l}\text { Ba zan } \\
\text { iya ba }\end{array}$ & $\begin{array}{l}\text { Da alamar } \\
\text { bazan iyaba }\end{array}$ & $\begin{array}{l}\text { Ban } \\
\text { damu ba }\end{array}$ & $\begin{array}{l}\text { Da alamar } \\
\text { zan iya }\end{array}$ & $\begin{array}{l}\text { Zan } \\
\text { yi }\end{array}$ & $\begin{array}{l}\text { Zanyi } \\
\text { sosai }\end{array}$ \\
\hline Hankin abinci & 1 & 2 & 3 & 4 & 5 & 6 & 7 \\
$\begin{array}{l}\text { Hakkin } \\
\text { mazauni/gida }\end{array}$ & 1 & 2 & 3 & 4 & 5 & 6 & 7 \\
Hakkin ruwa & 1 & 2 & 3 & 4 & 5 & 6 & 7 \\
Hakkin kyakkyawan & 1 & 2 & 3 & 4 & 5 & 6 & 7 \\
yanayi & 1 & 2 & 3 & 4 & 5 & 6 & 7 \\
Hakkin yin aiki & 1 & 2 & 3 & 4 & 5 & 6 & 7 \\
\hline Hakkin lafiya & 1 & 2 & & 4 & & 5 & \\
\hline
\end{tabular}

12. Idan kun taba kai koke ko kara akan wata matsala, zaqaye daya domin nuna yawan lokutan da kukayi amfani da wadannan kafofin: 
Appendixes

\begin{tabular}{lcccccc}
\hline & $\begin{array}{c}\text { Ban taba } \\
\text { amfani da } \\
\text { shiba }\end{array}$ & $\begin{array}{c}\text { Kusan } \\
\text { ban taba } \\
\text { ba }\end{array}$ & $\begin{array}{c}\text { Jefi } \\
\text { jefi }\end{array}$ & $\begin{array}{c}\text { Kusan } \\
\text { lokuta da } \\
\text { dama }\end{array}$ & $\begin{array}{c}\text { Lokuta } \\
\text { da dama }\end{array}$ & $\begin{array}{c}\text { Koda } \\
\text { yaushe }\end{array}$ \\
\hline $\begin{array}{l}\text { Mai unguwa } \\
\text { Kotu }\end{array}$ & 1 & 2 & 3 & 4 & 5 & 6 \\
$\begin{array}{l}\text { Hukumar kare } \\
\text { hakkin dan adam }\end{array}$ & 1 & 2 & 3 & 4 & 5 & 6 \\
$\begin{array}{l}\text { Kungiyoyin sa } \\
\text { kai }\end{array}$ & 1 & 2 & 3 & 4 & 5 & 6 \\
$\begin{array}{l}\text { Kafofin yada } \\
\text { labarai }\end{array}$ & 1 & 2 & 3 & 4 & 5 & 6 \\
Yan sanda & 1 & 2 & 3 & 4 & 5 & 6 \\
\hline
\end{tabular}

13. Hanyoyin da kuke samun ruwan sha (zagaye daya a kowanne)

\begin{tabular}{lcccccc}
\hline & $\begin{array}{c}\text { Bamu } \\
\text { taba ba }\end{array}$ & $\begin{array}{c}\text { Kusan } \\
\text { bamu } \\
\text { taba ba }\end{array}$ & Jefi jefi & $\begin{array}{c}\text { Lokuta } \\
\text { da dama }\end{array}$ & $\begin{array}{c}\text { Kusan } \\
\text { koda } \\
\text { yaushe }\end{array}$ & $\begin{array}{c}\text { Koda } \\
\text { yaushe }\end{array}$ \\
\hline Panpon gida & 1 & 2 & 3 & 4 & 5 & 6 \\
Panpon unguwa & 1 & 2 & 3 & 4 & 5 & 6 \\
Bohol na unguwa & 1 & 2 & 3 & 4 & 5 & 6 \\
Bohol na gida & 1 & 2 & 3 & 4 & 5 & 6 \\
Saye & 1 & 2 & 3 & 4 & 5 & 6 \\
Gulbi & 1 & 2 & 3 & 4 & 5 & 6 \\
Korama & 1 & 2 & 3 & 4 & 5 & 6 \\
Rijiya & 1 & 2 & 3 & 4 & 5 & 6 \\
Wata kafa daban & 1 & 2 & 3 & 4 & 5 & 6 \\
\hline
\end{tabular}

14. Idan ba a gida kuke samun ruwa ba, kamar yaya nisan wajen daga gida?

Kasa ga kilomita daya $\quad \square \quad$ Kilomita daya $\quad \square \quad$ Fiye da kilomita

15. Idan bohol ko rijiyar gida ne, akwai bukatar neman izinin gwamnati kafin a gina shi?

$$
\text { Na'am } \quad \square \quad \text { Aa }
$$

16. Ruwan da kuke sha yana da tsafta sosai?
$\mathrm{Na}$ 'am
Aa
Da dama dama

17. A kalla Naira nawa kuke kashewa a rana domin sayen ruwa?

$$
\begin{aligned}
& 0 \\
& 1-100 \\
& 101-200 \\
& 201-300
\end{aligned}
$$


Realising the Right to Water and Sanitation in Nigeria

Sama da 300

18. Yaya tsawon mintuna da yake daukar ku daga gida zuwa gurin da kuke samun ruwa?

$$
\begin{aligned}
& 0-15 \\
& 16-30 \\
& 31-60 \\
& \text { Sama da awa daya }
\end{aligned}
$$

19. A raayin ku, wa kuke tunanin aikinshi ne ya samar da ku ruwan sha?

Gwamnati

Yan Kasuwa

Masu Sayarwa

Ni Kaina

20. A raayinku, kuna ganin samar da ruwan sha da tsaftace muhalli suna daya daga cikin hakkokinku?

$$
\text { Na'am } \quad \square \quad \text { Aa } \quad \square \quad \text { Ban sani ba }
$$

21. Kun san hanyoyin samun bayanai akan matsalolin ruwan sha da tsaftace muhalli?
Na'am
Aa
Ban damu ba

22. Kun taba tuntubar wani ofishin gwamnati akan matsalar ruwan sha da tsaftar muhalli?
Na'am
Aa
Ban damu ba

23. Ko kuna da labarin cewa ruwan sha da tsaftace muhalli hakkin dan adam ne?
Na'am
Aa

24. A shekara biyu da suka gabata, wane daga cikin wadannan kuka tuntuba akan matsalar ruwa da tsaftace muhalli?
Dan Siyasa
Mai Unguwa
Kotu
Kungiyoyin sa Kai
Ba ko daya

25. Ta yaya daya daga cikin wadannan zasu iya hana ku zuwa kotu domin nemo hakkin ku na samun ruwan sha da tsaftace muhalli? 
Appendixes

\begin{tabular}{lccccccc}
\hline & $\begin{array}{c}\text { Akwai } \\
\text { Zashi } \\
\text { hananiba }\end{array}$ & $\begin{array}{c}\text { Ba zashi } \\
\text { hananiba } \\
\text { alamun } \\
\text { baza shi } \\
\text { iya } \\
\text { hanani }\end{array}$ & $\begin{array}{c}\text { Kilawa } \\
\text { kala }\end{array}$ & $\begin{array}{c}\text { Akwai } \\
\text { alamun } \\
\text { zashi iya } \\
\text { hanani }\end{array}$ & $\begin{array}{c}\text { Zashi } \\
\text { iya } \\
\text { hanani }\end{array}$ & $\begin{array}{c}\text { Zashi } \\
\text { hanani }\end{array}$ \\
\hline $\begin{array}{l}\text { Al'ada } \\
\text { Addini }\end{array}$ & 1 & 2 & 3 & 4 & 5 & 6 & 7 \\
Yan uwa & 1 & 2 & 3 & 4 & 5 & 6 & 7 \\
$\begin{array}{l}\text { Kudi } \\
\text { Mai }\end{array}$ & 1 & 2 & 3 & 4 & 5 & 6 & 7 \\
unguwa & 1 & 2 & 3 & 4 & 5 & 6 & 7 \\
$\begin{array}{l}\text { Kaidojin } \\
\text { gwamnati }\end{array}$ & 1 & 2 & 3 & 4 & 5 & 6 & 7 \\
$\begin{array}{l}\text { Nisa daga } \\
\text { hukuma }\end{array}$ & 1 & 2 & 3 & 4 & 5 & 6 & 7 \\
\hline
\end{tabular}

SASHI NA HUDU

26. Kuna da masaniya akan abinda ake kira nuna bambamce bambamce ko wariya?
Na'am
Aa

27. A wajenku, akwai mutanen da kuke ganin ana nunawa bambamci?
Na'am
Aa
Ban sani ba

28. Kuna da labarin mutanen da baa taba sakasu cikin tsarin bada ruwan sha ba?
Na'am
Aa
Ban sani ba

29. Idan kuna da labari, a tunanin ku, menene dalilin hakan?

\begin{tabular}{llllll}
\hline & $\begin{array}{l}\text { Na tabbatar } \\
\text { da hakan }\end{array}$ & $\begin{array}{l}\mathrm{Na} \text { yarda } \\
\text { da hakan }\end{array}$ & $\begin{array}{l}\text { Ban } \\
\text { sani ba }\end{array}$ & $\begin{array}{l}\text { Ban yarda } \\
\text { da hakan ba }\end{array}$ & $\begin{array}{l}\text { Na tabbatar ba } \\
\text { haka bane }\end{array}$ \\
\hline Nisan wajen & 1 & 2 & 3 & 4 & 5 \\
Rashin hanya & 1 & 2 & 3 & 4 & 5 \\
Rashin yawa & 1 & 2 & 3 & 4 & 5 \\
Matsayinsu & 1 & 2 & 3 & 4 & 5 \\
(yare, addini) & 1 & 2 & 3 & 4 & 5 \\
Talakawa ne & 1 & 2 & 3 & 4 & 5 \\
Nakassasu ne & 1 & 2 & 3 & 4 & 5 \\
Saboda jinsi & 1 & 2 & 3 & 4 & 5 \\
Wani dalilin & 1 & & 3 & & 5 \\
\hline
\end{tabular}

30. Idan gwamnati tana shiri ko gudanar da ayyukan samar da ruwan sha a gurin ku, ko an taba tuntubar ku domin bada shawara ko zama acikin maaikatan da zasu gabatar da aikin?

Na'am

Aa 
Realising the Right to Water and Sanitation in Nigeria

SASHE NA BIYAR

31. Yaya kuke ganin wadannan zasu iya taimakawa wajen samar da ruwan sha da tsafta a guraren ku? (zagaye daya)

\begin{tabular}{|c|c|c|c|c|c|c|c|}
\hline & $\begin{array}{l}\text { Sam } \\
\text { bazai } \\
\text { iya ba }\end{array}$ & $\begin{array}{l}\text { Ba } \\
\text { zai } \\
\text { iya } \\
\text { ba }\end{array}$ & $\begin{array}{l}\text { Akwai } \\
\text { alamun } \\
\text { bazai iya } \\
\text { ba }\end{array}$ & $\begin{array}{l}\text { Kila } \\
\text { wa } \\
\text { kala }\end{array}$ & $\begin{array}{l}\text { Akwai } \\
\text { alamun } \\
\text { zai iya }\end{array}$ & $\begin{array}{l}\text { Zai } \\
\text { iya }\end{array}$ & $\begin{array}{l}\text { Zai iya } \\
\text { kwarai da } \\
\text { gaske }\end{array}$ \\
\hline Mai unguwa & 1 & 2 & 3 & 4 & 5 & 6 & 7 \\
\hline $\begin{array}{l}\text { Kungiyoyi kare } \\
\text { hakkin dan } \\
\text { adam }\end{array}$ & 1 & 2 & 3 & 4 & 5 & 6 & 7 \\
\hline $\begin{array}{lr}\text { Hukomin } & \text { kare } \\
\text { hakkin } & \text { dan } \\
\text { adam } & \end{array}$ & 1 & 2 & 3 & 4 & 5 & 6 & 7 \\
\hline Yan siyasa & 1 & 2 & 3 & 4 & 5 & 6 & 7 \\
\hline $\begin{array}{l}\text { Kungiyoyin } \\
\text { addini }\end{array}$ & 1 & 2 & 3 & 4 & 5 & 6 & 7 \\
\hline $\begin{array}{l}\text { Kafofin } \quad \text { yada } \\
\text { labarai }\end{array}$ & 1 & 2 & 3 & 4 & 5 & 6 & 7 \\
\hline
\end{tabular}

32. Ko akwai wasu kafafen na ruwa a gurinku da kuke ganin idan aka yi gyara zaa iya amfani dashi domin samar da ruwan sha?
Na'am
Aa
Ban sani ba

33. Kuna da labarin cewa Majalisar Dinkin Duniya ta tabbatar da cewa ruwan sha da tsaftace muhalli hakkin dan adam ne?

$$
\text { Na'am } \quad \square \quad \text { Aa }
$$

34. Kuna da wata shawara akan yadda zaa samar da kyakyawan ruwan sha da tsaftace muhalli a gurinku? (Rubuta anan) 


\section{TYPE B \\ MINISTRIES, DEPARTMENTS AND AGENCIES (DUTY-BEARERS)}

Dear Respondent,

This survey is being conducted in pursuance to a $\mathrm{PhD}$ research. The research seeks to identify the factors militating against the realisation of access to quality water and basic sanitation in Nigeria and to recommend best possible options to address the situation.

Your opinion in this project is considered vital and extremely important. You are kindly requested to fill the attached questionnaire honestly and to the best of your ability. Your data will be treated as confidential and all responses are anonymous and would not in any way be used to identify you as a person. Please sign below to indicate your consent to give your opinion on this issue.

Thank you.

Signature and Date 
Realising the Right to Water and Sanitation in Nigeria

SECTION ONE

DEMOGRAPHICS

1. What is your gender?

$\square$ Male $\quad \square$ Female

2. What is your age group?

$18-24$

$25-40$

$41-50$

51 and above

I don't know

I don't want to mention

3. What is your highest qualification?

\section{$\square$ Primary $\quad \square$ Secondary $\quad \square$ Diploma $\quad \square$ Bachelor $\quad \square$ PGD $\square$ Masters $\square \mathrm{PhD} \quad \square$ Other}

4. Which of the following best describes you?

$\square$ Junior Staff $\quad \square$ Senior Staff $\quad \square$ Management Staff $\quad \square$ Other

5. How long have you been working with the Ministry/Water Board?

$\square$ Less than a year $\quad \square 1-3$ years $\quad \square 4-7$ years $\quad \square$ More than 7 years

SECTION TWO

PERSONNEL AND TECHNICAL CAPACITY

6. Are you conversant with national and international laws and policies on water and sanitation?

$\square$ Yes $\quad \square$ No $\quad \square$ Yes, but not the details

7. In the last two years how many in-house training relating to water and sanitation have you attended?
$\square 0$
$\square 1-3$
$\square 4-6$
$\square$ At least 7

8. In the last two years how many national training relating to water and sanitation have you attended?
$\square 0$
$\square 1-3$
$\square 4-6$
$\square$ At least 7

9. In the last two years how many foreign training relating to water and sanitation have you attended?
$\square 0$
$\square 1-3$
$\square 4-6$
At least 7 
10. Are staff contributions (ideas or opinions) requested in the areas of development, execution and management of water projects?

$\square$ Yes, always $\quad \square$ No $\quad \square$ Sometimes

11. Is there any internal policy in the Ministry on training of staff at all levels?

$\square$ Yes $\quad \square$ No $\quad \square$ I don't know

12. At the time of appointment or posting have you received any document detailing your job description?

$\square$ Yes $\quad \square$ No

13. Do you have detailed job description in your Ministry for every staff?
$\square$ Yes
$\square$ No
$\square$ I don't know

14. How would you rate the equipment you are using in water generation, distribution and management?

In efficient

Somewhat inefficient

Neither efficient nor inefficient

Somewhat efficient

Efficient

Very efficient

15. Does the Ministry have any reward or incentives for officers who have excelled in the discharge of their duties?

$\square$ Yes $\quad \square$ No $\quad \square$ I don't know

\section{SECTION THREE \\ HUMAN RIGHTS (GENERALLY)}

16. In the last two years, have you had any training, seminar or symposium on human rights issues?
$\square$ Yes
$\square$ No
$\square$ I can't remember

17. If yes did it have any impact on the way you perform your duties?

$\square$ Yes $\quad \square$ No $\quad \square$ I don't think so

18. Do you consider human rights issues in the allocation and distribution of water to areas under your operations?
$\square$ Yes
$\square$ No
$\square$ Sometimes 
Realising the Right to Water and Sanitation in Nigeria

19. Have you already heard about the right to water and sanitation?
$\square$ Yes
$\square$ No

20. If you aware that water and sanitation is a human right, how would that awareness impact on the performance of you work?

Very insignificant

Insignificant

Neither significant nor insignificant

Significant

Very significant

21. Are you aware of the term "marginalisation" or discrimination?
$\square$ Yes
$\square$ No

22. Does the term have any meaning on impact on your allocation of water to the population?
$\square$ Yes
$\square$ No

23. In your opinion, are there any group of people you can say are not covered or not taken into consideration in the planning or distribution of water in your areas of operation?
$\square$ Yes
$\square$ No

24. What would you say is the basis for not covering them? [

25. When calculating water rates, do you take into consideration the ability of people to pay?
$\square$ Yes, always
$\square$ No
$\square$ Sometimes

26. Do you set uniform water rates (cost) for all the people living in your geographical area of operations?

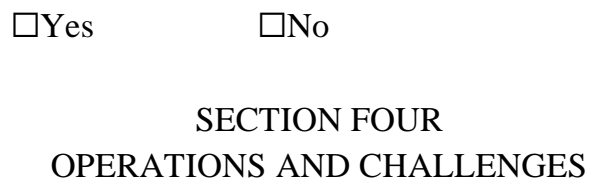

27. Please rate the following as factors (if any) that guide your distribution of water to locations? 


$\begin{array}{llllll} & & & & & \\ & & & & & \text { Appendixes }\end{array}$

28. Do you involve the local population, civil society or traditional rulers in the development, planning and execution of projects on water in their areas?

$\square$ Yes, always $\quad \square$ No $\quad \square$ Yes, but not always

29. If you do, what is the level of participation of the local population in the project?

Part of decision-makers

Advisers

Labourers

Others

30. Please rate the extent to which in your opinion the following inhibits or negatively impact on your Ministry or office's ability to realise its objectives?

\begin{tabular}{|c|c|c|c|c|c|}
\hline & $\begin{array}{l}\text { Strongly } \\
\text { agree }\end{array}$ & Agree & $\begin{array}{l}\text { Neither agree } \\
\text { nor disagree }\end{array}$ & Disagree & $\begin{array}{l}\text { Strongly } \\
\text { disagree }\end{array}$ \\
\hline Funding & $\square$ & $\square$ & $\square$ & $\square$ & $\square$ \\
\hline Delay in the release of funds & $\square$ & $\square$ & $\square$ & $\square$ & $\square$ \\
\hline Bureaucracy & $\square$ & $\square$ & $\square$ & $\square$ & $\square$ \\
\hline Corruption & $\square$ & $\square$ & $\square$ & $\square$ & $\square$ \\
\hline Changes in policy & $\square$ & $\square$ & $\square$ & $\square$ & $\square$ \\
\hline Lack of capacity & $\square$ & $\square$ & $\square$ & $\square$ & $\square$ \\
\hline Electricity & $\square$ & $\square$ & $\square$ & $\square$ & $\square$ \\
\hline $\begin{array}{l}\text { Technical obstacles (broken } \\
\text { pipes, pumps out of order etc.) }\end{array}$ & $\square$ & $\square$ & $\square$ & $\square$ & $\square$ \\
\hline Non-payment of water bills & $\square$ & $\square$ & $\square$ & $\square$ & $\square$ \\
\hline Other & $\square$ & $\square$ & $\square$ & $\square$ & $\square$ \\
\hline
\end{tabular}


Realising the Right to Water and Sanitation in Nigeria

31. In the last three years, have you ever received complaint from any of the following regarding access to water and sanitation?

\begin{tabular}{lll}
\hline & Yes & No \\
\hline Urban population & $\square$ & $\square$ \\
Local population & $\square$ & $\square$ \\
Civil Society Organisation & $\square$ & $\square$ \\
Traditional Rulers & $\square$ & $\square$ \\
Politicians & $\square$ & $\square$ \\
\hline
\end{tabular}

32. If you have answered yes above, please rate the frequency of complaint received.

\begin{tabular}{|c|c|c|c|c|c|}
\hline & $\begin{array}{l}\text { Not } \\
\text { frequent }\end{array}$ & $\begin{array}{l}\text { Somewhat } \\
\text { not frequent }\end{array}$ & $\begin{array}{l}\text { Neither } \\
\text { frequent nor } \\
\text { infrequent }\end{array}$ & $\begin{array}{l}\text { Somewhat } \\
\text { frequent }\end{array}$ & Frequent \\
\hline $\begin{array}{l}\text { Urban } \\
\text { population }\end{array}$ & $\square$ & $\square$ & $\square$ & $\square$ & $\square$ \\
\hline $\begin{array}{l}\text { Local } \\
\text { population }\end{array}$ & $\square$ & $\square$ & $\square$ & $\square$ & $\square$ \\
\hline $\begin{array}{l}\text { Civil Society } \\
\text { Organisation }\end{array}$ & $\square$ & $\square$ & $\square$ & $\square$ & $\square$ \\
\hline $\begin{array}{l}\text { Traditional } \\
\text { Rulers }\end{array}$ & $\square$ & $\square$ & $\square$ & $\square$ & $\square$ \\
\hline Politicians & $\square$ & $\square$ & $\square$ & $\square$ & $\square$ \\
\hline
\end{tabular}

33. In water generation, distribution and management, do you take environmental concerns into consideration? (for example, do you consider how your generation of water, distribution or management will impact on the environment such as whether it will lead to desertification or deforestation of the area, whether it will impact on preservation of natural resources, biodiversity etc)

$\square$ Yes $\quad \square$ No $\quad \square$ Sometimes

34. In your management of water, do you take into consideration the interest of future generations?

$\square$ Yes $\quad \square$ No

35. Do you monitor construction of personal boreholes and personal wells in your geographical area of operations?

$\square$ Yes $\quad \square$ No

36. Do you have any mechanism of monitoring water pollution in your geographical area of operations? 
Appendixes

$\square$ Yes $\quad \square$ No

37. How often do you receive request for information on water generation, distribution and management?

$\square$ Never $\quad \square$ Not often $\quad \square$ Often $\quad \square$ Very often

38. Do you disconnect water on the basis of inability to pay water rates?

$\square$ Yes, always $\quad \square$ No $\quad \square$ After notice is issued

39. Do you have any suggestion(s) on how to improve access to water and sanitation in your area? (Please write below)

40. Are there any other difficulties you are experiencing in the provision of access to water and sanitation? (if yes, please list them)

THANK YOU FOR YOUR PARTICIPATION. PLEASE WRITE YOUR EMAIL OR PHONE NUMBER IF WE CAN CONTACT YOU FOR FURTHER CLARIFICATIONS 
TYPE C

\section{CIVIL SOCIETY ORGANISATIONS}

Dear Respondent,

This survey is being conducted in pursuance to a $\mathrm{PhD}$ research. The research seeks to identify the factors militating against the realisation of access to quality water and basic sanitation in Nigeria and to recommend best possible options to address the situation.

Your opinion in this project is considered vital and extremely important. You are kindly requested to fill the attached questionnaire honestly and to the best of your ability. Your data will be treated as confidential and all responses are anonymous and would not in any way be used to identify you as a person. Please sign below to indicate your consent to give your opinion on this issue.

Thank you.

Signature and Date 


\section{SECTION ONE \\ DEMOGRAPHICS}

1. How would you describe your organisation?

Civil Society

NGO

INGO

Faith-based organisation

Other

2. Which zone(s) do you operate?

North-West

North-Central

North-East

South-West

South-East

South-South

3. What best describes your area of operations? [

\section{SECTION TWO}

OPERATIONS, HUMAN RIGHTS AND MARGINALISATION

4. Is your organisation aware of the human right to water and sanitation?
Yes
No

5. Has your organisation in the last two years been involved in any advocacy outreach/programme or in any seminar, public debate or conference on the right to water and sanitation?
Yes
No

6. Please rate the extent to which any of the following factors is negatively impacting on realising the right to water and sanitation in Nigeria

\begin{tabular}{llllll}
\hline & $\begin{array}{l}\text { Strongly } \\
\text { agree }\end{array}$ & Agree & $\begin{array}{l}\text { Neither agree } \\
\text { nor disagree }\end{array}$ & Disagree & $\begin{array}{l}\text { Strongly } \\
\text { disagree }\end{array}$ \\
\hline $\begin{array}{l}\text { Funding } \\
\text { Delay in the release of } \\
\text { funds }\end{array}$ & 1 & 2 & 3 & 4 & 5 \\
Bureaucracy & 1 & 2 & 3 & 4 & 5 \\
Corruption & 1 & 2 & 3 & 4 & 5 \\
Changes in policy & 1 & 2 & 3 & 4 & 5 \\
Lack of capacity & 1 & 2 & 3 & 4 & 5 \\
& 1 & 2 & 3 & 4 & 5
\end{tabular}


Realising the Right to Water and Sanitation in Nigeria

\begin{tabular}{llllll}
$\begin{array}{l}\text { Electricity } \\
\text { Technical obstacles }\end{array}$ & 1 & 2 & 3 & 4 & 5 \\
$\begin{array}{l}\text { (broken pipes, pumps out } \\
\text { of order etc.) }\end{array}$ & 1 & 2 & 3 & 4 & 5 \\
$\begin{array}{l}\text { Non-payment of water } \\
\text { bills }\end{array}$ & 1 & 2 & 3 & 4 & 5 \\
Other & 1 & 2 & 3 & 4 & 5 \\
\hline
\end{tabular}

7. Do you think there is a group of people or individuals in Nigeria which is being marginalised or discriminated against in the provision of access to water and sanitation?

Yes

No

I don't know

8. If yes, which of the following do you think could be the reason behind the marginalisation?

$\begin{array}{lll}\begin{array}{l}\text { Distance of the } \\ \text { area }\end{array} & \begin{array}{l}\text { Inaccessibility of the } \\ \text { area }\end{array} & \begin{array}{l}\text { Small number of } \\ \text { the population }\end{array} \\ \begin{array}{l}\text { Social status of } \\ \text { the population }\end{array} & \begin{array}{l}\text { Economic status of } \\ \text { the population }\end{array}\end{array} \quad \begin{aligned} & \text { Other } \\ & \text { then }\end{aligned}$

9. Do you think adopting a human right-based approach will add value to ensuring access to quality water and basic sanitation in Nigeria?
Yes
No
May be

10. What in your opinion can best ensure the realisation of the human right to water and sanitation?

11. To what extent in your opinion, the following can help in securing the realisation of the right to water and sanitation? (Please circle)

\begin{tabular}{llllllll}
\hline & $\begin{array}{l}\text { Very } \\
\text { unlikely }\end{array}$ & Unlikely & $\begin{array}{l}\text { Somewhat } \\
\text { unlikely }\end{array}$ & $\begin{array}{l}\text { Neither } \\
\text { likely nor } \\
\text { unlikely }\end{array}$ & $\begin{array}{l}\text { Somewhat } \\
\text { likely }\end{array}$ & Likely & $\begin{array}{l}\text { Very } \\
\text { likely }\end{array}$ \\
\hline $\begin{array}{l}\text { Traditional } \\
\text { rulers }\end{array}$ & 1 & 2 & 3 & 4 & 5 & 6 & 7 \\
Courts & 1 & 2 & 3 & 4 & 5 & 6 & 7 \\
Civil Society & 1 & 2 & 3 & 4 & 5 & 6 & 7
\end{tabular}




\begin{tabular}{|c|c|c|c|c|c|c|c|}
\hline \multirow{2}{*}{$\begin{array}{l}\text { Human } \\
\text { rights } \\
\text { institutions }\end{array}$} & \multirow[b]{2}{*}{1} & \multirow[b]{2}{*}{2} & \multirow[b]{2}{*}{3} & \multirow[b]{2}{*}{4} & & \multicolumn{2}{|c|}{ Appendixes } \\
\hline & & & & & 5 & 6 & 7 \\
\hline Media & 1 & 2 & 3 & 4 & 5 & 6 & 7 \\
\hline Other & 1 & 2 & 3 & 4 & 5 & 6 & 7 \\
\hline
\end{tabular}

THANK YOU FOR YOUR PARTICIPATION. PLEASE WRITE YOUR EMAIL OR PHONE NUMBER IF WE CAN CONTACT YOU FOR FURTHER CLARIFICATIONS 


\section{BibLIOGRAPHY}

Abbas IM, 'Trends of Rural-Urban Migration Nigeria' (2012) 8 European Scientific Journal Acreman M and Dubar MJ, 'Defining Environmental River Flow Requirement - A Review' (2004) 8 Hydrology and Earth System Sciences 861

ACTIONAID-Kenya, Country strategy paper, 2002-2005 (ActionAid Kenya 2002)

Adelegan JA, 'The History of Environmental Policy and Pollution of Water Sources in Nigeria (1960-2004): The Way Forward' (<http://nigerianlawguru.com/articles/environmental\%20law/THE\%20HISTORY $\% 20$ OF\%20ENVIRONMENTAL\%20POLICY\%20AND\%20POLLUTION\%20O F\%20WATER\%20SOURCES\%20IN\%20NIGERIA.pdf> accessed 29 September, 2013

Adenle D, 'Institutional Issues in Water Supply \& Sanitation (WSS) and their Role in the Attainment of Millennium Development Goals' Targets in Nigeria' (Federal Ministry of Water Resources, <www.fmwr.gov.ng> accessed 1 September, 2013

Adeoti O, 'Challenges to Managing Water Resources along the Hydrological Boundaries in Nigeria' (January, 2007) 9 Water Policy

Aduba JN, 'The Protection of Human Rights in Nigeria' in Obilade AO and Nwanko CO (eds), Text for Human Rights Teaching in Schools (Text for Human Rights Teaching in Schools Constitutional Rights Project 1999)

Afolayan A and Division IsR, Migration in Nigeria: A Country Profile 2009 (International Organization for Migration 2009)

African Development Bank, Nigeria: Rural Water Supply and Sanitation Sub-programmes in Yobe and Osun States, Appraisal Report, May, 2007)

Agarwal A and others, Integrated Water Resources Management (Global Water Partnership 2000)

Agbakwa SC, 'Reclaiming Humanity: Economic, Social and Cultural Rights as the Cornerstone of African Human Rights' (2002) 5 Yale Human Rights \& Development Law Journal

Agpalo RE, Statutory Construction' 2003 Ed (Rex Book Store 2003)

Aguda TA, 'Judicial Process and Stability in the Third Republic' National Concord Newspaper (Lagos 7 November)

Ahmad A, Audi J and Sada IN, Resolution of Civil Disputes in Jigawa State (Nigeria) (Access to Justice Programme - Research Report, June-August 2003)

Ahmad E and Singh R, 'Political Economy of Oil-Revenue Sharing in a Developing Country: Illustrations from Nigeria' (2003) IMF Working Paper WP/03/16

Aigbokhan BE, 'Poverty, Growth and Inequality in Nigeria: A Case Study' (2000) Working Papers, African Economic Research Consortium

Ajai O, 'Law, Water and Sustainable Development: Framework of Nigerian Law' (2012) 8 Law, Environment and Development Journal

Ajiboye AJ, Olaniyi AO and Adegbite BA, 'A Review of the Challenges of Sustainable Water Resources Management in Nigeria' (2012) 1 Int J Life Sc Bt \& Pharm Res

Ajomo MA and Adewale O (eds), Environmental Law and Sustainable Development in Nigeria (Nigerian Institute of Advanced Legal Studies 1994)

Akinseye-George Y, Improving Judicial Protection of Human Rights in Nigeria (Center for Socio-Legal Studies 2012) 
Realising the Right to Water and Sanitation in Nigeria

Akpor OB and Muchie M, 'Challenges in Meeting the MDGs: The Nigerian Drinking Water Supply and Distribution Sector' (2011) 5 Journal of Environmental Science and Technology

Alabi MA, 'Fundamental Objectives and Directive Principles Under the Nigerian Constitutional Law' (2006) 11 The Jurist

Albert IO and others, Informal Channels for Conflict Resolution in Ibadan, Nigeria (Institut français de recherche en Afrique 2013)

Albin-Lackey C, Chop Fine: The Human Rights Impact of Local Government Corruption and Mismanagement in Rivers State, Nigeria, vol 19 (2A) (Human Rights Watch: A Sub-Saharan Africa, Human Rights Watch 2007)

Alston P, 'The Rights Framework and Development Assistance' (1995) 34 Development Bulletin (Australia) 9

Alston P, 'Ships Passing in the Night: The Current State of the Human Rights and Development Debate seen through the Lens of the Millennium Development Goals' (2005) 27 Human Rights Quarterly

Amadi S, 'Access to Justice' (1999) 1 Human Rights Newsletter

Anantha L and Dandekar P, Towards Restoring Flows into the Earth's Arteries: Why, What and How of 'ENVIRONMENTAL FLOWS'

Anantha L and Dandekar P, Towards Restoring Flows into the Earth's Arteries: A Primer on Environmental Flow (May, 2012)

Andhyarujina TR, 'Disturbing Trends in Judicial Activism' (The Hindu, 6 August 2012) <http://www.thehindu.com/opinion/lead/Disturbing-trends-in-judicialactivism/article12680891.ece> accessed 20 February 2018

Appel PA, 'Intervention in Public Law Litigation: The Environmental Paradigm' (2000) 78 Wash U L Q

APRM, APRM Country Review Report No. 8: Federal Republic of Nigeria 2009)

Arambulo K, Strengthening the Supervision of the International Covenant on Economic, Social and Cultural Rights: Theoretical and Procedural Aspects (Intersentia 1999)

Assembly Online, 'Nigeria: WASH Media Network Calls on FG to Fulfil WASH Commitments' (<http://assemblyonline.info/?p=16520 $>$ accessed 18 February, 2014

Aturu B, 'The Legal Profession and Protection of Human Rights' (<http://bamideleaturuandco.com/THE\%20LEGAL\%20PROFESSION\%20AND $\%$ 20HUMAN\%20RIGHTS.pdf $>$ accessed 2 December, 2014

Austin G, The Indian Constitution: Cornerstone of a Nation (2nd edn, South Asia Books 1999)

Ayoade JO, 'Water Resources and their Development in Nigeria' (1975) XX, 4 Hydrological Sciences - Bulletin - des Sciences Hydrologiques

Azinge E and Owasanoye O (eds), Justiciability and Constitutionalism: An Economic Analysis of Law (Nigerian Institute of Advanced Legal Studies 2010)

B. S, 'Literal Interpretation Versus Liberal Interpretation' (8 July 2013) <https://ssrn.com/abstract=2290872> accessed 13 March 2018

Bankole-Oke CTA, 'Lawyers' Challenge and Burden of 1999 Constitution' Guardian (Lagos 28 April)

Batliwala S, 'When Rights Go Wrong' (2007) Seminar

Batliwala S, Engaging with Empowerment: An Intellectual and Experiential Journey (Women Unlimited 2015)

BBC News, 'Nigeria Profile - Timeline' (BBC, 13 July 2017) <http://www.bbc.com/news/world-africa-13951696> accessed 16 August 2017 
BBC News, 'Nigeria Leaders 'stole' \$380bn' (BBC, 2006) <http://news.bbc.co.uk/2/hi/africa/6069230.stm> accessed 24 May 2014

Bennion FAR, Understanding Common Law Legislation: Drafting and Interpretation (Oxford University Press 2009)

Birkland TA, An Introduction to the Policy Process: Theories, Concepts, and Models of Public Policy Making (3rd edn, M.E Sharpe 2010)

Biswas AK, 'Water Management for Major Urban Centres' (2006) 22 International Journal of Water Resources Development

Blackmar CB, 'Judicial Activism' (1997-1998) 42 Saint Louis University Law Journal

Boesen JK and others, Applying a Rights-based Approach: An Inspirational Guide for Civil Society (Danish Institute for Human Rights 2007)

Bolman LG and Deal TE, Reframing Organizations (5th edn, Jossey-Bass 2013)

Boyle AE and Anderson MR, Human Rights Approaches to Environmental Protection (Oxford University Press 1996)

Brems E and Adekoya CO, 'Human Rights Enforcement by People Living in Poverty: Access to Justice in Nigeria' (2010) 54 Journal of African Law 258

Brisbane Declaration, The Brisbane Declaration: Environmental Flows Are Essential for Freshwater Ecosystem Health and Human Well-Being (3-6 September 2007)

Brown A and Matlock MD, A Review of Water Scarcity Indices and Methodologies (The Sustainability Consortium April, 2011)

Brown C, 'Judicial Activism' (1986) 13 Ohio Northern University Law Review

Brownlie I, Principles of Public International Law (6 edn, Oxford University Press 2003)

Burchi S, 'The Interface Between Customary and Statutory Water Rights - A Statutory Perspective' (International workshop on 'African Water Laws: Plural Legislative Frameworks for Rural Water Management in Africa)

Burchi S, Balancing Development and Environmental Conservation and Protection of the Water Resource Base: The 'Greening' of Water Laws (Foundation Books 2010)

Cahill A, 'The Human Right to Water - A Right of Unique Status': The Legal Status and Normative Content of the Right to Water' (2005) 9 The International Journal of Human Rights 389

Campbell KM and others, The Age of Consequences: The Foreign Policy and National Security Implications of Global Climate Change, November, 2007)

Campese $\mathrm{J}$ and others (eds), Rights-Based Approaches: Exploring Issues and Opportunities for Conservation (Center for International Forestry Research 2009)

Care International UK, Principles into Practice: Learning from Innovative Rights-Based Programmes (September 2005)

Carius A, Dabelko GD and Wolf AT, Water, Conflict, and Cooperation (ECSP Report, 2004)

Central Intelligence Agency, 'Nigeria' (July, 2013) <https://www.cia.gov/library/publications/the-world-factbook/geos/ni.html> accessed 25 August, 2013

Central Intelligence Agency, 'The World Factbook' (May 2001) <https://www.cia.gov/library/publications/the-world-factbook/geos/ni.html> accessed 30 December 2016

Chayes A, 'The Role of the Judge in Public Law Litigation' (1976) 89 HARV L REV

Christian Fellowship and Care Foundation, 'Country Briefing: Nigeria' (<http://www.chrifacafinc.org/CFCFnew/pdf-files/NIGERIA1.pdf $>$ accessed 19 February, 2014

Chukwu KE, 'Water Supply Management Policy in Nigeria: Challenges in the Wetland Area of Niger Delta ' 11 European Scientific Journal 303 
Realising the Right to Water and Sanitation in Nigeria

Cismas I, 'The Intersection of Economic, Social, and Cultural Rights and Civil and Political Rights' in Riedel E and others (eds), Economic, Social, and Cultural Rights in International Law: Contemporary Issues and Challenges (Economic, Social, and Cultural Rights in International Law: Contemporary Issues and Challenges Oxford University Press 2014)

Clapham A, Human Rights Obligations of Non-state Actors (Oxford University Press 2006) Clark TW and Minta SC, Greater Yellowstone's Future: Prospects for Ecosytem Science, Management, and Policy (Homestead Pub. 1994)

COHRE and others, Manual on the Right to Water and Sanitation (COHRE 2007)

Connect US, '11 Principal Pros and Cons of Judicial Activism' (<https://connectusfund.org/11-principal-pros-and-cons-of-judicial-activism> accessed 20 February 2018

Constitution Debate Coordinating Committee, Report of the Constitution Debate Coordinating Committee (CDCC): Main Report, vol 1 (Government Printer, December 1999)

Constitution Writing and Conflict Resolution, 'Nigeria 1999' (Princeton University, $<$ https://www.princeton.edu/ pcwcr/reports/nigeria1999.html $>$ accessed 20 November, 2014

Cornwall A and Nyamu-Musembi C, 'Putting the 'Rights-Based Approach' to Development into Perspective' (2004) 25 Third World Quarterly 1415

Costanza R and others, 'The Value of the World's Ecosystem Services and Natural Capital' (1997) 387 Nature

Crabtree S, 'Religiosity Highest in World's Poorest Nations' (Gallup, 2010) $<$ http://www.gallup.com/poll/142727/religiosity-highest-world-poorestnations.aspx $>$ accessed 31 July, 2016

Cranston M, 'Human Rights, Real and Supposed' in Raphael DD (ed) Political Theory and the Rights of Man (Political Theory and the Rights of Man, Macmillan 1967)

Craven M, The International Covenant on Economic, Social and Cultural Rights: A Perspective on its Development (Oxford University Press 1995)

Crona M, 'The Principle of Dynamic Interpretation - A Matter of Legitimacy: The ECHR Principle of Dynamic Interpretation from a Constitutional Perspective' (University of Oslo 2009)

Cross R, Bell J and Engle G, Statutory Interpretation (Butterworths 1995)

Crozier M, On ne change pas la société par décret (Bernard Grasset 1979)

Dada JA, 'Human Rights under the Nigerian Constitution: Issues and Problems' (2012) 2 International Journal of Humanities and Social Science

Dada JA, 'Impediments to Human Rights Protection in Nigeria ' (2012) 18 Annual Survey of International \& Comparative Law 67

Dakas DCJ, 'Judicial Reform of the Legal Framework For Human Rights Litigation in Nigeria: Novelties and Perplexities' in Azinge E and others (eds), Judicial Reform and Transformation in Nigeria: A Tribute to Hon Justice Dahiru Musdapher, GCON, FNIALS, Chief Justice of Nigeria (Judicial Reform and Transformation in Nigeria: A Tribute to Hon Justice Dahiru Musdapher, GCON, FNIALS, Chief Justice of Nigeria, Nigerian Institute of Advanced Legal Studies 2012)

De Sloovere, 'Extrinsic Aids in the Interpretation of Statutes' (1940) 88 PA L Rev

Department of Water Supply and Quality Control, National Rural Water Supply and Sanitation Programme: A Strategic Framework (Federal Ministry of Water Resources 2004)

DFID, Realising Human Rights for Poor People (DFID 2000) 


\section{Bibliography}

Duru OWC, 'The Justiciability of the Fundamental Objectives and Directive Principles of State Policy Under Nigerian Law' (2012) <http://ssrn.com/abstract=2140361〉 accessed 1 December, 2014

Dutt O, 'Relation Between Environment and Human Rights with Special Reference to India' (August, 2013) 3 Indian Streams Research Journal

Dyson M, Bergkamp G and Scanlon J (eds), Flow: The Essentials of Environmental Flow (IUCN 2003)

Economist Intelligence Unit, 'Nigeria: Constitutions and Institutions' (15 June, 2004) $<$ http://country.eiu.com/Nigeria $>$ accessed

ECOSOC, Realization of the Right to Drinking Water and Sanitation: Report of the Special Rapporteur, El Hadji Guissé (11 July, 2005 )

Eide A, 'Economic, Social and Cultural Righs As Human Rights' in Eide A and others (eds), Economic, Social and Cultural Rights (Economic, Social and Cultural Rights, 2nd edn, Martinus Nijhoff Publishers 2001)

Elias TO, The Nature of African Customary Law (Manchester University Press 1956)

Elias TO, Nigerian Land Law (Sweet \& Maxwell 1971)

Emmanuel M, Federalism in Nigeria: Between Divisions in Conflict and Stability in Diversity (Globethicsnet Theses, Globethics.net 2016)

Emovon EU, 'Fundamental Objectives and Directive Principles and Public Accountability' in Kumo S and Aliyu A (eds), Issues in the Nigerian Draft Constitution: The Report of the Conference on Issues in the Draft Constitution, Held at the Institute of Administration, Ahmadu Bello University, Zaria, 21st - 24th March, 1977 (Issues in the Nigerian Draft Constitution: The Report of the Conference on Issues in the Draft Constitution, Held at the Institute of Administration, Ahmadu Bello University, Zaria, 21st - 24th March, 1977, Dept. of Research and Consultancy, Institute of Administration, Ahmadu Bello University 1977)

ESCR-Net, 'Caselaw Database' (<https://www.escr-net.org/caselaw $>$ accessed 17 November 2017

Ettenger K, "'A River That Was Once So Strong and Deep": Local Reflections on the Eastmain Diversion, James Bay Hydroelectric Project' in Donahue JM and Johnston BR (eds), Water, Culture, and Power: Struggles in a Global Context (Water, Culture, and Power: Struggles in a Global Context, Island Press 1998)

Eze OC, Human Rights in Africa: Some Selected Problems (Nigerian Institute of International Affairs 1984)

Falkenmark M, 'Fresh Water-Time for a Modified Approach' (1986) 15 Ambio 192

Falkenmark M, 'The Massive Water Scarcity Threatening Africa - Why isn't it Being Addressed' (1989) 18 Ambio 112

Falkenmark M and Widstrand C, 'Population and Water Resources: A Delicate Balance' (1992) 47 Population Bulletin

Falola T (ed), Nigerian History, Politics and Affairs: The Collected Essays of Adiele Afigbo (Africa World Press, Inc. 2005)

Falola T and Heaton MM, A History of Nigeria (Cambridge University Press 2008)

Farrington J, 'Sustainable Livelihoods, Rights and the New Architecture of Aid' Natural Resource Perspectives, vol 69 (Natural Resource Perspectives, Overseas Development Institute 2001)

Fawehinmi G, Nigerian Law of Habeas Corpus (Nigerian Law Publications 1986)

Fawehinmi G, 'Ouster of Court's Jurisdiction by Statutes' in Smaranda E (ed) Contemporary Issues in the Nigerian Legal System (Contemporary Issues in the Nigerian Legal System GLJ General Services, Nigerian Bar Association 1997) 
Realising the Right to Water and Sanitation in Nigeria

Federal Ministry of Environment, 'About the Ministry' (<http://www.environment.gov.ng/about.html $>$ accessed 11 February, 2017

Federal Ministry of Water Resources, 'History of the Ministry' (Federal Ministry of Water Resources, <http://www.waterresources.gov.ng/about/history-of-the-ministry> accessed 29 May 2014

Federal Ministry of Water Resources, Making Nigeria Open-Defecation-Free by 2025: A National Road Map (Federal Ministry of Water Resources 2016)

Federal Ministry of Water Resources, Partnership for Expanded Water Supply, Sanitation and Hygiene (PEWASH): Programme Strategy 2016-2030 (2016)

Federal Ministry of Water Resources, Nigeria Overview: Water, Sanitation and Hygiene (Achieving the SDGs Targets for Water, Sanitation and Hygiene, 2017)

Federal Ministry of Water Resources, Immediate and Longterm Strategies for the Water Sector 2016-2030 (August 2016)

Federal Republic of Nigeria, National Water Resources Master Plan (Federal Ministry of Water Resources 1995)

Constitution of the Federal Republic of Nigeria

Federal Republic of Nigeria, National Water Supply and Sanitation Policy (Federal Government Printing Press 2000)

Federal Republic of Nigeria, National Policy on Population for Sustainable Development (2004)

Federal Republic of Nigeria, 'National Water Policy' (2004)

Federal Republic of Nigeria, National Water Sanitation Policy (Federal Government Printing Press 2004)

Federal Republic of Nigeria, National Environmental Sanitation Policy (2005)

Federal Republic of Nigeria, 'Nigeria' (2014) <www.nigeria.gov.ng > accessed 24 June, 2014

Federal Republic of Nigeria, National Policy on the Environment (2017)

Federal Republic of Nigeria, Nigeria's 6th Periodic Country Report: 2015-2016 on the Implementation of the African Charter on Human and Peoples Rights in Nigeria (Federal Ministry of Justice, Abuja, August 2017)

Feitelson E and Chenoweth J, 'Water Poverty: Towards a Meaningful Indicator' (2002) 4 Water Policy 263

Ferguson CC, Global Social Policy Principles: Human Rights and Social Justice (DFID, SDD 1999)

Filmer-Wilson E, 'The Human Rights-based Approach to Development: The Right to Water' (2005) 23 Netherlands Quarterly of Human Rights 213

Financial Policy Assurance Unit, Guide to Preparing Virements (2011)

Frankovits A, The Human Rights Based Approach and the United Nations System (UNESCO 2006)

Frostell K, Human Rights of Women (KIOS 2006)

Gabriel E, 'Water Scarcity, Conflict, and Security in a Climate Change World: Challenges and Opportunities for International Law and Policy' (2009-2010) 27 Wis Int'1 LJ

Gabriel I and Angwe B, 'Legal and Institutional Framework for the Preservation and Protection of Water Resources in Nigeria' (1997) 3 Current Jos Law Journal

Galligan DJ, Discretionary Powers: A Legal Study of Official Discretion (Clarendon Press 1990)

Gaughran A, 'Business and Human Right and the Right to Water' (2012) American Society of International Law Proceedings

Gauri V and Brinks DM, Courting Social Justice: Judicial Enforcement of Social and Economic Rights in the Developing World (Cambridge University Press 2008) 
Bibliography

Giginyu IM, 'Nigeria: 194,000 Children Die of Diarrhoea Every Year' Daily Trust (Abuja 21 November)

Gleick P, 'The Human Right to Water' (1999) 1 Water Policy

Gleick PH, 'Basic Water Requirements for Human Activities: Meeting Basic Needs' (1996) 21 Water International

Global Water Partnership, 'A Secure World' (2010)accessed 29 January, 2017

Gneiting U and others, 'Setting Higher Goals: Rights and Development' (December, 2009) Monday Developments

Goldface-Irokalibe IJ, 'Enabling Environment and Institutions' (Regional Training of Trainers Workshop)

Goldface-Irokalibe IJ, 'Water Management in Federal and Federal - Type Countries: Nigerian Perspectives' (Forum of Federations, 2009) <http://www.forumfed.org/library/water-management-in-federal-and-federal-typecountries-nigerian-perspectives/> accessed 14 September, 2013

Goodstein D, Out of Gas: The End of the Age of Oil (W. W. Norton \& Company 2004)

Grumbine RE, 'What Is Ecosystem Management?' (March, 1994) 8 Conservation Biology 27

Gupta DK, Analyzing Public Policy: Concepts, Tools and Techniques (2nd edn, CQ Press 2011)

Hamm BI, 'A Human Rights Approach to Development' (2001) 23 Human Rights Quarterly

Heard A, 'Human Rights: Chimeras in Sheep's Clothing?' (Simon Fraser University 1997) <http://www.sfu.ca/ aheard/intro.html > accessed 19 February, 2014

Heath RC, Basic Ground-Water Hydrology: U.S . Geological Survey Water-Supply Paper 2220, 1983)

Hodgson S, Land and Water - The Right Interface (Food and Agricultural Organisation 2004)

Hon. Minister of Water Resources, Mid-Term Report on Water Sector Transformation (2011 - 2013) (June, 2013)

Hoof Gv, 'The Legal Nature of Economic, Social and Cultural Rights: A Rebuttal of Some Traditional Views' in Alston P and Tomasevski K (eds), The Right to Food (The Right to Food, Martinus Nijhoff 1984)

Howard G and Bartram J, Domestic Water Quantity, Service Level and Health (World Health Organisation 2003)

HRBA Portal, 'United Nations Practitioner's Portal on Human Rights Based Approaches to Programming' (<http://hrbaportal.org/faq $>$ accessed 25 July 2016

Human Rights Resource Center, 'The Right to a Healthy Environment' (University of Minnesota,

<http://hrlibrary.umn.edu/edumat/IHRIP/circle/modules/module15.htm $>$ accessed 28 May 2018

Human Rights Watch, Everyone's in on the Game: Corruption and Human Rights Abuses by the Nigerian Police August, 2010)

Human Rights Watch, 'Chop Fine: The Human Rights Impact of Local Government Corruption and Mismanagement in Rivers State, Nigeria' (January, 2007) 19 Human Rights Watch

Hunt P and MacNaughton G, 'A Human Rights-Based Approach to Health Indicators' in Baderin MA and McCorquodale R (eds), Economic, Social and Cultural Rights in Action (Economic, Social and Cultural Rights in Action, Oxford University Press 2007)

Ibe S, 'Beyond Justiciability: Realising the Promise of Socio-economic Rights in Nigeria' (2007) 7 African Human Rights Law Journal 225

Iliyas M, 'State of Urban Water Supply in Nigeria' (National Water and Sanitation Forum) 
Realising the Right to Water and Sanitation in Nigeria

Intergovernmental Panel on Climate Change, Technical Paper on Climate Change and Water, 2008)

International Commission of Jurists, Maastricht Guidelines on Violations of Economic, Social and Cultural Rights (International Commission of Jurists 26 January, 1997)

International Commission of Jurists, The Rule of Law and Human Rights: Principles and Definitions as Elaborated at the Congresses and Conferences Held Under the Auspices of the International Commission of Jurists, 1955-1966 (International Commission of Jurists 1966)

International Commission of Jurists, The Limburg Principles on the Implementation of the International Covenant on Economic, Social and Cultural Rights (International Commission of Jurists 1986)

International Commission of Jurists, Bangalore Declaration and Plan of Action (1995)

International Commission of Jurists, International Principles on the Independence and Accountability of Judges, Lawyers and Prosecutors: Practitioners Guide No. 1 (International Commission of Jurists 2007)

International Commission of Jurists, Courts and the Legal Enforcement of Economic, Social and Cultural Rights: Comparative Experiences of Justiciability (International Commission of Jurists 2008)

International Human Rights Network, 'Our Rights, Our future Human Rights based Approaches in Ireland: Principles, Policies and Practice' (2005) <http://www.ihrnetwork.org/files/IHRN-

AI\%20HRBA\%20Ireland\%20Sept05\%20FINAL.pdf> accessed 11 May, 2013

International Monetary Fund, World Economic Outlook Update, January 2018: Brighter Prospects, Optimistic Markets, Challenges Ahead, 22 January 2018)

International Monetary Fund, 'World Economic Outlook Database' (October 2016) <https://www.imf.org/external/pubs/ft/weo/2016/02/weodata/weorept.aspx?pr.x=6 $\underline{8} \&$ pr. $y=9 \& \mathrm{sy}=2016 \& \mathrm{ey}=2021 \& \mathrm{scsm}=1 \& \mathrm{ssd}=1 \&$ sort $=$ country $\& \mathrm{ds}=. \& \mathrm{br}=1 \& \mathrm{c}=69$ 4\&s=NGDP R\%2CNGDP RPCH\%2CNGDPD\%2CNGDPPC\%2CNGDPDPC\& grp $=0 \& a=>$ accessed 22 May 2018

Irujo AE, 'The Right to Water' (June, 2007) 23 International Journal of Water Resources Development 267

Ismail AAO, 'Towards the People's Constitution in Nigeria' (2010) 7 Journal of Law and Diplomacy

Ita E, Inland Fishery Resources of Nigeria (Food and Agriculture Organisation 1993)

IUCN, World Conservation Strategy: Living Resource Conservation for Sustainable Development (IUCN 1980)

IUCN, How Much is an Ecosystem Worth? Assessing the Economic Value of Conservation (The World Bank 2004)

Jimoh A, 'Nigeria: 17 Million Women Have No Toilet - Wateraid' Daily Trust (Abuja 20 November)

Johnston BR and Donahue JM, 'Introduction' in Donahue JM and Johnston BR (eds), Water, Culture, and Power: Struggles in a Global Context (Water, Culture, and Power: Struggles in a Global Context, Island Press 1998)

Johnstone Q, 'An Evaluation of the Rules of Statutory Interpretation' (1954-1955) 3 Kansas Law Review

Jones HW, 'The Plain Meaning Rule and Extrinsic Aids in the Interpretation of Federal Statutes' (1939) 25 Wash, ULQ 
Bibliography

Kale Y, 'Measuring Better: Rebasing/Re-benchmarking of Nigeria's Gross Domestic Product ' (Presentation of the Results of Nigeria's GDP Rebasing/Re-benchmarking Exercise )

Katsui H, Downside of the Human Rights-Based Approach to Disability in Development (Institute of Development Studies, Helsinki University 2008)

Keller S, 'Traditional Beliefs Part of People's Lives' (1996) 17 Netw Res Triangle Park N C

Kennedy D, The Dark Sides of Virtue: Reassessing International Humanitarianism (Princeton University Press 2004)

Keys P, Barron J and Lannerstad M, Releasing the Pressure: Water Resource Efficiencies and Gains for Ecosystem Services (United Nations Environment Programme \& Stockholm Environment Institute 2012)

Kiss A, 'Concept and Possible Implications of the Right to Environment' in Mahoney KE and Mahoney P (eds), Human Rights in the Twenty-first Century - A Global Challenge (Human Rights in the Twenty-first Century - A Global Challenge, Nijhoff 1993)

Kornfeld IE, 'Water: A Public Good or a Commodity?' (2012) American Society of International Law Proceedings

Kumar P and others, Guidance Manual for the Valuation of Regulating Services (United Nations Environment Programme 2010)

Kuruk P, 'Customary Water Laws and Practices: Nigeria' (Food and Agriculture Organization, 2004) 〈http://www.fao.org/legal/advserv/FAOIUCNcs/Nigeria.pdf > accessed 27 January, 2017

Laban P, 'Accountability and Rights in Right-based Approaches for Local Water Governance' (2007) 23 International Journal of Water Resources Development 355

Ladan MT, 'Review of the Regulatory and Policy Frameworks of the Nigerian Water Sector and International Legal Response for Sustainable Management and Protection of Water Resources' (7 January, 2013) <https://ssrn.com/abstract=2358884 > accessed 26 April, 2014

Ladan MT, Law, Cases and Policies on Energy, Mineral Resources, Climate Change, Environment, Water, Maritime and Human Rights in Nigeria (Ahmadu Bello University Press 2009)

Lagos State Government, Action Memorandum on Groundwater Regulation in Lagos State (Federal Ministry of Water Resources 2008)

Landman T, Studying Human Rights (Routledge 2006)

Landman T, 'Social Science Methods and Human Rights' in Coomans F and others (eds), Methods of Human Rights Research (Methods of Human Rights Research, Intersentia 2009)

Langford M, 'The United Nations Concept of Water as a Human Right: A New Paradigm for Old Problems?' (2005) 21 International Journal of Water Resources Development

Langford M (ed), Social Rights Jurisprudence: Emerging Trends in International and Comparative Law (Cambridge University Press 2008)

Lasswell HD and McDougal MS, 'Legal Education and Public Policy: Professional Training in Public Interests' (1943) 52 The Yale LJ

Latour B, Reassembling the Social: An Introduction to Actor-Network-Theory (Oxford University Press 2005)

Lee's Compliance Portal, 'The Importance of Legal Compliance' (<http://www.compliancetools.co.za/ComplianceInABox/ImportanceOfLegalCom pliance.aspx $>$ accessed 13 March 2018

Lindeman RL, 'The Trophic-Dynamic Aspect of Ecology' (1942) 23 Ecology 399

Lloyd PC, Yoruba Land Law (Oxford University Press 1962) 
Realising the Right to Water and Sanitation in Nigeria

Lord Lester of Herne Hill QC and O'Cinneide C, 'The Effective Protection of Socioeconomic Rights' in Ghai Y and Cottrell J (eds), Economic, Social and Cultural Rights in Practice: The Role of Judges in Implementing Economic, Social and Cultural Rights (Economic, Social and Cultural Rights in Practice: The Role of Judges in Implementing Economic, Social and Cultural Rights, Interights 2004)

MacDonald A and others, Developing Groundwater: A Guide for Rural Water Supply (ITDG Publishing 2005)

Magraw DB and Hawke LD, 'Sustainable Development' in Bodansky D and others (eds), The Oxford Handbook of International Environmental Law (The Oxford Handbook of International Environmental Law, Oxford University Press 2008)

Maidin AJ and others, 'Sustaining Development through Socio-Economic Rights: Prospect and Challenges in Selected African Countries' (2011) 7 Journal of Applied Sciences Research

Makeri SH, 'Jurisdictional Issues in the Application of Customary Law in Nigeria' (All Nigerian Judges Conference: The Judiciary and the Challenges of Nation Building)

Malemi E, Outline of Nigerian Legal System (Grace Publishers 1999)

Marie A, 'Preventing Water Wars in Northern Nigeria' (2011) $<$ http://aconerlycoleman.wordpress.com/2011/01/17/article-preventing-waterwars-in-northern-nigeria/> accessed 19 October, 2013

Markels A, 'Sin City's Continuous Flow' US News (27 May)

Martins R, 'Increasing the Success of Service Design Implementation: Bridging the Gap Between Design and Change Management' (2016) 8 Touchpoint

Martins R, 'Three Theories to Help Overcome Change Resistance in Service Design Implementation' (Integration and Implementation Insights, 2017) <https://i2insights.org/2017/03/23/overcoming-change-resistance/> accessed 26 March, 2017

Mason N, Matoso M and Smith W, Private Sector and Water Supply, Sanitation and Hygiene (ODI, October 2015)

McQuerrey L, 'Assessing the Role of Motivation on the Employees Performance' (<http://work.chron.com/assessing-role-motivation-employees-performance21649.html> accessed 14 December, 2016

Merrils JG, 'Environmental Rights' in Bodansky D and others (eds), The Oxford Handbook of International Environmental Law (The Oxford Handbook of International Environmental Law, Oxford University Press 2008)

Millennium Ecosystem Assessment, Ecosystems and Human Well-Being: Biodiversity Synthesis (Island Press 2005)

Miller RL and Campbell R, 'Taking Stock of Empowerment Evaluation: An Empirical Review. ' (2006) 27 American Journal of Evaluation 296

Miller V, VeneKlasen L and Clark C, 'Rights-based Development: Linking Rights and Participation - Challenges in Thinking and Action' (2005) 36 IDS Bulletin 31

Ministry of Budget and National Planning, 'Nigeria's Oil Sector Contribution to GDP Lowest in OPEC - Blueprint' (2017) <http://www.nationalplanning.gov.ng/index.php/newsmedia/news/news-summary/333-nigeria-s-oil-sector-contribution-to-gdp-lowestin-opec-blueprint> accessed 19 August 2017

Morgera E, 'Healthy Ecosystems Essential for Human Rights' (12 June 2017) <https://www.espa.ac.uk/news-blogs/blog/healthy-ecosystems-essential-humanrights $>$ accessed 26 January 2018

Moser C and others, To Claim Our Rights: Livelihood Security, Human Rights and Sustainable Development (Overseas Development Institute 2001) 
Bibliography

Moskowitz M, International Concern with Human Rights (Oceana Publications Inc. 1974)

Moulton TP, 'Ecosystem Theory and Conservation' (2012) 22 Aquatic Conservation: Marine and Freshwater Ecosystems 423

Municipal Association of Victoria and others, 'About Good Governance' (2012) <http://www.goodgovernance.org.au/about-good-governance/what-is-goodgovernance/> accessed 28 August, 2016

Narively VZ, Conflict: Right to Property and Directive Principles of the Indian Constitution (Sterling Publishers 1988)

National Bureau of 'Environmental Statistics, Statics' (<http://www.nigerianstat.gov.ng/pdfuploads/ENVIRONMENT\%20STATISTICS .pdf $>$ accessed 28 June, 2014

National Bureau of 'Water Statistics, Supply Statistics' (<http://nigerianstat.gov.ng/pages/NBS\%20eLibrary > accessed 6 June, 2014

National Bureau of Statistics, Multiple Indicator Cluster Survey 2007, 2007)

National Bureau of Statistics, 'Key Statistics' (2018) <http://www.nigerianstat.gov.ng/> accessed 22 May 2018

National Bureau of Statistics, Nigerian Gross Domestic Product Report Q1 2018, May, 2018)

National Bureau of Statistics and others, Multiple Indicator Cluster Survey 2016-17, February 2018)

National Human Rights Commission, 'Thematic Focus' (National Human Rights Commission, <http://www.nigeriarights.gov.ng/> accessed 25 May 2018

National Human Rights Commission, State of Human Rights in Nigeria, 2007)

National Human Rights Commission, Annual Report 2016, (2017)

National Human Rights Commission, Implementation of Presidential Executive Orders, (2017)

National Population Commission, 'Nigeria Demographic and Health Survey (NDHS) Fact Sheet: North West Zone' (2008) <http://www.measuredhs.com/pubs/pdf/OF12/OF12.NW.4.english.pdf $>$ accessed 22 July, 2013

National Population Commission, Nigeria Demographic and Health Survey 2013, June 2014)

National Research Council, Valuing Ground Water: Economic Concepts and Approaches (National Academy Press 1997)

Newbury CW, British Policy Towards West Africa: Selected Documents (1875 - 1914) (Hutchinson \& Co. Ltd 1960)

Nickel JW, 'Rethinking Indivisibility: Towards A Theory of Supporting Relations between Human Rights' (2008) 30 Human Rights Quarterly 984

Nwabueze BO, The Individual and the State under the New Constitution: Government Powers in Relation to Economic Affairs and the Economy under the Constitution (Nigerian Institute of International Affairs 19 February, 1979)

Nwankwoala HO, 'Localizing the Strategy for Achieving Rural Water Supply and Sanitation in Nigeria' (2011) 5 African Journal of Environmental Science and Technology

Nwaobi GC, 'Oil Policy in Nigeria: A Critical Assessment (1958-1992)' (<http://128.118.178.162/eps/pe/papers/0501/0501001.pdf $>$ accessed 29 April 2014

Nwauche E, 'Nigeria: Introductory Notes' (University of Pretoria, <https://web.up.ac.za/sitefiles/file/47/15338/Nigeria.pdf > accessed 13 May, 2014

Nweze CC, 'Evolution of the Concept of Socio-Economic Rights in Human Rights Jurisprudence: International and National Perspectives' in Nweze CC (ed) Justice in 
Realising the Right to Water and Sanitation in Nigeria

the Judicial Process (Justice in the Judicial Process, Fourth Dimension Publishers 2002)

Nwokocha EE, 'Engaging the Burden of Rural-Urban Migration in a Non-regulatory System: The Case of Nigeria' (<http://www.irmgard-coninxstiftung.de/fileadmin/user_upload/pdf/urbanplanet/Nwokocha.pdf $\rangle$ accessed 15 June 2014

Nyamu-Musembi C, Towards an Actor-Oriented Perspective on Human Rights (Institute of Development Studies 2002)

Nyamu-Musembi C and Cornwall A, What is the "Rights-Based Approach" all about? Perspectives from International Development Agencies (Institute of Development Studies 2004)

Nyong AO and Kanaroglou PS, 'Domestic Water Use in Rural Semi-Arid Africa: A Case Study of Katarko Village in Northeastern Nigeria' (2007) 27 Human Ecology 537

O'Keeffe J and Quesne TL, Keeping Rivers Alive: A Primer on Environmental Flows (2009)

Oba AA, 'The African Charter on Human and Peoples' Rights and Ouster Clauses under the Military Regimes in Nigeria: Before and after September 11' (2004) 4 African Human Rights Law Journal

Obilade AO, Nigerian Legal System (Sweet \& Maxwell 1979)

Odum EP, 'The Ecosystem Approach in the Teaching of Ecology Illustrated with Sample Class Data' (1957) 38 Ecology 531

Oestreich JE, 'The United Nations and the Rights-based Approach to Development in India' (2014) 20 Global Governance 77

Okhankhuele OT, 'Causes and Consequences of Rural-Urban Migration Nigeria: A Case Study of Ogun Waterside Local Government Area of Ogun State, Nigeria' (2013) 16 British Journal of Arts and Social Sciences

Okogbule NS, 'Access to Justice and Human Rights Protection in Nigeria: Problems and Prospects' (2005) 2 Sur Revista Internacional de Direitos Humanos 100

Oloka-Onyango J, 'Beyond the Rhetoric: Reinvigorating the Struggle for Economic Social and Cultural Rights in Africa' (1995) 26 California Western International Law Journal

Olowu D, 'Human Development Challenges in Africa: A Rights-Based Approach' (2004) 5 San Diego Int'l LJ 179

Olowu D, An Integrative Rights-based Approach to Human Development in Africa (Pretoria University Law Press 2009)

Olugbenga FP, Olumide A and Adeola A, 'Environmental Impact Assessment (EIA) Law and Practice in Nigeria: How Far? How Well?' (2015) 1 American Journal of Environmental Policy and Management

Onovughe IO and Andrew O, 'Planning the Nigerian Environment: Laws and Problems of Implementation'

<http://www.researchgate.net/publication/252628876_PLANNING_THE_NIGER IAN_ENVIRONMENT_LAWS_AND_PROBLEMS_OF_IMPLEMENTATION> accessed 12 June 2014

Oputa CA, Human Rights in the Political and Legal Culture of Nigeria (Nigerian Law Publications 1989)

Orellana M, 'The Case for a Right to a Healthy Environment' (Human Rights Watch, 1 March 2018) <https://www.hrw.org/news/2018/03/01/case-right-healthy-environment > accessed 28 May 2018 


\section{Bibliography}

Osipitan T, 'An Autochthonous Constitution for Nigeria: Myth or Reality?' (An Inaugural Lecture Delivered at University of Lagos Main Auditorium on Wednesday, 24 November, 2004)

Otaru R, 'Fundamental Objectives and Directive Principles of State Policy: The Need for Amendment to Ensure their Justiciability' (2006) 11 The Jurist

Oteze GE, 'Management Approaches for Nigeria's Water Resources' (2006) 42 Journal of Mining and Geology 15

Owasanoye B, 'Transparency, Accountability and Good Governance Under the 1999 Constitution' in Ayua IA and others (eds), Nigeria: Issues in the 1999 Constitution (Nigeria: Issues in the 1999 Constitution, Nigerian Institute of Advanced Legal Studies 2000)

Oyebande L, 'Overview of Water Sector Development in Nigeria' (Water Meetup)

Oyediran O (ed), The Nigerian 1979 Elections (MacMillan Nigeria 1981)

Paris21 Secretariat, 'Making the Case: National Strategy for the Development of Statistics (NSDS)'

(November, 2004) <http://www.paris21.org/sites/default/files/1406_0.pdf > accessed 9 June, 2014

Paul JCN, 'Participatory Approaches to Human Rights in Sub-Saharan Africa' in An-naim AA and Deng FM (eds), Human Rights in Africa: Cross-Cultural Perspectives (Human Rights in Africa: Cross-Cultural Perspectives, The Brookings Institution 1990)

Pegg S, 'Nigeria' in Forsythe DP (ed) Encyclopedia of Human Rights, vol 4 (Encyclopedia of Human Rights, Oxfod University Press USA 2009)

Pekelis AH, 'The Case for a Jurisprudence of Welfare' (1950) Law and Social Action

Perrault N, Hall E and Lundy C, Assessing Compliance of National Legislation with International Human Rights Norms and Standards, November 2008)

Pettit J and Wheeler J, 'Developing Rights? Relating Discourse to Context and Practice' (2005) 36 IDS Bulletin 1

Poff NL and others, 'The Natural Flow Regime: A Paradigm for River Conservation and Restoration' (1997) 47 BioScience

Proshare, 'National Assembly: The Biggest Democracy Cost Centre (<http://www.proshareng.com/articles/1823 > accessed 2nd June 2014

Public Complaint Commission, 'Public Complaint Commission Handbook' (<http://www1.businessindex.com.ng/WSWeb/WAND_attachment.asp?mfg_code $=50651332 \&$ iFile $\mathrm{ID}=1348>$ accessed 28 May, 2014

Rand J, CARE's Experience with Adoption of a Rights-Based Approach: Five Case Studies (Care International UK 2002)

Rapport DJ, Gaudet CL and Calow P (eds), Evaluating and Monitoring the Health of LargeScale Ecosystems (Springer Berlin Heidelberg 2013)

Republic of Namibia, The Constitution of the Republic of Namibia (Ministry of Information and Broadcasting 1990)

Riedel E, 'The Human Right to Water' in Dicke K (ed) Weltinnenrecht: Liber Amicorum Jost Delbrück (Weltinnenrecht: Liber Amicorum Jost Delbrück, Duncker \& Humblot 2005)

Rodríguez-Garavito C, 'Beyond the Courtroom: The Impact of Judicial Activism on Socioeconomic Rights in Latin America' (2011) 89 Tex L Rev 1669

Rogers P, Comprehensive Water Resources Management: A Concept Paper (World Bank 1992)

Rosenbloom J, 'A Framework for Application: Three Concrete Scalable Strategies to Accelerate Sustainability' in Owley J and Hirokawa K (eds), Rethinking 
Realising the Right to Water and Sanitation in Nigeria

Sustainability to Meet the Climate Change (Rethinking Sustainability to Meet the Climate Change, Environmental Law Institute 2015)

Rout C, 'Voices for Human Rights' (2014) 2 IMPACT: International Journal of Research in Humanities, Arts and Literature

Roy D, 'Negotiating Marginalities: Right to Water in Delhi' (2013) 10 Urban Water Journal 97

Ruhl JB and Salzman JE, 'The Law and Policy Beginnings of Ecosystem Services' (2007) 22 Journal of Land Use \& Environmental Law

Sabel CF and Simon WH, 'Destabilization Rights: How Public Law Litigation Succeeds' (2004) 117 Harv L Rev 1015

Salman SMA, 'The Human Right to Water - Challenges of Implementation' (2012) 106 American Society of International Law Proceedings

Salzman J, 'Valuing Ecosystem Services' (1997) 24 Ecology LQ

Salzman J, Thompson BH and Daily GC, 'Protecting Ecosystem Services: Science, Economics and Law' (2001) 20 Stanford Environmental Law Journal

Sangodoyin AY, 'Fundamentals and Trends of Water Services in a Nigerian Urban Settlement' (1990) 9 Int J Environ Educ Inform 181

Sanusi YA, 'Water, Sanitation and Human Development in Urban Fringe Settlements in Nigeria' (2010) 8 Theoretical and Empirical Researches in Urban Management 14

Scanlon J, Cassar A and Nemes N, Water as a Human Right? (IUCN Publications 2004)

Schulz AJ and others, 'Empowerment as a Multi-level Construct: Perceived Control at the Individual, Organizational, and Community Levels' (1995) 10 Health Education Research 309

Scott C and Macklem P, 'Constitutional Ropes of Sand or Justiciable Guarantees? Social Rights in a New South African Constitution' (November, 1992) 141 University of Pennsylvania Law Review

Scott JC, Seeing Like a State: How Certain Schemes to Improve the Human Condition Have Failed (Yale University Press 1998)

Secretariat of the Convention on Biological Diversity, Ecosystem Approach (CBD Guidelines) (Secretariat of the Convention on Biological Diversity 2004)

Seervai HM, Constitutional Law of India: A Critical Commentary, with Supplement (N.M. Tripathi 1967)

Sensi S, 'Human Rights and the Environment: A Practical Guide for Environmental Activists' (July, 2007) Policy Matters

Seppänen S and Castrén-instituutti E, Possibilities and Challenges of the Human Rightsbased Approach to Development (Erik Castrén Institute of International Law and Human Rights, University of Helsinki 2005)

Shepherd G, The Ecosystem Approach: Five Steps to Implementation (IUCN 2004)

Shepherd G (ed), Ecosystem Approach: Learning from Experience (IUCN 2008)

SIDA, 'Human Rights, Biodiversity and Ecosystems' (SIDA, April 2017) $<$ https://www.sida.se/globalassets/sida/eng/partners/green-tool-

box/human rights biodiversity and ecosystems.pdf> accessed 26 January 2018

Simpkins J, 'The Role of Constitution-Building Processes in Democratization' (International IDEA Democracy-building \& Conflict Management (DCM), 2004) 〈http://www.idea.int/cbp/upload/CBP-Nigeria-External.pdf $>\quad$ accessed 20 November, 2014

Slim H, Making Moral Low Ground: Rights as the Struggle for Justice and the Abolition of Development (Stamford Policy Paper, 2002)

Smets H, 'The Right to Water as a Human Right' (2000) 30 Environmental Policy and Law 
Bibliography

Smith B, Hard Times in the Lands of Plenty: Oil Politics in Iran and Indonesia (Cornell University Press 2007)

Society for Water and Sanitation, 'Newsletter' (January-March, 2013) <http://www.wiser.org/uploads/file_partitioned/6/3/0/e/630e78dea4499330d26104 8bcc398a72/newsan\%20newsletter\%20pdf[1].pdf> accessed 18 February, 2014.

Ssenyonjo M, 'Reflections on State Obligations with Respect to Economic, Social and Cultural Rights in International Human Rights Law' (2011) 15 The International Journal of Human Rights

Standards Organisation of Nigeria, Nigerian Standard for Drinking Water Quality (Standards Organisation of Nigeria 2007)

Stark B, 'Urban Despair and Nietzsche's "Eternal Return": From the Municipal Rhetoric of Economic Justice to the International Law of Economic Rights' (1995) 28 Vand J Transn'l L

Stein Jv, 'Compliance With International Law' (2017) Oxford Research Encyclopedia of International Studies

Stewart F, 'Basic Needs, Strategies, Human Rights and the Right to Development' (1989) 11 Human Rights Quarterly 347

Stoveland S and Bassey BU, 'Status of Water Supply and Sanitation in 37 Small Towns in Nigeria' (Donor Conference)

Supreme Military Council, State Security (Detention of Persons) Decree No. 2 (1984)

Tansley AG, 'The Use and Abuse of Vegetational Concepts and Terms' (1935) 16 Ecology 284

Tarlock D, 'Ecosystems' in Bodansky D and others (eds), The Oxford Handbook of International Environmental Law (The Oxford Handbook of International Environmental Law, Oxford University Press 2008)

Tharme RE, 'A Global Perspective on Environmental Flow Assessment: Emerging Trends in the Development and Application of Environmental Flow Methodologies for Rivers' (2003) 19 River Research and Applications 397

The African Commission on Human Rights, Social and Economic Rights Action Center and the Center for Economic and Social Rights v. Nigeria, vol Comm. No. 155/96 (2001)

The Observatory - Front Line, NIGERIA: Defending Human Rights: Not Everywhere Not Every Right, 2010)

The World Bank, 'Rural Population (\% of Total Population)' (2016) <http://data.worldbank.org/indicator/SP.RUR.TOTL.ZS > accessed 3rd January, 2017

ThisDay, 'Ribadu in Senate: 31 Governors under Investigation'(28 September)

Torjman S, 'What is Policy?' (The Caledon Institute of Social Policy, 2005) <http://www.caledoninst.org/publications/pdf/544eng.pdf > accessed 23 April 2014

Transparency International, 'Corruption Perceptions Index 2013: Nigeria' (2013) <http://www.transparency.org/country\#NGA> accessed 24 May 2014

Tremblay H, 'A Clash of Paradigms in the Water Sector? Tensions and Synergies Between Integrated Water Resources Management and the Human Rights- Based Approach to Development' (2011) 51 Natural Resources Journal 307

Trubek DM, 'Economic, Social, and Cultural Rights in the Third World: Human Rights Law and Human Needs Programs' in Meron T (ed) Human Rights in International Law: Legal and Policy Issues (Human Rights in International Law: Legal and Policy Issues, Oxford University Press 1986)

U.N World Commission on Environment and Development, Our Common Future, 1987) 
Realising the Right to Water and Sanitation in Nigeria

Udenfuna PN, Jumare F and Adebayo FO, 'Legislative Constituency Project in Nigeria: Implication for National Development ' (July, 2013) 4 Mediterranean Journal of Social Sciences

UN Commission on Human Rights, Report submitted by the Special Rapporteur on the Right to Education, Mr. V. Muñoz Villalobos (UN Doc E/CN4/2006/45, 8 February 2006)

UN Human Rights Committee, General Comment No. 6: Article 6 (Right to Life) (30 April, 1982)

UN Human Rights Committee, General Comment No. 29: States of Emergency (article 4) (UN Doc CCPR/C/21/Rev1/Add11, 2001)

UN Human Rights Council, Report of the Independent Expert on the Issue of Human Rights Obligations Related to Access to Safe Drinking Water and Sanitation, Catarina de Albuquerque (UN Doc A/HRC/12/24 1 July 2009)

UN Human Rights Council, Report of the Independent Expert on the Issue of Human Rights Obligations Related to Access to Safe Drinking Water and Sanitation, Catarina de Albuquerque (UN Doc A/HRC/12/24, 1 July 2009)

UN Human Rights Council, Report of the Special Rapporteur on Torture and other Cruel, Inhuman or Degrading Treatment or Punishment, Manfred Nowak (UN Doc A/HRC/7/3 15 January 2008)

UN Human Rights Council, Report of the Special Rapporteur on the Human Rights to Safe Drinking Water and Sanitation (UN Doc A/HRC/36/45, 19 July 2017)

UN Human Rights Council, The Human Right to Safe Drinking Water and Sanitation (A/HRC/18/L1, 23 September 2011)

UN Human Rights Council, Report of the Independent Expert on the Issue of Human Rights Obligations Relating to the Enjoyment of a Safe, Clean, Healthy and Sustainable Environment, John H. Knox: Scoring Report (UN Doc A/HRC/22/43, 24 December 2012)

UN Human Rights Council, Report of the Special Rapporteur on the Human Right to Safe Drinking Water and Sanitation (UN Doc A/HRC/33/49, 27 July 2016)

UN Human Rights Council, Report of the Independent Expert on the issue of human rights obligations relating to the enjoyment of a safe, clean, healthy and sustainable environment, John H. Knox: Mapping Report (UN Doc A/HRC/25/53, 30 December 2013)

UN Human Rights Council, Report of the Special Rapporteur on the Human Right to Safe Drinking Water and Sanitation, Catarina de Albuquerque (UN Doc A/HRC/18/33, 2011)

UN Water, UN DESA and UNICEF, The Post 2015 Water Thematic Consultation, 2013)

UNCESCR, General Comment No. 20: Non-discrimination in Economic, Social and Cultural Rights (Art. 2, Para. 2, of the International Covenant on Economic, Social and Cultural Rights) (2 July, 2009)

UNCESCR, Substantive Issues Arising in the Implementation of the International Covenant on Economic, Social and Cultural Rights: Poverty and the International Covenant on Economic, Social and Cultural Rights (10 May 2001)

UNCESCR, General Comment No. 3: The Nature of States Parties' Obligations (Art. 2, Para. 1, of the Covenant) (14 December, 1990)

UNCESCR, Statement on the Right to Sanitation (19 November 2010)

UNCESCR, General Comment No. 15: The Right to Water (Arts. 11 and 12 of the Covenant) (20 January, 2003)

UNCESCR, General Comment No. 6: The Economic, Social and Cultural Rights of Older Persons (1995) 
Bibliography

UNCESCR, General Comment No. 9: The Domestic Application of the Covenant (1998)

UNDP, Beyond Scarcity: Power, Poverty and Global Water Crisis (Human Development Report 2006, Palgrave Macmillan 2006)

UNDP, 'The Rise of the South: Human Progress in a Diverse World' (2013) <http://hdr.undp.org/en/2013-report> accessed 19 October, 2013

UNDP, 'Human Development Report 2016: Nigeria' (2016) <http://hdr.undp.org/sites/all/themes/hdr_theme/country-notes/NGA.pdf $>$ accessed 22 May 2018

UNDP,

'About

Nigeria'

<http://www.ng.undp.org/content/nigeria/en/home/countryinfo/> accessed 19 August 2017

UNEP, Nairobi Declaration, 1982)

UNEP, Global Environmental Outlook, 2000 (UNEP 1999)

UNEP, Environmental Assessment of Ogoniland (UNEP 2011)

UNESCO, High level International Round Table on Literacy: National Literacy Action Plan for 2012 - 2015, Nigeria (Reaching the 2015 Literacy Target: Delivering on the Promise, 6-7 September, 2012)

UNESCO, Water in A Changing World (2009)

UNHCHR, 'Good Governance Human Rights' (<http://www.ohchr.org/EN/Issues/Development/GoodGovernance/Pages/GoodGo vernanceIndex.aspx $>$ accessed 25 January 2018

UNHCHR, Principles and Guidelines for a Human Rights Approach to Poverty Reduction Strategies (UNHCHR)

UNHCHR, The Role of Good Governance in the Promotion of Human Rights (26 April 2000)

UNHCHR, 'The Right to Water: Fact Sheet No. 35' (UNHCHR, August 2010) 〈http://www.ohchr.org/Documents/Publications/FactSheet35en.pdf $>$ accessed 8 January

UNICEF, Gender Equality, UN Coherance and You: Glossary

UNICEF, 'Scaling Up Sanitation and Hygiene Promotion: The Case of Kadadaba' (<https://www.unicef.org/wcaro/WCARO_Nigeria_WASH-ScalinUp.pdf $>$ accessed 22 January, 2017

UNICEF, Knowledge, Attitude and Practice Studies, 1999)

UNICEF and WHO, 'Progress on Drinking Water and Sanitation: 2012 Update' (2012) <http://www.wssinfo.org/fileadmin/user_upload/resources/JMP-report-2012en.pdf $>$ accessed 12 February, 2014

United Nations, Report of the United Nations Water Conference (United Nations 14-25 March 1977)

United Nations, 'Call to Action on Sanitation' (United Nations, 21 March 2013) <http://www.un.org/millenniumgoals/pdf/DSG\%20sanitation\%20twopager\%20FINAL.pdf $>$ accessed 29 May 2018

United Nations, 'General Assembly Adopts Resolution Recognizing Access to Clean Water, Sanitation as Human Right, by Recorded Vote of 122 in Favour, None against, 41 Abstentions' (28 July, 2010) <http://www.un.org/press/en/2010/ga10967.doc.htm> accessed 17 August, 2013

United Nations, The Dublin Statement on Water and Sustainable Development (31 January, 1992)

United Nations, 'Declaration of the United Nations Conference on the Human Environment' (1972) < http://www.un-documents.net/unchedec.htm> accessed 28 May 2018 
Realising the Right to Water and Sanitation in Nigeria

United Nations, 'Agenda 21' (United Nations Conference on Environment \& Development, Rio de Janerio, Brazil, 3-14 June 1992)

United Nations, 'Rio Declaration on Environment and Development' (UNEP, 1992) $<$ http://www.unep.org/documents.multilingual/default.asp?documentid=78\&articl eid=1163> accessed 11 February, 2014

United Nations, '2005 World Summit Outcome' (2005) A/RES/60/1

United Nations Development Group, 'UNDAF/Programming Guidance' (2016) <https://undg.org/home/guidance-policies/common-country-programmingundaf/> accessed 29 July, 2016

United Nations Economic and Social Commission for Asia and the Pacific, 'What is Good Governance? ' (<http://www.unescap.org/sites/default/files/good-governance.pdf> accessed 28 August, 2016

United Nations Environment Programme, UNEP Annual Review, 1980 (UNEP 1981)

United Nations General Assembly, Report of the Special Rapporteur on the Human Right to Safe Drinking Water and Sanitation (UN Doc A/71/302, 5 August 2016)

United Nations General Assembly, Report of the Special Rapporteur on the Human Rights to Safe Drinking Water and Sanitation (UN Doc A/72/127, 13 July 2017)

United Nations General Assembly, Resolution 45/94: Need to Ensure a Healthy Environment for the Well-being of Individuals (UN Doc A/RES/45/94, 14 December 1990)

United Nations General Assembly, Report of the Special Rapporteur on the Issue of Human Rights Obligations Relating to the Enjoyment of a Safe, Clean, Healthy and Sustainable Environment (UN Doc A/HRC/34/49

19 January 2017)

United Nations General Assembly, National Institutions for the Promotion and Protection of Human Rights (20 December 1993)

United Nations General Assembly, Resolution 70/169: The Human Rights to Safe Drinking Water and Sanitation (UN Doc A/RES/70/169, 22 February 2016)

United Nations General Assembly, Sixty-Fourth Session: 108th Plenary Meeting 28 July 2010)

United Nations General Assembly, The Human Right to Water and Sanitation (United Nations 28 July, 2010)

United Nations Human Settlements Programme, State of the World's Cities 2008/2009: Harmonious Cities (Earthscan 2008)

USAID, 'Nigeria Water and Sanitation Profile' (〈www.usaid.gov $>$ accessed 15 October, 2013

Uvin P, Human Rights and Development (Kumarian Press 2004)

Uwais ML, 'Fundamental Objectives and Directive principles of State Policy in Modern Constitutions: Possibilities and Prospects' in Nwaeze CC (ed) Justice in the Judicial process: Essays in Honour of Honourable Justice Eugene Ubaezeonu JCA (Justice in the Judicial process: Essays in Honour of Honourable Justice Eugene Ubaezeonu JCA, Fourth Dimension Publishers 2002)

Uweru BC, 'Repugnancy Doctrine and Customary Law in Nigeria: A Positive Aspect of British Colonialism' (2008) 2 African Research Review

Vandenhole W and Gready P, 'Failures and Successes of Human Rights-Based Approaches to Development: Towards a Change Perspective' (2014) 32 Nordic Journal of Human Rights

VeneKlasen L and others, Rights-Based Approaches and Beyond: Challenges of Linking Rights and Participation (Institute of Development Studies 2004) 
Bibliography

Verschuuren J, 'The Right to Water as a Human Right or a Bird's Right: Does Cooperative Governance offer a Way Out of a Conflict of Interest and Legal Complexity?' in Cullet $\mathrm{P}$ and others (eds), Water Governance in Motion: Towards Socially and Environmentally Sustainable Water Laws (Water Governance in Motion: Towards Socially and Environmentally Sustainable Water Laws, Cambridge University Press India Pvt. Ltd. 2010)

Vierdag EW, 'The Legal Nature of the Rights Granted by the International Covenant on Economic, Social and Cultural Rights' (1978) 9 Netherlands Yearbook of International Law

Vining J, From Newton's Sleep (Princeton University Press 1995)

Visser Jd, Cottle E and Mettler J, 'Realising the Right of Access to Water: Pipe Dream or Watershed?' (2003) 7 Law, Democracy \& Development

Wai DN, 'Human Rights in Sub-Saharan Africa' in Pollis A and Schwab P (eds), Human Rights: Cultural and Ideological Perspectives (Human Rights: Cultural and Ideological Perspectives, Praeger 1979)

Wallis W, 'Nigeria's Central Bank and State Clash over 'missing billions" Financial Times (4 May) <https://www.ft.com/content/57d43418-bb14-11e3-948c-00144feabdc0>

Water and Sanitation Media Network and Nigeria for Society for Water and Sanitation in Nigeria, 'Nigeria's Progress on High Level WASH Financial Commitments' (February, 2013) <www.newsan.org/Files/SWA\%20STUDY\%20REPORTANEW.doc $>$ accessed 19 February, 2014

WaterAid, 'Court Cases' (<http://www.righttowater.info/rights-in-practice/legal-approachcase-studies/court-cases/> accessed 13 March 2018

WaterAid, Nigeria: Country Strategy 2010-2015)

WaterAid, 'Presidential Summit on 2013' (<http://www.wateraid.org/ /media/Publications/Presidential-Water-Summitfinal.pdf $>$ accessed 29 May 2014

WaterAid, Off Track, off Target: Why Investment in Water, Sanitation and Hygiene is not Reaching Those Who Need it Most, 2011)

WaterAid Nigeria, 'Water and Sanitation in Nigeria: Briefing on National Policy' (2008) <http://www.wsscc.org/sites/default/files/publications/wateraid_water_and_sanitat ion in nigeria briefing on national_policy_2008.pdf > accessed 6 July, 2014

Waterlex, 'The Human Rights to Water and Sanitation in Courts Worldwide: A Selection of National, Regional and International Case Law' (<https://www.waterlex.org/publications/the-human-rights-to-water-andsanitation-in-courts-worldwide/> accessed 17 November 2017

WaterLex and WASH United, The Human Rights to Water and Sanitation in Courts Worldwide: A Selection of National, Regional and International Case Law (WaterLex 2014)

White P, Developing Research Questions: A Guide for Social Scientists (Palgrave Macmillan 2009)

Whiteley P and Masayesva V, 'The Use and Abuse of Aquifers: Can the Hopi Indians Survive Multinational Mining?' in Donahue JM and Johnston BR (eds), Water, Culture, and Power: Struggles in a Global Context (Water, Culture, and Power: Struggles in a Global Context, Island Press 1998)

WHO, 'Definitions of Indicators

(<http://www.who.int/water_sanitation_health/monitoring/jmp04_2.pdf $>$ accessed 19 August 2017 
Realising the Right to Water and Sanitation in Nigeria

WHO and UNICEF, Joint Monitoring Programme for Water Supply and Sanitation: Meeting the MDG Drinking Water and Sanitation Target: Mid-term Assessment of Progress, 2010)

WHO and UNICEF, 'Joint Monitoring Programme for Water Supply and Sanitation: Estimates for the use of Improved Drinking-Water Sources in Nigeria' (2012) <www.wssinfo.org> accessed 15 October 2012

Willis AJ, 'Arthur Roy Clapham. 24 May 1904-18 December 1990' (1994) 39 Biographical Memoirs of Fellows of the Royal Society 73

Willis AJ, 'The Ecosystem: An Evolving Concept Viewed Historically' (1997) 11 Functional Ecology 268

Winkler IT, The Human Right to Water: Significance, Legal Status and Implications for Water Allocation (Hart Pub. 2012)

Winpenny J, Managing Water As An Economic Resource (Routledge 1994)

World Bank, 'Nigeria Loses NGN455 Billion Annually Due to Poor Sanitation' (March, 2012) <https://www.wsp.org/sites/wsp.org/files/publications/WSP-ESI-Nigeriabrochure.pdf $>$ accessed 12 February, 2014

World Commission on Environment and Development, Our Common Future (Oxford University Press 1987)

World Health Organisation, Right to Water (World Health Organisation 2003)

World Health Organisation, Guidelines for Drinking-Water Quality (4th edn, World Health Organisation 2011)

Yanow D and Schwartz-Shea P (eds), Interpretation and Method: Empirical Research Methods and the Interpretive Turn (M.E. Sharpe 2006)

Young CD, Charles A and Hjort A, Human Dimensions of the Ecosystem Approach to Fisheries: An Overview of Context, Concepts, Tools and Methods (FAO 2008)

Young O, Compliance and Public Authority (Johns Hopkins Press 1979)

Zack-Williams AB, 'No Democracy, No Development: Reflections on Democracy \& Development in Africa' (2001) 28 Rev Afr Pol Econ

Zimmerman MA, 'Empowerment Theory: Psychological, Organizational, and Community Levels of Analysis' in Rappaport J and Seidman E (eds), Handbook of Community Psychology (Handbook of Community Psychology, Kluwer Academic 2000) 


\section{List of Treaties, Legislations and Policies}

\section{TREATIES}

African Charter on Human and Peoples Rights

Agreement on the Conservation of African-Eurasian Migratory Waterbirds

Convention for Cooperation in the Protection and Development of the Marine and Coastal

Environment of the West and Central African Region

Convention on Biological Diversity, 1992, S. 2

Convention on the Elimination of All Forms of Discrimination against Women (CEDAW), Art. 14 (2)

Convention on the Rights of the Child (CRC). Arts. 24 and 27 (3) Convention on the Rights of Persons with Disabilities. Art. 28

Convention on Wetlands of International Importance especially as Waterfowl Habitat

Geneva Convention relative to the Treatment of Civilian Persons in Time of War, of 1949. Arts. 85, 89 and 127

Geneva Convention relative to the Treatment of Prisoners of War, of 1949. Arts. 20, 26, 29 and 46

International Covenant on Civil and Political Rights, Art. 1(2), 2, 26

International Covenant on Economic, Social and Cultural Rights, Arts. 1(2), 2, 11, 12

International Labour Organization (ILO) Convention No. 161 concerning Occupational Health Services. Art. 5

Protocol I Additional to the Geneva Convention of 1977. Arts. 54 and 55

Protocol II Additional Protocol to the Geneva Convention of 1977. Arts. 5 and 14

United Nations Convention to Combat Desertification

United Nations Framework Convention on Climate Change. Art. 3

Universal Declaration of Human Rights, 1948

\section{NATIONAL LEGISLATIONS}

African Charter on Human and Peoples' Right (Ratification and Enforcement) Act. Cap. A9 Laws of the Federation of Nigeria

Anambra State Customary Courts Law, 1984. S. 15 (1) (a)

Civil Disturbances (Special Tribunal) Decree No. 2 of 1987

Constitution (Suspension and Modification) Decree No 1 of 1984. S. 2

Constitution (Suspension and Modification) Decree No. 1 of 1966. S. 6

Corrupt Practices and other related Offences Act, 2000

Criminal Code Act. Cap C38 Laws of the Federation of Nigeria 2004

Economic and Financial Crimes Commission (Establishment) Act, 2004

Environmental Impact Assessment Act. Cap. E12 Laws of the Federation of Nigeria, 2004 
Realising the Right to Water and Sanitation in Nigeria

Federal Military Government (Supremacy and Enforcement of Powers) Decree No. 28 of 1970

Federal Military Government (Supremacy and Enforcement of Powers) Decree No. 28 of 1970

Food and Drugs and Related Products (Registration, Etc.) Act. Cap. F33 Laws of the Federation of Nigeria 2004

Freedom of Information Act, 2011

Fundamental Rights (Enforcement Procedure) Rules, 2009

Harmful Waste (Special Criminal Provisions, etc.) Act. Cap H1 Laws of the Federation of Nigeria, 2004

Kaduna State Customary Courts Law, No. 9 of 2001. S. 24(a)

Labour Act. Cap L1 Laws of the Federation of Nigeria

Lagos State Water Sector Law, No. 14 of 2004

Land Use Act. Cap L4 Laws of the Federation of Nigeria, 2004

Legal Aid Act, Cap L9 Laws of the Federation of Nigeria 2004 amended in 2011. S. 7

Minerals and Mining Act. Cap. M12 Laws of the Federation of Nigeria, 2004

National Agency for Food and Drug Administration and Control Act. Cap N1 Laws of the Federation of Nigeria, 2004

National Environmental (Sanitation and Wastes Control) Regulations, S. I. No. 28 of 2009

National Environmental (Surface and Groundwater Quality Control) Regulations, S. I. No. 22 of 2011

National Environmental Standards and Regulations Enforcement Agency (Establishment) Act, 2007

National Health Insurance Scheme Act. Cap. N42 Laws of the Federation of Nigeria, 2004

National Human Rights Commission Act, Cap N46 Laws of the Federation of Nigeria, 2004. SS. 5(b), 5(c), 5(d), 5(f), 5(g)

National Human Rights Commission Act, Cap. N46 Laws of the Federation of Nigeria, 2004

Nigeria Social Insurance Trust Fund Act. Cap. N88 Laws of the Federation of Nigeria, 2004

Nigerian Urban and Regional Planning Act. Cap N138, Laws of the Federation of Nigeria, 2004

Oil in Navigable Waters Act. Cap. O6 Laws of the Federation of Nigeria, 2004

Oil Pipelines Act. Cap. O7 Laws of the Federation of Nigeria, 2004, S. 14(c)

Penal Code (Northern States) Federal Provisions Act. Cap. P3 Laws of the Federation of Nigeria

Pension Reform Act (Repeal and Re-enactment) Act, 2014

Petroleum (Drilling and Production) Regulations

Petroleum Act, Cap. P10 Laws of the Federation of Nigeria, 2004, S. 25

Pre-Packaged Food (Labelling) Regulations 2005. S. 24

Public Complaint Commission Act, Cap P37 Laws of the Federation of Nigeria 2004. SS. 5, 8,9

Public Complaint Commission Act, Cap. P37 Laws of the Federation of Nigeria, 2004

River Basins Development Authorities. Cap R9 Laws of the Federation of Nigeria, 2004

River Basins Development Authority Act, Cap R9, Laws of the Federation of Nigeria 2004 


\section{List of Treaties, Legislations and Policies}

Robbery and Firearms (Special Provisions) Decree 5 of 1984. S. 10(3)

Water Resources Act. Cap W2, Laws of the Federation of Nigeria, 2004

Zamfara State Shariah Penal Code Law, S. 360

\section{POLICIES}

National Environmental Sanitation Policy, 2005

National Policy Guidelines on School Sanitation

National Policy Guidelines on Solid Waste Management

National Policy on Environment, 1999

National Policy on Sanitary Inspection of Premises

National Water Policy, 2004

National Water Sanitation Policy 2004

National Water Supply and Sanitation Policy, 2000

Nigeria Standards for Drinking Water Quality 2007

Rural Water Supply and Sanitation Policy, 2000

\section{UN RESOLUTIONS}

United Nations General Assembly Resolution (UNGA Res 64/292 (28 July 2010) UN Doc A/RES/64/292 on The Human Right to Water and Sanitation

United Nations General Assembly Resolution A/RES/48/134 "National Institution for the Promotion and Protection of Human Rights" 20 December, 1993 


\section{List OF CASES}

\section{AFRICAN COMMISSION ON HUMAN RIGHTS}

Institute for Human Rights and Development in Africa v Angola [2008] African Commission on Human and Peoples' Rights 292/04

Sudan Human Rights Organisation and Centre on Housing Rights and Evictions v. Sudan [2009] African Commission on Human and Peoples' Rights 279/03 and 296/05

The Social and Economic Rights Action Center and the Center for Economic and Social Rights v. Nigeria (2001) African Commission on Human and Peoples' Rights Comm. No. $155 / 96$

\section{ARGENTINA}

Asociación Civil por la Igualdad y la Justicia c/ Gobierno de la Ciudad de Buenos Aires (Spanish original version available at: www.acij.org.ar/blog/2011/12/13/sentencia-poraguaen-la-villa-31-bis/)

Asociación Civil por la Igualdad y la Justiciac/ Gobierno de la Ciudad de Buenos Aires Cámara de Apelaciones en lo Contencioso Administrativo y Tributario (Ciudad Autónoma de Buenos Aires) 18 July 2007

Asociación para la Protección del Medio Ambiente y Educación Ecológica '18 de Octubre' c/ Aguas Argentinas SA y Otros [2003] Cámara Federal de Apelaciones (La Plata) 3156/02, RDAmb 2004-0-193

Children of the Paynemil Community c/ Acción de amparo (2nd Chamber of Appeals for Civil Matters of the Province of Neuquén, File 311-CA - 199719 May 1997)

Defensor del Pueblo de la Nación c/ Estado Nacional y Provincia del Chaco (2007) Suprema Corte D.587.XLIII

Marchisio José Bautista y Otros c/ Superior Gobierno de la Provincia de Córdoba y Otros [2004] Juzgado de Primera Instancia Civil y Comercial (Ciudad de Córdoba) 500003/36

Quevedo, Miguel Ángel y Otros c/Aguas Cordobesas SA [2002] Juez Sustituta de Primera Instancia Civil y Comercial (Ciudad de Córdoba) <http://www.cedha.org.ar/docs/doc220spa.doc>

Usuarios y Consumidores en Defensa de sus Derechos Asociación Civil c/ Aguas del Gran Buenos Aires SA [2002] Juez de paz (Moreno, Buenos Aires) 44.453

\section{BANGLADESH}

Rabia Bhuiyan v Ministry of LGRD and Others (Appellate Division (Civil Appeal no 118 of 1999), 27 August 2005)

\section{BELGIUM}

Juge de Paix Fontaine-l'Evêque [2009], JJP [2012] 3061 
BRAZIL

Ademar Manoel Pereira x Companhia Catarinense de Agua e Saneamento - CASAN [1999] Superior Tribunal de Justiça Resp no 201.112

Santa Casa de Misericórdia de Santa Rosa do Viterbo x Companhiade Saneamento Básico do Estado de São Paulo - SABESP [2007] Superior Tribunal de Justiça REsp no 943.850

\section{CANADA}

Halalt First Nation v British Columbia (Environment) [2011] Supreme Court (British Columbia) S098232, 2011 BCSC 945

\section{COLOMBIA}

Carlos Alfonso Rojas Rodríguez c/ ACUAVENORTE y Otros [1992] Corte Constitucional T-578/92

Carolina Murcia Otálora c/ Empresas Públicas de Neiva ESP [2009] Corte Constitucional T$546 / 09$

Dagoberto Bohórquez Forero c/ EAAB Empresa de Acueducto y Alcantarillado de Bogotá y Otros [2012] Tribunal Administrativo (Cundinamarca) 11001-33-31-003-2007-00186-01

Flor Enid Jiménez de Correa c/ Empresas Públicas de Medellín [2007] Corte Constitucional $\mathrm{T}-270 / 07$

Hernán Galeano Díaz c/ Empresas Públicas de Medellín ESP, y Marco Gómez Otero y Otros c/ Hidropacífico SA ESP y Otros [2010] Corte Constitucional T-616/10

Jorge Hernán Gómez Ángel c/ Alcalde Municipal de Versalles - Valle del Cauca y el Gerente de la Empresa de Servicios Públicos de Versalles [2003] Corte Constitucional T-410/03

María de Jesús Medina Pérez y otros v. Alvaro Vásquez (Sala Séptima de Revisión de la Corte Constitucional 22 November 1994)

\section{COSTA RICA}

Comité Pro-No Construcción de la Urbanización Linda Vista, San Juan Sur de Poás c/ Ministerio de Ambiente y Energía y Otros [2004] Corte Suprema de Justicia 2004-01923

Gad Amit Kaufman y Otros c/ Municipalidad de Carrillo y Otros [2009] Corte Suprema de Justicia 2009-000262

Ileana Vives Luque c/ Empresa de Servicios Públicos de Heredia [2003] Corte Suprema de Justicia 2003-04654

\section{ENGLAND}

R v. North and East Devon Health Authority, ex parte Coughlan (2001) QB 213

R. (on the application of Batantu) v. Islington Local Borough Council (2001) 4 CLR 445

R. v. Birmingham City Council, ex parte Mohammed (1998) 3 All ER 161

R. v. Sefton Metropolitan Borough Council, ex parte Help the Aged (1997) 4 All ER 532 


\section{EUROPEAN COURT OF HUMAN RIGHTS}

List of Cases

Dubetska and Others v. Ukraine (App no 30499/03) ECHR 10 February 2011

Eugen Gabriel Radu v. Romania (App no 3036/04) ECHR 13 October 2009

Fedotov v. Russia (App no 5140/02) ECHR 25 October 2005

Marian Stoicescu v. Romania (App no 12934/02) ECHR 16 July 2009

Melnik v. Ukraine (App no 72286/2001) ECHR 28 March 2006

Riad and Idiab v. Belgium (App nos 29787/03 and 29810/03) ECHR 24 January 2008

Tadevosyan v Armenia (App no 41698/04) ECHR 2 December 2008

\section{$\underline{\text { FIJI }}$}

Naba v. The State [2001] FJHC 338, [2001] 2 FLR 187

State v. Senijieli Boila and Pita Nainoka [2004] High Court (Suva) HAC032D.04S

\section{FRANCE}

Aeroflex v. Air Cargo Egypt (Paris Court of Appeal of 25 March 1986 reported in the Uniform Law Review Biannual 1987 Vol. 2 669)

Federation Departementale des Syndicats d'Exploitants Agricoles du Finistere [2012] Conseil constitutionnel 2012-270 QPC

Laurent X [2010] Cour de cassation (Crim) 09-84012

Madame Sandra A c/ Commune de Gouvernes [2010] Conseil d'Etat 323250

Madame X c/ Commune d'Amiens [2004] Cour de Cassation (Civ 3) 02-20614

Madame X c/ Commune de Saint-Hilaire-de-Lavit [2012] Cour de cassation (Civ 1) 11 26814

Monsieur X c/ Syndicat d'Adduction d'Eau du Tregor [2006] Cour de cassation (Civ 1) 03 16335

Section francaise de l'Observatoire International des Prisons c/ Ministere de la Justice [2012] Conseil d'Etat (référés) 364584

\section{$\underline{\text { INDIA }}$}

Attakoya Thangal v Union of India (Availability - Water resources management) [1990]

High Court (Kerala) <http://www.indiankanoon.org/doc/1980528/>.

Bandhua Mukti Morcha v. Union of India Ors. (1984) 2 SCR 67

Francis Coralie Mullin v. The Administrator, Union Territory of Delhi \& Ors. (1981) AIR 746, (1981) SCR (2) 516

L.K. Koolwal v. State of Rajasthan and Others, AIR 1988 Raj 2, 1987 (1) WLN 134

M/S. Shantistar Builders v. Narayan Khimalal Totame \& Ors. (1990) AIR SC 630, (1990)

92 BOMLR 145, (1990) JT (1) SC 106, (1990) (1) SCALE 86, (1990) 1 SCC 520, (1990) (1) UJ 379 SC

Mohini Jain v. State of Karnataka and Ors (1992) AIR 1858; (1992) SCR (3) 658

Municipal Council, Ratlam v. Shri Vardhichand \& Others (1981) SCR (1) 97 
Realising the Right to Water and Sanitation in Nigeria

Olga Tellis \& Ors v. Bombay Municipal Corporation \& Ors. (1986) AIR 180, (1985) SCR Supl. (2) 51

Peoples Union for Civil Liberties (PUCL) v. Union of India \& others. Writ Petition (Civil) No. 196 of 2001

Perumatty Grama Panchayat v. State of Kerala [2003] High Court (Kerala, Ernakulam)

Writ Petition no 34292 of 2003, (2004) (1) KLT 731

State of Madras v. Champakam Dorairajan (1951) SCR 226525

Virendra Gaur and Others v. The State of Haryana (1995) 2 SCC 577

\section{INDONESIA}

Judicial Review of the Law of the Republic of Indonesia no 7 Year 2004 regarding Water Resources [2005] Constitutional Court 058-, 059-, 060- and 063/PUU-II/2004, and 008/PUU-III/20051

\section{INTER-AMERICAN COMMISSION ON HUMAN RIGHTS}

Paul Lallion v Grenada [2002] Inter-American Commission on Human Rights 11.765

Velez Loor v. Panama Inter-American Court of Human Rights Series C no 218 (23 November 2010)

Xakmok Kasek Indigenous Community v Paraguay Inter-American Court of Human Rights Series C no 21 (26 August 2010)

\section{IRELAND}

Kinsella v Governor of Mountjoy Prison [2011] High Court 20111125 SS, [2011] IEHC 235

\section{ISRAEL}

Abadallah Abu Massad and others v Water Commissioner and Israel Lands Administration [2011] Supreme Court Civil Appeal 9535/06

\section{KENYA}

Ibrahim Sangor Osman v. Minister of State for Provincial Administration \& Internal Security eKLR (2011) High Court (Embu) Constitutional Petition no 2 of 2011

\section{MALAYSIA}

Rajah Ramachandran v Perbadanan Bekalan Air Pulau Pinang Sdn Bhd [2004] High Court (Malaya) 22-716-2003

\section{NEPAL}

Advocate Prakash Mani Sharma and Others v Nepal Water Supply Corporation and Others [2001] Supreme Court WP2237/1990 


\section{NETHERLANDS}

List of Cases

HD 200.018.358 [2010] Gerechtshof ('s-Hertogenbosch) LJN BL6583, PRG (2010) 70

\section{NIGERIA}

Abubakar v. INEC (2004) 1 NWLR (Pt. 854) 207

Adamu v. Attorney-General of Borno State (1996) 8 NWLR 203

Adewole \& Ors. v. Alhaji Jakande \& Ors (1981) 1 NCLR 262

Agbai v. Okogbue (1991) 7 NWLR (Pt.204) 391

Anigboro v. Sea Trucks Ltd. (1995) 6 NWLR (Pt. 399) 35

Archbishop Okogie v. The Attorney-General of Lagos State (1981) 2 NCLR 350

Atiku and Action Congress and Others v. INEC (2007) All FWLR (Pt. 353) 3

Attorney-General of Ondo State v. Attorney-General of the Federation \& 35 Ors. (2002) 9

NWLR (part 772) 222 S.C

Attorney-General of the Federation v. Atiku \& Ors. 2 CLC 218

Chief JE Oshevire v. British Caledonia (1990) 7 NWLR (Pt. 163) 489

Director of SSS v. Olisa Agbakoba (1999) All N.L.R 110; (1999) 3 NWLR (Pt.595) 340; (1999) 3 SC 59

Egri v. Uperi (1973) 11 SC 299

Ekeocha v. Civil Service Commission, Imo State \& Ors (1981) 1 NCLR 154

Eshugbayi Eleko v. Government of Nigeria (1931) A.C 622

Federal Republic of Nigeria v. Alhaji Mika Anache \& Others (2004) 14 WRN 1-90

General Sani Abacha and Others v. Chief Gani Fawehinmi (2000) 4 SCNJ 401

Jonah Gbemre v. Shell, NNPC and AGF, Suit No. FHC/B/CS/53/05

Labiyi v. Anretiola (1992) NWLR (Pt. 258) 1392

Lakanmi and Another v. the Attorney-General (Western State) and others (1971) 1 UILR 201

Mariama v. Sadiku Ejo (1961) NRNLR 81

Mohammed Garuba and Others v. Lagos State Attorney General and Others 4 Journal of Human Rights Law and Practice (1994) p. 205

Nafiu Rabiu v. State (1981) 2 NCLR 293; (1980) 8 - 11 SC 130

Ngige v. Peter Obi and Others (2006) 14 NWLR (Pt. 999) 1

Okeke v. AG Anambra State (1992) 1 NWLR (Pt. 215) 60

Okonkwo v. Okagbue \& 2 Ors. (1994) 12 SCNJ 89

Okoroafor v. Miscellaneous Offences Tribunal (1995) 4 NWLR (Pt 387) 59

Olafisoye v. Federal Republic of Nigeria (2004) 4 NWLR (Pt. 864) 580

Osadebay v. AG Bendel State (1991) 1 NWLR (Pt. 169) 533

Otunba Oyewole Fashawe v. Attorney-General of the Federation \& 3 Others (2007) CHR 890

Oyewumi v. Ogunsesan (1990) NWLR 182

Reinsurance Corp v. Fantaye (1986) 1 NWLR (Pt. 14) 113

Sehindemi \& Ors. v. Governor of Lagos State \& Ors. (2006) 10 NWLR (Pt.987) 1 
Realising the Right to Water and Sanitation in Nigeria

The Registered Trustees of the Constitutional Rights Project (CRP) v. The President of the

Federal Republic of Nigeria and Others 4 Journal of Human Rights Law and Practice (1994) p. 243

Theresa Onwo v. Oko (1996) 6 NWLR (Pt. 456) 584

Transbridge Trading Company Limited v. Survey International Limited (1996) 4 NWLR (Part 37) 576

Zamani Lekwot \& Others v Judicial Tribunal on Civil Disturbances in Kaduna State \& Another (1993) 2 NWLR (Pt. 276) 410

\section{PAKISTAN}

General Secretary, West Pakistan Salt Miners Labour Union v. The Director, Industries and Mineral Development [1994] Supreme Court Human Rights Case 120 of 19938

Nestle Milkpak Limited v Sindh Institute of Urology and Transplantation and Other [2006] High Court (Sindh, Karachi) HCA 271 (2004)

\section{PANAMA}

Habeas Corpus Colectivo presentado por Víctor Atencio c/ el Ministerio de Gobierno y Justicia, Director General del Sistema Penitenciario [2011] Corte Suprema de Justicia 928-09

\section{PERU}

Red de Vigilancia y Exigibilidad de los Derechos Económicos, Sociales y Culturales Región Junín c/ Municipalidad Provincial de Huancayo [2005] Corte Superior de Justicia (Junín) 1230-2005

\section{Portugal}

A xEPAL - Empresa Publica das Aguas de Lisboa [2004] Tribunal Constitucional 685/2004

\section{SLOVENIA}

Ruling No Up-156/98 [1999] Constitutional Court Official Gazette RS, no 17/99; OdlUS VIII, 118

\section{SOUTH AFRICA}

Beja and Others v. Premier of the Western Cape and Others (2011) High Court (Western Cape) 21332/10, (2011) ZAWCHC 97

City of Cape Town v. Strumpher [2012] Supreme Court of Appeal 104/2011, [2012] ZASCA 54

Federation for Sustainable Environment and Others v. Minister of Water Affairs and Others [2012] High Court (North Gauteng, Pretoria) 35672/12, [2012] ZAGPPHC 128 
Government of the Republic of South Africa and Others v Grootboom and Others [2000] Constitutional Court CCT11/00, [2000] ZACC 19

Highveldridge Residents Concerned Party v Highveldridge TLC and Others [2002] High Court (Transvaal Provincial Division) 28521, (2002) (6) SA 66

Johnson Matotoba Nokotyana and Others v. Ekurhuleni Metropolitan Municipality and Others [2009] Constitutional Court CCT31/09, [2009] ZACC 33

Mandla Bushula v. Ukhahlamba District Municipality [2012] High Court (Eastern Cape Division) 2200/09, [2012] ZAECGHC 1

Mazibuko and Others v. City of Johannesburg and Others (Centre on Housing Rights and Evictions, Amicus Curiae) Constitutional Court of South Africa (CCT 39/09) [2009] ZACC 28; 2010 (3) BCLR 239 (CC); 2010 (4) SA 1 (CC) 8 October 2009

\section{UGANDA}

Byabazaire Grace v. Mukwano Industries, Miscellaneous Application No 909 of 2000

Dimanche Sharon v. Makerere University, Constitutional Cause No 01 of 2003

Emmanuel Mpondi v. The Chairman, Board of Governors, Ngwana High School and Others, Complaint No. 210 of 1998

Joseph Eryau v. Environmental Action Network, Miscellaneous Application No 39 of 2001

Kalyango Mutesasira v. Kunsa Kiwanuka and Others, Complaint No 501 of 2000

\section{UNITED STATES}

Brown v. Board of Education of Topeka (1954) 347 U.S. 483

Dowdell v. City of Apopka Florida 698 F. 2d 1181, United States Court of Appeals, Eleventh Circuit, 28 February 1983

Flast v. Cohen (1942) 392 US 83

Kennedy v. City of Zanesville [2008] District Court (Southern District of Ohio, Eastern Division) 2:03-cv-1047

Poe v. Ullman (1961) 367 US 497

United States v. Hudson \& Goodwin 7 Cranch 321812

\section{VENEZUELA}

Condominio del Conjunto Residencial Parque Choroní II c/ Compañía Anónima Hidrológica del Centro (Hidrocentro) [2005] Tribunal Supremo de Justicia AP42-N-000628 


\section{List of TABLE AND Figures}

Tables

Table 1.1

Table 3.1

Table 3.2

Table 4.1:

Table 4.2

Table 4.3

Table 4.4

Table 4.5

Table 4.6

Table 4.7

Table 4.8

Table 4.9

Table 4.10

Table 4.11

Table 4.12

Table 4.13

Table 4.14

Table 4.15

Table 4.16

Table 5.1

Table 5.2

Table 5.3

Table 5.4

Table 5.5

Table 5.6

Table 5.7

Table 5.8

Table 5.9

Table 6.1

Table 6.2

Table 8.1
Locations of Empirical Study

Proportion of Response on Trainings on Water and Sanitation Between 2013-2015

Perception of Efficiency of Equipment

Funding Arrangement for Water and Sanitation in Water and Sanitation Roadmap 2016-2030

Sanitation Policy Target

Water Sources and Frequency of Utilisation in Nigeria

Respondents (General Population) Perception of Water Quality

Distance and Time to a Water Source

Daily Spending on Water Supply from Water Vendors

Daily Spending on Water by Profession

Proportion of Complaints Received by Duty-Bearers on Water and Sanitation from 2012-2015

Awareness and Utilisation of Sources of Information by Gender

Involvement and Participation of Local Population in Water and Sanitation Projects

Gender Response on Right-Holders' Involvement and Participation

Discrimination: Awareness of Marginalised Groups and Existence

Possible Reasons for Discrimination and or Margination (Population)

Possible Reasons for Discrimination and or Marginalisation (CSOs)

Factors Impacting on Water Connection and Allocation

SDG Goal 6 Targets and Indicators

Demographics of the Respondents (Duty-Bearers and Rights-Holders)

Awareness of Human Rights and the Right to Water and Sanitation (Rights-Holders)

Ranking of Critical ESC Rights on Likelihood of Asserting Legal Claim

Awareness of How to Claim ESC Rights

Likelihood of Litigating for the Right to Water and Sanitation in Nigeria

Common Complaints Mechanisms and Rate of Utilisation in Nigeria

Common Complaints Mechanisms on Water and Sanitation and Rate of Utilisation

Comfortability of Litigating Human Rights Claims in Northwest Nigeria

Influence of Some Formal and Informal Factors on Human Rights Claims Funding Arrangement for Water under the NWSSP

Funding for Water and Sanitation under the NWSP

Definitions of a Human Rights-Based Approach 
Realising the Right to Water and Sanitation in Nigeria

\section{Figures}

Figure 1.1 North-West Geopolitical Zone of Nigeria

Figure 4.1 Cross Tabulation of Distance to Water Source by Gender

Figure 5.1 Ranking of ESC Rights on Likelihood of Asserting Legal Claim

Figure 5.2 Likelihood of Litigating the Right to Water and Sanitation (General)

Figure 5.3 Perception of Respondents on Who Has the Duty to Provide Access to Water and Sanitation

Figure 5.4 Relationship - Awareness and Comfortability (General)

Figure 5.5 Level of Impact of Possible Factors Influencing Human Rights Claims in NW Nigeria 


\title{
VALORISATION ADDENDUM
}

\author{
A. Social Relevance \\ $\mathrm{R}$ \\ ealisation of access to water and sanitation has been a fundamental social issue for many \\ countries around the world. According to a recent joint report of World Health
} Organisation and United Nations International Children's Emergency Fund, as at July 2017, globally, 2.1 billion people lack safe drinking water at home and 4.5 billion people lack safely managed sanitation. In Nigeria, more than 50 million people do not have access to improved water, more than 127 million do not have access to basic sanitation and about 46 million people defecate in the open. These bring with them social and economic implications on the country. For example, an estimated 8.5 million children of which the majority are females are currently out of school for reason connected to lack of separate basic sanitation facilities. About 240,000 die of respiratory infections due poor sanitary conditions every year and an estimated 150,000 to 200,000 diarrhoea-related deaths occur among children below the age of 5 each year. Cholera, Typhoid and Paratyphoid cases are on the increase and half of the population has experienced at least one episode of malaria annually. Economically, the poor sanitation condition is costing Nigeria US\$3 billion annually, representing US\$20 per person per year or $1.3 \%$ of the national GDP and 17 million of women and girls who have no toilet spend 3.1 billion productive hours each year finding an open space to defecate.

Access to water and sanitation also received additional attention in both United Nations Millennium Development Goals and Sustainable Development Goals with sets of targets to be achieved in the case of MDGs by 2015 and SDGs by 2030. Nigeria missed its MDG targets and if no concrete measures/strategies are adopted SDG targets will also be missed.

Recently in Nigeria, the international community, civil society, non-governmental organisations and academics have recently been active in advocating for the adoption of approaches to eradicate or mitigate the problems. This research is part of that larger context. It identified some of the problems and challenges hampering progress in water and sanitation sector and advocated for the adoption of approaches which will ensure the attainment of not only the recently recognised human right to water and sanitation and Goal 6 of the Sustainable Development Goals but also broader realisation of economic, social and cultural rights. Specifically, through the utilisation of local and national circumstances, the research advocated for the adoption of a liberal and progressive interpretation approaches by the Judiciary in promoting the protection and realisation of economic, social and cultural rights in the context where such rights have not been formally provided for in constitutional or legislative documents. The research further advocated as well as demonstrated how a human rights-based and an ecosystem approach can be utilised in addressing some of the identified challenges in the sector. A human rights-based approach will provide the framework through which rights of individuals and groups are factored into the plans and programs concerning water and sanitation while an ecosystem approach will help ensure that the needs of the environment are taken care of in a manner that ensures inter-generational equity and environmental sustainability. Several social benefits flow from the adoption of the advocated approaches including ensuring the removal of discrimination in the provision of water and sanitation, strengthening the accountability of duty-bearers, rights-holders and other relevant stakeholders, and promoting the participation of all stakeholders to make water, sanitation 
Realising the Right to Water and Sanitation in Nigeria

and environmental protection plans and projects all-inclusive. These are important social issues that can promote living a dignified life and promote human security and social justice.

The Research provides concrete recommendations to relevant stakeholders including the executive arm of the government and its relevant agencies; the legislature; the judiciary; the civil society organisations; the general population and the international and donor organisations. Some of the recommendations include the following:

- Domestication of relevant international human rights instruments especially those relevant in the realisation of the right to water and sanitation;

- The removal of non-justiciability clause concerning ESC rights in the Constitution;

- Adoption of a legislation which recognises the right to water and sanitation;

- Strengthening of agencies and institutions through the provisions of appropriate financial resources and political support to discharge their mandates;

- The lessening of bureaucratic procedures to some agencies in order to facilitate effective and efficient response especially during emergencies;

- Strengthening of ant-corruption agencies and removal of political interference from the actions of the agencies in order to be more efficient;

- Amending the National Policy on Water Resources to incorporate the recognition of the right to water and its contents;

- Adoption of a policy for the protection of vital ecosystems;

- Provision of periodic trainings on human rights and water and sanitations issues to relevant duty-bearers;

- Adoption of liberal, purposive and integrated approach to the interpretation of ESC provisions in the Constitution;

- Adoption of management-oriented research and research-oriented management by managers in the water and sanitation sector;

- Adoption of a policy on water connection and distribution that will address problems of marginalisation and discrimination;

- Utilisation of the opportunity provided by the domestication of the ACHPR in realising other critical ESC rights.

The above and other recommendations made in the thesis if adopted will contribute to finding solutions to water and sanitation problems not only in Nigeria but other developing countries having similar circumstances and challenges.

\section{B. Target Groups}

In addition to the academic community this research is relevant to a number of stakeholders. Primarily it is relevant to law and policy makers in its identification and analysis of problems and challenges in the realisation of the rights to water and sanitation and the concrete policy steps which are to be taken to address the problems and challenges. The Research is also relevant to the judiciary in its analysis and suggestions of how non-justiciable rights/fundamental objectives and directive principles of state policy can be transformed and can be given concrete meaning without breaching constitutional provisions. The research is also relevant to civil society and non-governmental organisations in its analysis of the role these actors can play in the realisation of not only right to water and sanitation but broader human rights in developing countries. Furthermore, the research is relevant to the general population in its analysis of the important role the population can play in the realisation of their human rights and in holding duty bearers accountable to their obligations. Additionally, the research is relevant to other developing countries who are 


\section{Valorisation Addendum}

experiencing similar problems and challenges on approaches they can adopt in addressing such issues. Lastly, the research is relevant to developed countries, development partners and donor agencies in appreciating national and local circumstances in developing countries, specifically Nigeria and how they can contribute to the realisation of the right to water and sanitation and other economic, social and cultural rights. In order to facilitate actions, copies of the thesis will be shared among identified stakeholders. Additionally, efforts will be made to realise with the FMWR, FME, NHRC, the Judiciary and civil society organisation for the possibility of organising a symposium through which the findings in this research will be shared.

\section{Concrete Products, Services and Activities}

The concrete products that result from this doctoral dissertation are legal and policy recommendations addressed to relevant stakeholders including, governments at various levels in Nigeria, relevant ministries, departments and agencies of government, members of the judiciary, civil society organisation, general population, development partners and donor agencies.

Its results can best be implemented through policy changes at both local level and national levels. A concrete product or activity that could be envisioned on the basis of this doctoral dissertation would therefore be the adoption of policy changes that incorporates the proposals made in the dissertation. Overall, it is expected that the ideas, findings, and recommendations contained in this dissertation will lead to the following:

i. the recognition of the right to water and sanitation as human right in Nigeria with adequate provisions made to address its various contents, freedoms and entitlements and the gender dimensions of the rights considered and provided for;

ii. the adoption of relevant tools by the Judiciary in addressing problems of justiciability of economic, social and cultural rights and in holding duty-bearers accountable in the case of serious omission to implement their human rights international legal obligations;

iii. the commencement of public interest litigation by the civil society organisations and the general population in the promotion of human rights and environmental protection; and

iv. the adoption of the advocated approaches by the relevant stakeholders in water and sanitation sectors in Nigeria.

\section{Innovation}

The Research is innovative in the following respects:

Firstly, its interdisciplinary nature and its utilisation of social sciences methodological approach in assessing a human rights situation. Its originality can also be seen in its generation and utilisation of empirical data from a survey conducted in the research. It demonstrated how legal and policy provisions are at variance with the reality on the ground and what needs to be done to ensure compliance with the legal obligations;

Secondly, it contextualised and rationalised legal, policy, judicial, institutional and funding problems associated with the realisation of the right to water and sanitation in Nigeria. This is important not only in the context of Nigeria but other developing countries which are struggling to meet their legal obligations in the context of the right to water and sanitation;

Thirdly, the research not only contextualised how human rights-based and ecosystem approaches can be applied simultaneously in the realisation and promotion of human rights to water and sanitation, but also struck a scientific balance in their simultaneous application. 


\section{E. Plans and Implementation}

This research will be published as part of human rights research series to ensure wider publicity. Attempt will also be made to publish a summary of the research in the African Journal of Human Rights. To ensure wider circulation and to ensure that the relevant target groups benefit from the findings in this research, free published copies of the research will be provided to the relevant governmental and non-organisations and authorities identified in the research as well as some selected universities in Nigeria.

It is suggested that additional research covering larger number of participants should be pursued in order to identify additional challenges in these areas. Similarly, the contents of the right to sanitation which has not been explored in this research should be conducted. In this regard, special attention should be made to the gender dimension of sanitation. 


\section{Curriculum Vitae}

Kasim Balarabe was born in Kware, Nigeria. He holds a Master of Law degree with I specialisation in Law and Politics of International Security from the Vrije Universiteit Amsterdam Netherlands and another Master of Law degree in International Humanitarian Law and Human Rights from the Geneva Academy of International Humanitarian Law and Human Rights (University of Geneva and Graduate Institute of International and Development Studies), a Barrister at Law certificate (BL) from the Nigerian Law School and a Bachelor of Law from the Ahmadu Bello University Zaria, Nigeria.

He began his career as an Associate at Aluko \& Oyebode, one of the Nigeria's foremost commercial law firms. He was Assistant Chief Legal Officer at the Nigeria's Federal Ministry of Justice and a former Special Assistant (Policy) to the Nigeria's Federal Commissioner for Refugees, Migrants and Internally Displaced Persons. He also served as a Research Associate with Public International Law and Policy Group (PILPG) Netherlands Office and was a former Head, Department of Public and Comparative Law, Kampala International University. He is currently a lecturer at Kampala International University and Islamic University in Uganda where he has received the best law lecturer awards from both management and students body.

He has research interest in international law, human rights, humanitarian, refugee law, and security issues and has attended several international trainings and conferences in Africa, Asia, Europe and United States.

He is a member of Nigerian Bar Association, International Association of Refugee Law Judges and a Graduate Member of the Nigerian Institute of Management (Chartered). He enjoys traveling and has been to 45 countries in four continents. He can be reached at qasimng@yahoo.com 